


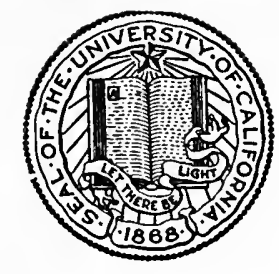

\section{THE LIBRARY OF}

\section{THE UNIVERSITY OF CALIFORNIA LOS ANGELES}

IN MEMORY OF

THOMAS S. DABAGH

I903-I 959

FIRST DIRECTOR OF THE

LAW LIBRARY 
Digitized by the Internet Archive in 2007 with funding from Microsoft Corporation 



Xegal Classic Weries

B R I T T O N 


\section{Legal Classic Series.}

\section{GLANVILLE}

Introluction by Joseph IFenry Beale. Jr.. A.M.. LL.D.

\section{BRITTON}

Introluction by Hon. Simeon L. Ballwin, LI.D.

\section{LITTLETON'S TENURES}

Introduction by Eugene Wambaugh, LL.D.

\section{MIRROUR OF JUSTICES}

Introduction by Hon. William C. Iobinson.

$$
\text { also }
$$

FLETA, and others. 


\section{BR ITTON}

\section{AN ENGLISH TRANSLATION AND NOTES}

\section{BY \\ FRANCIS MORGAN NICHOLS, M.A. , $26-1915$.}

OF LINCOI,'S INX, DARIRISTER AT LAW

FORMLRLY FELLOW OF WADHAMI COLLEGE

WITH AN INTRODUCTION

BY

HON. SIMEON E. BALDWIN, I,I.D.

PROFESSOR OF LAW IN YALE UNIVERSITY

WASHIFTON, D. C.

JOHN BYRNE \& CO.

LAW PUBLISHERS AND BOOKSELLERS

I 90 I 


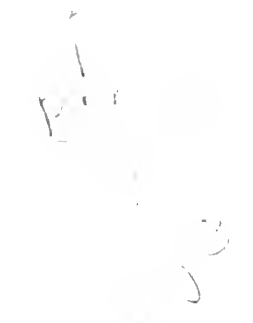

COPYRIGHTED, 1901

BI

JOHN BYRNE \& COMPANY. 


\section{INTRODUCTION.}

BY SIMEON E. BALDWIN, M.A., LI.1), PROFESSOR OF LAW IN YALE UNIVERSITY.

The founders of nations or of national institutions have a place by themselves. They are judged, not like other men, by their own talents or character, or immediate achievements, but rather by the ultimate consequences of the morements in which they shared.

Edward I is one of the few English sovereigns who has played a founder's part. Parliamentary history really dates from his convocation of the assemblage of the different estates of the realm at Westminster in 1275. The courts of England also, if we are to measure them by their relation, on the one hand, to the people, and, on the other, to the law, had first come into existence under the legislation of his reign, beginning, at its outset, with the Statute of Westminster, the First.

A few years before his accession English law had been put in form by Bracton. That great work, however, was written in Latin, and addressed to the scholar. It was too long to be a realy source of information to anyboly. Bulk and want of indexes made such trea- 
tises, before the invention of the art of printing, of litthe use in the practical administration of judicial business. An abridgment of Bracton, also in Latin, was prepared by the Chief Justice of the King's Bench, under Edward I, Gilbert de Thornton; but, like most abridgments, it was read by few. The treatise styled "Fleta" was published at about the same time; but this, again, was in Latin, and, so far as it has any pretensions to originality, contains little of value except its accomnt of the constitution of the royal household.

Edward I had brought his courts, and wished to bring his law, into close touch with the English people. This could only be lone by making the way in which it affected them known in a language commonly understood by those who were the natural leaders in tho community. Such was then the form of French userl in court circles. It is more intelligible to a Fenchman of our day than the English of the time of Elwarl I is to the Englishman of the time of Edward VII.

The treatise, of which a translation is given in this volume, was written in this "Jaw French," as it is often called, but what may be better styled the French of the thirteenth century. Law books have preserved it for us, but they took it from the common speech of the date. No English king wrote in English before IIenry $V$. If the contents of a Latin document were to be communicated to the courtiers at the royal palace, in the time of Edward I, it was done in Frenclu.* Who "Britton" was is mncertain. The authorship * Nichols Ed. of Britton. I, xlri, note. 
of the book was attributed by Sir Edward Coke to John Britton (or de Breton), bishop of Hereford. The bishop, however, died in 1275, and if he wrote it, great additions must have been made by a later hand, for statutes are mentioned which were enacted long after that date. It is more probable that the anthor was one of the justices of the inquisitorial tribunal instituted by Edward I, towards the close of his reign, and popularly called "Trailbaston." In a commission issued in $\mathbf{1 3 0 0}$ to those who were to hold it in the counties of Norfolk and Suffolk we find the name of John le Breton,* and that of 1304, for the county of York, ineludes "Johannes de Barton de Riton." + It is suggested by Nichols, in his edition of Britton, that this Joln le Breton was the same person who is variously deseribed in other annals of this reign as " $\mathrm{Sir}$ John le Breton," "Sir John de Breton," and "Johannes le Breton, dominus de Sporle." + We find also that in 1305 "Sir John de Bretaign" is assigned by the king to serve on a parliamentary commission to receive and answer petitions that concerned the people of Gascony. $\S$ The title of Edward I was " King of England, Lord of Ireland, and Duke of Aquitaine." Aqui-

* 1bid., xxi.

† Spellman's Glossary, Trailbaston. Dict. of Nat. Biography, Barton, John de. Possibly B. RITON may be the fanciful name assumed by the unknown author.

$\ddagger$ Nichols' Britton, I, xxi.

Sarliamentary History of England, I, * 127. 
taine was the Roman name for Gascony and, two years before, the English had regained possession of it by a treaty with France. In selecting the members of such a commission regard would naturally be paid to their familiarity with the French language as it was written, and Sir John de Bretaign was therefore presumably well acquainted with it, and so qualified, as far as scholarship was concerned, to compose such a treatise as Britton. Spelling in those days, when men knew their mother tongue mainly from oral conversation, often varied, and "Bretaign," which was certainly the same name as "Bretaigne" or "Britain," * may not improbably have been identical with "Briton," "Britton," "Breton," "Bretoun" or "Barton." The Britanni of the Romans passed both into Britones in monkish Latin and Bretons in French.

The Baron of Sporle t can harlly have been the author of Britton, for he inherited his lands and title in the reign of Henry III, and the book, if his, would

* Two years later (130\%) we find " John de Britain, Earl of Richmond," as one of those summoned to the Parliament of Carlisle. Parl. Hist. of Engl., I,*133. The first Earl, Alain Le Roux, came with William the Conqueror, and being from Brittany, was known as Count Alain the Red, of Brittany. His descendants made "de Bretagne," and later "de Britain," a part of their names.-Planché, The Conqueror and his Companions, I, 8265 .

t He is one of the barons who signed the famous protest to the Pope in 1301, and died a few months before Edward I, his name not occurring in the writ sumnoning the last parliament of that reign. -1 Parl. Hist., * $123,{ }^{*} 133$. 


\section{xi}

have been likely to go by the name of his barony rather than by that of his family. Probably it was the work of his son, Sir John le Breton, of Blatherwyk, in Northamptonshire, who died at a mature age in 1306 or 1307 (34, Edward I), * and who may also have been known as "Sir John de Bretaign."

But from whatever pen Britton may have come, its main authority is due to the stamp which it bears of royal approval. Like the Institutes of Justinian and many of the later barbarian codes, it speals in the name of the sovereign. The Roman Emperor gires the names of those to whom he entrusted the work of rerising his laws. The barbarian codes often refer in general terms to the aid given by the bishops and judges. $†$ Edward I, in his prologue to Britton, simply speaks of it as a compilation of the existing laws which he has had put in writing for the information of his subjects, and which be reserves the right to repeal or alter by the assent of his council.

Britton was, no doubt, prepared with the special view of familiarizing the people with the idea that the administration of justice belonged only to the crown and to those to whom the crown had committed it. It was the policy of Edward I to curtail or sweep away, so far as possible, the jurisdiction of the local

*Burke's Commoners, IV, 230; Nichols' Britton, I, xxii.

+ See, for instance, the captions to the Laws of Liutfrand, King of the Lombards, and to those of Peppinus, King of Italy, in the Corpus Juris Germanici, 102\%, 1282. 


\section{xii}

courts of a manorial or feudal character.* He had been at pains first to reform his own. Shortly before the publication of Britton, of the sixteen judges of England, fourteen had been convicted of extortion and corruption in office.t The beneh was then reconstituted, and a favorable opportunity thus given to make the king's courts more acceptable to the community at large. The two judges who were allowed to remain seem to have fully reflected his riews as to the royal prerogative. One of them, John de Metingham, when in 1296 Edward undertook to frighten the clergy into submission by a decree of general confiseation, we find announcing from his seat in the King's Bench that "for the future no manner of justice shall be done them in any of the King's courts on any cause whittsoever, but justice shall be had against them to every one that will complain and request it of us. ${ }_{+}^{+}$

The statutes of Gloucester and Westminster the Second, which were the expression of Edward's policy of coneentrating all judicial business of importance in the hands of his own judges, had been passed early in lis reign, but the corruption of those to whom the people had then been invited to entrust their eoncerns must have militated strongly in favor of the old order of things. The new judges, armed with Britton as a

* See Select Pleas in Manorial and other Seignorial Courts, Vol. I, in Selden Soc. Publ. in the introluction to which this subject is well and extensively discussed.

† In 1290. Parl. Hist., I, * 89 ; Spellman.Glossary, Justitiarius. $\ddagger$ Parl. Hist., I, * 104 . 


\section{xiii}

guide of procedure, entered upon their field of service under the most favorable circumstances. Nost of Edward's legal reforms, so far as Acts of Parliament could go, had been accomplished. "The laws," says Sir Matthew Hale, "diel never in any one Age receive so great and sudden an Advancement, nay, I think I may safely say, all the Ages since his Time have not done so much in Reference to the orderly settling and establishing of the distributive Justice of this Kingdom as he did within a short Compass of the thirty-fire Years of lis Reign, especially about the first thirteen Years thereof." * But Acts of Parliament could not execute themselves. It was through his new-made bench that Edward expected to incorporate them into the life of the people. It was by their aid also that he proposed to re-shape the common law in the interest of a strong and centralized government. So it was that, to quote again from Ilile, " gradually the Common Justice of the Kingdom came to be administered by Men lknowing in the Laws, and conversant in the great courts of B.R. and C.B. and before Justices Itinerant;" and "partly by the Jearning and Experience of his Judges, and partly by his own wise Interposition, he silently and without Noise abrogated many ill and inconvenient Usages, both in his Courts of Justice and in the Country." †

Britton, like Glanville, is primarily a book for

* History of the Common Law, * 158 .

† Ilbid., 160, 162. 
judges and lawyers. It looks at rights through rem. edies.

First (Book I, Chapters 1 to 4) comes a description of the various officers of justice and the general method of holding and conducting the King's courts. Then public rights and wrongs are discussed (Chapters 5 to 26). Next follows a statement of the remedies for certain private wrongs (Chapters 27 to 29 ). One chapter (30) is given to a description of the Sheriff's courts or "Tourns," a matter passed orer by Bracton. The next provides for the universal use of standard weights and measures, and for the regulation of prices of bread and beer. Villenage is the subject with which the first book closes.

Book II is deroted to remedies for wrongs affecting the possession of real estate, and mainly to disseisin.

Book III treats of inheritances and actions by heirs and coparceners.

Book IV takes up actions concerning the (hurch establishment and matters of religion, including adrowsons and false oaths.

Book $\mathrm{V}$ first sets forth the procedure to obtain dower, and then (Chapters 14 to 16) explains pleats or writs of entry.

Thus far possessory rights to property have been expounded. The last Book (VI) begins by taking up property actions, and (Chapters 1 to :3) the rules of intestate succession. Then comes an explanation of "Essoins" or excuses for non-attendance at court (Chapters 5 to 9), and the work closes abruptly with a 
statement (Chapter 10) of the nature and office of attorneys.

Throughout the whole of the treatise there is a steady endeavor to guard and magnify the royal prerogatives. The laws as they are set forth are to be obeyed because the king wills and commands it (Prologue I, 1). He may take jurisdiction over all manner of actions (I, 2). Holy Church shall " retain her liberties unimpaired" because the king so wills (I, 12). If a royal charter is set up, whether it be allowable or false or doubtful can be judged by none but the ling, " car a celi est respoundre et de juger qi en fu autour" $(\mathrm{I}, 99)$. If a law is to be abrogated or altered, the power to do this is saved to the king by the assent of his earls and barons and others of his "conseyl," who these others might be being left to the royal pleasure from time to time.

"Council" was of course the name for what we now call Parliament, and the Judges were often invited to it, and took an active part in drafting the statutes which they were afterwards to enforce.*

Trial by jury, in the time of Britton, was in a state of transition.

The jurors were tellers of the facts in issue rather than judges of these facts. They were to decide on what they knew before they entered the court room, more than on what they learned at the trial. If at its

* See Pollock \& Maitland, History of English Law, 2d Ed., I, 198; 200 . 


\section{xvi}

conclusion they reported a disagreement, and declared upon their oaths that they knew nothing about the fact in dispute (I, 126), a new jury was to be impanelled.

The system also lacked one of what we have come to consicler its essential features, the requirement of unanimity.

In trials for felony, if the jury failed to agree, the Judge could examine them one by one, and if he found that the majority knew the truth (I, 12b), judgment was to be rendered accorling to their opinion. A failure to agree, however, was only to be reported as a last resort. If they (that is, apparently, if a majority) were not certain where the truth lay, the defendant was to be discharged $(\mathrm{I}, 13)$.

In civil cases, after a disagreement had been reported, and the Judge, on examination of each, had found how the majority stood, the parties were asked if they would consent to adding enough more to the majority to make twelve. If both consented, a verdict could thus be obtained. If either refused his assent, judgment went against him (I, 136).

Felons, as now, were not to be brought to the bar in irons, nor in any manner of bonds $(I, 14)$, but apparently this provision was not always observed, for in a MSS. copy of Britton in the library of Cambridge University, made early in the fourteenth century, there is substituted for it the words "hors de trop gros fers et hors de trop gros liens.*

* Nichols' Ed. of Britton, I, 35, note, lix. Occasionally felons 


\section{xvii}

A humane saving in favor of burglars is worth notice. Infants under age, and poor persons who from famine made an entry for any victuals of less value than twelve pence, could not be convicted of this crime (I, 17). As three half-pence a day was then considered sufficient to support a man (I, 12), this exception in favor of the poor meant a good deal.

Britton is not without value to the modern lawyer for his definitions.

An obligation, for instance, it is said is a bond of law through which any one is bound to give or do any thing, and so is a mother of a plea, and takes its birth from some preceding trespass or contract (I, 61). Here is clearly brought out the notion which was the subject of discussion in Ogden v. Saunders, 12 Wheaton, 213 , that a contractual obligation is the consequence of a contract, and not a part of it.

An oath is "an affirmation or denial of anything whereby a man is charged on peril of his soul to say the truth" (II, 237).

The foundation of the still surviving doctrine as to the peculiar force which a seal gives to a written document is nowhere more plainly traceable than in the pages of Britton.

If suit is brought on a writing, and the defendant denies its execution, he cannot enter the plea of non

were arraigned in fetters as late as the time of Chief Justice Holt. -Campbell, Lives of the Chief Justices of England, III, 24. 


\section{xviii}

est factum if it bears his seal $(\mathrm{I}, 6+\mathrm{b})$.* That makes it his deed; but he may plead in avoidance that it was made after he had lost his seal and had had the loss eried and published by the churches and by the markets. $A$ plea that the plaintiff was once his seneschal or chamberlain or in other service with him, and that, for the great confidence he had in him, he gave him his seal to keep, and while he so had it in his keeping he made the writing without his knowledge, was bad; for he should have provided himself with a more trusty keeper. In such case his remedy was by an action of treason against the plaintiff by appeal of felony, or, if he preferred, by a civil action in trespass.

Attorneys-at-law Britton styles "general attorneys." They were to be admitted by royal letters patent, which could be issued by the Chaneellor (II, 286). The Justices on the eircuit conld only admit attorneys for a particular cause, upon the appointment of the parties to it (II, 2851)). All general attorneys eould levy fines and make the record of them (cirographe), the fee for this record being limited to four shillings $(1 ., 3 \pi \mathrm{b})$. The class of sergeants-at-law was alleady recognized (I, 37b), and if any appeal of felony were abated by reason of the mispleading or other default of a sergeint, since he ought to know the way to plead, he was to be fined a hundred shillings (I, 40 b), and if the error were malicions, punished criminally and deprived of his office.

* Cf. Fleta, 132, et seq. 


\section{xix}

As we compare Britton with his predecessors in English law, we find no such prominence given to mere form as marks the pages of Glanville; nor is there mueh of the scientific arrangement and eivil law learning of Bracton. When put by the side of Fleta, Britton appears to write with a freer pen and to eover a wider field. He has also a better understanding of the sourees of English law.* Torts receive more attention, for they are now more fully renlerliable in the king's courts (I, 23, 141, 157).

The main causes, however, why Britton supplanted the earlier treatises, so far as real use was concerned, were, first, that he wrote in a language commonly understood by those taking part in court proceedings, and, second, that he spoke in the king's name.

His general view of the royal prerogative was less favorable to the liberties of the people than that taken by Bracton. The latter, in speaking of the laws and customs of England, says that "Quae quidem cum fuerint approbatae consensu utentium et sacramento reguin confirmatae, mutari non poterunt nec destrui sine communi consensu et consilio eorum omnium quorum consilio et consensu fuerunt promulgatae." †

This has a more manly ring than the opening words of Britton's first book, in which the law of the realm is spoken of as "here ordained" (ceo qe cy est ordeyné)

Britton was widely read while it lay in manuseript,

* See Holmes, Hist. of the Common Law, 266.

$+I, 1,7$. 
and more than twenty-five copies made in the fourteenth century are still preserved in English libraries. The translation which follows was made from one of these (collated, however, with others), which was found at Lambeth palace. It may be one of the original publications furnished by the Crown for the use of the Church, and so date back to the last decade of the thirteenth century. This is the more probable because it bears no name or title.

Britton was first printed about the year 1530 , but that edition is an imperfect one.

Mr. Nichols was obliged to choose between different manuseripts in respect to the apportionment of some of the chapters between the different books. Villenage, for instance, be assigns to the first, when others place it in the second book.

The plan of throwing the work into sections separately numbered is his, and was not adopted in any previous publication.

This translation was published by Mr. Nichols in connection with the original in the French text, to which the upper half of each page was deroted. His book was issued from the Clarendon Press at Oxford in 1565, with a scholarly introduction, and the valuable notes to the translation which are reproduced in this volume. It was in two volmmes, each paged separately, but a marginal paging was also given which follows the paging of the earliest printed edition, above described.

In the present volume, the paging used is that which 


\section{xxi}

Mr. Nichols placed upon the margin of his volumes; but in order to facilitate the use of his very excellent index, his paging is reproduced on the margin. Thus, page 30 corresponds to page 75 of his first volume (I, 75 ). The references in this introduction are to the pages as numbered in the Oxford edition.

Yale UNIVERSITY,

Simeon E. Baldwin.

April, 1901. 



\section{CONTENTS.}

IntroduCtION .......................... vii

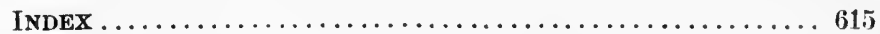

\section{ARRANGEMEN'TS OF BOOKS AND CHAPTERS.}

\section{BOUK I.}

OF THE AUTHORITY OF JUSTICES AND OTHER OFFICERS, AND OF PERSONAL PLEAS, INCLUDING PLEAS OF THE CROWN.

Prologue.................................. 1 CHAPTER

I. Of the Authority of Justices............... 2

II. Of Coroners.......................... 6

III. Of Eyres of Justices.................. 15

IV. Of the Chapters of the Eyre.............. 20

V. Of Counterfeiting the Seal and Coin; and of the Trial of Felons....................... 20

VI. Of Homicides.......................... 29

VII. Of Murder ... ......................... 32

VIII. Of Accidents... .................... 33

IX. Of Treasons....................... 34

X. Of Arsons........................... 35

XI. Of Burglars.......................... 36

XII. Of Prisoners.......................... 36 
Chapter

XIII. Of Outlaws...................... 41

$\mathrm{XIV}$. Of Inlawry, or being restored to law........ 44

$\mathrm{XV}$. Of Rape....................... 46

XVI. Of Larcenies ..................... 47

XVII. Of Abjurations................... 53

XVIII. Of Treasure-trove, Wrecks, Waifs, and Estrays... 56

XIX. Of the King's Rights................. 58

$\mathrm{XX}$. Of Franchises ...................... 62

XXI. Of various Wrongs $\ldots \ldots \ldots \ldots \ldots \ldots \ldots \ldots \ldots, 64$

XXII. Of the King's Officers................. 71

XXIII. Of Appeals........................ 81

XXIV. Of Appeals of Homicide................ 91

XXV. Of Appeals of Robberies and Larcenies........ 96

XXVI. Of Appeals of Mayhem ................ 103

XXVIr. Of Attachments..................... 10

XXVIII. Of Distresses.................... 112

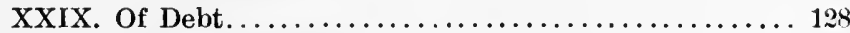

XXX. Of the Sheriff's Tourns $\ldots \ldots \ldots \ldots \ldots \ldots \ldots \ldots 146$

XXXI. Of Measures......................... 15:3

XXXII. Of Villenage...................

\section{BOOK II.}

\section{OF DISSEISINS AND THEIR REMEDIES.}

I. Of Suits concerning Land, pleadable by Attach-

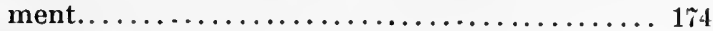

II. Of Purchase...................... 175

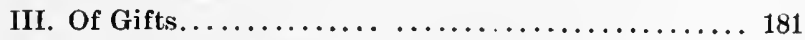

IV. Of Joint Purchases.................... 189

V. Of Conditional Purchases................ 193

VI. Of Reversions and Esclieats................. 201

VII. Of Purchases by Villains ................ 20:?

VIII. Of Charters ........................ 206

IX. Of Seisins...................... 212

X. Of Purchase of Rent................... 220

XI. Of Disseisins ....................... 222

XII. Where an Assize does not lie.............. 23:3

XIII. Of Remedies in Disseisin................. . 238

XIV. Of Views in Disseisin................. 24?

$\mathrm{XV}$. Of the Proceedings in Assises............ 246 


\section{CONTENTS.}

CHAPTER

XVI. Of Title to Freetold...

XVII. Of Exceptions to the Writ................ 253

XVIII. Of Exceptions to the Person of the Plaintiff..... 260

XIX. Of Exceptions to the Action............... 265

XX. Of Assises turned into Juries .............. . 268

XXI. Of the Challenge of Jurors, and of the Trial of the

Assise ............................... 277

XXII. Of Judgments........................ 281

XXIII. Of Appurtenances...................... 28

XXIV. Of Common of Pasture ................... 296

XXV. Of Remedy for Disseisin of Common........... 299

XXVI. Of Exceptions to Common................ 302

XXVII. Of Admeasurement of Pasture............... 305

XXviII. Of Quo jure........................... 309

XXIX. Of Reasonable Estorers..................... 314

XXX. Of Nusances.... . ...................... . \$16

XXXI. Of Remedy of Nusances .................. 320

XXXII. Of Exceptions in the Assise of Nusance......... 323

XXXIII. Of Farms........................... 329

\section{VOL. 11.}

BOOK III.

OF INTRUSIONS AND THEIR REMEDIES.

I. Of Intrusions......................... 333

II. Of Wardship ; of the various Tenures of Land ; and

of the Remedy against Supposititious Children. . 336

III. Of Marriage............................ 351

IV. Of Homage............................ 355

V. Of Reliefs.......................... 374

VI. Of Mortdancester....................... 376

VII. Of a Mixed Action ....................... 385

VIII. Of a Divisible Inheritance.................. 393

IX. Of the Plea De Rationabili Parte ............. 398

$\mathrm{X}$. Of Summons, and other proceedings in the $\Lambda$ ssise of Mortdancester...................... 402

XI. Of Warranties in Assise of Mortdancester........ 410

XII. Exception of 'same Descent'................ 424 
XIII. Exception upon the word 'seized' ...........426

XIV. Exception upon the words 'last seized'........ 429

XV. Exception upon the words ' in his demesne'. . . . 431

XVI. Exception founded on the words ' as of fee'..... 4335

XVII. Exception founded on the words 'the day whereon he died'. ........................ 4:38

XVIII. Exception founded on the words 'of so much land with the appurtenances'.............. 442

XIX. Exception founded on the words 'since the term'. 44:3

XX. Exception founded on the words 'next heir' .... 444

XXI. Exception founded on the words "who holds the

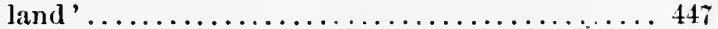

XXII. Exceptions of Felony and Bastardy, and other exceptions to the Assise . . . . . . . . . . . . 450

XXIII. Of Assises turned into juries............. 45

XXIV. Of the Trial and Judgment in Assise of Mortdancester . . . . . . . . . . . . . . . . . . . 459

XXV. Of the writ called Quod permittat........... 460

XXVI. Of the writs of Cosinage, Ael, and Besilel ....... 462

\section{BOOK IV.}

\section{OF PLEAS RELATIN(; TO ADVOWSONS ANI) THE} PROPERTY OF CHURCHES; AND OF ATTAINS.

I. Of the Assise of Last Presentation.......... $46 \pi$

II. Of the alay of Plea; and of the Count of the Plaintiff............................ 469

III. Of Exceptions in Assise of Last Presentation . . . . 470

IV. Of Exceptions independent of the Writ ....... 47\%

$V$. Of the Verdict and Judgment in Assise of latst Presentation. . .................... 489

VI. Of the Action of Quare imperlit............ $49^{\circ}$

VII. Of the $A$ ssise of $U t r u m \ldots \ldots \ldots \ldots \ldots \ldots \ldots \ldots \ldots 496$

VIII. Of Exceptions in the Assise of $C t r m m \ldots \ldots \ldots \ldots . .498$

IX. Of the nature of an Oath, and of the process of Altaint ........................... 501

X. In what cases Attaint lies .............. 507

XI. Of the Excuses of Jurors in mitigation of Attaint. 511

XII. Of the Trial and Judgment in Attaint........... 513 


\section{BOOK V.}

OF PLEAS OF DOWER, AND ENTRY.

6HAPTER

I. Of the Nature of Dower ......................

II. Of the Establishment of Dower............. 5.2\%

III. Of the Assignment of Dower............. . 527

IV. Of the Remedies for recovery of Dower......... 5:3:

V. Of Vouching to Warranty in Pleas of Dower .... 536

VI. Of Exceptions respecting the Husband's death.... 598

VII. Of Exceptions founded on the invalidity of the

Marriage, and on the Dower established being different from that claimed ..............5 540

VIII. Of the Pleadings when several Women claim Dower

of one Husband..................546

IX. Of Exceptions relating to the Assent of the Father 548

$X$. Of common Exceptions in Actions of Dower ..... 550

XI. Of the Judgment in an Action of Dower ....... 561

XII. Of the Plea of Right, of Dower............. 562

XIII. Of Admeasurement of Dower............ 56:

XIV. Of the Actions founded on Writs of Entry ...... 565

XV. Of the Proceedings in an Action of Entry....... 5\%0

XVI. Of Exceptions in an Action of Entry ......... 573

\section{BOOK VI.}

\section{OF PROPRIETARY ACTIONS.}

Istroduction. Of the Plea of Right............. 575

I. Of Proximity of Heirs............... . 57,

II. Of Succession, and the Law of Inheritance ..... 57 .

III. Of Degrees of Kindred................. 584

IV. Of the proceedings in a Plea of Right before the

Court Baron and County Court, and of its removal into the Royal Court............ 588

$\mathrm{V}$. Of Summons in a Plea of Right........... $59 \pi$

VI. Of Essoins........................6 602

VII. Of the Essoin de ultra mare.................604

VIII. Of the Essoin founded on the King's Service . . . . 608

IX. Of the Essoin de malo veniendi...............609

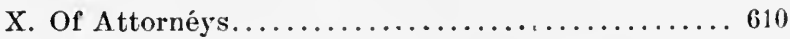





\section{BRITTON.}

\section{BOOK I.}

OF THE AUTHORITY OF JUSTICES AND OTHER OFFICERS, AND OF PERSONAL Pleas includiNg Pleas OF THE CROWN.

\section{Prologue.}

EDward ${ }^{1}$ by the grace of God, ling of England, lord of Ireland, and duke of Aquitaine, to all bis faithful people and subjects of England and Ireland, peace and grace of salvation.

Desiring peace among the people who by God's permission are under our protection, which peace cannot well be without law, we have caused such laws as have heretofore been used in our realm to be reduced into writing according to that which is here ordained. And we will and command, that throughout England and Ireland they be so used and observed in all points, saring to us the power of repealing extending restricting and amending them, whenerer we shall see good, by the assent of our earls and barons and others of our Council ; ${ }^{2}$ saving also to all persons such customs as by prescription of time have been differently used, so far as such customs are not contrary to law.

1 Edward I.

2 'This Preamble or Prologue is divided into two parts ; first, 


\section{CHAPTER I.}

\section{Of the Authority of Justices.}

1. First, with regard to ourselves and our Court, we have ordained, that, inasmuch as we are not sufficient in our proper person to hear and determine all the complaints of our said people, we have distributed our charge in several portions, as is here ordained.

2. We will that our jurisdiction be superior to all jurisdictions in our realm; so that in all kinds of felonies trespasses and contracts, and in all manner of other actions personal or real, we have power to give, or cause to be given, such judgment as the case re-

the regal style, where he says, "Edward \&c. ;" and then the salutation, where he says, "and we will and command \&c.;" affirming a prerogative in his person, that what he thinks right ought to be held to be law ; accorlling to the saying, "Quod principi placuit pro lege habetur." Because peace cannot be without law, nor law without a king: who can change the laws and establish others, but not without the assent of the Earls and others of his Council : 'quia ubi voluntas unius in toto dominatur, ratio plurimum succumbit.' (Note in MS. N.) 'This note is cited by Selden as from a MS. in his possession; Diss. ad Flet. p. 468. The passage from the Civil Law, "Quod principi \&c." (Inst. lib. i. tit. 2. \$6. Dig. lib. i. tit. 4. 1. I) was imported into English Law by Glanvill, in his Prologue. and was a frequent subject of controversy with subsequent writers. See Bracton f. 107; Fleta 16, 17. See also Selden. Diss. ad Flet. 466. 
quires without any other process, whenever we have certain knowledge of the truth, as judge. And the Steward of our household shall take our place within the verge of our household; and his office shall extend to the hearing and determining the presentments of the articles of our Crown, when we shall see good.

3. Further, we will that Justices Itinerant be assigned to hear and determine the same articles in every county and franchise every seven years; and that our Chief Justices of Ireland and Chester have the like power.

4. With respect to the Justices assigned to follow us: and hold our place wheresoever we shall be in England, we will that they have cognizance of amending false judgments, and of determining appeals and other pleas of trespass committed against our peace, and that their jurisdiction and record shall extend so far as we shall authorise by our writs.

5. We will that the Earl of Norfolk, by himself oranother knight, be attendant upon us anck upon our. Steward, to execute our commands and the attachments and executions of our judgments and those of our Steward throughout the verge of our house, so long as he shall hold the office of Marshal.

6. In our household let there be a Coroner to execute the business of the Crown throughout the rerge and wheresoever we shall be or come within our realm; and let the same person or some other be assigned to assay all weiglits and measures in every our verge throughout our realm according to our standards; and these two duties lue shall not fail to do by reason of 
any franchise, unless such franchise be granted in fee farm or in alms by us or our predecessors.

7. In every county let there be a sheriff who shall be attendant on our commands and those of our Justices ; and let him have record of pleas pleaded before him by our writs ; ${ }^{\mathbf{1}}$ and under the sheriffs let there be hundredres serjeants and beadles attendant on the sheriffs. And in every county let there be coroners chosen for keeping the pleas of our peace, as shall be authorised in the chapters concerning their office, and let them have record of things relating to their office.

8. Moreover our will is, that there be Justices constantly remaining at Westminster, or at such other place as we shall be pleased to ordain, to determine common pleas according as we shall authorise them by our writs; and these Justices shall have record of the proceelings held before them by virtue of our writs.

9. Also our will is, that at our Exchequers at Westminster and clsewhere our Treasurers and our Barons there have jurisdiction and record of things which concern their office, and to hear and letermine all causes relating to our debts and seignories and things incident thereto, without which such matters could not be tried; and that they have cognizance of debts owing to our debtors, by means whereof we may the more speedily recover our own.

10. And we will, that Justices be assigned in erery county to have cognizance in such causes of petty

${ }^{1}$ The text may admit of another interpretation. But see c. 28 , 8. 1 , and note there. 
assises and other matters, as we shall assign them by our letters patent, of which causes we will that they have record. Let Justices also be appointed to deliver the gaols in every county, once in every pleadable week, ${ }^{1}$ while they find anything to do; and let them likewise have record of the pleas brought before them and of their judgments.

11. And although we have granted to our Justices to bear record of pleas pleaded before them, yet we will not that their record be any warrant to them in their own wrong, nor that they be permitted to erase their rolls or amend them or record contrary to the enrollment. And we will that the power of our Justices be limited in this manner, that they go not beyond the articles of our writs, or of presentments of jurors, or of plaints before them made, save that they shall have the cognizance of vouchers to warranty, and of other incidental matters without which the original causes could not be determined. And we forbid, that any have power of amending any false judgment of our Justices, except the Justices who follow us in our Court, who are authorised by us for that purpose, or ourselves, with our Council; for this we specially reserve to our own jurisdiction.

12. We forbid all our Coroners and Justices, and all

1 The same rule is laid down in c. 12. s. 5, where the expression is chescune simeyne en tens pledable. Mr. Kelham interprets this as excluding times prohibited by the church (see book ii. c. $21 \mathrm{~s}$. 1) ; but the whole passage appears to require further explanation. See Kellum's Britton, p. 8. n. (24.) 
others to whom we have given authority of record, that any, except our Steward and our Justices of Ireland and of Chester, without our leave. substitute another in his place, to do any, act of which he him. self ought to make record; and if anything be done before such substitutes, we will that it be of no force, though it should be of abjuration or outlawry.

13. We will also, that in counties and hundreds, and in every freeholder's Court, the Courts be held by the suitors; the like in cities boroughs and franchises, and in sheriffs' 'Tourns and in view of frankpledge.

\section{CHAPTER II.}

\section{of Coroners.}

1. And because our will is, that coroners shall in every county be the principal guardians of our peace, to bear record of the pleas of our Crown, and of their views, and of abjurations and ontlawries, we will that they bechosen according as is contained in our statute concerning their election; and when they shall be chosen, we will that in full County they take the oath before the sheriff, that they will lawfully and without demanding any reward make their inquests and enrollments, and do whatsoever belongs to the office of coroner.

2. Also, we will, when any felony or misadventure has happened, or if treasure be found under ground and wickedly concealed, and in case of rape of women, 
or of the breaking of our prison, or of a man wounded near to death, or of any other aceident happening, that the coroner do speedily, as soon as he is informed of it, give notice to the sheriff and the bailiff of the place, that at a certain day he eause to appear before him, at the place where the accident happened, the four adjacent townships and others if need be, whereby he may inquire of the truth of the casualty. And when the is come, let him swear the townships upon the Holy Evangelists, that they will speak the truth of such artieles as he shall demand of them on our behalf. And in this case, and at the sheriffs' tourns, and at riew of frankpledge, and in the office of escheators, and in our presence before our Steward, and in the eyre of our Justices, we will that people be sworn though our writ come not.

3. Afterwards, let the coroner with the jurors go and view the body, and the wounds and blows, or if any one hath been strangled or scalded ${ }^{1}$ or by other violence come to his end; and immediately after the riew, let the body be buried. And if the coroner find the body buried before such view made, let him make an enrollment thereof; but let him nerertheless not fail to have the body disinterred, and view it openly, and have it viewed by the townships.

4. Those who are summoned, and eome not to the coroner's inquest, shall be in our merey at the coming of our Justices at the next assises in that county, if

1 Perhaps, suffocated,--a sense suggested by Carpentier. Ducange, Gloss. $s . v$. excaldare. 
such defaults be entered in the roll of the coroners; so that neither our coroncrs, nor our escheators, nor any mere inquirers, have authority to amerce any one for any default.

5. When the coroner shall have a sufficient number by whom he may make his inquests, let him in the first place inquire, whether such person was killed by felony or misadventure; and if by felony, whether the felony was committed in or out of a house, or whether in a tavern, or at a wrestling-match or other meeting. Then let it be iuquired, who were present at the fact, great and small, male and female; and who are guilty of the fact, and who of aid, or of force, or of commandment or consent, or of linowingly receiving such felons. And if the coroner on the first inquiry suspect concealment of the truth, or that there is need of further inquiry, and that by others, let inquiry be made again and again ; but let him not for any contraricty in the verdicts alter or curtail his enrollment in any point. And further, he must inquire of the manner of the killing, and witl what weapon, and of all the circumstances.

6. And let the sheriff forthwith cause all those who shall be indieted to be taken, if they be found. If they be not found, let the coroner inquire, who they are who have withdrawn themselves on that account; and let the sheriff forthwith seize their lands into onr hand simply, without removing bailiffs or putting in any one on our behalf, until the parties are convicted by judgment or cleared of the felony. Next, let him seize 
all their chattels into our hand, and appraise them by good inquest, and that, whether they be the chattels of villains, who bave fled and are suspected, or of freemen, and cause the value to be enrolled in the coroner's roll, and the goods to be delivered to the townships to be answered for to us, in case the person indicted shall either refuse to submit himself to justice in our Court, or be afterwards attainted as a felon. Afterwards let it be inquired, whether any of the persons indicted ever by virtue of our writ of menace found surety of our peace to the person killed; and let the names of the mainpernors be enrolled according as shall be found by the verdict.

7. If there be any one who would seek vengeance of the death by appeal of felony, let the male, of what age soever he be, be received before the female; and the next of blood before one more remote. And if the plaintiff is willing to prosecute his appeal within the year and day, let him find in full county two sufficient pledges, distrainable to the sheriff of the county in whose bailiwick the felony was committed, that he will prosecute his appeal according to the law of the land, and thereupon let him be admitted thereto. Then let the coroner enter his appeal and the names of his pledges. Afterwards, let the bailiff of the place where the felony was committed be commanded to have the bodies of the appellees at the next county court to answer to the plaintiff.

8. And if he appeal several, some of the fact and some of the force or accessory facts, to every appeal let 
two pledges to prosecute be entered; and let the appeal be entered separately against each person. If the bailiff at the second county court testify that he could not find them, then let it be awarded that the principals appealed of the fact be solemnly demanded that they do come to our peace, to take their trial for the felony whereof they are appealed; and let them be so demanded from county court to county court until they appear or be outlawed. And if the plaintiff makes default at any county court, then let the exigrent ${ }^{1}$ stand over till our coming into the county or the Eyre of the Justices; and if the plaintiff will resume his appeal, let him on finding other pledges to prosecute be received thereto, so as he pray it within the year and day.

9. But whether those who were appealed of consenting and of accessory facts withdraw themselves or appear, no exigent shall run against them, nor shall they be compelled to answer to the plaintiff before judgment be pronounced in the case of the principal. But if the principal be outlawed, then let exigents be immediately awarded against the accessories. And when any of them is outlawed, or hath withdrawn himself and is suspected, let the coroner inquire of whose tithing or whose mainpast such fugitive was, and make his enroll-

1 The exigend or exigent is the writ or precept in pursuance of which an absent defendant is exacted or required at the county court, with a view to his outlawry. The name and the practice still continue. See Termes de la ley, s. v. Exigent; 3 Blackst. Comm. 283. App. xix. ; 4 ib. 319. 
ment according to the verdiet; and let him inquire of the lands and chattels of every fugitive, and in what place he has had property elsewhere than in his bailiwick. And if they appear before the outlawry of the principal, let them be replevisable, and immediately after outlawry of the prineipal, let them come and answer to the plaintiff.

10. If the felony was committed out of a dwellinghouse, then let the coroner inquire, who first found the body, and let him or them, if there be sereral, women as well as men, young as well as old, be taken and released by pledges, until our coming into the county or the Eyre of the Justices; and let the coroner cause their names and the names of the pledges to be imbreviated.

11. We forbid every coroner, upon pain of imprisonment and heary ransom, to make his inquests of felonies accidlents or other things belonging to his office, by procurement of friends, ${ }^{1}$ or to remove a juror on the challenge of any party, or to take anything by him. self or other, or suffer anything to be taken by his clerk or any person belonging to him, for the executing of his office; or to erase, or alter, or practise any kind of fraud in his rolls, or suffer it to be done.

12. If he finds that any one has come to his death by accident, then let him inquire by what accident, whether he was drowned, or fell, or whether he was killed without felony prepensed of any,other, or was a

1 The meaning appears to be: by procuring friends of the parties implicated to make up the jury. 
felon of himself; and if he was drowned, whether in the sea, or in an arm of the sea, in fresh water, or in a well, or diteh, and by what occasion he was drowned; also from what vessel he fell, and what things were in such vessel, and to whose hands they came, and of what value they were, and who first found the body. If in a well, then let it be inquired, whose the well was. If by a fall, whether it was from a mill, or from a horse, or a house, or a tree. If from a mill, what things were then moving in the mill, who owned the mill, and the value of the things therein then moving; and likewise of houses, horses, trees, and earts.

13. If the person was killed, then let it be inquired, whether it was done by man or beast or any other thing; if by man, whether by the person himself, or by another; and if by another, whether the misadventure happened by chance, or from necessity to avoid death ; if by a beast, whether by a dog or other beast, and whether the beast was set on to do it, and encouraged to such misehief, or not, and by whom, and so of all the circumstances.

14. Of such as are drowned within our realm by falling from a vessel not at sea, our will is, that the ressel and whatsoever shall be found therein be appraised as a deodand and enrolled by the coroner, that is to say, whatsoever was moving; for if a man happens to fall from a ship uncler sail, mothing ean be deemed the cause of his death, except the ship itself and the things moving in it ; but the merehandise lying at the bottom of the ship, is not presumed to be the oceasion of his 


$$
\text { I, *7.] OF CORONERS. }
$$

death, and so in like cises. And of those drowned in fountains and wells, we will, as in the other cases, that the coroners admit to mainprise the first finders, and enroll their names and the names of their pledges; and of those who have come to their death by carts or mills, and in the like cases, let the coroner make his inquests and enrollments as above directed where persons are drowned.

15. Whenever the coroner takes his inquest on the body of a person feloniously lilled, let him cause one or more of kin to the deceased on the side of the father or mother to appear before him in proof of Englishery accorling to the custom of the country, and enroll their names.

16. We will also that the coroners receive the confessions of felonies made by approvers in the presence of the sheriff, whom we intend to be his controller in every part of his office; and let them eause such confessions to be enrolled. And when any man has fled to church, we will that the coroner as soon as he has notice of it, command the bailiff of the place, that he cause the neighbours and the four nearest townships to appear before him at a certain day at the church where the fugitive shall be; and in their presence he shall receive the confession of the folony; and if the fugitive pray to abjure our realm, let the coroner immediately do what is incumbent on him. But if he does not pray abjuration, let him be delivered to the township to keep at their peril.

17. If the coroner be to take an inquest of rape, let 
him carefully inquire into all the circumstances of the force and of the felony, and make enrollment of the presumptive signs, such as stains of blood, and tearing of clothes. If of a wounding, let him inquire with what weapon, and of the length and depth of the wound. Let him likewise enter in his roll all judgments of death given in his bailiwick by any other than our Justices; and in such cases, we will that their rolls be a record. And whereas it is declared above, that coroners ought to make enrollments of appeals of felonies of the death of a man, let them do the like in appeals of rape, robbery, larceny, and in appeals of every other kind of felony.

18. It also belongs to their office to inquire of ancient treasure found in the earth, of wreck of the sea, of sturgeons and whales, as soon as they shall have notice thereof; and to attach and let to mainprise those who have found or made away with them, and to enroll their names, and to secure such findings for oul use. And we will that our sheriffs and bailiffs be attendant on our coroners, and execute their precepts. 


\section{CHAPTER III.}

Of Eyres of Justices.

1. With respect to our coming, and the Eyre of our Justices, we will that general proclamation be solemnly made in the markets cities and boroughs throughout the county, as well within franchises as without: that all the freemen of the county, and four men and the provost of every vill, and all the mainpernors and those who have been let to mainprise throughout the county, appear at a certain day, which shall be forty days distant at least, before us, or such Justices as shall be named in our precept to keep the eyre in the same county : and that all those who claim any franchise in the same county be the same day before us or the same Justices, and that every one show distinctly in writing what franchises he claims; and that all those, who have any complaints to make against our ministers or bailiffs or those of others or any persons whatsoever, be there at the same day, to exhibit such complaints and find pledges to prosecute; and that the sheriff of the county have there all such writs as have been adjourned until the eyre, and all the assizes of novel disseisin, mortlancester, darrein presentment, utrum, and of dower, and all the prisoners and attachments. And meantime we will command our Justices of the bench, that they adjourn all the pleas of the 
county and send them before us or such Justices itinerant in that county, so that they be there at the day named.

2. And as to the coming of our Justices, our will is, that as soon as they be come to the place appointed for holding the eyre, they produce the authority they have of us by our letters patent, and cause them to be read in the hearing of the people; and afterwards let him who is first named in the letters, show and declare to the people the occasions and advantages of their coming into that county; this done, let them receive the essoins of the common summons, which shall be immediately determined and adjourned. Then let the essoins of pleas of land be received; and let these be aljuclged and the fourth day after adjourned.

3. Next let the letters whereby any persons whatever claim to hold franchises in that county be received, and let their claims be enrolled, and a transcript of the same enrollment be delivered to the sheriff; and as to all such franchises as are not claimed, let the sheriff be commanded to seize them into our hands by way of distress, and be answerable to us for the issues, until those who shall claim them have saved their defaults for not attending the summons; and let them then answer by what warrant they have held them.

4. Afterwards let the Justices take the wands of the heriff, and of the lords of the franchises, and of all the other inferior bailiffs, and then let the sheriff swear, that he will duly execute the lawful commands of our Justices, and will well conceal the secrets and counsels 
of their eyre, so help him God and the Saints. And after this oath is taken, let the wand be delivered back to him. Then let the sheriff present all his officers and bailiffs, clerks and others, by whom the precepts of the Justices and executions of their judgments are to be performed; and let them all take the same oath that the sheriff took, and their wands be delivered back to them.

5. And if there be any arehbishop, bishop, abbot or prior, earl or baron, or other, that elaims the franchise of return of our writs, let him take the same oath that the sheriff took; or let them take their wands in their hands, and present such bailiffs in their stead as will take the oath for them, and for whose acts they will be answerable as to that which to their office shall belong: and then let the wands be delivered by those lords to their bailiffs. Afterwards let proclamation be made, that all persons belonging to franchises, except the bailiffs, depart unto their own homes until further summons or until a certain day.

6. Next let the bailiffs of the sheriff swear, that they will truly present two or four ${ }^{1}$ of their bailiwick, or more or less, who are not appealed of any crime, nor are appellors, and such as shall best know and will

1 According to the so-called Statute of uncertain date, but probably of the early part of the reign of Edward I, entitled 'de sacramento ministrorum regis,' two knights or prodes homes were to be chosen by the bailiffs, and twelve knights or prodes homes to be chosen of themselves and others of their hundred by the first two. According to Bracton and Fleta four knights were to be first chosen. Cf. Blackst. Comm. vol. ir. p. 302. 
inquire and discover secret acts concerning the breach of our peace. And when the names are given in, let those come and swear, that they will lawfully associate to themselves such others, by whom the truth may best appear. Afterwarls, let them, together with those whom they have chosen for the most sufficient, swear, that they will lawful presentment make of such chapters as shall be delivered to them in writing, and that in this they will not fail for any love, hatred, fear, reward, or promise, and that they will conceal the seerets, ${ }^{1}$ so help them God, and the Saints. And then let the chapters be read to them, and delivered to every dozen separately. ${ }^{2}$

7. Afterwards, let proclamation be made, that none presume to amerce any man for making default in a court baron or hundred, who shall at that time be before us or our Justices; and that no market be kept within ten miles, except in the town where our Justices shall be, if the town is not able to find sufficient provision for such as shall abide there; and that, if any

1 This clause of the oath is not in Bracton or Fleta, nor in the statute 'for oaths of the king's officers.' In MS. $N$. a form of oath is given in French nearly resembling that in the text, and concluding, ' mes rostre conseil e de ceste eyre bien e loialmente celeray.'

2 'He [qu. the Justice] shall then read the articles distinctly in English. And that which they shall present, he shall put first in a roll, which shall be their note and shall remain with them. And afterwards of that and the other things, by command and direction of the more prudent of the twelve, he shall make his chief roll.' (Note in MS. $\Lambda_{\text {. }}$ ) 
person be come who has no business on hand, he shall make his attorney, if he please, and depart home.

8. Afterwards, let the coroners, or their heirs, be s:ommanded to deliver to the Justices their rolls since the last eyre; and we will that the Justices seal them moler their seals, and forthwith without any examination deliver the rolls back to them, so that they be every day with their clerks before the Justices, while they have occasion for them.

9. Afterwards, let the presentments upon the chapters delivered to the dozens be received in writing; and let the same be indented, so that the Justices may have one part thereof and the other may remain with the presentors. The chapters which are to be delivered to them are not however of any certain number; for as crimes increase, so much the chapters and other remedies increase. Some of these chapters are concern- ing counterfeiters, murders, accidents, and other matters, as will appear from the following heads. 


\section{CHAPTER IV.}

Of the Chapters of the Eyre.

In the first place, let the old articles presented in the last eyre in that county touching breaches of our peace, which then remained undetermined, be inquired of, heard, and determined. Of our mortal enemies abiding in our land presentment cannot properly be made, ${ }^{1}$ but accusation and appeal, as will appear in the chapter of appeals.

\section{CHAPTER V.}

Of counterfeiting the seal and coin ; and of the trial . of felons.

1. Let inquiry be made of forgers, and not only of such as counterfeit our seal, but of all those who shall have in any way falsified our seal, as those who have fraudulently hung it to any charter without our leave, or when it has been stolen or robbed or otherwise obtained, have sealed writs therewith without other

1 This appears to be a correction of Fleta 24 (li. 1. cap. 20. sect. 1), who puts treason as the first article of the eyre. It does not appear among the matters enumerated by Bracton, or in the Capitula Itineris (Stat. incert. temp.) But compare post. c. 30. s. 3. 
authority. And also of forgers who have counterfeited our coin, or put more alloy in it than according to the form and usage of our mint ought to be put, or that have coined money, whether good or bad, in our realm without our leave. Likewise of those who have clipped our coin or otherwise impaired it. Of those also who have brought into our realm counterfeit money in any way resembling ours in despite and damage of us and our people.

2. Upon presentment of this felony, we will that the sheriff do cause all those who are indicted of it to be instantly taken, and their bodies liept safely in prison; and that they be brought before us or our Justices; and, to the intent that no one may be unprepared with his answer, let those who are so taken have fifteen days at least, if they pray it, to provide their defence, and in the meantime let them be safely liept. And when they shall appear in judgment before us or before our Justices, let them be there arraigned by the sheriff or other officer on our behalf, and indicted of the felony according to the nature of the presentment. And if they will not put tremselves upon their acquittal, ${ }^{1}$ let them be put to their penance, until they

1 That is, if they reuse to be tried by an inquest or jury. This sort of trial appears, in theory at least, not to have been considered valid either in criminal or civil causes, without the consent of the parties. Compare liv. ii. c. 20 . $\$ 2$. So in liv. iii.. 23. $\S 4$, the consent of the party is extorted by the alternative of a judgment against him. It has been a question, whether the penance here described, which is referred to in Stat. West. I. c. 12, as prisone forte of dire, was introduced by that Statute. 
pray to do it; and let their penance be this, that ther be barefooted, ungirt and bareheaded, in the worst place in the prison, upon the bare ground continually night and day, that they eat only bread made of barley or bran, and that they drink not the day they eat; nor eat the day they drink, nor drink anything but water, and that they be put in irons.

3. If one indicted of felony alleges clergy, and be found to be a clerk and claimed by the ordinary, let it be inquired how he is suspected; and if the presenters upon inquiry find that there are no certain grounds

Coke contends (2 Inst. 178) that it was previously used in cases of appeals, (see post. c. 24. s. 7.; Fle. 51, $\$ 33$ ), but was extended by that Statute to indictments at the king's suit. Others have observed that no trace of it is to be found in any authorities anterior to the reign of Edwarl I ; and examples have been cited from earlier records, showing that by the practice of the previons reign, the inquest might be taken by jury without the consent of the prisoner, either. voluntary or enforced. (See Hale, Pleas of the Crown, vol. ii. p. 321 ; Kelham's Britton, p. 35.) This might appear to be in some degree confirmed ly the general statement of Glanville, that in cases of treason where there was no appellor, but the prisoner was accused by common fame, the truth was to be inquired by inquests and interrogations before the Justices. (Glan. li. 14. e. 1.) On the other hand, it does not appear to have been observed, that Bracton, although he does not mention the partieular means employed. expressly refers to a prisoner on trial for felony being forced to put himself upon the inquest per patriam. "Istam vero formam inquisitionis per patriam servabunt justiciarii generaliter in omnibus inquisitionibus quæ faciendæe sunt pro morte hominis, ubi quis se posuerit super inquisitionem sive sponte sive per cautelam inductus sive pez nocessitatem." Brac. $143 \mathrm{l}$. 
for suspicion, let the judgment be that ne be entirely acquitted; and if he is believed to be guilty, let his ehattels be appraised, and his lands taken into our hands, and his body delivered to the ordinary $;^{1}$ and if the ordinary deliver him out of prison before due acquittance according to the purgation of clerks, or if he keep him so negligently as to let him escape, or out of malice keep him in sueh manner as to prevent his coming to his purgation, and be convicted thereof, -in each of these cases let the ordinary be in our mercy. ${ }^{2}$ And according as the ordinary shall certify us of the acquittance ${ }^{3}$ of those clerks, we will cause restitution to be made them of their goods, if they have not fled from our peace.

If the principal accused refused to put limself on the country, and claimed clergy, the accessories could not be attainted of felony. A case to this effect is cited in the note in MS. $N$. as having occurred at Lincoln. "The accessory put himself on the country and by Sir John del Ille was commanded to the gallows. But Sir Elias de Preston said "Repeal that judgment, for the principal never put limself, and is not yet attainted." And he was ordered back to prison and afterwards made his fine for ten pounds.' John del Isle was a baron of the exchequer from $\mathbf{2 3}$ Ed. I. to 12 Ed. II. (Foss, Judges, vol. iii. p. 270). Elias de Prestou is not mentioned in Mr. Foss's work.

2 . The amercement shall be $100 \mathrm{~s}$. at least; and $100 \mathrm{l}$. for an escape from prison.' (Note in MS. N.)

3 'Et sic habet ordinarius recordum in eodem.' (Note in MS. N.)

4 'Hence the inquest may be had, whether the clerk put him. self thereupon or not, for two things ; namely, to know for what 
4. For we will that Holy Chureh retain her liberties unimpaired, so that she have cognizance of judging of mere spirituality, of testaments, of matrimony, of bastardy, of bigamy, and in the felonies of clerks, and in the correction of sins, provided the ordinaries take of the laity no money nor the value thereof, nor give judgment of any property except concerning testament and matrimony and mere spirituality, and of the repairs of churchyards and defects in churches, and of mortuaries, and of tithes, without prejudice to us.

5. And if any ordinary, either in person or by his proctor, demands one who is a mere layman, or a bigamist, ${ }^{1}$ or of such other condition that he ought not to enjoy the privilege of Holy Chureh, we will that he be committed to prison and punished by fine; and so of a proctor who presents himself for the ordinary without warrant in writing.

6. If any felons will confess their crimes and accuse others and become approvers, let them be put out of penance, and let their confessions be presently received

cause he onglit to be delivered to the bishop, and also for his chattels, whether he has forfeited them by his flight.' (Note in MS. N.)

1 Bigamus in the canon law is he that has married two or more virgins successively, or that has married a widow. See Coke, Inst. Pt. ii. p. 273 ; Blackstone, Comm. vol. iv. p. 163. By the council of Jyons, A. D.. 1274, Bigami were declared to be 'omni privilegio clericali nudati, et coertioni fori sacularis addicti, and forbidden under anathema to assume the tonsure. (Sext. Decr. tit. 12.) This was confirmed in England as to benefit of clergy by the Statute 4 Ed. I, thence called Statutum de bigamis. 
and enrolled by the coroner, and from that day forward let them have of the sheriffs three halfpence a day for their support.

7. When persons appealed at the eyre shall appear for trial, and demand judgment, whether they ought to answer concerning an act done before the last eyre and not then presented in that county, in all such cases they shall be put to their answer, ${ }^{1}$ because we will not that felonies remain unpunished; and if the article was not presented in the last eyre, the presenters for that hundred in the former eyre shall be in our mercy for the concealment, and any of them found to be living shall be punished by imprisonment and fine.

8. When the defendants have put themselves upon the country, and the jurors are come into court, they may be challenged in the following form. Sir, this man ought not to be upon the jury, because he indicted me, and I presume of him and all those who indicted me, that they stiil bear the same ill will against me as when they indicted me. And we will that, where a man's life is at stake, this exception shall be allowerl. They may also be challenged in many other ways besides this, as shall be shown in treating of exceptions. And when the accused either cannot or will not challenge the jurors, or there are jurors enough unchallenged, to the number of twelve, let them go to the book. If there are not sufficient, let the challenges be

1 This is mentioned as a valid exception by Bracton, who cites a case of the $9 \mathrm{Hen}$., III. in affirmance of it. Brac. $116 \mathrm{~b} .140 \mathrm{~b}$. 141 ; so Fleta $49(\$ 6)$. 
tried; and if the challenges be found true, so that there are not full twelve remaining, let another day be appointed, and let the sheriff summon more.

9. When they are to swear, let them swear one after another, that they will speak the truth of what shall be demanded of them on our part, so help them God and the Saints. And let no falsehood be erer knowingly practised; for they cannot swear in a matter of greater moment, than in that of life and menber. Afterwards let the jurors be charged of what fact they are to speak the truth. And then let them go and confer together, and be kept by a bailiff, so that no one speak to them; and if any one does so, or if there be any one among them who is not sworn, let him be committed to prison, and all the rest amerced for their folly in suffering it.

10. If they cannot all agree in one mind, let them be separated and examined why they cannot agree; and if the greater part of them know the truth and the other part do not, judgment shall be according to the opinion of the greater part. And if they declare upon their oaths, that they know nothing of the fact, let others be called who do know it $;^{1}$ and if he who put

1 The statements of the text as to receiving the verdict of a majority, and as to impanelling a fresh inquest in criminal cases require to be examined and compared with other authorities. Section 12 appears to be inconsistent. See a learned note by $\mathrm{Mr}$. Kelham upon this passage in his translation of the first book of Britton, and the authors there cited. The question as to the right of the judge in criminal cases to discharge a jury without 
himself on the first inquest will not put himself on a new jury, let him be remanded back to penance till he consents thereto.

11. We will also, that if any man, who is indieted of a erime touching life and $\operatorname{limb}$, and perceives that the verdict of the inquest, on which he has put himself, is likely to pass against him, desires to say that any one of the jurors is suborned to condemn him by the lord, of whom the aceused holds his land, through greediness of the escheat, or for other cause by any one else, the Justices thereupon shall earefully examine the jurors, whether they have any reason to think that such slander is true. And often a strict examination is necessary; for in such case inquiry may be made, how the jurors are informed of the truth of their verdiet; when they will say, by one of their fellows, and he peradventure will say, that he heard it told for truth at the tavern or elsewhere by some ribald or other person unworthy of eredit; or it may happen that he, or they, by whom the jurors have been informed, were intreated or suborned by the lords, or by the enemies of the person indicted, to get him condemned ; and if the Justices find this to be the fact, let such suborners be apprehended and punished by imprisonment and fine.

12. And if the jurors are in doubt of the matter and not eertain, the judgment ought always in such case to be for the defendant. If they say that he is not guilty of the felony, the award shall be, that he go quit, and a verdict, has been discussed in moderin times in the case of Regina v. Charlesworth, 1 Best and Suith, 460. 
that he have restitution of his lands and of all his goods. And if they find that he is guilty, as he hath offended by treason against us, let him be drawn and condemned to death.

13. In felony of counterfeiting there lies no appeal, except between the accuser on our behalf and the accused, and between the approred, who has confessed the felony, and him whom he has appealed as his accomplice, and between a person found in possession, and another whom he shall vouch to warrant; for in these cases no suit lies, except ours.

14. With regard to false writs or writs disavowed or writs of false judgment, found in any person's possession, we will, that such persons be arrested and detained in prison, until they are warranted, or until those whom they have vouched have either put themselves on their defence or are outlawed; and if the vouchees are outlawed, or if they have vouched such as are not known in the county, then we will, that they either acquit themselves by the county or be put to penance. If they are warranted by those who cannot justify those writs according to the laws and usages of our realm, let judgment be given against the warrantors; and if the vouchee refuses to warrant, then the course of law is such as shall be afterwards mentioned. And with respect to false and clipped money and money counterfeited like our coin, let proceedings be taken according to the statutes concerning our coin, or according to what is laid down concerning false writs found in any one's possession. 


\section{CHAP'TER VI.}

\section{Of IIomicides.}

1. Let inquiry also be made of homicides and murders; and our will is, that those, who command aid or connsel others to kill, be indicted of this felony as well as the principal actors. And inasmuch as this felony may be committed under colour of judgment through malice of the judge, or under some other pretence, as by false physicians and bad surgeons, and by poison and sundry other ways, our pleasure is, that all those who have conmmitted such secret felonies be indicted; and also those who falsely for hire, or in any other manner, have condemned, or cansed to be condemned, any man to death by means of a false oath.

2. According to the presentment of this article let it be commanded, that all those who are indicted be apprehended; and if any one suspected of this crime be dwelling out of the county, let his lands be immediately seized, and his chattels appraised and delivered to the townships ; and let him afterwards be put in exigent until he appenr or be outlawed. And when any felons appear in jndgment to answer of their felony, our will is, that they come barefooted, ungirt, uncoifed, and bareheaded, in their coat only, without irons or any kind of bonds, ${ }^{1}$ so that they may not be deprived of

${ }^{\prime}$ In MS. $N$. the above words, which probably originally stood 
reason by pain, nor be constrained to answer by force, but of their own free will; and then, agreeably to the presentment against them, let them be inclicted.

3 . If the prisoners are found guilty, let their judgment be death for death, and let their movable goods be ours, and their heirs disinherited; we will also have the year and day of their inheritances, of whomsoever they are holden, that they may remain one year and one day in our hands, so that we neither cause the tenements nor the woods to be destroyed or wasted, ${ }^{1}$ nor the meadows to be ploughed, as was wont to be done in memory of felonies attainted, such tenements being excepted whereof the felons were not invested or seised in their demesne as of fee; for of such lands as they held for term of life or years, or by fresh disseisin, or in fee farm rendering annually the true ralue, or in mortgage or on like condition, we will take nothing.

as in the text, are erased and altered, in the same hand as the notes frequently cited, as follows: "en lour peiore cote hors de trop gros fers e hors de trop gros liens." This may serve to show that the practice was not so indulgent as the rule laid down by our author.

${ }^{1}$ It was the opinion of Bracton that the year and day were given to the king in lieu of the right of laying waste the lands of felons. The Great Charter (c. 22) appears implicitly to give up the claim to waste, and to have been so understood by Bracton and the authors of Fleta and Britton (Brac. 129 ; Fle. liv. i. c. 28 , $\$ 6)$. But both rights were afterwards insisted on (Brac. 129, $129 b$; Stat. Prærog. Reg. 17 Ed. II.) ; and such appears to be the present law in cases of murder. See Hawkins's Pleas of the Crown (8th ed.), vol. ii. p. 638. 
We will also, that their lands aliened after commission of their felonies, be escheated to the lords of the fees, so that immediately after judgment given it shall be law ful for those lords to demand by our writ of escheat the tenements so aliened.

4. If any man be found killed, and another be found near him with the knife or other weapon in his hand all bloody, wherewith he killed him, the coroner shall be presently fetched, and in his presence the felon sball, upon the testimony of those who saw the felony done, be judged to death. The like when a person is found in a house, or other place where one shall be found killed, ${ }^{1}$ and the person found alive is neither hurt nor wounded, and has not raised the hue and cry, and has not charged any with the felony, and shall not be able to do so.

5 . We will also, that the heirs of felons, begotten before the felony committed, be disinherited of every inheritance which may fall to them on the part of the blood of the felon attainted by judgment; and heirs

1 Bracton (137, 137 b) mentions the two instances here given, as cases of presumptive guilt, in which there is no need of proof, seu per corpus seu per patriam, either by duel or jury ; and this, he says, is an old established law, antique constitutio. I find no mention either in Bracton or Fleta of judgment of death for homicide before the coroner. Cf. Mag. Char. c. 17. The coroner's presence was required at capital trials in courts of lords. Ante, c. 2. s. 17. In the Year Book 30, 31 Ed. I, app. ii. p. 545, a thief taken with the inainour is adjudged to death, by the custom of Yorkshire, coram quatuor villatis. Compare post c. 16. s. 1 . 
begotten after the felony committed, shall be excluded from all manner of succession to the inheritance, as well on the part of the mother as on the part of the father; the wives also of felons shall not hold in dower any tenement assigned them by such husbands.

\section{CHAPTER VII.}

\section{of Murder.}

Murder is the felonious killing of a person unknown, whereof it eannot be known by whom it was done. And our will is, that for every murder the hundred in which it shall be eommitterl be amerced, ${ }^{1}$ and if the act is found to have been done in two hundreds, let both the hundreds be amerced in proportion to the extent of each hundred. And it shall not be adjudged murder, where any of kin to the deceased can be found, who ean prove that he was an Englishman and thus make presentment of Englishery; nor, although the person killed was a foreigner, if he lived long enough to accuse the felons himself ; nor where any felon shall be apprehended for the fact ; nor in case of aceident or mischance; nor where any man shall have taken sanc- tuary for the felony ; nor in any case where the felon shall be known, so that the felony may be punished by outlawry or otherwise attainted; nor where two or more persons have feloniously lilled each other, although they be unknown or aliens.

1 'At 100s.' (Note in MS. N.). 


\section{CHAPTER VIII.}

Of Accidents.

An accident is that which occasions the death of a man without felony, as where people die suddenly by any sickness, or fall into the fire or into the water, and there lie until they are quite dead. A mischance is where a man is killed by a fall from a tree, ship, boat, cart, horse, or mill, or in the like cases, where no felony is committed, and in which there is no need of raising the hue and cry, or making any presentment by the kindred of the deceased or by the township at the next county court, but the coroner's inquest is sufficient. In such mischances, the things which cansed the death shall be adjudged to us as cleodands, as is mentioned before in the chapter concerning the office of coroner. And where a man is felon of himself, his chattels shall be adjudged ours, as the chattels of a felon, but his inheritance shall descend entire to his heirs. 


\section{CHA PTER IX.}

\section{Of Trectsons.}

1. Treason consists of any mischief, which a man knowingly does, or procures to be done, to one to whom he pretends to be a friend. And treasons may be either great or little, of which some require judgment of leath, some loss of limb, pillory, or imprisonment, and other's lighter punishment, according to the nature of the case.

2. Great or high treason is to compass our death or to disinherit us of our kinglom, or to falsify our seal, or to counterfeit our coin, or to clip it. A person may likewise commit great treason against others in several ways, as by procuring the death of any one who trusts him; as for instance those who poison their lords or others, and those who lead persons into such perils, that they lose life and nember or chattels.

3. The judgment in high treason is to be drawn and to suffer death for the felony. The same juclgment is incurred by those, who in appeals of felony are attainted of having counterfeited or otherwise falsilied the seal of their lord, of whose dependence or homage they are, or of adnltery with the wives of their lords, or of violation of the daughters of their lorels or the nurses of their children. And if a woman be attainted of any treason, let her be burnt. 
4. Where persons are attainted of crimes of this nature at our suit, let them be sentenced for falsifying a seal, if the act be of small consequence, to judgment of pillory only, or to lose an ear; but if the act be of importance and heinous, as touching disherison or lasting damage, they shall then be judged to death. And of the other offence let Holy Church have correction.

\section{CHAPTER X. \\ Of Arsons.}

Let inquiry also be made of those who feloniously in time of peace have burnt others' corn or houses, and those who are attainted thereof shall be burnt, ${ }^{1}$ so that they may be punisher in like manner as they have offended. The same sentence shall be passed upon sorcerers, sorceresses, renegades, sodomites, and heretics publicly convicted. ${ }^{2}$

1 As to this punishment for arson by burning, which is not. mentioned in Bracton or Fleta, see a record of 5 Hen. III. cited by Sir Samuel Clarke in his edition of the first book of Fleta, $c$. 18. p. $36 \mathrm{n}$. (d), and by Mr. Kelham in his notes on the first book of Britton, p. 40.

${ }^{2}$ It seems that as to these offences, though the king's court was in general ancillary to the ecclesiastical tribunal, it sometimes acted independently. 'Burners of corn and houses, wives guilty of treason against their husbands, sorcerers, sodomites, renegates, and misbelievers, run in a leash (currunt en une leesse) as to their sentence of being burned. But the inquirers of Holy 


\section{CHAPTER XI.}

\section{Of Burglars.}

Let inquiry also be made of burglars. Such we hold to be all those who feloniously in time of peace break churches, or the houses of others, or the walls or gates of our cities or boroughs. Infants unler age, and poor people, who through hunger enter the house for victuals under the value of twelve pence, are excepted; as are also idiots and madmen, and others, who are incapable of felony; and those, who enter into any tenement of seisin in respect of some right which they think they have, are not held to be burglars. The punishment of such felons is death.

\section{CHAPTER XII.}

\section{Of Prisoners.}

1. Let inquiry also be made of those who have broken our prison; for to escape from the prison of another is no felony. We will that a prison be accounted Church shall make their inquests of sorcerers, sodomites, renegates, and misbelievers; and if they find any such, they shall deliver him to the king's court to be put to death. Nevertheless, if the king by inquest find any persons guilty of such horrible sin, he may put them to death, as a good marshall of Christendom (come bon Mareschal de la Chrestieneté).' (Note in MS. N.) 
a place limited by us within certain bounds for the keeping of the bodies of men, which bounds we forbid on pain of death any one to pass with a felonious intent of escaping; and if any one having such intent is taken, and is attainted of compassing that felonious intent, let him receive judgment of death ${ }_{2}{ }^{1}$

2. If the prisoner was in the custody of any one claiming the wardenship in fee, let the franchise be seized into our hands. And if the prisoner, who made his escape, has escaped from the custody of any one of our officers, let that officer be amerced at 100s. in the eyre of the Justices. And if he who thus escaped was an approver, let the warden be ransomed at our will. If any prisoner escape from the custody of a township, let the township be in our mercy in the eyre of the Justices, according to the custom of the country ; and if from the custody of a private person, let such person be amerced; and if any gaoler be suspected of having consented to the escape, let him be taken and indicted for consenting to the felony; and if he be found guilty of consenting, let him have judgment of death.

3. As to prisoners, we will that none be put in irons but such as have been apprehended for felony, or are imprisoned for trespasses committed in parks or

1 This passage may serve to assist in ascertaining the age of the present book. By the Stat. de frangentibus prisonam (23 Ed. I.) it was enacted that none should undergo sentence of life or limb for breaking of prison only. See Introduction by the Editor. 
vivaries, or detained for arrears of accounts; and we forbid their being put to any pain or torture otherwise than by law they ought, ${ }^{1}$ or that any person be disseised, while in prison, of anything which shall belong to him. Their lands and goods shall be seized into our hand, but without ousting anything; the prisoners and their families shall be supported out of their own goods as long as they remain in prison, and none of their bailiffs shall be removed, nor others put in. And when they have lawfully acquitted themselves, all that was theirs shall be delivered back to them; and if anything belonging to them shall in the mean time have been removed, we will in such case af. ford our especial aid to recover it and to punish the offenders. But if judgment of death pass upon them, we will that then, and not before, our officers put out their wives and their bailiffs, and cause their chattels and lands to be seized into our hand, and that their movable goods be appraised by inquest of office of the coroner, and delivered to the townships, who shall be answerable to us in the eyre of the Justices.

4. If any person die in prison, our pleasure is, that the eoroner go and view the body and take a true inquest of his cleath, in what way it has happened. And if the inquest find that his death was hastened by

1 ' Note, that for a felon slain in prison judgment of homicide shall be given. For, though he was lawfully condemnable for the felony, yet it is necessary that it pass by judgment. For we ought not to hold them absolutely felons until the law has condemned them.' (Note in MS. N.) 
the harsh keeping of his gaolers, or by pain unlawfully inflicted on him, then let the borly be buried, and let all those, who are indicted as being the cause of his death, be immediately apprehended and detained as felons homieides.

5 . And we will, that in time pleadable our gaols be delivered once in every week of all prisoners deliverable, such being excepted as are not to be delivered without our special command.

6. Prisoners shall in general be answerable to such as shall implead them as long they remain in prison; others shall likewise be answerable to them ; and essoins shall be allowed to them, as well as to others, neither shall they lose anything by any default. But prisoners apprehended for felony we will by no means suffer to implead or be impleaded by any one, unless for some greater felony, so that a greater felony be not stifled or covered by a less. But our will is, that such prisoners may allege as an exception in every lesser plea whereof they shall be impleaded, not being the cause for which they have been apprehended, whether the plea be moved against them before their apprehension or after, that they are not bound to answer such pleas, until they are acquitted of the greater cause for which they are detained.

7. We forbid any one to take money, or the value thereof, for receiving prisoners, or to delay reeeiving them, or to take for the keeping any prisoner more than four pence, on pain of ransom and fine. Of the poor let nothing be taken, and let no prisoner 
be longer detained for default in payment of such fees.

*8. And we will, that whatever contracts shall be made in prison by prisoners not taken or detained for felony shall be held valid, unless made under such distress as includes fear of death or torture of body; and in such case they shall reclaim their deed, as soon as they are at liberty, and signify the fear they were under to the nearest neighbours and to the coroner; and if they do not reclaim such deeds by plaint within the year and day, the deeds shall be valid.

9. Those who claim the custody of any prison in fee shall not detain a prover, who has confessed himself to be a felon and appealed others of the felony, beyond a day and a night, but shall send him forthwith to our prison which is in our own hand, on peril of forfeiting the said custody; and no other person shall keep in prison any one apprehended for felony beyond a day and a night, but shall send him forthwith to our prison 1 on pain of ransom. And therefore with respect to this article, let it be inquired, who bas imprisoned another or detained him wrongfully in his custody, or in our prison maliciously and wrongfully under colour of

1 This rule was subject to an exception, where there was a franchise of Infangthef or Utfangthef ; for the lord might keep those in his prison whom he could judge in his court. Brac. $122 b, 123$. The abbot of Peterborough in the parliament of 3 Ed. I. established his right to keep in his own prison twentynine prisoners of his liberty appealed of homicide in the county court of Northampton. Chron. Petroburg. p. 21. 
judgment; and let such as shall be convicted thereof be punished by imprisonment and by ransom, which shall be greater or less in proportion to the offence.

\section{*CHAPTER XIII.}

\section{Of Outlaws.}

1. In the next place, let inquiry be made of felons outlawed, and of such as have abjured the realm for felony, who have returned without our leave; and of those who knowingly receive them. And because it is needful that every one should know the danger of receiving such persons, our will is, that all who are of the age of fourteen years ${ }^{1}$ or upwards shall take an oath to us, that they will be faithful and loyal to us, and will neither be felons nor assenting to felons; and that every one be in some tithing and pledged by their tithingmen, except persons in religion, clerks, knights and their eldest sons, and women; and let the obli-

1 Bracton (124b) and Fleta (p. 40) mention the age of twelve years as the time of taking the oath; and this is in some degree confirmed by the terms of the Stat. Marl. c. 25. The Mirror, however, as printed (p. 13, 283), agrees with our author in fixing the time at fourteen years. Coke ( 2 Inst. 121, 14\%) cites both Britton and the Mirror as naming the age of twelve, and says, that where old books mention sometimes fourteen years, it is but misprinted. The mistake, however, if it be one, appears to run through all the manuscripts. Compare Brac. $115 \mathrm{~b}$, where the age of fifteen is mentioned as the time for persons of higher station to take a similar oath. 
gation of the pledge be this, that if they do not proluce those for whom they are pledged, to be amenable to justice in our Court when required, the tithingmen with the tithings shall be in our merey. With regard to clerks, knights, persons of religion, and women, our pleasure is that the head of every household be answerable for all his chief domestics, and that they answer for those under them. As to guests, we will that every one answer for his guest that he shall have harboured for more than two nights together, so that the first night he shall be deemed a stranger and uncouth, ${ }^{1}$ the second night a guest, and the third night a hoghenhine. ${ }^{2}$

2. And for the maintaining of peace, we will that when a felony is committed, every one be ready to pursue and arrest *the felons, according to our Statutes of Winchester, with the company of horns and voices from township to township, until they are either taken or have been pursued as far as the chief town of the county or franchise. We will also, that every one who flies from our peace forfeit his ehattels to us for such flight, if he be suspected of felony, although he be afterwards acquitted of the principal fact. And if it be murder or other felony concerning the death of a man, let such felony be presented at the next county court by one or more townships, and by the first finder and the kindred of the person killed, that is to say, by one or more of kin on the part of the father, or on the

1 Anglo-Saxon, uncuò, unknown.

2 Anglo-Saxon, agen hina, his own hind or domestic. 
part of the mother, according to the custom of the county.

3. If one or more be appealed of the death, and others of the force and accessory facts, let the principals be first demanded at three county courts to come and answer concerning the felony, and if they do not come at the fourth court, and are not mainprised to appear at the fifth, they shall be outlawed at the fourth. ${ }^{1}$ A woman however cannot properly be outlawed because she is not appointed to any tithing or to the law, but she may be waived, which is equivalent to outlawry.

4. As to the punishment of outlaws in their lifetime for their felonies, their judgment shall be this, that, since they will not be amenable to the law, they be forejudged from all law, and put out of our peace, and be answerable to all, and none to them, and be judged felons, as shall also all those who knowingly receive them or bear them company after their outlawry; and he who shall kill them shall be acquitted of their death, except in cases where they shall offer to surrender themselves or where they might have been otherwise taken; neither in appeals shall they be heard against any man ; and if they are taken, and found

The practice has been to proclaim a fugitive at five county courts, so that he is not adjudged an outlaw until the fifth; and Bracton agrees with this practice. He says, howerer. that the proceeding at the first court is merely a calling of the fugitive, and is not part of the outlawry, and therefore the fifth court is salled the fourth. Brac. $125 \mathrm{~b}$. 
to be outlawed by record of the roll of the coroner, they shall be hanged, and their chattels shall be ours, and their heirs disinberited of every kind of inheritance.

\section{CHAPTER XIV.}

of Inlawry, or being restored to law.

1. Inlawry in many cases ought to be granted of right, and in others it may be of favour; and, where of favour, the outlaws ought always to carry about them our charter, containing the release of the outlawry before pronounced against them, that they may not fail to be protected by us, when they shall have occasion. But if they have been legally and deservedly outlawed, such release will not avail them to recover any of the lands or chattels which were theirs before the outlawry pronounced against them, or to demand any inheritance or debts, or any manner of remedy for an injury which they shall before have suffered.

2. Inlawry ought of right to be granted in these cases, namely, where a man has been outlawed before the fourth county court, or without suit and without command of the Justices Itinerant after their eyre encled, or without our writ, or where there was not a regular succession of county courts, or if the outlawry was not in the county court, or not in the presence of the coroner; or if the outlaw at the time of pronouncing the outlawry, was under the age of fourteen 
years, ${ }^{1}$ or out of his right mind, or deaf, or an idiot, or out of our realm, or detained in prison; or if the cause of outlawry be found null, as if the man who was supposed to have been killed be still alive, or if the outlawry was pronounced in any other county than where the felony was committed, or if the outlaw was then in our service in war or castle, or if it be found that the occasion of the outlawry was not felony.

3. In these and other like cases, if the outlaws return and surrender themselves to our prison, and acquit themselves of the principal fact, the Justices shall certify us thereof; and we will immediately, as of right, command by our writs the sheriff of that county and the counties adjoining, that they cause the peace of such outlaws to be proclaimed in cities and in boroughs, in fairs and in markets, and cause it to be solemnly declared that the cause of the outlawry is found to be false, and that the outlaws be restored to their lands and inheritances, saving to us their chattels, if they shall have given occasion of suspicion by flight.

4. We will that those who by malicious contrivance sue any man to an outlawry in any other county than where the principal fact was committed, and are convicted thereof, shall be banished our realm for their malice.

5. And although a person be rightfully and deservedly outlawed, yet it may appear that he was dead before the outlawry pronounced against him; in which

1 See note to chap. xiii. s. 1. ante, p. 48 . 
case his heirs shall enjoy their inheritance, because the ancestor lid not live to have judgment passed upon him.

6. If it be found that an outlawry was pronounced. before the third county court, or that the proceelings in the county court were in any other manner erroneous, let the county be adjulged in our mercy ; and if it be found that the outlawry was pronounced in the absence of the coroner, and that the coroner was in fault, let the coroner be punished by imprisonment and fine. The like of abjurations made in his absence, although he send his rolls by his clerk or other person not properly authorised.

7. As to lands and tenements aliened by felons attainted after commission of their felonies, we will, that such alienations be voidable by the chief lords of the fees by means of our writs of escheat.

\section{CHAPTER XV.}

\section{Of liape.}

Rape is a felony committed by a man by violence on the borly of a woman, whether she be a virgin or not. Of such felonies let inquiry be made ; and whoever is attainter thereof, either at the suit of the woman by appeal of felony, or at our suit, shall have the same judgment as for the death of a man, whether the woman have consented after commission of the felony or not, as is contained in our Statutes of Westminster. 


\section{CHAPTER XVI.}

\section{Of Larcenies.}

1. Let careful inquiry also be made concerning robbers, ${ }^{1}$ thieves, and such like offenders; as to whom our will is, that if those who rob, or steal the goods of another, amounting to twelvepence or more, ${ }^{2}$ be

1 'A robber is he who by force in the day or night despoils another of his goods. A thief is he who carries off or steals another's goods in the absence of the owner, or in his presence but without his knowledge.' (Note in MS. N.)

2 In the time of Edward I. the price of a cow varied from $5 s$. to $12 s$, the price of a sheep from $8 d$. to $3 s$. Wheat varied from $2 s$. to $16 s$. the quarter, and in times of scarcity rose much higher. See Fleetwood's Chronicon Preciosum; and see the provisions as to the assize of bread below, in c. xxxi. Bracton says that stealing a pig is a petty theft (Brac. 105); and we shall see below, in s. 7. p. 61, that stealing a sheaf of corn is so treated. The commentator in MS. $N$. states that three halfpence (iii mailles) a day was a poor living for a man, and gives the following singular reason for $12 d$. being fixed as the limit of petty larceny. "At three halfpence a day, 12rl. would be eight days' wages; and as a man going without sustenance for eight days might be expected to die on the ninth, the 12d. has regard to the destruction of life, for which offence a man is rightfully put to death.' 'The same note asserts, that 'in France and many other countries beyond sea, thieves are put to death for less than in England, as for the value of sixpence or one penny.' By the Anglo-Saxon laws no mercy was to be shown to a thief of above the value of 
freshly pursued for the same by the owners, or by those out of whose custody the things were stolen or robbed, and the goods are found upon them, they shall be forthwith taken and brought to trial in the court of the lord of the fee, if he has the franchise of infangthief, or in our eourt in the hundred, or county, or elsewhere ; and the eoroner shall be fetched forthwith, and in his presence the sakeber ${ }^{1}$ shall be heard in his own person, and if he claims the goods as stolen or robbed and there are lawful people as witnesses to prove it, such robbers shall be immediately adjudged to death.

8d. (Leg. Athelst. i. 1. Leg. Hen. I. lix. 20.) But by another law of Athelstan the sum is fixed at 12d. (Leg. Ath. v. 1.) Spelman points out the increased severity of the law arising from the change in the value of money. In quantam asperitatem ex rerum temporumque vicissitudine lex antiqua abripitur. Quod enim olim $12 d$. venit, hodie sæpe $20 s$., imo 40, vel pluris est. Nec vita hominis interea carior sed abjectior. (Spelm. Gloss. $s$. v. Laricinium.)

1 'Sakbere is he from whom the chattels are stolen, and is so called from sak (English) which is enchesun in French, and berc which is porteur in French : as being he who bears the cause to go to the deliverance of the thief.' (Note in MS. N.) Compare Spelman, Gloss. s. v. Sacaburth, Sacaber; Thorpe's Glossary to ancient English laws, s. v. Sagemannus. The former part of the word appears to be the A. S. Sacu, Germ. Sache, a cause or matter of contention, whence the legal term sak for jurisdiction. The latter part of the word is varionsly derived from the A.S. beran, to carry, the A. S. borh, a pledge or security, and the old Teutonic Bar ( $\Lambda$. S. war) a man, whence the French and English Baron. 
2. If they are not taken freshly ${ }^{1}$ upon the fact, although the goods are found upon them, they shall be permitted to answer, and then they may demand in what manner the plaintiff intends to proceed against them, and if he answer, 'by words of felony,' then the thief shall be either sent to our gaol or let to mainprise until the next county court or until the next gaol delivery, and there the plaintiff shall make his suit by words of appeal, as will be explained below in treating of appeals. And if the fact was committed out of the lord's jurisdiction, or if the lord has not suitors sufficient to take the inquest, then such felons shall be forthwith sent to our county gaol. The sakeber, if he pleases, may bring an action for his goods, as lost; and then he shall not sue judgment of felony, but of trespass only; but when the sakeber has begun his suit in the form of felony, if he does not prosecute it, we may ourselves proceed to conviction of the felony

3. If the accused has any warrant within our realm, then he may defend himself by voucher; and if he rouches to warrant any person who gave him the thing, or sold it, or otherwise made it over to him, let a day be given him to produce his warrant, if he be not then present; and if he cannot produce him, let him be compelled to appear by the aid of our Court; at which day if he fails to produce his warrant whom he has vouched, where he vouches him at his

1 The commentator in MS. $N$. explains the word freschement as denoting that the sakeber must make lis suit the same day. 
own peril and without aid of our Court, he shall be obliged to give some other answer, or be put to his penance, and the goods shall be delivered to the person who claims them. And when a person is rouched to warranty by aid of our Court, the sheriff, in whose bailiwick the warrant is expected to be found, shall be commanded to have his body at such a place on a certain day, either to undertake the warranty or to refuse it. If the sheriff returns that no such person is known in his bailiwick, the voncher shall be driven to his answer in chief, or to his penance if he refuse to answer; and if the sheriff returns that the vouchee is not found, then let our writ issue to the same sheriff, to cause him to be demanded from county court to county court until he either appear or be outlawed.

4. If the vouchee comes and enters into the warrant to defend the vouchor in the possession of the thing, let the plea against the principal be suspended, and one commenced against the warrant. And if the warrant malies good his case, then let both the rouchor and his warrant be acquitted, and the plaintiff be adjudged to prison for the reason which shall be given in the chapter of appeals. If judgment be given against the warrant, then the thing challenged shall be adjudged to the plaintiff, and the principal shall be indicted of the felony at our suit, upon presumption of his being an accomplice of the warrant, who is attainted of the felony.

5 . If the principal has no one to vouch, he may say that he bought the thing challenged in such a year and on such a day, at such a fair or at such a market, in 
the presence of a great number of people, and paid a toll to the bailiffs for it. And if he vouches the testimony of the said bailiffs and others then present, and evidence is given accordingly, or if he puts himself on the country and is aequitted of the felony, and yet the prosecutor has proved that the thing challenged belongerl to him, and that it was stolen from him or out of his custody, in such case he must be answerable to the owner, and make him satisfaction, and the judgment shall be, that the elaimant recover the thing demanded, and that the person ehallenged go quit, and lose what what he gave for the thing; and if he can produce no such witnesses, let him acquit himself by the country.

6 . If any one be indicted by presentment of robbery, or of larceny, or of cutting of purses, or of receiving of felons, or of enchantment, as those who send people to sleep, ${ }^{1}$ or of eheating by selling bad things for good, as pewter for silver, or latten for gold, or of other petty offences of the like nature, our will is that such be apprebended; or, if they cannot be found, they shall be demanded, and their lands and chattels be seized into our hands; and if, when they are tried, they cannot acquit themselves of the felony, whether at our suit or another's, let them be condemned to be hanged,

1 This seems to give some support to the conjecture, that the experiments of mesmerism and animal magnetism, which have created so much interest in our times, were not unknown in the 13th century. Endormeurs de genz are mentioned as offenders in the Consuet. S. Genov. f. 34. MS. cited in Ducange, Gloss. s. $v$. Dormitabilis. It is possible however that the effect may hare been produced by drugs. 
or to lose an ear, or to the pillory, according to the greatness of their crime, and according as they have been habitual offenders or not.

7. In small thefts, as of sheares of corn in harvest, or of pigeons or poultry, let the judgment be this, that if the thieves are not found to be otherwise of bad character, and the thing stolen is under the value of twelve pence, they shall be put in the pillory for an hour in the day, and be not admissible to make oath on any jury or inquest, or as witnesses; and the like as to all those who have been sentenced to undergo such punishments or the punishment of the tumbrel, or to lose a limb. And if these petty thieres are persons of bad character, or if they have offended out of mere wickedness, and not through want, then their sentence shall be to lose an ear, and be rendered infamous for ever, as above mentioned; and if they be found guilty of a second offence, then it shall be in the discretion of the Justices, either to judge them to death or order their other ear to be cut off ; and if they are convicted a third time, whether it be for a great or a small crime, and whether at our suit or another's, let them receive sentence of death.

8. As to cutpurses, if they have not been guilty of any other offence, let them be sentenced to the pillory for the cutting of the purse ; and if there be anything else stolen by the prisoner under twelve pence or of that value, he shall lose one of his ears, and if the thing exceed the value of twelve pence, then judgment of death shall be passed upon him. 


\section{CHAPTER XVII.}

\section{Of Abjurations.}

1. Concerning those who fly to churches for their crimes, our will is, that the coroner of the place go to them to inquire wherefore they have taken sanctuary, and hear their confessions; and if they will neither confess felony nor come out of church to be amenable to justice, they shall forfeit their chattels on account of their flight, and the coroner shall immediately cause their lands and their chattels to be seized into our hand, and their chattels to be ralued and delivered to the township. The admission which they shall make that they are not willing to appear to answer to our peace, shall be entered in the roll, to the intent that they may never be under our peace, until they are acquitted in our Court of the crimes wherewith they shall be charged; the coroner however is not obliged to go, unless he pleases, notwithstanding the fugitive is desirous of confessing felony and praying the favour of abjuration.

2. If the fugitives abide in sanctuary above forty days from the time of the coroner's first going to them, ${ }^{1}$ the whole county shall be charged with their custody,

1 Other authorities seem rather to show that the forty days were to be reckoned from the arrival in the church. See Brac. 136 ; Fle. 45, and compare Stat. $32 \mathrm{Hen}$. VIII. c. 12. 
and they accounted as felons or as persons out of our peace. And if they confess felony and pray to abjure our realm, and beg the protection of the ehurch until they have prorided for and settled their leparture, then our pleasure is, that they have such protection for forty days from the day of the coroner's coming to them; and forthwith after the enrollment of their confession, let them be given in charge to the constables of the townships, that they may not in the meantime be allowed to escape out of sanctuary.

3. Let the abjuration be made at the gate or fence ${ }^{1}$ of the churchyard, in this manner. Hear this, you coroner and other good people, that I for such an act which I feloniously dicl, or assented to the doing thereof, will depart from the realm of England, (or the land of Ireland,) and will never return thereto unless by leave of the king of England or his heirs, so help me God and the Saints.

4. Immediately after they shall choose for themselves ${ }^{2}$ some seaport, or passage into Scotland out of the realm, as far as which port or passage we admit them to our protection, provided they are not guilty of fraud. And then let them be forbidden on peril of life

${ }^{1} Q u$. Steps. See Ducange Gloss. s. v. Scalarium : Roquefort Gloss. s. $v$. Eschallier.

2 There is a note in the Year Book of $30 \mathrm{Ed}$. I. that he who wishes to alojure the realm shall take the port assigned him by the Coroner and no other. (Year Book 30 and 31 Ed. I. App. i. p. 509.) See also the Statutes of Wales (12 Ed. I.) c. 5. Bracton and Fleta agree with the text. 
and limb to turn aside anywhere ont of the high road, until they have left the kinglom, or country, at that port or passage which they have chosen, and no other, with all possible dispatch and without fraud. Let them then go with a wooden cross in their hands, barefooted, ungirded, and bareheaded, in their coat only. And we forbid any one under peril of life and limb to kill them so long as they are on their road pursuing their journey; nor shall they, or any other fugitives, be killed, if they can be taken in any other manner.

5. If such fugitives abide in sanctuary forty days after the col'oner's coming to them, they shall be debarred thereafter from the favour of abjuration, and deemed as felons convict, so as to have no right of accusing or appealing any others; and we forbid all laymen under forfeiture of life and limb, and clerks under pain of banishment from our kingdom during our pleasure, to give them any meat or drink after the said forty days, or to have any manner of communication with them.

6 . We will and grant, that whenever any one has abjured our realm through fear, and it can be afterwards proved that he was not guilty of the felony which he confessed, he may safely return, saving to every one his suit; and in such cases the heirs of the fugitives shall not be disinherited, but their chattels shall notwithstanding be forfeited by reason of their flight.

7. And our will is, that all abjurations taken by any one, who shall have meddled with the office of coroner 
without being authorized thereto by us or our predecessors, shall be held roid and may be disavowed and annulled; the like, if the coroner, though authorized, he did not attend in his own person.

8. In abjurations made on account of our game, or other trespasses, let none be disinherited of his lands or tenements, but forfeit his chattels only.

\section{CHAPTER XVIII.}

Of Treasure-trove, Wrecks, Waifs, and Estrays.

1. Concerning treasures found concealed in the earth, and eoneerning wrecks and waifs belonging to us, and sturgeons and whales, and other things found, which of right belong to and are detained from us, let careful inquiry be made, and of the names of those who found them, and to whose hands they have come, and to what amount. For treasure hid in the earth and found shall belong to us, but if found in the sea, it shall belong to the finder; and any person who shall find such treasure in the earth shall forthwith inform the coroner of the district or the bailiffs thereof; and the coroner shall go without delay and inquire, whether any of it has been carried off, and by whom, and save all that can be found for our use ; and those who carried it off shall be beld to mainprise until the eyre of the Justices; and if our Justices ean convict the eloiners of malice, they shall be punished by imprisonment and fine, but if malice be not found, they shall be punished by amercement only. 
2. As to things lost and found above ground, if the. owner demand them within the year and day, and can prove them to be his property, they shall be delivered to him; so likewise to him who lost the things, provided he can prove the loss; and if the things are not claimed within the year and day, and the finder has caused them to be cried and published in the neighbouring markets and churches, then the finder may keep them.

3. Waifs or estrays, not challenged within the year and day, shall belong to the lord of the franchise, if he be rightfully seised of such franchise; but if the lord did not cause the beast so found to be publicly cried in manner aforesaid, then no time shall run against the owner of the thing or beast, to bar him from replevying it whenever he pleases; and if the lord avow it to. be his own, the person demanding it may either bring. an action to recover his beast as lost, in form of trespass, or an appeal of larceny, by words of felony ; and if the lord by either proceeding be found guilty of a tortious detaining, he shall lose his franchise of estray for ever after.

4. With regard to wreck of sea found, the ordinance. of our statutes shall be observed. Sturgeons taken within our dominions shall belong to us, saving to the persons who took them their reasonable costs and expenses; and of whales caught within our jurisdiction the head shall belong to us and the tail to our consort, according to ancient usage. 


\section{CHAPTER XIX.}

\section{Of the King's Rights.}

1. With respect to our seigniories, let inquiry be made of cathedral, parochial, and conventual churches, and of religious houses and hospitals in the county, what are of our adrowson; and what ought to.be so, but are not; and who has deprived us of them, and how; also what demesnes in the same county we hold in our hands, and what demesnes we and others hold of the ancient demesnes of our crown, and what by escheat and by purchase, and who hold such lands besides ourselves, and what the lands are severally worth according to their true value; and of demesnes which ought to be ours and are not, how they have been aliened, and by whom, and who hold them. So likewise of seigniories and advowsons of churches.

2. Also of hundreds, which ought to be held of us in chief and are not, inquiry must be made how they have been aliened, and by whom, and who now hold them, and from what time, and what is their true value by the year; likewise of the true value of the county, and how much rent the sheriff pays us a year, and how many of the hundreds are in our hands, and what each hundred is worth, and how much the bailiffs annually pay to us or any other for them.

3. Inquiry must also be made of customs and serv- 
ices due to us, whether they have been withheld, and by whom, and how long. The like with respect to suits due at our county court, our hundreds, and our manors, and at the tourns of our sheriff, and our views of frankpledge, and at our mills, whether they have been fully performer ; and if not, how they have been withheld, and from what time, and by whom; and so of all services which of right are due to us.

4. Inquiry shall also be made concerning escheats, which ought to fall to us by the felony of felons, or by the death of our tenants without heirs, or by any kind of reversion; and concerning the lands of Normans, and of felons who held of us in chief, which have been aliened after the commission of their felonies, and ought to be our escheats, who hold them, and from what time, and how much a year they are worth with their whole profits at the true value; the like as to lands and tenements held of other lords, and aliened by felons after the commission of their felony, without compounding with us for the year and waste.

5. Also concerning earldoms, baronies, knights' fees, grand and petty serjeanties, dismembered without our leave, inquiry must be made how they are held, and who bold them, and of whom, whether of us in chief, or by mesne. Also whether there be anything in arrear to us for any service or profit which of right belongs to us; and whether we have fully liad the wardships, marriages, homages, reliefs, and heriots, wherever we ought to have them of right, and if not, by . whom they have been withheld from us, and how 
long, and what is their yearly value; so of all children, male and female, and widows, whose marriages belong to us, and who have been married without our leave, how often and to whom they have been married, and how much their lands are worth by the year.

6. Let inquiry also be made of all kinds of purprestures made upon us of lands or franchises; and those who shall be presented as deforceors and purprestors by fresh force since proelamation of the eyre, shall be summoned to appear at a certain day to answer for the wrong they have done, and the process against them shall be as in a plea of land by our writs of great and little C'ape.

7. The deforeeors also in the other articles aforesaid shall be summoned. And when any of them appears in eourt, and pleads that he found his ancestor seised and can prove it, the demand made without our writ shall be stayed, and those who are appointed to proseeute our right, shall immediately apply for a writ of right which is ealled a Precipe quod reddat nobis against the deforeeor; and if the writ be obtained for anything appendant to our erown, such as our ancient demesnes, let no time be limited in the count; and if the tenants desire to put themselves upon an inquest in form of the great assize, let them not be admitted thereto without the consent of us and our eouncil, unless our attoreys in any such case are of opinion that a verdiet will pass in our favour ; for we are bound to recover such rights of our erown as have been wrongfully aliened; in which rights no man ought to aid him- 
self by exception of long tenure, though he may by vouching to warranty, and by reasonable exceptions, as shall be hereafter set forth in treating of exceptions. And if the writ is obtained on our behalf concerning escheats or purchased lands which have been aliened, or other things which are not appurtenant to our crown, in such case the count ought not to go farther back than in a writ of right, and prescription shall run against us as well as against others.

8. Escheats deforced from us, shall be demanded by writ of escheat. And as to suits withheld from us, the proceeding shall be by distress, for this prerogative we claim on account of the great delays which occur in writs of customs and services. With respect to our fees dismembered and held of us by mesne since the last eyre, our will is, that they be taken into our hands, and the sheriff be ansiverable to us for the issues of them, and they shall not be restored without our leave. And as to wardships and marriages detained from us, we will that proceedings shall be taken immediately without writ, and the penalty provided by our statutes shall be enforced against the deforceors.

9. And we will have it known to all, that if any man dies who held of us by knights' fee, or by grand serjeanty,- - whether he held of the ancient demesnes of the crown, or lands escheated, or purchased,-and his inheritance after his death descends among several daughters as one heir, we will have the marriage of all the daughters as often as they shall be to marry ; and the like with regard to all widows, whose husbands 
held of us in chief; and if it be presented that any one, whether male or female, whose marriage belongs to us, has been married without our leave, let all their lands and the lands of their husbands be immediately seized into our hands, and the sheriff shall answer to us for the issues, and they shall not be restored to them without our leave.

10. As to purprestures our will is, that such as aro nusances shall be removed at the costs of those who have made them, and such as may be permitted to remain shall be taken into our hand, and the yearly value thereof enrolled; and according to the discretion of the treasurers and barons of our exchequers, they shall be let at fee farm to those who will give most for them.

\section{CHAP'TER XX.}

\section{Of Franchises.}

1. Let inquiry also be made, what persons in the county claim to have return of our writs, or custody of our gaol, or that the Justices in eyre shall cone into their franchises, or to have their own coroners, or chattels of felons, or view of frankpledge, or the franchise of infangthief and outfangthief and gallows, or fairs, or markets, or the execution of pillory or tumbrel, or to have wreck of sea, or to have pleas de vetito namio pleaded in their courts, or to have lestage, or amercements of their tenants, or traverse, or toll, 
or estray, or murage, or pontage, or cheminage, ${ }^{1}$ or warren in his demense lands or in other lands, or to be quit of doing suit at our county court, or at sheriffs' tourns, or at our views of frankpledge, or to be quit of lestage, murage, or pontage, or who claim any kind of liberty more than other people.

2. We will therefore that the presentments upon such articles shall be pleaded in this manner. First, the claimants shall be ordered to appear by reasonable summons, as shall be mentioned in treating of summonses; and then if the summons be attested and they make default, the franchise shall be taken into our hand, the sheriff answering to us for the issues, and so remain in our hand until the claimants appear and answer. And if those who make default have of their own wrong usurped such franchises upon us, they shall be distrained in such manner as shall be mentioned in the chapter concerning attachments in trespass and debt; and when they appear in court, if they cannot clear themselves of the personal wrongs committed against us to our disherison, let it then be awarded, that we recover the franchise, and that they be disinherited of the value thereof, or be in our mercy.

1 Murage was a tax for the repair of town-walls; pontage, a toll taken on bridges, or for their repair ; cheminage, a toll exacted for the use of a way through a forest; traverse, a toll paid for passing through the limits of a town or lordship; lestage or lastage, an impost in fairs and markets, calculated by the last. a measure by which several kinds of solid goods were sold. See Ducange, Glossary ; Comyns's Digest, s. v. Toll. 
3. But if it be found by their answer, that their ancestors died seised, then they shall not be obliged to answer without our writs, unless they choose to do so; but our attorneys shall immediately cause our writs of Quo warranto to be issued against them. By such writs they shall first be summoned to come and answer at a day certain, at which if they make default, the franchises shall be taken into our hand, as aforesaid, and so remain without any other summons, until we shall otherwise direct; so that they shall never be permitted to replevy such franchise if they do not answer forthwith. If in their answer they allege long possession, or vouch others to warrant who allege long tenure, in such case judgment shall be stayed for the determination of us and our council, whether such answer be a continuance of the wrong done to our crown, or a title of right in the tenants.

\section{CHAPTER XXI.}

\section{Of various wrongs.}

1. In the next place let it be inquired what persons - have built castles or fortlets or houses of stone, crenellated and defensible; and let those who have so done be summoned to come and answer, and show if they have any license from us or our ancestors for erecting or repairing such fortlets, and if they cannot produce any such license, let them be taken into our hand, either 
to be held by us or pulled down, according to our pleasure.

2. Afterwards, let inquiry be made of bridges and causeways, and of common highways destroyed, or otherwise in bad repair, who is bound to repair and amend them : and such as are named in the presentment shall be attached to appear by personal distress. And if it be found on their appearance in court, that any of them hold tenements of us, for the repairing of such ways, let the said tenements be taken into our hand, and the sheriff be charged to answer us for the issues, and to cause the repairs to be done; and where there is no tenement held of us by the performing of such services, our will is, that the persons who are bound to repair the ways, and have not done what they ought, shall be in our mercy, and the sheriff shall be commanded that be cause them to be distrained by their beasts and chattels, and detain the distresses until they have amended the defects, and this as often as it shall be needful.

3. Let inquiry also be made concerning those, who since the first day of the last eyre have erected any gallows, pillory, or tumbrel ; and such persons as are inclicted thereof shall be compelled by distress to come and answer; and if on their appearing, they can neither show sufficient warrant for what they have done, nor deny that they have done it, let them be awarded to be in our mercy, and let the instruments be pulled down. Let inquiry also be made concerning those, who, not being our Justices or our coroners, lave held pleas of felony and of important trespasses committed against 
our peace; and concerning those who have held pleas de vetito namio, or of debt exceeding forty shillings, or of trespass exceeding the same sum without our writs. And also concerning those who have the franchises of view of frankpledge and of infangthief, and have not the instruments of punishment which belong to such franchises, whereby such franchises have become disused.

4. Let inquiry also be made of those who keep their lands in warrens, other than those lands which they held in their demesne as of fee on the day of granting their charter of warren: or who have used any other franchise otherwise or more largely in any point than is warranted by the tenor of their charter whereby they ought to forfeit the whole for the abuse. Also of those who take fines for leave of beau pleader; ${ }^{1}$ and of those who hold pleas of persons not within their jurisdiction, and of all such as have aggrieved the people by distresses contrary to the ordinance of our statutes. Those who are accused thereof, shall be distrained to appear by the sheriff; and if on their appearance in court, they can neither deny the fact, nor justify what they have done, their court and their warrens shall be taken into our hand without replevin.

1 It was forbidden by Stat. Marl. c. 11, (confirmed by Stat. West. 1. c. 8) that arbitary fines should be imposed in Justices' Eyre, County Court, or Court Baron, pro pulchre placitando, that is, for license to amend a defective plea. But when such fines had become settled by custom they were allowed. See Coke Inst. pt. ii. p. 122. 
5. Inquiry shall also be matle concerning those who have detained felons or provers above a day and a night in prison elsewhere than in our gaol uncler the custody of our own officers. And if any one has died in prison and been buried without view of the coroner, then let it be inquired who buried him, and of the manner of his death; and those who are indicted and convicted of the first article shall lose their wardenship in fee, and if their offence extends farther, shall be punished more; and as to the other article, the township where such bodies were buried shall be in our mercy, and if there be any felony, let those who shall be indicted answer it.

6. Afterwards let inquiry be made concerning weirs raised in common waters, and concerning waters and highways stopped or straitened or in other manner appropriated, and concerning watercourses diverted; also of walls, houses, marlpits, or ditches, made near the common road to the nusance of passers by, and of those who are guilty of such nusances; and of highways not widened, and of those who have neglected to watch according to the ordinance of our Statutes of Winchester; and of landmarks and boundaries removed; and according to the presentment of these articles, let the abuses he redressed by view of the presentors at the cost of the offenders, and let the guilty be amerced in proportion to the damage they have done and the profit they have received therefrom.

7: Concerning those also who have tortiously dis- 
turbed the judgments of our Court, so that execution thereof cannot be made, or have knowingly broken the sequestrations of our officers; and let such be punished by imprisonment or fine.

8. Also concerning lands and tenements alienated in mortmain; and let such lands and tenements be taken into our hand without replevin; and the purchasers also shall be in our mercy and charged with the issues from one year after the purchase, and the sheriff shall be answerable to us for such issues.

9. Let inquiry be made of false weights and measures, and let such order be taken as shall be mentioned in the chapter concerning measures.

10. Let inquiry also be made of clerks who hold pleas of lay people concerning other matters than wills, marriages, or tithes, or who have adjudged any layman in Court Christian to any pecuniary payment, or in any other manner or case than in the articles aforesaid, or who have excommunicated lay people wrongfully, or wrongfully caused them to be apprehended and imprisoned; of those also who have aggrieved others by maliciously serving them with two bills ${ }^{1}$ or summonses for the same day at different places; and let all such be punished by imprisonment and fine.

1 The text here is doubtful. The mention of abuses of ecclesiastical courts immediately preceding lends some support to the reading bulles, which appeared in the former printed editions of Britton. Bracton (f. 402 b.) has a form of prohibition issued to an ecclesiastical court from proceeding in a cause concerning an advowson under the authority of a letter of the Pope. 
11. Moreover let inquiry be made of those who have taken thefbote, ${ }^{1}$ of menders of clothes dwelling out of boroughs or cities; ${ }^{2}$ and also of tanners who follow the trade both of a tanner and of a butcher retailing meat $;{ }^{3}$ and of those who blanch the skins of beasts which have been stolen, that they may not be known again ; also of cooks who knowingly cook stale or stolen meat or any kind of flesh hurtful to the health of man for the purpose of retailing it; also of forestallers; and of those who take up more carts for our use than we need ; and of all other offenders against the form of our statutes; also concerning messengers and others, who go about aggrieving the people by representing themselves as in the service of those with whom they

1 ' Taking thefbote' is explained in a note in MS. $N$, as equivalent to letting thieves escape for reward. In the Statutes of Wales it is thus defined: 'De Thefbote, hoc est de emenda furti capta sine consideratione curiæ Regis.' (Stat. Wall. (12 Ed. 1.) c. 4.) The word appears to have originally signified the legal bote or composition for theft; and then to have been applied to the illegal compounding of theft, or taking money to maintain or connive at such offenders. See the Glossaries of Ducange and Spelman; Terms de la ley, s. $v$. Theftbote; Coke, Inst. iii. 134.

2 ' It is forbidden,' says the commentator in MS. $N$., that any redubber of clothes or tanner or bleacher of skins (i. e. Wyttawiares), shall dwell elsewhere than in cities or boroughs, to avoid the mischief of receiving stolen goods. For a receiver may be the occasion of great wickedness, as is commonly said : $\mathrm{Ne}$ is non thef wythouten rescet.' As to whitetawers see Stat. Wall. (12 Ed. I.) c. 4 ; Cowel's Interpreter, s. v. Whitawarii.

${ }^{3}$ This restriction of trade was at a later time established by Statute. Stat. 1 Jac. I. c. 22. s. 3. 
are not; of those also who invent and report rumours and falsehoods concerning us ; of those also who flay or shear sheep; and of those who have coursed in others' warrens without leave; also concerning all hamsokens, and blood feloniously shed since the last eyre ; and upon every such presentment, let a speedy remedy be applied with punishment either of life or limb or other penalty.

12. Further, let inquiry be made concerning those who did not appear before us or before our Justices the first day of the eyre according to their - .mmons, and let such be amerced. The like concerning those who alienated their tenements against the eyre, that they might not be summoned upon juries or inquests.

13. Let inquiry also be made of eustoms used in the county differing from the common law, and what they are, and if there be any repugnant to the common law, let them be prohibited, unless they have been confirmed by us or our predecessors. 


\section{CHAPTER XXII.}

\section{Of our Officers.}

1. Let inquiry be made concerning our escheators and under escheators, and what lands they have seized into our hand in the county sinee the last eyre ; and of the several lands so seized let a separate inquiry be made of the true value of the profits which erery part returned to them or might have returned to others during the time of their possession; also of waste committed by them in parks and in vivaries, of venison, of fish, and of rabbits and of other destruetion done by them in warrens and woods and in other things, and of the value thereof; and of the chattels found in such tenements or elsewhere and taken by them during the time the lands remained in their custody.

2. Inquiry is also to be made of all their receipts to our use and their own use, how much they have taken for endowing widows, or for suffering them to be endowed, or for permitting heirs being infants to continue with their mothers; and also for making insufficient extents of land, or for certifying our wardships and our marriages to be less than their real value, or for concealing anything which ought to turn to our profit; or for procuring or suffering false inquests to pass upon the ages of our wards, or in any other thing, to our prej- 
udice; and let such presentments as shall be made concerning these officers be enrolled and transmitted to the exchequer, and there determined. We reserve however the judgments upon great offences committed by them for our own determination.

3. In the next place let inquiry be made concerning the fees taken and frauds committed by coroners, their clerks, and officers, according to that which is contained in our Statutes of Exeter. Also of sheriffs and other officers, who for reward or entreaty or out of friendship for any man have concealed felonies committed in their bailiwicks, or suffered prisoners to remain unapprehended, whether within franchises or without, or have let to mainprise prisoners who were not bailable, and have detained others who were bailable.

4. Likewise, how many prisoners have escaped out of our prison or from the custody of any others in that county since the last eyre, and who they are, and out of whose custody they escaped, what chattels they had, and what is become of their chattels, into whose hands their lands are come, what they are worth a year, and who has received the profits thereof since their escape, and from what time; also how many provers have escaped, and out of whosecustody, and by whose consent such prisoners have escaped. And for every escape ont of the custody of the sheriff, let the sheriff be amerced one hundred shillings, and for the escape of a prover, let him be committed to prison during our pleasure. Let inquiry also be made concerning the defects of gaols, what they are, and who ought to repair 
them, and through whose default such escapes have happened.

5. Also concerning sheriffs, their clerks and officers, who have falsely and maliciously made provers appeal innocent people, or hindered them from appealing the guilty; and let such as are guilty of this offence be imprisoned during our pleasure. Also concerning sheriffs who have knowingly let their hundreds to farm to persons of no substance at too high a rent, to the wrongful oppression of the people in divers manners; and let such be amerced.

6. Also concerning sheriffs and bailiffs who have levied money of the chattels of felons, or for the escape of prisoners, or from amercements for defaults made before coroners or escheators or other general inquirers, or for nonprosecution in appeals of felony, or from mainpernors who failed in producing the persons delivered to them on writs of menace, or for not pursuing the hue and cry raised, or for treasure or wreck of sea, or sturgeon or whale found and carried away, which amercements no man ought to levy without our writs of green wax by estreats of our exchequer ; and let such offenders be punished by fine.

7. Also concerning sheriffs, who have taken fines and amercements from persons in their bailiwick, that they might not be distrained to become knights, ${ }^{1}$ in which

1 As to the date attributed in the margin above to the so called Statutum de militibus, which has been commonly ascribed to 1 Ed. II., and the whole subject of compulsory knighthood, see a paper by the Editor in the Archæologia, vol. xxxix. p. 216. 
case the sheriffs are amerciable; or that have maintained suits or the parties to actions, and have procured false inquests, whereby justice has been hindered, in which case they shall be punished by fine; or that have levied one amercement $t$ wice, or of two persons bearing the same name, or have levied more than was contained in the estreats of our exchequer ; or if any sheriff has procured the removal of any coroner by obtaining our writs upon false suggestions, in which case they are amerciable; or if any sheriff through malice has kept any man in prison whom he ought to have brought before our Justices at our gaol delivery, and in this case they are to be punished by fine and imprisonment.

8. Or whether any sheriff through malice has taken more cattle for our debt, or another's, than the amount of the debt, or whether he has distrained beasts of the plough, or wethers, or ewes, or household utensils, or ricling-horses, or apparel, or things within doors, when other sufficient distress might have been found, and that without doors; and whether any one has caused such distresses to be driven out of the fee, ${ }^{1}$ or whether they would notsuffer such beasts to be fed and supported by the servants and at the cost of the owners, to the injury of one party and to the advantage of the other ; and in these cases they are amerciable; and who have kept such distresses impounded above fifteen days.

1 It is possible some words may have been lost in this sentence. The rule was, that distresses were not to be driven out of the county, or taken elsewhere than in the lord's fee. Stat. Marl. (52 Hen. III.) c. $2,4,15$, Stat. West. I. (3 Ed. I.) c. 16. 
9. Of those also who have suffered other pleas to be pleaded in Court Christian besides such as relate to wills, matrimony, and subjects merely spiritual, wherein no money is taken from any of the laity, or have suffered a layman to take oath before the ordinary.

10. It is also to be inquired who have taken fines for redisseisins, or for surcharge of pasture, and for purprestures; and who have accepted annual fees or robes or other bounty for suffering any wrong to be done to us. Also concerning sheriffs or bailiffs, who have summoned more people upon juries and inquests than were necessary, with intent to oppress some of them and take bribes from others for leave to stay at home, or to remove some from the panel and put others thereon; concerning those also who have put persons on juries or inquests who were sick, or disabled by gout, or maimed, or passed seventy years of age, or persons not resident in the county, or persons who live remote and may be supposed to have less knowledge of the truth of the matter in dispute; of such also as have put on the panel persons holling land under forty shillings to do duty out of the county, or under twenty shillings to be on inquests and juries in the county.

11. Let inquiry be also inade concerning bailiffs who make scotales, ${ }^{1}$ in order to collect money of poor

1 Scotales (A. S. scot, payment, eale, ale) appear to have been meetings for drinking, which were in some way made the occasion of extortion by foresters and other bailiffs. See Ducange: Gloss, s. $v$. Scotallium; Capitula itineris (printed among the 'Statutes of the Realm), c. 45. var. lect. ; Fleta, p. 28 (§ 102). 
people, and concerning such as collect sheaves in harvest and lambs and young pigs, and thus go about begging, and have them fed in their bailiwick, to the grievance of the people.

12. Further let inquiry be made concerning sheriffs who have held their tourn oftener than twice a year; and of their bundreders and others, who have beld their views of frankpledge oftener than twice a year $;^{1}$ also concerning sheriffs who have answered to us less than they ought for issues forfeited, in which case they are amerciable in double the value of the profit they have made.

13. The like of Justices, sheriffs, hundreders, and others who have courts, and of the stewards and bailiffs of the same, who through malice have procured suits to be stirred up against any to oppress them, or have caused our writs of right to be brought wrongfully in their court, in order to increase their court and the amercements of it; or have amerced people according to their own assessing, or in any other manner than by their peers, beyond the proportion of their offence, contrary to the ordinance of the Great Charter. And of all wrongful payments taken by our officers of traverse or of toll, as of lestage, pontage, murage, or causeage, in which case they are amerciable in double the amount of the damages. But as to trespasses of Justices we will that no judgment shall be given without our order.

${ }^{1}$ By the Anglo-Saxon customs hundred courts were held twelve times a year for other business, but twice only for filling up the tithings. (See leg. Hen. I. I. vii. s. 4 ; I. viii. s. 1.) 


\section{I, *3i] OF OFFICERS.}

14. Also of prises or seizures made by our castellans, and others ${ }^{1}$ who take upon themselves to be our takers of victuals or other things; let it be inquired by whom such prises have been taken, and to what damage, and of what people; and in such case our will is, that none be warranted by continuance of seisin to the damage of people, but satisfaction be made to all, nor shall any one make any manner of prises for us, unless he has the authority of our letters making express mention thereof.

15. Of sheriffs also and all other our officers, Justices, coroners, and others, who shall oppress religious communities and other persons, overburdening them by often coming with too great a crowd of people to lodge with them at their cost, or by quartering servants, horses, and dogs upon them, or else by borrowing horses or carts or money of them, or by begging timber or wood or other things for themselves or some of their household or friends; in which case let them be punished by fine.

16. Let inquiry also be made concerning our ser, jeants and our attorneys assigned to prosecute and

1 It is remarkable that the word 'purveyor,' which was afterwards in such ill repute, does not appear to have been used at this time, although the abuse of purveyance was at its height. No grievance is more frequently mentioned in the ancient statutebook. By a statute of Edward III. (36 Ed. 3, c. 2) it was enacted that the very name of purveyor (le haignous noun de purveour) should be abolished, and the officers called 'buyers' (achetours.) But the name very frequently makes its appearance in the statutes of subsequent reigns. 
defend our rights, whether through favour or otherwise they have permitted or suffered any great lord of the county or other to continue in seisin of any franchise, or any corporeal thing belonging of right to us; and let such be punished by fine. Also concerning those who have remitted, or have caused to be put out of the roll, or have omitted inserting in the roll, fines and amercements belonging to us; let such be ransomed and from thenceforth removed from the Court, and their superiors punished at our will.

17. Also concerning our officers who hare maintained any wrong, or hare accepted the presentment to any church, of which the adrowson was in litigation in our Court, and let such be punished according to the statutes; or who hare maintained any plea by champerty or in any other manner; and whether they have hindered justice in any point; and of the fees which they take, and of whom, secretly or openly.

18. Also concerning the clerks of our Court of Chancery, and of the one Bench and the other, and of the Exchequer, who take more than a penny for writing a writ; and of chirographers who take more than four shillings for the chirograph of a fine; and of criers, whether any of them take more than is appointed by our statute; and let such offenders be fined, and expelled the Court, and if their superiors knew of their extortion, and took no measures to correet it, let them be punisherl at our will. Also concerning the clerks of Justices Itinerant, whether they have taken more than two shillings for delivering the 
chapters of the eyre according to the ordinance of our statutes, or whether they have been guilty of any other excesses prohibited by our statutes, or whether any enrollment has been delayed, or any manner of damage or grievance done to any one, on account of damages not allowed to the clerks of our Justices, whoever the Justices may be ; and let them be punished by fine and expelled the Court.

19. Let it be also inquired concerning confederacies between the jurors and any of our officers, ${ }^{1}$ or between one neighbour and another, to the hinderance of justice; and what persons of the county procure themselves to be put upon inquests and juries, and who are ready to perjure themselves for hire or through fear of any one; and let such persons be ransomed at our pleasure, and their oath never after be admissible.

20. Let it also be inquired of cloth made out of the realm, brought into the county and sold there, not

1 The commentator in MS. $N$ gives the following example of an offence coming under this head. 'In the county of Northampton a sheriff named Sir Robert de Veer in the 30th year of King Edward made a confederacy with several others of the county, that some of them should indict persons, and the others save them, for bribes, according as the same sheriff should arrange the panels. These persons were afterwards called ' the company of the pouch' (les queux furent appelez puis : 'La Compaignie de la pouche).' Sir Robert de Vere here referred to was sheriff of Northampton 29-30 Ed. I., but was not continued in his office as was then usual, possibly on account of the above offence. See the list of Sheriffs in Bridges' History of Northamptonshire, vo!. i. p. 5.) 
being of the right assize according to the purport of the Great Charter, what quantity of such cloth has been sold since the last eyre, and by whom, and what was the value of the cloth so sold by each merchant separately, and who was appointed by us to seize such cloth into our hand; and let this article be determined in our Exchequer.

21. Let inquiry also be male of wines sold, whereof the tuns did not contain two hundred and forty gallons, and who those are who thus sold them by wholesale; and also of the prisage of wines, how many tuns have been taken to our use since the last eyre, and by whose hands, and whether those wines have been sold to any other than to ourselves without our orders; and let this article also be determined at our Exchequer.

22. In like manner let inquiry be made concerning all sorts of flesh and fish, and of every kind of spice, wax, silk, canvas, cloth, and avoirdupois, ${ }^{1}$ and of all manner of prises, which have been taken to our use since the last eyre, and of the value of each prise. And let inquiry also be made concerning our customs of leather and wool, who have collected them, and how many sacks of wool the collectors have permitted to pass without paying custom, and how much the yearly value of every kind of custom belonging to us amounts to); ancl let these articles likewise be determined at our Exchequer, according to the discretion of the Treasurer and Barons.

1 This word is said to have been applied to all goods sold by weight. See Ducange, Gloss. s. $v$. a verium ponderis. 


\section{CHAPTER XXIII.}

\section{Of Appeals.}

1. Having in part treated of the articles provided for our eyres, by which we desire to punish evildoers and to convict the wickedness of people at our own suit, we will now set forth how felonies and crimes may be punished at the suit of others; and first of appeals. An appeal is a plaint brought by one person against another in a set form of words with intent to convict him of felony. Not every man however can be an appellor; for neither an outlawed person, nor one who has abjured our realm, or been sentenced to death in our Court, nor an approver who has failed of his proof, nor an infant under the age of fourteen years, nor a madman, nor an idiot. nor one deaf, or dumb, nor a leper expelled from common society, nor a person in holy orders, is to be admitted in appeals; yet they may accuse our mortal enemies abiding within our dominions.

2. There are some felonies which concern our suit, and may be prosecuted for us and not by us, ${ }^{1}$ as against

${ }^{1}$ I understand this as meaning, that certain crimes affecting the king, as well as certain crimes affecting subjects, may be prosecuted by appeal, but in that case the appeal must be by a subject for the king and not by the king himself. So Bracton says that where, upon failure of an appeal by the death of the 
our mortal enemies, and for comterfeiting our seal and our eoin; and there are some which concern the suit of others and not ourselves, as of treason eommitted against any lord, by violating his wife or his claughter or the nurse of his children, or of comnterfeiting the seal of his lord. There are also some felonies, where no other execution follows at our suit than such as. takes place in trespass, as in maybems, wounds, and imprisonment; and there are others, where judgment of death ensues, as well at our suit as at another's, as in felonies of the death of a man, rape, arson, robberies, and others.

3. First we must treat of appeals of felonies which may be brought for us, and not by us; as of treason and a compassing designed against our person, to put us, or our consort, or our father, or our mother, or our children, to death, or to disinherit us of our lingdom, or to betray our host, although such compassing be not put in exeeution. Of which compassing, onr will is, that the aceusation be laid before ourselves, or some other who shall without delay inform us thereof; and any person shall be permitted to make such aceusation ${ }^{1}$

appellor, the appellee is brought to trial at the king's suit, he cannot defend himself by his body, but must put himself on the country, because the king does not fight, and has no other champion but the country, and, even if he were allowed to fight, he conld not use the words de visu et auditu necessary in an appeal. Brac. 142.

${ }^{1}$ In case of high treason, a servant or even a bondman might appeal his own lord. This was contrary to the general rule respecting appeals. Brac. $141,155 \mathrm{~b}$. 
for no presentment can be made thereof after any great length of time, without the presentors being in some degree implicated either in consent or in concealment.

4. When any person shall offer to prove this crime against one or more, we will cause the body of the accused to be immediately apprehended and brought before us. And when they appear for trial, let the accuser make his appeal for us by some serjeant in this manner. 'John who is here appeals Peter who is there of this, that being in such a place on such a day and year, the same John there heard such a death or such a treason contrired between the same Peter and another, such an one by name, and by such confederacies, and that the said Peter thus acted and thus contrived feloniously as a felon and traitorously as a traitor, lie the same John is ready to prove by his body, in any manner the Court shall award that he ought to prove it.' In every felony however battle may be hindered by many circumstances; in which cases it will be necessary to speak otherwise; for if the appellor be maimed, or under the age of fourteen years, or above seventy, or in holy orders, or a woman, or if he can be aiderl by record, then he shall say thus: 'This the same John is ready to prove, in whatsoever manner the Court shall award that a man, who is maimed, or of such an age, or of such a condition, ought to prove it ;' or he may say, 'And of this he, rouches record of such or such an one, and of their rolls, to warrant.' 1

1 It is not easy to see to what sort of cases this morle of proof 
5. We forbid any attorneys to be received either for the appellor or for the appellees, or any essoin to be allowed on one side or the other, in any cases of death.

6. And our will is, that if the appeal be pronounced by the mouth of a serjeant, and be abated on account of its being ill set forth, or through other default of the serjeant, who ought to understand the art of pleading, the serjeant himself shall be amerced one hundred shillings ; and if there was secret malice in the act, and he be convicted thereof, then let him be sent to prison, and suspended from his office.

7. And as to the defence, the appellee may defend himself in this manner. 'Peter who is here defendeth all the felonies, and all the treasons, and contrivances, and compassings of mischief against the person' of such an one, or such an one, according as he is charged, word by word. And we will that in these appeals, it shall be more necessary for the appellor to set forth the words orderly without any omission, that his appeal may stand, than for the defendant in his defence; and in every felony we allow the defendant to defend the words of the felony generally, without treating him as undefended, so that for default of a word or syllable he be not adjudged undefended, but it shall be suffi-

refers. Possibly to such a case of manifest homicide or petty treason as is mentioned before, (c. vi. s. 4) where the Coroner's roll may have been held conclusive, no other proof either by battle or by the country being required. See before, p. 37, note ' and compare Bracton. $133 \%$. 
cient for him to say, that he is not guilty of such felony as the appellor lays to his charge, and that he is ready to defend the same against him by his body, in such manner as the Court shall award that he ought to do it, or by the country. And in cases of death none shall be held convicted for being unclefended, but he shall be put to penance, until he be prepared to answer better, if he has spoken his defence by his own mouth; and if by a serjeant, who is avowed by the appellee, let the serjeant be amerced as above directed, and if he be disavowed, let him be punished by imprisonment and fine, and let the defendant provide himself with a better serjeant.

8. The appellee, having sufficiently defended the substance of the appeal, may then aid himself by exceptions, and first to the jurisdiction of the judge, afterwards to the person of the appellor, then to his own person, and next to the appeal, and lastly to the action, as shall be mentioned amongst exceptions. With respect to the jurisdiction, he may say, that he is not bound to answer in a place where the judge is a party, since in every judgment there ought not to be less than three persons, to wit, a judge, a plaintiff, and a defendant; and in cases where we are party, our pleasure is, that our Court, to wit, the earls and barons in time of parliament, shall be judges. The jurisdiction of the judge being established, he should consider whether he can aid himself by excepting either to the person of the plaintiff or to his own person ; and next in abatement of the appeal, which may occur in many 
cases, as by omitting to name in the appeal the year, day, or place, or naming one name instead of amother, or setting forth the appeal thus, "This showeth unto you John,' where he ought to say, 'John appeals '; or' by closing his appeal by these words, 'and this I will aver,' instead of saying, 'this I offer to prove,' or for variance, the appeal being made before the Justices in one form, and in the coroner's roll in inother.

9. If he can by any exception abate the appeal, then our will is that he be acquitted as against this appellor, and the appellor shall be committed to prison, because he has failed to prove that he bound himself to prove; and so it shall be in all appeals of felony, and also where the appellor withdraws himself from his appeal before judgment; ${ }^{1}$ and his pledges to prosecute shall also be in onr mercy, because they have failed in their engagement. But in these cases we will that moderation be used, inasmuch as such persons proffer themselves to fight in maintenance of our peace.

10. But though it happen that the appellees are thus

1 In later times an appellor could by release discharge an appeal, (Hale, Pl. Cr. sol. i. p. 9) ; and Blackstone is of opinion that the chief object of an appeal at all times was to compel the defendant to make a pecuniary compensation: and that when the verdict in the appeal was given in favom of the appellor, he might insist upon what terms he pleased as the ransom of the defendant's life, or for a commutation of the sentonce. (Blackst. Comm. vol. iv. p. 316.) It will be seen that this opinion, so far as regards appeals for minor offences, is confirmed by our anthor. sise below, ch. xxvi, s. 2. 
acquitted as against the plaintiff, it does not therefore follow that they are not guilty of what is laid to their charge; wherefore in such case let it be immediately demanded of them on our behalf, how they will acquit themselves of such slander; and if they say, by the conntry, then they shall be remanded to prison until a certain day, and in the meantime the country shall be summoned, and according to the verdict of the country charged thereon, judgment shall be given.

11. If the defendant cannot abate the appeal, then it shall be in his election, ${ }^{1}$ whether he will defend himself by his body or by the country, and so in all felonies prosecuted by private persons, except in special cases, as of women, persons maimed, and ${ }^{2}$ others who neither can nor ought to wage battle. ${ }^{3}$ And if he says

${ }^{1}$ In Glanvill's time, the appellee of felony appears to have been bound to defend himself by battle, unless he was excused for age or infirmity, in which case the trial was by ordeal. (Glan. li. 14. c. 1.) The beneficent change which gave the accused the election of purging himself by the country was introduced between the time of Glanvill and Bracton.

2 The commentator in MS. $N$. adds, that if the appellee, not being actually maimed, is otherwise 'in so poor a state' that his' inability to figlit is evident, the Court ought not to allow him to be wantonly destroyed : and that lepers are not permitted to wage battle, lest their disease should be communicated to the other combatant. See before, s. 1.

It was one of the privileges of the citizens of London, that they should not be obliged to wage battle. See the Charter of Henry I. in Ancient English Laws, p. 21\%, and the Charters of Richard I, Henry III., and Edward II., in Liler Custumarum, p. 
by his body, and it be in the case of felony at the proseeution of another, then let the matter be examined before battle is joined, whether the cause be trespass or felony, and if trespass, let the appeal be abated by the Justices ex officio. But if felony, then let the defendant give security to defend himself, and the appellor security to prove the cause; next let a day be given them to provide themselves with arms, and let the defendant in the meantime remain in prison.

12. When they appear armed in Court, let the plaintiff repeat his appeal word for word as he did before, and the defendant defend himself as before; and afterwards let them take each other by the hand, and let the defendant swear first in this manner, and the appellor afterwards as shall be presently more fully set forth. 'Hear this, you man whom I hold by the hand, who call yourself John by your name of baptism, that I, Peter, did not in such a year, nor on such a day, nor in such a place, compass or propose the death aforesaid, nor did assent to such felony as you have charged me with, so help me God and the Saints.' Afterwards the appellor shall swear thus. 'Hear this, you man whom I hold by the hand, who eall yourself Peter by your name of baptism, that you are perjured, inasmuch as on such a day, in such a year, and in such a place, you did propose such a treason. or such a death as I have $248,252,259$. The same immunity was claimed by the citizens of Lincoln (Kelham's Britton, p. 153, note), and the burgesses of Bury. Cron. Joc. de Brakelonda, p. 74. 
said against you in the appeal, so help me God and the Saints.' 1

13. Then let them both be brought to a place appointed for that purpose, where they must sivear thus. ' Hear this, ye Justices, that I John (or I Peter) have neither eaten nordrunk anything, nor done or caused to be done for me any other thing, whereby the law of God inay be abased, and the law of the devil advanced or exalted.' And thus let it be done in all battles in appeals of felony. And let proclamation be immediately made, that no one, except the combatants, whatever thing he see or hear, be so bold as to stir, or cry aloud, whereby the battle may be disturbed; and whosoever disobeys the proclamation shall be imprisoned a year and a day.

14. Next, let them go to combat, armed without iron and without the slightest armour, ${ }^{2}$ their heads uncovered, their hands and feet bare, with two staves. tipped with horn of equal length, and each of them a target of four corners, without any other arms where-

${ }^{1}$ Selden observes, that in these oaths the clause de visu et auditu, which occurs in Bracton (141 b), is omitted, and that this is in analogy to the rule established in civil trials by the Statute of Westminster the first, c. 41. Seldon's Duello, c. vii. See below, p. 91, note; and compare s. 5. p. 84.

2 These particulars as to the armour and weapons of the combatants in an appeal are not found in Bracton or Fleta. Leather armour appears according to most authorities to have been allowed. Other notices of this curious subject are to be found in Dugdale, Orig. Juridic. 68; Dyer, Rep. 301 ; Y. B. 1 Hen. VI. r $a^{\prime}$ : Selden's Duello, c. viii ; Archæologia, vol. xxxii. p. 287. 
by either of them may annoy the other ; and if either of them have any other arms concealed about him, and therewith annoy or offer to annoy his adversary, let it be done as shall be mentioned in treating of battle in a.plea of land. 1

15. If the defendant can defend himself until the stars can be seen in the firmament, and demands judgment whether he ought to combat any longer, our will is, that judgment pass for the defendant, and so in all battles between champions; and in the case of felony the appellor shall be committed to prison. And if the defendant will confess the felony before he is otherwise attainted, and appeal others of consenting to the same, we allow him to be admitted thereto.

16. And if the defendant be vanquished, let the judgment be this, that he be drawn and hanged, or put to such other painful death as we shall direct, and that all his movable goods be ours, and his heirs disinherited ; and his children shall be incapable of ever holding land in our realm. And let not any, unless they would be suspected themselves of the felony, presume to intercede for him; and let the accuser, who without delay shall prosecute such felony with good effect, receive from us a notable reward. Appeals may likewise be sued for us in the same manner for counterfeiting our seal and our coin, and also for violating our consort, or our daughters, or the' nurses of our children ; and in such cases, the judgment is, to be drawn and hanged,

1 The passage here referred to is not to be found in the work as it exists at present. See Introduction by the Editor. 
whether the conviction be upon an indictment at our suit or upon an appeal by another person for us.

\section{CHAPTER XXIV.}

\section{Of Appeals of Homicide.}

1. Concerning homicides, our will is, that those shall prosecute whom it concerns, to wit, the male nearest in blood of the kindred of him who has been feloniously killed, or one who has done homage to him or been of his household. ${ }^{1}$ And their right of action shall last

I A woman might bring an appeal of the death of her husband. Mag. Cart. c. 34 Glan. li. 14. c. 3 ; Brac. 125. (s. 3.) A godson might appeal the slayer of his sponsor. (Post, s. 3.) The alppellor in earlier times was required to be one who had been actually present at the homicide. (Glan. li. 14. c. 3. Brac. 125, 138, 141, 141 b.) There is no intimation in our author that this was considered necessary in his time; and in later times, when appeals were allowed only by the wife or the heir male, it was not required. Staundford Plac. Cor. $59 \mathrm{~b}$; Blackst. Comm. rol. iv. p. 314. Coke treats the change as a consequence of the Statute of Gloucester, c. 9, which provided that appeals should not be so lightly abated as they had previously been. Coke, Inst. ii. 31\%. The case of the champion in civil actions was analogous, the oath de visu et auditu (See Glan. li. 2. c. 3.) being abolished by Stat. West. 1. c. 41 , on the ground that it only led to perjury. 'The expression used by the older anthors as to the wife's appenl for the death of her husband. 'killed between her arms,' (Bracton, 125, $148 \mathrm{~b}$; Fleta 53 ; Britton, post, s. 7.) which implied the necessity of the wife being present at the killing (See Glan. li. 14. c. 3.) : was in later times explained to mean, that the wife was "in seisin" of her hushand as his lawful wife at the time of 
a year and a day. Every man must commence his appeal in the county where the felony was committed, and the plaintiff at the first county court, when he wishes to bring his plaint, must find two pledges to prosecute, and cause his appeal to be entered in the roll of the coroner, and then continue the same from county court to county court without interruption ; and if justice be not done either to the plaintiff or to the appellees, we will that upon reasonable occasion they may by writ out of our Chancery remove the appeal out of the county court before us wheresoever we shall be in England.

2. We forbil that any person be detained in prison for an accessory fact, if he can find mainpernors to answer for him, until conviction of the principal fact, or that any Justice proceed against the persons appealed of the force or accessory causes before conviction of the principal fact, or until those who are appealed of the principal fact are outlawed for their contumacy.

his death. See Coke. Inst. ii. 68, 317 : and compare Mirror, c. 3. s. 18. There is another observable change in the law of appeal, probably connected with the change already noticed. In the time of Glanvill and Bracton it would seem that any kinsman was admitted to appeal, although of several appeilors the nearer in blood was preferred. (Glan. li. 14. c. 3. Brac. 125.) In our author's time the appeal appears to have been abatable, if there was any person nearer in blood than the appellor, who might have appealed though he did not actually do so. See helow, s. 3 . But the author of the Mirror states this gronnd of exception in accordance with the older practice: Sir, cest actor n' avera nule accioun, de sicome il $y$ ad un autre pluis prochein de sank que ad attamé son appeal. (Mirr. c. 3. s. 18.) 
And if the person appealed as principal be acquitted of the fact, our will is, that those who are indicted or appealed of the force, or of the receipt, or of commanding, or of other accessory facts, shall be cleared thereof by the same judgment.

3. When the parties appear in judgment, let the plaintiff set forth his appeal; and let the defendant defend the felony, in words agreeable to the form of the Court, and then aid himself by exceptions, as where the appellor is outlawed, or adjudged to death for felony, or has adjured the realm; for in these cases they shall not be bound to answer such appellors. He may likewise abate the appeal several ways, as where the appeal was not commenced within the year and day, or not in the county where the felony appears to have been committed, or for variance between the appeal made there and in the roll of the coroner, or if there is any other male nearer of blood, who has a better right to bring the appeal, or if the plaintiff is not concerned to appeal, not being of the blood of the dead man, nor having been of his bomage, nor his fosterchild, nor his mainpast, nor by him lifted from the baptismal font; or if there is homage still subsisting between the plaintiff and defendant; or if the fact alleged is not felony ; it may likewise be abated for omission, as if no felony or treason is named in the appeal, or if the breaking of our peace, or other words of the substance of the appeal are omitted, as above mentioned ; so likewise for error, as if the name of Reyner is used for Reginald, as will be noticed in treating of exceptions. 
4. The appeal may also be abated for want of prosecution by the plaintiff, as when he has sued in the county at two courts, and made default at the third, and this can be proved by the coroner's roll; in which case our will is, that if the defendant can prove the nonsuit in the county to have been male before the date of our writ to remove the appeal, our Justices shall commit the plaintiff to prison for his nonsuit, and his pledges shall be in mercy. But if the appellor die or fall so grievously sick that he cannot carry on his suit, in such ease the pledges shall not be amereed for the nonsuit, and we allow that some other person, whose duty it is and who is capable of doing it, shall be permitted to revive the suit and prosecute it until the appellees are either acquitted or condemned. And if any of the appellees surrenders himself before he is outlawed, where the appellor makes default, let him be admitted to bail, as to our suit, until the first gaol lelivery, in cases where he is bailable. And although he acquit himself as to our suit, yet the suit of any other, who will prosecute within the year and day, is not thereby taken away.

5. The defendant may also answer by exception to the action in several ways; for he may say that at another time there was an appeal in our Court between the same persons for the same felony, and that he was acquitted thereof before such Justices: and if he avouches this by warrant of record, and the record passes in his favour, he shall be awarded quit, and the plaintiff to prison. Or he may say, that although he 
committed the act, yet he did not do it by felony prepense, but by necessity, in defending himself, or his wife, or his house, or his family, or his lord, or his lady, from death; or that he killed the man in defence of our peace, or by some mischance, without any thought of felony; in all which cases, if proved, the appellees shall have judgment of acquittal.

6. If the defendant cannot aid himself by any exception, let it be in his election to defend the felony by his body, if the plaintiff be able to fight, or by the country; and if he will not put himself on his defence, let him be put to penance until he prays to doit. And according to the event of the battle, or of the verdict of the country, judgment shall be given. The punishment of felons who have committed homicide shall be death, with disherison of their heirs, with further punishment if the occasion requires it.

7. As to women, our will is, that no woman shall bring an appeal of felony for the death of any man, except for the death of her husband killed within her arms, ${ }^{1}$ within the year and day. For an infant killed within her womb, ${ }^{2}$ she may not bring any appeal, no

1 As to the interpretation of this phrase, see note above, p. 109.

2 Although neither Glanvill nor Bracton specifically mention an appeal by a woman for the death of her unborn child, the expressions used by them, ' injuria corpori suo inflicta' (Glan. li. 14. c. 3.) 'iujuria et violentia corpori suo illata' (Brac. 148 b), may include this crime as well as rape. And it is clear from ancient records of the time of John and Henry III, that such an appeal was anciently allowed. (See Sir Sam. Clarke's Note on Fleta, li. i. c. 35, Kelham's Britton, p. 152.) Fleta expressly ad- 
one being bound to answer to an appeal of felony, where the plaintiff cannot set forth the name of the person against whom the felony was committed. With regard to an appeal of rape, our pleasure is, that every woman, whether virgin or not, shall have a right to sue vengeance for the felony by appeal in the county court within forty days, but after that time she shall lose her suit; in which case, if the defendant confesses the fact, but says that the woman at the same time conceiver by him, and can prove it, then our will is that it be adjudged no felony, because no woman can conceive if she does not consent.

\section{CHAPTER XXV.}

\section{Of Appeals of Robberies and Larcenies.}

1. W Iти respect to robberies and larcenies, our will is, that if other persons desire to bring an appeal and sue for revenge of such felonies, their right of prosecution shall continue a year and a day, and that appeais be commenced in the counties where the felonies were committed. The appeals may be made in this manner. 'John who is here appeals Peter who is there, that whereas the same John on such a day in such a year had such a horse, which he kept in his mits it, and gives the form of accusation (Fle. 53, 54.) ; and the statement in the text may have been intended as a correction of that author. Possibly it was corsidered that the right of appeal in this case was abolished by Magna Carta, s. 24. 
stible' or elsewhere in such certain place, 'the same Peter there came, and the same horse feloniously as a felon stole from him, and took and led away against the peace, and that this he wickedly did, the same Joln offers to prove by his body as the Court shall award that he ought to do it.' And if the horse was stolen out of his custody, or if he was robbed of it, let him change the words of his appeal according to the sense required; so if the plaintiff be maimed, or in such other condition that battle ought not to be joined.

2. Next let Peter answer and defend the felony by worts proper for defence; and then he may either defend himself by exceptions, or by his body if there are no circumstances to prevent the battle, or by the country, or vouch to warranty, if he has any one to call. And if he pleads that the horse was his own, and that he took him as his own and as his chattel lost out of his possession, and can prove it, the appeal shall be changed from felony to the nature of a trespass. In this case let it be awarded that the defendant lose his horse for ever; and the like of all usurpations in similar cases, because our will is that every one proceed rather by course of law than by force.

3. If the defendant vouches to warranty by aid of our Court, and the vouchee comes by aid of our Court, or without such aid, and enters into warranty, the principal plea shall cease, and the appeal begin anew against the warrant, and according to his defence let judgment be given.

4. If the vouchee will not enter into warranty, the 7 
vouchor may say thus. "Peter who is here, says that Thomas who is there, wrongfully refuses to warrant the same horse against Joln who is there, who challenges it as his own; and herein wrongfully, inasmuch as the same Thomas sold (or gare or lent) the silme horse to him said Peter on such a day and year, in such a place; and that he did so, the same Peter offers to prove by his body, in such a manner as the Court shall award he ought to prove it.' And in this case it behoves the vouchee to defend such contract, either by his body, or by the country, so that judgment of death may pass upon the one who is defeated, and the successful party be allowed to go quit; and the thing challenged shall be delivered to him who challenged it, if he properly prosecuted his suit, otherwise it shall belong to us.

5. And if there be any fraud in the warranty, as if the appellee by collusion vouches to warrant some champion or other strong man, or a clerk, who maliciously and for hire enters into warranty, and the demandant prays leave to lay open the fraud and the malice, as done to make him withdraw himself from the battle for fear of the might of the champion, or for the privilege of the elergy, inasmuch as the vouchee being a clerk intends to purge himself in Court Christian, should he be attainted by the lay Court, let him be admitted thereto; and if the malice be proved, both the warrantee and the warrant shall have judgment of death, ${ }^{1}$ and the demandant shall recover his demand.

' By this clause a severer punishment is imposed upon the 
6. As to larcenies and robberies committed in time of peace, where the offenders were not freshly pursued; the owners of the things shall have their suit by appeal of felony within the year and day as in other felonies; but after that time their right of appeal shall cease, and the suit shall be ours. It is equally so within the year and day, if no other suit is commenced, and so in all manner of felonies. And if the demandants bring their suit in form of trespass, they shall be heard, if they have not before commenced their suit in form of felony, in which case they cannot, by withdrawing from their suit, deprive us of ours. But where they have sued in form of trespass, although our peace may have been broken, we will not prosecute.

7. If any appellee has withdrawn himself, let him be demanded from county court to county court, till he either appear or is outlawed. And when he shall have come into Court, and the appellor shall have appealed him by words of felony, and the appellee de. fended himself by proper words of defence, let him in the first place consider whether he can aid himself by general exceptions, as to the person of the judge, that he has not authority to hear and determine the appeal, which exception may be true in many ways, as if the act wherewith the defendant is charged was

colluding vouchee than was before in use. According to Bracton and Fleta, the hireling champion was to lose a foot and hand. And according to Fleta, the clerk was to be imprisoned and ransoméd. (Brac. $151 b$; Fle. 55, 56.) 
not done within his jurisdiction, and this exception holds good in counties, or where the judge is not authorised thereto by our writ. Or he may except to the person of the appellor, which may also be in sundry ways; or to his own person. If no objection lies against any of the persons, then let him see whether he can aid himself by general exceptions to abate the appeal; and if he cannot, let him inen aid himself by exceptions to the action, as that the thing challenged is not of the value of twelve pence; and many other exceptions may be used. If he cannot avail himself of any exception, and has no warrant to vouch, he may lastly defend himself by his body, or by the country. And if he be attainted, let him have judgment of death.

8. The appellor may afterwards proceed against the receivers and the others for aiding and consenting, whosoever they are. And when one man is appealed by several, or several by one, and battles are to ensue, the battles shall not take place at one time, but at different times. Nevertheless the felon's wife may plead, that although she was privy to the crime of her husband, yet she neither could nor ought to accuse him as long as she was under coverture; but this answer must not be allowed in too general a manner to such wives to excuse them from acquitting themselves of the fact, and of the consent, by the country ; for it may often happen that the wives of felons hold the persons attacked whilst their husbands kill them, and in such case both of them are guilty of the felony; and as to 
the concubines of felons, they shall in no wise be allowed to excuse themselves by coverture. If it appears that any woman who is adjudged to death for this or any other felony be big with ehild, then execution of the judgment shall be delayed until the child be born. ${ }^{1}$

9. Felons, in this as in all other felonies, may have accomplices, receivers, and abettors, whom they may appeal for the sake of prolonging their own lives; and if they will become provers, then let the coroner go to them, and hear the confession of their own felonies, and cause such confessions to be enrolled, and also their appeals, together with their names and the names of the appellees. And if the provers make the justice of their appeals appear, and have lied in no particular, then they shall have our pardon of life and limb where we shall see meet because they have fought for our peace. $^{2}$ But our will is, that from the time any such prover has failed of his appeal, he shall be no more heard against any other whom he has appealed, but all others appealed by him shall be adjudged quit as to his appeal, and the prover shall be condemned to death;

I Bracton derives this rule of humanity from the Roman Law, citing a passage in Dig. lib. 48, tit. 19. 1. 3.

${ }^{2}$ The commentator in MS. $N$. states that it was considered that an approver had not merited pardon until he had made good his appeal by battle against seven accomplices; and that by some the number was put at nine; and that even then he was not to be permitted to remain in the country, but to be exiled, or to take the cross in the Holy Land. The latter point is confirmed by Bracton : "Vitam habeat et membra, sed in regno remanere non poterit, etiam si velit plegios invenire.' Brac. $153 \mathrm{~b}$. 
and if the persons appealed are suspected, let them answer at our suit, and clear themselves of the slander; but if they are of good fame, then we permit them to be let out by sufficient mainprise as to our suit until the eyre of the Justices, or until we shall take proceedings against them. The like liberty shall be granted to those who are indicted of any felony through hatred, and by procurement of their enemies; which hatred shall be convicted by inquest by virtue of our writ $D_{e}$ odio et atia, saving to every one his suit.

10. As to pigeons, fish, bees, or other wild animals, found in a wild condition, we ordain that no man have judgment of death on account of them; but otherwise if they have been feloniously stolen out of houses, or if they are tame beasts, out of parks. And no appeal shall lie where the damage is under twelve pence, nor in any case which shall be found by examination of the Justices to be rather trespass than felony; as where the appeal is made of a wound, and it appears to be only a bruise or scratch. 


\section{CHAPTER XXVI.}

\section{Of Appeals of Mayhem.}

1. Concerning mayhems, we are content that the maimed shall sue by appeals of felony against the offenders; and when any appellee is convicted of such felony, and brought up for judgment, let the judgment be this, that he lose the like member as he has destroyed of the plaintiff; and if the plaint be made against a woman who has deprived a man of his members, she shall have judgment to lose a hand, being the member wherewith she committed the offence. In this felony no prosecution shall lie at our suit with a view to the judgment of loss for loss ; but if the appeal be abated, the felons shall answer for such felonies, and if they are attainted at our suit, they shall be awarded to prison, and ransomed thence for breaking our peace. And our will is, that nothing be deemed a maybem unless a nember be lost, whereby a man is rendered less able to fight; as the loss of an eye, a band, or a foot, or fracture of the skull bone, or loss of the fore teeth; but the loss of the molar teeth, or of an ear, or of the nose, is not accounted a mayhem, but a disfigurement only.

2. Appeals of felony may also be brought for wounds, and for imprisonment of freemen, and for every other enormous trespass; but for aroiding the perilous risk 
of battle, it is better to proceed by our writs of trespass than by appeals; for if variance be found between the appeal as entered in the roll of the coroner and as set forth in the county court, or if there has been any omission, or any interruption of the county courts, or other error, the plaintiff shall be commanded to prison for not having performed what he bound himself to do, and shall make satisfaction to the defendant, and afterwards to us. But if the appeal be maintained, and the defendant have put himself for good or ill on the country, and the jury say that he is guilty, the same judgment shall be given against him as would have been in case he had bcen vanquished in battle, to wit, wound for wound, imprisonment for imprisonment, and trespass for trespass. But in such cases our will is, that the execution of the judgment be so far mitigated, that the appellees be sent to prison, and there remain in irons till they have made satisfaction to the plaintiffs; and they shall afterwards be punished for breach of our peace.

3 . The like judgment shall result where the proceeding is by our writ of trespass. But some trespasses deserve a greater punishment, as trespasses committed in time of peace against knights or other honourable persons by ribalds or other worthless people; in which case our pleasure is, that if a ribald be attainted at the suit of any knight of having feloniously struck him without any provocation from the knight, the ribald shall lose the hand wherewith he offended. We have said, in time of peace, because as to injuries done at tourna- 
ments and jousts, or such warlike feats, we will not interpose, unless the acts be done in our presence.

4. Our will also is, that the articles and penalties ordained by us and our council, and proclaimed to be put in force for a certain time with regard to strangers, be observed and executed according to such ordinances.

\section{CHAPTER XXVII.}

Of Attachments, and other proceedings in actions of trespass; and of the conclusion of the Eyre.

1. We have already treated of the manner of convicting offenders for breach of our peace by appeals and presentments ; we must now show how the breach of our peace is to be convicted by way of trespass. In the first place, when any one has obtained our writ of trespass for a mayhem, imprisonment, or wound, or for anything stolen or robbed or in any other manner wrongfully carried away or detained, or for brealing parks, or for battery, or for other things committed against our peace, or against a bailiff for refusing to render account to his lord, let him begin by delivering his writ to the sheriff; and afterwards let him find two pledges distrainable to the sheriff to prosecute his plaint. And let the sheriff cause the trespassers to be distrained by their cattle or by their chattels, and afterwards adjourn them to be in our Court at the day prefixed according as shall be contained in our writs, to answer to the plaintiffs for 
the trespasses contained in the writs; so that every defendant may have notice of his adversary's case.

2. And if the writs are returnable in a franchise, and the bailiffs will not execute our precept unless the plaintiff will find them pledges distrainable to them, in such case the sheriff may make a return in our Court, that he sent to the bailiffs of the person having the franchise of return of writs to do execution, but that they have nothing done; and we will immediately command the sheriff that he omit not by reason of the franchise to enter and do execution. And the plaintiff, if he will, may proceed against the bailiffs to recover his damages; for it would have been allowable for the plaintiffs to have found sureties to prosecute their plaints in our Chancery without prejudice to any one; wherefore the surety found to the sheriff on every writ is sufficient.

3. If the defendants suffer distresses to be taken into the hands of the sheriffs, the sheriffs may return that they have distrained them by such cattle or by such chattels; and if the defendants do not thereupon come into court, then it must be distinguished whether the plaint is in our Court, or elsewhere, as in the county, or in a court baron or other freeholder's court; and if in our Court before us or before our Justices, then we will that no default be adjudged in any plea until after the fourth day. If they do not come within. the fourth day, and are not essoined, and the plaintiff offers himself and demands judgment for the default, the great distress shall be awarded, and the sheriff shall be 
charged to answer unto us for the issues of the first distress; and the Justice shall adjourn the defendant to be in court on another day ; at which clay no essoin shall be allowed him, for we forbid the allowing of an essoin in any case after default, until such default be cleared in our Court. And if upon this day the defendants make default, the issues shall be forfeited to us, and the sheriff shall be charged to answer unto us for the same, and these distresses shall be continued from day to day until they appear and answer.

4. If the plea be in any other court than ours, and the defendants have neither appeared nor caused themselves to be essoined, we will not that judgment be delayed until the fourth day; but immediately on the first day let it be awarded by the suitors, that such distresses be detained, and more be seized, and so from court to court. If the sheriff or the bailiff has not executed the precept, let him be in mercy.

5. The same process of distress is to be awarded in defaults after essoins in a writ of trespass committed against our peace; but in an attachment of felony no distress runs excepting against the body, if it can be found. And if in the above cases the sheriff return, that the trespassers have nothing in his bailiwick whereby they may be attached, it shall be awarded that he take their bodies; and if he return that the bodies are not found in his bailiwick, then let it be ordered by our writ of judgment, that they be demanded from county court to county court until they be outlawed, if they do not appear. 
6. And when any person who has been distrained shall come into court, and cannot clear his default, let him be straightway adjudged in our mercy for his default; and if there be several defaults, let there be several amercements. And if any one be attached by pledges and make default, let the pledges be summoned to hear their jurlgment, for not having bim in court for whom they were pledged. At which day if they do not appear, or cannot deny their being pledged, they also shall be in our merey; but if they will deny the plevin, the debate shall be between them and the sheriff.

7. When the defendants have appeared in court, and heard the plaintiffs count against them, and have defended themselves by proper words of defence, they may then aid themselves by exceptions general or special; and first, by exceptions to the judge; afterwards to the person of the plaintiff or to their own person, as shall be mentioned amongst exeeptions in the writ of right; ${ }^{1}$ or they maly except to the writ, as where a writ is sued out into any other county than where the fact is alleged to have been committed, or for a fanlt, error, or omission therein.

8. If there be no dilatory exception, let them answer to the action; to which they may say that they were previously acquitted of the same trespass, as

1 The proposed chapter on Exceptions in the Writ of Right is not contained in the Treatise as it now exists: but some further observations upon exceptions to the person may be found in book ii. chap. 18. 
against the same plaintiff; and if -this be verified by recorl, let judgment be given accordingly. Or the defendants may say that the parties made accord of this trespass; and if the plaintiff deny it, let the truth be inquired by the country. And if the plaintiffs will not agree to the accord, let the defendants be awarded quit, and the plaintiffs in mercy.

9. With regard to receivers of trespassers, commanders and accessories, there is not as yet any punishment ordained, *except only against the principal trespassers. And if the plaintiff complains of a damage done to himself and to his men, or only on behalf of his men, the defendant may say that every man has a separate action; and in such cases we will that the plaintiffs recover nothing by their plaints beyond the damages which they can reasonably show they have sustained by the loss of the services of their men, who have been beaten or imprisoned, or so treated as to be incapable of service. And their action shall not be brought until after conviction of the trespass committed against the servants. ${ }^{1}$

10. If the sheriff return that the defendant is a clerk, and refuses to submit to his jurisdiction, and that he has no lay fee in his bailiwick whereby he can

1 According to Bracton, an action might be brought by the master for the insult and disgrace inflicted upon him in the person of his servant, although no loss of service followed; and even though the servant withdrew from his action, or refused to prosecute, the master might himself sue. (Brac. 115.) The change of law is indicative of an increase of personal independence. 
be distrained, let his ordinary, as the archbishop or bishop, be commanded by our writ that he eause such a one his clerk to appear. And if lie does not produce him at the day named in our writ, let the bishop be summoned to answer why he did not produce him at our precept. And if the bishop neglect our summons let lim be attached to come by distress, and if he does not come at the first distress, let the great distress as above said, proceed against him until he shall come; and when he has appeared in court, if he cannot clear his default, let him be amereed.

*11. There are however several actions of trespass which require greater expedition, as trespasses committed against us or our consort, or our children, or against foreign persons, as solemn ambassadors or alien friends, or against our officers, or against merchants, or against those who have taken the cross; in which eases no formality of attachment shall be required, but the bodies of the defendants shall be immediately attached, so that the sheriff shall have them to answer on the first day.

12. There are some actions also pleadable by like distresses as in trespass, where no outlawry ensues, and which are more dilatory by a day, and commience by summons; as a plea of debt, of covenant, in ease of warranty of charter, waste, sale, destruction of houses or wools or other freehold, and pleas of naifty and several others.

13. Whatever maly be pleaded in the county cont may also be pleaded in the eyre of the .Justices; as pleas 
de retito namio, of debt, of naifty, of wards, and marriages ; also presentments made in the sheriff's tourns and in views of frankpledge; and also pleas eoncerning false weights and measures, and many others, which are pleadable before our Justices assigned to take assises *in the county, and writs pleadable before our Justices of the Bench at Westminster.

14. If any presentment upon the articles of our Crown remain uncommenced or undetermined, then let. the Justices, unless they have a good and reasonable excuse, be punishable at our discretion. When the presentments on the articles of the eyre are determined, the pleas of land shall be immediately adjourned before them to another county; or if the eyre is not to be continued, they shall be adjourned into the Bench, in the presence of the parties. The amercements are immediately to be assessed, ${ }^{1}$ and the estreats sent to our Exchequer; the like as to fines and the chattels of felons and fugitives; and the names of the fugitives shall be enrolled in two rolls, whereof one shall remain with the coroners and the sheriff" of the county under the seal of the Justices thereto attached, and such persons are to be demanded by their names at the first county court after the eyre, to come and submit to justice in our Court, and so from county court to county court, until they appear or be outlawed. The other roll, together with all the rolls of the eyre, shall be transmitted to our Exchequer, and safely kept in our Treasury.

${ }^{1}$ See before, c. ii. s. 4 . 
15. If the suitors of the county be attainted of false judgment, or have made any other error in the usage of the law, the county shall be in our mercy. The hundreds also for the defaults of the suitors, and the townships for divers defaults; and the amercements shall be assessed according to our Statutes of Westminster. And afterwards let the sheriff be commanded to aid the presentors by causing the neighbours to raise reasonable contributions towards their expenses.

\section{CHAPTER XXVIII.}

\section{Of Distresses.}

1. In counties we have a twofold court; ${ }^{1}$ one of the pleas of our peace, which is held by our coroners and the suitors, and of which the coroners only have record; we have also a court of the nature of a court baron, in which the suitors are judges, and have no record out of their court, except by consent of the parties. For in their courts neither party may deny what he has before pleaded; but if the plea be removed

1 This description of the several branches of the county court is somewhat obscure. The twofold division probably applies to the original or ordinary jurisdiction of the county court on the one hand, and the derivative jurisdiction by virtue of the King's writ on the other. The first is again subdivided into the criminal jurisdiction, in which the coroner took part, and the jurisdiction in civil actions commenced by plaint, where the process was similar to that in courts baron. (See post, s. 20, and c. 29 . s. 1.) 
out of the court of such suitors, either of the parties may deny the record. But for that purpose he must have suit ready at hand, to wit, such a one his free man who was present at such court, and saw and heard that the plea was so pleaded, which he is ready to prove by his body, in whatever manner the Court shall award that he ought to prove it. We have also our court there, with the sheriff of the county for our Justice, whensoever we command our sheriffs by our writs, that for purposes of justice they cause any plaint to be brought before them, whereof the sheriff with the suitors bears record. ${ }^{1}$

2. And whereas they may be entrusted with the determination of several kinds of writs, in the first place we will that they understand the nature of the plea of distress; which plea we do not allow any one to determine without our writ. But to the intent that beasts and other distresses may not be too long detained or impounded, and to avoid further damage, we have granted that the sheriff by simple plaints and by pledges may deliver such distresses, and determine the

1 The sheriff, when sitting by virtue of the King's writ, is treated by our Author as the King's Justiciary, and as having the power of record incident to that office. See before, c. 1. s. 7 ; and farther on, li. ii. c. 30. s. 8. See also Brac. 117. Hengham Mag. c. iv. pp. 20,21. It was decided in later times, that the county court, though sitting by virtue of the King's writ of Justicies, or De Nativo habendo, had not the powers of a court of record. Y. B. 2 H. IV. 24 ; Brooke, Abr. Faux Imprisonment. 30 ; Dalton, Offic. Vicecom. p. 158 ; Jentleman's Case, 6 Coke. Rep. 11. 
taking without regard to the vee ${ }^{1}$ and tortious detaining, if the plea is not removed by our writ into the Bench, because vee is an article of the breach of our peace. The substance of this plea consists in two things, to wit, in the taking and in the detaining; and forasmuch as one may take, and another detain, it is necessary that both be named in our writ. And because he who. wrongfully detains, does a greater injury than he who wrongfully takes, the principal burden of the answer shall in such case fall upon the detainers. Naam $^{2}$ is a general term for cattle, chattels, and for all other movable things which may be taken by way of distress.

3. When any one, finding himself aggrieved by a wrongful detaining of his cattle or of his chattels, shall have obtained our writ to his sheriff, and found pledges to prosecute his plaint, let the sheriff immediately go or send some known bailiff to the place where the plaintiff says the distress is detained; and when the sheriff or his bailiff come there, let him demand a view of the beasts or chattels whereof the plaint is made. And if he cannot have a view by reason of disturbance from any detainer, or other person, whereby he cannot discharge the duty of his office, let him immediately raise the hue and cry, and cause all the disturbers to

1 The vee (from the old French vier or véer, Latin vetare) was the refusal to deliver the distress upon offer of surety. See below, s. 6.

2 Naam (Anglo-Saxon, name, from niman, German, nehmen, to take), a seizure, or taking. 
be apprehended and liept safely in prison, so that they may not be set at liberty without our leave, for the disturbance of our peace. And if the beasts are shut up within a house or within pound, or if they are driven out of the county, or if the bailiff meet with other disturbance, let him immediately cause beasts of the deforcer to be taken to the extent of double the value by way of withernam, ${ }^{1}$ and keep that distress without permitting it to be replevied, until the distress eloined be brought back.

4. If the taker or detainer admit the bailiff to view, and avow the thing distrained to be his property, so that the plaintiff has nothing therein, then the jurisdiction of the sheriff and bailiff ceases. And if the plaintiff is not a villain of the deforcer, let him immediately raise the hue and cry ; and at the first county court let him sue for his chattel, as being robbed from him, by appeal of felony, if he thinks fit to do so.

5. When the sheriff and the bailiffs hare had the view of the distress without disturbance, the distress shall be lelivered to the plaintiff; and the sheriff or bailiff shall give a day to the parties at the next county court. At which day no essoin shall be allowed against the plaintiff, since this suit, like disseisin, is nearly connected with robbery; but if the defendant makes default, the distress shall be adjudged to the plaintiff, and the distrainor in mercy. If the plaintiff does not come at the day nor cause himself to be essoined, and the defendant offers himself and demands judgment of 1 Withernam, Anglo-Saxon, wiver-name, a counterdistress. 
the nonsuit of the plaintiff, let it be awarded that the defendant have the distress returned, and that the plaintiff and his pledges to prosecute be in mercy.

6. When both parties appear in court, the plaintiff shall set forth his plaint, that 'whereas he had his beasts, to wit two oxen,' or two cows, or two horses, or such chattels, according to the nature of the distress, ' on such a day in such a year of our reign, in such a township,' or in such a certain place, 'there came such an one (the detainer) and took the same beasts there found,' or 'caused them to be taken by such a one,' or 'by other persons unknown, and drove them away,' or 'caused them to be driven away, from the same place, to another place, and there came the plaintiff, and demanded to have his cattle quietly, and could not have them, and afterwards tendered security for the sake of peace, and offered pledges to appear in his court or elsewhere to stand to justice, if he had any demand to make against him, and yet he wrongfully against gage and pledge detained them, or caused them to be detained, until the same beasts were delivered by the sheriff; this wrong did he to him, and this distress against gage and pledge wrongfully him refused,-and if he did him any other injury, it should be assigned,'to his dimages of a hundred shillings,'-or more or less, according to what he shall have suffered,-_'against the peace, and if the defendant do deny the same, he has good suit.'

7. Then let the defendant answer, and defend 'the wrong and force, and the breaking of the peace, and the 
tortions taking, and the tortious detaining, and the refusal of the beasts aforesaid, and the clamage of a hundred shillings,' or more or less as the plaintiff shall have counted against him, 'and this he will defend where and when he ought so to do.'

8. When he has thus defended himself, let him try if he can aid himself by exception against the judge; as for example, if the detaining was not done in the jurisdiction of the judge, and afterwards by exception against the person of the plaintiff, and afterwards against his own person, and then to the writ, as, if the writ was obtained before the day of the taking mentioned in his plaint. Also, if there are several plaintiffs, who are named together in the writ, and they have complained in common where the cause of action is several, the writ fails. He may afterwards aid himself by exceptions to the action; and he may answer to the tal: ing in several ways, and may defend the vee by his law ; but if the plea is removed out of the county court, this proceeding shall not be allowed to the defendant; but although he can justify the taking, nevertheless he shall answer concerning the vee and the tortious detainer, which is an article committed against our peace, of which none may acquit himself by his law, for to refuse gage and pledge is a total renunciation of our peace.

9. Or he may avow the taking and detaining as rightful, 'for that on the same day he found the said beasts in his meadow,' or in his corn or elsewhere, ' to his, damage, in such a vill, and he according to the 
law and custom of the realm caused those beasts to be driven to his house in the same vill, and there detained them until due amends shonld be made him for the damage aforesaid, or until pledges should be tendered to him for a reasonable satisfaction, so that he never refused him the beasts in any other manner'; and of this he may tender averment by the county.

10. To this the plaintiff may answer by way of replication, and say that he 'tendered him plectges to make satisfaction, and to appear in his *ourt, and to make him due amends by the award of neighbours; but he not complying with reason and right, refused him the beasts, as he hath before alleged in his plaint.' To this the defendant may answer by way of triplication, and admit that the plaintiff tendered him pledges, but not distrainable to him ; and if the plaintiff cannot prove the contrary, let the distress be awarled back to the defendant, and the plaintiff in mercy for his wrongful plaint.

11. And also as to what the defendant says, that he took the beasts doing him damage, it may be answered by the plaintiff, that he tendered pledges to make amends for his damages, but when the damage was to have been shown, the defendant conld not show or assign any clamage, and thereof he may tender averment; or he may say that concerning satisfaction for those damages, they referred themselves to the arbitration of such and such persons, who awarded that no damage wis done: or that he male him some settled amends for the damage's, and thereof found 
pledges, and thereupon he may tenderaverment. And according as the truth shall be found, judgment shall be given for the one or other.

12. When the taking and detaining are made by other bailiffs than ours, and the plaintiff has obtained his writ against the bailiffs jointly with the lords, in such case the lords may either avow or disavow the act of their servants; and the plea shall be pleaded accordingly. *If the writ be obtained against the bailiffs only, in such ease we will that each shall answer for his own act, if the act was done in the absence of the lords ; but if the lords come before judginent, and are willing of their own accord to warrant the acts of their bailiffs, the lords shall be eharged with the acts of their bailiffs, and the bailiffs discharged.

13. Another answer of the defendant may be by avowing the taking and detaining as ' good and rightful, inasmuch as the plaintiff is his tenant and is in arrear for relief,' or suit at his court or other service, ' for the tenement which he holds of him, so that whenever the plaintiff would have performed to him what was in reason due, or to that end would have found reasonable security by pledges, he would have delivered to lim his cattle.' To which the plaintiff may reply, that for every taking and detaining for service, three things ought to be assigned in order to rencler the taking reasonable, to wit, a certain place, out of which the service ought to issue, a certain cause for which the taking was made, and a certain seisin, unless the distrainor can show a deed warranting him to distrain 
per my th per tout wheresoever he please, when his rent shall be in arrear, although he have no fee. If the defendant in his defence has omitted any of these three *points, and the plaintiff demands judgment against him as being undefended, judgment shall be given for the plaintiff. And if the defendant counts of any seisin, and the plaintiff denies it, the point shall be verified by the country, and judgment be given according to the verdict.

14. Where the defendant assigns the taking and cletaining to be rightful on account of service in arrear, and in particular for relief, the plaintiff may answer that he tendered him his homage, and that he would not then take it; whereupon he may demand judgment whether he was obliged to perform any service to him, or to acknowledge him for his lord, until he had taken his homage and accepted him as his man. And if the plaintiff ean aver it, let it be adjudged against the defendant. For relief and other services due from an! tenement held by knight's fee, are things accessory to honage, which is the principal, and, the principal ceasing, the accessories ought of right to cease.

15. Another answer of the defendant may be by arowing the taking and detaining as rightful, and assigning it to be for reasonable aid, to make his eldest son a knight, or to marry his eldest daughter. To which the plaintiff may reply, and say, that what he has assigned ought not to arail him, inasmuch as he is not a knight himself, or inasmuch as he las no son or no daughter ; or inasmuch as the one or the other 
is not yet of age to receive the order of knighthood, or to consent to a husband; or inasmuch as the plaintiff did before pay his reasonable contribution towards such aid to the same *lord. And if one or more of these answers be averred, it shall be adjulged for the plaintiff, unless the defendant can prove the contrary.

16. When the defendants arow the distresses and detainings to be made upon the plaintiffs as upon tenants for arrears of rent or other services, and the plaintiffs disarow them for their lords, let it be awarded that the lords in such case be in mercy, and that the plaintiffs have their cattle quietly delivered to them and recover their damages; and the lords shall have their action to recover the tenements in demesne, according as shall be mentioned in the chapter upon IIomage.

17. And if the lords assign that the taking and detaining was for the arrears of some service issuing out of a tenement which the plaintiffs hold, and the plaintiffs be enfeoffed by any to hold of those who are mesne between them and the chief lords, the tenants will then have the right to be acquitted by the mesne tenants, who are their lords, as against the chief lords distraining, according as such mesne tenants are bound by their charters of feoffment. And if they will not acquit them of their own accord, let the plaintiffs be aided by our writs of Warranty of Charter, and of Mesne, and by proclamations, according to the ordinance of our statutes. 
*18. When the mesue tenants shall appear in court and enter into warranty and acquittance against the lords, then let the original pleas cease, and the pleas of warranty commence; wherein the mesnes may answer several ways. For they may disavow holding of them, or say that the tenements where they took the distresses are not of their fee; which answers being verified, let it be adjudged for the first plaintiffs against the lords.

19. The mesnes may also aid themselves by exceptions against the tenants; for they may demand whether the plaintiffs have anything whereby they are held and bound to aequittanee. And if the plaintiffs cannot produee eharter or writing binding them, let it be adjudged against the plaintiffs. But if the pleas were remored out of the eounty, so as to be before our justices, and their charters have been burned or stolen, and they allege the same in court by way of exception, the trutl shall be inquired by the country, and according to the rerdict of the inquest, judgment shall pass in faror of the mesnes or of the plaintiffs. Or if any writ of Mesne is obtained against one parcener which ought to be sued out against all the parceners, where all are bound to acquittance as one heir by their eommon ancestor, the writ is abatable for error in the obtaining of it, and so in all real pleas. And also any mesne may say by way of exception, that he is not bound to aequit his tenant, because the same tenant never performed to him homage, fealty, or other service; and if this be verified, and that the 
*lefault was in the tenant, it shall be adjudged against the plaintiff.

20. Again, the defenclant may avow the taking and detaining to be rightful, and assign that he did it by judgment of his court,-and thereof he may vouch his court to warranty,-and in particular for a plaint made against the plaintiff by such an one his neighbour, who found security to prosecute his plaint, to which plaint the same plaintiff was summoned to answer at a certain day, at which day he neither came nor was essoined, wherefore the court awarded at the suit of the plaintiff, that he who now is plaintiff should be distrained to come to the next court, until he would sub. mit himsolf to justice by law. If the plaintiff, as to the matter alleged, is willing to put himself upon the record of the court, the defendant shall cause the record thereof to be brought into court, and if the record make for the defendant, a return of the cattle shall be awarded to him, and the plaintiff in mercy for his false plaint. But if the record make for the plaintiff, let it be awarded that the plaintiff have his distress free, and recover his damages, and the defend. ant be in mercy. And if false judgment or erroneous proceedings be found in the record, and the action be in the county, we will not that the sheriff or suitors have cognizance thereof; but he who shall find himself aggrieved slull make his complaint, and cause the proceedings and the record to be brought by our writ before our justices of the Bench at Westminster, and the error shall be there redressed, if any be found therein. 
*21. If the plaintiff acknowledge the distress to be made by award of the court of the defendant, he so far admits the taking to be legal; but if he further say that, when he tendered him pledges to appear in his court, and there to submit to justice according to law, the defendant rejected such plevin, and refused to permit him to replevy the distress, and if the defendant deny it, a verment shall be made, and according to the verdict, it shall be adjudged for one party or the other.

22. If the plaintiff complain only against one, and has by his plaint made him both taker and detainer, and in evidence of this produces suit; in such case the defendant may deny the taking, and if the suit on examination be found to disagree, let it he adjudged for the defendant, and the plaintiff be in mercy for his false suit. If the suit be found to agree, then the defendant may defend the taking by his law against the plaintiff and his suit; and if he tenders his law to the plaintiff and he refuses it, it shall be adjudged against the plaintiff, and so in the reverse case. If the plaintiff accepts it, a day shall be given to the defendant, that he come that other day to perfect his law with his twelre co-jurors ; at which day he may be essoined from making his law, and the plaintiff may also be essoined. But if either make default, it shall be adjudged against the absent party. If the defendant has not fully twelveco-jurors, or any of them are refusable upon good exception, as by the exception that he is a villain, or excommunicated, or has been attainted of 
*perjury, or condemned to the pillory, let it be adjudged for the plaintiff, and the defendant.in mercy, inasmuch as he has failed in performing his law.

23. If the plaintiff say that the defendant designedly absented himself, in order not to be found where pledges might be tendered to him; or if he say that he tendered pledges to his bailiff, such a one by name, and he would not deliver them, because his lord had forbidden the deliverance; in both these eases defence by law lies, if the plaintiff has his suit agreeing therein. But if he has no suit, or such as do not agree, then it will be unnecessary for the defendant to wage law against the sole word of the plaintiff; but it shall be adjudged against the plaintiff. For we will that none be obliged to wage law against another without proper suit produced upon the point. And if the plaintiff would complain of the bailiff in respect of the refusal, the contest shall be between the plaintiff and the bailiff.

24. Where the defendant avows the taking and detaining to be justifiable on acesunt of service which was in arrear for a tenement in such a vill, which the same plaintiff holds, and whereof he was himself seised or some other his ancestor by the hands of the plaintiff or other certain tenant, since the time limiterl in assise of novel disseisin, if the plaintiff cannot deny the sei$\sin$, let it be adjudged for the defendant. For we will not have it tried by such writ, whether the seisin has been rightful or tortious; but the tenant may procure by our writ, that his lord do not demand of him other 
*services or other customs than he ought of right to do to him ; so that if he is agrrieved by the possession, it is our will that he shall procure his remedy in the right; and that every writ shall have its proper nature, and one shall not be pleaded by means of another.

25. Another plea of the defendant may be, 'that he took and detained the cattle rightfully, and by reason of a soil which was his sereral, in the which he found the same cattle feeding several times, and from the which he had often warned the plaintiff to turn them out, and he nevertheless sent them in another time contrary to his prohibition, and he was always ready to deliver them, if the plaintiff had been willing to abstain from cloing those wrongs, and thereof to have found surety, whereas the plaintiff never would do so.' To this the plaintiff may reply, that 'the defendant wrongfully took them and wrongfully detained them; because the pasture of the same soil is his common, and his common ought to be where he and his ancestors have always had common, and this he is ready to verify, where and when he ought.' And because he would not deliver the beasts quit, the plaintiff might by means of this writ recover title of common and freehold, where peradventure he had never any right of common, if an inquest were to decide in his favour ${ }^{1}$

1 This passage is obscurely expressed. If we understand it as implying that the inquest upon the title to common is taken in the action of rejlevin, it is contrary to the general rule, that a title to freelsold is not to be tried in such an action (see before, s. 24) ; and is contradicted by the parallel place in Fleta, where 
*in such case it is our will that the cattle remain with the plaintiff, and the defendant be in mercy; and if the plaintiff will still be a commoner and claim a freehold of common, the defendant shall have his remedy by our writ of Novel Disseisin if he thinks fit to pursue it.

26. Such as shall be convicted of taking a distress beyond the value of their demand, although they have avowed the cause of their distress to be legal, shall nevertheless be in mercy for the excess. And if any one has made a double distress for one demand, and in particular, after the deliverance of the first distress, pending the plea concerning the first taking, in such case the plaintiff shall be entitled to our writ, to cause his cattle to be delivered, and the distrainor shall be bound by gage and pledge to be before us or our justices at a certain day to answer for such trespass committer against our peace. Whosoever shall be convicted of this offence, damages shall be first awarled to the plaintiff, and afterwarls the distrainor shall be punished by imprisonment and fine; or in such cases

it is expressly said, that the sheriff upon such a plea has no. power to proceed further. (Fle. 101, \$ 24.) Yet this construction appears to be adopted by the commentator in MS. $N$, who says : ' par cas poet il recoverir title de franc tenement parmi verdyt en le replegiari, tot seit ceo a tort.' I should rather suppose that the sense of pur ceo qe in the beginning of the sentence ouglit to be repeated, and that the true translation would be, 'And because, on account of the non-delivery of the beasts, the plaintiff might recover title of freehold, \&c. ; therefore it is our will in sucl case, \&c.' 
we will command our sheriffs, *that if they find such trespasses to be committed against our peace, they shall speedily inflict such punishment by imprisonment of the trespassers and by heary amercements, that others by their example may be corrected in like cases.

\section{CHAPTER XXIX.}

\section{Of Debt.}

1. Is county courts also before our sheriffs and the suitors, and in hunclred courts, and in courts of freemen, pleas of trespass and debt may be pleaded without our writs, ${ }^{1}$ simply by gage and pledge, provided that neither the goods carried away in trespass nor the debt demanded exceed forty shillings; except trespass of mayhems and wounds, and inprisonment, and batteries committed against our peace. For we will that no one have cognizance or jurisdiction to hold pleas of such complaints, nor of other trespasses for goods

1 The following note explains some of the disadrantages of proceeding in the inferior courts: 'In pleas commenced by plaint, issne cannot be taken by averment of the country, but only by suit or proof. And although there may be jurisdiction in the county court or in the court of a liberty, extending to ten, twenty, or thirty pounds, still it is more advantageous to plead in Bank by the procipe quod reddat, on account of the fieri ficias which follows by statute. But the sheriff or bailiff has no power to levy the debt out of the lands and chattels, though he lias power to distrain by virtue of execution of judgment.' (Note in MS. N.) 
carried away beyond the value of forty shillings, or of debts exceeding the same sum, without our writs; which writs shall sometimes be pleaded in the county court, and in franchises, unless removed therefrom by our precept, and sometimes elsewhere before our justices; and we will that great trespasses be pleaded before ourselves.

2. An obligation is a legal bond, whereby a person is bound to give or do anything, and thus it is the parent of an action, and takes its origin from some precedent trespass or contract. *An obligation by con. tract may arise in many ways by the united consent of the parties; which consent is sometimes naked and without clothing, and sometimes clothed. From a nalked obligation no action arises, except by common assent; it is necessary therefore in every obligation that it be clothed. An obligation should be clothed by five incidents, by a material thing, by words, by writing, by unity of will, by delivery, by relation. ${ }^{1}$

3. It is clothed by a matcrial thing, when anything is lent and borrowed, to be restored on a certain day; and by such loans the clebtors are bound to restore to the creditors the things borrowed in as good or better conclition than they received them, or else their value, unless by accident of fire, water, robbery, or larceny, they have lost them; for against such accidents no one

1 Our author gives no explanation of the meaning of joynture. The word is borrowed from Bracton, where it appears to be used to denote the connection of several contracts relating to the same subject matter. (Brac. 99, $100 \mathrm{~b}$; Fle. 128, c. 60, § 2.) 
ought to answer for things lost, unless they happened by his own fault or negligence. But if a debtor carries money about him and foolishly shows it among thieves, and is robbed of it, it does not follow that he is not bound to the creditor; because he did not use his diligence to keep the money, for he might have taken better care of it.

4. The second lind of clothing is by words passing between the creditor and debtor, by which they come to an agreement by offers and stipulations.

5. The next incident is by writing, which may be pure and simple, and without day or condition; in which case the creditor may demand tine thing presently or whenever he pleases. *But if a day of payment be specified in the writing, the debtor is not bound to pay before the day, and when the clay arrives, it is sufficient if he makes the payment any time of the day, for the debtor has the whole day; and likewise it is with regard to a certain year, or a certain montl, named in the writing, if no certain day be specified. Also, the writing may be conditional, and will or will not take effect, according as shall be mentioned below concerning conditional purchases. But whatever the conditions may be, no writing or obligation shall be binding as a conditional contract, if the condition be impossible or unlawful. Impossible, as in this ease, if you will procure me the moon, I will give you ten shillings. Unlawful, thus, if you kill such a man, I will give you ten shillings. Yet in the negative such conditional obligations would hold good, thus, if you do not pro- 
cure me the monn, or if you do not kill such a man, I will give you ten shillings. And if the debtor binds himself in any allowable and innocent penalty, the penalty shall stand, for the debtor was willing when he bound himself thereto, and no injury is done him against his will.

6. The next incident is unity of will and consent; and this is mentioned with reference to those who know not how or are not able to consent, as the deaf, 1 and the mad, and mere idiots, and infants in their tencler age, and lunatics and frantic persons during their fury, and *married women, and persons in religion removable by their superiors of the same order, ${ }^{2}$ and those who are compelled to bind themselves, and pure villains. ${ }^{3}$

1 Bracton admits, that a deaf man may contract by writing; so also Fleta. See the passages referred to in the margin above.

2 Among the statutes of the Benedictine order, confirmed at a council of the heads of the order in England, A. D. 1249, is the following: "Nullus monachus obedientiarius vel claustralis det aliquid vel suscipiat absque licentia sui superioris." (Matth. Paris. Addit. p. 1096.) By the same regulations no prior or other officer or obedientiary was to be appointed for life, but all were to be subject to removal. (ib. 1096, 1098.) See Littleton, Ten. s. 200 .

${ }^{3}$ A villain might acquire property real or personal, and his acquisitions enured to the benefit of his lord, if the latter chose to take them ; but the villain while in possession could make a good title to a stranger. See li. ii. c. 7. s. 1 ; Brac. $25 \mathrm{~b}$. It follows from s. 25, below, p. 139, that debts and executory contracts could not be enforced against a villain pleading his own villenage. But no reason appears why a contract should not have been enforced by a villain against a third party, if the rule 
With such persons no contract or obligation is binding.

The next incident is delivery, which is an induction of the thing into possession with the consent of the creditor, as shall be mentioned concerning such inductions in treating of purchases after gifts.

8. When any one will sue for a debt within the sum of forty shillings, or for any small trespass, first, let him find security to the sheriff to prosecute his plaint, if be will proceed in the county court, or to some bailiff, according as he chooses to proceed in the hundred court, or in a freeholders' court. And let the debtor be summoned to be at the next court to answer the plaintiff upon such demand as he has made against him, so that he have reasonable warning to answer the demand of the plaintiff.

9. Upon the day named in the summons both parties may be essoined; but if the debtors or any persons against whom a plaint of trespass is brought without our writ shall make default whether such default be before essoin or after, it shall be awarded that they be distrained by their cattle or by their chattels to be at the next court. And if they make default another time. it shall be awarled that the first distress * be retained, and a fresh one taken, and so from court to court, and that they may not replery the beasts, until they find pledges

generally held, that an exception of villenage against the person of the plaintiff could only be pleaded by his lord. Compare below, li. ii. c. 18. ss. 2,5 ; Brac. 193 b, 196 b, 197 ; Hengham P. c. 8. p. 103 ; Littleton, Ten. s. 189. 
to ansiver the plaintiff. In plaints of trespass no summons shall be made, but they shall be distrained on the first day. And if the plea be removed before our justices, the grand distress shall take place, and the sheriff be charged to answer for the issues, as above mentioned in the chapter of Attachments.

10. And when the defendants come to have their distresses delivered, let them find pledges to answer at the next court, and to return the distresses if they do not appear, and then let the distresses be delivered. At which day, if they do not appear, let it be awarded that the pledges be summoned to be at the next court, to show why they did not produce those for whom they were pledged according to their undertaking; and whether they come on the day on which they are summoned or not, let them be amerced; and they shall have their recovery against those whom they pledged, for not acquitting them of their suretyship, as they ought to have done. The defendants shall then be distrained again to come and answer to the plaintiff, and these distresses shall remain irreplevisable until they have answered.

11. When any defendant shall be found in court, *after he has been attached, let him immediately answer, or be treated as undefended, whether he has before made default or not; and when he has answered, then and not before let the distress be delivered to him. This shall be done upon presumption of his malice, in that he was not willing before to find pledges to be amenable to justice. 
12. When the parties shall have appeared in court, then let the plaintiff open his plaint, and saly that ' the defendant wrongfully detains from him and does not render to him twenty shillings, which he lent him on such a day in such a year in such a town, in ready money, and which money he ought to have rendered to him on such a day following in the same year, and the said money did not render, but detained the same wrongfully and to his damage of ten shillings, and if he will deny it,' then the plaintiff may tender suit.

13. To this the defendant must answer and def'and the wrong and force, and the debt and the damages. And as an obligation is contracted in divers ways, so likewise it may be defended ; hence the debtors may aid themselves in many ways by exceptions. Wherefore let the defendant aid himself by exceptions, if there be any which can avail him. Among the rest, he may demand whether the plaintiff has anything from him, whereby he has bound himself to render that debt; and if he produces a tally, or a suit, and the suit is found to agree, then he may deny the debt by his law, and in that case the proceedings are the same as are before mentioned in the chapter on Distress.

14. If the plaintiff produces a writing, the defendant may answer thereto in several ways; *for he may deny the writing, and tender averment by the country that the same is not his deed. And if the plaintiff prays the averment, then let the truth be inquired by means of the witnesses naned in the writing, when there are any or by the country. 
15. Or, if the writing be the deed of his ancestor, he may demand judgment of the writing, whether he is bound to ansiver to that writing for the debt of his ancestor, whereas there is no mention made in the writing of his being obliged to the payment thereof. For in this ease we will that none be bound to pay the debt of his ancestor, whose heir he is, to any other but to us, unless he be thereto especially bound by the deed of his aneestor.

16. Or he may say that the writing ouglit not to affect him, for when he made it he was under the age of ten years $;^{1}$ and if this be verified, let it be adjudged against the plaintiff.

17. Or he may plead, that this writing ought not to affect him, for at the time of it being made he had lost his seal, and caused it to be eried and published at the churehes and markets, so that if anything was made under that seal after a eertain day on which it was lost, it ought not to affect him; and in such manner he may deny the deed, ${ }^{2}$ and thereupon let the

${ }^{1}$ The age under ten years appears to be selected merely as an example of pleading in a particular instance, with no reference to any especial disability connected with that age.

${ }^{2}$ There is an entry in MS. M. of an assise of novel disseisin concerning land at Thorley, between William de Gerburg and William de Clifford and others, which appears to belong to the end of the reign of Henry III or the beginning of Edward I, in which this defence is set up against the deed of Arnald de Thorley under which the demandant claimed. The jury found, 'quod prædictus Arnaldus amisit sigillum suum, et si aliqua carta vel scriptum ab illa hora in posterum proferatur sigillatum 
truth beinquired by the neighbourhood where the deed is supposed to have been made, and according to the verdict of the country, let him who shall be found to have been guilty of falsehood be adjudged to prison, and punished by fine.

18. And if the deed was not made within our jurisdiction, so that the truth * cannot be inquired by us, the proof shall be left to the plaintiff, so that if he can prove the contract by good witnesses, it shall be adjudged in his favor. These exceptions shall have place in our court and before our justices ; for in county courts and other petty courts no one can prove a foreign contract, if it is denied.

19. If there is in the writing any erasure in the number or in proper names, or in the date, or day of payment, or if there be other signs of falsification in it, as diversity of hands or of ink in the writing, or if the seal be so attached that it may be taken off and put on again by contrivance, then the defendant may præelicto sigillo, quod pro nullo haberetur. Et dicit, quod prædicta carta et scriptum facta fuerunt tempore quo prædictus A. amiserat predictum sigillum ; unde dicit præcise quod licet prædicta carta et seriptum signatum fuit de sigillo suo, unquam de voluntate predicti Arnaldi facta fuerunt.' Fortunately the lemandant had also pleaded an acknowledgment of the deed by Arnald de Thorley before Gilbert de Preston and his companions Justices Itinerant in the county of Hertford, $39 \mathrm{Hen}$. III, and as to this fact had vonched the rolls of the said Iter. "And because the said William had put himself as well upon the rolls of the said Iter as upon the assise, the trial was adjourned.' Upon the subsequent day the acknowledgment to Arnald was found upon the rolls; and the plaintiff obtained judgment. 
demand judgment whether he is bound to answer to such a defective deed; in which case we will that judgment be given against the plaintiff for the great presumption of fraud.

20. Or he may say that the writing ought not to affect him, because it was made at a time when the defendant was in prison; which answer must either be allowed or disallowed, according as fear or force was used against him in prison, as above mentioned in the chapter upon prisoners. Or he may say that the writing ought not to affect him, by reason that he executed it when he was not in his right senses. This exception shall hold in the case of madmen and those who have lost their memory by sickness or any *other pain ; but not in the case of drunkards, or of such as are lightheaded, although they may sometimes not be in their right mind.

21. Or he may say, that the deed ought not to affect him, because the plaintiff was once his steward, or his chamberlain, or in other service with him, and on account of the great confidence which he had in him, he delivered him his seal to keep, and while he had it in his custody he caused the said deed to be made without his privity. Inasmuch as he thus in part acknowledges the deed to be his, it shall be awarded for the plaintiff ; and let the defendant provide himself for the future with one who will keep his seal safer. And he shall have his action of treason against the plaintiff by appeal of felony, if he pleases ; which action must be prosecuted within a year and a day from the time when 
he first knew of that writing ; or if he will not sue by appeal of felony, he may bring his suit in form of trespass. For if the exception were tried by an inquest, and given against the plaintiff, he would be punished as in form of trespass, and the felony would remain unpunished.

22. Or he may say that the deed ought not to affect him, because it was made on condition, so that if the plaintiff had performed the condition, then he would have been bound to him. *But in proof of this he must show some writing of the plaintiff or enrollment in court of record, in default of which the plaintiff may defend the condition by his law, and recover the demand against the debtor. And if he produce a writing containing the condition, which the plaintiff eannot deny, it shall be tried, whether the plaintiff has performed the condition or not, and this not by rigour of law, but by means of the exception, and according as shall be found concerning the satisfaction of the conclition it shall be aljulged for one or the other. For rigour of law would require that one action should not be tried by another, any more than one question can be resolved by another. But if the condition is contained in the writing produced by the plaintiff, in such ease there shall not be two callses of action.

23. Or the defendant may allege payment, and show an acquittance.

24. Or, if the debt is demanded against him as a surety, and he demands judgment, whether he ought to answer for the debt so long as the principal debtor 
is eapable of doing so, this exception shall be allowed to the defendant, if the cause be true. But if the principal debtor and the pledges are bound each for the whole severally, then the exception shall not be allowed, but judgment shall go for the plaintiff, and the surety shall have his action and his recovery over against the prineipal debtor. And if pledges are jointly bound, and the demand is made severally against one, when there are more than one, and this pledge demands judgment whether he ought to answer severally for the joint obligation, this exception shall be allowed, if the cause be true, and it shall be awarded that the pledge do go without day, and the plaintiff in mercy.

*25. Or he may say that this deed ought not to affect him, because he is the villain of such a one, by reason of his blood and of his tenement, and was of that condition when he made the writing, and whatsoever he has belongs to his lord, so that he has nothing of his own; and he may demand judgment whether he ought to answer to such contract without his lord. And if the plaintiff eannot deny this, it shall be awarded that the plaintiff take nothing by his plaint, but be in merey, and the villain without day. And if the plaintiff brings his plaint against the lord, and the lord demands judgment whether his villain ean bind him, or whether he is bound to answer for the personal act of his villain, it shall also be adjudged against the plaintiff. And the like, in ease where a married woman is bound ; for, we will not that a wife shall have power to bind 
her husband, or a villain his lord, or any other his superior, or a parson his church without the bishop and patron, on account of the mischief which might arise therefrom.

26. Or he may say, that he is impleaded or appealed of felony, and if he demands judgment whether he ought to answer in a plea of debt until he is acquitted of the felony, and if the cause be true, and the felony be capital, then we will that the exception be allower.

27. Or he may say, that he was formerly impleaded for the same debt and by the same person in our court, or in another, where he was acquitted by judgment, and the plaintiff in mercy. And if the plaintiff cannot deny this, or if the parties *put themselves upon proof by the record, let it be adjudged according to the record for one or the other.

28. Or he may plead, that he ought not there to answer concerning this debt, because there is a plea depending concerning the same debt between the same persons in a superior court, or elsewhere in our court. And if the plaintiff cannot deny it, he loses his plaint.

29. Or, if the debt be issuing out of any tenement as an annual rent payable yearly for term of life at least, and the debtor demand judgment whether he ought to answer concerning frank tenement to a plaint or writ of debt without other writ, in such case we will that the plaintiff take nothing, but proceed by writ of annual rent, or by distress.

30. If the plaint is before us or before our Steward, then we will that the debtor answer concerning 
every debt for which he shall be found bound to the plaintiff under the distress and jurisdiction of the Steward of our household, wherever the contract was made, whether within our realm or without, and whether the debt be great or small, so as it does not concern frank tenement. And we will that plaintiffs prosecute their plaints before our Steward for such debts without our writs, but by simple plaint only, and by finding surety to prosecute the plaints; and the like of trespasses *and felonies committed within the verge of our household, wheresoever we shall be in our realm; which verge shall comprise a circumference of twelve miles around our dwelling.

31. When any one shall be attached and shall appear in court before our Steward, being impleaded of a debt, which debt he cannot deny, let it be awarded that the plaintiff recover his debt, and damages by taxation of the court; and let the debtor be delivered to the Marshal, to be kept at his peril, until satisfaction be made of the plaintiff's demand and of the amercement due to us for the wrongful detainer. And if any debtor is bound by pledges at the commencement of the attachment, or after, and the debtor does not acquit his pledges accorling as they are bound for him, let the pledges be immediately distrained to satisfy the plaintiff. Nevertheless let earls and barons found within our verge, and the servants of our household, be summoned for debts, before they are distrained or attached by their bodies, the first out of respect for their persons, and the others out of regard for our 
service. And wherever the Marshal is to exeente his attachments, and does not find sufficient distress to the value of the demand of the plaintiff, he shall execute the attachments by the bodies, whether the lefendants be clerks or laymen, and safely keep the bodies until they submit to the determination of the law, whether the plaints are for debt, or trespass, or felony.

*32. And we will that none be attached by our marshal, except where the debtors are especially bound by their writing to the jurisdiction of our steward. Such as withdraw themselves out of our verge to avoid being attachable by our marshal, shall, wheresoever they are again found within our verge, be answerable for their trespasses or felonies committed within our verge, though not in the same place where they are found. If any one, accused before our steward of a trespass or felony, can prove that the fact was not committed within our verge, or that he was not found within our verge when he was attached, in such eases we will that such exeeptions be allowed to the afendant. Execution of the judgments of our steward, and attachments within our verge shall be made by our marshal, and without the verge by our sheriffs and by virtue of our writs.

33. A person may be indebted several other ways besicles by money borrowed, as by his own recognizance, or by that of his ancestor, who has acknowledged in our eourt that he was inclebted to another in a eertain sum of money to be paid at a certain day, and granted that if he shuuld not pay it, the sheriff should levy it 
out of his lands and chattels. And by virtue of such recognizances made in our court, we will that the lands and heirs of *the recognizors remain bound, whether the heirs are especially mentioned as bound in the recognizances or not; and not only the heirs, but the lands and tenements of the recognizors, into whosesoever hands they come.

34. Also, as a person may be indebted for money borrowed, so he may likewise be indebted by reason of any movable thing borrowed and not returned at the day; and of such things the value and damages should be demanded.

35. And what a person cannot demand of his debtors. by reason of their deaths, shall be demanded against their executors; which demand need not in every case be made against all the executors, but only against such as administer the goods and chattels of the deceased. There are however some debts, which shall not be pleaded in our court, or in any lay court, as those arising from testament and marriage, that is to say, concerning chattels left in the possession of the testator, ${ }^{1}$ and chattels given as a marriage portion.

1 The amnotator in MS. $N$. observes upon this, that will and intention not carried into act are spiritual matters; and that the will and conscience of a testator are so obscure and secret that. no earthly judge can be certified thereof. For that the law of this land determines nothing that is not open and certain, as where an intention is carried into effect by an act. "But the king,' he adds, 'hath sometimes cognizance of devises, not of movable chattels, but of tenements purchased in an enfranchised town, as London or Northampton, which may be devised in like 
But as to chattels of the deceased of which he was not possessed on the day of making his will, such as debts owing to him, and chattels in the hands of others, and also chattels promised and due on account of marriage, of these the cognizance shall belong to our court. And if any debtor die without making any testament, *let those into whose hands the goods of the deceased shall come be answerable for his debts, as is laid down in our statutes of Westminster. But if any person who dies shall simply and without any specialty commit his last will respecting the distribution of all his movables to the disposal of some friend, and such last will can be proved, this shall be a sufficient testament.

36. When any debt is recovered in our court, judg.

manner as movable chattels, because burgesses being in trade generally employ (enplaient) the half, or more, of their goods in their houses (herbergage), the purchase whereof they nay devise, but not their inheritance. The king hath therefore of necessity cognizance thereof as of a thing annexed to freehold. For though the spiritual judge had cognizance of such tenements so devised, he would have no power of execution, inasmuch as such tenements savour more of freehold, yea and of fee and søigniory (oyl e de fee e de sr'), and testament in sucl case is in lieu of cliarter. Wherefore such testaments ought to be solemnly proved in the boroughs, as is customarily done in London, not hy proof of the testament, but by proof that the testament hath been proved in court christian, on account of the disherison done by false testaments.' The writer then gives the form of a writ, addressed to the king's bailiffs of Northampton, which differs little from the writ Ex gravi querela, which may be seen in Reg. Brev. Orig. $244 b$; Vet. Nat. Brev. $85 b$; Fitzl. Nat. Brev. 199. 
ment and execution shall be had according to the ordinance of our statutes, and from him who has nothing, nothing shall be recovered.

37. There is also a kind of debt due to persons from their servants who detain from them their property, and refuse to give an account thereof; in which case the plaintiffs shall have remedy according to the ordinance of our statutes. And if any servant allege, by way of exception, that he has given in his accounts to his lord, or to his lord's attorney, and that the lord or the attorney has his rolls and other memoranda relating to the matters whereof he should render account; in such case if he can verify his exception, it shall be allowed, unless the lord redeliver to him his rolls under the servant's seal. In cases where the action is removed into our court on account of an alleged * wrong of the first auditors, we will that whatsoever was allowed before the first auditors shall remain allowed before the second, so that it shall not be the duty of the auditors in our court to determine anything relating to the account, except as to the wrong which the first auditors may have done to the servant. And we will that no one shall be obliged to render an account to any lord, except ourselves, elsewhere than in the neighborhood where he was his bailiff.

33. There are also other personal actions of which sheriffs may take cognizance by virtue of our writs of Justicies, concerning torts in contracts, as where a covenant is broken, or concerning account, or to enforce a reasonable aid for knighting the lord's son, or 
marrying his daughter, or a right to take water at another's well, or to have a free bull, or free boar, or to have common at a watering-place for his cattle or to take reasonable estovers, or to have a way, or common of fishery, or to enforce an acquittance, or concerning gages damaged or not returned, or eharters, or concerning suits detained, or mills wrongfully ereeted, or houses or folds, or other such nusances; and many other actions, wherein the proceeding is by distress of chattels, and by damages, and the trial is by juries.

\section{*CHAPTER XXX. \\ Of the Sheriff's Tourns.}

1. There are some articles coneerning our Crown and the breach of our peace of which sheriffs may hold plea at other times than on the county days, and in a different place from that where the pleas of the county are held. These pleas are called the tourns of the sheriff, who ought to hold them twice in the year, within every hundred of his county. And that which before the sheriff is called the sheriff's tourn, is in the court of a freeman and in franchises, and in our hundreds, called view of frankpledge, where a more special inquiry is made concerning those whose who are not in any tithing, than is done in the sheriff's tourn.

2. At these tourns all the freemen of the hundred and other landholders being summoned by general summons ought to appear, except clerks, persons in 
religion, and women. At which day let the sheriff cause twelve of the most sage, lawful, and sufficient men out of the whole hundred to be chosen, and to swear they will present the truth of the articles hereinafter mentioned. Afterwards the rest shall be sworn by dozens, and by townships, that they will make lawful presentment to the first twelve jurors upon the articles wherewith they shall be charged by them. Next it shall be enjoined them, that if they find any offender, from whom there may be any danger of life or limb, the name of such offender be secretly presented. Afterwards the following articles shall be delivered to the twelve first jurors, who are to be charged upon their oaths that they will lawfully present the wrongs and offences which they *shall find upon inquiry from the townships by means of these articles.

3. Of mortal enemies of the king or queen, of their children, and of those consenting to them ; of counterfeiters of the king's seal and of his money; of homicides and murlerers; of those who feloniously set fire to the houses or corn of others; of burglars, robbers, and thieves ; of breakers of the king's prison; of ravishers of women; of outlaws and abjurors of the realm who are returned; of sorcerers; and sorceresses ; of apostates and heretics; of traitors ; of poisoners ; of cutpurses ; of usurers; of salesmen knowingly buying and selling stolen meat; of those who knowingly bleach skins of stolen beasts ; and of menders of clothes knowingly buying stolen clothes and turning them into other shapes; of treasure hidden and found in the earth ; of hue and 
cry wrongfully raised, or duly raised and not pursued; of waters stopped or narrowed or turned from their course; of roads stopped, narrowed, or turned; of boundaries removed or wrongfully altered; of walls, houses, gates, marl-pits, ditches, or other nusances raised or made in any common way to the annoyance of the same way and to the danger of passengers; of petty thieves, who shear or *flay sheep or other cattle in the night to steal their skins; of those who take thefbote; and of those who have made a prison in their houses; or committed hamsoken, or breach of pound; and of offenders in parks or in vivaries; of takers of others' pigeons; of breach of the assise of bread and beer, and of those who buy and sell by weights and measures not according to the assise ; of affrays, of brawlers, and of bloodshed; of watches not kept; of the king's highways not widened; of those who have detained approvers in any other prison than in our custody, or other felons elsewhere than in our prison above a day and night; of new franchises, customs, or instruments of correction, ${ }^{1}$ set up since the last tourn, in water or land ; of waif, or wreck of sea found and retainel ; of bridges and highways broken, and who ought to repair them; of rights belonging to the king withheld, as wards, marriages, reliefs, demesnes, advowsons of churches, and all kinds of suits; and of those who claim royal franchises and powers of punishment; and of those of twelve years old and upwards in the hundred who have not come to the tourn.

1 'Gallows, pillory, tumbrel, or the like.' (Note in MS. N.) 
4. All these articles shall also be inquired of at the view of frankpledge; and the following articles besides; whether all the headboroughs are come to the view, and whether they have their tithings complete; *of those of twelve years old or upwards, except clerks, and knights and their children, and women, who are not in tithings, and of their receivers, and of whose mainpast they are $;^{1}$ of vagrants through the country who are not of any one's mainpast, and are of suspicious character.

5. When the townships have given in their verdict to the first jurors, and they are certified of the truth, let the first jurors immediately go and deliver up their presentment to the sheriff, such as they will abide by without being questioned, and let them exhibit the

1 The annotator in MS. $N$ observes here, that frankpledge was so called, 'because villains and naifs ought not to be in tithings, secundum quosdam.' It is not improbable that the term frank, or free, pledge arose from a misinterpretation of the Saxon Friòborh, or pledge of peace. It is true however that the AngloSaxon tithings were composed of 'freemen;' (Leg. Cnut. 20; Cart. Will. I. de stat. 14) ; but the churl was in Saxon nomenclature 'free.' In the laws of William I. it is provided that ' all the villains shall be in frankpledge.' Leg. Will. I. 20. There can be no doubt that the peasants were the principal subjects of this regulation when in its vigour, the military tenants, the liberi homines of Norman law, being exempt. See Bracton $124 b$; Fleta $62(\S 10)$. The doubt above mentioned as to the admission of villains seems to show that at the time when it was entertained either the institution of frankpledge was already in decay, or the peasants were in a great measure enfranchised. 
presentments for felony privately, and the other presentments openly.

6. If any persom indicted of felony be present, he shall be immediately apprehended and carried to our gaol, unless it be any thief or robber in possession of his theft 'handhaving and backbearing,' and the sakeber be present to make his suit, in which case let the evidence be examined, and judgment executed upon him, if the sakeber verifies the thing as his own, or as stolen or robbed out of his custody; and let the punishment be according to the quantity of the thing stolen as before is mentioned. As to such of the persons indicted as shall not be found present, let the persentment be sealed under the seals of the twelve persentors. And the sheriff shall cause them to be apprehend-' ed, and keep such as are not bailable safe in prison until the *first gaol delivery, and bail those who are bailable until the same time.

7. What persons are bailable and what not, is mentioned in our statutes. Besides, those persons are not. bailable, who are indicted or appealed of compassing our death, as is above said; nor those who are apprehended by the judgment of our justices, as persons convicted of open deceit committed in our court, nor those who are apprehended for redisseisin, nor those who by judgment of our court are committed to prison for arrears of accounts, nor those who are taken for rape of women, or by statute merchant, nor those who are convicted of trespassing in parlis and vivaries, or of impeding the execution of judgments of our court, nor 
those who have carried off religious women from their convent, nor those who have carried off infants whose marriages belong to others.

8. As to the presentments made of boundaries removed, ways and waters obstructed, and such other personal trespasses, let the trespassers, if they are present, immediately answer thereto; and if they will not; or if they are not present, then let the twelve presentors be commanded immediately to go and remedy such nusances, if they have been done since the last tourn, by restoring matters to their lawful and usual state. And if such jurors have wrongfully aggrieved any persons in their absence by their presentment, in such case the persons *aggrieved shall have an action to be reinstated, by plaint in the county court, or by our writ, if necessary, either against all the twelve presentors jointly, or against any of them severally. And if the plaintiffs cannot make good their plaints, then let the defendants recover their damage, and the plaintiffs be in mercy.

9. Afterwards let all those be amerced who shall be named as trespassers by the presentments, and those also of twelve years and upwards who have not appeared, except prelates, earls, barons, persons of religion, and women, and except also those who are not living or constantly resident in the hundreds, although they may have dwellings there. As to breach of assises, let the proceedings be as mentioned in the next chapter. In views of frankpledge, let the headboroughs be amerced, who shall not have their tithings complete, 
there present, unless they are excusable by reason of the death of any one or more. Also let those be amerced who are twelve years old and upwards, and who ought to be in a titling and have not been, and those also of whose mainpast they are and have been; but if any person be elsewhere in a tithing, it is sufficient.

10. When any one is to be admitted into a tithing, first he shall find pledges to our bailiffs, that he will be amenable to justice in *our court as often as there shall be occasion, and shall take the oath of fealty to us and to our heirs; and let him be delivered to his pledges, and let his name and the names of his pledges be enrolled.

11. Fealty shall be sworn in these words : Hear this you, N., bailiff, that I, P., from this day forward will be faithful and loyal to our lord E. king of England and his heirs, and will bear unto them faith and loyalty of life and limb, of body and chattels, and of earthly honour, and will neither know nor hear of their hurt or damage, but I will oppose it to the best of my power; so help me God and the Saints. 


\section{CHAPTER XXXI.}

Of Measures.

1. We will that no one have measures in our realm except ourselves, but that every one take his measures and his weights from our standards, as of bushels, gallons, pounds, ells, and other such measures. ${ }^{1}$

2. And we will that the assise of bread be observed in this manner. ${ }^{2}$ When the quarter of wheat is sold for twelvepence, the farthing loaf of wastel bread white and well baked shall weigh $6 \mathrm{lb} .16 \mathrm{~s}$. ; coket bread of the same corn and the same bolter shall weigh more than wastel by two shillings; bread of a lower price than coket and of another bolter shall weigh more than the wastel by $5 s$. ; *simnel bread shall weigh less than the wastel bread by $2 s$, , because it shall be twice baked; the farthing loaf of entire wheat shall weigh one and a half of coket; bread of trayt shall weigh two wastels; bread of all corn shall weigh two cokets. When wheat is sold for $18 d$. the quarter, then the farthing loaf of wastel shall weigh $4 \mathrm{lb} .10 \mathrm{~s}$. $8 d$; ; when

1 As to the measures used in England in the thirteenth century, and their respective quantities, see Assisa de Ponderibus (Stat. incert. temp.), Flet. 72, 73.

2 It should be observed, that the same standard of weight is used for bread and money. The solidus or shilling (s.), is the 20 th, and the denarius, penny or pennyweight $(d$.$) , the 240$ th part of a pound. See below, s. 5 . 
for $2 s$, it shall weigh $68 s$.; when for $2 s .6 \imath l$, the weight shall be $54 s$. $4 \frac{3}{4} d$.; when for $3 s$, the weight shall be $48 s$.; when for $3 s .6 d$, the weight shall be $42 s$; when for $4 s$, the weight shall be $34 s$.; when for $4 s$. $6 d$, then $30 s$.; when for $5 s$, the weight shall be $27 s$. $2 \frac{1}{2} d$.; when for $5 s .6 d$., it shall be $24 s .8 \frac{1}{4} d$.; when for $6 s$., the weight shall be $21 s .8 \frac{1}{4} d$.; when for $6 s 6 d$., it shall be $20 s .11 d$; when for $7 s$. , the weight shall be $19 s .1 d$. ; when for $7 s$. $6 d$., the weight shall be $18 s$. $1 \frac{1}{2} d$. ; when for $8 s$, the weight shall be $17 s$.; when for $8 s .6 d$., the weight shall be $16 s$.; when for $9 s$, then $15 s .0 \frac{1}{4} d$. ; when for $9 s 6 d$., the weight shall be $14 s .4 \frac{1}{2} d$.; when for $10 s$, then $* 13 s .8 d$.; when for $10 s$. $6 d$., the weight shall be $12 s .11 \frac{1}{4} d$; when for $11 s$, then it shall be $12 s$. $4 d$; when for $11 s$. $6 d$., then the weight shall be $11 s$. $10 d$; when for $12 s$, the weight shall be $11 s .4 d$; so that the weight of the loaf shall be changed for every $6 d$. rising or falling in the quarter of corn.

3. The baker may still gain out of every quarter of wheat threepence, and the bran and two loaves of the value of two sterlings ${ }^{1}$ for his oven, three halfpence for the wages of his three servants, and one halfpenny for the wages of two boys, and one halfpenny for salt and for the bolter. We will that if a baker be convicted of false weight, ${ }^{2}$ where there is found a deficiency

${ }^{1} \mathrm{~A}$ sterling appears to be the same as a penny. 'Denarius Anglicanus, qui vocatur sterlingus, rotundus et sine tonsura, ponderabit xxxii. grana frumenti in medio spice.' Assisa de ponderibus. (Stat. incert. temp.) : Fleta 72.73.

${ }^{2}$ Similar varieties of readings to those mentioned in the note 
of the weight of one farthing in the weight of two shillings, he shall be amerciable; and for any greater default he shall be set in the pillory.

*4. The assise of beer shall be observed in this manner. When a quarter of wheat is worth from three shillings to forty pence, and a quarter of barley from twenty pence to two shillings, and a quarter of oats sixteen pence, then two gallons of beer shall be sold in cities and boroughs for one penny, and in country places three gallons of beer for one penny; and when three gallons are sold in cities and boroughs for one penny, then four shall be sold without for a penny; and when the quarter of barley shall be sold for two shillings, three gallons of beer shall be worth a penny; thus the market of beer shall rise and fall according to the current price of corn.

5. And whereas we have entrusted one of our officers with the custody of the standards and samples of our weights and measures, we will that this officer shall have jurisdiction and cognizance of false weights and measures throughout our verge, wheresoever we be in our territory, within franchise and without, and to burn such as be shall find false, and to amerce and otherwise punish those who have made use of such weights or measures. We have also appointed him to delirer standards to all those who require them, where-

above are also found in the several copies of the Latin Assisa panis, (Stat. incert. temp.) See Statutes of the Realm, (Rec. Com.) p. 200. See also Fleta 72. The Assisa panis was formerly printed as a statute of the 51st year of Henry III. 
of the pound shall weigh twenty shillings of current money; the ell shall be two cubits and two inches; a bushel shall contain two hundred pounds in pence, and a gallon twenty-five pounds. Merchants *nevertheless shall have their weights as far as regards avoirdupois ${ }^{1}$ according to their customs.

6 . When the officer of the measures is to perform his office, let him do it in this manner. First let him go with his standards from market to market, wherever he shall find any within the verge, and immediately summon the bailiffs to come before him to perform what he shall enjoin them on our behalf. And if they will not come, or if they come and will not be obedient to him, let the franchise of the market be taken into our hand, if it is held by any other than by us; and if they are our bailiffs, let them be punished by imprisonment and fine. If the bailiffs appear as they ought to do, then let them be commanded that they cause to be brought before him all the bushels and half bushels, and quarts, gallons, and half gallons, and all other measures whereby people have bought or sold in the town, and from every baker a loaf of every sort, and all the bakers and brewers of the town, and the taverners, and all those to whom the measures belong, and other good people of the town, by whom be may inquire the truth concerning the articles of his office. And those who are summoned and do not come, if the summons be proved, shall be in mercy. When they are come before him, he shall immediately cause twelve

${ }^{1}$ See above, c. $\mathbf{x x i i .}$ s. 22, and note there, p. 80 . 
of the most lawful householders to be sworn, that they will present the truth of the articles wherewith they shall be charged on our behalf.

*7. The articles shall be these: whether the lord of the franchise hath set up a market there of his own authority, or by our warrant, and if by our charter, whether he hath the franchise of view of frankpledge or not, and whether he has the correction of the breach of assise of bread and beer, and whether he has the instruments of punishment appendant to such franchises, as gallows, pillory, and tumbrel. And if it be found that he has no market or franchise by our warrant, the franchise shall be seised into our hand, and the sheriff of the place shall be responsible to us for the issues. Likewise if he has the franchise of view, but no gallows, the view shall be seised into our hands, and also the correction of breach of assise, for want of other instruments of punishment. ${ }^{1}$

8. Afterwards let inquiry be made concerning bakers and brewers, ${ }^{2}$ who have baked and brewed out of the right assise, how many times they have been amerced, and how many times sentenced to the pillory, and for what amount of offence they were amerced or put in the pillory; and for every illegal judgment let the

1 This passage is obscure, and possibly corrupt. The fourches or gallows would only be required where the lord had jurisdiction of infangthief.

2 It will be observed, that the word in the original implies that the trade was carried on by females. So in the Latin Assisa panis (Stat. inc. temp.) the; word is braciatrix. 
franchise be seised into our hands. Let inquiry afterwards be made whether any man or woman has been destroyed in consequence of the instruments of punishment being faulty or out of repair, and if such default be found, the franchise shall be seised into our hands; and if our bailiffs are in fault, they shall be punished by imprisonment and fine.

9. Afterwards let it be inquired concerning taverners, who since the last eyre in the *county have sold wine contrary to the legal assise, and how much their profit above the right assise amounts to; and if they are living, let them be punished by pillory and fined in double the value of their gain. Afterwards let inquiry be made concerning those who buy by one kind of measure, and sell by a false measure of less quantity ; and let them be punished as the sellers of wines; and likewise those who shall be convicted of false ells and of false weights; also salesmen and cooks, who make a practice of selling to passers-by bad meat, tainted or diseased, or otherwise dangerous to the health of man. Likewise forestallers, who raise the market price of victuals by their dealings outside the market.

10. Afterwards let the weights and measures be severally examined, and the good ones be restored to the owners, and the false ones burned. And let the bakers and brewers convicted of breaking the assise be punished in proportion to their offence either by amercements or pillory. And let our officer of measures without delay cause the estreats and the enrollment of his proceedings to be delivered to the 
Steward of our household, who shall speedily cause such estreats to be levied by the marshal, or by summons out of our Exchequer.

Here ends the subject of pure personalty, and begins that of the condition of villuins.

\section{*CHAPTER XXXII.}

\section{Of Villenage.}

1. We have above in part treated of the law of free persons ; we must now treat of the condition of villains. This condition was of ancient time changed from freedom to bondage by the constitution of nations, and not by the law of nature, as it stood at the time of the flood and earlier, when all things were common to every one, and all men were entirely free, and lived according to the law of nature. But from the increase of mankind and the appropriation of goods which before were common, battles arose in divers places in the world, and to avoid bloodshed and the perilous chances of battle, it was then orlained by the constitution of nations that men should not kill one another, but whenever one could take another in battle, that the person taken should for ever remain a bondman to him who took him, to do with him and all his issue that should proceed from him whatsoever he would, as with his beast or chattel, to give, to sell, and to kill. Afterwards it was ordained, on account of the cruelty of some lords, that no one should kill them, but that their 
lives and limbs, as well as those of free men, should be under the protection of kings and prinees. 1 Whence the law is this, that whosoever kills his villain, shall bear the same judgment as if he had killed a free man.

2. There is another kind of naifs who are not naifs by ancient birth, but are properly villains, ${ }^{2}$ such as *free

1 Although the property of villains is in their lord, yet he may not kill them. inasmuch as life and limb belong to the king, who has in every subject a sort of remote fee by title of seignory (qi ad en chescun homme auxi come un fee sutyl en noun de seignurie). The lord is therefore in the position of a mesne between his bondsman (serf) and the king, and ought to treat his villain in due manner as for his employment, and not for his destruction (pur lui enprower e ne mie dampnier.' Note in MS. $N$.

2 The annotator in MS. $N$. distinguishes between naifs, villains, and serfs in the following way: "Naif is he that has come of such lineage that they lave been in servitude for several generations (qe tote voirs de eve e de treve unt esté en servage). Villain is he that has come afresh into servitude, from which he cannot depart though he be of a free stock. Serf is he who is not absolutely a villain, nor absolutely free, but is de facto in servitude, as a freeman who marries a nief and enters into the villain tenement, and does to his wife's lord the villain customs which belong to the land held in the villenage. Wherefore this freeman and the issue he has by the nief, are serfs de facto and freemen de jure, and are called serfs for the servitude in which they are. Wherefore if the issue of this freeman remains in servitude, and his issue the same all their lives, and so on to the fourth degree, the fourth will be a villain for ever, and those who come of him.' I do not know any other authority for this last statement, which is inconsistent with the text of Britton, (see below, ss. 3, 19.) but may probably have agreed well with the earlier practice. (See note on sect. 4.) The whole passage. 
men who have acknowledged themselves in our court to be villains, or who have been in any manner convicted as villains by plea under our writ of Naifty. Beside those mentioned, there are no other kinds of villains.

3. With respect to those who by reason of any tenement have made redemption of blood ${ }^{1}$ or done other villain services, although they and their ancestors have performed such services from one generation to another, ${ }^{2}$ if any one sprung from such a stock has fled from his lord, and is demanded by him as his villain, . and such fugitive can prove his stock to be free by good inquest of the neighbourhood, and that the lord claiming him was not seised of him and his ancestors as compared with the other authorities, shows the uncertain and fluctuating condition both of the law on this subject, and of the meaning of the terms employed.

1 'Redemption of blood' is the same as mercheta or merchetum, called in Fleta, merchetum sanguinis (Fle. 193), a customary payment made by a tenant for license to give his daughter in marriage. This custom was considered a special mark of tenure in villenage. (Brac. 26, 195, $208 b$; Littleton, Tenures, ss. 174, 209).

2 The annotator in MS. $N$, in a note upon Bracton, c. 11, has the following explanation of the expression of the text : 'Unum est genus hominum, qui dicuntur villici sive rustiei et nativi ex avo et tritavo; unde Gallice dicitur, vileyn de eyve e de trey ve; quia villici sunt personaliter.' It will be seen that the annotator himself uses the phrase in the note last cited. Coke has a different explanation. See Coke Lit. $25 b$. The same expression is found in the Year Books. Hil. 1 Edw. II. p. 4. ; Pasck. 15 Edw. II. p. 464. 
as his villains by reason of their bodies, but by reason of the tenement which they held of him in villenage; in such case judgment shall be given against the lords. For justice will not allow that villenage, by any long. seisin of a servile tenement, shall make any freeman a bondman; nor, on the other hand, that long seisin of a free tenement shall change the condition of a villain into free estate. So that none can be a villain except. by birth, or by recognizance. Nor can one be more a villain than another; for they are all of equal condition,-whosoever is a bondman, is as absolutely a bondman as any other. ${ }^{1}$

4. Nevertheless all who are begotten by villains are not bondmen, for no one begotten by a bondman of a free woman out of *matrimony is a bondman, although

1 The doctrine that there is no distinction of condition among those not accounted free, appears to have been imported by Bracton or his predecessors from the civil law. 'In servorum conditione nulla est differentia.' (Justin. Inst. li. 1. tit. 3. § 5.) In Anglo-Saxon and early Norman times nothing is more remarkable than the gradations of servitude among the peasants. In Domesday Book the various classes inferiol to the liberi homines (villani, bordarii cotseti, \&c.) are clearly distinguished from the bondmen or slaves (servi). In Glanvill (li. 5. s. 4.) the word servitus is used as equivalent to villenagium or nativitas, but I think that the term serves is not employed, the various expressions being in villenagium positus nativus (li. 5. passim), and rusticus (li. 14. c. 1). In Bracton and Fleta servus nativus, and villanus appear to be synonymous. This confusion of ancient distinctions was pointed out in the fourteenth century by Andrew Horne in the Mirror of Justices. (Mirror. c. 2. s. 28. p. 169 ; c. 5. s. 1. pp. 291 , 295.) 
it happen that the issue be afterwards born within matrimony. Nor shall he be a bondman who was begotten on a bondwoman in matrimony, so as the father be free. ${ }^{1}$

5. Where any one is by birth a bondman, he shall be merely the chattel of his lord to give and sell at his pleasure. But as bondmen are annexed to the freehold of the lord, ${ }^{2}$ they are not derisable by testament; and therefore Holy Church can take no cognizance of them in Court Christian, although devised in a testament.

${ }^{1}$ In Glanvill's time the children followed the status of the mother, according to the rule of the civil law: 'Servi sunt qui ex ancillis nostris nascuntner'; (Dig. li. 1. tit. 5. 1. 5.) and the free husband, if he adopted his wife's estate, and lived upon a tenement held by her in villenage, forfeited 'his law.' (Glan. li. 5. c. 6.) In the time of Bracton, if the father was a freeholder, and the children were born in librero toro. they were free; but if the husband adopted his wife's estate, and the children were born in villenagio, they followed their mother's condition. (Brac. 5, 193 b.) The more liberal rule stated in the text prevailed in later times. (Littleton, Tenures, s. 187.)

${ }^{2}$ It should not pass without notice, that there is no mention in Breton or in the other earlier authors (so far as I an aware) of the class of boudman described by Littleton as villains in gross. (Littleton, Tenures, s. 181.) Examples may be found of villains being transferred in the thirteenth century from one lord to another without the soil on which they lived; but they were probably held to become annexed to the new manor upon which they were settled. The Mirror agrees with our author in treating villains as always annexed to the freehold. (Mirror, c. 2. s. 23. p. 166.) Servitude, as a personal relation, eppears to have been then unknown in England. 
6. A villain may recover his freelom several ways, as if his lord enfeoff him of any tenement to him and his heirs, whether he receive his homage or not; for since it is the lord's pleasure that his bondman shall have heirs of his own other than the lord, and that his heirs shall succeed to his inheritance, it sufficiently appears that he intends his bondman have the status of a freeman. A bondman also becomes free if he marries his lady, as well as a nief when her lord marries her; for otherwise so great inconvenience would ensue, that the heir should be villain to himself, and the land should escheat to the chief lord, who wonld hold the heir as his villain, when perhaps neither he nor any of his lineage were ever so. ${ }^{1}$ But if a villain espouses a free woman who has land in fee, their son born in matrimony $*$ is a villain, and his lord shall acquire the land of the mother either by his own entry or by means of his villain, heir to his mother, by assise of Mortdancester, if she does not assign it over in her lifetime, and the son survives her, and she has no other issue which is free. Wherefore when any bondman or bondwoman once becomes free, or is enfranchised by the free bed of his lord or of any other, we ordain in favour of freedom and of matrimony that they and their issue shall for ever be held free, and the husbands be entitled to hold by the courtesy of England, and the wives to dower.

7. We will that villains in all actions be answerable to every one, and every one to them, so that the excep-

1 That is they were not the villains of that lord. 
tion of villenage shall only hold good between the lord and his villain, ${ }^{1}$ and that only when the lord has been in recent possession of him and of his suit, or at the least has been seised of him as his villain within a year and a day.

8. A bondman may be enfranchised also by the recognizance of his lord, as if his lord has acknowledged him to be free in a court of record. So also if he be waived by the lord, as where the lord has abandoned him. Likewise, by writing of his lord, as if his lord has for himself and his heirs quitclaimed to the bondman and his heirs all manner of right which he had or might have in the person of the naif by reason of the bondage of his blood. *Villains may also recover their freedom by the negligence of their lords, as if any lord suffer his villain to be fugitive for time of prescription limited in our writ of Mortdancester; or to abide within our demesnes without challenge for a year and a day,-a privilege which was heretofore granted to us by eommon allowance for our profit and for the improvement of our towns. Likewise, if he permit his naif ${ }^{2}$ to be ordained clerk, or created a knight,

1 The principle here stated was of gradual introduction. According to Glanvill a stranger might in some cases except to the competency of a naif to take part in certain legal proceedings even after his enfranchisement. For the lord could make him free as against himself, but not as against third parties. (Glan. li. 5. c. 5.) Compare before c. 29. s. 6, p. 159, and the note there.

2 "The lord who permits his villain to be on the level of a freenań (a foer de franc homme) loses the right to his service; or if 
at least until they be degraded from their orders ; and so in the case of his naif, if he suffer her to be married to a freeman, she and all her issue shall for ever after be of free estate, as before is said.

9. Where any naif flies from his lord, his lord may pursue him as his chattel, to apprehend and bring him back into his fee wheresoever he shall find him within the year and day. But after that time they shall be deemed free as much as they please, until the lords can recover them by judgment of our court. It is not however necessary for every lord to keep his villain as a prisoner; but it is sufficient if the lords are in possession of their services, so as to take of some the services due from their tenements, and from others, who hold nothing in villenage, a penny a year for chevage, and one day's work in harvest, or other service, small *or great, according to their ability. So that the lord's right of action to recover his fugitive naif commences when the naif ceases to preform such services and to acknowlerlge him for his lord.

10. If the lord cannot find the fugitive in his fee, nor bring him to justice within the year and day, we will command the sheriff of the place in whose bailiwick the villain shall be residing, that he ' justly and without delay cause such a one the plaintiff to have such a one his naif and fugitive with all his chattels and all

he suffers him to be his attorney, or juror on an assise (ou assisr) or clerk, or knight, or burgess, and in other cases where the sufferance of the lord shows his intention that the villain should have any reverence out of servitude.' (Note in MS. N.) 
his suit.' In this plaint no summons lies, but the first process is distress, and the first distress is retained and others taken, if the plea be in the county court, until the defendant appears or is attached by pledges.

11. And because the fugitive may allege freedom, a matter which the sheriff has not jurisdiction to try, we have, in favour of freedom, granted to such fugitives that whenever they find themselves aggrieved by such proceedings of their lords, they shall have peace from such grievances until the eyre of our justices in that county, and that they shall have our writs for that purpose, whenever they wish to obtain them, upon fincling pledges to the sheriffs to prove their freedom in the eyre aforesaid; and that in the meantime they shall have peace.

12. This writ of peace is called the writ De libertate, and in favour of freedom the pleadings are sooner dispatched than in a writ * De nativo, unless the person who purchased the writ fail to appear, upon which he and his pledges shall be in mercy for his nonsuit. If, on the other hand, he prosecutes his suit, and the lord makes default, and the summons be in evidence, let it be awarded that he be free, and the lord in mercy, because he has wrongfully aggrieved him, and let the sheriff be commanded not to permit the lord to aggrieve him for the future. If the lord appears, it then lies on the bondman to prove his freedom, which he may do in divers ways, as appears by the several points, which have been stated in this chapter.

13. In a plea of naifty (as also in pleas of Replegiari 
facias, Venire facias, and the like) no essoin is to be allowed to the defendant until after appearance. And if the lord offers himself, and the fugitive makes default, let it be awarded on account of his default, that the fugitive and his pledges be in mercy, and that the plaintiff by the default of the fugitive do make proof of his naifty against the fugitive, so that the fugitive be never afterwards admitted in our court to prove his freedom, and that he be distrained by the grand distress until he appear.

14. If any lord has obtained a writ to remove the plaints by Pone to a higher court, before any plaint upon the original writ is commenced in the county court the Pone shall thereby be abatable, on account of the false suggestion therein contained, which supposes a plaint to be in the *county court, where in fact no summons was ever made. For before summons or attachment or appearance, a plaint is never in court. And this may be verified by the date of the Pone and the day of the summons.

15. And when he is in court, let the plaintiff count against him by himself or his serjeant in this manner: 'John who is bere declareth this to you, that Peter who is there wrongfully fled from him, and herein wrongfully, that he is his villain who fled from his land within the term, \&c., and of whom he was seised as of his villain until such a year when be fled from him.' Forasmuch as the effect of this writ is to determine the possession as of a chattel, it is not proper to count in this plea by descent nor by resort, nor to touch at 
all upon the right ${ }^{1}$, no mention being made thereof in the writ. For then there would be a variance between the writ and the declaration, and so the writ would be abatable. And besides, if one could so count, the defendant might then defend the right by battle, or by the great assise, which would be a great inconvenience to the lord. And because proof of naifty is made by suit, he must add thus, ' and if he denies this, he denies it wrongfully, for the plaintiff hath thereof suit good and sufficient.'

16. And immediately let the suit be examined, not only by taking their acknowledgments whether they are villains to the plaintiff, but whether he against whom the plaint is prosecuted was ever upon the land of the plaintiff, and in what manner the plaintiff was seised of him. *And if the suit be found to disagree, in so much is it bad and defective, and the plaint shall be lost.

17. But if the suit agrees, then let the defendant answer thus: "Peter who is here defends the wrong and force, and the flight from the land of John and the naifty, and will defend the same where and when he ought.'

18. Afterwards he shall aid himself by exceptions to the judge, and then to the person of the plaintiff, and afterwards to his own person; and next by exception to the writ if there is any defect or error; and afterwards to the declaration, if there is any defect, omission, or variance in it; and lastly to the action.

1 The property, as distinguished from the possession. 
19. Thus he may say that 'he is a freeman, and Robert his father was free, and those of the suit were free, until they acknowledged themselves villains; for in the reign of king Richard,' or of some other king, ' it came to pass that a certain linight begot one Theobald, great-grandfather of this same Peter, which Theobald married the nief of the ancestor of the same John, who held land of him in villenage, which Theobald as long as he lived performed the villain services to the tenement appertaining, and died in the same villenage ; that from Theobald came Philip, from Philip William, from William Simon, from Simon Robert, from Robert Peter who is here, all of whom performed the services aforesaicl by reason of the *villain tenement, and not by reason of their persons, until the time of Robert, father of this same Peter. $\Lambda$ nd if he can prove this by inquest, it shall be adjudged against the plaintiff.

20. The defendant may also aid himself by exceptions against the suit, for he may say that as to one of his kindred loe is not admissible in evidence. For if there were three of his male kindred, and fire females, or more or less, and he can aver of one of the kinsmen that he was begotten out of matrimony of a free woman, and that the second kinsman who offers himself for suit was begotten in marriage by a freenan although his mother was a nief, notwithstanding he has no exception to make against the third kinsman of the suit, we will that if he demands judgment whether he ought to answer to the suit of a single man, it shall 
in such case be adjudged against the plaintiff; because the blood of a man cannot nor ought to be tried by means of women, neither is one male alone without more to be admitted as sufficient suit.

21. Or he may plead that he has done homage to his lord for a tenement; or that his lord has released bim from all actions; or that he married his lady; or (if the defendant is a woman) that she was married to her lord or to another freeman. Or he may be aided by other peremptory exceptions, as above is mentioned.

22. If any one pleads that he is a clerk or knight, in such ease judgment shall be given against the plaintiff, * who must impute it to his own negligence. And if the clerk or the knight had not leave from the lord to talie upon him such orler, or those who ordained them to confer the same upon them, then the lord shall have his action to recover against those who ordained them to be knights or clerks such damages as he can reasonably assign. And if such knights or clerks refuse to perform honourable, services becoming their station more readily and eheerfully to such natural lords than to others, or behave in any other manner unnaturally to them, in such cases we will that they be degraded; and if this cannot be done, that satisfaction be made to their lords out of their chattels ; and if their chattels are not sufficient, let those who ordained them be answerable.

23. Or the defendant may say that the plaintiff is not entitled to an answer, inasmuch as this is an action limited within a certain term (as other actions are), 
and inasmuch as neither he nor any of his ancestors were ever within the term seised of him or any of his ancestors, as their villains, he may demand judgment whether he is at this time bound to answer to him. And if this be proved, the plaintiff shall be convicted of false plaint. But to this, as in all other actions, he may reply that such plea ought not to arail the defendant, for that by continual claims he has been *theretofore demanded and his ancestors likewise, by him and his ancestors by other like writs, but by the death of his ancestors or by the king's death those writs abated.

24. Or the defendant may plead that he has resided upon our demesne lands or elsewhere in any of our towns or cities for a year and a day without having been claimed by the plaintiff, and if he demands judgment whether in such case he ought to answer, and can verify this exception, the lord shall be forejudged of his action for his negligence. So also, where the defendant can prove by record of our court that the lord has knowingly suffered him to be upon juries and inquests in our court as a freeman. So, if he can verify by record that he has recovered frank tenement against him by judgment of our court, wherein the plaintiff did not allege any exception of villenage against him.

25. Or he may say that the plaintiff ought not to be answered until he has fully restored to him whatever goods of his he detains from him, or hath detained since he claimed free estate; which plea shall be 
allowable by reason of the words contained in our writ, which says, 'with all his chattels and all his suit,' so that the plaintiff in his own writ supposes himself not to be seised of any of the chattels.

26. If judgment is given for the plaintiff, let it be awarded that the plaintiff recover him as his villain with all his suit and *all his chattels and all his acquisitions, and that the villain have no heir other than the lord, and the villain shall remain in our mercy.

Here ends the book of personal pleas, and begins that of real pleas. 


\section{BOOK II.}

OF DISSEISINS AND THEIR REMEDIES.

\section{CHA PTER I.}

Of Suits concerning Land, pleadable by Attachment.

HAvivg gone through the form and manner of pleading personal pleas pleadable by attachments of the body or by distresses of movable goods, we must now treat of pleas concerning land, in which the process is by attachment of the very thing demanded. And first, of those pleas which more nearly concern the breach of our peace by fresh force, as when a person is wrongfully ejected or disturbed in the peaceable possession of his freehold, which act of violence is called disseisin, and fiesh force. And in favour of complainants it is ordained that disseisins may be pleaded by petty assises in the connties where the lands lie, in the $a b-$ sence as well as in the presence of the offenders.

2. There can be no disseisin except of a freehold. ${ }^{1}$ A freehold is a possession of soil or of services is suing out of the soil by a freeman holding in fee to

1 . Note that there is a difference between seisin and possession, for one supposes a term of life, and the other a term of rears. Note in MS. $N$.

174 
him and his heirs, or at the least for term of life, whether the soil be charged with free or other services. Fee is a right vested in the person of the true heir, or any other who hath acquired it by lawful title, whoever may be seised of the freehold. And this is the property, whereof one may have more and another less, as the heir of the disseisor has one kind of fee and of property, but the disseisee has a greater. But inasmuch as no one can be disseised unless he be first seised, we will therefore, before we proceed to pleas, show in what manner seisin may be acquired.

\section{CHAPTER II.}

\section{Of Purchase.}

1. Some things are corporeal, as those which one may touch; others incorporeal, as properties, rights, fees, and easements of tenements. Some things are common, as the sea, the air, and the sea shore, and as the right of fishing in tidal waters and in the sea, and in common waters and rivers; and some things are common in a less degree, as being common to certain communities, as the walls and gates of cities and boroughs; other sare common in a more special manner, as lands, rents, and other possessions and rights granted for the common advantage of a community, for which no single plaint can be made by a stranger who is not of the community, *nor can any single person bring such tenements in judgment, in the absence of the 
community, or plead or be impleaded by any stranger; for a member cannot answer for the whole body, except as an attorney.

2. There are some things which are no one's property, as things sacred and dedicated to God by prelates of holy church, such as are churchyards, burialplaces, churches, chapels, and other consecrated places, whether they are built upon or not. For things divine ought not to be appropriated to human purposes. And if they have been built upon, although the structure fall down, the place still remains sacred. There are also some things which are not the goods of any person, and which are consecrated in the name of God in holy church, such as chalices, censers, crosses, vestments and other like things, which are forbidden to be sold, given away, or alienated, except for ransoming Christian slaves from the lands of pagans.

3. There are also some things which in their natural state are no one's property, and whereof none can make a gift, as birds, stags, does, and other wild beasts, and fishes. So likewise land or other hereditament whereof no person is in seisin. So likewise freemen; and villains deserted and ejected by their lords, whoimmediately become free; *and all other things abandoned and remaining out of the possession of any one, but in which things a property may be acquired by occupancy.

4. Acquisition or purchase may be in divers ways; for wild creatures taken elsewhere than in a forbidden place or a warren, belong to the taker so long as he 
keeps them. But if the creature escapes, and resumes its wildness and its natural state, so that there is no likelihood of its return, it will afterwards belong, not to him who can wound it, but only to him who can take it. ${ }^{1}$ One may also acquire a property by inclosing of fish and other wild creatures, as bees. For though bees settle upon a tree, yet the bees do not belong to the owner of the tree, until he has inclosed them in his hive; no more than birds which have built their nest on a tree, for if another takes them, they are his. But if the owner of the tree takes another person's bees in bis tree, and knows whose they are, he will be bound to restore them, or to keep them upon terms of divided enjoyment for half the profit which they shall produce. No person can detain from another birls or beasts ferce nature, which have been domesticated, without being guilty of robbery or of open trespass against our peace, if due pursuit be made thereof within the year and day, to prevent their being claimed as estrays.

*5. Property may also be acquired by virtue of franchises granted by us concerning things found, which do not belong to anybody, as wreck of sea, beasts estray, rabbits, hares, fish, pheasants, partridges, and other wild creatures; that is to say, by a franchise to

1 This passage appears obscure. The sense is borrowed from Bracton, who observes that the mere pursuit of a wild animal, even though the pursuer succeeds in so wounding it as to make it possible to take it, will not make it his property, but it will belong to the first person who secures it. Brac. $8 b$. 
have wreck of sea found on his soil, waifs and estrays found in his fee, and warrens in his demesne lands. Property may likewise be acquired by the increase and produce of beasts and other animals belonging to people; and also by the finding of gems and precious stones on the sea beach or elsewhere in places common to all; so by fishing and by other labour as well at sea as on land. And if any island is found in the sea which is not any one's property, whatever is found therein shall belong to the finder as long as he shall keep it in his hands or in his possession.

6. A purchase or acquisition may also accrue from the fraud and folly of another, as where persons by malice or ignorance build with their own timber on another's soil, or where they plant or engraft trees or sow their grain in another's land, without the leave of the owner of the soil. In such cases what is built, planted, and sown shall belong to the owner of the soil, upon the presumption of a gift; for there is a great presumption that such builders, planters, or sowers intend that *what is so built, planted, or sown should belong to the owners of the soil, especially if such structures are fixed with nails, or the plants or seeds bave taken root. But if any one becomes aware of his folly, and speedily removes his timber or his trees, before our prohibition comes against his removing them, and before the timber is fastened with nails, or the trees have taken root, he may lawfully do so.

7. With regard to immovable things of common right, found in the possession of no one, a property 
may be purchased in many ways. One way is by a subtraction of water whereby any one's soil is increased by little and little, provided the lands are not bounded between neighbours. But it would be otherwise in case of a sudden increase; for if one neighbour by the riolence of a flood is deprived of part of his soil, whereby the soil of his neighbour on the other side of the water is increased, by such a sudden increase nothing shall be lost, unless the river be an arm of the sea; but the soil may be recovered by this assise, if the true possessor be deforced, unless he be barred by negligence. But if the increase has been so gradual, that no one could discover or see it, and has been added by length of time, as in a course of many years, and not in one day or in one year, and the channel and course of the water is itself moving towards the loser, in that case such addition remains the purchase *and the fee and freehold of the purchaser, if certain bounds are not found. And by increase of the demesne the seigniories and fees of the lords increase, and the lords may distrain as well in such alditions as elsewhere in their fees without doing a wrong.

8. If a new island is formed in the water, the island shall belong to him whose soil is nearest adjoining to it, in whole or in part according as it rises in the middle or towards one bank of the water. If an island grows up in the sea, it shall belong to the person who shall be found in possession of it. It is otherwis? however of an island made by the sea in any one's so: for the island shall belong to the owner of the fee and 
of the soil; and if he be deforced, he shall be aided by. this assise.

9. There is also a good title, called succession, as that of the right heir to his inheritance, and of successor to the rights of his church, whereof his predlecessor died seised. How an inheritance descends, and to whom, shall be explained in the book concerning Right in the chapter concerning Successions. There is also a kind of title which has some resemblance to succession, namely, title by accruer. This is where by the death of one parcener without heir his share accrues to the other parceners.

10. Things which are not in the seisin of another may be purchased by title of gift, and of feoffment, and also by succession, escheat, reversion, *assignment of dower, hiring, borrowing, and by title of testament. A freehold may also be acquired by being the father of issue born alive, by a special privilege which has the force of law in England and Ireland, and in many other ways. And with regard to the purchase of corporeal things, no gift is sufticient without delivery of seisin. 


\section{CHAPTER III.}

\section{Of Gifts.}

1. A gift is an act whereby anything is voluntarily transferred from the true possessor to another person, with the full intention that the thing shall not return to the donor, and with full intention on the part of the receiver to retain the thing entirely as his own without restoring it to the giver. For a gift cannot be properly made, if the thing given does not so belong to the receiver, that the two rights, of property and of possession, are united in his person, so that the gift cannot be revoked by the donor, or made void by another, in whom the lawful property is vested; as may be done in the case of donations and feoffments by disseisors, and other like gifts in prejudice of the right of another. Gift is a more general term than feoffment; for gift is applicable to all things movable and *immovable, and feoffment is only of soil, whereof a person, being wrongfully ejected, may recover seisin by this assise.

2. It should be known, that some persons have power to give, and others not. For no one can effectually give but he in whose person the possession and the property are vested, and sometimes those who have nothing but the fee and the property, as by assignments 
and recognizances in our court; all other manner of gifts are revocable.

3. Kings also may not so alion the rights of their crown or of their royalty as not to be revocable by their successors. It is nevertheless allowable for kings to grant baronies and other demesnes, and franchises, sometimes in alms, at other times to have the prelates and other sage persons of the realm of their council, so as they be summonable by the king and amenable to his justice; and in other cases in fee farm, as cities, boroughs, and other demesnes; and in other cases to retain the love of their people; and in other cases for dispatch of justice, for which several franchises are granted, as that of infangthef, and the power of holding plea in a writ of right, and other franchises.

4. Neither can prelates of holy church so alien the rights of their ehurches, nor templars, hospitallers, or other persons in religion, as that their gifts shall not be revocable by the clonors. *Neither can earls, barons, knights, or serjeants, who hold in chief of us, so dismember our fees without our leave as that we may not lawfully eject the purchasers; nor in such case will it avail to allege length of scisin, inasmuch as no time is limited for the recovery of our rights.

5. Felons cannot after the commission of their felony makeany alienation, which may not be revolied by the lords of the fee by our writs of Entry and Escheat. And bastards enfeoffed to themselves and their heirs (where assigns are not specified in the feoffment) cannot alien so as to prevent the lords of the fees from 
having the lands aliened as their escheat. Nor may infants within age, nor natural fools, nor madmen, nor deaf persons, nor dumb, nor lepers removed from the society of people, nor villains, make any alienation, nor solkemen of their socage.

6. Neither can married women alien without their husbands; nor can husbands without their wives make such a gift of any part of the inheritance of their wives as shall not be revocable by the wives if they survive their husbands; nor yet wives with their husbands in prejudice of those in whose persons the fee and property are vested by form of the gift, *as in fees tail; nor may husbands give anything to their wives, nor the reverse, after the contract of marriage.

7. Those also cannot effectually give who do so through fear of death, prorided they will revoke their deeds as soon as they escape from prison. But unless fear of death can be alleged, any one may give as well in prison as without. Likewise lunatics and frenzied persons may give an alien, but not during their madness. And persons in religion may give before they are professed, and lepers before they are put out of the society of healthy people; fools also, so as they are not fools born.

8. But whether a gift be lawful or wrongful, if the purchaser be challenged in his seisin it becomes the duty of the donor to warrant his gift as long as he lives, although he be not bound thereto by any special clause in a deed, and although the purchaser do homage for the same to another than the donor, as to the 
chief lord. And if the donor has bound his heirs to warranty, and the purchaser is impleaded, he shall never be deprived of the gift without the heirs making it up to him in value, supposing they have wherewith to do so, if they cannot defend him in his seisin, and the purchaser proceeds according to law. *But if warranty is excepted, then he must proceed according as it was covenanted between them. Such purchasers may act foolishly, and defeat their own right in this manner, and in like cases. A. ejects B. of his freehold, and gives it to C.; B. proceeds by this assise; A., doubting the result of the assise, ejects $C$., and restores the land to $\mathrm{B}$., who receives it as his freehold restored, and not by gift. If $\mathrm{C}$. proceeds by this assise, he shall have judgment to eject B., and so B. will lose the possession through his own folly.

9. There are other kinds of gifts, which are not absolute gifts, but are rather leases and demises for a term, or in fee, and whereont a man looks for the reversion or some annual service. Of which gifts some are conditional, and in such the fee is cut down and in suspense until a certain thing happens, as shall be afterwarls mentioned; and some are made for a particular purpose, as on occasion of marriage, and for several other causes. Some gifts are absolute and large, others are restrained and in special form, as to some certain heirs named in the gifts, or where certain persons are excepted in the gifts. Some gifts may be ab-

${ }^{1}$ B. will be put to his proprietary action or writ of right, his last possession having been wrongful. 
solute at the beginning, and afterwards restrained by this clause, so that the purchaser shall not have power to alien the gift to certain persons, or except to certain persons, or to any one. *Some gifts are complete, where both rights unite in the purchaser; others are begun, but not completed; and such titles are bad, as in case of gifts granted, whereof no livery of seisin follows.

10. Some are weak in their commencement, but are afterwards strengthened by the confirmation of those who have the property, as in the case of gifts made by infants under age, and by those who have no property in the thing, in whatever way they may have come into possession of it. But however such possessions be acquired, where the purchasers have purchased an estate other than their feoffors could legally convey to them, if such purchasers be presently ejected by those in whose persons the property remains or rests; the ejected shall never recover by this assise, on account of the defective entry. And if such purchasers are not presently ejected, they may be afterwards ejected by judgment of our court by virtue of this assise, and of our writs of Entry, and other writs. In some cases, however, the remedy for such disheritable alienations must be delayed until after the decease of the alienors, as in case where the alienors held for the term of their lives. And in case of alienations made by those who had an inferior estate, this assise shall be maintained against the feoffors and feoffees jointly.

* 11 . There are some also who cannot without our leave purchase anything but movables, as persons in 
religion. Neither can a husband purchase more than the movables of his wife, nor the reverse, after marriage celebrated between them; neverthel sss whatsoever is the wife's is the husband's, and not the reverse. For the law forbids gifts between husband and wife for two reasons; first, from a presumption of excessive fondness ; secondly, lest the donor should through such good-nature remain poor and necessitous. Neither can an infant under age, nor any other person whatsoever, purchase anything where the lonor remains in seisin, whether he retain the possession as owner or as guardian. Nor can leper's expelled society, nor madmen, nor idliots, nor such as are incapable of consenting to a purchase, acquire anything without guardians.

12. If any one would make a gift to an infant under age, and yet retain an estate for the term of his life, let him first make a complete gift, and put the infant in seisin, and give him some stranger as his guardian; and when the infant has been in peaceable seisin, let him eject him, and after the donor has been a considerable time in seisin, let him procure himself to be ejected by the infant, so that the donor may recover his seisin by this assise and by convietion, claiming a freehold by title of term of life. But for this proceeding the assent of the infant and guardian will be necessary.

*13. There are some purchases which are invalicl, unless induction into seisin follows, as of corporeal things; others which are good without institution of seisin made immediately on the gift, as of things 
incorporeal, such as franchises, and easements relating to land, for which this assise lies as well before seisin as after, as to have a way in another's soil, or common for a certain annual rent. For the act of the mind in the union of wills, and the delivery of the writings from one neighbour to another, are suffieient for seisin, as appears by the franchise of infangthef $;^{1}$ for it often happens that we grant to persons the franchise of outfangthef, that is to say, to have the punishment of their people and tenants, wheresoever they may be apprehended ont of their fee, and adjudged to be hanged, so that after such judgment given, they may take them and bring them back into their franchise, and cause them to be hanged upon their own gallows. ${ }^{2}$ In sueh a franchise, no one to whom we have granted the franchise in that form ought to be disturberl, although he has not hitherto been seised thereof. For it may

1 The above reading is found in all the MSS. which I have consulted, though the context seems to require 'outfangenthef.'

${ }^{2}$ Bracton defines outfangthef to be the right of trying thieves coming from other parts, and taken within the limits of the lord's jurisdiction; and says expressly that this franchise does not anthorise the lord to bring back into his liberty and try one who has left his jurisdiction and been taken elsewhere. (Brac. 154 b.) Fleta follows Bracton, but adds, that though the lord cannot try his own man taken elsewhere, yet when convicted, he has a right to hang him on his own gallows. (Fle. 62.) Later authors, following the 'Termes de la ley,' have explained outfungthef to be the right of the lord to call to judgment in his court one of his own men apprehended for felony out of his fee. See Ducange, Gloss. ; Tomline's Law Dict.; Wharton's Law Lexicon. 
well happen, that such a chance may not occur within ten years. Whereby it plainly appears that a man may be seised of incorporeal purchases without institution of speedy seisin.

*14. There are some incorporeal things which cannot be well purchased without the aid of our court; as fees and properties $;^{1}$ of which by agreement of the purchaser and the donor a fine should be levied in our court, by means whereof this kind of purchase derives effect and stability. ${ }^{2}$ Nevertheless there are some fees which are not to be purchased by certain persons with. out a mesne. For husbands cannot, purchase the fees of their wives' dowers, ${ }^{3}$ by reason of the service which cannot be attorned from the wife to the husband. Hence the use in such cases of quitclaims from those to whom the reversion belongs.

15. Sometimes it happens that he to whom the reversion legally belongs by the form of the gift, cannot give his right to any person he may choose until he is

1 The word fee is here used for seignory : the word property for a proprietary right not accompanied by possession.

2 - The right which is severed from the possession is sometimes not vested in the purchaser without recognizance in the King's Court, and then by a judicial writ, called Quid juris clamat ; sometimes it is vested by quitclaim, and sometimes the two rights must be united, that is, the possession and the property before the right can be aliened.' (Note in MS. N.) As to the writ of Quid juris clamat, see Reg. Brev. Judic. 36 b.

${ }^{3}$ That is, the immediate seignory of the tenements held by the wife by title of dower under a former marriage. 
himself seised, as in case of those heirs to whom an inheritance accrues after the decease of the purchasers who were seised for the term of their lives. But the tenants may deliver their seisin to the person to whom the reversion belongs, and he may reenfeoff them or others; and then not only the fee is granted, but the possession at the same time, together with the fee and the freehold.

\section{CHAPTER IV. \\ Of joint purchases. 1}

1. As one person may make a separate purchase, so may many purchase in common, to them and their heirs and assigns, *or to certain heirs by a limited feoffment, and sometimes to issue born, and sometimes to issue to be born, where one can not be heir to the other. It is thus with the gifts which persons make to their mistresses or concubines, ${ }^{2}$ - to have and to hold to the

${ }^{1}$ It should be observed that throughout this chapter, and elsewhere, the word commun is used of joint tenancy. No reference is made to tenancy in common, which appears to have been of later growth.

${ }^{2}$ With respect to the supposed gift to a concubine and her children born and to be born, (an example which is borrowed from Bracton,) the annotator in MS. $N$. observes as follows :- ' To that it is said that a concubine can purchase to her and her children born and to be born, I do not at all agree, (Je ne m'y acord poynt.) For, suppose the concubine to have two children at the time of the purchase, and the deed to speak thus : Sciant \&c. 
concubine and her children begotten and to be begotten and their heirs; none of which children can be heir to the others. And if the mother be ejected, although

quod ego dedi Beatriciæ et Clementi et Darid pueris suis et omnibus aliis pueris de me procreatis ex eadem Beatricia nascituris, habendum et tenendum prædictis B. C. et D, et eorum hæredibus et assignatis ; -if Beatrice have afterwards children who claim estate by this feoffment, and are kept out by the first purchasers, and bring assise ; being driven to state their title, they must claim either by title of purchase or of succession. And by purchase they can demand nothing, because they are not named by name in the feoffment, and were no parties to the livery of seisin. For in feoffments it behoveth to name certain donor, certain purchaser, and certain tenement : and those who were not in rerum natura at the time of the translation cannot claim part in the thing transferred, the nature of the translation being, that when the thing transferred becomes vested in the purchasers, it is extinct in the donors, and the reverse. But in this feoffment everything is extinct in the donor, and is vested in those purchasers who were parties to the induction of seisin, and in none other. Therefore it appears that the word nascitu$r i s$ is vain and ineffectual. And if the concubine be pregnant, and the donor say, Dedi Beatricize et Clementi filio suo ; and order that the child which shall be born be called Clement; although this happen accordingly, and the child remain ten or twelve years with his mother, as it were continuing his seisin, if he be afterwards ejected by his mother, he shall not recover by the assise, as some say. For the alienation gave forthwith a new tenant to the lord ; and if the mother liad committed felony and been attainted, although execution had been delayed until the infant's birth, yet the right of the lord to have the escheat would have accrued immediately ; which right cannot be extinguished by him who could claim no estate at the time of the felony committed, for-jus semper in aliquo sibi vindicat, locum, nec in 
the children have not had seisin, yet the mother and children shall recover by this assise, by reason of the seisin which the mother had in their name. And if the mother be dead, again the children shall recorer by this assise by virtue of the same seisin, because she took the seisin for herself and her children as their guardian. For that person is seised, for whom and in whose name the seisin is taken; as is the case with the purchases of villains to the use of their lords.

2. Nevertheless if one of them allows himself to die seised of his part before division, it accrues to his parceners, and to their heirs, and so on to all the rest until the last. And if the last die without heirs and without assign, the inheritance shall escheat to the lord. And if any man purchase to himself and his heirs, without assigns being named in the gift, such purchaser, if he has no heirs, cannot alien or make an assign; *but if he has heirs either near or remote, who loco racuo requiescere potest.' This latter opinion is upon a point respecting which there is little anthority in our common law. By the civil law children in the womb were treated as capable of acquiring property, (see Dig. li. 1. t. 5. 1. 26); and this law was followed in our courts. having cognizance of wills and administrations. (See Beale $v$. Beale, 1 P. Will. 244. Doe $v$. Lancashire, 5 Term. Rep. 49.) This however was not the case at common law, for it seems to have been the general opinion that if a remainder was limited to a child, who was in ventre su mere at the determination of the particular estate, the remainder failed, the child not being considered to be in esse. The contrary rule was finally laid down by Statute 10 and 11 Will. III. c. 16. See Reeve $v$. Long, 1 Salk. 227 ; Coke Lit. 298 a. (note by Butler); Coke Lit. 390 a. ; Blackstone, Comnı. vol. i. p. 130. 
can warrant the gift, he may in such case give, sell, and make assigns: but if there be no heir, then the tenement will escheat to the lord of the fee.

3. If purchasers holding in common be ejected out of such purchase, they shall all jointly recover their seisin to hold in common, by this assise, whether the disseisor be a stranger or one of the parceners.

4. But if any one die seised of his part in secreralty without an heir, and without having created assigns, that part shall not accrue to the parceners after the division, but shall escheat to the lord. And if the lord immediately after the decease of the tenant put himself in seisin by merely setting his foot thereon, it is a sufficient seisin; and if he be ejected or deforced, he shall recover by this assise.

5. There are some purchases which are valid as to some of the purchasers, and not as to others; as, where gifts are made by a husband after marriage to his wife and their common children, or to the wife and the wife's children, such gifts will not avail the wife, but will stand good as to the children.

6. If two brothers purchase jointly to them and their heirs, the elder may be tutor and guardian to the younger, if the younger is under age and the eliler of full age; and if both are legitimate, one shall be the other's heir, *if he has no heirs of his own body, and has not made assigns, whether partition was marle between them or not. And if one be deforced or ejected after the other's decease, and after having merely set his foot upon the land in the name of seisin of his 
inheritance, he shall recover by this assise. And if the assise be brought against the chief lord, and he plead that he claims only wardship in respect of the share of the deceased brother, this defence shall not prevail, although the deceased's brother have left a son or other heir apparent under age, inasmuch as no separate property was ever recognized in the tenement.

\section{CHAPTER V. \\ Of conditional purchases.}

1. Notwithstanding heirs are named in a purchase, yet no purchase thereby accrues to the heirs. And it must be understood that where any one purchases to himself and his heirs, he purchases to himself and his heirs near or remote, and to have and to hold from heir to heir, as well to those begotten as to those which are to be begotten.

2. And as heirs may by the form of the purchase acquire a property in the purchase of their ancestor, so may they by the form of the contract between the donors and the purchasers be excluded from the purchase. For a covenant sometimes bars succession, and effect must be given to the contract and the will of the donors, as in the following and like cases. * If any one purchase to himself and his wife and their issue begotten in lawful matrimony; by such a purchase the 
purchasers have only a freebold for their two lives, and the fee accrues their issue if there be any already born; and if not, then the fee remains in the person of the donor until they have issue $;^{1}$ and in case the purchasers have no issue, or have issue which fails, the purchase will revert to the donor. And if one of the purchasers die, the other shall retain the purchase for the term of his life. And if they have no issue, and the tenant commits felony, the donor shall have the reversion, and the chief lord shall have no escheat. And if the donor has set his foot on the land in name of

1 The treatise of Britton appears to have been compiled after the date of the statute De donis conditionalibus, $13 \mathrm{Edw}$. I., and even of the statute Quia emptores terrarum, $18 \mathrm{Edw}$. I., (see the Editor's Introduction); but before the effect of these statutes upon the law had become apparent. The observations of the annotator in MS. $N$. further illustrates this change of law. 'Before the statute [Quia emptores] the donor could charge or discharge the tenements at his will, and put one or more conditions in the charter. But since the statute no charter or gift was conditional save gift in fee tail, because every tenant by force of the statute must hold of his chief without mesne. Wherefore some of our companions (les uns de nos compaignons) say that this chapter [of Britton] is vain and antiquated (veyn e antiquité). But let them say what they will (dient lur talent); for it is said 'covenant conquers law, as, if any one desires that any of these conditions may hold, he may give the tenement in fee simple, and then make indentures containing the conditions at his will; and thus by these collateral covenants (covenans den en costé) one may recover the land either by his own force or by force of law as by writ of covenant. So that, although the charter was not conditional, the conditional writings defeat the charter.' See some further observations on sections 4,5 , and 6 . 
seisin, and is ejected or deforced, he shall recover by this assise.

3. A condition may be made in many ways ; in one way to the advantage of the purchaser, as upon condition that he does not give or alien, and sometimes to his prejudice, as upon condition that he clo not hold in fee, but only for a term. There are four principal heads of conditions which are allowable in gifts and other contracts, namely these: I give to thee, so that thou give to me: I do, so that thou do: I do, so that thou give: I give, so that thou do. These conditions so bind the parties by their contracts, *that each is bound to the other in such a manner, that if the one gives or does such a thing, the other is bound and obliged to do the counterpart according to the contract; so, in the negative, that if the one does not do such a thing, the other is not bound to do such a thing. And if the one does the act, and the other will not do the act, it is lawful for the donor to take back his gift; and if he is deforced thereof, he shall be aided by this assise.

4. A purchaser shall also have the like remedy, where certain lands are promised to him, and writings made thereof, on condition that he marry the sister or daughter of the donor, and the purchaser marries her before the donor puts him in seisin of the lands. If the purchaser, seeing that the donor will not keep his covenant with him, puts himself in seisin of the land, in person or by another who takes possession in his name, and he is ejected or deforced, he shall be aided 
by this assise. ${ }^{1}$ And if the donor performs his contract in part, and in part not, in such case the purchaser shall be aided by our writ of covenant; or of escheat by detainer of the services for two years, as was provided at Gloucester. ${ }^{2}$

5. If the clonor says thus: I give thee so much land with the appurtenances, to have and to hold to thee and thy heirs if thou have heirs of thy body begotten: in such gifts the purchaser purchaseth only a freehold, but if he has issue, the fee and the right then first accrue to him, * so that he will be able to give and alien the land, although the issue fail, because the condition is satisfied $;^{3}$ and the brothers of the purchasers or their other remote heirs shall inherit such a purchase.

1 'That which is said, that the purchaser may thrust himself into seisin upon the marriage, is not well said as to the present law (quant a ore). For, if he can aid himself by writ of covenant, well ; if not, let lim provide better another time. Note in MS. $N$.

2 The conclusion of this sentence is obscure; and probably the text is corrupt. The reference appears to be to the fourth chapter of the Statute of Gloucester ( $6 \mathrm{Ed}$. I.), by which a remedy was provided to a donor or lessor to recover the land in case of the nonpayment for two years of a fee-farm rent or other service reserved amounting to a fourth part of the value of the land. The writ by which this remedy was enforced was called C'essavit per biennium. (Vet. Nat. Brev. 138.) This statute is cited in the corresponding passage of Fleta, as furnishing a remedy for a breach of a condition.

3 " This is all void ; for the gift is [qu. treated in the text as] a conditional gift, anıl not in fee tail.' Note in MS. $N$. 
6. If the donor say, I give thee this land because thou hast served me well : although the cause may be false, it does not follow that the gift is not good. And in the following case also the gift shall be good and firm, whether the cause be true or false: I give thee this land because thou wilt serve me well. But if the donor say, I give thee this land if thou wilt serve me well, the gift here is doubtful and in suspense until the condition is satisfied. ${ }^{1}$

7. Where a gift is made upon condition of something in future, and the condition is possible, there the gift will be deferred until satisfaction of the condition; and if the purchaser brings any plaint, the donor may plead this exception, that no action or plaint can accrue to him until after satisfaction of the condition; as where a gift is made to another on condition that he give $10 l$. But if the condition be impossible, then the gift is of no virtue or force, as if the condition be thus : I give to thee, upon condition thou procure me the moon.

8. Some gifts depend upon the will of another, as in the following case: *I give to thee, if John is willing; here the purchase is of no avail, unless John assents to it. Some purchases are casual, as in this case: I give to thee to hold, if I shall be made a bishop.

1 . What is here said of gifts made for a certain cause, and also of gifts depending upon the will of another or upon chance, is bad law, (rien ne valt.) For it matters not (il ne me chaud) for what cause you give, so you put me in seisin to bave and to hold to me and my heirs of the chief lord. Note in MS. $N$. 
9. If a gift be made upon more conditions than one, and one of the conditions is satisfied, the gift will be valid, if the conditions are several; but if they are joint, then all must be fulfilled to make the purchase effectual. For it is not the same thing to say, I give to thee, if thou do such a thing or such a thing, and to say, I give if thou do such a thing and such a thing, jointly. For in one case, satisfaction of one of the conditions is sufficient, and in the other it is not sufficient unless all the conditions are satisfied.

10. Another kind of condition which is permissible in gifts is negative, as where a gift is made to the youngest son, or to a stranger, to have and to hold to him and his heirs, if the elder brother shall have no issue of his own, or no issue by such a wife. So, where the gift is male to the purchaser, to have and to hold to him and the heirs of his body begotten, and if he shall have no issue, that then the gift shall revert to the donor, or to certain other persons, to hold jointly, or' severally, one after the other.

11. There are other kinds of conditions, which are double; as where the donor says, if thou shalt have no heirs of thy *hody begotten, or if thou shalt have heirs and they shall fail, then the gift shall revert to meand my heirs: or thus, if such a thing do not happen, then thon shalt have the land for ever. ${ }^{1}$ Gifts nay also be made upon several conditions, as in this example: to have and to hold, so thou do, or so thou do not such

1 This example appears imperfect. Probably some words aro lost out of the text. 
and such things, and if thou do, the gift shall return to me; or thus, to have and to hold so thou do not do such a thing, or several things, without my leave, and if thou so do, then it shall be lawful for me to put myself in seisin of the gift and retain it for ever.

12. If the purchaser do not in such case according to the covenant, and the donor throw himself into seisin, he shall keep it; and if he be thereof ejected or deforced, he shall recover by this assise. But if he cannot in any way put himself in seisin, then he may avail himself of our writ of covenant, in which the process is by the great and little Cape, as in a real action. And if the charters or writings of the original contract are denied in judgment, it will not avail to prove the deeds without making proof withal of the condition being satisfied. For these two things may well stand together, that the deeds may be legal, and that the condition may not have been satisfied.

13. A condition sometimes bars the descent of an inheritance to the right heirs; as in this manner: I give thee such land for a certain term; *and if I die within that time, then the land shall remain to thee and thine heirs, or for term of life, or for other term. Sometimes a condition makes a freehold of a term, and the reverse; as in this case: I give thee, to have and to hold during the life of the purchaser, and for such a time over; and if thou die within that term, then I will that thy heirs or thy executors shall hold the gift for the same term. The chief lords however cannot be deprived of anything; for a term does not take away 
wardship, but only delays it until a certain time; unless the heir is an idiot, in which ease the lord loses his warlship and the farmer his term, until it be otherwise ordained, at least during the life of the idiot. This rule was laid down by the common assent of the great lords of the realm and by the provision of Robert Walrand, in whose heir and the heir of his heir the statute first took effect. ${ }^{1}$

14. If a gift is made on condition that if the donor shall pay so much at certain days and at a certain place, the gift shall return to the donor, and if not, the land shall remain to the creditor in fee, to him and his heirs; now although it be so expressed in the charter of feoffment, if the creditor dies before the day when the payment should be made, his heirs can demand nothing *before the day; as shall be mentioned among the exceptions in Mortdancester.

15. A fee may be made to arise out of a term; as is the case where one going a pilgrimage leases his land for a term of years with this condition, that if he does not return, the land shall remain in fee to the termor; such a condition shall always be a bar to the action of the heir of the pilgrim. And thus it appears that feoffments and purchases may be conditional as well as simple and without condition.

1 'See Coke, Inst. pt. 2. p. 109 . Robert Walrand was a Justiciary of the latter part of the reign of Henry III. (Foss, Judges of England, vol. iii. p. 503.) 


\section{CHAPTER VI.}

\section{Of Reversions and Escheats.}

1. A purchase sometimes reverts to the donor; as is the case with a gift made in marriage, for default of heirs. So likewise by form of gift; and sometimes for want of the words "heirs of assigns," and for want of " assigns of assigns." It is therefore necessary in every good purchase that the feoffment be made to have and to hold to the purchaser, his heirs and assigns, and to the heirs and assigns of his heir and to the heirs and assigns of his assigns. For if no mention is made of any of these, and alienation is afterwards made contrary to the form of the gift, the donor may have his action for the reversion. Land also returns to the feoffor or his heirs, or to his assigns by virtue of a fine levied in our court, when it has been leased for term of life or for years, however long the term may be.

*2. Some purchases escheat to the lord of the fee, as where the purchaser is guilty of felony and undergoes judgment. So also, when the purchasers die withont heirs. So, when the tenants abandon their tenements. In these cases, if the lords do but set their foot upon the land in name of seisin, they are sufficiently seised in respect of the proprietary right which descended to them, unless they are barred by negligence on account 
of too long a delay. But if they put tinemselves in seisin as soon as the fee is vacant, or within four days after the vacancy, if they are resident near, or within fifteen days if they live at a distance, or within a still longer time as is mentioned below, or any other person does so in their names, and they are afterwards ejected or cleforced, they shall have their recorery by this assise. But if they delay too long, it may then be more troublesome to eject the tenants than to proceed by judgment of our court. It is therefore their better course to recover their right by writ of escheat.

3. If a villain or a sokeman make a gift or feoffment of the villenage of their lords, or if the lord's bailiff or farmer, or other in whose person both rights are not united, make a gift of what belongs to another, or if a married woman disposes of her own property without her husband, *the seisin may in the same manner be taken back, whoever be tenant, whether the disseisor or his son, and although the latter may be uncler age, provided it be clone in time; but, if not, it is then better for him to proceed by judgment of our writ of entry than by his own force. 


\section{CHAPTER VII. \\ Of Purchases by Villains.}

1. Villains may purchase as well as freemen; but nevertheless whatsoever a villain fairly purchases, he purchases to the use of his lord, unless the purchase be made of the lord, provided that the lord is in seisin of him and of his chattels and of his suit; so that the lord may enter upon the purchase of his villain, later or sooner, as he pleases. For in this case no time runs against bim. Villains, therefore, ejected by their lords, in whosesoever fee the purchase may be, shall not recover against their lords by this assise, or have any other remedy. The lord however, after he has been seised of the purchase, and of the charter of his villain, may give to his villain other land to the value, or the same land, *to hold of him in villenage, or may thenceforth hold it in demesne. But in this case the the lord will be bound to perform the services which are due to the chief lord in respect of such purchase.

2. But if the villain purchases any land or other tenement from his lord himself, who enfeoffs him to have and to hold to him and his heirs, whether the purchase is given to be held by free services or by villain customs, and though there is to be merchet or redemption of flesh and blood for the tenement, yet if the lord after- 
wards ejects the villain from that or any other purchase, the purchaser shall recover his seisin by this assise. For since the lord intended in his feoffment that the villain should have heirs, he thereby renounced every exception of villenage on account of the villain services issuing therefrom, so that this will avail him nothing. For it is not the same thing to hold freely, and to hold by free services. For whosoever holds to him and his. heirs, although he does not hold by free services, yet it follows not that he does not hold freely, that is, as a freeman. And by such feoffment the villain becomes a freeman, whether homage be expressed or not.

3. And if a villain purchase tenements to himself and his heirs of any other than his lord, and some other than his lord eject him, *the villain may recover by this assise against any person except his lord, ${ }^{\mathrm{s}}$ if the lord be not seised of him, his chattels, and his suit, as in the case of a villain fugitive from his lord, and claiming freedom by any title, as by clergy, or long continuance in a free condition without being claimed by his lord, or by any other title, as has been said in the chapter concerning Naifty. And therefore if such villains die in that condition, and the lords put out their heirs, they shall recover by assise of Mort. dancester. For where assise of Novel Disseisin holds in the case of the father, there assise of Mortdancester will lie for his heir.

1 Some words equivalent to 'and even against his lord' have probably slipped from the text here. See above, l. i. c. 32. s. 7 . p. 199 ; and below, c. 18. s. $2,3$. 
4. If one who is villain to more than one lord purchases to himself and his heirs, whichever of his lords shall first oust him may retain the seisin for ever $;^{1}$ and if all the lords seize the purchase of the villain at the same time, then let it be theirs to hold in common, until they have divided it.

5. If the villain sells in fee the purchase which he has bought in fee, before the lord shall have taken and seized it, and the lord ejects the free purchaser after he has had peaceable seisin of the gift of the villain, the person ejected shall recover his seisin by this assise; and the lord will be for ever after barred of his action by his negligence.

6. When any villain who is a fugitive from his lord makes a purchase, the lord cannot have any action or set up any *claim against this purchase, until he has recovered and established his right to the villain. And if he has taken anything from him, the villain need never answer his demand, until he has fully restored to him the land and the chattels found out of his fee, which his lord has taken from him. This is by reason of the words in writ, 'with his chattels and all his suit.' For if the villain was not fully reinstated, and put in possession of the same, the words of the writ

1 ' When sereral parceners are seised of a villain, if he purchase in the name of one parcener, the property accrues to that parcener ; if in the name of all, to all ; if in his own name, the one who enters may hold it, and the others are without recovery. For if the purchase of a villain be aliened before the entry of the lord, no advantage can accrue to him.' (Note in MS. N.) The several cases are similarly distinguished by Bracton, f. $25 b$. 
would be thrown away, and our precept would be vain, in commanding a man to be put in possession of a thing of which he is himself seised. But when he has proved his title to the person, then he may by judgment and by law seize the lands and chattels and all the purchase of his villain.

\section{CHAPTER VIII.}

\section{Of Charters.}

1. It has been said above in the chapter concerning Debt that it is necessary for an obligation to be clothed in five different ways. The same clothing is also necessary for gifts and purchases. And as to that clothing by writing, which is called Charter, it must be under. stood that there are several kinds of charters, as charters of kings and charters of private persons; and of the king's charters some are single, some common, some universal. *Of simple charters, some are of pure feoffment and single, others of conclitional feoffment; some are charters of confirmation, and some of quit. claim. $^{1}$

2. Single charters of pure feoffment without condi-

1 This is from Bracton; but there is some confusion arising from the equivocal use of the word simple. The word privata is similarly employed in Bracton to denote, on the one hand, a charter made by a private person : and on the other, one granted by the king to an individual, in distinction from one granted to a community or to the entire kingdom. 
tion ought to remain with the purchasers and their heirs. Conditional charters ought to be indented in two or three parts, so that one part sealed by the purchaser may remain with the donor, and another part sealed with the seal of the donor may remain with the purchaser and his heirs, and the third part be put into an impartial hand, ${ }^{1}$ so that no one may afterwards demand a right in anything by form of gift or by condition, but that our court may be certified of the form by the charter. For no action or exception avails unless it can be proved, and it is useless to pray the court that the adverse party may be compelled to produce a deed, because no one is obliged to arm his adversary.

3. As to royal charters, whether they are allowable, or false or doubtful, can be adjudged by none but ourselves. For it is the office of the author to determine and judge concerning them. Wherefore we will that such doubts and illegalities be referred to none but ourselves, and that all interpretations be made by us.

*4. In single gifts it is sufficient to say thus: ' Know all men present and to come that I, John, have given to Peter so much land with the appurtenances in such a town;' and it is proper to specify between what boundaries. And it is not necessary to say, 'to Peter and his heirs,' where Peter intends to purchase fee and frank tenement, but the heirs will be specified afterwards, thus: 'To have and to hold to the same Peter

1 Bracton advises, that the deed should be either in two parts, or, if in one, should be deposited in aqua manu. Bracton, f. 33 b. So Flete, 196 ( $\$ 2$ ). 
and his heirs.' Neither is it necessary to say, 'grants and confirms,' though it is usual to do so ; nor is there occasion to say, ' for homage,' nor 'for service,' if it is not intended by the contract; for however homage or service are expressed in the charter, yet the chief lord of the fee shall not lose anything. Some persons however may do so in an exchange of seigniories, ${ }^{1}$ as in making a feoffment by custom of knight's service; and in such case it is proper to specify the homage in the feoffment. Appurtenances are named to inclucle both corporeal things, such as hamlets appurtenant to chief manors, and common of pasture, turbary, fishery, or the like; and things incorporeal, as franchises, and servitudes of tenements. Then follows: 'to have and to hold the aforesaid land with the appurtenances, to the same Peter and his heirs, doing therefore to the chief lorls of the fee the services thereto belonging.' * And it should be understood, that it is a very necessary clause to specify the service by number, quality, and quantity, and to what persons they are clue, so that neither the lorks of the fee nor any other may demand more than right, without the feoffors being specially obliged to acquit and defend the purchasers. Then follows: ' for all services, customs, and demands.' And . if the gift is made for term of life, or for term of years

I There is a difficulty in the interpretation of this passage, which I confess I cannot clear up. The full effect of the statute Quia emp'ores terrarum, recently passed at the time when tisis brok was composed, does not appear to have been understood. See p. 236 note. 
over, or in marriage, or in fee tail, or upon condition, the condition shall be specified in the charter indented, as above mentioned.

5. In absolute feoffments it is not proper to say, 'to hold of the donor and of his heirs;' for whatever be said, it will not follow but that the purchaser will become tenant to the lord of the fee, in chief without mesne. And beyond this there is no occasion to say, 'freely, quietly, well, and in peace.' For these words belong rather to the form than to the substance of the business; but if such words are put in, they are harmless. With respect to tenements given in marriage, the form and issue supply the place of a charter ; nevertheless a charter does no harm.

6. Sometimes a gift may be enlarged, sometimes restricted. It may be enlarged in this manner: 'to have and to hold to the aforesaid Peter, his heirs, and assigns;' and sometimes further thus: 'and to the heirs and assigns of his assigns.' *It may be restricted as follows: ' to hold until I pay him ten pounds,' or 'until I or my heirs pay him ten pounds,' or 'until I or my heirs or assigns pay Peter or his heirs or assigns.' In another way thus: ' to hold to him and his heirs without making alienation,' or 'without making alienation to such a one,' or 'except to such a one,' or thus, ' to bold during the life of Peter, and after his decease that the gift revert to Thomas and the heirs issuing from him, and if he has no such heirs, then return to 'Theobald, his heirs and assigns.' And in all these cases we will that the intention of the 
donor be observed, so far forth as law and right will allow.

7. It must be understood that no feoffor is bound by the general clanse of acquittance to acquit the fee from making contribution for the linighting, of the lord's eldest son, or the marrying of his eldest daughter, nor from sheriff's aid, nor from common amercements or fines of the county or hundred, nor from suits due to the county or hundred court or elsewhere. Any one, however, may by a special clause bind himself to aequit his purchaser from all these services, and such obligations are enforced by writs of mesne.

8. Then there is the clause, 'And I and my heirs will warrant the tenement with the appurtenances, and will acquit and defend the same to the aforesaid Peter, his heirs and assigns for ever.' And this clause of warranty may be more full thus: 'his heirs and assigns and the assigns of his assigns.' And by reason of this clause it is useful in many cases for purchasers to take to themselves the charters of their feoffors, so that if the the feoffors have nothing whereby they can warrant if need be, then the purchasers by virtue of the charters of their feoffors may vouch to warrant the feoffors of their feoffors, to which voucher they shall be admitted wheresoever it is found that the warranty of the first feoffors extends to warranty without mesne. Acquittance and defence are inserted to the intent that the person of whom the purehaser is to hold in chief may be obliged to acquit and defend him, ${ }_{1}^{1}$ in case any lord paramount or

1 This sentence appears to imply that the purchaser will hold 
other should demand of him other services than the *purchaser shall owe to the lord, of whom the purchaser holds in chief.

9. As to charters of comfirmation and of quitclaim, let every one know that such charters made between persons out of seisin of any right are of no avail, where the parties to them are divested of the right of possession or the right of property. ${ }^{1}$ Therefore it is a good precaution for those who are having charters prepared, to take care that the date of the place and of the year be inserted.

10. Afterwards let some of the neighbours who are freemen be called as witnesses, in whose presence the charter should be read and sealed, and the names of the witnesses should be written in the charter. It would also be a good precaution to procure the seals of the witnesses to be affixed, together with the seal of the lord of the fee; or in the presence of the parties to have the charter enrolled in a court of record. And although the witnesses be not called, it is sufficient if the deed be afterwards recorded and acknowledged before them. If the feoffor has no seal of his own, a bor-

of the donor, who promises to acquit and defend him, and therefore to be inapplicable to the law as altered by the statute Quia emptores terrarum. (18 Ed. I. c. 1.)

1 This passage appears to be taken from Fleta, where, however, the text is scarcely less obscure. I understand the meaning to be, that, in order to give validity to a charter of confirmation, the confirmee must be in possession, and the confirmer must have the right of property. 
rowed seal will be sufficient. There are many modes of purchase in which no charter is required; as by lawful judgment of our court; by surrender; by release and quitclaim; by default; by assignment of dower ; by having issue by the law of England; and by several other ways.

11. But inasmuch as, although a charter is made, witnesses called, and the deed sealed in their presence, yet whatever has been done and said avails nothing unless livery of seisin be made by * the donor to the purchaser, we must therefore say somewhat concerning induction into seisin, how seisin ought to be delivered, and how purchasers ought to receive it, of what things a man may be put into seisin immediately, and of what not until a certain time; and of what things induction into seisin is unnecessary.

\section{CHAPTER IX.}

\section{Of Seisins.}

1. Forasmuch as the mere grant and authorization of the donor is not in general sufficient for purchasers, unless possession follows, with respect to possessions it must be understood, that possession is properly the seisin and holding of anything in fact and in intention, together with the property. There are some things howerer of which one cannot commonly retain possession or seisin ; for of things incorporeal there can be no 
delivery; nor any proper seisin without a corporeal substance. But usage by long prescription supplies in time a legal title.

2. Livery and induction of seisin is a voluntary translation of a corporeal thing belonging to the person transferring it or to another, from the seisin of the true owner to the person of the purchaser, whether the owner transfers it in person, or by another on his behalf attorned and appointed by his letters patent. *Such letters should be in duplicate, one to remain with the attorney, the other with the purchaser.

3. When any livery of seisin is to be made, the donor should first remove all his morable things which he has in the tenement, and his wife and children and all his family, so that there be nothing of his which he has not either removed or sold or let to farm, so that there may be no presumption that the donor intends to retain anything. For as long as he has any intention of retaining, no freehold ever accrues to the purchaser.

4. But if the donor vacates the tenement in fact and in intention, and delivers the seisin thereof to the purchaser, who receires it in fact and in intention, and so keeps it, a freehold, and fee (if the purchase be in fee) immediately accrue to the purchaser, by only setting his foot in the tenement, by virtue of the right, and of the union of wills which are joined, to wit, of the true owner in whose person both the right and the seisin were united, and of the purchaser who receires both the right and the seisin. Therefore, if any one ejected the 
purchaser from the land immediately after the gift, he should recover it by this assise as his freehold, although he had not taken any esplees, by virtue of the seisin. For neither user nor esplees are of the substance of the gift, but are equivalent to a declaration and evidence of seisin. And whereas the purchaser will thus have had the seisin in deed and in intention, *so without both act and intention he can never so lose it, as not to be able to recover it.

5. But where any farmer has a term in the land, and is neither cjected nor attorns to the purchaser, if the donor dies during that term, his heir may recover the land by reason of the continuance of the seisin of the termor, who occupied it in the name of the clonor. Wherefore no scisin can be legally delivered, except by judgment of our court unless while the seisin be vacant. The heir also shall recover seisin in case the seisin of the farmer has continued with that of the purchaser, inasmuch as the purchaser never had peaceable seisin in the lifetime of the donor. But if the farmer attorns to the purchaser, although he continues to hold his term, provided he has admitted that he holds of the purchaser, the gift is not thereby of less validity ; for in such case the feoffment and term may woll exist together in different persons.

6. Where there is nothing of the donor's in the tenement, and the tenement is a principal manor or mansion, there it is enough for the donor in the presence of some free neighbours as witnesses, and of some of the tenants, to deliver seisin to the purchaser 
by the hasp or ring of the door, or by shutting the gate; and thereby the purchaser becomes seised not only of the mansion, but of whatsoever was named in the charter and was properly the donor's, annexed to the mansion, as demesnes, rents, woods, * ${ }^{*}$ meadows, pastures, and other frank tenements. But if a villain of the donor has made a free purchase, of which the donor has never been seised, the purchaser does not immediately become seised of such purchase. If seisin is to be make of a tenement where there is no house, then sufficient livery is made by a rod or by a glove in the presence of good witnesses.

7. It is to be understood, that the freehold never validly attaches to the purchaser until it is extinct in the donor, except by long and peaceable seisin. Nor can anything prevent the freehold from remaining in one of the two persons, and it may happen to remain in the person of the donor, although the donor may intend that the freehold and right should be transferred to the person of the purchaser, and although he may put the purchaser in seisin thereof,-as by his family or chattels remaining in the tenement, which creates a presumption in favour of the heirs of the donor, that the donor retained the fee and freehold in intention, although he made it otherwise appear by colour of deed. And in such case if the purchaser be ejected by the heir of the donor, he shall not recover by this assise, by reason that the donor did not wholly divest himself in his lifetime, but the purchaser found the tenement full, and the donor always in seisin by his chattels and family; 
for by the continuance of the seisin it appears that the donor did not intend to part with the freehold. *But if the chattels be stolen or otherwise lost upon the tenement, and the bailiffs and servants of the donor are ordered by him from that day forward not to remain there, unless to wait upon the purchaser as owner of the tenement, in such case there is no presumption that the donor meant to retain anything. So if it was not by the donor's consent or allowance that any of his family or of his chattels remained in the tenement in his name.

8. If a single person or a single beast abides on the part of the donor in the tenement given, the donor thereby retains the seisin as well as by several; as in the case of a feoffor who having given his common of pasture still causes the common to be fed by one beast; for by that one beast the donor retains all the common. So a lord may retain a rent by the hand of one tenant, where several tenants are jointly bound to pay the rent, and the lord has sold it and yet retains the rent, as above said, by means of one of the parceners. And because such presumptions are prejudicial, it is proper that in every regular livery of seisin the possession be absolutely vacant before the freehold can attach to the purchaser by the livery.

*9. When a lawful livery of vacant seisin has been made with the solemnity of witnesses, so that the donor is voluntarily ousted of the seisin and the purchaser put therein, the donor may not afterwards repent thereof. For if he should return immediately after his departure, 


$$
\text { I, *104 b.] OF SEISINS. }
$$

and eject the purchaser, the ejected would recover by this assise.

10. If the donor perchance return after such seisin made to the purchaser, and pray to be admitted into the tenement as a stranger, although the donor die in the tenement, yet by such abode and such seisin no right accrues to his heirs, unless they can prove that the donor conducted himself in the tenement as owner in the same way as he had before done, and not as bailiff or servant of the purchaser. But to remove all disputes, it is better for donors to make their abode elsewhere than in tenements of their own gift. And if any donor by the good nature of the purchaser is after the gift admitted into the tenement, and the purchaser perceives that the donor intends to eject or disturb him in his seisin, or to act as if in his own property, let him immediately proceed by this assise, or if he thinks it better eject him without judgment. And if the assise pass in favour of the purchaser his estate is so far confirmed.

11. If the donor or the purchaser dies before livery of seisin, *nothing accrues by the gift to the heirs of the purchaser, nor is anything lost to the heirs of the donor; and if the purchaser thrust himself in after the decease of the donor, the heir of the donor is not to be prevented from putting himself in; and if he be ejected or disturbed, he shall recover by this assise. And if by his own negligence he cannot arail himself of this assise, he shall recover by assise, of Mortdancestor, or by other writ according to the occasion.

12. If any person has made a purchase in another's 
name, and by virtue thereof keeps himself in seisin, and he in whose nane the purchase is made disavows the deed and the purchase, and some stranger ejects the procurator, the ejected shall not recover by this assise, because he did not hold the seisin in his own name, neither shall he in whose name the purchase was made recover, since be never was in seisin either in deed or in intention. Therefore, as the freebold is not in the heirs of the purchaser, it still remains in the donor, and in such case the lonor shall recover by this assise. Children however under age, and such as want discretion, cannot to their own detriment disarow a purchase; for, as a general rule, their estate may be rendered better but not worse.

13. If any donor appoints a servant or friend to put the purchaser in seisin, and livery of seisin is accordingly made to the purchaser in the lifetime of the feoffor, the feofment shall be good. * So likewise, if livery be made soon after the cleath of the feoffor, before the purchaser knows of his death. But if the heir of the feoffer after his death prohibits the seisin, before livery is made to the purchaser, the gift will be annulled, and the heir shall recover the tenements, because his ancestor died seised.

14. Advowsons of churches cannot be given or purchased simply without some corporeal thing annexed, as soil, rent, or other thing issuing out of the soil. And even if they should be so aliened, yet purchasers cannot be in full seisin of the advowsons until they have presented to the churches, and their presentees have 
been admitted and instituted by the bishop. For if the purchaser sell the advowson before he has been so seised by his clerk, and the buyer be impleaded by another, and thereupon vouches his feoffor to warranty, the feoffor may plead that he is not bound to warranty, by reason that he never was seised of the advowson, the church not having been void, but the seisin still remains in the first donor by reason that it never took affect in the person of another. And this reason would be allowable, inasmuch as no one can give that which be hath not,-although the feoffor or the purchaser was fully seised of the manor with all the appurtenances.

15. It is to be understood, that in some cases an adrowson may be included in appurtenances, and in some not. For if one give a manor with all the appurtenances without any reservation being specified in the gift, and the advowson of one or more churches is appendant thereto, in such a case the purchaser purchases the adrowsons under the word appurtenances. But where the donor gives the manor entirely or by parcels, and in each gift the appurtenances are expressed, yet if the donor reserves to himself any parcel of the whole, entire with the appurtenances, in such case the adrowson remains in this parcel, unless the advorson is specified in the alienation. So if the manor be aliened in parcels to divers persons, without anything being reserved to the donor, and each parcel be aliened with the appurtenances without specifying the advowson, the advowson shall belong to the last purchaser. 


\section{CHAPTER $X$.}

\section{Of Purchase of Rent.}

1. There still remains another kind of purchase, which is made by attornment of rent or other service, with or without the consent of the tenants; as where one attorns his tenant to become subject to a stranger, as concerning his services issuing out of some tenement. *In this manner are purchased seigniories, which sometimes by forfeiture or default of blood fall into demesne. But in order that a tenant may be attorned without his consent, it will be necessary to have the aid of our court by levying a fine.

2. There is likewise another kind of purchase, which is made of an annual fee, in money or other things, in fee or for term of life, given in reward of service or for exchange of land, or other thing, and for which the donor may charge his tenement with distress if any part thereof be in arrear to the purchaser, either by recognizance in our court or by charter. The charter may be in the following form.

3. 'To all who shall see or hear this letter I, J. of B., send greeting. Know that $\mathrm{I}$ have given to $\mathrm{P}$. for the service which he has done me (or for some other thing certain) $£ 100$ of annual rent in $\mathrm{N}$. and in $\mathrm{S}$., so that out of the manors aforesaid he may take the aforesaid rent from year to year on the day of St. Michael, in whose- 
soever hands the manors shall come, during the life of the same P. (or in fee to him his heirs and assigns), and whereof in the name of seisin $I$ have delivered to him $100 \mathrm{~s}$. beforehand, and to the intent that the aforesaid fee may not be detained from him, and that this grant may be firm, I bind the aforesaid manors to the distress of the same P. (or to P. his heirs and assigns), so that they may *distrain in whosesoever hands they come, so far forth as I myself might do, until they are fully paid the principal fee and their damages. And I and my heirs will warrant the aforesaid fee to the aforesaid $P$. his heirs and assigns for ever.' As to the date and the witnesses, let that be done which is mentioned in the chapter concerning Charters.

4. Therefore, if there be any arrear of the annuity due to such a purchaser, he may distrain the tenements charged, and if he be disturbed therein, he shall have remedy by this assise, provided the writings are proved to be genuine. 


\section{CHAPTER XI.}

\section{Of Disseisins.}

1. Petty assise is the recognizance of twelve jurors concerning the plaintiff's right upon the possession; and it is called petty to distinguish it from the great assise, after which there is no action or remedy. ${ }^{1}$ This is not the case with the petty assise; for though the cause is lost in the petty assise, yet the plaintiff may recover by attaint, or by writ of right, in respect of property.

2. A person may be disseised in many ways. For one is properly said to be disseised who is wrongfully ejected out of any tenement which he peaceably held, and in whose person the right of property in the fee, and the right of possession of the freehold, and the seisin were united.

*3. All seisins do not equally give a freehold title. For the right heir hath sooner a freehold than he who hath no right; for the seisin of every right heir is so tencler, that the mere setting of his foot in the capital

1 'There is no remedy beyond the great assise, on account of the solemu dignity of the knights, who are as it were the king's companions : for a knight cannot be attainted of falsehood but by battle and by his peers. Therefore it is not to be supposed that so noble persons will perjure themselves for any consideration (a nul foer.)' Note in MS. $N$. 
mansion of his inheritance is sufficient for title of freehold, if it is done in the name of seisin, and while the inheritance is vacant, no other person being found in seisin. And the reason is on account of the conjunction of the right of possession with the right of property. So likewise of every seisin taken to his use. Wherefore if such heirs so seised by themselves, or by their procurators or bailiffs or others who may be put in seisin in their name, be ejected by any but ourselves, we will that, of what age soever they be, they shall recover by this assise. Also, if they be under age, and have been in their lords' ward and admitted as heirs, and their lord afterwards refuse to acknowledge them as heirs, such heirs shall be forthwith aided by this assise, whether the lord or any other be found tenant.

4. And if any lord after the death of his tenant finds his fee vacant, and holds possession thereof, claiming a freehold in the fee for default of appearance of the heir, *and is ejected by one who is not heir, he shall be aicled to recover the possession by this assise, saving to every one his right.

5 . Where any younger brother finding the inheritance of his ancestor vacant, enters and sets himself up for heir, elaiming fee and freehold, if he be ejected by the right heir or another out of his peaceable seisin, the disseisee shall recover his estate by this assise. For the right of proximity, or which of them is the nearest heir, cannot be tried but by writ of right only, unless by consent of the tenant. But if the right heir ejects his bastard or younger brother, or other person, 
within fiftcen days after their entry, the ejected shall never recover by this assise. But if they have had peaceable seisin so long that they might have aliened the inheritance to a stranger, and such purchaser might have enjoyed his seisin so that an action would lie to recover his seisin by this assise if he was ejected,-inasmuch as the same time, and less, suffices to constitute a right in the person of one privy in blood to the right heir, than in a stranger,--it is reasonable that those who might claim by the same descent in an assise of Mortclancester, should, if they are ejected from their seisin, recover by this assise against the right heirs and all others, as well as a stranger enfeoffed in the *meantime by such intruders might do, if he were ejected from his purchase.

6. IIe, in whose person were united the right of possession of the freehold and the seisin from which he was ejected, is considered as disseised, although the fee be all the while in the person of the desseisor or in another. And not only is be disseised who is ejected from his freehold in his proper person, but he is disseised if his wife, bailiff, attorney, or farmer, be ejected, although he is not himself present. Moreover, not only he who is ejected from his freehold is disseised, but he also who, at what time he returns from market, or pilgrimage, or elsewhere, finds any one else in his freehold who will not suffer him to enter the tenement, or at least keeps himself therein together with the right owner, elaiming a freehold in the demesne of the true owner. A person is likewise disseised from the time 
that he or his fannily is disturbed in the enjoyment of his peaceable seisin by another, who by such disturbances claims freehold therein, either as to the whole or part, and either in the principal or in the appurtenilnces.

7. So likewise is he disseised, who is disturbed in such a manner that be cannot freely enter into his fee and distrain for arrears of services due from the tenement, of which services the lord has been seised. Likewise if the tenant has impeded his distress *by a wall, ditch, or hedge, or by driving his cattle into another's fee; or if no distress is found therein, or any other act has been done, so that the lord cannot go in and out at his pleasure as he was wont to do. Also he is disseised to whom reasonable distress is refused, or reseued by the tenant, where the lord has been seised thereof. Also if the tenant wrongfnlly replevies the distress made upon him by the lord for arrears of services, whereof the lord has been seised.

8. So likewise is he disseised who is ejected from his freehold by a judgment which is not binding, as by a judgment given without our original writ.

9. Some persons also are disseised who hold for terms of their own life or of the lives of those who had only a freehold. But if he in whom both rights rest leases bis land for the term of the lessor's life, no freehold thereby accrues to the purchaser, although the lease of the land be made to the purchaser and his heirs to have and to hold for all the life of the donor; and therefore if the purchaser or his heirs should be I 5 
ejected, this assise will not avail them. Those also are disseised who are ejected from tenements which they held by judgment of our court, or without judgment, until such or such a thing be done, or for a qualified term, as in gage or by conditional feoffments.

*10. Disseisin is not only made of lands and tenements, but also of rents, estovers, and all kinds of annual profits due for the term of the life of the disseisee, where view can be given of any certain place from whence these profits are to arise.

11. A person is also disseised at what time another disturbs and deforees him of his freehold, and does not deliver it up after our command to delirer it. One is likewise disseised when the seisin of his inheritance is denied him by the chief lord his guardian, to whom he has done homage, and in whose ward he has been for the same inheritance, so as he can prove the same, although he was in ward but a very short time.

12. Although there be sereral disseisors, it is sufficient to name two, or one, where the same person is found to be both disseisor and tenant. For one disseisor and one tenant at least must always be named in the plaint. And if several disseisors are named as having done the wrong and force, it does not hurt. But in ease of disseisin by a judgment which is not binding, where a person is ejected from seisin of his freehold by judgment in a freeman's court, or in the county or hundred, or in any franchise without our writ, the names of the suitors, together with those of the bailiff and tenant, must be mentioned; but if in our 
* court before our Justices, then it will be proper to mention the name of the Justice who pronounced the judgment, and the name of the sheriff, and of the bailiff, and of the tenants.

13. A disseisin is also done by those who convey a freehold to others, where they themselves have none; and in such case the donor as well as the disseisor should be named. But in all disseisins if the writ of novel disseisin falls by the death of the disseisor, or of the tenant, a writ of entry in the second degree takes its place.

14. There are several nusances, which may be prosecuted by this assise, and yet not to recover a freehold, but to remove wrongful nusances, as if a watercourse or way is wrongfully turned or enlarged or straightened, or a ditch, house, wall, hedge, or market wrongfully set up, or a pond wrongfully raised or lowered to the annoyance of his neighbour. Some nusances however are determinable by sheriffs in county courts and not by assises, as in the case of encroachments of curtilage upon common weirs, watering-places for cattle, erection of gates, folds, cowhouses, windmills, ovens, or sheepcotes.

15. There is another kind of disseisin, as of a fishery. For none can have a warren in other's demesnes, except by special deed ; but the fishery belongs to him whose land arljoins the river on both sides. And if it adjoins on one side only, then the fishery is his as far as the line of mid-stream, unless it be a common fishery. *Therefore where a stranger disturbs such an 
owner for fishing in right of his soil, claiming a freehold in the fishery, he commits manifest disseisin of the owner of the soil, if he has had seisin of the fishery. The like of a woman to whom such a fishery has been assigned in right of dower. Disseisin may also be made of corrodies, and of bailiwicks, and of many other profits, as is said in our statutes.

16. Assise of disseisin will also lie in some cases for a husband against his wife, when after having left her husband for adultery, she attempts without his leare, and without any award of court Christian, to keep herself by force in her husband's freehold or in her own, whereas she has forfeited everything for their two lives by her offence. So in all cases where the wife disseises her husband.

17. This assise lies also for the lord of any fee against all persons wrongfully distraining his tenants, and also against the tenants jointly with the wrongful distrainers, if the tenants subject themselves to any wrongful services, to impose on the fee a greater service than it ought to bear, on account of the disherison and damage which may accrue to the lord, if the fee should by any means fall into his hands by escheat.

18. If any one denies his service and disavows holding of his lord, *in such cases distress does not lie, except where distraining and disarowing are compatible, but this assise takes place, as in the case where the tenant replevies reasonable distress out of the hands of the' lorl, by which contest he makes himself a peer to his lord, and so far denies the seigniory, although he 
does it tacitly; and by reason of this assertion of equality this assise holds in both cases.

19. This assise lies also in the person of a villain and his free wife against the lord of the villain, as in case where a villain, holding nothing in villenage, marries a free woman, having a free tenement where the villain and his wife divell, if the lord eject them after the year and day, they shall recover by this assise although the lord can prove him his villain by suit of his kindred. The son likewise of a villain ejected from the purchase of his father, who died in a free estate, may recover by this assise as well against his lord as against a stranger.

20. This assise also takes place in favour of those who are ejected by false warranties, as in the following and like cases. John brings an assise of Mortdancester wrongfully against Peter. Peter comes into court and rouches to warrant Theobald. Theobald makes default, whereupon the assise is thus awarded for his default, that although he come another day, yet he shall not be heard to allege any cause wherefore the assise should remain to be taken. *Suppose that for some cause another day is given, as for default of jurors or for any other reason, if Theobald comes at the second day, and says thus, I warrant to Peter, and surrender the tenement to John, if the Justices are so unadvised as to admit such warranty, Peter shall recover by this assise. And the Justices and the sheriff or bailiff, who delivered seisin of the tenement, will be disseisors as well as the tenant; for they had no war- 
rant to take cognizance of anything concerning Theobald, inasmuch as he had then no day. And if Theobald has given land in exchange to John, he shall never recover it, because he did it of his own accord without another judgment. For no one vouches another to warrant in order to be disseised by him, but to be defended by him in bis possession.

21. If any man takes seisin of a tenement under colour of feoffment, but is not put into seisin by the feoffor, if the feoffee be presently ejected by the feoffor, he shall not recover by this assise. But if two or more thrust themselves into seisin under colour of feoffment, and a contest or dispute arises between them which shall have the seisin in several, he whose seisin is ratified by the donor shall have the best right to recover. And if there is a contest between feoffees who have no right beyond a naked colour of feoffment, this assise shall assist the one who has been ejected from peaceable seisin, against the other who had no right to eject him, by reason of the possessory right which he had, whereas the disseisor had no sort of right to eject him. *And if two or nore contend about a tenement to which neither of them has any right, as if both of them are bastards, he who was first in seisin may avail himself of this assise, and shall retain the seisin, until it is recovered by him who has a better right.

22. And as one may be disseised of his own proper tenement which he held in demesne and in severalty, so several persons may be disseised of a tenement 
which they hold jointly, as in the case of a husband and his wife, neither of whom shall be aided by this assise or beard without the other, except in the case of adultery, where the wife has eloped from her husband. It is the same with respect to boundaries and landmarks between neighbours whereof both are disseised; for then neither shall be assisted by bringing this assise separately by himself, since such boundaries were never held in severalty; but if such boundaries are ploughed up, moved, or taken away, by any stranger appropriating the soil as his own freehold, the two neighbours or more according as the boundaries were held must be joined in the plaint. For as a river, unless it be a common river dividing counties or hundreds, belongs, as far as the line of mid-water, to him whose soil joins the water, so it is with boundaries of land, except in case of a common way, which none may turn or narrow, and other such like boundaries. *And if a boundary between neighbours be ploughed up by one of the neighbours, then this assise lies to have the boundaries restored to their proper state. Running water however is no longer a boundary than whilst it continues its proper course; but as soon as it changes its channel in its course, it shall no longer be a bounclary between neighbours.

23. Parceners and others holding in common, so that none can distinguish his several, may suffer a common disseisin; or, although there has been at one time a severalty, if by the common consent of the parceners the tenement has been afterwards assigned to some 
common use, they may avail themselves of this assise if they be afterwards ejected or disturbed. And if one of the parceners be ejected or disturbed of his seisin, by one or more of his co-parceners, the disseisee may have recourse to this assise by a several plaint against his co-parceners, and shall recover; but not to hold in severalty but in common, as he did before. *And if two or more parceners are disseised by the other parceners, each parcener shall have his several assise, and they shall recover to hold in common. And like judgment shall be given in all other possessory writs between parceners before the join-tenancy is severed. But when their tenements have been serered, so that each knows his own part, and one of the parceners is afterward disseised by the other, then this assise lies between them as between strangers holding in severalty ; and one or more parceners disseised shall have the like judgment against their co-parceners, disseisors, as against strangers. Where there are several disseisins, several assises shall be instituted, and each disseisor, whether parcener or other, shall answer for his own wrong. What we have said of parceners holding jointly as one heir, by reason of the unity of right of them all, shall be equally understood of neighbours, who though strangers in blood, jointly hold as parceners, by feoffment, and in like cases. 


\section{CHAPTER XII.}

Where an assise does not lie.

1. All persons have not equally a right of action to recorer by this assise. For this remedy shall not be granted to any person ejected from a possession which he held in another's name, as bailiff, guardian, or attorney, or to a farmer holding for term of years, or to those who hold any demesnes by villain customs without title of gift or feoffment, ${ }^{1}$ or to persons in religion or others who shall have purchased land of another's fee in mortmain, if they be ejected by the lords of the fee, according to the ordinance of our statute. A villain, of whom his lord has been seised

1 'Note, that he who holds ancient demesnes without charter, if he enfeoff a stranger, is as a disseisor. And the proof is this. He who makes a higher estate to another than he himself had, as he who makes frank tenement, where he hath none himself, is a disseisor. And the tenant in ancient demesne hath not frank tenement, for he who hath frank tenement can recover by assise, which the sokeman cannot do. And the lord of the manor hath the freehold, wherefore by such alienation he is disseised. And as soon as the sokeman withholds his services, the lord may take the tenement in his hand, and if he were tenant, then the lord would need to recover by way of distress or by cessavit.' (Note in MS. $N$.) See Judge Blackstone's argument as to the status of a tenant in ancient demesne, Considerations on Copyholders, Blackstone's Tracts, p. 199-23\%. See also Bracton, $165 b, 166,168$. 
within a year and day as his villain, can never recorer against his lord; *nor a freeman who has in our court acknowledged himself to be the villain of the disseisor. Nor can an intruder ever recover if be be presently ejected by the true heir, within the year and day. ${ }^{1}$

2. Nor shall he recover by this assise, from whose soil buildings are removed, which were erected thereon through the ignorance of another and afterwards taken away as soon as the builder perceived his folly. But if the owner of the soil shall carry to the builder our prohibition against his removing them, or if he built them contrary to the forbiddance of the owner of the soil, or in ill faith, and not through ignorance, or where anything is sown or planted in another's soil through ignorance, and that plant remain till it has taken root, if the builder or planter afterwards carry it away without julgment, the owner of the soil shall recover damages as much as if they had been of his own building or planting.

3. Neither shall those persons ever recover against the true heirs by this assise, who shall be ejected from

1 'To that he saith, that an intruder shall not recover if he be ejected within the year, I do not agree (ne m $\mathrm{i}$ acorde je mie); because it seemeth that he should not be in a worse condition than the disseisor would be.' (Note in MS. N.) In Bracton and Fleta the time is not even limited to a year; non competit [assisa] intrusori, nisi tempus habuerit longum et pacificum. quod sufficere possit pro titulo (Brac. 168). A comparison of those statements shows the rapidly growing inclination on the part of the king's court to repress the practice of recovering possession without julgment. 
tenements which they claim to hold by the law of England presently after proof made that the children in whose name they must hold were bastards, or such as cannot be heirs, or where they had no issue by *their wives, or were not the first husbands, even if they had issue. ${ }^{3}$

4. Purchasers with whom the donors have all along continued in seisin until their death, shall not recover if such purchasers are presently ejected by the right heirs. Nor can a husband recover his wife's freehold without the wife, nor the wife without the husband; nor the husband alone where the wife is jointly enfeoffed of the freehold with the husband. Nor shall those ever recover by this assise who have been ejected by their own consent, where such consent can be shown and verified by deed covenant or by the country. Nor shall he recover by this assise who is prevented from using his seisin by reason of waste committed by the tenant, until satisfaction be made for the waste and

1 The opinion, that tenancy by the curtesy is a privilege of a first husband only, is supported by Fleta, but not by Bracton. (See the passages referred to above.) The contrary appears to be implied by the statute De donis (13 Ed. I.), which enacted, that for the future the second husband should not have any estate per legem Anglice in a tenement of which his wife had been enfeoffed in frank-marriage with her first husband. And in a case in the Cornish Iter, $30 \mathrm{Edw}$. I., an estate by the curtesy was allowed to the second husband, of land which had been given in frank-marriage with the first before the statute De donis, upon the ground of this implication. (Year-book, $30 \mathrm{Edw}$. I., p. 126.) 
destruction. ${ }^{1}$ Nor shall the lord recover by this assise, when he complains that the tenant has disseised him, before he has distrained for his arrears of service, or until he has been in some way prevented from distraining.

5. Nor will this assise assist one who has before withdrawn himself in the same action of assise from his writ against the same person, if it can be proved by record of the rolls of the Justices. Now a wife ejected from her dower, of whom it is proved in court Christian that she was never joined in lawful matrimony to. the husband by whose assignment she claims to be endowed, if she be ejected by the right heir. *Nor those who by quitclaim, exchange, or in some other manner, have made accord of the wrong done them. Nor one who by another writ of earlier date has brought his plaint for the same assise, or where an action is pending for the same tenement between the same persons by a writ of higher nature.

6. Nor can he avail himself of this assise, who was enfeoffed upon an express condition specified in writing, or a tacit condition which can be proved by the country, if he be ejected by the feoffor after he has failed to perform the covenant. Thus, if John gave

1 It appears to follow from this and the parallel passages in Bracton and Fleta, that when waste had been committed by the freeholder, the reversioner might enter without judgment upon the tenement, and lold it until satisfaction had been made for the waste ; and further (according to Bracton), until security had been given against further destruction. 
land to Peter upon condition that Peter took to wife one of the kindred of John, or some other, or the reverse; if the feoffee changes his mind and takes another wife, and the feoffor afterwards ejects him from the tenement, this assise will not avail the disseisee.

7. Nor will this assise avail him who shall have been ejected pursuant to a judgment of our court, as in the following and similar cases. A younger brother, by default of the next heir, recovers an inheritance by award of our court by judgment in this form, that if the right heir appear, he may presently after his appearance eject whomsoever he may find tenant, whether it be he who so recovers upon the decease of his ancestor or a stranger feoffee; and in that case if the heir is not able to eject the tenant, yet, *where he is known to be the next heir, if he can prove the setting of his foot in the house in the name of seisin, and he is thrust out, he shall be aided by this assise.

8. This assise cioes not lie for a person ejected by the chief lord, who put himself in seisin of his fee presently after the death of his tenant, where some one who wrongfully pretends to be the next heir ejects the chief lord, and the chief lord again ejects him, once or oftener; and if such pretended heirs bring this assise against the lord, it shall avail them nothing, because they did not find the fee vacant. But if they had found the fee vacant, and had entered as heirs, and had been afterwards ejected by the lord, or any other, from their peaceable seisin, in such case this assise would have availed them. 
9. Nor does this assise help him who is disturbed from distraining for a rent not issuing out of land; nor one who is distrained in accordance with his liability.

10. This assise does not take place in respect to churchyards, common ways, walls of boroughs or cities, or of like things common to everybody, because no single person can claim any property or severalty in such common things; and therefore in such cases the remedy is by plaint of trespass.

\section{*CHAPTER XIII.}

Of Remedies in Disseisin.

1. The first remedy in disseisin is for the disseisee to gather friends and foree, and without any delay after he may have knowledge of the disseisin to eject the disseisors. And if he can do no more, he should at least keep himself in possession with the disseisors, and make such use of his seisin as he can; in this way the disseisor will never gain a freehold without the consent of the true owner.

2. But if the disseisors have been for a long time in peaceable seisin in the presence of the disseisee, then it is not lawful for the disseisee to eject the disseisors without judgment. In such ease inquiry may be made, where the disseisse was at the time of the disseisin $;^{1}$ for

1 The time allowed for re-ejectment is not very clearly stated in the text; and the readings in several of the MSS. vary. The following note is from MS. $N$. Where the disseisin is done in 
if he was present, and knowingly suffered the disseisor to enjoy his peaceable seisin, the disseisee has no such right after a long space of time to eject the disseisor, but that the latter may recover his seisin by this assise, with his damages; for in such ease it may reasonably be presumed that the disseisees were willing that the tenements should belong to the disseisors; inasmuch as they suffered their right to lie so long dormant.

3. But if the disseisee was in a distant country at the time when the disseisin was committed, then it is proper to consider and determine within what time his family might have reasonably given him intelligence of the disseisin, and in what time he might have returned to assemble his friends and eject the disseisors. *And that such determinations may not be arbitrary,

presence of the disseisee, the disseisor must be ejected within five days; because the law of ancient time granted that the disseisee should go one day to the east, the second day to the west, the third day to the south, and the fourth day to the north, to seek succour of his friends all the country round. If he be disseised in his absence, then if he was ont of his district in any other place within the realm, let him be warned forthwith by his household, and let his reasonable days of journey (ses resnables journees) be allowed, and then four days. If beyond sea in pilgrimage, he shall have forty days, two floods and an ebb, and fifteen days to come from the sea to his house, and then four days. If beyond the sea of Greece in sinple pilgrimage, he shall have a year, and two floods and an ebb, and fifteen days, and four days. If beyond the sea of Greece in a general passage, then let three years, two floods, one ebb, fifteen days, and four days be allowed.' 'This statement of the law agrees with Bracton: As to the time allowed in essoins, see below, book vi. c. 7 . 
we will that they be adjudged according to the periods allowed in essoins; so that if the disseisee be gone in a general passige to the land of Jerusalem, and after his return he eject the disseisor, or any other who may have been enfeoffer by the disseisor, it is lawful for him so to do, whether it be an infant within age or any other whom he find therein, so as it be clone within the fourth day from his return into the country, three days being allowed him to collect arms, friends, and forces; and although the person so ejected brings this assise against the ejector, yet he shall not recover any freehold; for we will not that the absence of such persons be so prejudicial that they be in any way damaged thereby. If the disseisee went on a simple pilgrimage to the holy land, then let there be reckoned a year and a day, and one ebb and flow for delays at sea, and fifteen days for his journey to the land, and four days for assembling his force; and if he has within such time ejected whosoever was found in his tenement, the person ejected shall not recover the land by this assise, even though his ancestor died seised thereof. And if the pilgrimage of the disseisee was on this sile of the Grecian sea, the reckoning shall be four months, one ebb and flow, fifteen days, and four days; if in England, fifteen days. And if the disseisee after that time eject the disseisors *withont judgment, inasmuch as they have been all that time or longer in peaceable seisin with the knowledge of the disseisees, the disseisors shall have recovery of their estate by this assise: for we will that all persons after the prescribed time 
of limitation proceed rather by judgment than force; and the first disseisees shall not be afterwards aided by this assise; for he who acts in opposition to the law has no right to claim aid of the law.

4. And as such disseisors have after a certain time and term a right of action to recover against the disseisees by this assise, so they have also before the time so limited a right of action to recover by this assise against all other disseisors baving no right to eject them. For where neither of two persons has any right, the disseisee has a greater right than the disseisor. And although the original disseisor may thus recover by judgment of our court, yet the true owner shall not lose anything of the right when he shall choose to bring his plaint. So also, if during the time limited for ejectment he cannot recover his seisin without our aid, our writ shall be granted to him returnable at the eyre of our Justices, or we will assign him Justices to hear and determine the plaint according to the case.

5. Where a woman is disseised, and afterwards takes a husband, if they will afterwards proceed by this assise, the form of the writ shall be thus: 'John and Peronel his wife have complained to us that Peter has wrongfully disseised the aforesaid Peronel.' *And if the husband desires to purchase a writ against his wife, then thus: 'John and Peronel his wife have complained to us that Peronel of such a town has disseised the aforesaid Peronel': so that the wife is plaintiff although she is disseisor; but the surname is altered before she is named as disseisor.

16 


\section{CHAPTER XIV.}

\section{Of Views in Disseisin.}

1. If the person ejected cannot or ought not to eject his disseisor, or if the tenant hinders him from using his seisin together with him, he must then complain to us, and we will thereupon grant him our writ to the sheriff of the county in whose bailiwick the tenement. is ; which writ shall contain the names of the disseisors, of the tenants, and of those who come with force and aid to help the disseisors, and the name of the plaintiff. But let every plaintiff beware of putting in his plaint any who were not wrongdoers, because for every one named in the writ who can aequit himself of the wrong the plaintiff shall be in merey for his false plaint.

2. When any one has purchased onr writs, and also letters from our Justices to the sheriff to inform him of the day and place of their session; the *original writ and the Justices' letter shall be immediately taken to the sheriff; and the plaintiff shall keep our letter's patent by him until the day of the plea, and then he shall deliver them up to the Justices to be their warrant; for without either a general or speeial warrant they cannot determine anything.

3. In the next place it is the sheriff's duty to take pledges, two at least, distrainable to himself, that the 
plaintiff will prosecute his plaint, except where on account of his poverty we have permitted him to sue his plaint upon the pledge of his promise only; and then he shall find no other security to the sheriff. And if he goes without our aid, and is unable to recover his seisin, he may then obtain our writ, returnable at our eyre or that of our Justices, or we will grant him Justices to hear and determine the plaint according to the case. When pledges to prosecute are found to the sheriff, or to us in our Chancery, whereof two pledges are sufficient though there are several plaintiffs in one writ, the plaintiffs are not to be required to find any other security, although the return is to be made in a franchise.

4. Security being thus taken if the writ require it, let two freeholders of the neighbourhood be im: mediately enjoined to summon the neighbours to be at a certain day and place before our Justices to make recognizance upon their oaths, whether the plaintiff has been disseised, as he complains, of his freehold, in such a certain place or not, and that in the meantime they view the tenements in this manner, whether the disseisin be made of land or of rent, of private property or of common; and if of common, whether common to everybody, or only to a certain number of people; also to how much in quantity the thing whereof the *plaint is made amounts, so that they may be prepared with a certain answer when they shall be asked whether the plaintiff hath put too much or too little in his plaint. They ought also to see whether all the 
tenement is situate in the county and in the vill named in the writ or not. It is not the sheriff's or bailiff's office to give them the view, but the plaintiff's, who is bound to inform them within what boundaries and divisions the tenements named in the plaint lie.

5. If the plaint be made of corrodies or estovers, or of the delivery of corn yearly, or other provisions or necessaries, or of bailiwicks or wardenships, or of the keepership of a park, or the ward of gates, or other kind of annual office, or of common of pasture, turbary, fishery, or other easements, then the jurors are required to make view of the tenement from whence the easements or estovers arise, or at least of those tenements where the annual necessaries are accustomed to be delivered or are assigned to be received.

- 6. And if the plaint be made of rent, then the jurors must view the soil from which the rent issues; and not only the soil, but the thing also for which the rent is paid; as in the following and like cases, where rent is granted by one neighbour to another to have a right of driving cattle through any tenement, *or where a rent issuing out of any tenement is partly or wholly released on condition of having an easement in another soil. For although the one party docs not require the easement, yet he cannot refuse to pay the rent, or prevent the covenant from being binding in relation to him who is willing to keep it; and the contract shall never be dissolved but by common assent as it was at first made ; and therefore, although the person who his granted a rent in fee or for term of life whereof the purchaser 
has been seised, does not wish to have the driftway or other easement in the soil of his neighbour, yet if be refuse to pay the rent according as it was covenanted between them, be to whom the rent is due may distrain for the arrears of the rent ; and if he cannot find anything to distrain, or if he be hindered from distraining, he shall recover by this assise, if he can show that any soil is charged with the rent; and if not, it is sufficient to view the tenement for which the rent was given.

7. If the plaint is made of a nusance, then let them view the nusance, whether it be a wall, ditch, hedge, or market, or a pond raised or lowered, or otherwise injurious; and in such case it is not sufficient to view the nusince only, but they must also view the tenement to which the annoyance is done. *And in the preceding case also, if the disseisin be by a disturbance of an easement, such as having common in another's soil, or right of drift or way, or water at another's well, or other like easement, it is sufficient to riew the tenement subject to the easement, but the tenement to which the pasture belongs must likewise be viewed.

8. The parties, if they please, may be present at the view, and challenge the jurors; and if the parties agree upon jurors, the names of those upon whom they have agreed shall be imbreviated, to be presented to the Justices at the day of plea.

9. Afterwards let the tenant and all the disseisors, or their bailiffs if they cannot themselves be found, be attached, and required to find pledges to be present at 
the day of the plea to hear the recognizance of the jurors upon the plaint, so that they may know of what offence they are to be accused.

\section{CHAPTER XV.}

Of the Proceedings in Assises.

1. When the Justices are come, they shall forthwith receive the essoins, and afterwards adjourn them. Aind if the plaintiff in this assise neither appears nor causes himself to be essoined, the writ shall be immediately taken out of the hands of the sheriff, and the names of the jurors presented; and the plaintiff shall be called. *And if he makes default, let him and lis pledges to prosecute be in mercy. Then let the tenant or his bailiff and the rest of the disseisor's be demanded, and if they make default, or cause themsel ves to be essoined (since in this assise no essoin avails them,) and it be proved by the sheriff that they were attached by pledges, then their pledges shall be in mercy, because they have not produced them in comrt according to their engagement. Afterwards let the jurors of the assise, according to the panel, be required to answer to their names; and let such as do not appear according as they have been summoned be in our mercy.

2. If the plaintiff appears, or causes himself to be essoined, and neither the tenant, nor his bailiff, nor his attorney, is present, the pledges as before mentioned shall be immediately amerced, and by way of punish- 
ment for the default of the parties it shall be awarded that they be not afterwards allowed to allege any reason for staying the assise, and that the assise be taken by their default.

3. And it should be known that in this and in no other assise every disseisor may answer either in person or by attorney, or by bailiff. Yet they have not all an equal power; for a bailiff cannot do all that his lord can. For a bailiff cannot acknowledge or grant that the disseisin was committed by his lord, so as to prevent the necessity of taking the recognizance, as the clisseisor might himself do, if present. ${ }^{*}$ Moreover the bailiff cannot make any accord or partition, nor put the right of his lord into hotchpot, whereby the lord might lose any freehold without the recognizance of the assise. Yet the bailiff may, as well as his master, allege any objection, wherefore the assise ought not to pass, or for the purpose of barring the assise by dilatory or peremptory exceptions, as by an exception, against the judge, or the plaintiff, or the jurors, or against the writ, and by all other exceptions and replications.

4. An attorney may do all that his lord can, except make accord, for as soon as the proceeding in court is ended, the power of the attorney ceases, and in making the accord another proceeding is begun, which was not before in court, when he was appointed attorney only in the proceeding then in court. This however must be understood of special, not of general attorneys. For a general attorney can do as much as his client from the commencement to the end of the suit. 
5. When both the plaintiff and the defendants are in court, if the plaintiff declares that he will not further prosecute his writ, in whatever suit this may occur, he shall not afterwards resort to another like writ, *but both he and his pledges to prosecute shall remain in our mercy. And if he withdraws himself from the action, he shall be barred of his action for ever; but if he has leave to seek a better writ, or if the writ be abated for error or for other fault, and likewise if the plea be opened, and in the course of pleading the writ be found defective, although the plaintiff in such case say that he will not further prosecute that writ, yet he shall not thereby be barred from resorting to a better writ of the like kind, because no proceeding is as yet commenced upon the action, but the whole is to the writ, whereby the action remains entire. But if any one withdraw himself from his writ after the action is opened, he shall never resort to the like writ against the same persons for the same tenement, but the writ shall be liable to abate, if the fact be arerred by exception. But if upon replication it can be averred that the tenant against whom the first writ was brought was not tenant of the tenement when the writ was abated, and that he obtained it by some means since that time by purchase, succession, or escheat, in such case the plaintiff may resort to another like writ, and the writ shall hold good, in respect of the right of action which commenced after the writ abated.

6. If any person attached declare in court that he has nothing in the tenement nor claims anything, without 
*making any reservation, and such confession be recorded, he will be thereby for ever after foreclosed of every right which he may lave had until that time in the tenement, if this exception be used against him. ${ }^{1}$

7. If when the parties are come to trial the plaintiff has not our letter patent for trial of his suit, the Justices have no power to hear or determine anything. And if the tenant enter nevertheless into his defence, and lose, he may still recover his former position, and whatsoever the Justices shall do in such case shall be held entirely null and void. But if the plaintiff has the patent, let it be immediately read in audience, and if any doubt arises thereon, the tenant $m y$ have on that accounta dilatory exception to ward off the assise. ${ }^{2}$ Afterwards let oyer be had of the writ close. And let it be immediately demanded of the plaintiff of what freehold he makes his plaint, and let the quality and quantity be imbreviated. Next let our Justices examine how and by what title the plaintiff had a freehold therein ; for in every demand it is not sufficient merely to demand, but the plaintiff must show by what right he demands; and this rule applies not only to things movable, but to things immovable, and not only

1 ' Suppose $A$ to bring a writ of novel disseisin against $B$, who is tenant. B disclaims. The writ abates. A desires to enter. $\mathrm{B}$ will not suffer him. What remedy shall A have? qu.' Note in MS. $N$.

2 'Note, that if the Justice takes cognizance of any plea without or beyond their warrant or otherwise, recovery may be had upon them by bill to the king's parliament.' Note in MS. $N$. 
to claims of possession, but to elaims of riglit. And whoever will not make that appear, is not entitled to be answered.

\section{*CHAPTER XVI.}

\section{Of Title to Freeloold.}

1. A title of freehold may be acquired sereral ways, ${ }^{1}$ as by succession of inheritance, by feoffment, confirmation, quitclaim, recognizance of gift in court of record, chirograph, judgment of our court, escheat, reversion,

1 'Note, that albeit the first part of this chapter saith, that there are sundry titles of frank-tenement, John de Longeville of Northampton tells you shortly (Johan de Longeville de Northampton vus dist curtement) that there are but two, and no more, to wit, inheritance and purchase, which are principals, and all the rest are accessories and comprised in the two. For recognizance and judgment of court are sometimes given by reason of purchase, sometimes of inheritance. But confirmation, quitclaim, action of dower and of curtesy of England, and in all other cases, (except inheritance and its accessories, as reversion and escheat,) are comprised in purchase. Seignory purchased also gives rise to escheat. And if the lordship descend before the escheat happens, this is rather inheritance than purchase ; for the purchase is the acquisition (conqueste) of some right to which the purchaser before was entirely a stranger.' (Note ir MS. N.) I have extracted this note, principally on account of the light which it may throw on the origin of the whole series of notes of which I have made such frequent use. See the Introduction by the Editor. 
ciower, curtesy of England, fee-tail, in mortgage, or by condition, or until so much money be levied by judgment of our court, or by simple feoffment, or by peaceable seisin after a wrongful entry, or by the other cases aforesaid ; in which it is necessary for the plaintiff, if he expeets to be answered, to set forth his title, or at least to say that he was in peaceable seisin so long a time, that he ought not to have been disseised without judgment, so that a freehold had accrued to him by the sufferance and negligence of the true owner, whatever his entry may have been, and that this seisin continued until the tenant and the other disseisors named in the writ wrongfully and without judgment disseised him, and thereof he prays the assise.

2. If the plaintiff states his title by succession of inheritance, then it must be inquired whether he found the fee vacant or not. For if he found no other person in seisin, and he is next heir to the ancestor whose inheritance he claims, the bare setting his foot in the capital messuage of his inheritance is enough to give him a seisin, whoever may be the *deforeeor, whether brother or stranger, and that not only of the messuage but of as much of the inheritance whereof his ancestor died seised as belongs to the messuage, by reason of both rights being united in him, that is to say, the possession and the property. In like manner it is with respect to a right by escheat, reversion, or formedon, and in all cases where the possession is actually united with the property.

3. It is otherwise where both rights are not imme- 
diately united in one person, as in the case of intruders, bastards, pretended heirs, and others who have no right of property but only the naked possession. The same is true of some purehasers, as those who under colour of feoffment thrust themselves into any tenement, whereof the feoffors never so far put them in seisin but that they themselves died seised thereof. So it is of those who are excepted in feoffments, as Jews, persons in religion, and other exclucled or prohibited persons. So of those who enter by disseisin or through disseisors, and of all others who enter to the damage or prejudice of any one. For those who enter into any tenement by such as have no right to give or alienate the same, as by farmers or termors, or by those who hold under condition, or by bailiff, guardian, *villains, or others not being the true owners, can have no freehold unless by peaceable seisin and lapse of time, or where the alienation was conditional, until the condition be satisfied. Neither can such as enter by those who have committed felony of which they are afterwards attainted. Nor those who enter by virtue of feoffments made by bastards, where the bastards were not themselves enfeoffed to them and their assigns; for it was in favour of bastarls that the word assigns was first devised to be inserted in feoffments.

4. When the plaintiff shall have set forth his intent and title, it then behoves the tenant to make out his defence, if he can, and to show what right he had to eject or disturb the plaintiff. And if the tenant in support of his title produces a charter of the plaintiff, 
that shall not avail him, unless livery of seisin was made to him by the free will of the donor.

5. And if the tenant say that he has no title and claims none, still it does not follow but that inquisition be made by the assise, whether he disseised the plaintiff tortiously or not, and whether with arms or by force, and whether in the night or by day. And concerning the damages and the other circumstances, let judgment be given as shall be hereafter mentioned, according to the rerdict.

\section{*CHAPTER XVII.}

\section{Of exceptions to the writ.}

1. The immediate taking of this assise is prevented in many ways, as by peremptory exceptions, such as exceptions of naifty or villenage, of condition, covenant, quitclaim, confirmation, release, difficulty of judgment, ${ }^{1}$ fine and chirograph, lapse of time and others; and also by dilatory exceptions, as by exceptions to abate the writ, exceptions to the judge, and to the person of the plaintiff, and to the tenant's own person ; but excep-

1 - Difficulty of judgmeut is a shameful reason for delay (un delay mult honteus); because the king, who ought to govern the people by the law, ought not to be ignorant of it (la mesconustre); nor his Justices, unless it be in some outrageous and perplexed case (cas horrible e deguisé,) then common counsel is better than private laste.' Note in MS. $N$. 
tions to abate the writ must be proposed before the exception to the person of the plaintiff.

2. Supposing the jurisdiction of the Justice to be confirmed, the tenant may then aid himself by exceptions in abatement of the writ, as for a defect found in the writ, as by an erasure in a suspicious place, or if the writ was never sealed with our seal, or if the ordinance or style of our Chancery is not observed. The writ is also abatable and defective for want of date; likewise for a defect in the writing, as being written in two hands, or with different inks ; and for damage to the writ, as if it be torn, marrel, or cancelled ; likewise for defect of the patent, as on account of an erasure, or by reason of the seal being fraudulently attached thereto. And in all cases of falsification of our writs, we will that such suspicions be cleared up, and the like as to illegal distresses $;^{1}$ but these cases shall be determined only by Justices thereto anthorised. The suspected persons howerer shall be forthwith attached.

3. The words in the writ, 'has complained to us,' may furnish ground for an exception to abate the writ

1 The text in this passage seems to be corrupt, and the true reading is not recoverable with certainty. I have rentured to introduce the word purgez (perhaps originally written puriez), of which there appear to be traces in the various readings. I think the whole may possibly have stood as follows: "ge les suspecciouns soint puriez et les manueis brefs detenus et determinez,' \&c. : 'that the suspicions be cleared up, and the forged or suspected writs impounded.' The verb purger is similarly used in 1. i. c. 2. s. 6, ante, p. 11. 
* for want of another who has as much or more right to complain than the plaintiff ; as where the plaint is of the wife's freehold, and the husband only is named, 1 and in other like cases, where the writ ought to run, ' have complained to us,' \&c.

4. The writ is also abatable if purchased before the disseisin, and also if the cause of action has ceased though the disseisin was in fact committed, as if the disseisor has restored the tenement to the disseisee, who has consented to take it back by such surrender. But if he had retaken it by his own force, then it should be worse for the plaintiff. Also if the plaintiff has before withdrawn himself from a like writ, or a like assise, if this be verified. So likewise if the plaintiff has before made his plaint by a writ pending, founded upon the seisin of another, or by a writ of a higher nature, because the order of pleas has not been observed.

5. The writ is also abatable if it is not well framed according to the ease. So if the writ be badly pur-

1 The annotator in MS. $N$. discusses the law here laid down at some length, and distinguishes as follows: "If the husband has had issue and consequently action to hold by the curtesy, he shall be answered; otherwise not. For the husband detained by his wife out of his wife's right, whereof an estate by the curtesy has accrued to him, shall recover against the wife by the assise, much more against the stranger. So likewise of their common purchase, and of the several right of the husband. But suppose the wife to keep out her husband from the wife's right, quaro whether he shall recover.' See above, c. 11. s. 16, c. 13. s. 5, and below, c. 18 . s. 
ehased, as if several plaintiffs are named in a writ where there ought to be lifferent assises or the reverse. So where any tenement is acknowledged to two men to bold jointly, if one has seisin thereof, and is afterwards ejected, and he brings plaint alone of being ejected and disseised of the whole, the writ fails, though the other parcener was never in seisin; for the seisin was delivered to him as well in the name of his parcener as in his own proper name ; *and he is sufficiently seised in whose name the seisin is taken, if he holds good what was done in his name.

6. The writ may be faulty in several ways, as if it is purchased against him who is tenant in the name of another, as against a bailiff, or farmer, or a guardian, or a canon, or a servant, without naming the principal in the writ. Also by mistake of Christian names in the writ, as Reynard for Reyner, Amice for Avice, or for mistake of surnames ; likewise for omission of syllables or of letters in the words or sentences; likewise for want of a surname of dignity, as if John is a secular man, and Master of a Hospital, and complains that he is disseised for a freehold appendant to the same hospital, and is not named Master of the Hospital. The same rule holds in the case of a parson of a church, and all prelates and persons of religion, demanding tenements as appurtenant to their churches or prebends, where they have not named themselves parson of such a church, or archbishop or bishop or canon or prelate. So if a canon secular has a certain dignity in any church whereof he is a canon, to which dignity he 
claims the tenant in demand to be appendant, as to a deanery, treasury, or chantry, if he is not named in the writ by the same surname of dignity or office, the writ is abatable. So, in case of the tenant, ${ }^{*}$ if the dignity and office to which he claims the tenant named in the plaint to be annexed are not specified.

7. The writ may also abate for mistake in the town, as if a hamlet is named where the town to which the hamlet belongs ought to have been named. The difference between manors, townships, and hamlets will be noticed in the chapter concerning Recovery of Right. So likewise for want of distinction in the writ between vills of a like name in the same county; as also if the tenant is not situate in the vill named in the writ.

8. If the situation be disputed between the parties, the truth shall be inquired by office, but not so that the gaining or losing of the action shall be at stake, though the parties be willing that it should be so. For the exception is put forward to abate the writ, and not against the assise. And if the jurors say that the tenement is not in the vill named in the writ, the writ abates, but the assise and the wrong nevertheless remain undetermined, and the plaintiff may resort to another like writ, whether he withdrew himself from his writ with or without leave. And if they say that the tenement is in the vill named in the writ, then let the assise be taken. And if the jurors do not know for certain in which of the two vills the tenement lies, then let it be demanded of the plaintiff whether he 
claims anything of this tenement in any vill not named in the writ, and afterwarls of the tenant, whether he claims anything in the vill named; and if they say no, then *let the jurors of the assise and others of the neighbourhood be ordered to set up proper metes and bounds between the two vills. The like shall be done where a difference arises between parties concerning the bounclaries of two manors or two counties, so that the plea and dispute shall be tried and determined by perambulation. And if the plaintiff is under age, the plea must be suspended and respited until he is of age; for no infant can answer to his own prejudice, whether. he claims such a thing in such a county, or in such a vill or manor, or not, on account of the perambulation which follows, whereby the right as to the boundaries would be determined for ever. Therefore the plea and perambulation shall stand to be taken at the plaintiff's majority, for before that time he cannot give his assise to the perambulation.

9. If the jurors say, that part of the tenement is in one vill or one county and part in the other, then let the assise be taken for that part of the tenement which is in the vill or in the county named in the writ, and not for the rest. It may thus happen that both the parties remain in our mercy. In the same manner perambulation shall be made in case of a difference between the parties, where the contest is in what fees or in what baronies the tenement lies, where one says in one fee and the other in another, and in particular where the jurors are uncertain; saving that in all these. 
*cases it shall be demanded of the parties, as before mentioned, whether they claim anything or not.

10. The writ will also abate, if one demands a tenement in privileged soil, where such writs do not run, as in our ancient demesnes, where no writs run except a writ of right elose according to the custom of the manor. Exceptions may also be founded upon those words of the writ which say, ' of his freehold,' inasmuch, for example, as the freehold never was the plaintiff's, but his wife's; and if the husband and wife are both plaintiffs and complain that they are disseised, they thereby suppose that they both had a freehold, and that they held in common; and upon this an exception may chance to arise to abate the writ. So also, for not distinguishing between the father and the son, where the son has committed the disseisin and bears the same Christian name and surname as his father. And where any one has two surnames, that surname shall hold by which he is best known. There are several other exceptions to abate the writ which shall be noticed among exceptions in a plea of right.

12. If the writ be lost or maliciously taken off the files, then the authority of the Justice ceases; for without warrunt by original writ out of our Chancery no Justice hath record. But if there be any suspicion of malice, let it be forthwith inquired by whose malice the writ was removed; and whosoever shall be convicted thereof shall be taken and punished by imprisonment and heavy ransom. 


\section{*CHAPTER XVIII.}

\section{Of exceptions to the person of the plaintiff.}

1. The writ being established, the tenant may still aid himself by exceptions against the person of the plaintiff, as that he is excommunicated. For a person excommunicate is one that is out of communion on account of a leprosy of the soul, as a leper is for the disease of his body; and so long as a person is excommunicated, he ought not to commune with any one nor any one with him, neither is he entitled to be answered in any action, as shall be noticed in the plea of right.

2. The tenant may also aid himself in a proper case by exception of villenage against the plaintiff in the following form: 'Assise ought not to lie, inasmuch as the plaintiff is my villain.' But then he must also add, that he is seised of his suit and of his chattels, or that he holds of him in villenage; - not however for the purpose of recovering him for his villain, but to bar the assise in the plaintiff's action. But if the plaintiff has by his pleading or by consent put himself upon the jury concerning any circumstance of his estate, and he be thus as it were attainted for the villain of the tenant, the tenant may well take him away and put him in the stocks, or drive him off the land, as he shonld his 
villain, yet not so as to be justified by the judgment of our court without another writ, but at his own peril. *For if the alleged villain can prove himself to be of free condition, as having been enfeoffed to himself and his heirs by his lord, or in any other manner, he shall have an action by writ of trespass or otherwise, against every one who has done him wrong or grievance.

3. So likewise the exception will fail if the plaintiff can prove by the assise or by attaint that he has lived out of the lord's fee and out of his seisin for a year and a day, claiming free estate, without claim by the lord; so that the lord cannot take or recover him as his villain without a writ of naifty. For no one can claim any right to the appurtenances or accessories who has no right in the principal subject of action; and therefore the lord in such eases should first demand the body of his villain by writ of naifty ; and after he has recovered the body, he shail have the goods and the land and all that belongs to the body. And if the lord take anything from such fugitive without judgment of our court, he acts against our peace. And therefore we will that such fugitives shall have their action to recover from their lords what their lords shall have taken from them by force after a year and a day from their flight, until the right in the bodies be proved.

4. Therefore in this exception it is proper to examine whether the lords who put forward such exceptions are at that very time seised of those whom they allege to'be their villains, and of their suit and chattels, or 
whether they were formerly their villains, and have since fled from them; and if so, how long since. For if they have been fugitives above a year, there is no room for the exception, as has been before said; but if the lords can aver their seisin within a year and day, then it holds good; and in like manner, if the lord can aver diligent suit to reclaim and recover him as his fugitive and villain, although he has not been seized of him within the year and day.

5 . If the tenant pleads that the plaintiff is the villain of another, he must further say, that he does not hold the tenements which he demands in his own name, but in the name of the lord whose villain he is; in which case the assise shall stand over, unless the plaintiff can show by charter of feoffment that he was enfeoffed to him and his heirs. And even if he proves such a purchase, this proof will not avail unless he further show that his lord was nerer seised thereof since his purehase; and if it be found that the lord seised the tenement after it had been purchased by his villain, althongh he afterwards delivered it back to the villain to hold at his will, the assise fails, because the villain was not tenant in his own name, but in the name of his lord. *And if the lord was never seised of the land, then the exception of villenage shall not hold against any stranger.

6. If the plaintiff pleads in replication to the exception of villenage, that he will not nor ought to have his condition, whether he be free or not, tried by the assise, in such case the assise shall be taken upon 
the disseisin ex officio judicis, unless the tenant will waive the exception; and judgment shall be given according to the verdict; for we will that in favour of liberty no one of free estate be in such case obliged to put himself upon the jurors of the assise to determine his condition without his consent; but it is just that the spoliation, which is founded simply upon possession, be first tried, and afterwards the right concerning the condition, which is of a higher nature.

7. But in writs which concern the property and the right, as in the writs of right of customs and services, where no other customs or services are demanded than those which are due of right, and in other writs of right this exception is of so great force, that if the villain, or he who is alleged to be a villain, refuses to take issue upon it, judgment shall thereupon be given against him ; and if the plaintiff puts himself upon the assise, and the assise passes against the lord, then the villain shall for ever after be quit from the claim of his lord; and if against the villain, he shall for ever after remain *his villain as much as if he had recovered him by writ of naifty.

8. But in a possessory writ it has not so much force, for although it pass against his condition, it is not thereby impaired or prejudiced. For the exception serves only to bar the plaintiff of his demand, and does not alter the condition in any point, whether the inquiry of the jury be concerning the plaintiff or concerning his father, whether he died a villain, or in the condition of a freeman although he was a villain. An 
inquest upon bastardy is similar in its effect; for if an inquest be taken upon the exception that the father or other ancestor of the plaintiff died a bastard, although it be taken by consent of the parties, and the inquest find that he did die a bastard, yet the status of no person is thereby altered or changed.

9. Other exceptions there are against the person of the plaintiff, as if the writ is purchased in his own name, where the complaint is of a wrong done to another as well as himself; as where the husband alone is named in the writ, and the freehold is the wife's, except in the case of disseisin done by a wife to her husband. And if the writ be purchased in the name of the husband and his wife, jointly enfeoffed of the freehold of the wife, and one of them clie pending the writ. the writ is thereby abatable. And the like, where any woman takes a husband pending her writ in which she alone is named. ${ }^{1}$ Some plaintiffs also may be debarred from their plaints, inasmuch as they have no several action to demand anything certain in severalty ; as parceners and others holding in *ommon, none of whom could ever tell where his own share was. But if the plaintiff demands to hold in common, he shall be heard. 10. Sometimes an exception arises on behalf of the

1. Ex hoc nota, that none can be party to the purchase, if he be not expressly named, as when the husband marries the disseisee after purchase of her writ. But it is not so of a feme sole dịsseiseress who takes husband after a wit purchased [against her] ; because she may do it of malice [to defeat the action].' Note in MS. $N$. 
tenant, from his own person, as where he can prove by the assise that he is not disseisor. Also, where the lord of the fee is plaintiff for arrears of his rent, with which the tenement that has been viewed is charged, before he has tried to distrain his fee. For if the tenant demand judgment, whether the assise ought to pass, before the lord has essayed to distrain his fee, or is disavowed as lord, where the tenant acknowledges the services in whole or in part, in such case this assise does not lie, but distress from time to time for the service acknowledged. ${ }^{1}$ And if the lord by reason of his poverty is not able to distrain his tenant, then let the sheriff be commanded by precept of the Justices that he aid the plaintiff in distraining his fee.

\section{CHAPTER XIX.}

\section{Of Exceptions to the Action.}

1. To the words in the writ, 'unjustly and without judgment,' the tenant may plead that it was by judgment; and then it must be examined whether by judgment of our court or of that of another, and whether by our writ or without. *And if it was by judgment of our court or of another without our writ, then the exception shall not avail, but all that was done shall be

1 There appears to be some corruption in the text, which the MSS. do not enable us to set right. Possibly we ought to read, 'destresce soulement del service conu et otreié,' ' distress only for the service acknowledged and granted.' 
annulled. For without an authority given and defined by us no one can be judge orer another, especially to take cognizance of or determine concerning the freehold of another. If the plaintiff admits that the judgment was by original writ, but says that it was wrongful, the assise in such case shall fall, and he must be told to seek his remedy by writ of false judgment. But the assise shall not stand over for any juclicial writ not issuing out of an original.

2. If any one puts in view a tenement consecrated by the bishop, or any other thing which ought not to be the property of any one, the action and assise thereby fall, and the plaintiff shall be in mercy for his false plaint. And as such tenement ought not to continue in the possession of the tenant, let inquiry be made concerning the tenement; and if it be found that the tenement ought not to remain with the tenant, let the tenant be in mercy for his tortious occupation, and the tenement be restored to its former state. Let like proceedings be taken with regard to a tenement occupied in severalty which ought to be common to any general body, or other community. With respect to the king's highway, or other like thing, an assise shall always fall and be turned into trespass; and inquiry shall be made of the trespass and purpresture, and judgment shall be given according to the verdict.

*3. Sometimes the assise falls for uncertainty, although it is not on that account turned into a jury or perambulation, ${ }^{1}$ as happens between a woman and 1 See c. xvii. s. 8, p. 319 , and c. $x x$. below. 
the warrant of her dower before any assignment is made to her of her dower in certain, where if both are ejected, and the woman alone complains and puts in view the third of the whole tenement as her dower, get she shall not recover any tenement or any seisin by the assise, inasmuch as her portion was never ascertained. But if general seisin has been made to her, then it is sufficient to put her in such seisin as she had before; and if special seisin was given her, but she cannot now tell in what place by reason of the boundaries being removed, or by a like accident, then let land of the like value be assigned to her by the estimation of the jurors of the assise, as much as they can estimate among themselves to have been the amount of the tenement whereof she was disseised.

4. The assise also falls for uncertainty in the person of the plaintiff, as if the jurors have no knowledge of him at all. So, where they do not know for certain whether he held the seisin in his own name or in the name of another. The assise also falls where the jurors do not know who has the better right, the plaintiff or the tenant, as well to the possession as to the property. *Likewise, where the plaintiff claims by title of gift or feoffment, if he was never seised in the lifetime of the feoffor. The assise also falls, when brought by two sisters, who complain in common with their husbands, but the husband of one of them is not named, and this whether he be a felon or not, so long as he is living. ${ }^{1}$ So if the principal town is not named; for in 1"A freeholder (un prudome) has four daughters, two of whom 
one town there may be several parishes, and in one parish several manors, and several hamlets may belong to one manor, as shall be mentioned in the plea of right; but if the principal town is not named, the assise shall stand over.

\section{CHAPTER XX. \\ Of Assises turned into Juries.}

1. Assises are put off several ways, some for a time, some for ever; and some are turned into juries by assent of the parties, where he who refuses his assent after he has pleaded shall be held to fail in his plaint, or be condemned as undefended; others ex officio judicis, as where the parties differ in what vill, county, manor, fee, or barony, the tenement is. Assises are put off for a time by pleas in abatement and dilatory exceptions. By peremptory exceptions they are barred for ever.

*2. Some are turned into juries by the exceptions being denied, as in this case, where the plaintiff says that he was seised by title of succession after the death of his ancestor, who died seised, and whose next heir he is, and after whose death he presently entered

take husbands. The husband of one commits felony, for which he is outlawed, and abjures the realu. The father then dies. The inheritance is occupied by a stranger, and the four daughters are to purchase by the assise. $Q u$. Whether it is proper to name the felon, husband of one of the daughters, or not. Note in MS. $N$. 
and kept himself in seisin until the disseisor wrongfully and without judgment ejected him,--if the tenant meets this by saying that the ancestor of whom he speaks never died seised in his demesne as of fee, inasmuch as he held only for term of life, and that therefore the plaintiff cannot have a freehold by any title of succession; and if the plaintiff replies that the ancestor died seised as of fee, then the assise shall drop, and by the assent of the parties the jurors become as it were arbitrators; and judgment shall pass according to their verdict; ${ }^{1}$ nevertheless upon such verdicts, though passed by common assent of the parties, an attaint may lie.

3. So if it be disputed between the parties whether the ancestor held the tenement in gage or under any other condition or not, and whether the condition was satisfied or not. The like, where the younger brother, or bastard, or other, is ousted by the true heir, if the contest be which is eldest or legitimate, the truth of these questions shall be inquired by a jury by assent of the parties; and the like in other such cases which are numberless, in which the assise is turned into a jury by dilatory exceptions between the parties.

*4. If the plaintiff says that he was seised by title of gift, until he was wrongfully ejected, it may be said in answer, that he by whose gift he claims title was never

1. These things are necessary to succession, true ancestor, true ownership in him, true succession, true heir, and true seisin ; of which the four turn the assise, and the fifth makes the assise in its proper nature (en sa grasse nature).' Note in MS. $N$. 
in seisin, so as to enable him to make any gift; or if the donor was seised, he never divested himself of the seisin in his lifetime; nor was he who is plaintiff ever seised in the lifetime of the donor, but after the death of the donor he by his own force abated himself into the tenement, out of which the tenant as next heir presently ejected him, so that he was in only by mere abatement; and if the parties by common consent pray averment, the assise shall cease, and it shall be inquired by jury whether the plaintiff was seised by his own abatement or by the livery or induction of seisin by the donor in his lifetime; and judgment shall be given according to the verdict.

5. If the jurors know nothing of the facts, the plaintiff shall take nothing by his plaint, but be in mercy for not proving his contention. And if the jurors are in doubt, the assise shall be stayed, and it shall be adjudged, as before, against the plaintiff.

6. If the plaintiff derive his title under gage or conditional purchase, and the adverse party say that the condition was satisfied, or that satisfaction was ready to made be on the day *named in the deed, by denial of the party the assise shall cease, and shall be turned into a jury, if the parties consent, to inquire whether such satisfaction or tender was made or not. For suppose now that the plaintiff should say that he is disseised of his freehold, and should derive his title under a gift and feoffment, and say that by the gift and feoffment of the disseisor himself he was seised of this tenement, and did homage to him, and took the profits, and enjoyed 
his peaceable seisin from Easter until Christmas, when the feoffor himself wrongfully ejected him; if the tenant answer, he may well acknowledge the gift and the feoffment, and the charter and the homage, but if he can prove by writing that all these acts were conditional, - as thus, I enfeoffed you and took your homage upon this condition, that if I find within the year and day that you hold land anywhere of the king in chief, I may put myself in seisin and eject you without wrong, so that when I shall have found for certain that you hold elsewhere of the king in chief, I shall lawfully eject you by virtue of that condition to which you assent,-if such conditions can be shown by writing on one side and on the other, then the plea shall proceed according as the writings are admitted or denied.

*7. And if the conditional writings are falsely denied, although this falsity be afterwards proved, yet as it may happen that the condition has not been satisfied, an inquiry must of necessity be made concerning such

1 ' Nota, quod modernis diebus no charter can be conditional on account of the statute Quia emptores terrarum. For the purchaser must hold either of his feoffor or of his chief ; and of his feoffor only in fee tail. For when once the purcliaser is in rightful seisin of the fee and freehold, he cannot be ousted except by lis own consent ; neither can the donor, who has once divested himself, have it again except by a new title. But as soon as he gives to hold of the chief lord, he divests himself entirely (se demet tot nettement). Wherefore the charter must be absolute (simple); and if there be any collateral deed of covenant, the donor cannot retain his seisin by his own force, but must use his writ of covenant.' (Note in MS. N.) See above, pp. 236, 238 , and notes there. 
satisfaction, and jurlgment shall go accordingly, as appears in the chapter concerning Right. For although the charter be proved good, yet it may be void and of no force by reason of its false testimony in saying, I have given, whereas no gift was ever made, although there was some proposal of a gift. Hence it is not sufficient to prove the charter alone, unless the gift is proved; for it may be that the charter is good and genuine, and yet the purchaser clid not acquire the tenement by the gift of him who made the charter, but by his own abatement, or by disseisin or intrusion. So on the other hand, although the charter be proved to be false, yet it may be that the gift was good and lawful; wherefore both the gift and the charter must be proved.

8. If such conditions are set up without evidence of any writings, the adverse party may deny by their law, with eleven compurgators, that there ever was such a condition. And if the charter be one of simple feoffment without condition, and the gift be admitted or proved, then no credit need be given to an oral allegation of a condition on account of the presumption arising from the charter which does not mention any condition.

*9. If the donor by virtue of any condition contained in the deed between him and the purchaser cannot put himself in seisin and eject the purchaser according to the condition, he must in that case be aided by writ of covenant, in which the process shall be by the great and little Cape, as is in a real action. 
10. It often happens that the plaintiffs are prevented from recovering seisin by means of their plaints; as where the jurors of the assise have no kind of knowledge or presumption as to the agreements affecting the plaintiff,' 1 or concerning the thing whereof the plaint is made. They may also be impeded by their own will, as in case of conditions; also by release and quitclaim; and by accord, as where the person ejected has agreed to accept the value; also, by charter of confirmation from the person ejected; also by consent, as if the disseisor makes a gift of the tenement, and the person ejected executes a charter of confirmation. They may also be prevented from recovering by their own force and usurpation, as if they take back by their own force what they ought to have repurchased by judgment. Difficulty of judgment is another impediment. So also a legal judgment. And in all these cases upon a difference between the parties the assise shall be turned into a jury, and by way of jury such questions shall be determined.

*11. Where the plaintiff grounds his title on the "law of England,' and the tenant pleads that he cannot have a freehold by this title because he nerer had issue by such a wife, or if he ever begat a child the child died in the womb, or if born alive it was not a child but a monster, or supposing it to be a child it was never heard to cry; and if the plaintiff replies to the contrary, the assise

2 The sense of the original is doubtful. There appears to be some corruption in the text, which I have found it impossible to remove. 
shall cease and be turned into a jury. And if the jurors say that they saw the plaintiff in full seisin, and that he was ejected therefrom, but that they know nothing concerning any child by reason that the wife of the plaintiff died in childbed in another part of the country, then the sheriff of that place shall be commanded that he take with him the coroner of the country, and in the presence of the parties, if they choose to be there, inquire where the wife of the plaintiff died, and whethershe died in childbed or not, and whether she ever had a child by this plaintiff after he espoused her, and whether it was heard to ery or not, and that he make his return, on such a clay and at such a place, of that which he shall find by inquest; and judgment shall be giren according to the return.

12. Or the tenant may admit that the woman in whom the fee and freehold were rested had children by the plaintiff, yet that the same ought not to avail him, inasmuch as those chilchen were afterwards proved to be bastards; and if the plaintiff denies this, the assise shall cease and be made a jury by consent of the parties. And if the plaintiff demands how they *were bastards, and the tenant answer, because they were born before the plaintiff married their mother, in such case the truth shall be inquired by mears of a jury, and not in the form of an assise. And if he says, by reason that the plantiff nerer married their mother, and the plaintiff alleges the affirmative, then the assise shall stand over until it be determined in court Christian whether he ever married her or not. The mode 
of proceeding in sueh eases shall be described in treating of exceptions in the Plea of Right.

13. The assises are sometimes also turned into juries on account of trespass, as where any one desires to use the soil of another against the eonsent of the owner. And if any parcener or other would make severance of what is common against the will of the commoners, or if any commoner commits excess by taking more than his due, the act amounts to a disseisin ; and yet it may be a trespass according to the distinction, as where he does not elain any freehold; and then the assise shall cease and be turned into a jury to inquire of the trespass and damages. But because one cannot in such ease immediately discover the intention of the trespasser, the plaintiff acts prudently if he proceeds by this assise. And if the act be done a second time, then the assise holds, so that the plaintiff may recover his peaceable seisin. *If it be done a third time, the penalty of redisseisin shall be ineurred. If the disseisor claims a freehold, upon this the assise shall take place; and if the assise say that he has a freehold as a commoner and not in sereralty, let him be adjudged to bave the same seisin as he had before, and be punished as a disseisor for the excess.

14. But in the ease of common tenements where disseisins are made secretly and are begun by little and little, it is expedient to take pledges of the trespassers, and to impound the beasts, if any do damage in the eommons or sureharge them with cattle, so that upón such seizures satisfaction may be made by the 
award of neighbours. And if any one claims a freehold, the owner will act wisely, in the first place, if he keeps him out, so that he may not do any disseisin ; and if he cannot be prevented, then this assise takes place.

15. So likewise for trespass by waste and destruction, and also for excessive distress. For excess in distraining sometimes breeds disseisin, and sometimes trespass; disseisin, where any one distrains another, whereby husbandry is disturbed, whereas there is no occasion for the distress ; trespass, where one distrains the tenant of the tenant instead of the mesne tenant, the mesne being of sufficient ability. So if the demesnes are distrained when the villenages are sufficient; or the distress is by immovables where there are movables enough to be distrained, *or within the house when enough may be found out of door's, or by beasts of the plough where there are enongh of other beasts not used for libour, or by apparel or riding-horse or vessel where the other chattels may be distrained, or if the distress taken be in excess, as twenty pounds for twenty shillings, or if the distress be driven out of the county or out of the fee. And according as it shall be found to be disseisin or trespass, the assise is held as an assise or is turned into a jury to inquire of the trespass. There are more exceptions that cannot all be particularly mentioned here, some of which hold in other pleas, as will further appear in treating of challenges of jurors. 


\section{CHAPTER XXI.}

Of the challenge of jurors, and of the trial of the assise.

1. When the parties have pleaded to an assise or to a simple jury upon any exception, the day may be delayed many ways, as for default of jurors. Or if a sufficient number of jurors appear, yet some may be removable by the just challenge of the parties.

2. Sometimes the day is delayed on account of the season; for all seasons are not fit. For it is forbidden in the Canon by holy Church upon pain of excommunieation, that from Septuagesima until the Octaves of Easter, and from the beginning of Advent until the Oetaves of *the Epiphany, and on Ember days, and on the days of the greater litanies, and on Rogation days, and in the week of Pentecost, and in the time of harvest or vintage, which last from St. Margaret's day until fifteen days after Michaelmas, and on solemn festivals of Saints, no one shall be sworn upon the holy Gospels, or hold any seeular plea, or make any summons in the times aforesaid, so that all these seasons be set apart for prayer, and for appeasing of quarrels and reconciling those who are at variance, and for gathering the fruits of the earth which are to be the food of man. Nevertheless the bishops and prelates of holy Chureh do sometimes grant dispensations, that 
assises and juries be taken in such seasons for reasonable cause.

3. When the day cannot be put off on account of the season being improper, the jurors may be challenged, and sufficient and reasonable exceptions alleged why they ought not to be sworn or be in rerlict against the party. For the same objections lie against jurors tak.. ing the oath as against a suspected witness giving his testimony, inasmuch as no one who has been once convicted of perjury ought to be sworn, for such are held to have forfeited their free law, so as not to be crediterl upon any oath which they take. Norought those to be sworn who have suffered judgment of life and limb, or punishment of pillory or tumbrell ; nor those who want discretion; *nor excommmnicated persons; nor lepers removed from society ; nor priests or clerks within holy orlers; nor women; nor such as dwell away from the neighbourhood; nor those who are above serenty years of age; nor allies in blood; nor such as can claim any right in the tenement; nor villains ; nor persons indicted or appealed of felony ; nor those of the household of any of the parties; nor those who are liable to be distrained by either of the parties! nor their lords, or counsellors, or accountants.

4. When the parties have agreed upon the jury, then let the first juror, touching the holy Gospels, swear after this manner. 'Hear this, ye Justices, that I will speak the truth of this assise,' (if the assise is to be taken in manner of an assise and not as a jury, ' of the tenement of which 1 have had the view by the 
king's precept;' or thus: 'of the tenement whereout such rent is said to arise;' or thus: 'of the pasture and of the tenement,' or 'of the common, whereof I have had the view.' Thus the words of the oath must be varied according to the form of the writ. and declaration; and if the plaint be made of nusance, then it shall be said thus: 'of the nusance and of the tenement to which the nusance is said to have been committed ;' or thus: 'of the wall, or pond, and of the tenement,' without adding 'whereof $I$ have had the view.' Then it continues thus: 'and I will not fail for anything to speak the truth, so help me God and his Saints.' Then let the rest swear thus: 'The same oath which such a one hath thus sworn, I for my part will keep, so belp me God and the Saints.' Then let the Gospels be kissed with all reverence as *our faith and salvation. If several assises are to be taken under one oath, then it shall be said: 'of the assises and of the tenements whereof $I$ have had the view ;' or thus : 'of all assises, and of those tenements whereout such rent is supposed to arise ;' or thus: 'of those tenements, and of the common of pasture, or turbary, or other, and of the tenements to which it is said they ought to belong, whereof I have had the view;' or thus: 'of this assise, and of the corrody, and of the tenement,' and so of others. And in the other assises of mortdancester and darrein presentment the oath shall be taken in the same manner.

5 . When twelve are sworn, and their names enrolled, then let the writ be read to them by the clerk pro- 
thonotary, who shall address them in this manner: 'You shall say by the oath you have taken whether such a one wrongfully and without judgment has disseised the plaintiff of his freehold in suck a vill within the term, or not.' The Justice also shall straightway rehearse the substance of the plaint thus: "John, who is present here, complains of Peter that he has wrong: fully and withont judgment disseised him of his freehold in snch a vill, whereof he puts in his view ten acres of land (or more or less), with the appurtenances ;' and then let him mention the declaration of the plaintiff and the allegations of the defendant for the informition of the jurors.

*6. The jurors shall immediately withdraw by themselves to confer together; and then let them be so kept, that none of them speak with any other person except the jurors, nor any other person with them. And if any do so maliciously, and be found guilty thereof, let him be punished by imprisonment and fine, and let the jurors be amerced, if they have not themselves accused him. Moreover let the jurors be watehed, that they do not give warning to any one, by motion or the eye or by other sign, against which of the parties they intend to pronounce their verdict; and whosoever shalt do so, and be found guilty thereof, shall be amerciable? or otherwise punishable according to the mischief which may arise.

7. If the jurors cannot agree, let others be added to the majority of the jury, if the parties consent; and if not, let the judgment be against him who refuses to 
consent, so that if the plaintiff refuses, the seisin shall remain as before, and he be in mercy; and if the disseisor refuses, he shall be adjudged as undlefended. If the jurors cannot pronounce the truth, nor return any verdict as to the fact, let the seisin remain in the tenant, and let the plaintiff be in mercy for not having provel the case made by his plaint. If the jury refuse to pronounce any verdict in the matter through favour to either of the parties, or for any otler reason, then let them be shut up without meat or drink until they have given their verdict.

\section{*CHAPTER XXII.}

\section{Of Judgments.}

1. When the jurors are all agreed, let them immediately go to the bar before the Justices, and declare their verdict; and according to their verdict let judgment be given for one of the parties, unless any doubt or difficulty arise, which may make it necessary to examine the facts by the jurors or others, or to defer judgment until another day, so that the Justices may in the mean time be advised and consult what is best. to do therein. Where the Justices however are doubtful about the verdict, and the jurors have not been sufficiently examined, or have been too hasty in their judgment on account of some word or sentence whicli might have a double intendment, in such case a certification may be taken by the same or other Justices. 
But it is better and safer for the Justices thoroughly to examine the reasons of the jurors so that they may give a good and sound judgment, and that no error may be found either in their office or in the proceedings.

2. When the jurors have declared their verdict upon the substance of the assise, or upon any exception, and such verdict is given against the plaintiff, then let it be awarded that the tenant and the others named in the writ go quit of that assise without day, and that the plaintiff take nothing by his writ, but be in *our mercy for his false plaint. Nevertheless his pledges to prosecute shall not in such case be amerciable, inasmuch as the plaintiff has prosecuted his suit to the end.

3. When the assise is taken after the manner of an assise, regard must be had to the quantity and quality of the plaint, and how much the plaintiff has put in his view and set forth in his plaint; since the oath of the jurors does not extend to that which he has not put in his plaint. And if the Justice awards to the plaintiff more than he has put in his plaint, or if the jurors give him seisin of more than he has put in his view, they commit a manifest disseisin on the tenant $:^{1}$ as does the sheriff also, who puts in execution the command of the judge, because in such a case, or in any

1 E.x hoc nota, that the plaintiff's demand is the Justice's warrant, and the foundation of the judgment. Wherefore if the judgment is given upon a lemand other than that which the plaintiff has truly made. whether more or less, the judgment is false.' Note in MS. $N$. 
other where the Justiee's jurisdiction does not extend, no bailiff ought to obey him in exeeuting his commands. The plaintiff is in a like position who reeeives such defeetive seisin. So likewise where the plaintiff eneroaches upon the disseisor more than right under colour of judgment. And if the plaintiff puts too much in his view, he is anereiable for his exeessive demand.

4. If the verdict be given for the plaintiff, it shall be forth with inquired who were present at the disseisin, and the manner of the fact, whether the disseisin was committed with banner displayed, or horses harnessed, or by other foree of arms, and by what foree, and by what arms. And it should be understood that there are divers sorts of arms and divers kinds of force. For all those are said to be armed who earry anything wherewith they may lo hurt to people or overpower other's, as well as bows, arrows, knives, hatehets, and staves, as hauberks, lances, and swords. So there is armed foree, and simple foree without arms, as by multitude of people.

*5. And beeause many a man, having no right, gains seisin by such foree, upon which the tenant who has a right to retain and abide in possession leaves the tenement to a void further misehief, and forasmuch as sueh ways of obtaining seisin are in part against our peace, we will that the Justices inquire, who eame in the foree along with the principal disseisor, so that the disseisor and those of the force be punished by imprisonment and fine if they are eonvieted of a disseisin effected by 
force, and if by arms, then ransomed. And if any be convicted of a disseisin done under colour of right, and without breach of the peace, as by a simple disseisin done in the daytime, without force and arms, with a white wand in sign of peace; in such case let the disseisor be annerciable by their peers, and also make satisfaction to the plaintiff in damages. The penalty above mentioned, which is to be imposed upon disseisors who eject people from their freehold, whether by force or arms, or, as it should be done, after a peaceable manner, shall also be imposed upon disseisors who with force or arms, or simply without arms, keep a man out of his freehold when he expects to enter peaceably therein.

6. Sometimes it happens in this assise that the disseisors shelter themselves by us, and say that they neither have or claim anything in the tenement, *but whatso. ever they did was done in our name, and that without us the assise cannot pass, nor the fact be brought in judgment without prejudice to us; in which cases we will not that under such pretext the assise shall stand over ; but if the disseisin be clear and manifest, let it be adjudged for the plaintiff, and let the common law take its course against the tenant as against any other person ; and if any doubt be perceived, let judgment be respited to another day, and let the proceedings in the meantime be laicl before us, so that judgment may be ordained by our advice.

7. And because it often happens that the tenant has not committed any disseisin or wrong, but has possibly 
purchased the tenement by feoffment of the disseisor ; in such case it is reasonable that the tenant should be able to vouch to warranty the clisseisor, so that he who has done no wrong may not be punished for the trespass of another, without recorering to the value from his feoffor; and then let the same proceeding be observed as shall be mentioned concerning warranties in the assise of Mortdancester. If two or more assises are prosecuted by several persons against one, the last seisin shall be first tried, and so backwards to the first disseisin. ${ }^{1}$

*s. Afterwards let it be inquired of the jurors what damages the disseisors and the tenants have committed in houses, woods, gardens, warrens, vivaries, parks, rabbit-warrens, and elsewhere ; and how much has or might have been by good husbandry received in the

1 A $\mathrm{A}$ is disseised by B. B continues seised, and is ejected by $\mathrm{C} . \mathrm{C}$ is ousted by $\mathrm{D}$, who enfeoffs $\mathrm{E} ; \mathrm{A}$ brings assise against $\mathrm{B}$ and $\mathrm{E} ; \mathrm{B}$ brings assise against $\mathrm{C}$ and $\mathrm{E} ; \mathrm{C}$ against $\mathrm{D}$ and E. Quastio, whether E, tenant, ought to answer to all at the same time, or if not to all, to whom first? Solutio: The Justices ex officio ougint to inquire of the last seisin in this manner : 'Good people of the assize, you shall tell us by your oaths which of these three, who bring assise of the same tenement against the same tenant $\mathrm{E}$, was last seised, whether A or B or C.' And if they say C, and before him B. and before him $A$, then the judgment shall be thus: "For as much as we find that $B$ hath disseised $A$, and $C$ hath disseised $B$, and D hath disseised $C$; therefore this Court doth award that $B$ and $\mathrm{C}$, being disseisors, do take nothing by their writs, but be amerced, and that $\mathrm{A}$ do recover his seisin against $\mathrm{E}$ by your views.' (Note in MS. N.) Compare Bracton, 177, 178. 
meantime of all kinds of issues of the tenement, and what profit in value the plaintiff might have had if he had not been disseised; and it shall be awarded accordingly that the plaintiff recover his full damages. And if the Justices perceive that the jurors are disposed to relieve the disseisor by assessing light damages, because on the other hand they have made him suffer by the loss of the tenement, let the lands be extended by the same jurors at their true value in the presence of the parties, if they will be there; and according to the yearly vahe let the danages be taxed by the Justices, single or clouble, according to the ordinance of our statutes, and according as the assise shall have been falsely defended or not.

9. If the disseisors have taken away or detained from the plaintiff any vessel, robe, or chattel, it shall be in the election of the plaintiff either to sue for his chattels by appeal of robbery or trespass, or to have them taxed with the rest of his damages. The damages for wild animals taken in parks or chases, and for fish taken out of ponds, shall be assessed by the jurors ; for in such cases the penalty of three years' imprisonment does not lie, *nor in any case except where judgment of felony can be given, if the offenter is in peril of life and limb. If houses have been burnt or other clamage has happened in the meantime, although it was by an unforeseen ac. cident, without any human malice, yet the disseisor is not thereby discharged from making satisfaction as well for the chattels of the disseisee as for the goods of others wrongfully detained by the disseisor. 


\section{CHAPTER XXIII.}

\section{Of Appurtenances.}

1. Having spoken above of disseisins of things corporeal, we must now speak of disseisors of things incorporeal, as of appurtenances. For although a tenement be freehold according to the definition of it, yet in respect of the services wherewith it is eharged another tenement may be more free; and yet both are free tenements. Wherefore if one tenement be charged with any service to another tenement, such service is properly an appurtenance to the tenement to which the service is due, which appurtenances no one ought to disseise another, and if any one does so, the disseisee may be aided by this assise, or by our writ to the sheriff, as shall be hereafter mentioned.

2. It should be known that some appurtenances are free, others servile; free as in respect of the *persons and tenements to which they are due, servile as regards the tenements from which they issue, ${ }^{1}$ and such servitudes are always due from the tenement of another;

1 Unless the text is corrupt, the above sentence appears to be a mistaken rendering of the parallel passage in Bracton or Fleta, when the sense is, that the same things which are rights or liberties (jura sive libertates) in relation to the dominant, are servitudes (servitutes) in relation to the servient tenement. This observation is found subsequently in Britton, post, s. 8, p. 292. 
although no one ean subjeet the soil of any one to servitude but his own. And in this way some tenements are more free than others ; for that soil is more free which owes nothing to the soil of its neighbour, than that which is bound to a servitule.

3. A person may subject his tenement to a servitude in several ways, as by granting that another, who has nothing therein, shall have a right of pasturing or mowing, or fishing, or of driving cattle, or of way, or of carrying therein, or by other servitudes which may be infinite and numberless, according as they are simple or compounded of other appurtenanees. For there are appurtenances, and also appurtenances of appurtenances. For to a watermill, the course of water is one of the appurtenances, and way is another, to which cleansing and repairing are appurtenant, and are therefore appurtenances to appurtenanees; and if any one be disturbed thereof, remedy may be had by this assise.

4. And whether the servitude be due from one soil to that of another or to the person of another by the consent of the true owners, for a certain service or by reason of vieinage, they are not bound to the soil only, or to the person only, but to the certain soil of another, and also to the owner of the soil, whosoever the owner may be. Hence it follows, that whosoever purchases the soil *purchases the appurtenanees due to the soil, unless hindered by special exception. Some of which servitudes are ordained and established by those who have power to charge the soil, and others by long 
usage on the one side, and by sufferance and negligence on the other. For in such a case it is presumed that sufferance with knowledge amounts by prescription of time to consent. For although a tenement be not burthened with any kind of servitude by appointment or other good title from the owner of the soil, yet if the neighbour has taken by encroachment upon the soil of his neighbour any servitude, as the depasturing of the herbage on his neighbour's soil, and the hindering of the owner from pasturing, and has been seised thereof, claiming freehold, without force and without asking leave of the owner of the soil, and this continually, and not privately by stealth, but boldly and openly, he can never be ejected or disturbed with. out being disseised. And if he to whom the wrong is done by his own consent, disseise such purchasor by force and not by judgment, that presumption shall be so far prejudicial to him, that if the ejected recover his seisin by judgment of our court, he shall not afterwards eject him but by plea in the right by writ of Quo Jure. But by a precarious or secret disseisin, as in the absence of the owner of the soil, *although the bailiffs of such owner be present or consenting, a freehold never accrues to such purchasers.

5. Sometimes the soil is subject to a servitude by law, although not by any man's appointment, or by the establishment of peaceable seisin, as, for example, to the obligation that no one shall do anything in his own soil that may be a grievance or annoyance to his neighbour; of which annoyances there are various 
sorts; for some annoyances may be lawful, and in particular such as no neighbour can forbid another to do, as to erect a mill on his own soil ; and some may be tortious, as if any one do in his own soil a thing which is a grievance to his neighbour, and which he by law may be prohibited from doing. For the law forbicls any one to raise or heighten his pond so as to drown the tenement of his neighbour, or to make a ditch in his own soil whereby the water is diverted from his neighbour, or whereby it is hindered from remaining in its ancient course, or to do any act in his own soil whereby his neighbour may be less able to use his seisin of the servitude wherewith the soil is bound and charged to him, or to use his peaceable seisin where and when he ought, in all such ways as he was wont and ought to use it, in number, kind, quality, and quantity.

6. For there is secret as well as open disseisin; forasmuch as he is equally disseised who is not suffered to have his driftway over *another's soil which is subject thereto, or is not permitted to repair and put in order the way, as if the way was entirely destroyed, or the whole soil turned into a fishpond; and he who is hindered from eleaning out the watercourse of his mill is as much disseised as if the whole watercourse were disturbed or diverted; for to a right of watercourse the right of cleansing is appurtenant, as the right of repairing is appurtenant to a right of way. And he is as much guilty of disseisin who partly hinders another's seisin, as if he disturbed him of the whole. 
And if any one has common in another's soil with free ingress and egress by a certain place, if the owner of the soil commits disturbance by making a hedge, wall, or ditch, whereby the ingress and egress is less easy than before, inasmuch as he must drive his cattle a long way round where he could formerly drive them straight, these and like acts may be treated as disseisins, unless the nusances are redressed by presentment in the sheriff's tourn, or in view of frankpledge. So in this case,- - where any one has a right of pasture granted to him for his cattle at whatsoever times he pleases, and he is afterwards disturbed so that he can put them in only at a certain time, or when he has a right to pasture throughout the whole and he is hindered from having it except in certain places, or where he ought to have pasture for all manner of beasts and he is al lowed to have it only for one kind of beasts, or where he ought to have pasture for a certain number and he is suffered to have it only for a less number; or if it is granted to any one that he may draw away water at his pleasure from another's well and he is disturbed *as above mentioned concerning pasture,---in all these cases this assise is applicable, as much as if complete disturbance had been made of the whole.

7. In all cases where this assise lies for the grantee of such a franchise, it lies also for the owner of the soil if he to whom the franchise is granted uses his seisin in a different or more extensive manner than he ought. Nevertheless it is well to hinder such excesses, so far as possible, at the beginning, so that the dis- 
seisors may not avail themselves of peaceable seisin as title of freehold.

8. The servitudes to which a man may subject his land are innunerable; and such rights and franchises are purchased in the same manner and for the like causes as corporeal things. But for the purchase of these franchises the same formality of giving seisin is not requisite, as in purchases of corporeal things. For if the parties are agreed, the delivery of the deeds together with the view of the tenements in the presence of neighbours is sufficient; and if the purchaser be thereafter hindered from enjoying the franchise granted to him by one who had power to grant it, he shall be helped by this assise, although he has not taken any esplees. Thus, where pasture in another's soil is granted in fee or for term *of life, and the writings are delivered, and the soil assigned by view of neighbour's, if the purchaser, whether the next day or a long while after, has a mind to feed his cattle on the pasture of that soil according to the tenor of his purchase, and is hindered by the donor or another, he shall be aided by this assise, although he never en joyed the pasture. For such franchises are so simple that they do not admit of delivery of seisin, as gross, coarse, and material things do. It should be understood that such purchases, in relation to the purehaser and also to the tenement to which they are assigned to belong, are franchises and rights, and with regard to the owner of the soil which is charged, and to the tenement bound thereto, such purchases are servitudes. 
9. But although the purchaser is thus in seisin, this does not prove that such seisin is sufficient for ever. For until he has taken other seisin of the pasture, he cannot alien the same; as in the like case of the advowson of a church, which cannot be granted before the donor has been seised of the advowson by presentation. The purchaser may also be barred of his seisin, if the soil be aliened to a stranger before any other seisin was taken thereof beyond the bare delivery of the writings. Therefore it is proper to put in the beasts forthwith. *For the putting in of one beast is a sufficient seisin for all the rest which he might have put in, although the beast be borrowed by the purchaser of some other person, so it be not the donor, unless it be specially excepted in the gift that he shall depasture his own beasts only, and not those of others; and if he omits doing this he may lose his purchase by his negligence, since it is presumed that he did not intend to take any seisin.

10. If the purchaser has neither beast of his own nor can borrow another for the purpose, then it is sufficient to hinder the owner of the soil as much as he can from ploughing and sowing, so that by such molestation he retains a kind of seisin, and may put in his beasts whensoever he chooses to send them, although the land be ploughed and sown, or although the corn be ripe. But if he has been so negligent as to suffer the owner of the soil to plough and sow without any dispute, and then takes seisin for the first time wliile the corn is growing by feeding his beasts in the 
corn, in sucl case he commits a disseisin against the owner of the soil; and if the owner recovers by this assise, the purchaser shall be barred of his pasture for ever after by his negligence in too long delaying the taking of seisin. But some one may say on the other hand thus, Although you till and sow my land without my leave and I knowingly suffer it, yet no wrong is done me until you carry the produce away; how then is my negligence and the sufferance more dangerous in the one case than in the other? In answer to this, it is to be observed that there is a negligent sufferance and a sufferable caution. *For by suffering lands to be ploughed the lands are improved, and by sowing also; and in such case the sufferanee is good and prudent to permit a man to sow another's land; and it is no disseisin to the owner of the soil, since nothing has been done against his consent: but where no profit accrues to him by the sufferance, but on the contrary loss, as in the case in question, then it is negligent sufferance; for in the one case the condition of him who permits the ploughing is made better, and in the other worse.

11. Some enjoy the seisin of common in their own right, and some in the right of others. And as a guardian enjoys the seisin of common in the name of the infant under age whose guardian he is, so likewise the parson of a church enjoys it in the name of his church. For a church is always supposed to be in the same state as an infant under age, by reason of its always being under the guardianship of its parson, by which 
guardians churches may purchase and amend their estate, as infants may by their guardians; but they cannot assent to anything to their damage. Wherefore if any church is seised of a common, although the parson dies, yet the church does not in any manner lose its seisin of its common, or any other seisin, any more than an infant under age does by the change of his guazdians, by which change his estate is not impaired or altered in any point. *Therefore every parson may use that seisin which his predecessor left to the church; and if he be disturbed therein, he shall recover by this assise. But if the predecessor was beforedisturbed, or if the church was disseised in the time of its aroidance, then another remedy is required, as by our writs of entry, or of Quod permittat.

12. Forasmuch as there are several kinds of servitudes, as we have before said, and the most important of these is the right of pasture in another's soil, we shall therefore first treat of common of pasture. 


\section{CHAPTER XXIV.}

Of Common of Pasture.

1. Common is a general name, and no community can be so restricted but that it be understood that there are at least two or more parceners to whom it is common. And it properly signifies that one person has a right to common with another in another's soil. Pasture likewise is a general name for herbage, acorns, mast, and nuts, and for leaves and flowers, and for all things comprised under the name of pannage.

2. Purchases of common may be large or limited, as at all times, or only at certain hours; and as per my et per tout, or only in certain places; or as for all manner of beasts, or only for certain kinds. Reasonable prohibitions are nevertheless excepted in such purchases, sometimes expressly and sometimes tacitly ; *for none ought to common in respect of any purchase in seasons of reasonable prohibition, as in hay time or harvest time; so in places particularly reserved for the pasture of lambs or calves, oxen or cows, no more than within the curtilage, or in gardens, orchards, or parks, or in demesnes, which the lord may fence in or enclose at his pleasure.

3. Common is acquired several ways; as by gift, where one gives to another any soil with common ap- 
purtenant; and by sale, as if one buy common in another's soil, so that for ever after it be appurtenant to his own soil, although the two soils be in different fees or different baronies or counties, so long as they are adjoining; by vicinage also, as if one neighbour gives common to another, and the reverse ; or by long sufferance without other title, with the knowledge and consent of the owners of the soil ; for neither the sufferance nor consent of their bailiffs will ever give title of freehold, nor will any arbitrary usurpation, if he who thus acquired it hath not continued and used his seisin with the knowledge of the owners ; * yet notwithstanding, if any one having no right but only recent seisin by his own abatement be ejected by another who has less right, he who is thus ejected from his posession shall recover such estate as he had by this assise. For although he has no right to be thus in seisin, yet the disseisors have no right to eject him from his seisin, such as it is. But if he in whose person the property is rested ejects him as soon as he knows of the usurpation, the ejected shall never recover by this assise by title of peaceable continuance in seisin.

4. If any one purchases coinmon of pasture in another's soil, and has no tenement to which the common may belong, this is not properly a purchase of common, but a hiring of the pasture or herbage.

5. As common is acquired by the will and mutual agreement of the donor and purchaser, so is it extinguished and destroyed by the mutual agreement of the parties to the contrary, so that the assent or disassent of 
one is of no avail either for purchasing common or for waiving the purchase, unless there be a union of assents or disassents by their common will. And as common is sometimes purchased by long sufferance, so it is lost by long negligence, but only on cases where seisin has been openly enjoyed with the knowledge of the owners.

6. By mutual consent also that may become several which before was held in common. For as land which is common among parceners may by division become several, in the same way any tenement of which the pasture is *ommon may be divided among the commoners, to be held in severalty. But for this the assent of all the commoners is necessary. And when they have once consented, and the boundaries are fixed, and every one knows his several, no dissent afterwards will avail.

7. Where any soil is charged with a serritule, the servitude may be lessened, restrained, altered, and limited, and in the same manner enlarged and increased, but not against the eonsent of the donors and purchasers. For if any one should do it against their consent, this assise would lie for him whose soil it was intended to burthen with more than was right; or, on the other hand, the remedy may belong to him to whom the servitude is due, where less is performed than is right.

8. When a gift is to be made of a common, there must be a transfer of it from one person to another, and from one tenement to another, and the persons and tenements should be specified on both parts, as 
well the persons of the purchasers and the tenements for which the common is purchased, as the persons of the donors and the tenements which are to be charged with the common; for it is a general rule that there can be no common without soil, that is to say, without soil to which it is servient, nor without soil charged with the service.

\section{*CHAP'TER XXV. \\ Of the Remedy for Disseisin of Common.}

1. Those who are ejected or disturbed of their common may have remedy by our writs, when they shall be unable to retain or peaceably to enjoy their seisin. The forms of remedy however are to be distinguished. For according to the diversities of the cases the writs must be varied; for the same soil may be charged with several servitudes to several soils, as well in the whole as in part: and this may be true in divers ways; one way, on account of the different tenements to which the servitudes belong; another way, by reason of the different persons to whom they are due; and the third way, by reason of a diversity both of the persons and of the tenements. In the first case one writ is sulficient, because of the unity of the person of the plaintiff ; but in the second and third cases there are divers rights, and of divers rights there may be divers disseisins, and for divers disseisins there must be divers writs. 
2. But if there be a unity in the tenement to which the servitude is due, although there are divers persons, as in case of parceners who hold a tenement in common, in such case, whether there be one plaintiff or more, there need be only one writ, and that by reason of the unity of their right, although they are divers persons, and on account of the unity of the tenement, which is held in common. *But if the tenement be divided between the parceners, and any one of them be afterwards disseised of common belonging to his part, to such case separate plaints and separate writs lie, so that each parcener shall bring a separate assise. If a parcener is disseised of his common by one of his coparceners, the disseisor and disseisee only are to be named in the writ, without naming the other parceners, whether the parceners be merely neighbours or entitled as one heir.

3. When we have thus granted our writs to the plaintiffs, let them be forthwith attached by pledges $;^{1}$ and let jurors be chosen, and let the soil and place of the common be riewed, as well as the tenement to which it is due, so that the jury may be certified of the extent and boundaries of the common, and for what sort of cattle, and how many, and of all the circumstances as to which they will be charged by our Justices.

1 The French text is somewhat obscure; but it is clear from the parallel place in Bracton that the pledges spoken of aro pledges to prosecute. The expression attachiato brevi occurs in Fleta, 259 . 
4. When our Justices are come into the county, and the patent has been read, let the parties be inmediately called; and if the plaintiff does not appear, or cause himself to be essoined, whether the disseisor be present or not, in every plea, it shall be adjudged that the plaintiff and his pledges to prosecute be in mercy; whereby the writ is abated, so as never after to be of service to the plaintiff, but he must purchase a new writ. *If the plaintiff be in court, whether the disseisor be there or not, let the original writ be read.

5. Afterwards let the plaintiff be asked of what common be makes his plaint, and of how much, and to what tenement he claims the common to belong. And then let him declare his title, as above is said. For if he has no fee tenement to which the common may belong, he shall fail in his plaint without any other recognisance of the assise. He may then say that the common is appurtenant to his free tenement in such a vill by reason that he was enfeoffed of such a tenement, at which time that common was appurtenant thereto, and by such purchase he was seised thereof, and his seisin peaceably enjoyed, until he was ejected or disturbed. If he says that he is disseised of one hundred acres of common, he may fail in his plaint, inasmuch as he ought to say that he is disseised of the pasture of one hundred acres of common. 


\section{CHAPTER XXVI. \\ Of Exceptions to C'ommon.}

1. The plaintiff's contention being thus set forth, if the tenant or his bailiff does not appear, the assise shall proceed by his default; but if the tenant is in court, let him first consider how he may aid himself by exceptions against the judge, or against the plaintiff ; against whom he may object, that the action and plaint do not belong to him, inasmuch as he is only a farmer, bailiff, or guardian; *or he may say that he is his villain. Nevertheless, in case where a villain of whom his lord is not seised has married a free woman, who holds of her own inheritance the tenement to which the common is appurtenant, and whereof the lord of the villain has disseised them, the assise shall not be barred by the exception of villenage, but the common shall be united again to the freehold ; and the lord may tatke proceedings to prove his right to the person of the plaintiff if he thinks proper to do so. ${ }^{1}$

2. There are several other exceptions; thus, whereas writ says 'hath unjustly disseised him, the tenan' may traverse this statement, and say that he was

1The above case is more fully explained in Bracton, where it appears that even though the villain was in the lord's seisin. yet the common might be recovered by the assise, as accessory to the wife's freehold. (Bracton, 22t b, s. 8.) 
never seised; and if he can verify this, the writ shall fail. But before proceeding to the assise, the plaintiff should be asked in what manner he was seised; and if he says by title of gift, then a slighter seisin is sufficient on account of the union of the wills of the donor and the purchaser, together with the view and assignment of the tenements in the presence of the neighbours, than where the title is by succession. For in case of a feoffment, if the purchaser be ejected immediately after the assignment of the clonor, although such purchaser has not put his beasts in the pasture, yet it does not follow that he shall not recover by this assise. But in case of succession it is otherwise. For it may well be that the predecessor was disseised in his lifetime; or the seisin may have been usurped by intrusion of the tenant during the vacancy * of seisin; in which case this assise will not avail the successor, as above is mentioned.

3. To that which is contained in the writ, 'of his common of pasture appurtenant to his freehold in such a vill,' it may be answered that the soil of the common, and the tenement to which the plaintiff alleges the common to belong, are of diverse baronies or diverse fees, and that the fee in which the common is demanded is so free that it is not charged with any sort of servitude to the other fee, and that the plaintiff never commoned or had any right of common either by title, usage, ricinage, or otherwise; and if, notwithstanding, he ever did common, it was by force, or secretly by stealth, or by leave, or at will; and if he otherwise 
commoned, he never did so peaceably, but his beasts were driven away or impounded, and he and his servants released upon security. To which the plaintiff may reply, and allege the contrary, if he thinks fit to do so.

4. Or the tenant may say, that the soil where the plaintiff demands common is his several, which he may plough, sow, and enclose at his pleasure, and at all times keep enclosed. Or he may say that the plaintiff hath no land or tenement to which that common was ever bound or appurtenant; or if he hath land or tenement, yet no common is appurtenant thereto, for the same tenement to which he claims the common to belong used to be forest, or heath, or marsh, or other waste, and *common to all those of the neighbourhood, though the same be now asserted and ploughed up, and that one common cannot be appurtenant to a nother. Or he may say that the principal disseisor named in the writ is dead. Or he may say that he recovered the common by judgment of our court as appurtenant to such a tenement which he recovered.

5. Or he may say that the plaintiff wrongfully complains, for that at the time of the plaint, and on the day of the date of the writ, the plaintiff himself was seized, and that the present plaint cannot try a fact of more recent time; and therefore at the time of the plaint he had no cause of action, and consequently the plaint is null; or that, if he was disseised at the time he complains, yet he had no cause of action, for that after he was disseised he took back his seisin without 
judgment, whereby he is become a disseisor, and that an assise is therefore commenced against him. And according as such exceptions shall be made good, judgment shall be given for one party or the other.

\section{CHAPTER XXVII.}

\section{Of Admeasurement of Pasture.}

1. Although a person has some right of common, yet he ought not to exceed by putting in more cattle or usurping more common than he is entitled to, or than belongs to his freehold, but only to that to which the common is appurtenant. *For if any person holds an hundred acres of land and common be appurtenant to all the land, and if he aliens this land and purchases other to which common is not appurtenant, in such case he cannot retain any part of the common, except by title of usage beyond the term of limitation running in an assise of Mortdancester. And although he has reserved one acre to which common is appurtenant, yet he ought to have common only in proportion to the quantity of land so reserved.

2. If he will perforce have more, the lord or owner of the soil should apply a remedy by impounding the surcharge or excess of his cattle. And if he cannot do it by himself, he may avail himself of the remedy by this assise for the excess of the cattle, in like manner as this assise would also lie between the owner of 20 
the soil and any one who in spite of the owner insisted upon commoning where he had no manner of right or title to claim common.

3. If the lord will not interpose, a remedy is afforded at the plaint of the commoners by our writ to the sheriff of the county, to remove every outrage, and bring every excess to a certain limit; in which writ our command runs thus:

'John has complained to us that Peter has unjustly surcharged his common of pasture in N., and has put in more beasts than belongs to him to put; therefore we command thee, that without delay thou cause the aforesaid common to be admeasured, so that the same *Peter shall not have more beasts than to him belongs to have according to the free tenement which he holds in the same vill; and that the aforesaid John have as much common as belongs to him, and that we hear no further complaint.'

4. In such case it is the sheriff's duty to take pledges. to prosecute, and afterwards to cause the lord of the soil and all the commoners and other neighbours, as well as the person against whom the plaint is brought, to be summoned, to be upon the same common at a certain day, to cause the common to be measured ac. cording to our command; and that the parties be then prepared, the one to show his grievances, and the other his right, if he chooses to appear. At the day named, if the plaintiff does not come, he and his pledges shall remain in mercy of the sheriff, and nothing more shall be done upon that writ. If the plaintiff appears at 
the day, although his adversary does not appear, yet the admeasurement is not to be put off.

5. If the defendant comes and produces his muniments an $I$ explains his title, then let the sheriff causc twelve good men ${ }^{1}$ to be chosen, who are to swear that they will lawfully do what the sheriff shall charge them on our behalf. Then let them be charged to declare whether he against whom the plaint is brought has any freehold to which the common is appurtenant, and how many beasts the commoners may common there in respect of every acre, and what sort of beasts; and whether at all times in the year, or only at certain times; and whether all kinds of beasts, or only a certain number ; and whether in each part and all parts, or only in a certain part.

6. If the defendant claims common by title of gift, then it shall further be inquired whether he was seised thereof before the * ${ }^{*}$ oil was given to become common to the other commoners, or not. And if before, let him remain in his seisin; and if after, then it must be asked whether he enjoyed his seisin under that gift or not, and whether the donor was himself seized of the thing which he is supposed to have given; and judgment shall be given accordingly. And if the gift be prejudicial to the commoners, the gift shall be good only to the extent to which the donor might give without prejudice to any.

1 The word prodehomme, as well as the similar expression good and lawful man, implied the possession of a freehold. Compare the note in p. 267. 
7. If he elaims his seisin and title by usage in the same manner as the other commoners, and can verify this title, then let the pasture fall into hotchpot among the eommoners according to every freehold to which the eommon is appurtenant, so that every acre be put on equal terms with the others.

8 . When the jurors have brought in their verdiet, let it be immediately put in writing, and sealed under the seals of the jurors, and also entered on the roll, so that if the defendant would again surcharge the pasture, the plaintiff may have his remedy by the penalty provided in our statutes for a seeond surcharge of pasture.

9. With regard to a tenement held jointly among parceners, and turned into common by their mutual consent, if one of the pareeners will surcharge this common with more eattle than he ought, or in any other manner than according to the purport of the first agreement, a remedy lies for the other pareeners by our writ of admeasurement, and also by the assise if they please, ${ }^{1}$ *as is above explained concerning the owner of the land.

${ }^{1}$ That is, if they decide upon treating the wrong as a disseisin of their freehold, and not merely as a surcharge of common. See Brac. $229 b$; Fle. 263 (§ 4). 


\section{CHAPTER XXVIII.}

Of Quo jure.

1. Although some acquire common through negligence of the owners of the soil by long usage and peaceable seisin, and by the folly and sufferance of the owner's with knowledge of the fact, and although, if any one who has thus enjoyed his seisin be ejected or disturbecl. he may recover his seisin by this assise, yet because there would be a great defect in the law if the common thus purchased should remain in that manner with the purchaser, such title arising rather by time than by right, and because the law will not deprive the owners of their remedy in the right of property, therefore a writ upon the right called Quo jure has been provided, by which the owner shall recover in the right of property that which he has lost in the right of possession.

2. Not every one however can proceed by this writ. For no one is allowed to have his action by this writ except the chief lord of the manor or vill in which the common lies, or of the principal part thereof. It is moreover necessary, in order that this writ may lie, that the tenement to which the plaintiff alleges the common to belong, and the soil of the common be of different fees or of *different baronies or of different feoffments, so that the plaintiff and the person of whom he complains do not hold their tenements and their 
pastures in common but in severalty. For in cases where there are several feoffees of one lord in the same manor or vill, this writ does not take place between the neighbours, because between neighbours residlent in one fee such common is more properly called vieinage than eommon; as where one neighbour allows another to eommon with him, provided the other allows the same, but not otherwise. When therefore any lord has lost by judgment in the possessory right, and another has gained by assise of Novel Disseisin by reason of his usage and seisin, yet the latter may lose by this writ if he ean show no other title, unless he has enjoyed his seisin before the time limited in a writ of right. And one chief lord or more may implead one chief lord or more, as well as one lord another, whether their tenements lie in one or sereral vills, so long' as they are of diverse fees.

3. When this plea comes into court, the person impleated may be essoined on the first clay as well as the plaintiff, and shall by his essoiner have another day ; at which day if he makes default an attachment shall be awarded agrainst him, as in personal pleas, because no pasture is here demanded, as is sometimes demanded in a writ of right. But when the person impleaded has appeared in court, and it is speeified in our eourt what common *he elaims, then from this point the same process lies as in a writ of right; and therefore if the party impleaded afterwards makes default, the pasture shall be taken into our hand by the little Cape.

4. At the day of plea, the parties being present, the 
plaintiff shall state his declaration in this form: 'This showeth to you John, who is here, that Peter and the others named in the writ, who are there, (if there are more than one impleaded,) wrongfully demand common in his lands in N., which they ought not to have:' he should also specify the quantity of acres and number of cattle, and in what seasons, according as the person impleaded specifically claimed in our Court :- ' and herein wrongfully, in that the same Peter or the others do not pay him any rent, or perform to him any service, nor does he elsewhere common with them, whereby they ought to common in his lands; and if they deny it, then he tenders averment by suit and proof.'

5 . Then let it be asked by the Justice what common they claim, and how much, and let their answer be enrolled. And then let it be inquired of them what services they perform for having such common; or, if they were enfeoffed of any tenement to which this common is and then was appurtenant, let it be specified what service and what tenement, and the quantity, and who are tenants thereof. So likewise, where they set up peaceable seisin as a title.

*6. Then let the defendants answer and defend themselves by proper words of defence in this manner: - Peter (and the others named in the writ) defend the wrong and force, and well show unto you that they rightfully demand to common in the land of the same John in $\mathrm{N}$. by reason that they and their ancestors and their tenants of $\mathrm{N}$. have commoned there by continuance of peaceable seisin before the term limited in 
the writ of right, performing to John the following service, to wit, that every astrier in the same vill was used to give to the same John and his ancestors a hen yearly at Christmas, whereof they put themselves on God and the great assise, whether they and their people of $\mathrm{N}$. have better right to common in the lands of the aforesaid John in $\mathrm{N}$. by such service that every commoner who has his hearth in the same vill of $\mathrm{N}$. ought to give to the aforesaid John one hen by the year at Christmas, as is aforesaid, or the same John to hold his land in N. as his several, without the aforesaid Peter and the others having any right to common there.'

7. There are several sorts of services which are performed to the owner of a fee for having common in his fee, as service in money, or by reaping at harvest time so many days or one day; so likewise by mowing or ploughing one day or more, or by some *other compliment of annual courtesy reduced to certainty and of a certain value, so that such rent may be comprised in the extent of the manor.

8. Or the defence may run thus : 'well and truly say that they lawfully demand common by reason that the same John hath commoned throughout all the lands of the same Peter (and the others) until within three years last past, when he of his own accord maliciously withdrew himself therefrom, with the intent thereby to exclude the same Peter (and the others) from commoning in his lands.' And if this be verified by a jury, or acknowledged by both parties, Peter and the others shall retain their common, and John shall remain in 
mercy; but he may nevertheless common in their lands as he used to do; and if he be disturbed thereof, he shall recover by assise of novel disseisin, unless he has by his own folly acknowledged in our court that he does not claim any common.

9. If the persons impleaded can neither assign any service or consideration of vicinage, then they must show some other title, as title of purchase or long seisin by prescription of time. Or they may say, that if John does not now common with them, he may impute it to his own negligence, or to the negligence of his ancestors, inasmuch as they used to common in their lands in $\mathrm{N}$. in return for having this common now in dispute; but * that the ancestors of John were ejected, and suffered the soil to be ploughed or built upon, the which common he might still obtain if he had not excluded himself from his action by non-claim. If the parties go to a jury upon this point, the truth thereof shall be inquired by these words, whether John and his men of such a vill, and Peter and the others and their men of the other vill, were erer used to common together in such a place or not; and according to the verdict judgment shall be given. Other exceptions may be used, some of which have been before, and others shall be hereafter mentioned.

10. If the tenements are of one fee, then one neighbour cannot hinder another from reasonable common in respect of vicinage, unless by virtue of some special saving, but that the person disturbed shall recover his. seisin by the assise. 
11. With regard to seisin of common of pasture recovered by the assise, and afterwards lost by a Quo jure in the manner pointed out in this chapter, we will have it understood that seisin may also be recovered, and then got back again by him who has the better right by means of a Quo jure in the case of all other commons, such as common rights of digging, of fishing, of watering cattle, or of ehase, and others which are innumerable, with their appurtenances, which are free ingress and egress.

\section{*CHAPTER XXIX. \\ Of reasonable Estovers.}

2. There is another sort of common, as of mowing, lopping, digging, or cutting in another's wood, or in a forest or quarry, marsh, heath, or waste, to the extent of such reasonable estovers as are required for burning, building, or feneing, and doing such other necessary things according as one tenement shall be subject and charged to another, to be enjoyed at least for term of life; and if any one be ejected or disturbed in his seisin thereof, he shall have remedy by this assise, provided that he can aver certain soil to be charged or appointed where he is to receive his estovers, and which he ean cause to be viewed by the jurors of the assise. He may be disturbed thereof many ways, as if the owner of the wood cause the whole of the wood to be cut down to the 
ground, so that none remains, or at least if as much as is required for common is not planted again ; or if he is not permitted to take any, or not sufficient, or only by delivery, or only at certain times.

2. And because great dispute may be set at rest by proper specification in the writings upon the first contract, it is well that all estovers should be plainly expressed in writings, whether they are to be taken in every part, or whether in a certain place, and whether at all times or only at certain times, and of what woods, and in what places, and within what boundaries, and for what tenement; *so that all things be reduced to a certainty and to just measure, and that the one party may not commit waste, nor the other hinder a measurement.

3. But if turbary, heath, herbage, mast, wood, waste, or other thing just above named, be beld in common between parceners or neighbours, and any one of them commit excess, waste, or destruction, then let such remedy be applied as is ordained in our statutes. 


\section{CHAPTER XXX.}

\section{Of Nusances.}

1. There still remain other kinds of disseisins, which are to be remedied by this assise, and which arise from tortious nusances done by one neighbour to another; as when a watercourse is wrongfully diverted or stopped, to the annoyance of the neighbour's freehold. For it is a right which may belong to any tenement that the tenant may convey water out of another's soil and through another's soil to his own, at all times or at certain times, and in what quantity he pleases, or only to a certain quantity ; and if he is wrongfully disturbed thereof in the whole or in part, then the remedy by this assise is applicable. So in case any one does in his own soil something injurious to the free tenement of his neighbour; as if one raise his pond so high as to damage his neighbour's freehold.

$*_{2}$. Of nusances, however, some are both tortious and hurtful, others hurtful yet not tortious; therefore it behoves every plaintiff in this ase to show what lamage is occasioned to him by the nusance. And if the nusance be found to be both hurtful and tortious, then matters are to be entirely restored to their former condition. If not tortious, it must be tolerated, however hurtful it may be. For unto common in another"s suil always belong a drove-way and free ingress and 
egress, although the drove-way may be hurtful; and if the owner of the soil destroys the ingress, and stops it by a wall, hedge, or ditch, so as to commit an evident nusance to the commoner, this nusance is both tortious and hurtful; and therefore the whole is to be removed and restored to its former condition by this assise, or even without writ, so as it be done immediately upon the fact.

3. The like proceedings must be taken where one has a right to go through another's soil, and the way is stopped or straitened in such a manner that he cannot go, or not so conveniently as he used. The like where the free course of water through another's soil is due by ancient usage or grant, if such course be stopped or diverted in part or entirely. So if a pond be newly made, or heightened, or lowered, whereby the adjoining tenement is drowned or injured; *in such case the nusance is both tortious and hurtful, although this servitude be rather created by law than established by man; and therefore all is to be restored by this assise to the condition it used to be in, at the cost of the offenders. So if he to whom belongs the servitude of having a free chase in another's soil be disturbed entirely or in part, so that he cannot enjoy his chase according as he ought and used to have it.

4. And such nusance may be assigned before the Justices in various mauners; as if a man be entirely turned out of his way or disturbed in any manner; or if a way be diverted to the nusance of the commoner, so that he is obliged to go far round, whereas he used 
to go and drive straight; or if the way be narrowed, so that he cannot drive a wagon or cart therein as he ought and used to do, although room enough may be left for horses and beasts. So where any one has done an act whereby his neighbour, who has a right to common with him either by watering his cattle at his watering-place, or by drawing water from his well, or otherwise, is hindered from commoning as he ought, either by disturbance of the way leading to or from the water, or by disturbance of the water itself. For as manifest a disseisin is committed by him who does not suffer a watercourse which should move a mill to be repaired where it is stopped, as by him who does not allow the mill to be used.

5 . A watercourse is sometimes granted to a person, and sometimes to the tenement of another. A grant made to a person becomes extinct upon the death of the person. *But that which is purchased to my soil remains perpetual; and according to the purchase, and usage, and seisin, the right is to be recovered, if the owner is disseised of it; and in this and the like eases there lies a remedy by this assise, for redressing the nusance at the cost of the disseisors.

6. With regard to the servitude which consists in this, that it is not lawful for any neighbour to erect in his own soil a mill, or weir, or sluice, or other like thing, to the damage of the free tenement of his neighbour, a remedy also lies by this assise to abate the whole, if any nusance be done contrary to this obligation. So likewise, where a nusance is committed by 
pulling down or destroying that which at first was lawfully raised, as by pulling down a wall, filling up a diteh, destroying a fishery, pond, bridge, or sluice, or other such thing, the thing shall be restored by this assise to its former condition at the cost of the offenders, and thus the nusance shall be removed.

7. As one may do a wrong and a disseisin by an aet, in doing or undoing, so a person may commit a disseisin by negligence without doing anything; as where one is bound to fence or repair or eleanse or the like, and lets the matter be without doing anything, which omission is prejudicial to the free tenement of his neighbour; and this negleet is punishable by the assise. And as one *may commit a tortious nusance by not doing something, so the like may be done by not permitting something; as where a person will not suffer him to fence or to reap who is bound to do so in easement of the complainant's freehold; and this wrong may also be remedied by the assise.

s. There are however some nusances which sheriffs are authorised to ledress, as are also our hundreders, and many other freemen, who have view of francpledge for the common benefit $;^{1}$ as in the ease of a way being stopped, in orcler that passengers may not be too long deprived of their way, and in the ease of several other

1 ' It should be known that the sheriff ought not to redress any nuisance presented at his tourn, if it be not wrongful and injurious to the community (a commune des gentz). For nuisance done to a single person shall be redressed by a single suit and not. otherwise,' Note in MS. $N$. 
nusances. But it is not lawful for any one to redress such wrongs without our writ, except those which have been done since the last view, or since the last sheriff's tourn. And although nusanees may be redressed by the assise, yet it does not follow that they may not be set right by another remedy, as by removing the nusance immediately upon the fact, or if this be not done, by writ of Justicies to the sheriff, whereby he has authority to redress the wrong, being made our Justice to cause the wrong to be remedied; and of matters which concern the writ he is to bear record.

\section{${ }^{*}$ CHAPTER XXXI.}

\section{Of remedy of nusances.}

1. If a Justicies, or a Writ of Novel Disseisin is to be obtained for a thing done in one county to the annoyance of a tenement lying in another county, the writ is always to be directed to that sheriff in whose bailiwick the nusance has been committed.

2. Of ponds or of weirs raised, heightened, or demolished, amounting to a tortious nusance, it must be seen whether they are raised in the tenement of the plaintiff where the soil is his own on both sides, as in a river;-for in such case an assise of Novel Disseisin of the freehold of the plaintiff will lie. But if it be in the tenement of him of whom the plaint is made, this assise of nusance is applicable. And if part is in the one soil 
and part in the other, as it sometimes happens in rivers where the lands on either side belong to different persons, then properly an assise of freehold lies for the act done in the soil of the plaintiff, and an assise of nusance for the rest of the nusance committed in the other's soil, to remove the nusance ; and thus two assises would take place upon a single fact. But to avoid the charge of bringing two assises, the assise of nusance is sufficient to redress the whole wrong.

3. Again, for a single act there may arise several disseisins of freehold, as well as several tortious nusances; as where a person makes a ditch in another's soil against the consent of the owner of the soil, he thereby *disseises him of his freehold, inasmuch as he works his soil against his consent, and the ditch perhaps is made in such a place that the owner is either disturbed of his right of driving cattle, because some way is stopped, or some water is diverted from its right course, or partly hindered from running. And in this and the like cases a remedy lies by this assise of the freehold of the plaintiff, and by this assise the whole matter shall be terminated, as well for the recorery of the freehold as for the removal and redress of the nusances; and since all the torts arise from a single act, they may be remedied by a single judgment.

4. A person may likewise do such an act on his own soil as may injure his neighbour in several ways; as if he stops a way, although the way be his own soil, whereby his neighbour cannot freely drive his cattle and have free ingress and egress for his pasture as he 
used; in this ease he deprives him of his common, and consequently disseises lim of that, and also disseises him of his way by obstrueting it; and yet the whole may be redressed by one assise, as by assise of way stopped.

5. There are moreover some cases where a person may by a single act commit several disseisins, and to several people; as if any one cause a common to be enclosed, or a tenement in which one man has a freehold, another (or several others) common of pasture, a third the right of digging or of cutting, a fourth the right of watering his eattle, a fifth a drove-way, *and thus of numberless other services, in such case several disseisins are committed, which may be all restored to their right condition by this assise of freehold, if the owner of the soil will be plaintiff; but if he will not, then every one who would have and recover his estate must bring his plaint each for himself.

6. When the sheriff has received our writ of Justicies of Common of pasture, reasonable estovers, common of fishery, marsh, or the like, and the plaintiff has found pledges of suit to the sheriff, it is the sheriff's duty immediately to summon the party against whom the plaint is made, and the neighbours of the hundred, to be at the next county court, or at the place where the nusance or the disseisin is committed, and that the neighbours in the meantime go and view the nusance, and the pasture, and the tenement in which the nusance is done, and the tenement of the plaintiff to which it is supposed to be done. 
7. At the day named no essoin shall be allowed to the defendant, any more than to a disseisor, but the inquest shall be taken, whether the defenclant come or not; and according to the verdict by view of the jurors the right condition of things shall be restored as it used to be, at the cost of the offender, who shall also repay to the plaintiff bis damages, and remain in our mercy.

\section{*CHAPTER XXXII.}

Of Exceptions in the Assise of $N$ usance.

1. When this assise is brought for any nusance, he against whom the plaint is made may aid himself by several exceptions. Thus, he may say that he did not commit any nusance, or raise a wall, or heighten a pond, or throw down the diteh, but that another person not named in the writ did it; and if this is verified or not denied, the writ falls. Or he may say that the plaintiff had not the tenement to which the nusance was done, at the time when it was first done, but another then held it, and none ought to complain of a wrong done to any except himself.

2. Or he may say that there is no nusance, or if there be any, yet the assise ought not to pass, inasmuch as the nusance is not tortious, because the plaintiff has no right to forbid it; as in the instance of a mill, which one neighbour may erect in his own soil without committing a tort to another neighbour, although the mill 
may happen to be an annoyance to that neighbour; and the like of other nusances which are not tortious, and which if any abate or remove by force, he is guilty of a manifest offence against.our peace.

3. The parties having pleacled to the assise, let the assise be taken, and if it pass for the plaintiff, then let the sheriff be commanded to cause the nusance to be removed, and the place restored to the condition in which it used to be, *at the cost of the trespassor, whether water is to be brought back into its ancient course, or the course cleansed and turned, or opened, or a ditch filled up or abated, or a pond lowered, or a wall or hedge repaired, or way enlarged, or any other such nusance set right according to its former condition. And in all these cases the thing is to be restored to its ancient condition, in breacth, length, height and clepth ; and the watercourse is not to be made more or less running, or lower or higher, or in any manner altered, unless for the better, from what it used to be.

4. Every one should always beware of taking by his own force what he ought to recover by judginent; for if hedoes so, and the other party recover by judgment, the true owner shall hardly after succeed in uniting by judgment the seisin with the property.

5. With regard to the word 'wrongfully' contained in the writ, care must be taken to see whether the nusance be wrongful or not; for if it be not wrongful, an exception theroby accrues to the respondent. But if it be both tortious and hurtful, then it is to be removed and redressed. If it be hurtful, a distinction is 
to be made. For if it be hurtful to many others, although it be not hurtful to the plaintiff, yet it ought to be removed by the Justices ex officio. For we will always, that the general advantage be regarded and promoted before the advantage of a private person. And if it be not tortious, although it be hurtful, the plaintiff's action ceases so far as respects himself, although it may not as it regards others.

*6. Or he may say, that although at one time it was tortious to the plaintiff, yet he has now lost his action; for he of his own authority and without judgment, a year or more after the nusance was done, abated it, and proceeded by his own force, whereas he ought to have proceeded by judgment_-although he might have so abated it immediately after the fact, or at least as soon as be knew of it. And this exception, if verified or not denied, shall be allowea.

7. And whereas the words in the writ are, 'of nusance done in the water, \&c.' regard must be had in what county, in what vill, or in what place, the wrong is done ; and the like of a pond, weir, or other nusance; and whether the water in which the nusance is done be in all or in part common $;^{1}$ and whether the plaintiff, or the other, has the fishery, or only a right of fishing. And with reference to such considerations, exceptions may be allowable. For if the water belongs entirely to him against whom the plaint is made, and

1 The text is probably corrupt. The sense, following Bracton, would be: whether the water is appropriated in the whole or in part, or is common. 
is in the vill named in the writ, and the tenement to which the nusance is done is in the same vill, or in the same comnty, the writ is good and well purchased ; but if not, the writ is abatable by reason of these words, 'to the nusance of his freehold in the same vill.' And il the plaintiff has nothing in the water but a common of fishery, and has erected a weir in the same water, and the owner of the water has granted to another a right of fishing in the same water, if the last purchaser ereet a weir to the damage of the other weir, the nusance *shall be removed by this assise; as where a market or other franchise is granted, so that it be not a nusance to another aljoining market. ${ }^{1}$

8. In the case last mentioned, a distinction must be male as to the proximity of a market, what may be alled aljoining and what not, and within what distance by road a man may eomplain of a musance done by one inarket to another. In order to justify the remoral of a market by this assise as a nusance to another adjoining market, the plaintiff must assign the nusance thus: that whereas he hath his market on a certain

1. I fair is a market of all mamer of victual, and of all manner of other things, as of horses and other beasts. and birds, and also of aceer de poyz, as spiceries and other such things: also of gold, silver, tin, and other metals, of precions stones, linen, cloth, furs, arms, and all linds of merchandise; and this once a year. But markets in country towns may be one day in the woek ; in boronghs, two days : in cities, three. Bnt in London ancl in a town having the same liberties as Tondon. (enfranchie come en Jondres) every day of the week, sare Sunlay' Note in Ms. $N$. 
day of the week in such a town, he against whom the plaint is made has caused another market to be pro. claimed and set up on the same day in the same town, or in another town within six miles and a half and the third part of a mile ${ }^{1}$ from his market. For if the plaintiff say that he has set up a market on another day, or if he say that the markets do not adjoin by seven miles, he shall take nothing by his plaint. For a common day's journey is at least twenty miles; let therefore the day be divided into three parts, and one part be allowed for going to market, another for marketing, and the third for returning home; so that people may do all in the day, and not be obliged to go *or return in the night for fear of evil doers. If therefore any market be set up adjoining to another market within the third part of twenty miles, and on the same day as the other market, it is a manifest nusance; and such nusance may be redressed or removed by this assise, because it is both hurtful and tortious.

9. If any person feels himself aggrieved by any franchise granted by us on account of a nusance accruing to a franchise belonging to him, and sets himself by force to disturb this franchise, or entirely to de-

${ }^{1}$ It should be by the calculation six miles and a half and the third of a half mile, and is so in the parallel passages of Bracton and Fleta. The following clause is in the charter of Edward III. to the city of London: 'Item Quod nullum mercatum de cætero teneatur infra septem leucas in circuitu civitatis prædictæ.' (Liber Albus. 147.) The Latin word leuca, French lue appears to have been used in England for the English mile. (See Spellman, Gloss. s. v. leuca.) 
feat our act, he thereby appears to despise the law, and is therefore liable to be heavily amerced. And, by way of punishment for his force, the other shall retain his franchise, whether it be prejudicial to him or not. For none ought to interpret our grants or our will except ourselves. Therefore we will that in all cases those who think themselves injured by our grants, or otherwise, have a suitable remedy by our orders.

10. It should be known that in all cases of disseisin, where no disseisor is alive at the time when the assise of a freehold, or of a common, or of reasonable estovers, or of a nusance, ought to be taken, the assise shall abate, and the plaintiff shall take nothing by his writ or by his plaint, but be in our mercy, and the tenant go quit without day ; and remedy be given to the plaintiff by writ of entry founded upon disseisin, whereby the tenant will be bound to restitution, although he is not punishable for the first tort, and in which the view shall be made in all points as in the assise of disseisin.

11. Concerning redisseisin, enough is said in our Statutes. 


\section{*CHAPTER XXXIII.}

\section{Of Farms.}

1. There is a kind of action somewhat resembling . that of disseisin, for the disturbance or spoliation of a term. For the farmer has as much right to recover his term and his chattel as the freeholder his freehold. Yet he hath not any recovery by his assise, because it never lies for a certain term except where it is awarded to the termor by:judgment of our court for a debt or for other cause ; for in the case of such terms this assise doth well lie, and the penalty of redisseisin if necessary.

2. But with regard to the first case, where the farmer has nothing of freehold, if he be ejected, the nature of his term is to be regarded, whether the freehold remains in his lessor or in a stranger; for if in the lessor, he may have bis remedy by the following writ : ' Command Peter that he render to John so much land with the appurtenances in such a vill, which the same Peter leased to him for a term which is not yet expired.

3. But if the lessor gives away the fee and the freehold, or the freehold alone, to a stranger, and he puts another person in seisin and ousts the farmer without making him any satisfaction for his term, and if it 
happen that the lessor retains nothing by which he can be attached to make him keep his * covenant with the termor, or otherwise satisfy him for his damages; in such case there is not yet any certain remedy provided against the lessors; and therefore the best advice in such a case is, that the termors should keep themsel res in seisin as much as they can ; and if they are ejected, should nevertheless do their utmost to use their seisin, and hinder the purchaser from using it as much as they can, until satisfaction be in some way made to them.

4. There are however some cases in which a person has no right to oppose his being ejected, as where the chief lord ejects the termors on account of the wardship of the lands of an infant who falls in his ward. And this the farmers ought to permit, because they shall have their recovery of the remainder of their term when such wards had attained their full age.

5. There are some eases where the farmers are eject. ed without the consent of the owners of the tenements, and in such cases a recovery lies by assise of novel disseisin at the suit of the owner of the soil, where the damages however ought to be delivered by the Justices $e x$ officio to the termor. And if the owner of the soil when he has thus recovered his tenement will not deliver it again to his termor, he must recover it by writ of covenant: in which writ the process is by summons and attachment. And whereas there are several whose actions are sometimes limited to them and their heirs, sometimes to their assigns, sometimes to the executors, and sometimes against executors and others ; therefore 
remedies lie by our writs formed according to the particular case. ${ }^{1}$

Here ends the Book of Disseisin; and begins the Book of Mortdancester.

1 This passage is somewhat obscure, and it will be seen that in some valuable manuscripts a reading is found which gives a totally different aspect to the whole sentence. The following note from the margin of MS. $N$, appears to explain the expression, 'dount les acciouns sount affermez,' as referring to what in our modern terminology are called the limitations introduced into the lease.

'In this part a recovery is given against the lessor where he is not guilty of the ejectment; with an example of a demise in large terms (ovesques une touche de ferme lessee largement). Wherefore when the deed of lease makes mention thus. habendum et tenendum præditis B. et C. et eorum hæredibus et assignatis sive legatariis: if one of the termors keep out the other, or if the executors keep out the heirs, or the heirs the executors; or if one die within the term, and his heirs or executors be kept out by the other joint farmer, the recovery appears in the writing which commences thus: 'Every possession' (en la escrowette qe comence issi. Chescune p'on, etc).' Note in MS. N. I am unable to explain to what treatise or other writing the last words refer. The same contraction is used for possession elsewhere in the same handwriting. See li. iii. c. 15. s. 2. note. 



\section{VOLUME II.}

\section{BOOK III.}

OF INTRUSIONS AND THEIR REMEDIES.

\section{CHAPTER I.}

of Intrusions.

I.

Having concluded the process whereby a plaintiff may recover his seisin of freehold, in redress of a wrong done to his own person, we shall now speak of the method of recovering by plea the seisin of his ances: tor. For when any one dies, his heir ought to succeed to whatsoever he died seised of in his demesne as of fee, although another may have had more right of property therein, unless he died as a felon convict. And if he died without any heir, the chief lord shall stand in the place of heir.

2. But because a person that has no right may immediately after the death of any one abate himself into the inheritance of the right heir, and keep out the heir and the chief lord of the fee, and no law would permit the seisin to remain in that fashion, the law allows such intruders to be ejected while the intrusion 
is fresh by the right heirs or the chief lord of the fee without any wrong being done; and the word 'fresh' shall be so understood, according as the right heir has means of knowing the fact, and aceording as he was near or far, as has been said in the Book of Disseisins. * If they eannot so eject, or if the abators have had so long and so peaceable a seisin, that they ought not to be ejected without judgment, then they must be aided by remedy of our court. But because there are sereral kinds of intrusions, the form of the writ must be varied aecording to the different eases.

3. Intrusion is a wrongful abatement during the vaeancy of the soil, when no one is in seisin either by corporeal presence or by continuance of will; as after the death of a person who died seised of the fee and freehold, before the heir of the deceased has taken any sort of seisin; or after the decease of one who in like manner died seised of the fee and freehold without heir or as a felon, before the lord to whom the escheat belongs has attained to seisin thereof; or after the death of any one who died seised only of the freehold by fine levied and chirograph, or by form of gift, or by other kind of tenure for ter'm of life, before he to whom the land ought to revert has attained to seisin.

4. As all these cases are intrusions, the forms of the writs must be varied aceording to the diversity of the cases. Sometimes the action and the plaint belong to the right heirs, and sometimes to the ehief lords by reason of escheat, and sometimes by reason of wardship. And because pleas ought rather to be hastened 
than delayed, it is proper that such writs be provided as drive the intruders to answer by the * great and little Cape, rather than other kind of writs pleadable by personal distresses. In this writ neitler view nor voucher lies, because the plea savours in part of the nature of novel disseisin and of trespass by reason of the abatement.

5 . If the heir be of full age at the time of the death of his ancestor, and holds himself in seisin of his inheritance with the deceased, and after the decease is found in seisin, or if after the death of his ancestor he finds the inheritance vacant, and enters before the chief lord has seised it, it is lawful for such heir being of full age to keep out the chief lord if he can, unless he ought to hold the inheritance of us in chief, so as he be always ready to perform to the lord homage or relief or other service according as law and right require.

6. But becanse all heirs are not bound to perform homage to their lords, we must first understand the nature of tenements,--which are subject in relation to the lords of the fees, to homage, and which not; and what tenements and what heirs ought to be in ward of the lords, and what not; and in respect of what kind of tenements lords ought to have wardship, marriage, homage, and relief, and of what not. 


\section{*CHAPTER II.}

Of Wardship ; of the various tenures of land; and of the remedy against supposititious children.

1. There are several kinds of fees and tenures, the chief whereof are those of knight service and grand serjeanty, ${ }^{1}$ which fees were provided for the defence

1 'Note, that knight's fee is dependent on the shield (del escu); and signifietl that one ought to do knight's duty (fere chivalerie) for such tenements, i. e. exercise arms (hantier les armes) in time of war. So Grand Serjeanty is a diminutive of the shield (un deminutif del' escu); and signifieth that one should do esquire's duties (esquierie) for such tenure, i. e. be armed, as belongeth to an esquire, to combat in time of war, or otherwise serve, as the king or his lord hath need. And he shall do homage, for he will do honourable service (honeste fra) in battle, and fight armed with his target hanging from his neck, which is to him in stead of shield. And this you may understand by the name, for esquier is, as it were, escuer. But there is a difference between the arms (armures) of knights and esquires. So Petty Serjeanty is a diminutive of Grand Serjeanty. For knights and - serjeants cannot endure in war without being served with provisions (vitaille) and other things. Wherefore for footmen (home a pié) were such tenures provided, to do such various duties as belong to their service; because a footman (poun) cannot do noble acts (honesté fere); and gentlemen (gentiz gentz) hold no feat honourable except prowess of arms. All the other tenures. save ancient demesnes, are dependent upon the fer's afor'saitl. 
of our realm, and of which the heirs are not capable of defence or of bearing arms until they have accomplished the age of twenty-one years; and it is therefore ordained that the lords of the fees shall have for all the intermediate time the wardship of their fees, and all the profits of the issues, and the adrowsons of churches, and the wardship of wards, without making waste of woods, destruction of tenements, exile of villains, or sale of lands.

2. The same tenant may be heir to several fees, of which one is of more ancient feoffment than another. And whereas the first feoffor or the lord of the most ancient fee has a better right to the wardship of the body, and consequently to the marriage, by reason of the allegiance, than another later feoffor, it sometimes happens, where the last feoffor thinks that he is the first and has a greater right, that he who has no right deforees the wardship from him who has a better right. For which wrong a remedy is provided by our writ of right of ward, which is intended to be determined by a simple jury upon the priority of feoffment

For frank farms, fee farms, and frank almoigne, were changed (translateez) from knights' fees into socages discharged of such foreign service for a certain sum by the year. Ancient demeynes were and are the king's villenages; whereof burgages and sokemanries are changed for such villenages into free tenure (franchise) at a certain service done to their lord. And as ancient demesnes are the king's villenages, to be cultivated and dealt with as may please him (pur gayner e pur fere quantque Iui plest), so are other kinds of villenages the demesnes of other lordships.' Note in MS. $N$. 
without battle or great assise. *So writs of right of marriage are not frank tenement, but movable chattels derisable by testament; the manner of proceeding in which writ, after the great distress a warded, is contained in our Statutes of Westminster.

3. Nevertheless if there be any such heirs whose ancestors died seised of any land held of us in chief of the ancient fees of our Crown, we will that we have the wardship of all the lands which ought to descend to those heirs as their inheritance, with all the corn found on such lands, to whose fee soever the lands belong. And if the ancestors of such heirs held any land of us in chief as of our escheats, or of our purchases, or of our petty serjeanties, or of our socages, or of our fee farms, in that case the custody of the bodies of such heirs during their tender age shall remain with us, and their marriages shall be ours ; ${ }^{2}$ but each lord shall have the wardship of his own fee and of the land held of him, until such heirs have proved their age in our court, and have recovered their inheritance out of our hand.

1 The annotator in MS. $N$. applies the term 'homage ancestrel' to the case here supposed, and says that it was then to be presumed (dunc deyt hom entendre) that the tenant or his ancestors were enfeoffed by the king before any of his other feoffors.

2 There is some confusion in this statement; the rule that the custody of the body and the marriage belonged to the king applied only where the land was held of the king, though not de corona, by military service, and not to the other cases mentioned in the text of tenants in socage or by petty serjeanty. Compare Magna Carta, c. 27 ; and the parallel passage in Bracton. 
4. As long as the lands of such heirs remain in our hand, we will that they be quit as against all people of suits of courts and of all other serrices which may be demanded of them by reason of their tenements, and be quit also so long as they are in our wardship, of all *manner of obligations and demands which may be made upon them on account of their ancestors. And if any lands have been let to farm for term of years, or otherwise for a less term than term of life or in fee, such lands being part of the inheritance of the infants, we will that the farmers be ejected from the lands, saving to them their chattels found thereon, so that each lord may have the wardship of his fee. And when the heirs shall have accomplished their age, then the farmers shall have their action by our writ of covenant to recover the remainder of their terms, if they cannot recover it without writ.

5 . There are other kind of tenures, as petty serjeanties, sokemanries, free farms, fee farms, burgages, ancient demesnes, free alms, free marriages, and villenages; to which fees no wardship appertains, but only nurture by him who shall be nearest of kin to the heir on the mother's side when the inheritance descends on the part of the father, or by the nearest of blood on the father's side when the inheritance descends from the mother. Such guardians are rather bailiffs than guardians; for if they do not render a lawful account of the issues of such inheritances, at such time as the heirs choose to require the same, such guardians may be imprisoned and punished like other bailiffs, accord- 
ing to the penalty provided in our statute. *And in the case of such heirs no certain time is limited for their full age; but as soon as they have discretion to till land, measure cloth, count money, and to manage their trade, they shall be deemed of age; and the females as soon as they have attained discretion and have learned the management of household affairs. ${ }^{1}$

${ }^{1}$ The older authorities fix fifteen years as the age of majority for socage tenants, and apply the shifting test of 'discretion" only to the children of burgesses or tenants in burgage. The following note may serve in some measure to show how the old rule in this respect was gradually set aside, and the age of twenty-one established as the period of majority for all classes. - Of heirs in socage, the common age for males is sixteen years, and for females fourteen. This is so (Oyl), for having and aclministering their inheritance; but not for aliening it conclusively (finalment) secundam quosdam : for they say that the writ of entry dum fuit infra cetatem supposes the age of twenty-one years. Others say that this age is given for knights' fees only, and that they are so long in ward in regard to the administration for fear of the aliening and dismemberment of their inheritance. Whence it follows, he who by law can and ought to ackminister, can by law alien; but in socage the tenant at sixteen years of age can and ought to administer,-eudem ratione, to alien.' Note in MS. $N$.

Shortly after the time of this note, the question as to the power of alienation by socage tenants under twenty-one appears to have been settled in the negative ; and in the following case, deciled is $\mathrm{Edw}$. IJI, the power of aliening a burgage tenement before that age is treated as resting upon special custom. 'In dum fuit infra cetatem in Gloncester, the tenant plealed that the usage of the town is such, that when a man knows how to count $12 d$. and to measure an ell of cloth, he is of age to alien his land, 
6. Grand serjeanty is a service due from a tenement, which service concerns the defence of the country; as to be Marshal or to set our host in battle, or to find a man mounted and armed for the field $;^{1}$ so, to be the keeper of our goshawks, ${ }^{2}$ or other like great services. Petty serjeanty is a service issuing from a tenement by performing to us ${ }^{3}$ some little service, when we are

and of such age was the demandant when he leased. And because the tenant did not state the age in certain, so that the demandant might answer it, it was awarded that the demandant should recover.' T. 13 Ed. III. cited Vet. Nat. Br. 128; Bro. Abr. Dum fuit. 3 ; Fitzh. Nat. Brev. 192 H. (note by Hale).

${ }^{1}$ As to the question whether this is great or little serjeanty, see Lit. Ten. s. 157 ; Co. Lit. 107 a. ; and Butler's Note, ib.

2 This example does not agree with the description of grand serjeanty, as connected with the defence of the country. Some of the manuscripts remedy this inconsistency by reading estours, or estovers, so as to make the service that of guarding the king s stores or provisions. Abundant examples of tenure by the service of keeping hawks and falcons may be found in Blount's Tenures by Beckwith, pp. 263-280. In one case at least (p. 2i5) the service was connected with homage, which affords some presumption that it was considered a grand serjeanty. (See Bracton 79 ( $\$$ ); Fleta 204 (c. $16 . \S 2)$; 207 ( $\$ 19$ ); Co. Lit. 86 a). And the estates held by such services were frequently of importance. The lords Grey of Wilton are stated by Camden to have held their manor of Acton by the service of keeping a gerfalcon for the king. Camden's Britannia by Gough vol. i. p. 315. In later times such tenures were classed as petty serjeanties.

${ }^{3}$ This passage of Britton appears to be the first authority for confining the term Serjeanty to tenures in capite. (See Lit. Ten. s. 161.) In Bracton, serjeanty is a tenure by a special or ex- 
about to take the field, amounting to half a mark or less, as are the services of bringing to us in field a bag, or a brooch, ${ }^{1}$ or an arrow, or a bow without a string, or a pair of spurs or gloves, or some like service.

traordinary service either to the king or any other lord. And Britton in a subsequent cliapter speaks of a grand serjeanty not held of the king in chief. (Post, c. iv. s. 31.) The words of Britton may also have given occasion to the distinction afterwards adopted, by which the term 'petty serjeanty' was confined to 'small things belonging to var.' (Lit. Ten. s. 159.) The principal examples of minor serjeanties in Bracton are connected with the occupations of peace, as the serjeanty of riding with the lord from one manor to another, of holding the lord's court, or of carrying his precepts (portandi brevia). We may also see in Britton's examples the germ of Littleton's distinction of great and little serjeanty, that the one ouglit to be done in the tenant's proper person, while the other obliges him to nothing lut a mere rendering or payment, as of a rent, (Lit. Ten. 153, 160.) In Bracton, serjeanties are called great and little, either with reference to their value (Brac. 87 b), or to the nature of the duty, as concerning the king's army or the defence of the realm on the one hand, and peaceable services or duties to inferior lords on the other. (Brac. 35 b.) And it would seem to have been Bracton's opinion, that all serjeanties in capite, whether great or small, brought to the king the right of wardship. (Brac. $8 \pi \mathrm{b}$ : 3is $b$, 36.) The account given of great and little serjeanty and their incidents in the fragment of law, printed under the title of Statutum de Wardis et Releviis (Stat. temp. incer.), is similar to that of Britton.

I Thomas Carnifex tenet de domino Rege in capite manerium de R. in com. Ebor. per serjantiam inveniendi domino Regi in exercitu in Wallia umm equm, unum falcem, unam brochiam, et unum saccum, \&c.; et pradictus Thomas in misericorlia pro injusta detentione.' Plac. Cor. 7 Ed. I. Ebor. cited in Blount's 
7. Sokemanries are lands and tenements which are not held by knight service or by grand or petty serjeanties, but by simple services, as lands enfranchised by us or our predecessors of our ancient demesnes.

8. Free farms are lands and tenements, whereof the nature of the fee is changed by feoffment out of chivalry, to be held by fixed yearly services, and in respect whereof neither homage, wardship, marriage, * nor relief can be demanded, nor any other service not specified in the feoffment. Fee farms are lands held in fee by rendering for them yearly the true value, or more or less; which rent if the feoffees cease to pay for two years together, an action thereby accrues to the feoffors, or their heirs, to demand the tenements in demesne; for which tenements neither homage, wardship, marriage, nor relief can be demanded without specialty in writing.

9. Free alms is where land is given to God, and to some persons serving God, in pure and perpetual alms, for which the feoffors can demand no kind of earthly service, so long as the lands remain in the hands of the feoffees; the constitution of which alms is to be duly observed. Land held in alms is when land or tenement is given in alms, some service being reserved thereout Tenures, p. 49 ; Blount's Tenures by Beckwith, p. 13\%. See also Bracton, f. 36. The word brochia, which in several services reserved in tenures is connected with saccus, is conjectured to mean the instrument, either a pin, or a brooch or buckle, with which the bag of leather or canvas was fastened. See Blount's Tenures by Beckwith, p. 110, 133; Ducange Gloss. s. v. broca, brochice. 
to the feoffor. And as it is of free alms and of land given in alms so it is of land given in free marriage.

10. Burgage is a tenement in a city or borough or other place privileged by us or our predecessors; and such tenements are devisable according as they are derived by purchase or inheritance, agreeably to the custom of the place.

11. Aneient demesnes are lands which were part of the ancient manors *annexed to our Crown, in which demesnes dwell some who have been freely enfeoffed by charter,-and these are our free tenants,-and others who are free of blood and hold land of us in villenage,-and these are properly our sokemen, and are privileged in this manner, that they are not to be ousted from such tenements so long as they perform the services which appertain to their tenements, nor can their service be increased or altered, so that they shall do any other or greater services, or in any other way than as they have been used to do. And because such sokemen are the tillers of our lands, we will that they be not summoned anywhere to toil in juries or inquests, except in the manors to which they belong. And because we will that they enjoy such immunity, the writ of right close is provided, which is pleadable before the bailiff of the manor for a wrong done by one sokeman to another, that bailiff may do the plaintiff right according to the custom of the manor by means of simple inquests. Nevertheless we will that in pleas of trespass and other personal actions, sokemen be sum. monable and answerable as well as others. 
12. Villenage is a tenement of the demesne of any lord, delivered to be held at his will by villain services, to be cultivated for the use of the lord, and whereot livery is given by the rod and not by title of deed or by succession of inheritance. Neither wardship nor marriage nor other real services, as homage and relief, ean be demanded from ancient demesne or villenages. *In the same manors of our ancient clemesnes there are also pure villains both by blood and by tenure, who may be ousted from their tenements and deprived of their chattels at the will of their lords.

13. It sometimes happens that women at the time of the death of their husbands feign themselves with child by their husbands when in fact they are not, to the great damage of the heirs; in which case we will that the following remedy be ordained. When any one complains of such discreet, he shall have our writ to the sheriff of the district, commanding lim without delay to cause to come before him and before the coroners in full eounty court the woman against whom the complaint is made; and it shall be inquired of her, whether she be with child, and by whom; and if she says, by her husband who is clead, the sheriff shall forth with eause to come disereet and lawful women to the number of six at least, who are to be sworn upon the holy Evangelists, that they will lawfully act and true presentment make of the articles wherewith they shall be charged on our behalf. Then let them be charged that they upon their oath search the woman who pretends to be with child by handling her belly 
and her breasts, and using all other means whereby they may be certified whether she is with child or not. Then they shall take her privately into a house, and inquire into the truth.

${ }^{*} 14$. If the women declare that she is with child, or they are in doubt whether she be or not, then the sheriff shall cause the woman to be placed in our castle or elsewhere in safe custody, so that no woman or other person who may be suspected of any fraud have access to her; and there she shall remain at her own charge till the time when she should be delivered, and no woman in the meantime shall go near her, unless she be of the lineage of the plaintiff. And if she have not a child within forty weeks after the death of her husband, or if she is not found to be with child, let her be punished by imprisonment and fine; and the chief lords of the fees shall forthwith take the homage of the heir without further delay.

15. If she is delivered of a child within the forty weeks, the child shall be admitted to the inheritance, unless the next heir can prove that such child was begotten by another man than her husband, as if he show that the husband was impotent, or that he was in prison or in another kingdom for two or three years before the child was born, and remained so until after the birth, without coming near his wife, or aver some other apparent presumption notorious to everybody. For in such cases we will not that the right heirs shall be disinherited by the wife's adultery. 
*16. If two brothers, or other persons, offer themselves to do homage to their lord for the same inheritance, and one of them was born in marriage and the other before marriage, we will that in such case the lord shall admit to the inheritance him who was born within marriage, although he be younger than the other. And if any heir offer himself to do homage to his lord for the inheritance of his ancestor, whose father and mother were divorced by holy church by reason of the marriage between them being found unlawful, the lord shall not upon that account fail to take the homage of such children begotten in marriage, whether the marriage was lawful or unlawful.

17. If any heir is begotten by another than the lusband of his mother, that is to say, at a time when it may be presumed that the husband might have begotten the child in matrimony, we will not that the adultery of the mother be a bar to the inheritance of the child. So, where a child begotten by another and imposed upon the husband as his issue, is brought up by the husband and owned by him as his heir, we will that such children be admissible to the inheritance, if it may be presumed that the husband of the mother may have begotten them. But if the husbands of such wives, who bring up as their lawful heirs children that were begotten by others than the husbands, were hindered by manifest infirmity or distance of place and time, so that evident presumption and common fame, as before inentioned, operates against the husbands having been capable of begetting those children, 
*aithough they choose to bring them up in their houses and to acknowledge them as their own, yet such clildren shall not be admissible to the inheritances. Neither shall those whom husbands shall find in their houses begotten by others, and whom they shall straight. way remove ont of their houses and disown as their issue. Therefore we will that every one in such case do openly disown and straightway cause to be removed such supposititious issue, as soon as he shall linow of it. For after he has once owned the child to be his, and this fact is testified by the neighbourhood, he may never after disown it.

18. And if a complaint come before us from any right heir concerning a supposititious child so brought up and acknowledged as heir by any husband and his wife to the disherison of the right heir, we will straightway command the sheriff of the county, at the suit of the plaintiff, that he have the bodies of such husband, and of such a one his wife, and of such child whom they are bringing up, before our Justices at a certain day and place to answer to such plaintiff, who alleges himself to be heir to the same husband, why they do in disherison of the plaintiff bring up the aforesaid child and own him for their issue, which he is not. At which day it will be necessary for the plaintiff to show some presumptions in his favour to make good his charge; which if he cannot do, it shall be adjudged against him. And if by the proceedings in the plea between the parties judgment be given against the infant and for the plaintiff, the 
malice of the husband and of his wife shall be punished by imprisonment and fine.

*19. And if any child which is born a monster,-as one that has more than the proper number of members, ${ }^{1}$ as three hands or three feet, or a deficiency in the same, as no hands or no feet,-lemands the inheritance of his ancestor, such children shall not be admissible to any inheritance, or accounted as children, but as beasts and monsters. Wherefore no one who has begotten them can by such issue claim title of freehold in the inheritance of his wife by virtue of the law of England.

20. And whereas it sometimes happens that the heir is an idiot from his birth whereby he is incapable of taking care of his inheritance, we will that such heirs, of whomsoever they hold, and whether they be male or female, remain in our custody, with all their inheritances, saving to every lord all other services belonging to him for lands held of him, and that they so remain in our wardship as long as they continue in their idiocy. But this rule shall not hold with regard to those who become insane by any sickness.

21. When any one who has been in ward, and who ought to hold of us in chief, has reached the age of twenty-one years, if he demand the inheritance ont of

1 Bracton repeats in all the passages above cited, that an increase or decrease in the number of members not affecting the human form of the offspring, as where a child is born with six fingers on one hand, or only four, does not affect its rights, See Digest, li. i. tit. 6. 1. 14. 
our hands, or if any other heir of whatever age he be do the like, such persons must first, by solemn inquests taken by virtue of our writs, prove their age by their kindred *and by other lawful people of the neighbourhood where they were born,- - to wit, whether they are of the full age of twenty-one years or not, and whether they are next heirs.

22. And if any one proves his age by good inquest sealed under the seals of the jurors and returned into our Chancery to be safely kept, then we will that he perform homage and swear fealty to us, and obtain our writ to our escheator or to our sheriff, that he cause him to have seisin of the lands which were in our hand, by the death of the ancestor of such heir, in his bailiwick. But if our escheator or sheriff perceives that fraud has been practised upon us in the aforesaid proof, he shall defer the delivery of seisin until we have taken an attaint against the twelve first jurors. And if they are attainted of a false oath, let them be punished as shall be mentioned in the chapter concerning attaints. And if they have been falsely accused, let the accuser be punished by imprisonment and fine, which may be great or small in proportion to the malice of the offencler.

23. When the heir has obtained the seisin of the lands held of us, let him straightway have seisin of his lands held of the fees of others, without making fine to the lords, and without giving anything of his goods except his reliefs. And when he shall recover the seisin of his inheritance out of the hands of others, we 
will that his lands shall be delivered up to him stocked with ploughs and other stock at least as well as the lords found them. *And if the lords make waste, sale, destruction, or exile in such inheritances, before the heirs have proved their age, then the heirs may be aided either by our writs of trespass or of waste, or by assise of novel disseisin, to be brought by themselves or their friends according as is contained in our statutes, in which the penalties are ordained. All guardians shall however be excused from liability in respect of accident by fire or water, or other like waste, where they shall not be guilty of any malice.

\section{CHAPTER III.}

\section{Of Marriage.}

1. When any one holding of us in chief shall die, leaving a male heir of full age, we will that such heir may marry where he pleases without paying a fine to us or to any other. But if such heir be under age, then the marriage of him shall belong to us, and he may not marry without our leave under pain of heary forfeiture.

2. With respect to female heirs, where an inheritance wholly or partly held of us in chief descends to several daughters or their issue, as one heir, the eldest shall do homage to us for all her parceners, and the others shall do homage to the eldest. We will nerer- 
theless have the marriages of them all of whatever age they may be, as often as they are to be married, so that they cannct be married withont our leave. This prohibition was fir'st made, lest the female heirs of our land * shonld marry with our enemies, whose homage we should then be obliged to take, if the heirs might marry at their will.

3. With respect to marriages belonging to others than us, we will that the lords give or offer marriages to the heirs male before they have completed their age. And if they have not tendered them marriage while under age, then the lords shall be barred of any action to demand anything for their marriage. But if the lords have tendered them marriage without disparagement, and the heirs will not consent thereto, the penalty provided in our statute shall take effect. Marriages shall be tendered to female heirs before they be fourteen years old, otherwise the lords shall be debarred of their right. ${ }^{1}$

t. If any female heir of tender years be married where she is disparaged, then we will that, if she was

1 Our author onits to state the modification of the law introduced by the Statute of Westminster I (3 Ed. I. c. 22), by which the right was granted, or confirmed, to lords to retain the wardship of female heirs for two years after they had reached the age of fourteen years, and to offer them a suitable marriage within that time. If the heiress refused the marriage, the lord night hold the lands till she attained twenty-one, and for a further time until he had received the value of the marriage. Cf. Littleton, Tenures, s. 103 ; Coke Lit. 79 a ; 2 Inst. 202 ; Lord Darcie's Case, 6 Co. Rep. 71. 
of fourteen years or upwards, so that she was able to consent to inarriage, no penalty shall be incurred; but if she was under that age, the penalty shall be this, that the lord shall lose the wartship for that time, and make satisfaction to the friends of the person so married, and that all the profit received for the marriage shall be restored to the friends and kindred of the woman, to be improved for her use. *And if she be married to any of his villains, the lord who gave her away shall be punished by imprisonment, until due amends be made by appointment of the kindred of the wife; and such persons shall afterwards be put to ransom for the malice.

5. We forbid any lord to force an infant in lis ward, male or female, to take wife or husband. And when any heirs, male or female, have once been married by their lords in whose wardship they were, or have once made satisfaction for their marriage, if they be to marry again, they shall for ever after be at their own disposal, provided they hold nothing of us. So also, where they have been married in the lifetime of their fathers. ${ }^{1}$

1 . An infant under age, married in the life of his ancestor, comes into ward of his lord. His wife dies. His lord tenders him another wife, whom he refuses. $Q u$. Whether forfeiture of marriage lies or not. Surely not; for no force of law can compel the heir to be bigamous.' (Note in MS. $N$.) This question is resolved in the same way by Babington, the king's attorney, in the seventh year of Henry VI, the same reason being given.- ' Par le prise del seconde feme efficitur bigamus, a qe la Ley'ne luy coherte.' So Vet. Nat. Brev. 93. b. But if the heir 
6. When two or more lords claim the marriage of one infant, it is impossible for all of them to hare it, although the aneestors of such infant may have held of all by knight service; in which ease let it be adjulged according to the priority of the feoffments, so that the marriage shall be awarded to that lord by whose ancestor the earliest feoffment shall be found to have been made; and let the deforceor be punished according to the tenor of our statutes. If no priority of feoffment is found by the inquest, as where the ancestor of the infant purchased of all the lords at once at the time of the Conquest, or in like eases, the judgment shall be in favour of hiin who shall be in seisin of the infant.

*7. Where any one who has no right has seised the body of the heir within age, and sold the marriage of such infant to another, and he is impleaded, in such case the person impleaded may vouch to warrant, so that each offender may bear the penalty of his own trespass.

was married by his ancestor, infra annos nubiles, and the wife died before the age of consent, the lord, it is said, should have the marriage. (Y. B. 7 Hen. VI. f. 11 b.) This latter statement is adopted by Fitzherbert (Nat. Brev. 143 M.), and Coke (Co. Lit. 79. b.) It will be remembered that bigamy (in the ancient and proper sense of the worl) involved the loss of the benefit of clergy. (See Ante, 1. 1. c. 5. s. 5, p. 28.) On this account it was', according to Lord Coke, a disparagement for a lorl to marry an heir to a widow, " whereby he should by reason of the bigamie lave lost the benefit of his cleargie, whereby he might save his life.' (Co. Lit. 80. b.) 


\section{CHAPTER IV.}

\section{Of Homage.}

1. Homage is a legal bond, whereby a person is bound and obliged to warrant, acquit, and defend his tenant in his seisin against all persons for the services due from the tenements which he holds of him, and whereby, on the other hand, the tenant is obliged and bound to return to perform to his lord the services due from the tenement, which he holds of him, in service or in demesne, and to keep his faith towards him inviolate. And the lord is thereby as much bound to his man as the man is to his lord, reverence only. excepted.

2. Nevertheless if any one be vouched by reason of homage, and the lord offers to prove that the tenement for which he is rouched was transferred from the blood of the first purchaser by feoffment or some other conveyance, in such case the tenement shall be charged to vouch his feoffor or the feoffor of his ancestors. ${ }^{i}$.

1 Note, that homage ancestral, and homage purchased by attornment made in the king's court, give warranty and: none other, without an especial clause of warranty, or what is equivalent thereto, as the word dedi; as, where Bheld of A by homage before the statute [Stat. Quia Emptores, 18 Ed. I.], and afterwards has given the land to another, doing the services to the 
3. Homage binds two persons by their mutual consent; and by their mutual consent it may be released and undone, but not by the assent of one of them only.

*4. When any heir is desirous of being admitted to the inheritance of his ancestor, and there is no doubt of his being the nearest heir, we will that he in the first place do homage to his lord, or offer to do it,--in respect that is to say, of his lands held by knight's service,-and that the lord receive his homage, unless there is a reasonable impediment. This may arise in the case of homage tendered for a fee not held by knight's service or grand serjeanty, except where the custom of the place is contrary ; and sometimes on account of the condition of the tenants, as where the hold is villenage.

5. On the part of the tenant again, homage is some-

chief lord. For all purchases are now made by dedi, and with an especial clause of warranty ; and the purchaser may thus vouch the feoffor or his heirs, who are bound to warranty by deed. Therefore he who holds by specialty ought to vouch by specialty, and he who holds by homage ancestral, ought to rouch by the same. And note, that homage is ancestral from the time of the Conquest, or before the limitation of the writ of right, or from the great grandfather of the lord, of whom the great grandfather of the tenant held, and so from heir to heir on each side. When there are fewer degrees, the tenant cannot vouch by homage without specialty.' (Note in MS. N.) Cf. ante, liv. ii. cap. 3. 8. 8. See the later doctrine as to homage ancestral in I ittleton, Ten. Sect. 143-152, with Coke's Commentary, Co. Lit. 100 . b. See also 2 Inst. 275 . 
times refused, and that rightly, as where the lands are given in free alms, or are held by petty serjeanties or by free socage ; and sometimes on account of the persons of the lords, as where they have married femalc heirs, and demand the homage in their own names, whereas their wives ought to demand it; so likewise where the lords demands homage before their tenants are in seisin, or before they are themselves seised of their inheritance; and when it is demanded by those who have no right to demand homage, as termors and others.

6. When an inheritance descends to any heir who holds of us and of several others, in such case the allegiance of the seigniory shall belong to us, and we shall not be barred by reason of the priority of any other feoffor. But if such heir does not hold of us, the allegiance of the seigniory shall belong to that lord who has the best right to his marriage.

*7. Whereas damage might accrue to us and other lords of fees in course of time, if several persons, to whom an inheritance descends as to one heir, should perform their services to the lords according to their portions, we will that every lord, if he pleases, may take the homage of all the parceners, male and female, as of one heir, such homage being considered as only one homage by reason of the unity of right, so that no lord may lose the wardship or marriage of any tcnants in chivalry of his fee; but that one of the parceners may, if the lord choose, swear the fealty to perform to him the services of the whole inheritance, so that 
neither we nor any other may receive the services of our fees by parcels nor by different hands; ${ }^{1}$ and in such case the other parceners shall do fealty and the services of their portions to their chief parceners.

8. Although an infant under age do homage, yet we will not have him take the oath of fealty until lie be of full age. And although it is common!y saicl, that the act of an infant, done under age, ought not to be held binding, yet we will that every man and woman aclmissible to an inheritance, of what age soever they be, do homage to their lords aceorling to the statute of the Great Charter ; *so that the lords shall not have the profits of wardships or marriages on the one hand without being bound to the risk of warranties on the other.

9. All those who hold by knight's service in their own names may do homage; but persons in religion, and clerks, and others holding in others' names, ought not to do homage for the tenements so held, as in the ease of tenements which they hold in the names of their churches, where the persons are named last in the feoffments, as appears by the charters, which begin thus: I give to God and the chureh of such a place, and to the persons therein serving God. In these gifts

It appears from a subsequent section, that it was not considered altogether safe for a lord to avail himself of the right of taking the entire service by the hands of the eldest parcener, inasmuch as his title to the wardship of the descendants of the junior parcener might be thereby endangered. See below, s. $\mathbf{2 3 .}$ 
therefore the feoffment is made first to God and his Church and afterwards to the persons therein serving God. Which persons cannot do any homage, but only take the oath of fealty. And such persons do sometimes make a payment to their lords of double the yearly value of their services at the end of every thirty years, in remembrance of relief, as is the common custom in Normandy.

10. He who is to do homage ought to seek out his lorl from reverence to him; and when he has found him let him tender his homage, with his hands clasped, before good people, who, if there be occasion, may bear witness thereof. If the lord refuses to take his homage, let him seek him again fifteen days after, and tender it to him as before, and so for three times. *And if he wrongfully refuse it three times by the testimony of good people, then we will that the lords be foreclosed of such homage, and that the tenants may perform their homage to the superior lords of the fees. And when another lord has thus received his homage, we will that the services be performed to him; and yet, if the tenant be impleaded concerning his tenement, the first lord shall be bound to warranty. And if the next superior lord refuse his homage, let it be tendered from lord to lord until it comes to us; which homage we may safely take.

11. If any lord fraudulently refuses or dulays to take the homage of his tenant, in order, perchance, that he may not be held to warranty, the tenant in such case may keep back relief and all kinds of services due from 
him to the lord until he has taken his homage, so that the lord shall have no seigniory over him until he has received him as his tenant; and no tenant in such case shall be obliged to make satisfaction for arrears of services before the homage has been received.

12. And if such tenants are not willing to transfer their homage to another lord, let them be aided by our writ to the sheriff of the county, *to command the lord that he justly and without delay take the homage of such a one who holds or claims to hold of him by knight's service; and that, if he omits doing it, he be at a certain day and place before our Justices to show cause why he has not done it. At which day both may be essoined; and if the lord make default, the process against him shall be by great distresses, as in personal pleas, until he shall appear.

13. When the lord appears and has to answer to the action of the plaintiff, he may say that he refused to take his homage, beeause he is not next heir to the ancestor whose heir he claims to be, inasmuch as he has an elder brother alive beyond sea or elsewhere, who is nearer heir to the same ancestor; or because he is a bastard; or because he is the feoffee of one who has committed felony, or who is appealed of a felony from which judgment of death, ontlawry, or abjuration may ensue, and which feoffor is still living; or by reason that he or some of his ancestors entered into the tenements which he claims to hold of him by a defective entry, as by intrusion, disseisin, or by default after def:ult made in our court, or by means of one who 
held the tenements for term of life, or in villenage, or at will, or for term of years, or in mortgage, or in fee tail, or in ward, or by means of a bailiff, or in like cases; or because the tenement for which he tendered homage, was given in marriage, and therefore he expects the reversion until the appearance of heirs; or because the tenant has no heir of his body, *wherefore the defendant contends that the tenant's portion ought still to accrue to him if the tenant should die without any heir of his own $;^{1}$ or because this same tenant has done some act by which the lord is discharged from receiving his homage; and such exceptions, if true, shall be allowed.

14. Therefore it behoves every lord, before he takes the homage of his tenant, to examine whether he is the right heir, and eoncerning all the circumstances named in the above exceptions, and that he know for what tenement and for how much he ought to take homage, and of how much the tenant is seised in de-

1 These two justifications of refusal of homage refer to the two cases of tenants in frank-marriage, and so-parceners; the feoffor in the one case and the elder parcener in the other being justified in refusing the homage until the thrd generation. See Glan. li. 7. c. 3 ; li. 9. c. 2 ; Brac. $21,21 b$; Fle. 190,191 . The reason of this was, that the acceptance of homage might prejudice his right of succession to the inheritance, upon the principle laid down in Glanville: ' Nemo potest simul esse hæres et dominus.' See Glan. li. 7. c. 1. Compare Littleton's Tenures, s. 19, 20, where it appears that in later times the tenantin frank-marriage was quit of all service, except fealty, until the succession of the issúe in the fifth degree. 
mesne, and oî how much in service, so that no one may be deceived as to the risk which he runs in respect of warranty.

15. Again, the lord, when he comes into court, in answer to the allegation of the plaintiff, that his father held of him and did homage to him, or to his father or other ancestor, by such certain services, may say that he held nothing of him, nor did any homage to him, nor ought to hold anything of him. And if he offers to make this good by his champion, he shall be admitted thereto if the tenant chooses to accept it; but if he chooses to put himself upon the great assise, it shall be charged to say, whether the lord, of whom the tenant complains, has the better right to hold the tenement in demesne, or the tenant to hold it of him. For it may well be, that the plaintiff or his ancestor did homage to the ancestors of the same person of whom he complains, and yet never had seisin of the tenement or of the fee for which they performed the homage; *or if they had seisin, yet they liad it by their own intrusion, and not by induction of any feoffor at a time when the tenement was vacant; in which case homage may lawfully be refused, on aecount of the right of action which the lord has to demand the tenement in demesne by reason of the defective entry of the tenant or his ancestors.

16. When any tenant resists doing homage to his lord, the lord should distrain for the arrears of the services if any are due. And if the tenant causes the distress to be replevied, the lord, where he cannot count of his 
own seisin, shall have his remedy by writ of customs and services. ${ }^{1}$ And if the tenant has sworl fealty to his lord, although he has done no other service to him, he cannot disclaim holding of his lord in any court of record, without an action immediately accruing to the lord to demand his fee in demesne. And if the lord

1 'If the tenant refuses homage, the lord may distrain his fee for the services which are in arrear. But he should make avowry in the first place for custom, as well as for service; as for homage and fealty, which are not properly services, but customs depending upon service. For lomage is appurtenant to escuage, and is a security for whatever belongs to knight's service; and fealty is appurtenant to rent, and is a security for what belongs to socage. Wherefore the security should first be demanded between lord and tenant, as between others who make contracts. And the lord may make avowry of his own seisin, or that of his father or grandfather, against the tenant by whose hand, or that of his father or grandfather, he was seised; so, in more distant degrees, provided he can assign seisin of his ancestors within the time limited in writs of novel disseisin. But where he can only say that his ancestors, or himself, were seised of the homage or fealty, withont seisin of escuage or rent, he cannot say that he is disseised; for rent gives seisin, and not fealty, nor homage. But the lord ought not to distrain but for arrears of rent or service, of which he can allege seisin as aforesaid ; which seisin of rent gives him continuance of possession, and authority to distrain for the arrears, and for the fealty by reason of the service which is in arrear. And if he cannot allege seisin as aforesaid, he cannot make avowry for homage or fealty, although he have received them within the time limited, nor consequently recover by assise of novel disseisin for the replevin of him who should be his tenant, but shall be driven to his writ of customs and services.' (Note in MS. N.) Compare Brác. $83 b, 84$ : Fle. 211. 
has been seised of any service of that fee by the hand of any actual tenant, although he was not seised by means of him who replevied the cattle, the lord shall nevertheless recover by assise of novel disseisin.

17. When homage is to be done, it should be done in this manner. The tenant should tender his homage to his lord with his hands joined in tolken of subjection and reverence; and the lord, in token of warranty ac. quittance and defence, ought to hold the tenant's hands between his own. And where homage is to be done to us, it ought to be done with these *words : 'I become your man for the fees and tenements which I hold and ought to hold of you, and will bear you faith of life and limb of body and chattels and of every earthly honour against all who can live or die.' Then the lord, whosoever he may be, whether ourself or another, and whether male or female, clerk or lay, old or young, ought to kiss his tenant, whether he be poor or rich, ugly or handsome, in token of perpetual affiance, and obligation of strict friendship. And when any one has done homage to us, every other lord shall be foreclosed of the allegiance of seigniory.

18. Where lomage is to be done to any other liege lord than us, let it be done in these words: "I become your man for the fees and tenements which I loold and ought to hold of you, and particularly for such a tenement named by certain quantity and certain bounds, and for such fees, and will bear you faith of life and 
limb above ${ }^{1}$ all people, saving the faith which I owe to the ling and his heirs.' The lord may thus know for how much he will be bound to warrant his tenant.

19. If homage is to be performed to any other than to a liege lord, the tenant shall say thus: 'I become your man for the fees and tenements which I hold and ought to hold of you, *and in particular for certain land or a certain tenement in such a vill,' as is abovesaid, 'and I. will bear you faith above all people, saving the faith which $\mathrm{I}$ owe to the king and to my other lords.'

20. When any one is to do homage for a pension $e x$ camera, ${ }^{2}$ as a servant may do to his lord, as his servant and not as his man, the words shall be simply these: 'I become your man, and will bear you faith above all

1 In Bracton and Fleta the word is contra, and a misreading may be suspected. Compare the form in s. 17. But outre is found in all the MSS. which have been consulted, both here and in the corresponding places of ss. 19,20 .

2 Compare Bracton, $79 b(\S 6)$; Fle. $20(\$ 18,19)$; and see post, s. 31. Bracton says, that no homage was done for a rent ex camerâ, where no land was bound: Fleta, that it ought not to be done, and if it be done, no right of wardship or marriage arises. The general rule is laid down by Glanville, and repeated by Bracton : 'Pro solo dominio fieri non debent homagia alicui excepto Principe.' (Glan. li. 9. c. 2 ; Brac. $79 b, \S 6$ ). But it is mentioned by Bracton and Fleta, that it was the common practice for champions to do homage to their principals, which could only be ratione dominii: and see post, s. 31. This probably arose from the form in which the wager of battle was tendered: 'et hoc promptus sum probare per hunc liberum meum hominem.' (Glanc. li. 2. c. 3.) 
people as long as the homage shall endure, saving the faith which I owe to the ling and to all my other lords.' And such homages may be released by waiver of the pensions and by release of the obligations. And a recent change in the law has had this effect, that homages taken by feoffors to the prejudice of the chief lord are not binding or of any force. ${ }^{1}$

21. As soon as homage is performed, those who are bound to do any services to the lords for the tenements shall straightway take the oath of fealty,-if to us, in the following form, laying their hands upon the Holy Gospels: 'Ilear' this, ye good people, that I, such a one by name, faith will bear to our lord king Ed-. ward from this day forward, of life and limb, of body and chattels, and of earthly honour, and the services which belong to lim for the fees and tenements which I hold of him, will lawfully perform to him as they. become due to the best of my power, so help ine God and the Saints.'

22. If fealty is to be done to any other liegre lord than to us, then let it be done in these words: 'Hear. you this, my lord John, that I, Peter, from this diy, from this day forward, will bear you faith of life anil limb, saving my faith to the king and his heirs, and the services, which belong to you for the fees and,

1 This passage is important, as shewing the age of Britton. The statuite referred to as a "new constitution' can be no other. than the statute of Westminster the third, Quia emptores terra. rum, passed in the 18th year of Edward I, A. D. 1290. See Introduction by the Editor. 
tenements which I hold of you, lawfully will perform to you as they become due to the best of my power, so help me God and the Saints.'

*23. If any one refuses to do fealty to his lord, the lord may distrain his tenant until he does it. But no parcener or his issue shall swear fealty except to the eldest parcener, nor to him, unless the lord consents; but it shall be in the election of the lord to take his services by the hands of one or of all the pareeners. For otherwise he might lose the wardships and marriages of the other parceners, by reason of the words in the writ of ward, where the plaintiff says that the ancestor of the infant, in respect of whom he demands wardship, was his tenant, and performed to him knight's service; which would be false, if the service was done to any other than to him.

24. From parcener to parcener fealty is sworn thus: ' Hear you this, John, that I, Peter, will bear you faith from this day forward, and the services due for my portion of the inheritance which was Theobald's, our common ancestor's, lawfully will perform to you as they become due to the best of my powel': so help me God and the Saints.' And to the other lords thus: 'Hear you this, my lord John, that I, Peter, will bear you faith from this day forward, and the services which belong to you for the fees and tenements, - and so on, as before, fealty of life and limb being nerer sworn except to us and to liege lords.

25. For allegiance is of so high a nature, that if two lords are at difference, the tenant must perform his 
service to his liege lord against his other lord in his own person, and must perform his service to his other lord by attorney. And homage is so strong a bond between lord and tenant, that none may without judgment *or the mutual consent of the parties recede from the honage, so loug as the tenant shall keep in his hands the tenements or fees, for which he is bound to perform such service; neither may the lord do anything which touches the disherison of the tenant or other great wrong to his damage in life or limb, nor the tenant to the lord after performance of homage, without by the very act breaking the league between them and extinguishing the homage.

26. If the lord be convicted by judgment of this great wrong, it shall be awarded that he be forejudged of his seigniory for ever, and be otherwise punished according to the offence, and that the tenant perform his homage to his superior lord. And if the wrong be convicted in the person of the tenant, let it be awarded that he lose the tenement or fee for which he did homage.

27. And we will that if any tenants disavow their lord, or disclaim holding of him in a court bearing record, the lord, on account of the homage and the oath of fealty which the tenant has broken, shall have an action to recover the tenement of such tenant of his foe in demesne, by the following writ: 'Command such an one that justly and without delay he surrender to such an one so much land, or so many fees, with the appurtenances in such a place, which the aforesaid 
*such an one detains from him, and for which he did homage and service to him, and which ought to be his escheat, inasmueh as the aforesaid such an one, contrary to his honage and the oath of fealty which he had taken to him for the same, malieiously to his disherison disclaimed him for his lord and the holding of anything of him, and that, if he omits doing it, he be at a certain clay and place before our Justices to show why he has not done it.'

28. This writ need not be pleaded by descent, but may be determined by a jury and inquest as to the fee and the quantity thereof. For the lord cannot properly count by descent by reason of the ancestors of the ten. ant, who have been always in possession. And whether he plead by descent or not, we will not have the aetion determined by battle or great assise; but we allow, if there be oceasion, that the tenant may put himself on a jury after the manner of a great assise by these words, to wit, whether he has most right to hold this fee, or the tenement demanded, in demesne, or he who demands it, and to whom this same tenant, or some of his ancestors whose heir he is, did homage and service for the same, and afterwards, contrary to his homage and fealty, maliciously disclaimed him. And let judgment be given according to the verdict.

*29. The lord has likewise the same action against his tenant, where the tenant has performed to another that homage which he ought to have done to him, if it be found that there was fraud or malice in the act; or if he has done homage wrongfully to another after he 
had rightfully performed homage to him. But if the tenant has clone it by the distress of another, or by folly and not by malice, in such case we will that the lords and the tenant be made to appear in our court, and it shall be there discussed which has the better right to the homage. And he who is in the right shall recover, and he who is in the wrong shall be punished.

30. Whereas battle may not be joined between lord and tenant during the homage, we will that if any tenant would appeal his lord of felony or otherwise fight with him, that he surrender to the lord the fee or tenement which he holds of him, so that the homage may thus be released. For homage cannot in any other way be released.

31. If homage be done without the possession of any fee or tenement, that homage shall be of no force. Neither let homage be done for those fees or tenements from which no wardship or marriage arises. ${ }^{1}$ Neither let homage for grand serjeanty, although it

I This rule was not of universal application, since homage was sometimes due from socage tenements, where neither wardship nor marriage could be claimed. Brac. 776 ; Fle. $207(\$ 17,18)$. The rights of wardship and marriage were inseparably connected, as appears in the argument used in the following note: 'An infant under age marries a wife, to whom after marriage a knight's fee descends. Qu. Shall the lord have relief, or warkship until the husband's age? Some say wardship, because he must take his homage, and he ought to have the wardship of his tenant holding of him by homage. But wardship belongs where marriage belongs; and the marriage of the infant, even if he were unmarried, could not belong to the lord. Therefore the wardship does not belong to him.' (Note in MS. N.) 
be performed, be of any force, unless the serjeanty be held of us in chief,-no more than homage done for a rent ex camer $\hat{a}$, or by a champion of other servant.

*32. For homage once properly performed between tenant and lord endures as long as they both live. And although homage fail by the death of the lord, vet it remains entire in the person of the tenant. For although the tenant does homage to the heir of his lord, and so from heir to heir, yet he does not thereby perform several homages, but renews several times the same homage. Therefore it is sufficient for a tenant to take up his land by relief once, although he does homage several times. But if several homages become due on the part of the tenant, as from heir to heir, we will that wardship or relief follow every homage. One tenant nevertheless may perform several homages for different tenements at one time, or at several times, to the same lord; but when homage has been once performed between lord and tenant, it ought not to be done again between the same persons for the same tenement.

33. Neither will we that the lord attorn the homage and service of his tenant against the will of the tenant to whomsoever he pleases, and particularly to the mortal enemy of the tenant, or to one who has nothing whereby he can warrant him if need be. But in other cases we are willing it should be so far permitted, that if a tenant will not of his own consent attorn to hold of another lord according to the wish of the lord, the feoffment shall be made 
*by fine levied in our court between the lord and his feoffee, of the service of the tenant. By virtue of which fine, we will conmand the sheriff of the county by our writ of judgment to cause the tenant to come into our court to shew what tenements and what fees he holds of the lord and by what services. When he appears, if he says that he holds nothing, and does not claim to loold anything of him, it shall be awarded that he go quit, and that the lord be in mercy ; and the lord may then obtain his remely as above mentioned. If the tenant say that he holds of the lord certain tenements or fees, and by certain services, let it be awarded that he be released from the first lord and his homage transferred to the third party, to whom his lord has attorned him.

34. If the tenant say that he has done homage for the tenement, which homage is not yet extinct, and demand judgment whether he ought to perform two homages to two persons for one tenement in the lifetime of his first lord, from whom he does not wish to separate; in such case we will not have it awarded that any do homage against his will to another than him to whom he first did it in the lifetime of his first lord. But if he can give no reason why he ought not to do fealty to him to whom he is attorned, let it be awarded that he take the oath of fealty to him; and if he will not do it of his own accord, let it be awarded that the purchaser distrain the tenements or the fees whereout the services shonld issue, until he shall do fealty to him. For whosoever grants service, grants 
*a right to distrain. And when the feoffor dies, we will that the homage be immediately extinct in the persons of the heirs of the feoffor, and take place anew in that of the purchaser according to the force of the fine levied in our court.

35. And if such purchaser distrain the tenant for homage or for other service, and the tenant cause his distress to be replevied, and in his pleading says that he wrongfully took his cattle, inasmuch he does not claim to hold anything of him, yet notwithstanding such replication, we will not that he cease to distrain; for in this case distress and disclaimer may well stand together.

36. Nevertheless there are cases, in which such tenants may avail themselves of the exception, that they ought not to be attorned against their consent, as where a lord, for the purpose of burdening his tenant and discharging himself, wishes to attorn his tenant to one who has nothing whereby he can warrant him, or satisfy him for the value, if need be. In this case the exception shall be allowable to every tenant, so that it shall not be in the power of any lord, on account of the smallness of the service, to waive his fee, in order to be discharged from the risk of warranty. 


\section{*CHAPTER V. \\ of Reliefs.}

1. If any tenant is of full age at the time of the death of his ancestor whose heir he is, let him immediasely go and find his lord, and do him homage and relieve his inheritance which lies dormant and unsupported upon the death of his ancestor. Which relief is reducel to a certainty among the articles of the Great Charter.

2. But if anyone has been so long in ward of his lord after the death of his ancestor, that the lord has taken any sort of profits of his inheritance in however small a quantity on account of wardship, the heir shall be quit of relief. And although homage be often renewed on the death of several lords, yet no tenant shall be obliged to relieve his land more than once in his lifetime, and his heir another time, and so from heir to heir, as above is mentioned in treating of homage.

3. And although any one alien his tenements, yet the lord of the fee may not demand of the feoffee any relief. For we will that all purchasers shall be quit of relief for their lives in respect of the tenements purchased. So likewise, all those whose lords are changed. And those who hold for term of life only. 
And those, who marry women, who were some time in ward of their lords, that is to say, for the inheritances of their wives. And as we will not that any under the age of twenty-one years shall give relief, so *neither will we that relief be paid to any under that age, nor before the lord is seised of his inheritance, nor before the lord has restored to the tenant the charters of his inheritances, if in his hands.

4. Although the law does not require relief in the case of any tenement other than a fee of ehivalry or grand serjeanty, yet for tenements which are not of such fees, where the service is fixed, we will that every tenant give to his lord in acknowledgment of his seigniory the amount of one year's rent, so that the lord in that year shall have as mueh as double his tenant's rent. And in such acknowledgments the same rule shall be observed as has been mentioned eoneerning reliefs, that none make the acknowledgment before he is of age to take the oath of fealty,-nor more than once,- - nor until his lord be of full age and in seisin of his inberitance. And for tenements held in fee-farm or in free alms, let nothing be given, except what is speeially expressed in the deed.

5. With respeet to heriots, we will that no tenement, nor any heir, be bound. For the gift of an heriot is a payment made, on account of the death of the tenant of some lord, of the best beast found in the possession of the deceased, or of one not the best, aceording to the appointment of the dying person, to the use of the lord; wheh payment does not at all concern the heir or his 
inheritance. Neither is it to be compared with relief ; for it arises more out of favour than of right, and is more paid by villains than by freemen.

\section{*C H A P T E R V.}

\section{Of Mortdancester.}

1. It is always the duty of heirs, when they come to their inheritances by succession, to permit their lords to make a simple seisin, ${ }^{1}$ without doing any sort of damage, whereby they may be recognised as lords. And if such heirs are under age, and ought to hold by knights' service, let the lords first take their homages, and afterwards have the wardship of their fees. If the lords find their fees vacant, they may seize them simply in right of seigniory, and fully in right of the lawful heir, whosoever he may be. And this last clause shall be a justification for all such lords delaying

1 This is the rule laid down by Bracton (f. $252 \mathrm{~b}$ ), and confirmed by the Statute of Marlborongh, c. 16. Lord Coke, in commenting upon this statute, interprets ' simple seisin' to mean relief. But although in all probability it soon became the practice to be contented with this recognition of seigniory, the words of the statute, as well as those of Bracton, appear rather to contemplate a formal possession of the tenement, it being expressly provided that the lord was not to take or remove anything from the land, or to eject the heir. It will be seen that in the next sentence of the text, the simple, or formal, seisin of the lord, is contrasted with the full, or beneficial, possession of the heir. 
to take the homage or to yield up the inheritance to any otber than the lawful heir.

2. If any lord through malice or negligence sball take the homage of one who is not the right heir, where the lord well knows that there is a nearer heir, or has reason to suspect it by another offering himself as right heir, or by common report of the neighbourhood, and after receiving such homage, shall deliver to him seisin of the inheritance in demand, and the right heir shall then bring an assise of Mortdancester against. the tenant, *and the tenant shall vouch the lord to warranty by reason of the homage which the lord received of him; we will that in such case the lord shall be bound to warranty and to exchange, although he alleges by exception that he took his homage saving every person's right, since he took the first step to disinherit the right heir. But if no other had claimed the inheritance, and the lord had had no suspicion that another was heir, it would have been reasonable that such a condition in the taking of homage should have been allowable; and in such a case we will that such conditional receptions of homages shall be allowed, but in no other cases.

3. If any lord be in seisin of his fee, and be doubtful of several persons who demand the inheritance and offer themselves as heirs, whose homage he ought to take, such lord may keep himself in the inheritance, without elaiming anything but the seigniory, until he be certainly informed which is the nearest heir to the deceased. ancestor. 
4. If it happens that the elder brother and right heir is out of the country at the tine of the death of his ancestor, and the younger brother finds the inheritance vacant, and thrusts himself in, claiming the inheritance as right heir; in such case the lord may take the homage of the younger brother, under condition that seisin of the inheritance be delivered to the elder brother or his *issue whenever he shall appear to demand his inheritance, whoever be then tenant. For if the lord eject the younger brother after he has been seised, he shall recover by assise of Novel Disseisin, to hold nevertheless according to the condition aforesaid. And if the lord is in seisin, and keeps out the younger brother, who proceeds against the lord by assise of Mortdancester, and it is found by the assise that he has an elder brother, seisin shall be awarded to him under the before-mentioned condition. But if a bastard keeps himself in seisin, where no heir offers himself for the inheritance, in such case it is lawful for the lord to eject such bastard, except where his long possession through the negligence or weakness of the lord constitutes a valid title to the freehold.

5 . Therefore it behoves every lord to seize his fee without delay upon the death of his tenant, if he finds it vacant. And if the heir is of full age, and in seisin, and will not suffer the lord to have seisin nor acknowledge him as lord; in such case the lord may lawfully keep himself in seisin, together with the heir or the person who pretends to be heir, but he must not eject him; and if he can do nothing more, he nay disturb 
such heir in the enjoyment of his seisin until *he acknowledges him as his lord. When he shall acknowledge him, let the lord forthwith take his homage and security for his relief, and his oath of fealty, and that he will lawfully perform to him the services which belong to his inheritance; and let his inheritance and the free management thereof be then restored to him without delay.

6. If the lord obtains the first seisin, the heir being of full age, and the lord will not acknowledge him as heir, his first remedy is by assise of Mortdancester. And when any person wishes to proceed before our Justices for an inheritance thus detained from him, let him first find security by known pledges to prosecute his plaint, if he has such pledges ready; and if he has not, we will command the sheriff of the county to take security; and if the plaintiff be so poor that he cannot find security, the pledging of his own faith shall be sufficient; and such writs as his suit requires shall be forthwith granted to him. And if the plaintiff is under age, he need not find security to prosecute his plaint, nor need any term be mentioned in his writ. ${ }^{1}$

7. As this assise is limited between certain persons, so likewise it is confined within certain degrees; for assise is to be granted *of the death of the father, mother, uncle, aunt, brother, and sister, and not ascend-

1 That is, no tern of limitation need be named, since, if his immediate ancestor died seised, the minority of the heir is itself a proof of the recent accruer of his title. See Bracton, f. 254. 
ing higher, as to the grandfather, nor descending lower, as to the nephew; so that neither of the death of the grandfather nor of the death of the nephew alone, ${ }^{1}$ nor in any higher or lower degree is this assise ever allowed. And the more clearly to see of what ancestors this assise lies, let four degrees be set down, of which father and mother make one degree, uncle and aunt on the father's side the second degree collateral, uncle and aunt on the mother's side the third degree collateral, and the child of the father or of the mother, the son's own brother or sister, make the fourth degree in the right line descending from the father and the mother. And this fourth degree is divisible into three, as appears by the above figure.

8. And if the son is to institute this assise against any stranger in blood, being tenant, then this assise may well be had of the death of his father, or of the death of his mother, and not in the reverse case. ${ }^{2}$ For this assise always supposes priority in the ancestor, or at least equality; and requires to be bronght by the lower of the higher, ascending and not descending, and also from equal to equal, as of the death of the brother by the brother or by the sister, and of the death of the sister on behalf the brother or sister. And if any one in a more remote degree is

1 'This word 'alone' appears to have reference to the exception afterwards stated concerning the case of a joint assise. See s.10.

2 This appears to imply the possibility of a father claining as heir to his son. though not by this assise. See post, 1. vi. c. 4, s. 4 , and note there. 
aided by this assise, it will be rather in consequence of some other person who makes the assise, than for himself, as shall be afterwards mentioned. Therefore we will that if any separate assise be brought to trial concerning the death of any person not within these two degrees, the assise shall fall, unless some person is joined who may make good the assise.

9. Neither by this assise nor by any other possessory writ shall any proximity of blood be tried; that is to say, between demandant and tenant claiming by the same descent; but between all strangers in blood the assise shall lie so far as it may extend. And such kindred as cannot be aided by this assise shall have their remedy by our writs of Cosinage, of Ael, Aele, Besael, and Besaele; which writs do not deternine anything of the mere right, but spring out of this assise, and determine by means of juries the right of possession. The assise however takes place among privies of blood claiming by different descents, as between two brothers by different fathers or by different mothers. *For the brother begotten by any other father is an entire stranger, so far as concerns the demanding of anything upon the death of the father or ancestor of the other brother, and so of two brothers born of different mothers. But this assise does not lie between a legitimate brother and a bastard seised of the other's inheritance, because the proof of the proximity of blood cannot be tried by any possessory plea.

10. Sometimes two or three persons in different 
degrees are joined together, and obtain their remedy by assise of Mortdancester, where the plea partakes of the nature of an assise of Mortclancester and of Cosinage; as in the case of an inheritance which descended from one stock to two persons, constituting a single heir, by different lines, as to a daughter on the one sicle, in whose person the assise of Mortdancester takes place, and to a grandson by another daughter on the other side, in whose person the writ of Ael lies, being in a degree to which assise of Mortdancester does not extend. In the which case we will that the recognitors of the assise come and make recognisance upon their oath, whether the father (or mother) of the daughter, and the grandfather (or grandmother) of the grandson was seized in his demesne, \&c. And what is said of the seisin of the grandfather or grandmother as regards the grandson may also be said and reputed for law concerning their brothers and sisters, uncles and aunts of the daughter, and cousins ${ }^{1}$ to the grandson, since they are in the same degree with the grandfather and grandmother; but higher the assise of Mortdancester does not ascend.

*11. And because there is more speedly remedy in the assise of Mortdancester than in the plea of Cosinage de Ael, we will that such plaintiffs have relief by assise of Mortdancester, whether the parties wish to join in one plaint or not, so that the daughter shall not be able to proceed by an assise without naming in the writ the grandson or his issue in what-

1 That is, as I understand, greai-tincles and great-aunts. 
soever degree found; nor can the grandson or his issue proceed by writ of Cosinage in the lifetime of the daughter who is his co-parcener and nearer by one degree or more. For the nearest person makes the assise, and draws to itself the person in the more remote degree.

12. There are other writs somewhat resembling this last double action, as of the death of the uncle or aunt in a partible inheritance ${ }^{1}$; where in every case the nephew ought to be joined in the same action with the uncle and the aunt in an assise of Mortdancester, and this action is not mixed with Cosinage; and the recognitors of the assise ought to come and make recognisance upon their oath whether the unclo or the aunt on the father's or mother's side of the nephew demandant on the one part, and the brother or the sister of the uncle or the aunt on the side of the other demandant, whose heirs these two demandants are, was seized in his or her demesne.

13. Where the inheritance is not partible, and the uncle brings an assise of Mortdancester of the death of his father or mother, uncle or aunt, *and the nephew by the brother brings a writ of Cosinage for the same tenement against the same strangers, or if both have instituted an assise of Mortdancester against the same stranger, that is to say, the nephew,

1 It will be remembered that in early times, by common custom, tenements in socage were partible or divisible among the sons. See Glan. 1. 7, c. 3 ; 1. 13, s. 11 ; Brac. 76 ; Fle. 300 (§2). 
upon the death of his uncle or aunt, and the uncle of the same nephew, upon the death of his brother or sister; in both these cases the nephew is to be received to the inheritance before the uncle. And if one of them either by assise or by Cosinage demands against the other an inheritanee descending. from the same stock; in such case it shall be adjudged in favour of whichever party is in possession, if the tenant elaims by the same descent as the demandant does, although the demandant may have a better right; and let him afterwards proceed by writ of right, by which writ alone the proximity of blood and the right can be tried.

14. If any stranger, as, for example, the chief lord or other, deforce parceners of their inheritance, and some of them are diligent in demanding their inheritances and others negligent, it behores the diligent, whether one or more, to make his plaint and purehase his writ in the names of all the parceners who have not their portions, by reason of the unity of the right which remains united until division; after which any party who will may sue; and those who ehoose to sue shall have remedy by this assise of the death of their common ancestor.

*15. Whereas this assise does not lie between privies of blood, and in particular between parceners who take as one heir, we propose, before more is said of the assise, in part to explain by what actions, and by what writs, and how one parcener may compel his other parceners to malie severance of their inheritance which 
they hold in common, so that each may know his several, and that each may have his reasonable portion according to his due; and if any one be deforced of the whole by his parceners, how and by what writ he may have redress, and by what writ he may recover part if he be disseised of part.

\section{CHAPTER VII:}

\section{Of a Mixed Action.}

1. There is a kind of action which may be tried in our court, called a mixed action, inasmuch it concerns the person against whom the demand is made as well as the thing demanded; and therefore is pleadable by personal distresses and by real also, as by the great and little Cape. Of such kind is an action to sever a thing held in common, wherein each party is plaintiff and defendant, as where strangers without affinity or kindred have something to be divided between them which they hold in *ommon, as in the case of neighbors who proceed by action to divide some tenement between them, so that each may have severalty. Another kind of mixed action is that called in the Imperial law actio familice herciscundce, ${ }^{1}$ which takes place

1 'Nota hic de actione que dicitur Familia Herciscunde.' (Note in MS. N.) The word herciscundo, (from herciscere, 'to divide.') which is scarcely found except in this connection, ap25 
between those who have a common inheritance to divide.

2. Nevertheless two actions ${ }^{1}$ (lo not arise as soon as the inheritance or other thing is held between such parceners in common, but from the time that any of them begins to compel the others to a division. And this action obtains among several parceners and coheirs, as where several brothers ${ }^{2}$ or sisters or their issue hold an inheritance in common as one heir, and wish to proceed for a division, so that every one may have his portion in severalty. It also lies between parceners who are as one heir in respect of a common tenement which they are desirous of having divided, and which is divisible by reason of the tenement. These actions are called mixed, because either party is plaintiff and either defendant, that party being plaintiff who. first complains.

pears to have been taken for a proper name by our author or his transcribers.

I The word cestes, 'these,' appears to be wanting at the begimning of this sentence. In Bracton it is, 'Sed hæ duæ actiones;' but in Fleta we find, 'Sed duæ actiones.' Accepting the omission, we should perliaps translate the words, 'double or mixed action.' As to the relation of this work to Fleta, see the Introduction by the Editor.

2 The worls 'brothers or' ' seem to have crept into the text by mistake. The two cases intended in this and the following clause are, first, where a tenement is divisible by the common law among sisters; secondly, where a tenement is divisible by custom (par la resoun del tenement) among brothers. See the corresponding passage in Bracton and Fleta. 
3. In these two cases, if any parcener demand against another his reasonable share, and the tenant or tenants make default, there shall be taken into our hand, out of the entire common inheritance, the portion which belongs to the plaintiff ; *and thus the distress will be real and not personal. And such shall be the proceeding in a plea derationabili parte, which takes place where one is denied to be a parcener and is deforced of his share. But where all are acknowledged to be heirs and parceners, there should be no plea de rationabili parte, although an action may arise on account of one of them having less for his share than he ought to have.

4. It is proper therefore in such ease, as soon as the pareeners have performed their homage to their chief lords and are desirous to have their inheritance divided between them, so that each may know his several portion, that an extent should first be taken, and that according to the extent partition should be made between them. And if such parceners would have our aid in making the division, whereby an oath is taken to do it lawfully, then at the request of any plaintiff parcener we will command the sheriff that he lo by knights and other good men of the county, in the presence of the parceners, if they will be there, cause an extent to be made of all the lands and tenements which were of such an one (the common ancestor of the parceners), in such a county; and according to this extent livery shall be made of his share to every parcener. 
5. The extent shall be made in this manner. ${ }^{1}$ First let an inquest be taken upon the oath of the jurors, how much the buildings in the capital manor, and the moats, vivaries, hays, pools and other *fisheries are worth by the year, clear of outgoings. Then let the true value be inquired of the gardens, curtilages, dorecots, and the other issues within the court; then how many fields and closes of arable land there are in the demesne, and how many acres each close contains, and how much every acre is worth by the year; and how many acres of meadow there are in demesne, and how much every acre is worth by the year; and how many acres there are of every kind of pasture, and sufficient for how many beasts, and what kind of beasts, and how much the pasturage of one beast is worth by the year according to the kind of beast. Under this article is comprised as well common of pasture for sheep, logs, and goats, as pasture several for oxen, cows, and heifers, and for studs of mares and colts in woods or parks, or in enclosures or elsewhere in their severals. Afterwards let inquiry be made concerning the said woods, how much each acre is worth by the year, to keep as wood, or to assart and improve; and how many acres the parks and the other demesne wools contain; then, of the value of the reasonable estovers from land belonging to others, how much they are worth by the

1 This section much resembles the ancient summary, called Extenta manerii, printed among the Statuta temporis incerti, in the Statutes at large. 
year, as wood for building, fencing, and burning, and rights of fishing in another's river, and of digging turfs in another's soil or in some common soil and other necessaries. Afterwards let inquiry be made of *honey, and of pannage, and of mast of acorns, nuts, and other kinds of fruits, and of all manner of profits arising from forests, woods, moors, heaths, turbaries, wastes, and every other kind of commodity issuing from commons, how much they are worth by the year. Then, of rents issuing out of the fees belonging to the manor, and of rents due to the manor for common granted in the fees of the manor, and of all other sorts of rents. Next, of mills, vivaries out of the manor, and several fisheries, how much they are worth by the year. Then, of pleas and perquisites of courts and of franchises, markets, warrens, rabbit-warrens, traverses, tolls, customs, and views of frank pledge, and of the yearly issues of every kind of franchise: and then, of the advowsons of churches, how much each church is woith by the year; and of suits of freeholders, how much each suit is worth upon every default. It should also be inquired concerning aids, presents, heriots, and every kind of annual compliment. And afterwards, of villains, and of the villenages let every house be separately extended, and then their closes, meadows, and pastures ; also their rents, services, talliages, and customs.

6. The whole amount of the extent shall be entered on a roll, together with a verdict. And for every marc in the value of a church, one shilling shall be put 
in the extent; *so that if the church be worth one hunIred marcs a year, the yearly value shall be extended at a hundred shillings; and according to this valuation those who do not keep the advowson of the church shall be compensated in land. For an advowson is not divisible; but if it were to be sold, the reasonable price would be according to the annual value of the church. This extent being so made, shall be enrolled and sealed under the seals of the sworn extendors.

7. If the parceners are present, they shall be asked whether any of them can show cause why any person who calls himself a parcener ought not to have his share of the inheritance. And when it is declared how many are to divide the inheritance, or where no cause can be shown why all should not share, or if none of the parceners appear, and the summons is proved, let the inheritance be forthwith divided into so many parts as there are parceners, accorling to the extent, so that each portion may be severed from the other by divisions and bounds.

8. Afterwards let the parcels be entered and specified in several scrolls, and let those scrolls be delivered to some layman who knows nothing of letters or of the contents, and let him deliver one scroll to each parcener; and according to the lot of those scrolls let each parcener take to his share. *And if any of the parceners lias improved or damaged the land while it was in his hands, either in part or in the whole, let such damage be taken into account in the extent against the person who did it, and likewise let his por- 
tion be increased according to the improvement he may have made.

9. If the sheriff be negligent in this matter, we will send our precept to the coroners of the district, or we will assign by our letters patent some Justice to execute it. For such delivery of shares touches very nearly upon the right of property by reason of the assignment of boundaries; and it is therefore necessary that such partitions be discreetly, properly, and lawfully made.

10. And whether such deliveries are made by lot, or by election, the eldest parcener choosing first, and so one after the other according to their ages, let the parcels be presently imbreviated on a roll, that is to say, what each parcel is, and how much, and between what bounds the parcel is assigned, and to what parcener by name, so that all the parcels of each share be enrolled, ${ }^{1}$ as well demesnes as fees and services and dowers or other lands held in any manner for term of life, which are to revert after the death of the tenants, and to whom these lands are to revert, and to which of the parceners the services of such tenants are assigned. $\Lambda$ nd he to whom any service is assigned towards his share shall forthwith take the homage of the tenant;

1 ' Upon a division being made, each parcener has a like title to his several. This title, when the division is made by the king's mandate, is a title of law, and requires to be vouched by record. But division made by assent of parties requires to be averred by specialty of writing, upon which issue shall be joined (le averrement se joyndra).' Note in US. $N$. 
and he who has to await the * reversion shall have assigned to him in the meantime a portion of some other tenement according to the value of the land which is to revert to him, to be held until that land falls in.

11. If any one of the parceners die after the partition, not having any heir of his body begotten, then his share shall accrue to the other parceners or their issue, to be divided between them by equal portions, yet not by succession of inheritance, for none of them is heir to the other, but by right of accruer. ${ }^{1}$

12. And if any one of the parceners is not contented with the partition, we will cause the proceedings and the record to come before our Justices of the Bench ; and the plaintiff shall there state what errors have been mate, and the errors shall there be redressed by a new extent if need be. And after assignment of the shares, either by lot or election, let seisin be executed by judgment of our court.

1 "Whereas it is said that the parceners shall have the proportion of the one who dies by right of accruer, our companions say (si dient nos compaygnons) that this is not so. For after division, each parcener is inherited of his portion (est enhite de sa purpartie), as if he had purchased of a stranger: and if he had purchased of a stranger, and died without issue, his brothers or sisters would be his heirs.' (Note in MS. N.) The statement in the text, that the portion is taken per jus accrescendi, is derived from Bracton, who however does not say that the parceners are not heirs to eacl other. 


\section{CHAPTER VIII.}

\section{Of the Division of Inheritances.}

1. All inheritances do not fall into partition or hotchpot, to be divided among parceners; as the capital manors or capital castles of counties or baronies, and as parks, vivaries, and advowsons of churches. *But where the inheritance is divisible, the eldest brother or the eldest sister by right of seniority shall have the capital mansion for his share, unless this mansion be the head of an earldom or of a barony, as is said above, by reason of the right of the sword, which does not bear division, and of the risk that the strength of the realm may be diminished thereby, which strength was originally constituted and divided by counties and baronies.

2. But if there are several capital houses or castles of earldoms or baronies, then partition may be made. of such castles or houses, yet so as to leave them in their entirety, saving to the eldest the prerogative of choosing first. For in such cases the rights of the sword are preserved uninjured and undismemberesl, which would not be if one capital mansion of an earldom or barony was divided among several persons. For if there be but one castle or one house as head of the earldom or barony, that shall remain entire 
to the eldest, so that a proportionate allowance be made to the others according to its value, out of the remainder of the inheritance.

3. If there are several capital mansions, then let the eldest have the first choice after the inheritance is divided into parcels, and the second next, and so of the other degrees, descending from degree to degree. And if there are more parceners than there are capital mansions, then let that parcener who has no house fallen into his share have the value of a house delivered to him out of the entire inheritance. *And if there are more capital houses than parceners, let the houses in excess be divided among them in equal portions, unless the parceners agree that some or all of them shall remain entirely with one or more of the parceners, and that an allowance in proportion to the value be made to the others. And if there is but one capital mansion, let not that be subject to partition, provided that there is some other part of the inheritance out of which satisfaction ean be made to the parceners of the value of their proportions, supposing that the inheritance is partible by custom. If otherwise, it will remain entirely to the eldest.

4. With regard to lands in ancient demesne, the ancient custom of the place shall be observed; for in some places it is held as a custom that the inheritance is divisible among all the children, both brothers and sisters; in some places, that the eldest son shall take all and in others, that the whole shall go to the youngest brother. 
5. Sometimes the hall of a house is divided into two halves, or into several parts; and sometimes it is separated from the chambers, and so of other buildings, as shall be mentioned in treating of pleas of dower. But advowsons of churches, servitudes of soil, and such kinds of incorporeal things, are from their nature incapable of partition. Nevertheless several advowsons and several rights may admit of a partition among parceners, where each right remains entire. *But the advowson of a single church ought not to be divided, although sometimes the body of the church may have become partible or divisible in ancient times by reason of different baronies. For if a church is void by the death of the parson, and several parceners are patrons as one heir and one body, by reason of the unity of their right, no one has a right to present to such ehurch without the others, until the advowson be wholly assigned to one of the parceners as part of his share, or so limited by agreement between them, that one shall present one turn, the second the next turn, and so on in succession. And if any one before such agreement offers to present by reason of seniority, the clerk shall not be admissible to institution, so long as any of the parceners oppose the presentation.

6. The like of servitudes; for if a tenement to which a servitude is due falls in partition and division among parceners, the servitude is neither diminished nor altered, but remains in its unity so far as regards the land charged. And although a servitude is divided intó several parts, as regards the land to which it is due 
by reason of the plurality of parceners, and although there may be several entire rights thereto, yet the land shall not be more burdened than it was before the partition; and thus the servitude shall remain in its unity.

7. There are some parts of an inheritance which will not admit of a division, *and therefore ought to be wholly assigned to one of the parceners, satisfaction being made to the others according to the value out of the remainder of the inheritance. Such are vivaries, fisheries, hays, and parks, provided there are other hereditaments whereout satisfaction may be made in proportion to the other parceners. Nevertheless the parties may come to terms, and it is allowable, if they so agree, that one of them shall bave one dranght or one fish, or one beast in the park, and the sccond another, and a third the third and so on.

8. With respect to land or other hereditament before given with any of the parceners in frank marriage, the usage shall be this; that if she to whom the land was given in marriage chooses to share in the inheritance whereof their common aneestor died seised in demesne as of fee, she shall yield up and relinquish that which was before given her in marriage, and it shall fall into hotchpot with the remainder of the inheritance, and then she shall take her share according to the chance of the allotment with her other parceners. And if she keeps to her estate in marriage for her share, still it must be seen whether this is worth more than belongs to her proportion or not. For if 
more, a measurement shall be made,--and this whether the land came by descent from the part of the father *or of the mother or by purchase,- - and the excess shall be divided by equal portions between all the parceners. The same usage shall hold where a mother in her widowhood gives to any of her daughters all her estate held in marriage. But where the feoffment is absolute, partition never takes place. For we will that such gifts by pure feoffment without mention of marriage shall be held as valid in the case of privies of blood as they would be in that of a stranger. And if either father or mother or both give to one of the parceners in marriage all their inheritance, in such case the inheritance shall not fall into partition, because nothing remains to be divided between the other parceners.

9. If the eldest die in the lifetime of her father or mother from whom the inheritance is to descend, the second daughter shall have her prerogative of election, although the deceased have left behind her a son or a daughter lawfully begotten, because the eldest did not survive her ancestor, whose heir she would have been. We have next to deal with the action de rationabili parte. 


\section{CHAPTER IX.}

Of the Plea de Rationabili Parte. ${ }^{1}$

1. When any of the parceners is deforeed by his eoparceners of all his reasonable share of the inheritance of their common ancestor, the proper proceeding is by the writ close de rationabili parte, and not by assise of Mortdancester. *For this writ, and no other, tries and determines the right of possession between parceners and coheirs, because at the instant of the aneestor's death every parcener has the same undivided right, and the mere right deseended to each equally,the youngest as well as the eldest,- whieh is not the case between brothers or other kindred, not being parceners, where the mere right deseends sooner to one than to the other.

2. There are other kind of writs de rationabili parte, for there is one concerning the possession, and three concerning right. The possessory writ does not lie between strangers, but between parceners only, and it is a close writ. Its effect is to require an answer as well from several to one as from one to several, wherefore he deforces them of the reasonable share

1 The greater part of the materials of this chapter appears to be in Fleta, though not always in the same order, and not in Bracton. 
belonging to them of the inheritance which was of such an one their father, mother, brother, sister, uncle, aunt, grandfather, grandmother, or cousin, wholately died, as it is said. Or if any parcener be in a more remote degree than another, then thus: of the inberitance which belonged to such an one, father of the aforesaid Helice, and grandfather of the aforcsaid Peronel, and so on according to the degrees.

3. This writ lies only between parcener plaintiff and parcener tenant, and extends as far as the time limited in an assise of Novel Disseisin, and not further, by reason of the word 'lately,' ' which does not suppose a longer time. And this writ extends to every ancestor in the ascending * line as far as the great-greatgrandfather, and in the descending to the nephew in the lowest degree, so far as the time aforesaid will permit. If the plaintiff in this writ count in the right, the writ is abatable for the reason which shall be given in the Chapter of Cosinage.

4. There are three writs of right, and these ought to be open writs, and are pleadable in the court of the chief lord. Two of them lie at any time either within or after the term aforesaid ; whereof one serves to recover a part of the inheritance, where a parcener is seised of part, and lacks the residue of his reasonable share; and the other serves to recover the appurtenances, in all or in part, where he is deprived of them by his coparceners. The third writ of right takes place after the time aforesaid, to recover the whole

'1 The Latin word in the writ is nuper. Fle. $315(\$ 40)$. 
of the reasonable share; as, where one parcener is deforceor, and the eoparceners negligently omit to demand their portions beyond the time limited in an assise of Novel Disseisin; for thenceforth such sleepers shall be foreclosed of their recovery by the close writ de rationabili parte, so that they shall never recover against the parcener deforceor but by writ of right patent de rationabili parte; in which writ exceptions lie as in the great writ of right, but not battle, nor great assise, by reason of the nearness of blood.

5. When the close writ is obtained, and surety found to prosecute, and the summons made and proved, in case the tenant parcener *or parceners make default, although the aetion seems to be personal, because no certain thing is demanded, yet no attachment shall be made exeept by the great Cape, of the bulk of the inheritance to the value of the share of the plaintiff.

6. If several parceners are tenants in common or in proportions, and the writ does not comprise them all, the writ is thereby defective and abatable. For their right is so far one, that one ought not to answer without the rest on account of contribution. And if any one of them do so, it shall not prejudice the other parceners tenants. And where sereral parceners are plaintiffs, unless each makes his plaint separately, the writ shall be abatable, because such a writ obtained on a joint plaint cannot lead to a judgment that every one shall have his reasonable share. In this plea there lies 
neither view, nor voucher to warranty, nor abatement of writ for non-tenure.

7. When the parties are come into court, the deforceor may plead that the land is not partible; or that the plaintiff hath no right in his demand because he is not of the blood; or, although he be of the blood, yet he ought not to have any share, or to be a parcener with the tenant for a certain reason; or although he should have been a parcener, yet he was excluded from the succession by the form of gift of his ancestor.

*8. If any one who was enfeoffed of all or a part of the inheritance by the common ancestor of the parceners is impleaded thereof, he shall vouch to warranty, not one only, but all the parceners; and if he do not, and the voucher be challenged, the tenant may lose by his foolish voucher. For since there is only one right, it would be unjust to make one of the parceners answerable for the entire right, and to oblige him to make warranty or exchange without the rest of the parceners making contribution according as belongs to each of them ; for else he would not retain his reasonable share. Nevertheless where one alone is vouched, and he enters into warranty without demanding aid of his parceners, the other parceners, if he miscarry, shall not be bound to contribute to make up his share.

9. Although the issue of one of the sisters be begotten in matrimony by a villain, yet such issue shall not thereby be barred from recovering his reasonable 26 
share from his aunt. But felony, bastardy, and the like general exceptions, mily bar such plaintitis from recovering their proportions.

\section{*CHAPTER X.}

Of Summons, and other proceedings in the Assise of Mortdancester.

1. The writ of Mortdancester being obtained according to the nature of the plaint, and the patent produced to our Justices, we will that, inasmuch as assises of Mortdancester and Novel Disseisin are pleadable only in the counties where the tenements lie, our Justices, upon sight of our letters patent, shall set a day to the plaintiff, and afterwards give notice by their letter to the sheriff of the county on what day and at what place in the county they will come to hear the plea. Then let the plaintiff take that letter and our writ close and carry them to the sheriff, and keep the patent by him until the day of plea.

2. The sheriff having received our writ, and taken pledges to prosecute, if required by our writ, shall forthwith cause jurors to be chosen of the neighbourhood by the assent of the parties, if they agree. And when they are chosen, let two freemen, terre-tenants, be enjoined to summon these jurors in their proper persons, as shall be mentioned in the chapter concerning summons in the writ of right. And the sheriff shall command them to summon the jurors to be at a 
certain clay and place before our Justices, to make recognisance, whether such an one is lead, and whether he died since the time named in our writ seised of the tenement in such a vill in his demesne as of fee, and whether such plaintiff is his next heir ; and that in the meantime they view the tenement, as before has been mentioned among the proceedings in novel disseisin, so that every juror *in all particulars be distinctly warned, fifteen days at least before his coming. into our court, upon what point he ought to inform limself. And let the summoners be charged to be there on the same day to prove their summons; as is the rule with all summoners upon every summons.

3. Upon the day named the parties may be essoined de malo veniendi; and if the plaintiff is essoined on the first day, and the tenant offers himself, then another day shall be giren to the tenant and to the plaintiff's essoiner; at which day if the plaintiff does not appear to warrant his essoiner, the writ shall abate, and it shall be awarded that the tenant go quit without day, and that the plaintiff and his pledges to prosecute be in merey. And if the plaintiff appears, and the tenant eauses himself to be essoined de mulo veniendi, it shall be allowed, if he is of full age, and another day shall be given to the plaintiff and to the tenant's essoiner; so that in this assise one essoin de malo veniendi lies for each party, and no more essoins are allowed, although there be several demandants or several tenants where they demand or hold in common. But let no essoin be allowed to any person under age for 
the reason which shall be given in the plea of right. Neither let any essoin be allowed to the tenant though of full age, as against an infant under age demandant, but let the assise be presently taken by clefault of the tenant, and no resummons take place.

4. If the tenant is under age, regard must be had low and by what title he is in seisin; for if he is in any manner seized by title of purchase, the assise immediately lies; but in such ease he may arail himself of an essoin as well as one of full age. If by title of succession, another inquiry is necessary; for if his ancestor died seised in his demesne as of fee, he shall not answer, but the assise shall stancl orer till he is of age, however he may perchance answer to the writ of entry of the disseisin of his ancestor. But if he did not die seised in his demesne as of fee, inasmuch as he held only for term of life, the assise shall not stand over. And if he died seised for a certain term under a condition, or by julgment of our court, in such cases it will be necessiry to know whether the condition is satisfied, or the judgment executed, or not; and the assise shall pass or stand over accordingly.

5. If there are several plaintiffs. Who demand by . this assise, or if it is brought against several tenants, then it nust be observed whether they are pareeners entitled as one heir, or strangers to each other, and whether one or more are under age, or all of full age, and whether they hold in *severalty or in common. And although one or all or some of the plaintiffs are luder age, yet the assise shall not stand orer respecting 
the tenements beld in severalty, on account of their nonage, except only as against the chief lord. But if one or more or all of the tenants are under age, and their tenements are not severed, but are held in common, in such case the assise shall be stayed until the youngest has attained his age and they are all of full age; and this by reason of the unity of their right, which has not yet been divided, and concerning which one cannot answer without the other as long as the tenement is held in common. But if each knew his several, then the assise should pass so far as regards those that are of age.

6. Where several daughters and coheirs have brought this assise against the chief lord, the assise shall pass for those that are of full age, provided there is no dispute respecting their marriages $;^{1}$ but with regard to the others who are under age, the assise shall stand over till they are of age; and when they have attained their age, they shall recover their reasonable shares either by this assise against the chief lord, or by writ close de rationabili parte against the other sisters, if they are deforceors.

7. Where a common inheritance is divided between parceners, the assise need only be brought against him or them who hold the tenement demanded. *But if any parcener be summoned and appear in court, anrt say that he cannot answer without his parceners by

1 That is, provided the lord has no claim against the land for the value of the marriages of the several demandants. See before, 1. iii. c. :3. s. 3 , note. 
reason of the unity of right which is between them, the writ shall not thereby abate, but the other pareeners shall be summoned to come and answer, so that if he against whom the plaint is made shall lose, he shall not do so without all the other pirceners being bound to contribute. But where they hold in common, the writ abates if all are not named.

8. If the tenant makes defanlt, and the plaintiff presents himself, command shall be given to the sheriff that the tenant be resummoned to be before the Justices another day to hear the recognisance of the assise, and to answer why he was not before them on such a day according as he was summoned; after which resummons he shall not be essoined. But whether the tenant cause himself to be essoined or otherwise make defanlt, the recognisanee of the assise shall be taken by default. Neither does a resummons ever lie after an essoin, for by the essoin cast for the tenant he admits the summons.

9. When the tenant comes into court by resummous, first let him answer for his contumacy, as to which he may say that he was not summoned. And thereupon let the summoners be examined, and if upon examination they are found to disagree *in the circumstances of the summoning, let the tenant be adjudged quit as to the defanlt, and the summoners in mercy. And if they are found to agree, then he may defend the summons by his law; and for the more speety dispatch of justice, let him forthwith make his law by himself alone, that he did not know of any summons before 
the day of the former session, and be quit of the default; and let him straightway answer to the assise. But if he has been essoined, he cannot afterwards deny the summons.

10. Where the tenant appears on the first day, he may still put off the day of assise by excepting that he had not a reasonable summons; as where it was made the day before the session of the Justices, or two or three days, or less than fifteen days before. This objection shall be tried by examination of the summoners as above mentioned; and if it be found that he had not a reasonable summons, let the parties and the assise be adjourned to another day; at which day he may be essoined. And if at that day he make default, be shall not be resummoned; for he may not deny the adjournment of the Justices; but the assise, if ready, shall be taken by his default. And if it is not then ready the plaintiff shall be adjourned to another day, and the sheriff shall be commanded that he then have the bodies of those of the assise. At which day let such of the assise as were not present on the former day pursuant to their summons be amereed, if they cannot excuse themselves respecting the summons.

*11. Although the tenant come into court on the adjourned day, and is ready to answer, yet he shall not be admitted thereto, for the contempt done to us and our court by his neglect, except in some special cases, as to produce some charter whereby the jurors maý be better informed, or at the least whereby ho 
may vouch some person to warrant; in which case we allow him to be admitted thereto, but not to allege any reason to stay the assise, nor to plead any dilatory exeeptions. Neither shall he be aulmitted to plead peremptory exceptions, wherein perhaps he might say that the ancestor of whose death the assise is brought held the lands only for term of his life by a fine levied in our court, ${ }^{1}$ or the exception of felony, or other peremptory exceptions; but the recognisance of the assise shall be taken, and it shall be awarded that he be in our mercy for his default.

12. When the parties come in court without making" default, let the plaintiff straightway deliver his patent to the Justices; and if it is found to be sufficient warrant for them, then let them cause such writ, together with the original writ close which was sent to the sheriff, to be read in audience. And then let the plaintiff state his contention according to the articles of the origrinal writ, and say how he is next heir to such ancestor.

13. And if the tenant has nothing to ohject, or if the denies the demand of the plaintiff and contradicts the substance of his contention *wholly or in part, let the truth be inquiped by twelve jurors, and not less, summoned for that purpose, whereof seven at least shall have been present at the view, and none of whom

1 In this point our anthor differs from Bracton (f. 255), who states the exceptions here mentioned as those which miglit be pleaded by the tenant in default. Fleta appears to agree with Britton. 
are removable by just challenge of the parties. They shall take the oath, as hath been said before in the assise of novel disseisin; and judgment shall be given according to their verdict either for the plaintiff or for the tenant.

14. If the assise has been taken upon the substance, and upon the points mentioned in the writ, and either party feels himself aggrieved by the verdict, whether the assise was taken by the tenant's default or not, and whether the tenant put himself as to the point in question upon the verdict of the assise or not, the party aggrieved shall have his remedy by attaint. The like upon a false oath by the assise touching any exception, as an exception of villenage and naifty, or of fine levied in our court, or of any covenant, $\mathrm{Ol}^{\circ}$ of a judgment before given in our court concerning the same tenement, or upon other like manifest exception. But in exceptions upon which verdicts are pronounced by way of jury and not of assise, and upon which the parties have put themselves by consent, and against which verdicts there is no evident presumption of perjury, attaints shall not be allowed, inasmuch as, the jurors are by the assent of both parties made as it. were judicial arbitrators.

*15. If the parties agree before taking the recognisance of the assise, let the accord be received and enrolled, and according to the enrolment let the sheriff be conmanded to deliver seisin. And we will that parties pleading, if they pray leave to accord in our court, shall have leave for that purpose, except in felonies in. 
which a man's life is in peril, saving to us the amercements to us bolonging.

16. If any one by assise of Mortdancester recorer's seisin of his inheritance out of the hands of the lord of the fee claiming wardship, where the fee is neither held in chivalry nor in grand serjeanty, or if the kindred of any infant in ward recover seisin of the inheritance of the heir in ward on account of waste and destruction committed by the lord in the wardship, the proceedings in the plea shall be enrolled, and according to the enrolment the sheriff shall be commanded to deliver seisin as aforesaid.

\section{CHAPTER XI.}

Of Warranties in Assise of Mortdancester.

1. When the parties are at trial and the jurors ready, if the tenant has any warrant who is bound to warrant and defend him in his seisin, it is more for his advantage to vouch him than at his own peril to take upon himself to defend the tenement against the plaintiff. And if he vouches, then it is material whether the warrant vonched be under age or of full age. If under age, the tenant must produce a charter to the guardian, or show that *homage was done to the infant's ancestor whose heir lie is, or some other clear reason why he is bound to warranty; otherwise the vouchee under age shall not answer.

2. If the warrant be of full age, then there is no need to show a charter or other presumption; but 
he may be vouched by aid of the court, or without aid, as shall be said in treating of warranties in a writ of right." 1 If it be done by aid of the court, and the warrant resides in the county, let the sheriff be commanded to summon him to appear before the same Justices on another day, to warrant according as he shall be vouched, or to refuse. And if the warrant has land elsewhere, and none in that county, let him be summoned by our writ of julgment. ${ }^{1}$

3 . If the tenant vouches to warrant separately, where he ought to vouch more than one together, or many where he ought to vouch only one, and the warrants demand judgment of the bad voucher, in such case the tenant shall fail in his voucher, as he would have done in case of a writ ill purchased.

4. When the tenant has vouched to warrant any one who comes into court and warrants him, or several tenants in common as one heir, who warrant him, and these vouch some other, and so on from warrant to warrant, if any one of the whole number makes

${ }_{1}^{1}$ The chapter here referred to is wanting in all the copies. See before, vol. i. p. 107, note; and see the last chapter of Britton, s. 5, where reference is made to the same chapter alluded to above. As to the incompleteness of the work, see the Introduction by the Editor.

2 If the vouchee had land in the connty, he was summoned without writ by precept of the Justices to the sheriff ; if his land was in another county, it was necessary to obtain a writ out of the Chancery. See the parallel passages of Bracton and Fleta. The expression 'writ of judgment' is in Fleta, not in Bracton. The form of the judicial writ is in Reg. Brev. Judic. $46 b$. 
default, the assise shall be taken by his default, as if all had made default, whether they be any of them under age or not. *And what is said concerning one tenant, shall be observed where there are sereral.

5. If the warrant appears at the day for which he is summoned, and the plaintiff also, but not the tenant, let the assise be forthwith taken by the default of the tenant, if the jurors are present; and if not, let another day be given to the parties. And if the warrant has waited until the fourth day, let it be awarded that he go quit of his warranty without day, and that the assise be taken by the default of the tenant, as abore said. The reason why the plaintiff shall not straightway recover his demand without recognisance of the assise, is because all the points of his writ or some of them may be false; for although the tenement demander ceases presumptively to be the tenant's by reason of his default, yet still it is necessary that our court be informed of the right of the plaintiff ; for if the assise say that the plaintiff hath no right in his demand, there is no reason that he should recover, inasmuch as he cannot prove the points of his case.

6. If the tenant appears and the warrants also, and the plaintiff makes defiult on the fourth day, let it be awarded that the tenant go quit of that writ without day, and the warrants of their warranty, and that the plaintiff and his pledges of suit remain in mercy in our court.

7. If the tenant and the plaintiff appear in court, 
and *the warrant makes default, let the assise be taken by the default of the warrant, but let no caption of land be awarded against the warrant until it be known by the assise whether the tenant ought to retain the land or to lose it. For if he ought to retain it, then there will be no need of proceeding to the plea of warranty.

8. And if the taking of the assise is delayed by any chance to another day, and the warrant comes on that day and is ready to warrant, yet he shall not be admitted thereto, except with a view to making the exchanges, ${ }^{1}$ before the assise is taken in form of assise ; and this for three reasons; first, because he had no day given him to warrant; secondly, because he lost the benefit of his exceptions and all his defences by the default which he made on the former day; and thirdly, because there is no need of his being admitted thereto before the necessity of it is known, as hath been said above. Hence it is apparent that there is no need of his presence until he is caused to appear by distress, after the assise has passed against the tenant. For if he were allowed to come into court after his default, and to warrant and say, 'I warrant, and I restore the tenement demanded to the plaintiff', the warrant would be guilty of a manifest disseisin against the tenant, if it were done against his consent, and particularly as the warrant had then no day in court. For although the warrant is obliged to defend his tenant in his possession, he ought not upon that pre

1 See below, s. 16. 
tence * to disseise him by surrendering to the plaintiff his demand, inasmuch as surrendering and defending are contraries.

9. When the taking of the assise is awarded by default of the warrant, and the assise passes against the tenant, then for the first time seisin shall be awarded to the plaintiff, ${ }^{1}$ and the warmant shall be distrained to appear on another day in the following manner. The sheriff shall take into our hand of the lands of the warrant as much as the value of the land demanded, and he shall be summoned, as will be mentioned in the plea of right. ${ }^{2}$ For warranty in one sense signifies the defending of the tenant in his seisin, and in another sense it signifies that if he does not defend him after being properly summoned, the warrant is bound to exchange, and to make him satisfaction to the value. And in this manner let him be distrained, if he has land in the same county.

10. If the land lost and the land whereout exchange is to be made are in diverse counties, first let the tenant's land be extended ; and when our Justices shall be certified of the value, let the sheriff in whose bailiwick the warrant laas land be commanded by writ of judgment to take into our hand to the value according

1 This statement about seisin being awarded at this stage of the proceedings is not found in the corresponding place of Bracton or Fleta, and appears inconsistent with s. 11. See also s. 23, 24. Perhaps we should read, gardé la seisine al tenaunt, the tenant's possession being undisturber.

2 See note above, s. 2 . 
to the extent, and let the warrant be summoned to be before them on another day. *And if several warrants are to be thus distrained, having their lands in diverse counties, the sheriffs shall be commanded that each of them take into our hand proportionally much as each ought to warrant according to the valuation of the land of the tenant.

11. The reason why the plaintiff shall not recover his demand immediately after the default of the warrant, and after the assise passed in his favour, is this, because the warrant may perhaps excuse himself for the default by alleging some hindrance ; by which excuse the proceedings may be annulled as far back as the summons, as in a plea of right; for it cannot be properly adjudged a default so long as it may be defended by law; and it would be ill, if the warrant should lose his answer to the demandant, and gire the tenant his exchange when he had a good defence. But if the warrant does not come into court, or if he comes and cannot excuse himself for the default, then and not before let the assise be taken by the default of the warrant; and if it be found that the plaintiff has right in his demand, let it be awarded that the plaintiff recover

1 This statement is difficult to reconcile with what is said before in $\mathrm{s} . \%$, where the assise is directed to be taken immediately upon the first default of the vouchee. (See also s. 8, 12.) The same apparent inconsistency is found in the parallel passages of Bracton and Fleta. Perhaps we should understand here, that the assise taken in the absence of the warrant should not be treated as taken by his default, so as to be binding upon him, until he had had an opportunity of clearing his clefault. 
his demand against the tenant, and that the tenant recover to the value of the land of the warrant, and the warrant remain in our merey. And if the plaintiff has no right, let it be adjudged against him, as before is said.

12. And becanse it would be wrong for the tenant to recover against the warrant by his default to the value of the *land demanded, and at the same time to hold his own land in peace, supposing the assise to declare against the plaintiff, therefore we will that the assise be taken before any plea is commenced against the warrant. And if the warrant, whose land is taken into our hand, does not appear on the day for which he is a second time summoned, and the assise, being sworn and lawfully charged, has passed for the plaintiff, let judgment then be given against the war. rant, as is before more fully set forth.

13. If the warrant comes into court, and says by way of counter-plea to the warranty, that he ought not, neither is able to warrant, by reason that is the defending of the tenant in his seisin, nevertheless, as warranty in another sense signifies the giving to the tenant an equivalent exchange, if he has lost his land by default of the warrant, we will that the plaintiff recover his exchanges. And yet if he can defend himself from the liability to make satisfaction to the valne, it shall be awarded by our Justices that he go quit withont day.

14. If he enter into warranty and vouch another to warrant, let the second warrant be summoned against 
another day; at which if he makes default, let there be taken into our hands of his land to the value of the land demanded, and let him be summoned against another day; at which day if he does not appear, or if he appears and cannot clear his default, the judgment shall be by process of the lesser Cape, as shall be more fully and plainly said in treating of the plea of right. ${ }^{1}$ *15. If the second rouchee comes into court and counterpleads the warranty, and says that he is not bound to warrant because the other holds nothing of him, nor does any service to him, nor ever did homage to him, or if he says that he is not now bound to warranty, because, although he were bound thereto, yet the vouchor has made default to him, and has lost his aid by such default, which was prejudicial to him, inasmuch as where he might have answered to the assise if he had appeared at the day, he by his default lost all his defences and exceptions, which loss he may impute to his own negligence, and if he thereof demands judgment, we will that judgment be given against the vouchor. So likewise, if a third vouchee gives the same answer.

16. Hence it plainly appears, that when the warrant makes default the first day, whereupon the assise is adjudged to be taken, but through some accident the recognisance of the assise is delayed until another day, and the warrant comes at that day, and before the assise is taken, is ready to warrant, he may be ad-

I See note ante, s. 2. The practice referred to is described in Bracton 384 ; Fleta 411, c. 25. 
mitted thereto, yet not so as to allege any reason for staying the assise, or to defend the tenant in his seisin, but in order to make the exchanges if the tenant should lose by the assise,-and much more after the recognisance of the assise,-and that a vouchee in that position will not be assisted by vonching another warrant.

*17. If any warrant, after he has vouched another, makes default in court, and the plaintiff and tenant are in court, let the recognisance of the assise be immediately taken, whether the seeond warrant appears or not; and let the same course be taken, where the tenant makes default, although the warrant is present. For although the tenant or warrant might have some reason to allege for hindering the assise, yet the warrant shall not be therefore quit of the warranty ${ }^{1}$. For the assise shall not be stayed for anything the tenant can say, forasmuch as he has put his whole defence in the mouth of the warrant, and cannot resume it at his

1 I think there is some confusion here, arising from the conpiler having followed Fleta's abridgment of Bracton, in which the sense of the latter is not truly represented. The reason given by Bracton for excluding the warrant from taking exceptions to the assise in the absence of his vouchor is that by the default of the latter he is quit of the warranty. Bracton afterwards supposes another case, in which the vonchee has appeared and denied his liability to warranty; then, he says, neither the tenant nor the vouchee are in a position to raise any objection to the taking of the assise, for the same reasons as are stated by Britton in the next sentence. Brac. 260 ; Fle. 284 (§9). $\Lambda$ s to the relation between Fleta and Britton, see the Editor's Introluction. 
pleasure; and the warrant has nothing to do but to defend himself as to the warranty.

18. If the warrant makes no default and enters into warranty, then he is allowed to answer and allege against the assise any reason why it ought not to pass, since all the exceptions and defences are allowed him which would have been allowable to the tenant, inasmuch as by his warranty he is put in the place of tenant. Or the first warrant may vouch a second, and he another, and so of scveral.

19. When several are thus vouched, and the last cannot defend the tenant, or if the assise is taken by default of any warrant, and the last warrant cannot defend himself from liability to exchange, let it be awarded that the vouchor have of the land of his *warrant to the value, and so from vouchor to vouchor until the plaintiff recover his demand against the tenant, and he in value against his warrant, and the last warrant shall remain in our mercy.

20. If one or more of the warrants are uncler age, the plea shall stand over without day until their age. Where of several demandants in common one dies before the assise is taken, the writ does not thereby abate. Neither shall it abate if one die out of several tenants in common. But if the inheritance bas been divided between parceners who before held in common' and one of the parceners die, the assise shall abate on account of the writ being bad. And if husband and wife are impleaded of the right of the wife, and the husband dies before the assise is taken, neither the 
assise nor the writ shall abate; but otherwise in the reverse case.

21. If the plaintiff or the tenant or both die before the assise, the assise shall fail for want of a foundation. Ind if any warrant dies after he is vouched, but before he has warranted, neither the assise nor the writ thereby abates, but the tenant must begin again to vouch his heir. But if he dies after he has warranted, the writ shall abate for want of a foundation, as the vouchee by his warranty has made himself, as it were, principal tenant, and taken upon himself the conduct of the principal plea.

*22. If any tenant or warrant shall say by way of answer, that he cannot answer without us, and thereupon puts forward a charter of us or some of our predecessors, the assise nevertheless shall not be stayed. But if it passes for the plaintiff, let judgment be deferred until the next session, in case by the eharter we may be bound to warranty by virtue of some special words, although the clause of warranty may not be therein expressed, and in the meantime let our Justices be consulted by us upon the judgment. But if it be a charter of confirmation of ling Canute, or of any other who was not our ancestor, or if the charter express that we have granted as much as was in us saving the rights of all other parties, in that and the like cases we will not have judgment delayed.

23. If it shall happen that some great ${ }^{1}$ dispute or

1 It would seem from this, that when the warrant appeared, 
difficult question arises in a plea of warranty, by the discussion of which the assise is like to be delayed for a day or more, in such case there will be no harm in taking the assise, by the recognisance whereof it may be ascertained, whether there be any need of continuing the plea of warranty or not; for if the assise passes against the plaintiff, there will be no need of determining the plea of warranty.

24. If the younger brother has entered into the inheritance of his father, and during the time of his seisin has enfeoffed a stranger, against whom the elder *brother brings an assise of mortdancester, and the tenant vouches to warrant the younger brother his feoffor, and the latter appears to warrant, and says, that assise ought not to be between him and his elder brother, inasmuch as he claims to hold the tenement by the same descent, the assise shall not be thereby stayed; for, although the younger brother is bound to defend the tenant by his warranty, yet he is not very tenant, for the tenant shall never part with his seisin pending the plea of warranty; but when the warrant can no longer defend him in his seisin, and judgment is given against the warrant, then and not before he shall be ousted by judgment. For if the assise between these brothers were to fail by reason of the exception of the same descent, then a right of action ought to arise in favour of the elder to demand the same tenements by writ of right, which could not be unless the the Justices were accustomed, in a simple case, to go into the question of warranty before deciding the original plea. 
younger brother was actual tenant; and if he be required to bring the writ of right against tenant, then it will be lawful for the tenant to defend the right of the elder brother either by battle or by great assise. Therefore to avoid this great inconvenience, we will not that this exception be allowed in any possessory writ unless between the demandant and the actual tenant.

*25. If one enfeoff another of any tenement, and the feoffee makes an intrusion or other eneroachment upon a third person, who brings an assise of mortdancester against the feoffee,-as suppose John enfeoffs Peter, and Peter effeoffs Robert of the same tenement, after whose death Peter enters into the tenement as chief lord, and the heir of Robert brings an assise against Peter; if Peter thereupon wishes to vouch John to warrant, and John can aver that Peter did not enter into the tenement by the act of John, but by his own intrusion, in such case John, or any one in like position, shall not be bound to warrant; but in such circumstances every one shall answer for his personal act.

26. If an assise of Mortdancester is to be brought for a tenement held for a term of years, and the farmer only is named tenant in the writ, the term being for ten or twelve years, or more or less, the farmer may say upon the trial, that he elaims nothing in the tenement but a term of years under the lease of such an one; and if it be so, the writ shall fail. And if thr lessor alone is named as tenant, the writ shall 
likewise fail, so that the assise may not pass to the prejudice of the farmer, who has as much right to his term as the lessor to the freehold. But if both are named in the writ, the writ shall stand; and the farmer shall be present at the day, and rouch his lessor to warrant his term, if he thinks fit to do so.

*27. Nevertheless, in some eases the farmer only needs to be named in the writ as where a lord has sold the wardship of any lands for a certain term of years, before which term the heir attains his full age and brings an assise against the farmer, if the tenant vouches the lord to warrant by virtue of some deed of covenant, which witnesses that the lord is bound to warranty until a certain term extending beyond the majority of the right heir, we will that such cases be favorably viewed in relation to the heirs plaintiffs, so that they may not be delayed of their right of inheritance by such vouchers; and the farmers shall have their recovery against their warrants by writ of covenant.

28. If the parties present themselves in court, but it is necessary to delay the day by the default of the jurors, let the parties be adjourned to their said day without further essoin, as is ordained in our statutes. At which day if the assise passes, whether as an assise or as a jury, for the plaintiff in the absence of the tenant, let the judgment be delayed until another day, and the tenant be summoned to come upon such day to hear his judgment; at which day, whether he come or not, judgment shall be given for the plaintiff, for 
the default of the tenant after appearance. * But if it has been agreed between the parties that the assise be taken and judgment given the first day, then, whether the tenant come or not, the agreement between the parties shall take effect.

\section{CHAPTER XII.}

\section{Exception of 'sane Descent.'}

1. To the points of the writ the tenant may answer several ways; for as to that which is first contained in the writ, namely, whether such ancestor was seised, he may plead, that as this ancestor was the plaintiff's father or other ancestor by whose seisin he claims the inheritanee, so was he likewise ancestor to the tenant, and by reason of the death of such ancestor he holds himself in the inheritance as next heir; and if he demands judgment whether the assise ought to take place between such privies in blood claiming by the same descent, in such ease we will that the tenant go without day, and the plaintiff take nothing by his writ for the reasons after mentioned, but remain in our mercy for his false plaint. And if he thinks proper, he may proceed by writ of right to try the proximity of blood.

2. Nevertheless in some cases the plaintiff may have a valid replication, as where a plaintiff elaims the tenement by the feoffment of a common ancestor of himself and the tenant, and thereof produces charters 
*or tenders arerment, and says that he elaims nothing by descent. But the tenant may answer by way of triplieation, that the same feoffment ought not to prejudiee him, because the donor never altered his estate, and the plaintiff was never in seisin, but the donor all along continued in seisin and died seised; and according as he can verify this, so let judgment be given.

3. Nevertheless between two privies in blood, brothers or eousins or other privies, this assise may lie, as also the writ of Cosinage and of $A \mathrm{el}$, if it has been customarily used, ${ }^{1}$ where the right heir is plaintiff immediately after the death of their common ancestor, before the tenants ean elaim title of freehold by long and peaceable seisin. The time allowed must be determined by considering whether the right heir demanded his inheritance immediately after he knew of it, or could know of it, according as he was far off or near, on this side or beyond the seas, in prison or out, or according as he shall have been negligent in suffering the tenant to sleep in his seisin.

4. If one parcener demand against another by this assise, as where a sister demands her share against her sister, the writ and assise shall fail; and the writ de rationabili parte lies. Where the tenant says that the plaintiff had a sister who had issue children, who are alive, and who would have as much right to demand the inheritanee as she, if this be verified, the writ shall fail, and the assise be stayed, whether those children

' 1 The statement here made is not confimed by anything in Bracton or Fleta. 
were begotten in matrimony or not. And as this assise does not lie between parceners and coheirs, so neither does it take place between parceners who hold in common or in severalty by reason of the land which is in itself partible; but only the writ de rationabili parte. And as it lies not between privies of blood being legitimate, so does it not lie between a bastard brother, tenant, and a legitimate brother, plaintiff,--nor any writ except the writ of right, whereby the proximity and right of blood is tried and determined.

\section{CHAPTER XIII.}

\section{Exception upon the word 'seised.'}

1. With respect to the clause expressed in the writ, ' died seised,' many exceptions may arise. For one may die seised in several ways, as by bodily presence, and also by intention, although not present in person. And in like manner may seisin be acquired. A person may also retain seisin by bodily presence, *although he has no intention to retain it, as happens with those who make a gift and then die seised, before the purchasers have had complete seisin. And a man may die seised by intention, as is the case with those who go on a pilgrimage leaving no one in their tenements, and die on their way.

2. A person may die seised by bailiff, attorney, or guardian, as well as if he died seised in his own person. Thus, where a guardian in the name of an infant under 
age, or any other procurator or attorney in the name of another receives seisin of any tenement, if he in whose name the seisin is taken die so seised, we are content that such persons be deemed to have died seised, although they do not come to be seised in their own persons, and that their heirs may demand such seisin by this assise on their fathers' deaths.

3. Again, several persons may die seised of the same tenement, which they have held as of fee by divers feoffments. And when several assises have been brought by them, ${ }^{1}$ for it the assise brought for the death of the person last seised must be first determined, and so backwards from seisin to seisin, until the right of possession is united by judgment with the right of property.

4. Where any one is enfeoffed to him and his heirs by him begotten, and if he have no issue or if his issue die, then over to others, if the purchaser dies having issue, his child may proceed by this assise. *But if he has no issue, or if the issue is lead, then the right descends to the others named in the feoffment; in whose persons however no recovery lies by this assise, but by writ of formedon.

1 That is, apparently by the heirs of the persons so dying seised (cf. Brac. 262 b). The case supposed is sonewhat obscure, but appears to be that of several successive abatements. Upon the death of $\mathrm{A}$ seised in the fee, $\mathrm{B}$ a stranger enters, and enfeoffs $\mathrm{C}$ in fee. $C$ dies seised, and $D$ a stranger enters and enfeoffs $E$, who dies seised. $\mathbf{F}$ a stranger enters. The respective heirs of $\mathrm{E}, \mathrm{C}$, and A bring several assises of the deaths of their respective ancestors. The assise of the death of $\mathbf{E}$ is taken first. 
5. A man also may make such a feoffment that his heirs cannot be aided by this assise. Thus, where one has enfeoffed another for the life of the feoffor, if the purchaser survive the feoffor and retain the seisin, the heirs of the feoffor shall not avail themselves of this assise, but of a writ of entry ad terminum qui prateriit. And if any one make purchase of a tenement for his life only, the feoffor shall have his recovery after the purchaser's decease, if he be deforced, by the same writ of entry. If any one be enfeoffed to him and his heirs so long as the feoffor shall live, in such case this assise will lie in favour of the heirs of the purchaser after their father's death during the life of the feoffor $;^{1}$ and the heirs of the feoffor after their father's death shall have their recovery by writ of entry, as aforesaid.

6. The tenant may traverse, and tender averment by the assise, that the ancestor did not ever die seised, or that if he died seised, he was seised not in his own right but in the name of another, or for a term without having fee or freehold. And if the plaintiff say that he was seised by virtue of some feoffment, to this it, may be answered by triplication, as hath been said above.

${ }^{1}$ Compare below, c. 15 , s. 2 , and note there. 


\section{*CHAPTER XIV.}

Exception upon the words 'last seised.'

1. The tenant may urge as another exception, that the plaintiff wrongfully demands by this assise as upon the death of his ancestor; inasmuch as the plaintiff himself, or another, was in seisin since the death of the same ancestor by whose seisin he demands. For where after the heir is of full age and has had his seisin upon the death of his ancestor, he aliens his inheritance and sells it in fee, if he could recover it from the purchaser by demanding it in respect of the seisin of his ancestor, the feoffment would be invalidated and ineffectual, and this would be greatly inconvenient.

2. It is necessary therefore to observe what seisin thus had after the death of an ancestor excludes the assise, and what does not. For the seisin of the right heir at a time when the inheritance was vacant after his ancestor's death, of whaterer age the heir may be, shall always bar him from recovering by this assise, because then the assise of Novel Disseisin lies. But if he is not in a position to aver seisin in that assise, then the assise of Mortlancester is in place. But if an heir has had a wrongful seisin from which he has been presently ejected, such seisin bars not this assise, so that this exception is not allowable, unless the tenant 
say that another died more lately seised as right heir of the :ncestor whose seisin is demanded, and whose heir the plaintiff is. ${ }^{1}$ And where two parceners, coheirs, bring this assise against a stranger *upon the death of their ancestor, if the tenunt say that one of the parceners was since seised, the assise sball not be stayed if this seisin took none effect.

1 The latter part of the above sentence is not easily intelligible ; and the text appears doubtful. I do not find in Bracton or Fleta anything which throws light upon it. According to these authors, the objection, founded upon a former possession of the demandant, was held only where, being of age, he had been in lawful seisin for so long a time that he might have conveyed away the property. (Brac. $273,273 b$; Fle. 297.) Seisin by an infant was immaterial, since the objection was founded only upon the danger of one, who had aliened the land, recovering it by the assise against his own donee. (Brac. 273 b.) Where the demandant had had a tortious seisin from which he had been ejected, the seisin did not furnish in itself a valid exception to the assise ; but another objection might be taken, namely, that the demandant had forfeited his right to the assise by usurping the possession without judgment. (Brac. 273.) 


\section{CHAPTER XV.}

Exception "upon the words ' in his demesne.'

1. Whereas it is said in the writ, ' in his demesne,' the tenant may aid himself by exceptions. For in demesne may be held lands and rents, in fee and for term of life. But demesne is properly a tenement which is held severally in fee. Those tenements also which are held in villenage and farmed at will from day to day, and commonly for terms of years, and are in the care or custody of others, are the demesne of him of whom they are so holden. The word demesne is also used in distinction from that which is holden in seignory or service, or in common with others. For then my demesnes are the same as your demesnes; so that this assise shall fail if it be brought upon the death of several persons tenants in clemesne, inasmuch as its nature requires that it should be always brought in respect of the death of the person last seised, as hereafter shall be said.

2. But this assise does not hold concerning any manner of demesne, save that whereof the ancestor died seised *as of fee, whether it be land or service. For it lieth not concerning the seisin of any farmer for term of years, or of him who hath held in villenage, 
or in ward, or in gage, or for term of life, ${ }^{1}$ or by condition in fee, where the heirs are excluded by the form of the feoffment either for a time or for ever.

3. But if the heirs of a creditor proceed by this assise, and the deforciant pleads against them that their ancestor held the tenements demanded only in gage, and the heirs of the creditor reply that the land was engaged to their ancestor, whose heirs they are, until a certain day upon this condition, that, if the lebtor did not pay to their ancestor a sum of money at a certain day since passed, the land should remain to the creditor and his heirs in fee, and if the demandants can aver this by writing or in any other manner, then this assise shall take place concerning the seisin of the creditor, unless the deforciant can aver payment, or at least that the making of such payment was offered at the day, and openly tenclered at a certain place in the

1 'A termor holding to him and his heirs and assigns for the life of the lessor shall recover by Disseisin; and his heir if ejected by the lessor or a stranger by Mortdancestor. Which implies as it were the possession of a fee (qe sone tot en la p'on come de fee), which fee becomes extinct in the purchaser by virtue of the covenant, upon the death of the lessor, and not before. And it is to be understood, that he who hath only a term - of years hath barely (escharcement) a chattel ; and shall therefore recover nothing but damages by the Justicies (le Iustice), or by the Quare ejecit. But he who can in any way claim more than a term of years shall recover by assise of Novel Disseisin. For term of years and no more is chattel; and more than a chattel he cannot have without having a freehold.' (Note in ISS. $N$.) 
presence of lawful people, in full view and to the full amount without any default. For if a part is paid or tendered, but the whole is neither paid nor tendered, the debtor shall gain nothing by his exception. *And the same reason shall hold, if a breach has been made of one day out of several, where the payment was to have been made by parcels at several times.

4. If the assise is brought by the heirs of the debtor against the ereditor or his heirs, when this condition comes in question, and it is found that the money was not paid or tendered according to the condition, let the assise abate and let the intention of the feoffer be observed. And if the assise be brought before the day for fulfilment of the condition, let it be awarded that the tenant go withont day and the plaintiff be in mercy for his false plaint, because the time for complaining is not yet come, and the creditor or his heir shall not be obliged to receive his money or part with his security before the day, unless he is willing so to do.

5 . And if the condition of payment does not extend to the heirs of the debtor, and the debtor dies before the day, the lands shall remain with the creditor according to the covenant, although the heir of the debtor be ready to pay the money borrowed, inasmuch as heirs are not named in the covenant. ${ }^{1}$ And so on

1 In the time of Littleton, a more liberal construction was put upon a conditional clause of this kind, the heirs, though not named, being allowed to perform the condition. Lit. Ten, s. 334 ; Co.' I it. 2057 . 
the other laand we will that the covenants shall be observed, where no mention is made of the heirs of the creditor; so that if the heirs of the debtor bring an assise against the creditor or his heirs, ${ }^{1}$ and the heirs of the creditor plead to the assise and say that their ancestor died seised in fee, and the heirs of the debtor reply that he was seised not purely in fee but in gage for a sum of money, which they are ready to pay, and the deforceors say, that they cannot be admitted thereto, *beeause the day of payment is passed, and the payment does not extend to their persons, and the plaintiffs say, that neither does the gage extend to the deforceors - if it be found by the writings of covenant, which cannot be contradicted, that the land was engaged in the following form, that if the debtor dicl not pay the money at the day passed the land should remain to the creditor in fee, in such case the plaintiffs. shall take nothing, although it is not specified in the writings that the land shall remain to the heirs of the creditor, by reason of the word fee, which is equivalent thereto.

6. And if the plaintiffs say that equity ought to assist them, by reason of the smallness of the debt, that shall not avail them, since every freeman may dispose of his property at his will without doing any wrong to his heirs, except in particular cases, as in formedon or in marriage, or when the gift is to persons in religion or other prohibited persons.

7. We will also that the covenant be performed 'It should be, 'against the heirs of the creditors.' 
between the debtor and creditor concerning land let to farm to the creditor, where the condition is, that if the debtor happen to die within the term, the land shall remain to the creditor in fee, or for his whole life; or if it be covenanted, that if the creditor die within a certain term, then the tenement so engaged shall remain to some third person, such covenant shall stand good. And although the heirs of the debtor have some colour for bringing this assise of the death of their ancestor, inasmuch as he died in a manner seised in fee, yet their right must stand or fall by the corenant. And whereas a simple covenant bars the assise for a time or for ever, there is much greater reason for its being stayed in pursuance of a judgment of our court.

\section{CHAPTER XVI.}

Exception founded on the words 'as of fee.'

1. As to the words contained in the writ, 'as of fee,' one person may hold in fee in respect of the service and not in demesne, as the lord of the fee; and another may hold in fee and in demesne and not in service, as any free tenant. Fee is also whatsoever any person holds to himself and his heirs, whether it be land or rent issuing out of land. And there is a third kind of fee, which is a general name for all fees, as well for a knight's fee as all others.

2. But the fee specified in this assise always signifies land or rent which the ancestor held to himself and his 
heirs, and which he might in his lifetime have sold in fee *without doing a prejudice or wrong to any one. And if the assise be brought of any other manner of seisin, as of land held for term of lite or for term of years, the assise shall fall. The words in the writ, ' as of fee,' may be understood in two ways, according as the word 'as' imports an apparent truth, as in the case of disseisors intruders and others, who withhold another's right and die seised as of fee, or signifies the mere truth, when persons who hold by a good title, and than whom none has a better right, die seised in fee. In both these cases we will that this assise take place.

3. Again, the tenant may say, that although the ancestor died seised as of fee, yet no part thereof could descend to his heirs because he was a bastarl. And, although no one can be attained as a bastard except in his lifetime and in court Christian, yet if the parties consent that it shall be inquired by the assise, by way of jury, whether the ancestor was a bastard or not, let the recognisance be taken, and judgment be given according to the verdict. And if any one will not put himself on the averment, then let judgment be given against him whether he be tenant or plaintiff. And let the like be done, in cases where it is put forward as an exception, that the ancestor died a bastard without any heir to the tenement, whereof he was enfeoffed only to himself and to his heirs. ${ }^{1}$

${ }^{1}$ It is not easy to see how the case added in this clause differs from the one first mentioned. The whole passage is paraphrased from Bracton or Fleta, where the expressions are somewhat dif. 
4. Or the tenant may say that he holds the tenements demanded only as bailiff, or at will, or by wardship of *some third person, without waom he cannot answer ; and if this be proved, the assise shall fall. So, if he says that the ancestor did not die seised of the land in demesne, but only of the fee.

5. Again, the tenant may grant that the ancestor of the plaintiff died seised as of fee, but say that nerertheless he cannot take anything by this assise, for that the same ancestor let the tenement to the tenant for a term on condition that, if the lessor died before the end of the term, the termor should have a freehold for term of life, or a fee and freehold, wherefore that which he held before as at farm, he holds now as his freehold ; and if such a covenant be rerified, the assise is at an end. In like manner it shall be stayed, where the land has been put in gage, if the debtor has not discharged it or at least offered to discharge it at the day, according as we have said before; or if he holds the land as a security by judgment of our court.

6. Again, the tenant may say that he has nothing and claims nothing at this time except in seigniory, or by title of wardship, or to hold in another's name by the lease of such an one, as a farmer, at the will of his

ferent. The latter case may possibly be that, where a bastard enfeoffed to himself and his heirs (without 'assigns') gives to another in fee, and dies leaving no heir, upon which the lord enters. The question however in this case would not arise upon an assise of Mortdancester of the death of the bastard, as seems to be implied in the text. See vol. i. p. 312 . 
lessor, who is not named in the writ, and if this be proved or not denied, and the jury testify that he has not claimed anything in his own mame, the writ is thereby abatable. * So, if the tenant acknowledges himself to be the villain of another, and thus to hold in another's name.

7. If any one demands by this assise that which a widow holds in excess of her right dower, the assise shatl fail, inasmuch as she claims nothing but her lower; and remedy shall be had by writ of admeasurement of dower.

\section{CHAPTER XVII.}

Exception founded on the words 'the day whereon he died."

1. With regard to the words in the writ, 'the day whereon he died,' or ' the day whereon he assumed the. religious habit,' or 'the day whereon he departed from his house on pilgrimage and undertook the journey in which he died,'-it is necessary to attend to the following points. For there is a solar day and a lunar day, according as God dirided the light from the darkness, and these two days make one artificial day, which is made up of the day and of the night following, and contains twenty-four hours, and is divisible into four parts. The first may begin at nightfall and end at midnight, the second may begin at midnight and end at daybreak, the third may begin at daybreak and end 
at noon, the fourth may begin at noon and continue till nightfall. Therefore whether any one dies in the night *or in the day, he dies in the artificial day, and for this reason it is said in our writ, 'the day whereon he died,' and not 'the night whereon he died.'

2 . It behoves him therefore who would recover his inheritance by this assise not only to aver that his ancestor, of whose death he has brought this assise, was seised some time of the day on which he died, but he must also shew that he died seised. For these two propositions may stand together, that the ancestor was seised on the day on which he died, and that he did not die seised ; since one may be seised of a tenement in his demesne as of fee at daybreak, and yet before noon in the same quarter of a day he may give it away, and put another in seisin thereof with a full intention of divesting himself, and the purchaser may take seisin thereof with full intention to retain it, by the union of which assent there accrues to the purchaser a freehold and fee and demesne by the will of the feoffor, who put himself out of the seisin of the whole, and has no intention of retaining any part of it. And if the feoffor dies immediately in the second quarter, and his heir demands by this assise the land aliened, and the tenant says that the ancestor did not die seised as in the ease aforesaid, and thereof produces a charter of feoffment which witnesseth the same, although the plaintiff say that the grant of his ancestor ought not at. all to arail the purchaser, inasmuch as he never took esplees in full seisin before the death of the grantor, 
*yet the plaintiff shall not succeed by this assise, unless it be found by the assise that the intention of the donor was contrary to his gift, or the plaintiff can prove that the ancestor was not in good memory and right mind at the time of the feoffment.

3. For where the ancestor, if he had lived and had repented of his gift, could not have had his recovery by assise of Novel Disseisin at the time that this assise is brought, it would be unjust if this assise should lie in the person of his heir. But the ancestor could never have recorered by assise of Novel Disseisin, so long as it could have been proved by recognisance of the assise that of his own accord he made the gift, and of his own accord went out and dispossessed himself, and of his own accord put the tenant in seisin. And according to this reasoning it would appear, and it is true, that, if the donor had remained alive and repented of his gift, and the next day or the third day or soon after the gift had ejected the purchaser, the purchaser might have recovered by assise of Novel Disseisin by reason of the conjunction of their two wills, which took place at the transferring of the seisin.

4. Hence it appears, and so it is, that two or more persons may on the same day be severally seised of the same tenement in their demesne as of fee, provided perhaps, by reason of the words of the count in the plea of right, that each can take seisin of the homages -and rents and lands to the value of half a mark or more. Whereof if the donor dies on the day of his gift, and the purchaser also,-or the purchasers, supposing ser- 
eral *suecessive feoffments to have been macie the same day from one to the other,-and diverse assises are brought of the same tenement by the heirs of the donor and by the heirs of the sereral purchasers, for every such plaintiff the assise will lie, but the heir of him who died last seised on the same day shall retain the tenement by judgment.

5. The same rule appears from the ease of him who undertakes a pilgrimage, for he may divest himself of his seisin and enfeoff some stranger, and straightway on the same day begin his journey, and die the same day or the next; in which case, although his heir can aver by the assise that his ancestor was seised on the day that he set out on his journey towards his pilgrimage, yet he doth not thereby prove that his ancestor left him any seisin or any right, since he neither died seised corporeally nor by intention. And the same reason may be assigned where a person makes a gift to another and puts him in seisin, and the same day assumes the religious habit. From all which considerations it appears that this assise lies only for those whose ancestors died or are treated as having died seised, for the reasons aforesaid.

6. Again, the tenant may say that the ancestor is not yet dead, and if this is verified, the assise shall fall. 


\section{*CHAPTER XVIII.}

Exception founded on the words 'of so much land with the appurtenances.'

1. The writ also contains these words, 'of so much land with the appurtenanees in such a vill;' from which words exceptions may arise in favour of the tenant; as, for an error in the demand, if 'tenement' is named instead of 'rent,' or the reverse, or 'rent' insteal of 'enstoms and services,' or two carucates of land for one, or if any one demands service, when he ought to demand annual rent. Wherefore if a tenement be demanded of him, who elaims nothing therein, ${ }^{1}$ or nothing but in the name of another, as guardian, farmer, villain, or bailiff, or in the name of his wife, where sueh others are not named in the writ, or nothing but the seigniory and services, or if service is demanded where tenement should be demanded in demesne in all or in part, or if the plaintiff says that he demands that as in demesne which the

1 'Note, that when one demands by Mortdancester otherwise than as the defendant holds, the assise shall fall: thus, if the demandant supposes in the tenant other estate than he hath, as where he is not "tenant in his demesne as of fee." For one ought to demand of him that hath the thing demanded; for of him that hath nothing, nothing can be demanded.' (Note in MS. N.) 
tenant holds in clemesne, and that in service which the tenant holds in service, the writ thereby falls. For in this assise every one ought to make his demand agreeably to the tenour of the writ, and according as his ancestor died seised.

2. And if the plaintiff cannot shew the jurors the tenement which he demands, nor where he ought to recover, the assise thereby falls. "So, if the tenant says that he does not hold all that is demanded, and the jurors of the assise say that they do not know whether he holds the whole or not.

\section{CHAPTER XIX.}

Exception founded on the words 'after the term.'

It is also contained in the writ, "whether the ancestor died after' a certain term named in the same writ, from which an exception may arise in favour of the tenant. For if he can prove that the ancestor did not die seised after such term in his demesne as of fee, the assise shall fall. 


\section{CHAPTER XX.}

Exception founded on the words ' next heir.'

1. The next article in the writ is, "whether the plaintiff is next heir.' Who is nearer heir than another has been in part mentioned above, and shall be more fully set forth in treating of the writ of right. And as to the proximity, the tenant may answer that another is nearer heir than the plaintiff, or he may absolutely traverse his being the next heir, and thereupon descend to averment by the assise.

2. Or he may say, supposing the land to be partible, that the plaintiff is not the nearest heir, there being another as near not named in the writ; and if this exception is proved or not denied, the assise shall fali." So if an assise is brought against one parcener, where several parceners hold in eommon, *the writ is thereby abatable. And when this assise is brought against several parceners, or others holding in common, and one of the tenants dies, the writ falls.

3. Again, the tenant may say that the plaintiff cannot be next heir, for that the ancestor of whose death

${ }^{1}$ See the entry of an assise $16 \mathrm{Edw}$. I, cited in Cowel's Interpreter, s. $v$. Partitione facienda. 
he brings the assise did not hold the tenements in his own name, but in the name of such an one, and was his villain, which case being proved or not denied, the assise shall fall.

4. As to an assise brought by one sister against another of a tenement descending from their common ancestor, we will that such an assise shall not lie, by reason of the parity of the possessory right among them, but the remedy shall be by writ of partition. And where two sisters, one of whom is legitimate and the other is a bastard, have brought this assise against a tenant, although the assise say that one was born in matrimony and the other before, yet it does not therefore follow that the seisin shall not be adjudged to both, saving to the legitimate her action to recover the bastard's share by writ of right when she is of age to do so ; and let the objection of bastardy be then determined upon replication. The same rule also holds among parceners, some of whom are villains and others free. ${ }^{1}$

*5. Again, the tenant may admit that the plaintiff is next heir, but still may say that he ought not as yet to have the seisin, for that the tenant holds it by feoffment of the ancestor for term of life, or in gage, or upon condition, or for a certain time by judgment of our court, or by the law of England for term of life.

1 The case in which this point would arise is explained by Bracton, by reference to a custom of Cornwall : according to which, if a freeman married a neif, half the children were free, and half were villains. 
But for this he must prove that he had irsue, which was heard to cry, and which had human form, and not that of a monster and was never attainted as bastard.

6. Again, he may say that there is a nearer heir, as where the youngest of three brothers bring this assise of the death of his second brother, if the tenant produces in court any issue of the eldest brother, the assise shall fall.

7. Or he may say, that although the plaintiff is the next heir to his ancestor, yet his ancestor excluded hin by a disposition made in his last will by testament; and if this be rerified, and the tene. ment be devisable by usage and custom of the place, as is the case with burgage tenements, the assise shall fall.

8. Or the tenant may say, that although the plaintiff be right heir, yet he cannot have remedy by this writ by reason of an usage to the contrary, to wit, that no writ shall rum, except the writ of right close accorling to the custom of the manor. And if the tenement is parcel of the ancient demesnes of our Crown, and both the plaintiff and tenant are sokemen, or if the plaintiff being a sokeman has brought this assise against the *lord of the manor, the writ shall thereby abate, unless the plaintiff can shew how by feoffment the tenement has been changed from socage.

9. Or he may say, that although the plaintiff is next heir, yet his ancestor did not so die seised, but 
that the donor always continued in seisin together with him, and still is seised; and if this be rerified, the assise shall be stayed.

\section{CHAPTER XXI.}

Liceptions founded on the words 'who holds the land.'

1. As to the words in the writ, 'summon sueh an one who holds the aforesaid land,' or 'holds the rent deforeed,'-inquiry should be made whether the tenant holds all according as the ancestor held it, or only part of it. For the whole may be of various kinds. Thus, where the plaintiff demands a manor with the appurtenances, or one earucate of land with the appurtenanees, or twenty librates of land with the appurtenances, the jurors according to the demand. must particularly view what tenement and how much the plaintiff demands, and whether the whole aceording as the ancestor held it or part only ; and if the whole be demanded, and a part of that. whole not excepted in the writ be alienated, the assise shall fall.

2. And if the plaintiff makes his demand by parcels, then every pareel is a separate whole, and therefore if the tenant does not hold the whole of any parcel the writ shall fall as to the whole of that parcel, and shall hold good as to the other *entire pareels. For though there is but one plaintiff against several tenants, yet several (although similar) actions shall accrue, by reason of the plurality of pareels and of tenants. And 
where one parcel is demanded against one tenant by several particulars, as one caracute of land by several virgates, or one virgate by several acres, if the tenant does not hold the whole according to the demand, the writ shall fall, either because the tenant never held any part of it, or because he aliened part before the writ was obtained, of which alienation no notice is taken.

3. If any alienation be made after the obtaining of the writ, the assise shall not be thereby stayed, by reason of the presumption of fraud in the alienor, as in such cases there is a great presumption that such alienations are made to delay the plaintiffs of their right, and to evade the judgments of our court. But if any such alienation be made, and the feoffor die before the day of plea, the writ shall not abate; but the tenant must come and answer to the assise, or vouch to warrant the heir of the feoffor. And if the heir is under age, yet the assise shall not stand over to be taken; *for in such cases we will that the heir shall answer of what age soever he be, as it is ordained in our statutes that he shall answer to the writ of entry founded on disseisin. And if the heir recover, let the tenant's right be saved to recover his warranty, when the heir shall be of age, by resummons out of the rolls of our Justices, wherein we will that special mention be made thereof.

4. If the tenant says that be does not hold the whole, then he ought to declare who holds the residue. For we will that before writs be abated for a fault or 
error, the tenants inform the plaintiffs how they shall purchase good writs. And if the tenant sets forth the name of him who holds the residue, the plaintiff may perhaps answer thereto, that the writ ought not thereby to abate, for the tenant himself held the whole the day that the writ was purchased.

5. Or the plaintiff may say that the person who holds such residue holds it for a term of years, or at will, or in villenage, and is the villain of him who is named tenant in the writ; and in such case the writ shall stand. And if the tenant says that the person who holds the residue is his freeman, and holds such residue of him freely, and the plaintiff is not prepared with suit of the blood of the villain to prove that he is a villain, the writ shall fall; and let the plaintiff obtain a good writ against both the tenants. If the tenants allege non-tenure, and cannot say who holds the residue, let them answer for what they hold.

*6. This exception of non-tenure lies properly in this assise, together with the other exceptions concerning the words in the writ. For in other writs, if it be put forward with effect, it is of such force, that there is no room for other exceptions, but judgment must be given according as proof is made of this exception. And that in different ways; for in writs of escheat, entry, formedon, cosinage, and others, in which battle and the great assise do not lie, if the verdict upon this exception be given for the tenant, the writ abates, and so the exception is dilatory,--if against the tenant, the plaintiff shall recover, saving to the tenant his action 
in the right; but if it be put forward sucessfully in a plea of right, it will be peremptory against whomsoever it passes.

7. If the plaintiff makes his plaint and demands a tenement in demesne, and the writ says, 'whereof the tenant deforceth him,' the writ is thereby abatable for fault in such writ, for it ought to have said, 'which the tenant holds.' And if he does not demand land or tenement in demesne, but rent and service, and the writ says, 'which the tenant holds,' the writ, if it be challenged, is in that respect defective and abatable, for it ought to have been, "who deforceth the aforesaid rent.' *And if there is error in the writ as to the name of the vill, as to where a hamlet is named, where it should have been a vill, or any other kind of error, the writ is thereby abatable.

\section{CHAPTER XXII.}

Exceptions of felony and bastardy, and other exceptions to the assise.

1. Again, the tenant may say that assise ought not to be, for that the ancestor whose seisin he demands was a felon, so that no right or seisin could descend through him to any other, but to the chief $\operatorname{lord}^{1}$ as an escheat. But this is not sufficient; unless it be said

1 The expression ' chief lord' denotes not the superior or sorereign, but the immediate lord; as the tenant in chief is the immediate tenant. See before, book ii. c. 8, ss. 5, 8 . 
how he was a felon, as in an exception of bastardy, it must be set forth how a bastard. And when he has explained how he was a felon, then he must aver it by record, on account of the danger there might be of an attaint, if the jurors of the assise should make a false verdict. For if he says that he was adjudged felon at such or such a place, yet this is not sufficient, unless the judgment was fully executed, and for this some record should be vouched as a warrant. And for this reason it plainly appears that no judgment of felony ought to be given except in presence of some one to bear record thereof. If the tenant says that he was outlawed, to this it may be answered that such outlawry was afterwards legally reversed, as is above mentioned.

2. If the tenant says that the plaintiff had an elder brother who committed felony for which he suffered judgment, *so that no right could descend from the ancestor except through him, by reason of whose felony he, as chief lord, entered into the tenements as his escheat,- whereas there are diverse opinions upon this point, we will that it be understood that the law in such case as to all writs is this: that if the eldest brother survived the ancestor of whose seisin this assise is brought, or if he died before the ancestor and left any issue still living, this assise shall fall, and otherwise it shall not, but the assise shall be taken by virtue of the right which descended from the ancestor to the younger son, since the right never found any eld́er brother, or issue of him, to whom it might 
descend; and such case shall be treated as if he had never been born, and no mention shall be ever made of him in counting of any descent. And if such a count be challenged for the omission, it shall be answered that he did not live until any right could descend to him; and that if any did descend to him, it nevertheless resulted to the ancestor from whom it came, so that the right descended from the father or other ancestor to the younger brother without any intermediate, as if no elder had ever existed.

3. Exception of bastardy being objected against any plaintiff or tenant in this assise stays the assise in all eases; and sometimes it turns it into a jury, and sometimes the cognisance thereof is transferred to be decided in Court Christian. *Nevertheless against one who is under age and tenant, no averment shall pass upon an exception of bastardy before he is of full age, because that exception determines the right. But if the exception be pleaded against the plaintiff, although he be uncler age, yet it does not follow that a jury shall not be had to aseertain the truth concerning such exception. And if the tenant say that the plaintiff's father was never married to his mother, this fact must be certified by the bishop and ordinaries. And if the same exception is put forward against both, the legitimaey of the plaintiff must first be ascertained; for if he cannot prove his legitimacy, the possession will remain with the tenant, whether he is a bastard or not.

4. Again, the tenant may say that if the plaintiff 
ever had any right, or if his ancestor had it, that right has he released and quitclaimed. In this case however it is not cnough to plead this in words, although he may have suffieient suit, but he must make it appear by record of our court, or by writing, or charter of the plaintiff. And even this quitclaim will not avail if the plaintiff can prove that no fee or freehold or right had descended to him at the time of making it, or that he was under age, or not in his right mind, or that the person to whom the quitclaim was made was not at the time in seisin of the tenement, but afterwards thrust himself into seisin by intrusion or by force.

*5. Again, the tenant may say that the plaintiff wrongfully impleads him, for that the ancestor of the plaintiff enfeoffed him, and bound the plaintiff to warranty, and therefore if he were impleaded by another, he should vouch him to warranty; -and if this be proved or not denied the action shall fall $;^{\mathbf{1}}$ - wherefore the purchaser entered therein when the seisin was vacant by the assent and induction of the feoffor, or by julgment of our court, and not by his own intrusion or force; or, although the entry was wrongful and defective, yet the plaintiff, or another who had as great a right, afterwards ratified it by confirmation; and if this be true, the assise shall fall.

6. Again, the tenant may claim title by reversion, or through a fine in our court, which supposes a

${ }^{1}$ There appears to be an error or omission in the text at this point, which I have been unable to correct. 
reversion in default of issue, ${ }^{1}$ althongh it be prejudicial to the plaintiff; and if the plaintiff does not avoid the fine, the action shall fail, unless the plaintiff has a fee-tail by form of gift. The fine may he aroided several ways; for it is sufficient if he to whom it is prejudicial was detained in prison or ont of the realm of England, or under age, or ont of his right inind, or deaf or dumb, whereby he could not reclaim the fine within the year and day.

7. Where the tenant says that he cannot answer without us, if he produces a eharter, whereby we are bound to warranty and exchange, the assise shall staml over, but not otherwise.

*8. Again, he may claim title by judgment of our court, either by surrender or by default made by the

1 There is a confusion here, which I am unable satisfactorily to clear up. The words par reversioun on appear to have been slipped into the text by mistake. The words fin qe suppose reversioun are from Fleta, where the word snpponit is perhaps used in the sense of 'suppresses' or ' lestroys.' After the statute De donis conditionalibus, which is alluded to above. but is not noticed in Fleta, a reversion for default of issue could not bo barred by fine, as had previously been the usage. But at the time when Britton and Fleta were written, such a plea might still be common with reference to a fine levied before the passing of the statute, it being expressly provided that this enactment should not be retrospective. The later operation of a fint to bar the issue in tail was a consequence of the construction put upon the Stat. 4 Hen. VII. c. 24 ; see Coke, Inst. ii. 517, 518; Brooke, Abr. ti. Fine pl. 1 ; Blackstone, Comm. rol. ii. pp. 118, 35.1; Reeves, Hist. Eng. Law, vol. iv. 1p. 135, 138; Hallaw. Const. Ifist. vol. i. p. 14. 
plaintiff or his ancester, or in some other manner. Or he may say, that although he had once a right to bring this assise, nevertheless he has defeated that right, inasmuch as he has not observed the proper order of pleading; for he formerly brought his plaint against the same tenant for the same tenements in the property by writ of right, wherefore he cannot come back afterwards to plead upon the possession. Or thus: that assise ought not to be, because an assise formerly passed between the same persons of the same tenements, and in favour of the tenant; and if this be rerified, the second action in all kinds of assises shall abate. So, if there is another assise concerning the same tenement between the same persons still pending, as by reason of a plea of bastardy pending in Court Christian, or for other reason. The like if the tenant can aver that the plaintiff holds to an equal value by exchange.

9. Again, the tenant may say that the tenement is the right of another, which the plaintiff cannot bring in judgment without the tenant's wife, in whom the freehold rests, and that he holds nothing therein sare jointly with his wife. *And this he may rerify three ways, either because they were enfeoffed to hold in common, in which case he must either shew a charter or vouch some record; or because he found his wife seised thereof before he married her; or because the tenement descended to his wife as her inheritance after his marriage with her.

10. Or he may say that the plaintiff is his villain 
and his astrer, and abiding in his villenage ${ }^{\mathbf{1}}$ and if this be verified, the action shall fall.

11. If the tenant is deaf and dumb naturally, and the same is not lately come upon him through sickness, or if he is a mere madman or an idiot from his birtl, so as to be incapable of discretion, the assise shall stand over until he is in a better state. ${ }^{2}$ In the same manner also where the tenant is under age, the assise shall stand over until his age, if his ancestor died seised of the tenement as of fee, of whatever lind of fee it be, whether knights' fee, free farm, burgage or other. And if the plaintiff who brings a plaint against his chief lord is under age, in such case the assise shall stand over until his age, if the lord claims nothing but the seigniory; but if he or another claims a freehold therein, the assise shall go.

1 That is. as I understand it, in the lord's villenage, or upon his. demesne. An astrer (Lat. astrarius) was a peasant householder, residing at the hearth or home (astre) where he was bred, "villanus in veteri astro suo commorans.' (Fle. 217 (\$8); Hengham Mag. c. viii. p. 103.) The word astre, in this sense, has been supposed to be connected with the English hearth, Anglo-Saxon heorư, but seems to be common to many of the medieval Roman dialects. See Spelman, Gloss. s. $v$. astre ; Ducange, Gloss. $s . v v$. astre, stare.

2 This appears to be one of those instances in which Bracton or Fleta has been carelessly paraphrased. The direction to put off the assise refers to the case where the incapacity arises from sickness. Compare Brac. 274 ; Fle. $298(\$ 29)$. In the other case, according to Bracton, cadit assisa. 


\section{*CHAPTER XXIII.}

\section{Of Assises of Mortdancester turned into Juries.}

1. Sometimes this assise descends from its collprehensive nature, and is turned into a jury ; and this for many causes in the same way as the assise of Norel Disseisin. ${ }^{1}$ Thus, it sometimes happens by reason of form of gift, where the heir female is to be admitted to the inheritance before the heir male.

2. So, where any one has brought this assise against his lord, and the lord answers that he claims nothing but wardship, and to this it is replied that he cannot claim wardship, because the fee is neither chivalry nor serjeanty, and the lord says that he and his ancestor's lave had the wardship thereof from the time whereof memory runneth not,-if the party traverses and denies this, in such case the truth shall be inquired by the jurors in form of jury.

1 - The first point in the writ is whether the ancestor died seised; the second, whether he died within the term; the third, whether the demandant is next heir. If the assise passes upon the substance (sus le gros) of these three points, it passes in its general nature (grosse nature). But if the tenant put forward an exception against the demandant, to which he answers, and says that it ought not to affect him, and for such a reason. and tenders averment by the assise, if then it passes, it is as a jury.' (Note in MS. N.) 
3. So, upon the exception of sale, as where the plaintiff is answered, that be had an elder brother acknowledged as heir and seised of the inheritance, who sold the land to the tenant, if the plaintiff says that this brother was nerer seised, so as to be able to make alienation, or that although he was himself seised, yet he never put the tenant in seisin during his lifetime, the truth shall be inquired by jury. The same, where the tenant puts forward a release from the plaintiff's ancestor, and he denies that it was ever the deed of his ancestor.

4. Likewise, if the tenant says that he claims nothing save by the law of England for term of life, *and the plaintiff says that he never had issue by his wife; in such and in many other cases the assise shall be turned into a jury if the parties consent, and if not, it shall be adjudged against him that will not consent.

5. So, on account of a supposititious child, as where any one, pretencling to be heir, demands by this assise against the true heir, if such right heir says that the plaintiff was not begotten by him whose seisin he demands, for that at the time of his birth the person whom he alleges to be his father was in parts beyond sea, and had been so for two years and upwards before, or impotent, or labouring under such an infirmity that he could not be presumed capable of begetting children, but that as soon as he returned he removed him from his house as the offspring of another, or that although he acknowledged him for his own, it was well known and notorious that he was not begotten by such ancestor; 
if this point be eontesterl between the parties, the assise is at an end, and the truth shall be inquired by jury; and so in numberless other cases.

\section{CHAPTER XXIV.}

Of the Judgment in an assise of Mortdancester.

1. When the parties have pleaded to the assise, let the jurors be ealled, and let those who are absent be *amereed, and the rest go and lay their hands on the book. Then let it be asked of the parties, whether they have anything to say wherefore the jurors should not be sworn one after another; anc after their ehallenges are allowed, as we have said before in treating of the assise of Novel Disseisin, if there do not remain as many as twelve unchallenged, let that day be respited and let the sheriff be commanded to eause a sufficient number to come on another day.

2. When there are jurors enough, let them go and be sworn in the mammer described in assise of Novel Disseisin. Afterwards let them be eharged, and safely kept so that no one come near them until they have given in their answer. And according to their verdict let judgment be given for the one party or the other. And afterwards let the damages be taxed by the jurors, as before is said.

3. If several persons bring this assise of the death of their common ancestor, and the jurors eannot say which of them all is nearest heir, in such case the 
seisin shall remain with the tenant, unless the plaintiffs for the manifestation of their right cause the jurors to be charged upon some point, or they themselves declare it, whereby the Justices may be informed which of them has the best right of action. If several assises are brought against one tenant for one and the same tenement demanded by divers descents, in such case the *recognisance must first be taken of that assise which is brought upon the last seisin. If a perambulation is necessury, let it be made as hath been said above. The party which is in the wrong shall be moderately or heavily amereed, according as his claim was malicious or founded on a colour of right.

\section{CHAP'TER XXY.}

Of the writ called Quod permittat.

1. Sometimes it happens that although the right heir has obtained the seisin of his inheritance, nerertheless he is hindered from having the seisen of some common or other appurtenance annexed to his inheritance, in another's soil, and whereof his ancestor lied seised; in which case no remedy lies for the heir by this assise, but by a simple jury proceeding by virtue of a writ provided in this case, called Quod permittat. The same remedy is provided for successors against the deforceors of such appurtenanees whereof their predecessors died seised as in right of their 
churches. And if there are several deforceors who hold in common, then all must be named in the writ, or the writ, if it be challenged, will be abatable.

2. This writ tries only the right of possession, ${ }^{1}$ and is therefore limited within the same term, and to the sume persons, as the assise of Mortdancester; *and beyond this term no writ lies in this case except a writ of right patent pleadable in the court of the lord of the fee.

3. In this writ of possession an essoin lies the first day as well for the tenant as for the plaintiff. And

1 - Sometimes the Quod permittat may be altogether in the Right, when it contains the words habere debet; sometimes altogether in the Possession, by reason of the word solet, and this when the demandant demands of his own seisin. But when one demands the seisin of his ancestor, this savours of the nature of Mortdancester, because the writ shall make mention that the ancestor was seised of the thing as of fee as appurtenant to his freehold in such a town the day whereon he died.' (Note in IS. N.) A writ of Quod permittut containing the words habere debet was treated as a writ of right, triable by battle or great assise; and accordingly it was decided in $22 \mathrm{Edw}$. I. that a parson could not prosecute such an action without aid of the patron and the bishop. Year Book, 32 Edw. I. pp. 117, 510. Compare Vetus Natura Brevium, 68 b. In the examples given by Bracton of this writ, which he, as well as our author, describes as affecting the possession and not the property. the action is founded upon the seisin of the ancestor of the plaintiff. or of the predecessor of a parson claiming in right of his church. For the forms of writ in which the demandant founded his claim upon his own seisin, and of those in which the words debet and solet were contained, see Regist. Brev. Orig. 155, 156 ; Fitzherbert, Nat. Brev. 123 ; and compare below, l. v. c. 14. s. 1. 
if the tenant makes default, let the distress run according to the process before-mentioned in the chapter of Quo jure. Demand of view and voucher of warranty both lie in this writ.

\section{CHAPTER XXVI.}

Of the writs of Cosinage, Ael, and Besael.

1. As the assise of Mortclancester is limited within certain degrees, and holds only of the death of certain persons and against eertain persons and extends no further, certain writs in degrees adjoining, to which that assise does not extend except by reason of another person joined with the plaintiff, have been provided in aid of that assise, whereby in all eases of so recent a seisin a plaintiff will not be compelled to have recourse to a writ of right, wherein there are many delays and risks. These writs are those of Cosinage, Ael, and Besael, by which, if the time allows, the right of possession may be tried.

2. As these writs are provided in aid of that assise, it is reasonable that they should in a great measure follow the nature of it, as in respeet of the term, and therefore the same limitation of term *is fixed for ono and the other; so likewise they hold between the same persons out of the degrees, for these writs take effect between the same persons beyond the limits of the assise, between whom the assise lies within the limits, (and not between other persons, as privies of blood 
claiming by the same descent), ascending to the grandfather's grandfather, if the time admits of it, and descending to the remotest blood.

3. It should be understood, that all those who issue from uncles and aunts, as well on the part of the father as on the part of the mother, and all those who issue from brothers and sisters, and those also who issue from their issue, in the degrees to which the assise of Mortdancester does not extend, are properly cousins to each other. And in the right line descending they are cousins, as well as in the collateral lines. For ascending they are ancestors, or grandfathers or greatgrandfathers, and descending they are cousins, because the great-grandfather or the grandfather's grandfather may by writ of Cosinage demand the seisin of the lowest found in the right line, and the grandfather or father or mother by the same writ may demand the seisin of the son or daughter $;^{1}$ where in the other

1 Our author appears to stand alone in asserting a right of inheritance in the ascending line. (See post, l. vi. c. 3. s. 4.) $\cdot A$ has a son $\mathrm{B}$, and no other of his blood; B purchases, and dies without issue. Quastio. Whether his father can or ought to have the purchase. Solutio. The chief lord and not the father, because the son is of the blood of the father, but the father is not of the blood of the son. But the purchase shall ascend rollaterally, as to uncle or aunt, and this is the first resort. for in every Cosinage the count must be by resort. The second resort is to the grandfather's or grandmother's brother or sister; the third to the brother or sister of the great-grandfather or greatgrandmother. But the seisin of the grandfather's grandfather cannot be counted of, sare in the writ of right; so that by the 
direction assise of Mortdancester, writs of Ael and Besael, and writ of right would lie.

4. In order to see plainly in what degrees they are cousins in relation to the father or others found in the direct line, let a line be drawn straight down, and let there be placed therein four degrees, one above the other, in the first of which let great-grandfather and great-grandmother be placed, in the second grandfather and grandmother, in the third *father and mother and in the fourth son and daughter. From the three upper degrees let three cross lines be drawn on each side, and for every male child let a degree be made by itself on the one side, and likewise for every female child on the other side, and for every child of thesc children let a degree be made further down, and so on for the issue of that issue from clegree to degree, the eldest always filling the degree adjoining the father or mother in the right line descending. The degree found under the great-grandfather signifies his eldest son, and in the degrees at the sirle of the son, who is called grandfather, are the younger brother's and sisters of the grandfather, who are uncles and aunts to the father or mother, and so by like reason it is to be understood of all the other degrees below.

5. All those, of whose death neither assise of Mort-

fourth resort demand can only be made in a writ of right.' (Note in MS. N.) For the purpose of limitation the degrees appear to have been counted back from the person whose seisin was demanded, not from the claimant. See Year Book, 32 Edw. I. p. 145. 
dancester nor writ of Ael or Besael lies, are cousins, and where no remedy lies by these writs, it lies by writ of Cosinage, as long as the time allows, beyond which no kind of remedy lies but by writ of right, which is the *]ast remedy of all. The nature of the plea of Cosinage serves to explain the descents and the resorts as well of the right line as of the collateral, and the descent and the resort of the kindred out of the right line to the collateral.

6. In counting upon this writ no mention should be made of the right, nor in any writ of possession, where no mention is made thereof in the writ; for by variance between the writ and the declaration the writ would be abatable; but in this writ and in those of Ael and Besael it is sufficient to count of the sesin of the cousin or grandfather or great-grandfather, who died seised in his demesne as of fee, withont speaking of the right. For these two words, 'in his demesne as of fee,' bring in judgment all the possessory right; and when the word 'right' is expressed in the count, it imports that the plaintiff intends to bring in question the property, whereof if the writ makes no mention, and the error is challenged, the writ thereby abates.

7. Moreover it is not essential to count in any possessory writ of any taking of profits, and this is no more necessary in pleas of Cosinage or Ael or other writs of possession, than in assise of Novel Disseisin or Mortdancester. For one may be seised without taking profits, as the right heir becomes seised after the 30 
death of his *ancestor, the inheritance being vacant, by setting his foot thereon, and others in whose persons the property rests by a single conjunction of the right with the possession, the tenement being first vacant; in which cases although such heir should die before taking any of the profits, yet he would nevertheless die seised in his demesne as of fee. If however the taking of esplees is mentioned and can be verified, these words are rather of service than otherwise, since they tend strongly to declare the seisin.

8. In this writ lie essoins, process by Cape upon default, demand of view, voucher of warrant, exceptions of the same descent, of seisin, of last seised, of his demesne as of fee, of so much land, of term of proximity, of non-tenure, of felony, of errors, of bastardy, and the others mentioned above in assise of Mortdancester. 


\section{BOOK IV.}

OF PLEAS RELATING TO ADVOWSONS AND THE PROPERTY OF CHURCHES; AND OF ATTAINTS.

\section{CHAPTER I. \\ Of the Assise of Last Presentation.}

I.

As assise of last presentation is the recognisance of twelve jurors, which tries the right of possession to the adrowson of any church, that is, who last presented in his own name in time of peace. *This may sometimes be pleaded before our Justices Itinerant, sometimes in the Bench at Westminster by the ordinance of the Great Charter, and sometimes for the dispatch of justice before our Justices especially authorized for that purpose. Sometimes the assise is begun in one place and is ended in another; and sometimes it is begun out of the county, and the recogniance or jury is taken in the county; and sometimes the parties are adjourned to hear their judgment, and sometimes not adjourned.

2. Therefore where any person has presented to a vacant church to which he or his ancestors have presented in time of peace, inasmuch as every heir ought to enjoy the scisin which his ancestor had, unless the 
disturbor or deforeeor ean show plain reasons to the contrary, which contest is determinable by this assise of last presentation, we must first see to whom it belongs to bring this assise. For it belongs only to him who has, once or oftener, presented in his own name, or to his heir by reason of his succeeding to the inheritance and the right of an ancestor who died seised of the advowson.

3. What is said of one heir may be understood of several who are parceners and as one heir. But if several parceners * reeover the advowson of any church by this assise, and the church is void, no parcener can present without the other by any prerogative of seniority, or for any other reason. By this assise shall never lie for those who hold in eommon by feoffment and not by descent, before they have been seised of the presentation, since two persons ean never recover by this assise who make their demand of the seisin of him or of them whose heirs they are not, any more than in pleas of right. Neither does it lie for those who hold for term of years, or for term of life by reason of dower, or by the law of England, or in gage, or by feoffment, or by escheat, or by any mode of acquisition other than succession.

4. If the plea is not in the Bench, then one essoin and no more lies for each party, so that after their appearance there is no essoin. And if the deforeeor makes default, then the proeess above-mentioned in the chapter of summons takes place. And if the pleat is in the county, although it commenced out of the 
county, no resummons after default shall lie, nor any essoin, nor any delay. And if the plaintiff is under age, neither essoin nor resummons ever takes place, whether the plea be within the county or without; * for in such case the absence of the tenant is as good as his presence. Neither does resummons lie in cases of contumacy; as, where the tenant or the disturbant appears in court, and contemptuously departs, after he has been seen by the Justice in court; but in such case the assise shall be forthwith taken without any resummons ; also, if the defendant makes default, ${ }^{1}$ resummons shall not lie. So, when he appears, and will not or cannot allege any cause why the assise should be stayed, let the assise be presently taken, if the jurors are present, and if not, let the sheriff be commanded to have their bodies at another day.

\section{CHAPTER II.}

Of the day of Plea; and of the Count of the Plaintiff.

When the parties appear in court, it will then behove the plaintiff, after the writ has been read in audience, to declare his case in such a way as to show how he hath right of action and reason to complain, and of whose seisin he has brought the assise,- -whether of his own seisin or of that of another. If of his own

1 That is, default after resummons; see the parallel places in Bracton and Fleta. Perhaps we should read, 'defaute apres defaute.' 
seisin, it will be necessary for him, in order to certify the court of his right, to say further, whether, when he presented, he held any glebe, such as rent or soil, to which the adrowson was appendant, or not, *and if he loolds such glebe, then he must set forth how he holds it, whether in fee or for term of life or for any other term. 1 If he says that he demands the seisin of some ancestor, them he must show how he is the heir of such ancestor, so that it may appear by his statement whether he has a several action, or one in common with any parcener. And if his plaint is in an action upon a common right, it should be further known whether it be his turn to present this time or not.

\section{CHAPTER III.}

Of Exceptions in Assise of Last Presentation.

1. The deforeeor must thereupon answer. For voucher of warrant does not lie, because the object of the writ is to ascertain by the assise, who has the best right to the presentation. The deforeeor may answer to the deckaration by exceptions, of which the dilatory are first to be proposed.

2. As to the words in the writ, "who is the

1 The word 'glebe' is used for the land to which the advowson is appurtenant. 'Nota, quod verus adrocatıs dicitur ille, qui patronus est ut de feodo et recto ex descensu hareditatis. Quasi advocatus est ille, qui possidet glebam, ad quam pertinet advocatio, nou in feodo sed ad terminum.' (Note in MS. N.) 
advocate,' it must be understood that the advocate is he to whom the right of the advowson of any church belongs, so that he may present to that church in his own name, and he is called advocate by way of distinction from those who have occasion *to present in the name of another, as guardians do in the name of infants under age, whose lands are in their ward, and also from those who hold the tenement to which an advowson is appendant for a term of life or years only, ${ }^{1}$ or by intrusion or disseisin, provided these have never presented; for if they have presented, and so are in seisin of the advowson, they are thereby become in a manner adrocates, so far as regards the seisin of the presentation, as long as they hold the tenements to which the adrowson is annexed; for until the disseisee or the true possessor has recovered the tenement, which is the principal subject, he can have no claim to anything accessory thereto.

3. The words aiso ' in time of peace' are used in distinction from time of war, under which are comprehended all times of injuries done by one neighbour to another by violence, and by intrusions, disseisins, robberies, disturbances, oppressions, and other wrongs; whence time of peace may be thus distinguished and understood; for one may present before the time of war, or in the time, or after the time, and yet the presentation will be sufficient and lawful; and so in the reverse case, a presentation may be made by extortion, in despite of the true possessor, by fraud and

1 See the note from MS. $N$. in p. 173. 
contention. *And as the one is in all points good and lawful, so the wrongful presentation is never of any effect, because in wrong and so not in time of peace. And from such wrongful acts of riolence and oppression there do always arise exceptions in favour of the plaintiff against the title of the disturbor.

4. With regard to the word also contained in the writ, 'presented,' care must be taken to see whether the parson who was then presented was upon the presentation of such an one admitted and instituted by the bishop or not; for otherwise the presentation was of no avail. And if two clerls are presented to the same church by different patrons, both of them cannot be admitted at the same time, but one at least must be refused; and it may also well happen that neither of them shall be admitted, although one of the patrons have the right to present, and this for two reasons. One is, that if the church remains unprovided beyond six months, then according to the Council of Lateran, upon the disagreement of the parties, the bishop of the diocese shall provide for it, ancl shall ex officio give the church to some clerk saving every one's right. The other reason is the minority of one of the presentors, as where charters of his ancestors are produced against any presentor who is under age, to which charters he can give no answer before he is of age; in such case if the parties do not agree in the presentation of a parson, the collation belongs to the ordinary of the place, saving every one's right when the person under age comes of age; but in such case it should be so 


\section{II, *226.] OF EXCEPTIONS IN ASSISES. 473}

ordered by advice of the Justices, that some annual pension be reserved to the infant until he comes of age, for the saving of his right to present when he shall attain his age.

5. Two persons may present at the same time, one having a right and the other none, or both of them some colour of right; and if it should happen that they both agree in one clerk, without trying the right, by that presentation the right of no one is diminished or altered, but resort must be had to the seisin of that patron, of whom it is certain that he last presented of right alone. But if any one has once presenterl without opposition, and some person at the next avoidance makes a disturbance, and afterwards assents to the presentation of the true patron, by this assent the estate of the patron, as regards lis right of presentation at another avoidance, is not prejudiced. For it is one thing to assent and another to consent. Assenting is where any person who has no right to present, after having made a disturbance, says, 'I assent to this presentation, saving my future right:' and such assent is not prejudicial to the true patron, nor does any right *accrue thereby to the disturbor. Consenting is when any one who is in seisin of the advowson consents to the presentation of him who has a better right. For the one may be in seisin of the possessory right, and the other of the property, and he who has more of the property has the greater right. And such consent may be made simply, or with protestation. If made simply, he thereby renounces all his right; 
if with protestation in these words, 'saring to me my right at other avoidances,' he thereby retains the right that he has, whatever it may be. The same rule holds in advowsons of chapels, prebends, vicarages, hospitals, abbeys, priories, and other places to which one may present on occasion of aroidance.

6. That which is said in the writ, 'the parson who is dead,' is said to distinguish him from a vicar, to whose vicarage none can present. The word 'dead' laas a double meaning, being userl either of natural death, or death to the world, as in the case of him who becomes professed in religion, and has renounced all worldly things, or of that which in this matter is equivalent to death, as where a parson has married a wife, or done any other thing whereby he is unable to retain any ehurch.

7. It is contained in the writ, "to such a church which is roid; and here it must be observed whether it is entirely void, or the parsonage only ; *or if any pension has been granted by virtue of some accord between parties or by way of a simple benefice, and he who received that benefice dies, the church and parsonage do not thereby become vacant. The same is to be understood of a vicar whose vicarage is not in any one's presentation, and which upon his death accrues entirely to the parson, and in particular of a vicarage endowed by the ordinary for the reasonable support of a vicar.' The worl 'church' is also used

1 There appears to be an error here. In the parallel passage of Bracton the case here mentioned is stated as an exception to the 
by way of distinction from chapel, and therefore if in the writ it is said 'church' where it ought to have been 'chapel,' the writ is thereby abatable. But whether it is a chapel or not is not to be tried in lay courts, but in court Christian.'

8. If the assise is brought of the entire church, where the moiety only or the third or fourth part is void, and there is a dispute about the avoidance, for that one side says it is void and the other that it is full, let the truth thereof be inquired by the assise. For if the cognisance thereof was referred to the bishop, the church might be encumbered by him, or the truth perhaps would not be returned; as suppose he had admitted and instituted any clerk in such church upon the presentation of one who had no right to present, in such case he might return that the church was full and provided, which would be a prejudice to the true patron.

*9. And upon the verdict of the assise let the bishop be commanded that he admit the clerk presented, and if he will not, let him be forthwith summoned to answer why he refuses; and thus the incumbrance

general rule, by which a vicarage became merged in the parsonage. 'Et hoc dico nisi taxata fuerit per ordinarios ad rationabilem sustentationem vicarii.' Brac. $241 \mathrm{~b}$. The same error occurs in Fleta (as printed), where the words are, 'et hoc ubi taxata fueri, \&c. Fle. $322(\$ 9)$.

1 This question was treated in $32 \mathrm{Edw}$. I. as one determinable by the assise. Year Book, 32 Edw. I. pp. 10\%, 349. Compare Fle. $323(\$ 18)$. 
of the bishop or other ordinary, if any there be, may be proved. And if any ordinary is found guilty of such incumbrance, let it be immediately adjudged that he set the church free, or otherwise make satisfaction to the patron and let the ordinary remain in our mercy. Thus the church may be void in law but not in fact. But where it is void both in law and in fact, the assise shall run immediately, for then the church is truly and rightfully void.

10. And if any clerk has of his own folly thrust himself into the church at the time of avoidance, yet the assise shall not be stayed, but shall be taken as if it was entirely void and unprovided. And if the jurors say that it is full by the intrusion of such a clerk, let the plea be immediately sent to the court Christian, that the bishop of the diocese may certify our Justices whether the intrusion be rightful or tortions, and upon this let julgment be given. For the recognisance of spiritual intrusions, whether they are rightful or not. does not belong to the temporal court any more than that of other spiritual matters. Yet such returns of bishops are not always fully sufficient, without further support from muniments or other evidence.

*11. Whereas it is said in the writ, 'which advowson such an one saith belongs to him,' it is right that the plaintiff should plainly show how he hath riglit, and reason for complaint. It is likewise said, 'summons such an one;' therefore the plaintifl nust in the declaration of his case point ont how and in what way the defendant wrongfully deforces him. 
12. Although the writ says, "who deforeeth him of the aforesaid advowson,' yet it is not to be understood thereby that the deforceor is in seisin of the advowson. But the word 'deforce' is used because he is sufficiently a deforceor who disturbs another in the whole or in part, although he does not actually eject him from the whole, as above is said. From the points aforesaid exceptions may be drawn either wholly to destroy the assise or to delay it.

\section{CHAPTER IV.}

\section{Of Exceptions independent of the Writ.}

1. Although the disturbor admits all the artieles of the writ, yet he may except against the assise, and say, that, whereas the plaintiff counts of the seisin and presentation of his ancestors, he wrongfully complains, because after lis own presentation, he granted to this same disturbor or to one of his ancestors a tenement to which the alvowson was appendant, and that by such a charter; and therefore, although the plaintiff or any of his ancestors did present, yet he ought not to present on account of the aforesaid deed.

*2. If, then, the plaintiff is of full age, he may acknowledge the eharter and admit the gift, and say in answer to the exception, that after the making of such gift he presented such an one by name, who was admitted on his presentation, whereby the gift is null and the charter void. And if this be proved or not 
denied, there is an end to the exception, ${ }^{1}$ unless the deforceor can say that although that charter be void and the gift null for the last presentation of the donor, yet after such presentation this same plaintiff or his ancestor made a new gift and a new charter to him, whereby the presentation belongs to him. Or he may say that the plaintiff confirmed the first charter to him, and so that which was before weakened by want of seisin he did afterwards strengthen by confirmation; and if this be verified or not denied, the assise shall fall, unless the plaintiff can aver a later presentation. Or he may grant that the presentation was so made by the plaintiff or his ancestor after the gift and after the making of the charter; but he may say that he purchased out against him a writ of warranty of charter, upon which the plaintiff was summoned, and

1 A gives a manor with the advowson of a church to B: A dies. $C$, son and heir of $A$, is under age, and in ward of $D$. The church avoids. D presents in right of wardship, and his clerk is admitted and instituted. When $\mathrm{C}$ is of age, the parson lies. $\mathrm{C}$ presents, and $\mathrm{B}$, the purchaser, presents also. $\mathrm{C}$ brings assise. B, the disturbor, alleges his purchase. $\mathrm{C}$ replies of the continuance of seisin by the last presentation. Quastio. quit fiet. Solutio. $\mathrm{C}$ shall recover, and $\mathrm{B}$ take nothing: because jurchase without fine levied is invalid (riens ne valt) without seisin. Contra. Induction of seisin of the principal substance (del gros e del principal), to which the appurtenances are appendant and accessory, suffices for seisin of both. But the glebe is a principalsubstance to which the advowson is appendant and accessory ; therefore the induction of seisin of the glebe is sufficient for the principal and for the accessory.' (Note in MS. N.) See before, p. 173, note. 
in our court acknowledged the charter to be his deed, and allowed the gift, so that a fine was leried, and a chirograph made; and thus the plea shall be ended.

3. In order to see this matter elearly, let us suppose that one has granted to another a manor, with the advowson of a church, to him and his heirs in fee, and before the church * becomes void the purchaser gives the same manor with the adrowson to another; then the parson of the first donor dies, and the former purchaser presents, and the latter also. The first purchaser has no right, inasmuch as he was never seised; neither has the latter any right, for no one could give a thing which he had not; so that the right of presentation must of necessity remain with the first donor, who always continued in possession of the right of presentation, inasmuch as the purchaser aliened his right before seisin, that is to say, before he presented. ${ }^{1}$ And the same reason holds in case of several alienors.

1 ' If one purchase a tenement to which an adrowson is appendant, and alien the tenement before he has presented to the church, the second purchaser hath lost for ever his action to recover the advowson by reason of his purchase. Probatio hujus. Feoffor cannot make higher estate to his feoffee than he himself had; but the feoffor had no estate in the advowson. Therefore he could make none. Contra. Seisin of principal is seisin of accessory ; but the purchaser, by means of the glebe, takes seisin of the principal ; therefore of the accessory. Responsio. Seisin cannot be taken more largely than it is delivered, but seisin was never delivered of the advowson ; therefore it could not be taken. Solutio. There are some appurtenances which may be serered by the owner; as a garden belongs to a house, but if the owner gives the house with its appurtenances, retaining the garden, 
4. For if the last purchaser could in any way rouch his feoffor to warranty, it would not avail him, because the warrant was never seised. For no one is bound to defend any other in his seisin, except him who is found in possession ; ${ }^{1}$ and if the rouchee should warrant to him in fact,--since in law he would not be bound to do so,-and should himself vouch the first alienor, the latter would not be bound to warranty, and this for two reasons; first, because the vouchor is not in seisin ; and, secondly, because the last purchaser cannot claim or have again what he never had or could have. And although the first alienor confirm the gift to the first purchaser ${ }^{2}{ }^{*}$ yet the last purchase is not thereby strengthened, since that gift is not the

there are two principal matters where before there was but one (sunt deuz gros qe avant ne furent fors qe un gros). So in the former case (Auxi par decha); the donor aliened the land with the advowson, but retained the advowson by the presentation after the gift; as, if I enfeoff you of two acres. and continue in seisin of one, the charter is void as to that acre. But if he who purchased the land with the advowson had not aliened the land, but had presented in time of avoidance, and had been disturber by his feoffor or other, and had proceeded by law, he might have recovered the advowson. But since he did not do so, the right remains with the donor. Et sic nota, quod actio alienari non - potest.' (Note in MS. N.)

1 The text here is ambiguous, and the previous sentence might seem to show celi to be used in the nominative case. But the meaning is shown by the parallel places of Bracton and Fleta.

2 The sense appears to require ' last purchaser ;' compare Brac. 243, Fle. 324 (§ 2$)$. 
deed of the eonfirmor or any of his ancestors, and because the gift itself was never of any effect. And therefore if the first clonor presents, and the last purchaser also presents, whether he has a confirmation of his purehase or not, the seisin shall be awarded by the assise to the eonfirmor on account of the seisin from which he never parted, since it never began to attach any where else.

5. But where the last purchaser in fact presents a clerk, who is admitted on his presentation, and then it is aliened from hand to hand, each purchaser being in seisin of the presentation, and upon the avoidance of the ehureh, both the first donor and the last purchaser present, if both bring this assise, let the assise be first taken of the last seisin, and let no assise upon assise be afterwards taken, but let the first donor proceed by writ of right upon the property, if he thinks fit to do so ; and he may impute it to his own negligence that he has lost his recorery in the possession.

6. If a eharter produced against this assise is denied, let it be proved by the witnesses therein named, and by the assise taken in the manner of a jury, unless he against whom it is proffered is under age; for an infant in that condition eannot answer to any charter; but to a fine or other recognisance made * by his aneestor every heir, of whatever age he may be, shall answer. ${ }^{1}$ In case of nonage, the assise shall be put off until age; but by advice of our court an annual pension shall be provided

1 - Carta dedici poterit, finis vero dedici non poterit; unde minor ad finem respondere cogetu r.' (Note in MS. N.)

31 
for such infant, to be taken until he is of age. But if no charter is produced, the assise shall run forthwith, although one of the parties be under age. So where a fine or other recognisance male by the ancestor of any of the parties is vouched, the assise shall not be stayed by reason of the nonage of the heir.

7. If a charter only of an ancestor is produced, and the same is denied, let it be proved; and if it is admitted, but is objected against it that it is void and of no force by reason of the subsequent presentation, and the adverse party denies that there was any such presentation after the making of the charter, let the assise forthwith run in manner of a jury by the consent of the parties upon this question, whether the donor who brings the assise presented to the church, after lie made the gift to such an one, which the charter witnesseth, or not.

8. Again, it may be answered to the assise, that it ought not to pass, because he who brings the assise, or some of his ancestors, gave and aliened to the other party, or to some of his ancestors, the whole of the tenement in right whereof he has presented, with all its appurtenances, ${ }^{1}$ without retaining anything, whether they were in possession of the presentation or not, and without any exception or condition, or without any

1. Nota quod unum est dicere, Do tibi cum pertinentiis, et aliud, cum omnibus pertinentiis, vel, cum pertinentiis sine ullo retenemento; quia per hoe quod dico, cum pertinentiis, aliqua possunt pertinentia transmutari, et aliqua retineri.' (Note in MS. N.) 
lease for term of life or years. ${ }^{1}$ And this allegation may sometimes be manifested by charter and by writings, which being produced in court, the assise shall procesd, and if any of them be denied, averment shall lie by the assise taken in form of jury, if the parties consent thereto. Charter must always be produced before judgment given; for afterwards they are not admissible, except in certifications and attaints.

9. Again, it may be excepted against the assise, that he who brings it hath not in hand any tenement to which the advowson was ever appurtenant, inasmuch as he lost such tenement by judgment, or by disseisin, ${ }^{2}$ or in some other way, and therefore, even if he has a right in the tenement and in its appurtenances, yet he ought first to recover the tenement to which the advowson belongs, which is the principal subject, before he has any ground for presenting. And upon his point it is said that, if any one has once recovered the presentation of

1 The sense requires, 'or leased it for term of life or years;' compare Bract. 243, and Fle. 325 (§ 2).

2 'A man inherits a manor to which an adrowson is appendant; and is disseised of the entire manor. The church avoids. The disseisee and disseisor both present. The disseisee brings assise, and the disseisor Quare impedit. The disseisor shall recover. Contra. The disseisor ought not to be in a better condition than a purchaser, but if a purchaser had purchased the manor with the appurtenances, without special mention of the advowson, the advowson had remained with the donor; with much stronger reason should it remain with the disseisee. Responsio. True it is, the disseisor is in a better condition quoad hoc.', (Note in MS. N.) 
a church by this assise, and there is another having a greater right to it who demands the advowson, or the tenement to which the advowson belongs, by writ of right, and pending the plea the parson dies, still the plaintiff has no right to present before he has deraigned the advowson or the tenement in the plea of right.

10. The party may also except against the assise, that neither he who brings it nor any of his ancestors ever had any *right in the advowson except for term of life or other term which is passed. And if any woman after the decease of her husband disturbs the presentation of the heir, who is warrant of her dower, and alleges that the presentation belongs to her by reason of her dower which she has in the same vill where the church is situate, thereupon purchases a writ of Quare impedit against the same warrant, care must be taken to observe in what manner her dower was assigned to her. For if she has the third part of a vill with the appurtenances in dower, and in virtue of this dower claims the third presentation, the claim cannot be allowed, unless she has some specialty which makes mention thereof, as where the adrowson has been assigned to her in her third part; for otherwise she cannot claim or challenge anything, although the church be situate in her third. And if she is endowed of the whole vill entirely, with all the appurtenances without any exception, than she has a right; but if the arlvowson be excepted, she has no right.

11. If the bishop is asked to admit any clerk to a presentation by parcels, as where a manor, to which 
the advowson of some church is appendant, is aliencil by parcels to divers tenants, each of whom is enfeofferl of his portion with the appurtenances, and all the tenants severally present to the church, when it becomes roid, the presentation of the *tenant of the last remaining parcel is to be taken, as before is mentioned. For in such case the advorson, not being expressly aliened, always remains with the portion retained.

12. If one presents to a church, and such presentec is admitted, and another person raises a dispute by some other clerk, and it is afterwards agreed between the presentors that he who raised the dispute shall de facto a second time present to the bishop the clerk already instituted, and the bishop thereupon admits him in prejudice of the right of the first presentor, and so this clerk remains instituted all his lifetime, having been twice presented and twice instituted, and if upon a new avoidance the person who presented last desires to proceed by this assise, he ought not to be heard. For presentation upon presentation at one turn and one avoidance is of no force.

13. If any one presents to a church, and before the presentee is admitted, the presentor pending the presentation dies, and the guardian of the heir by reason of the nonage of the heir and in right of the wardship presents another clerk, and during the litigation between the clerks thus presented the heir becomes of full age, and presents a third clerk; in such case the presentee of the heir is to be admitted to the church. 
14. If a woman endowed of an advowson presents her clerk, who is admittel, and the heir who is the warrant of her dower makes a gift of the adrowson in the lifetime of the widow ; and before the *purchaser has seisin of the adrowson by presentation the widow dies, so that the dower falls into the hands of the right heir ; in such case the purchaser must get his purchase renewed or confirmed; for until he can allege seisin, he ean never plead in the property.

15. If there are several parceners and heirs, some of whom are under age and others of fill age, and some in seisin of their inheritance by their grumdians and some in their own names, and there is only one church vacant, all ought to present thereto jointly, and to consent in one clerk; othewise the presentation shall not take place so long as they disagree, and the bishop when the time comes shall dispose of the chureh. But if all are of age, and every one knows his several share, then the presentation shall go according as they shall agree in the partition. Neither cloes the collation belong to the bishop if every such parcener severally presents his clerk, when they are all of age and have made partition of their inheritanee, ${ }^{1}$ because in such case the bishop could not admit the clerk of one without prejuclice to the other parceners. But it might be otherwise, if one single person who had the entire

'This clause, ' when they are all,' \&c., appears to have slipped into the text by mistake. The sense intended appears to be, that where of several parceners each presents his own clerk, the bishop is not entitled to make his choice. 
right of presentation presented two or more clerks at onee, or one after the other.

*16. Whereas in respeet of one avoidance and of the presentation to one church several persons may be plaintiffs upon different grounds, for two or more may complain and bring this assise, and demand the presentation by title of succession as of the seisin of their ancestors, or of their own presentation and a widlow endowed, or several widows, in right of their dower, or of any manner of term of life or years according to the different kinds of tenures, either by writ of Quare Impedit or Quarenon permittit, or by reason that such a widow holds part of the vill where the ehureh is situate, and therefore might present in turn, and upon sereral other grounds, - all these reasons should be earefully examined in proper order, so that it may be ascertained who has a right to the action and who not; and in the letters to be directed to the bishop mention should be made of the proceedings in the ease of person.

17. When a widow in right of her dower has presented to any ehureh, and her elerk is admitted by the bishop, and the heir, who is the warrant of her dower, afterwards grants away the advowson, and the ehurch being again void in the lifetime of the widow she presents again, if her clerk is admitted, the right of presentation is thereby reserved to the heir and to his heirs ; and the grant will be ineffectual, and the charter void for want of seisin.

18. When any one says, by way of defence to this 
assise, that he who brings it cannot present by reason of a gift and feoffment, and thereupon shows a charter, if the charter and feoffment cannot be denied, the assise is at an end, and the other shall retain his seisin, when he is thus as it were in seisin after the gift and making of the eharter. *And if the charter and gift are denied, let them be proved; and if they are proved, the plaintiff eannot further hinder the presentation. And if the donor acknowledge the charter and the gift, and say that he afterwarls: presented, as aforesaid, let this be inquired by the assise, for lis bare allegation is not to be believed, nor any presumption alone, although he should produce in evidence the letters patent of the bishop of the diocese testifying that he admitted his clerk to that cliurch. Nor need the assise in this case incuire concerning the seisin of the donor ; for by acknowletging the charter he has barred himself from the seisin and from his presentation, when he is mable to show that he has presented after his gift or after the making of the charter.

19. When the plaintiff counts of his own seisin or of that of his ancestors, and says that he presented a certain parson, who was admitted, and thereof puts himself upon the jurors of the assise, if the jurors say that they do not know who presented the last parson, or the one before him, or if they say that they absolutely know nothing thereof, in such case let the plaintifl take nothing, but remain in merey. ${ }^{1}$ So, if in one vill

${ }^{1}$ Bracton cites a case of the tenth year of Henry III. to show 
there are two lords and diverse fees, and but one church, and the jurors cannot say who last presenterl, nor in whose fee the church is, or if the *ground on which the church is built is common to both parties, in such case the parties must be told to agree upon a parson, ${ }^{1}$ or neither of them will take anything, but the plaintiff shall remain in mercy, not for want of right, but for want of proving his right.

\section{CHAPTER V.}

Of the Verdict and Judgment in Assise of Last Presentation.

1. When the jurors are present in court, and the parties have pleaded to the assise, if the jurors are notrejected by the challenges of the parties, they shall swear one after the other thus: "Hear this, ye Justices, that I will speak the truth concerning this assise of the church (or of the chapel), whereof by the king $s$ precept I have made the view, and that I will not fail for anything to speak the truth, so help me God and the Saints.' Then let the writ be rehearsed to them, and the manner in which the parties have pleaded, so far as necessary.

that in the above circumstances the parties without further writ might proceed upon the proprietary right, which would be tried by battle or the great assise.

${ }^{1}$ Bracton says they should agree to present alternately. 
2. When the jurors have spoken together, and are agreed in their verdiet, they may say that tine plaintiff presented the last parson, who is dead, to the aforesaid church in time of peace, to wit, such a clerk by name, who last died parson in the same church; or they may say, on the other hand, that he did not present the last elerk, but that another, such an one by name, did so; or they may give all the reasons which the deforceor himself might allege, if he were present, why the presentation does not belong to the plaintiff, and show that the other does not wrongfully deforee him, as where the plaintiff or his ancestor after the last presentation aliened the adrowson in some manner in fee or for a tern.

3. It is not suffieient for the jurors to say merely that the plaintiff or his ancestor presented last, but they must also declare how the deforeeor has wrongfully disturbed the presentation. Likewise, it is not enough to say ' wrongfully,' without saying that the wrong was done to him who complains, since this must appear before the plaintiff can take anything by this assise, howerer useful the verdiet might be to another person having the right. Or they may say that they know nothing of the fact; and then they must inquire who presented the next parson before, and so from parson to parson as long as the limited time permits.

4. If the jurors say that the plaintiff presented, then judgment shall pass for him; and if they say that his ancestors presented the last parson but one, but they 
know not who presented the parson who died last, still let judgment be given for the plaintiff, unless there is any reason to exclude the Justices from the presump). tion that the plaintiff, who is right heir to him who last presented, has the mere righit by title of succession But if the presentation was made before the time limited in a plea of Mortdancester, the assise falls; and let the plaintiff proceed by writ of right, if he thinks fit to do it. And if the jurors are undecided and in doubt, then let the seisin remain where it is, and the plaintiff in mercy. The like where the jurors have no knowledge of the person of the plaintiff, or although they have some knowledge of him, yet they do not know for certain whether he is the next heir of the ancestor who last presented or not.

5 . If any one has once recovered seisin of a presentation by this assise, and he against whom he has recovered proceeds to demand the advowson by writ of right, and pending the plea the church becomes void, and both of them present, the presentee of the person who recovered by the assise ought to be admitted, saving to the plaintiff his right in the property. 


\section{CHAPTER VI.}

Of the Action of the Quare impedit.

1. Not all those to whom an advowson belongs have an action to demand it by the assise of last presentation, either in virtue of their own presentation or of the seisin of their ancestors, as hath been explained in treating of the assise of last presentation. For there. are some who purchase advowsons of churches and a right to present by good titles, as by title of gift in fee or for a term, or by judgment in our court ; also by disseisins and by intrusions in the tenements to which the advowsons are annexed, and in many other ways, whereby if such churches become roid, and the purchasers present thereto and are disturbed, they can have no remedy by the aforsaicl assise. For the writ of last presentation is a writ of possession, and such purchasers cannot count of their possession. And therefore the writ of Quare impedit was provided as a remedy for such purchasers; which wit is pleadable by summons, attachments aud distress.

*2. The force of this writ lies wholly in the trespass of the tortious disturbance. Therefore where any one having a right to present by a good title desires to present, and another who has less right interposes a disturbance by presenting another elerk or in any 
other manner, if he who is thus disturbed cannot count of his own seisin or of the seisin of his ancestor, then this writ of Quare impedit properly lies, which is as much as to say, wherefore the disturbor wrongfully sets his foot in that right which the plaintiff has in the presentation, and whereof, although he was never fully seised of the possessory right, he is seised of the property by title of goorl purchase; and therefore the disturbing him is equivalent to ejecting him from the whole, and is equally injurious; and thus remedy lies by this writ.

3. But if the plaintiff presentor has no sort of seisin either of the possessory right or of the property by any colour of tenure of tenement, or other title in his right, therc can be no setting foot wrongfully, because he has no right upon which a man can set his foot either rightfuliy or wrongfully; and in this case the writ of Quere impedit does not properly lie, but that of Quod permittat. This writ of Quod permittat also lies in the person of a purehaser against his feoffor, if he disturbs him in using his seisin of the advowson which he has given to him.

1 The above section is a perverted paraphrase of Bracton, whose text, as printed, is somewhat obscure, but appears to mean, that where the plaintiff had not had seisin and did not claim property, but only an usufructuary or possessory right, his remedy was by Quare non permittit; so that if the plaintiff or his ancestor had had actual seisin by a former presentation, his remedy was by assise of Darreign presentment; if he claimed the advowson, and had not had seisin by himself or his ancestor, 
4. When the parties have appeared in court, the *disturbor may say that he has a right to clisturb the plaintiff, by reason that he and his ancestors have always presented, so that he is seised both of the one right and the other. Or he may say that he has not wrongfully disturbed, because he holds the tenement, to which the advowson is appendant, with all its appurtenances, by sale of the plaintiff or his ancestor, or by some other title, as by release, quitclaim, or otherwise.

5. And when any one, who bas lost the right to the presentation by judgment, or any other person who has not any right presents, and causes the clerk who lias already been instituted to be summoned to answer why he disturbs the plaintiff from presenting, the clerk may say that the plaintiff ought not to present save in time of vacation, and that the church is full and provided, wherefore he ought not now immediately to present. And if the plaintiff say, that the church is void, the court shall be certified thereof by the ordinary of the place; and according to the bishop's return the plea shall be determined.

6. One clerk may wrongfully molest another after he has been instituted, and after his patron has made good his right of presentation by judgment of our court. And because such molestation is prejudicial to our dignity, and tends to defeat that which has been his remedy was by Quare impedit; if he claimed only a posses. sory right as tenant in dower or by the curtesy, his remedy was by Quare non permittit. See before, c. 4. s. 16. 
legally done in our court, we will that such as are so troubled be aided by us and by our prohibitions, and by attachments in pursuance thereof, as well to the judges, that they hold not such plea, as to the parties, that they do not prosecute the same.

7. The bishop also pending the plea in our court may wrongfully incumber the church by his clerk within the six months. *Therefore if any one be apprehensive of this, let him purchase our writ of prohibition to the bishop that he do no such thing, or that he do not admit any clerk upon the presentation of any until the plea pending in our court be concluded, and in particular within the period of six months $;^{1}$

And if the bishop acts contrary to our prohibition, an attachment presently follows. And if he does not admit the clerks presented pursuant to our mandate, let him be immediately summoned to answer why he has not done so.

1 These words, which are derived from Bracton or Fleta, seem to imply some uncertainty as to the bishop's right to present by lapse where the suit is undetermined at the end of the six months. It has been held in later times, that if he is not a party to the action of Quare impedit, he may present by lapse. Consequently it is now the universal practice to make the bishop a party. See Iancaster v. Lowe. Croke's Reports, t. Jac. 93; Blackstone's Comm. vol. iii. p. 247. 'The bishop shall present in all cases, where there is disturbance and the king does not write to the bishop to certify him of the right patron within the term of six months. Which may be for diverse reasons; either because the court cannot take cognizance thereof so soon, or because the plea cannot be ended so soon, or cannot be encled at all for want 


\section{CIIAPTER VII. \\ Of the Assise of Utrum.}

1. The fourth assise is that of Utrum, which partakes very much of both rights, because both are determined by it. For after judgment in this assise there is no recovery except sometimes by attaint. By this assise recognisance is made whether the tenement, whereof the plea is brought, be the lay fee of the tenant or frankialmoigne belonging to the church of the plaintiff,-whether the clerk or the layman be plaintiff. ${ }^{1}$ For the assise may well lie at the suit of either, yet not of all clerks, but for such only as are parsons and rectors of parochial churches instituted therein by bishops or other ordinaries, *and also for canons in cathedral churches, and abbots and priors who have ehurches appropriated to their use, and are in the position of parsons; and this, although they

of proof of right; and although the court may certify, yet the collation belongeth to the bishop where there are several perceners, and they caunot agree.' (Note in MIS. N.)

1 Bracton informs us, it had been at one time decided that this assise could only be harl upon the plaint of the parson, but its extension was considered advisable, as it offered a means of avoiding the delays of a writ of right, and the decision by battlo $o r$ great assise. Brac. $285 b$. 
lave only moieties by reason of there being divers fees and divers patrons, for which moieties each patron may severally plead and be impleaded; though it would be otherwise of a thing held in common between them. And if any church is given to two parsons by one patron, neither of them can plead or be impleated by this assise without the other.

2. The Writ of Utrum in favour of the clerk was provided as his writ of right, beeause he could not comt by descent in the right. Thus, it is of the nature of a plea of right, and therefore they are limited by the same term. ${ }^{2}$ The proceedings in this writ are similar to those in an assise of last presentation. Nevertheless the tenant may vouch to warranty.

1. There are sometimes two parsons, or more; and this by reason that it was the original ordinance of the first patron, or because the church is founded upon divers fees, whereof each lord is patron and advocate of his own lordship.' (Note in MS. N.) Half-churches, and smaller fractions of churches, occur frequently in Domesday-book. Compare before, c. 3. s. 8.

2 It was said by Brumpton, Justice, in the Cornish Iter, 30 Edw. I., that the right of action in this writ was not barred by prescription of time. Year Book, 30 Edw. I. p. 207. 


\section{CHAPTER VIII.}

Of Exceptions in the Assise of Utrum.

1. The tenant may aid himself by his general and dilatory exceptions. And if the layman is tenant, he may plead that the church was never seised of the tenement demanded : and that, although it were at any time seised, yet the plaintiff cannot recover anything therein, for he hath received fealty and service for the same tenement; and if this be verified or not denied, *the assise shall fall at least for the parson's life. For in this case the taking of fealty bars the action, as in other cases the taking of homage, because homage excludes the demesne. The assise is also at an end if his predecessor aliened the tenement in fee to a layman, who has since obtained a confirmation of the feoffment from the bishop of the diocess and the patron.

2. The assise also fails as to any kind of tenements. given to cathedral or conventual churches, if the writ be purchased of such a tenement, because such persons have the same remedy as laymen; but in gifts made to parochial churches the parsons are not included, and therefore this writ lies only for them. In respect however of their own seisin, if they are ejected or disturber, they shall have remedy by assise of Novel Disseisin; and by writ of Entry upon a disseisin done to their 


$$
\text { II, *236.] OF UTRUM. }
$$

predecessor as long as the time will admit. The assise likewise fails, if the tenement be demanded in demesne where the church was never seised but of the seignory. So in some cases on account of a condition comprised and contained in the feoffment by which the church was enfeoffed. 1

3. When a layman complains against a clerk who is a parson, he does so either by a possessory writ by descent from some ancestor or by writ of right. If by a possessory writ, then the process between them shall be the same as it would be between other persons. If by writ of right, then the elerk has either a *warrant or not. If he has a warrant who will warrant to him, let the proceedings be carried on between the demandant and warrant as in a writ of right by battle or great assise or otherwise, as between any other persons. If he has no warrant, but defends the action, and answers for himself, in such case he has a double remedy by reason of the writ of right, and he may choose whichever he will; either he may put himself upon a jury, whether the land demanded be frank-almoigne, \&ce, or lay fee, just as if the layman had brought an assise ;not that the proprietary cause is thus turned to a possessory one, although the jury tries and determines both rights,-or he may defend himself by battle or

The nature of the condition alluded to is more fully explained in Bracton. It was not uncommon for a layman to enfeoff a church on condition of being re-enfeoffed to hold of the church ; and thus to make the land feudally subject to the church in order to obtain its protection. (Brac. 286 b.) 
the great assise, if permitted by the anthority of the ordinary and the consent of the patron.

4. Where a layman brings this assise, the clerk may answer and plead, that the ancestor of the plaintifl was never seised. And if he demands in demesne what he ought to demand in service, the assise falls, as before is mentioned in the case of a plaint by a clerk. And if the tenement was aforetime held of the church, and the plaintiff or his ancestor forfeited it by some judgment of felony, in such case the tenement is escheated to the church, and the exception of felony holds. Again, if the tenant dies without heirs, the tenement will also escheat to the church by reason of the mere right, which takes refuge and shelter there *for want of finding any other place where it may descend. But if the ehurch, or the parson in its name, has received nothing from the tenement except a payment by way of alms, nothing can thereby escheat to the church.

5. When the parties have pleaded to the assise, or when the assise is awarded by default of the tenant, and re-suinmons is proved, or when the assise is demanded by reason of the contumacy of the tenant, having been seen in court by record of the Iustices, if the jurors of the assise are present, and none of them is challenged, or, if they be, after the challenges of the parties have been tried, let them straightway be sworn in these words: "Hear this, sirs .Justices, that I will speak the truth of this assise, and of so much land with the appurtenances in $\mathrm{N}$., whereof I have made the 
view by the king's precept, whether the aforesaid land with the appurtenanees is frank-almoigne belonging to such a chureh, whereof the plaintiff is parson, or lay fee of the tenant' (or the reverse if the layman be plaintiff), 'and will not upon any account omit,' \&c. Afterwards let them be instructed and informed upon what point they are to certify the court. And let judgment be given aceording to the verdict. And when the assise has once passed in favour of the layman after the manner of an assise, and the tenement is adjudged to the lay plaintiff, the elerk shall never have any recovery but by attaint, the form of which will appear in the following chapter.

\section{*CHAPTER IX.}

Of the nature of an Oath, and of the process of Attaint.

1. An oath is an affirmation or denial of anything, whereby a person is charged upon peril of his soul to speak the truth; and it was provided on account of people difficult of belief that oaths should be taken upon the Holy Gospels of God for avoidance of idolatry. Oaths were instituted that men might thereby do good service; for by means of an oath many crimes are convicted and punished, and many a man doth by an oath great good and great service to his neighbour. It was likewise provided that one should swear by God and not by his creatures, or his members, to avoid the sin of blasphemy, and that none should swear but with an interition of doing service by the oath, upon nec- 
essary and just occasions. An oath therefore is allowable when the conseience within agrees in every point with the lips, without any addition or abatement; and if there be any disagreement, it is perjury.

2. If any one wilfully perjures himself in obedience to his superior, both of them are to be punished with the same penalty. And he who causes or procures another to take an oath well knowing that he swears falsely, as well as he who knowingly admits such it false oath, is in relation to God a homicide, although he do not kill the body, but is partner in the *felony, forasmuch as he knowingly destroys the soul of him who at such peril takes the oath; and they consequently destroy their souls who are consenting. The like is true of him who is present and hears the oath without speaking and reprehending it. Perjury is a lie atfirmed by oath. A person may be guilty of this sin in three ways; first, where he who knows or believes a thing to be false affirms it by his oath to be true; secondly, where one is deceived and thinks a thing to be true which is false, and declares it upon his oath; thirdly, where he who says upou his oath that something is true, which in fact is so, yet in his eonscience belieres it to be false, as when the Jew swore that Saint Mary was the mother of the Son of God. A lie is a false expression of the voice with an intent to deceive; and this sin is so poisonons that no one onght to be willing to lie, even to ransom another person's life.

3. Of oaths some are promissory respecting the future, and of such oaths there are three kinds. The 
first is where any one promises by an oath that he will tho or assist in something which ought not to be done, as feloniously to kill a man; and such an oath ought not to be kept. The second is where a person swears that he will do something which he may lawfully do, and this solemnly, but without necessity or reason, and in so doing he is guilty of sin. The third kind of swearing is that which proceeds from a levity in talking and from a bad habit; this kind of swearing is sinful, but less so than the former. *But of these three kinds of oaths we shall not speak in this chapter; for they are not subject to any earthly attaint, nor is any oath except that of assertion, which relates only to time past or present.

4. Therefore if it happens that the jurors in any petty assise have taken a false oath, they may on the complaint of the losing party in the assise be attainted in several ways. Sometimes upon the oaths of twentyfour jurors, sometimes by their own acknowledgment upon examination by the Justices, and sometimes by their repentance and of their own free will; and in the last case there is room for mitigation and mercy. Therefore when any one desires to attaint any jurors, it must be seen how many and what jurors were open upon the assise, so that each juror may have two attainors at least; but if there be more, it is no harm. It is also proper that they be of equal or better conditions than the jurors. ${ }^{1}$

1 The attainors ought to be persons of better condition than the jurors; and therefore the writ says : Summone xxiiii. milites ; whereas it is said in the writ of assise : summone xii. legales homines.' (Note in MS. N.) 
5. Of this offence sometimes the Justice is guilty and sometimes the jurors. But whoever is in fault, credit must always be given to the enrolment of the record of the Justice until it be altered by judgment. Therefore in the first place, before the attainors are summoned, the proceedings and record of the Justice should be examined; for if he only is found to be in fault, it is not to be imputed to the jurors, nor the reverse. *Therefore after examination of the record, and not before, it may be immediately seen whether the assise was taken as a jury, or as an assise. If it was taken by way of jury, then every one may have remerly by attaint; if by way of assise, then an attaint lies only for these persons and their heirs who were seised in their own names, and not for those who were seised in the name of others, as villains, termors, bailiffs, $\mathrm{Or}^{2}$ guardians.

6. It is not the duty of all Justices to take attaints or certifications. For it belongs to those Justices who took the verdict of the assise, to take certifications, so as they do it before they are removed from their office. But it belongs not to those Justices who took the recognisance of the assise to take attaints after judgment given; because we liave reserved the amendment of judgments for our own jurisdiction. But if the Justices at the taking of any assise are required before judgment given to attaint the jurors of the assise, they may immediately, ${ }^{1}$ upon security and pledge of the party, cause the jury of twenty-four attainors to be taken if

1 See the note to chap. xi. s. 2 , below. 
they are present, as well as upon a eertification. For since the full power is given them to hear and determine the whole matter, *they are authorized to acquaint themselves with every thing neeessary to clear the way to their judgment. And where certification or attaint is accessory to the assise, and the Justices see that without certification, or without attaint, they cannot proceed to judgment to determine the assise, it appears, and true it is, that it belongs to those who have full jurisdiction to determine that assise, to take such attaints and certifications, provided it be presently done; for if not, this duty does not belong to them, neither ought this authority to be granterl to them. ${ }^{1}$

7. Although it is contained in the Great Charter of liberties that some assises shall be taken in counties, yet it shall not be understood that certifications and attaints must likewise be taken there. For that is not necessary except in eases where no anthority is given but upon the assise. But if any Justice be assigned with fresh power to take an attaint or certification, then it will not be necessary by virtue of that statute to take it in the same county. For assise, certification, attaint, and jury differ in their privilege and nature.

8. When the attaint is brought, the verdict of the assise ought to be thoroughly examined, in what

1 - When the Justice, out of favour for one party, allows a. false verdict to pass, how shall the falsehood be punished? Responsio. Either by the Judge himself, by resummoning the parties, or by another Justice; and this by attaint, or by bill to the king's council.' (Note in MS. N.) 
manner the twelve jurors pronounced their verdict. For jurors sometimes swear falsely with full knowledge of what they do; and then are more openly perjured and are more severely to be punished than those who are forsworn through some indiscretion. *For some persons lie openly, when conscience does not rest in their thoughts. Others swear falsely, and lie through a foolish hastiness, which does not come directly from their thoughts, as in the case of those who pronounce their verdict before they have thoroughly examined their thoughts, and these are less punishable than such as perjure themselves with malice afore-thought against their conscience. And some are forsworn by a foolish verdict, not being. aware of it on account of a presumption that appears true, but is not so; and if they can make it plainly appear how they were deceived, some extenuation should be had as to their punishment, but not as to the rellessing of their judgment.

9. Where the jurors luave said too little for want of examination by the Justices, or have given their verdict too obscurely, or have not answered fully, as, if they have concealed any part of the truth, being induced thereto by some mistake, in such case the better remedy is by certification than by attaint, that by such certification the jurors may render certain what is uncertain, and reduce to truth what was doubtful and erroneous. But if the record is not found defective or insufficient, but full and sufficient, then there is no room for certification; for the jurors cannot gainsay or challenge the reeord. 
*CHAPTER $\mathrm{X}$.

\section{In what cases an attaint lies.}

1. In the examination of every record, before the attaint is granted or takes place, it must be carefully observed whether the assise passed in form of assise upon some material point in the writ, or by way of jury, and whether it was taken in the presence of the tenant or not. And if it passed upon any exception, then it must be seen whether the exception was dilatory or peremptory ; and if peremptory, whether peremptory of the writ only, and not of the action, by reason of some mistake in the name of a vill or of a person, which does not affect the assise, or peremptory of the assise as well as of the writ. In the former ease attaint does not lie, although the verdiet of the jurors may have been mistaken or false, on account of the assise and the action remaining entire. In the latter case, as, where any person demands by the assise a tenement where he ought to have demanded a rent, if the jurors find for the plaintiff, an attaint lies by reason of the falsity.

2. If the writ is suitable and good, the plaintiff must offer to prove the whole of his case by the jurors of the assise; and where the tenant consents, and straightway puts himself on the assise, if the jurors make a false verdict, it is a proper case for attaint; as if they 
* find that the tenant disseised the plaintiff, where he did not disseise him at all. Sometimes also an attaint may be brought upon their verdict as to matters. which touch the substance of the assise, as where they find that the tenant hath disseised the plaintiff of his freebold, whereas he never held except in villenage, and in like cases. It lies also upon a point of their verdict concerning some exception, although not concerning the action or the assise, where the verdict does not pronounce simply, but adds a reason, as that the plaintiff could not have a freehold, because he is a villain, and holds the tenement in villenage, whereas this is false, because the man is free and holds freely,-and in the reverse case; - if this plaintiff can afterwards by four-and-twenty jurors prove himself to be free, and that the first jurors gave a false verdiet, attaint lies, because the assise was charged with the substance of the plaint, and not with an incidental matter for a jury.

3. If the plaintiff had simply denied the exception of the tenant, and said that he was free, and was ready to verify the same by the jurors of the assise, in such case, whether the proof were male against the plain. tiff by the jurors or by evidence of suit of kindred or not, although the jurors gave a false verdict, yet no attaint would lie, because the parties of their own consent put themselves *upon their verdiet, as upon a jury, to prove the exeeption; and whether they find for or against the plaintiff, yet his eondition is not rendered better or worse or in anywise altered by thrir 
verdict. In such cases the proof always lies upon the tenant; and if the plaintiff in answer to the exception of villenage says that he is free, still it lies on the tenant to prove his exception, unless the plaintiff chooses to prove the negative; and if no suit be brought of the lindred of the plaintiff to make good his exception, then of necessity it must be proved by the jurors.

4. Although the tenant should tacitly admit the declaration of the plaintiff, yet the assise may be stayed by some exception, as by setting up some deed against the plaintiff, such as his writing of covenant of some condition or other title. Aud if the tenant offers to aver this writing to be the deed of the plaintiff or of his ancestor whose heir he is, and this is either verified or not denied, the assise and the action fall. And if the deed is clenied, in that way the assise and the action are brought at an end, and a new plea begins upon the proof of the covenant. This may be proved in several ways; somctimes by the deed and the witnesses therein named, and sometimes where there is no charter, by the jurors of assise, and this will be done in the form of a jury, if the parties *consent, and then no attaint will lie; and if the plaintiff will not consent, let him take nothing by his plaint, and if the tenant refuses, let him be treated as without defence.

5 . The same reason holds in the exception of villenage; for in such case the tenant must prove the villenage, and according as the proof turns out for or against the plaintiff the action will be determined. Yet when the tenant alleges that the plaintiff is his villain, it. is 
not necessary to prove the exception by the kindred of the plaintiff ; for such proof, if made against the lord, might be prejudicial to him and would afford the plaintiff a strong exception in a plea of Naifty, if ever the lord chose to claim him as his villain. ${ }^{1}$ But if the lord is sure that the proof will be made against the villain, that he was his astrer, ${ }^{2}$ reseant in his villenage, and he in seisin of him, with his chattels and his suit, as of his villain within the year, in such case the proof may well pass by the kindred and by the jurors of the assise, and thus, if the plaintiff consents, both the status and the assise will be determined.

6. But if the plaintiff says that he is free and of free condition, and demands award and judgment, whether he ought to put himself concerning his condition upon the assise, before full restitution of all his goods moveable and immoveable, in such case the asssise shall cease, and the tenant will be forced to proceed by writ of Naifty, supposing that the villain is a run-away, and not to be found within the lord's fee. *And if the exception of villenage be tried and proved by the assise by common consent of the parties, yet such proof shall not be prejudicial to the condition of the plaintiff, neither does any attaint lie. For the effect of the exception is not to prove the plaintiff a villain, but to bar

1 This agrees with Fleta, 1. 33\%. It would appear from Bracton, that the objection to the proof by suit of kindred, where the alleged villain was not actually in his lord's seisin, was rather founded upon consideration for the villain than for the lord. (Brac. 290.)

2 See before, p. 456 , note. 
him from taking anything by his plaint. And thus it appears that in these two exceptions of covenant and of villenage the assise remains entire, although it be altered by some collateral matter determined by jury.

7. Where the assise is taken in the absence of the tenant, or if he is present and alleges no cause why the assise ought to be stayed, but forthwith puts himself thereupon, in such case, whether the jurors find for the one party or the other upon the points of the writ, supposing they find what is false, or if they say that there was a covenant, as aforesaid, where there was none, or that the plaintiff is the villain of the tenant, when he is free, or that he is a bastarl, when he is legitimate, or other like thing,--in all these cases an attaint will lie. And whereas the substance of the original writ ought to be contained in the writ of attaint, it follows, and it is true, that an attaint does not properly lie except upon the points of the original writ.

\section{*CHAPTER XI.}

Of the Excuses of Jurors in mitigation of Attaint.

1. Where the tenant is absent at the taking of the assise, the jurors are then more liable to err, inasmuch as they are not instructed by any one how to find for the tenant; and if they should forswear themselves, a probable error ought to excuse them in the attaint, so that they may be spared the penalty either in part or entirely, according as the error has been gross or slight, rightful or colourable. 
2. Ittaint never lies in the great assise, because the tenant puts himself thereon by his own election. But in petty assises there is frequent occasion for it. Many oilths are taken upon which no attaint lies, as an oath taken by one man alone to another, for in that case vengeance belongeth only to God. Moreover no attaint Jies upon the verdiet concerning damages, ${ }^{1}$ nor in certifications, nor in purgations, nor in defences by wager of law against the suit produced by the plaintiff, nor generally in inquests or juries, except by our special command.

3. With respect to jurors, in order that the punishment upon attaint may be mitigated, it must be observed whether the error be patent or secret; for if it be secret, as it frequently happens in contracts made secretly between the parties where two or three only are privy to it, *in such case the jurors, from their ignorance of the contract, may be easily mistaken, and such error is excuable. But of a thing done openly, so that the greatest part of the country lnows it, an error is not excusable.

4. Where the jurors relate the whole truth of the fact just as it happened, and judgment is given accord.

${ }^{1}$ So Bracton and Fleta say that an error in danages is not a - case for attaint, but for certification by the jurors. But in the Cornish Iter, $30 \mathrm{Edw}$. I., Berewick, Justice, being dissatisfied with the verdict of an assise upon the point of damages, warned the jury, that there might be an attaint as well for the damages as for the principal matter, and that immediately, without issuing a writ out of the Chancery. (Year Book, 30, $31 \mathrm{Edw}$. I. p. 124.) As to the immediate attaint, see before, c. 19. s. 6. 
ing to the verdict, if error be found in the judgment, the dustices are in fault for the folly of their judgment rather than the jurors for any false oath. 'Therefore the Justice must needs make diligent examination into every verdict, whereby matters which are doubtful or erroneous inay be reduced to certainty and truth. And if any difficulty arises in giving judgment, it is needful to advise with one more learned. For it is safer for a Justice to be in some doubt as to all matters than to be too conficlent in his own opinion; and repentance often follows upon rash counsel, and still oftener upon rash judgment.

\section{CHAPTER XII.}

Of the Trial and Judgment in Attaint.

1. The writ of attaint being obtained, and the party summoned, he has a right to be essoined at the day. And when the parties on the second day are present in court, but the attainors are not, let another day be given to the parties, and the attainors * be required to find security and pledges to appear at the same day. And if the party summoned makes default, let him be attached to be there some other day. And if the plaintiff makes default, and the party attached or summoned offers himself, the writ falls, and the jurors shall go without day, and the plaintiff and his pledges to proscute remain in mercy.

2. When the parties, the jurors, and the attainors 33 
are present in court, and the party summoned or attached alleges no exception why the attaint ought not to pass, then in the first place let the record of the assise be heard, to wit, how it passed. Next, let the plaintiff be asked in what points the jurors of the assise are perjured, whether in the articles of the writ, or upon some exception, such exception not having been put forward by the tenant, but only by the jurors of the assise in their verdict, when they were charged to find upon the whole matter of the assise. Thereupon let the attainors be charged by their oath to speak the truth; and the oath whereby they shall be charged shall not be the oath of assise, but the oath of jury. And after they are sworn, let the form of the plaint be forthwith shown to them, and upon what points they are to speak the truth; as for instance, whether he who complains has been wrongfully disseised or not. And let them be informed of the plaintiff's case.

*3. When the jurors are returned, and are ready to give in their verdict, their reasons ought to be strictly examined, so that manifest truth or presumption at least may be on their side, and their verdict grounded on probable reasons; and according thereto let julgment be given. For sometimes they may be as easily deceived by some probable error as the first juror's, and thus for want of good examination by the Justices a false juclgment may be given.

4. If the attainors cannot agree in one opinion, let them be afforced by others. And if they say that they know nothing of the fact, or that they are in doubt, so 
that they cannot fully declare the truth, let the posses. sion remain undisturbed. So, if they are agreed, and find against the plaintiff in the same way as the jurors of the assise, the possession shall remain as before, and it shall be adjudged that the twelve made a lawful verdict, and that the plaintiff be committed to gaol, and there punished by imprisonment and fine.

5. If the last verdict is contrary to the first, it follows that the first jurors will be attainted of a false oath; and it shall be awarded that the plaintiff recover his seisin, and the tenant be in mercy, and that the first jurors, if they are present, do for ever after lose their free law, so that thenceforth they shall not be credited upon any oath, and that their lands and chattels be taken into our hand, and they be sent to gaol, and there put to ransom. *And if they are absent, it shall be commanded that they be taken. Some jurors however may be sometimes excused with regard to the loss of their free law, although they be not as to the ransom, namely, those who through tenderness of conscience before the exhibition of any plaint confess they took a false oath by reason of some probable error, and pray that they may amend; and in such case, if all the jurors pray to amend their verdict, the attaint need not pass by writ, but the parties should be called to reverse the judgment.' The jurors however are

1 Casus. A parson brings assise of Utrum against a lay tenant. The twelve jurors, against their conscience or by a misguided conscience, (ou de conscience blesmie,) say that the land is frank-almoigne belonging to the church. The parson 
punishable by simple fines only; and if all the jurors do not repent, yet those who do so shall have the benefit of their goodness.

6. An attaint may be barred from passing in several ways, as where judgment was never given upon the proceedings in the assise, the Justices being divided ; or although it was given, yet it was never put in execution ; or although it was partly put in execution, part of it still remains to be performed. It is likewise often stayed by agreement of the parties, and in that case let seisin be exeeuted by judginent aecording to the reeord of the Justices. *It onght also to be stayed where the fault is in the Justice, which may be owing either to a foolish juclgment or to error in the enrolment, or because the Justice would not allow the party his reasonable exceptions or his reasonable challenges of the jurors ; and in such eases the proceedings are to be restored to the state they were in at the time of the exception being put forward. An attaint ought likewise to be stayed where the plaintiff is tenant of the tenement which he lost, or of part of it, by his own intrusion, or by redisseisin, because he has lost his right to recover by judgment a thing which has obtained by his own foree in despite of the law.

7. As an assise is not to be taken upon an assise, so neither is an attaint to be taken upon an attaint, that is, between the same persons, of the same fact, and of

takes possession. Then the jurors, except two who are dead, come before Justices, and acknowledge of their own accord that they made false oath. Quid juris?' (Note in MS. N.) 
the same thing. Yet two attaints may follow one assise, as where the jurors ought to have given or taken away the whole, when they gave or took away part only ; ${ }^{1}$ not however by different attainors, but by the same jurors, to avoid the peril which might ensue if there should happen to be a contrariety between the different attainors. And although an attaint should have once passed, yet the attainors may be aided by certifications in the same manner and in the like cases as in verdiets of assises.

1 In this case each party might complain of the verdict, and therefore there might be two attaints. See Bracton, f. $295 b$. 


\section{BOOK V.}

OF PLEAS OF DOWER, AND ENTRY.

\section{${ }^{*}$ CHAPTER I. \\ Of the Nature of Dower.}

I.

Matrinony is no other thing than the union of a woman with a man with the consent of both by junction of Holy Church, to live together as one flesh all their lives without expectation of separation. Therefore it is expedient that married women should be endowed, in order to give women the better disposition to love matrimony, although dower is prejudicial to the lords of fees, that is to say, such dowers as are incident to matrimony. Dower is that which a freeman gives to his wife at the church door in regard of the charge of matrimony, and by way of consideration for the marriage, for support of the wife and nurture of the children to be begotten, if the wife shall survive the husband.

2. Dower is not assigned in all places nor at all times but at certain, to wit, at the commencement of the contract and at the door of the church only, with the solemnity of witnesses and not in private. For as secret marriages, performed in private, are prejudicial to 518 


\section{II, *247.] OF THE NATURE OF DOWER. 519}

heirs with reference to the succession, so are they prejulicial to wives with respect to the recovery of their dowers. The nature of dower then is such, that where espousals are solemnized at the church in the presence of the people, in such case and not otherwise dower may be demanded. ${ }^{1}$ *And if the marriage be in any

- Every contract of marriage, at which there is present a parish priest (prestre parochiel) and his clerk, is at the church door, and sufficiently solemn; for it is in facie ecclesice. And because usage of dower is become law, a wife is sufficiently enlowed thongh her husband say nothing. But suppose that the husband protests distinctly and solemnly at the time of the marriage, that he does not intend that his wife shall be in any way endowed after his decease, and this is a known and notorious fict; quostio, whether she ought to recover dower or not. Responsio. It seems not, for if the husband had established her rower in certain, however much less than might have been proper (qe ne affierreit), and she had agreed thereto, she would be barred ; so in the other case, when she agreed to the marriage without having dower, she cannot have her action for dower. Contra. Dower is accessory to marriage, and, the principal established, the accessories are also established. (Vermm est, if it had not been contradicted by the husband.) Further, dower was ordained by common constitution of people: and cannot be undone by any single person. For if by one, then by another, and so the constitution would be destroyed ; quod non est permissum, ne pereat lex approbata.' (Note in MS. N.) The reasons here stated against permitting the common rights of the wife to be taken away by private agreement so far prevailed, that before the time of Littleton it becamean established rule, that the wife might, if she pleased, after the death of her husband refuse the dower established ad ostium ecclesia, and fall back upon her common law right. (Vet. Nat. Brer. 6. b. ; Litt. Ten. s. 41.) The restriction of dower ad ostium ecclesice to a third, hat also 
way dissolved by judgment in their lifetime, the wife has no right of action for recovery of dower, unless there was a special clause granted by the husband in the first contract, that if a divorce should happen, she should have a certain provision for the term of her life or otherwise; and such specialty made for dower beyond the general assigmment of dower, shall entitle her to an action.

3. Dowers are sometimes given by the father, grandfather, or other kinsman or friend of the wife, of certain land or tenement, or of part of their chattels. And sometimes land, tenement, or ehattel is given by the wife or some of her kindred or friends for the marriage. Reasonable dower is sometimes increased by an addition from some kinsman, which may happen as well after the espousals during the marriage, as at the time of the espousals; and this increase, whether the gift be made solely to the wife or to the husband and wife jointly, does not fall into division or partition, provided the gift be simple and absolute, and not in consideration of the marriage. ${ }^{1}$

t. Reasonable dower in knights' fees and grand ser-

at that time been abolished. (Litt. Ten. s. 39 ; Co. Litt. $34 b$. ; Fitzherbert, Nat. Brev. 150 P.) The Statute 27 Hen. VIII. c. 10. by which a jointure might be made in bar of dower, was a restoration of the old law in another form.

1 This must be understood by reference to book iii. chap. 8 . sect. 8 , where it is said that a colheiress claiming her part of the inheritance is bound to bring her estate in marriage into hotchpot. Compare Bracton f. $92,92 b$. 
jeanties is the third part of all the lands, together with the fees and services, which the husband held in his demesne as of fee on the *day of his marriage, and whereof he could afterward endow his wife. ${ }^{1}$ In socagres, free farms, petty serjeanties, and other fees, let dowers be granted according to custom. Reasonable dower does not extend beyond this, but the wife may be endowed of less, if she is contented to be so. And if there should be any excess, as sometimes happens from too large an assignment by guardians, while the heirs are under age, such excess may be revolied by writ of admeasurement of dower.

5. Wives are not only dowable of the lands and tenements whereof their husbands were seised in their. demense as of fee, but they may be endowed also of any lands which are to revert to the heir of the husband upon the death of a tenant holding only for term of life. ${ }^{2}$ And in that case the widow shall wait until

1 The right of the wife to be endowed of land acquired after the marriage is somew hat ambiguously stated. Compare below, chap. 2. s. 4 ; Hengham Parva, cap. 3. p. 87. This right, which did not exist in the time of Glanvill, and is not admitted by Bracton or Fleta, was held to have been given by Magna Charta, cap. 7. See the Year Book, Mich., 5 Edw. II. p. 133.

2 This should be understood of an express establishment of dower, not of dower by common right. Compare the parallel passage in Bracton f. 93. 'Case. A. has four carucates of land, and aliens one carucate to D. for his life. A. afterwards takes wife, and dies. His heir $B$. enters, and assigns one carucate to the wife in dower. D. the termor dies. Qucestio. Shall the wife have the third of this land? She shall not, for the 
the death of such tenants, unless it was otherwise agreed in the first contract, that some tenement should be especially assigned to her to hold in tenancy until the land so assigned to her after the other's death should fall in.

6. Although dower may in the first instance be assigned as well of entire manors as of the third part of all the manors, yet that manor which is the head of the barony or county shall remain entire to the heir, if the widow can elsewhere have her dower. * But if there are several capital manors of several baronies or counties, and the widow cannot elsewhere be fully endowed, in such case she must be endowed thereof by necessity, which orercomes law and usage.

\section{CIIAPTER II.}

\section{Of the Establishment of Dower.}

1. Dower, properly speaking, is established by husbands on their wives, and is assigned by the heirs in pursuance of the establishment of the ancestor. And it may be so established from the beginning, that the insband may assign to his wife some certain thing for her dower, if she is satisfied therewith, yet so that if such certain thing be sufficient for her reasonable dower, it shall remain entire; if there be any deficiency, it shall be made up to her ; and if there be any husband had nothing of the demesne the day he married or ever after.' (Note in MS. $N$.) 
excess, it shall be restored to the heir. And as wives may be endowed of certain tenements, so they may also be endowed in a certain sum of money or goods, so as they be contented therewith; and if such wives survive their husbands, they cannot demand for their dower more than according to the first appointment. And if the chattels of the deceased are not sufficient, their recovery shall be for the difference. ${ }^{1}$

*2. It may happen that dower is established by a husband not on one wife only, but on several, whether they be all living, or on one after the death of another, or after a dirorce pronounced between husband and wife. For it has sometimes been, that a man from wickedness has married several women, all living at the same time; but Holy Church says that of such women none but the first is his lawful wife; wherefore the law regards the others only as false wives or con. cubines; and therefore they are excluded from any action of dower. Sometimes however she takes the dower who was found last seised of the husband; and sometimes none of them have dower, as will be mentioned

1 The expression here is obscure. Bracton says in effect, that when a burgess, or other, endows his wife with a sum of money, whether he has lands or not, she can ask no more out of his tenements or chattels, but may insist on having the full amount named, quamdiu ibi fuerit unicus obolus, so far as the chattels of the husband will extend. And Fleta says, more distinctly, that such dowers cannot be demanded except so far as the chattels of the deceased suffice to pay them. See the passages cited in the margin above. 
afterwards. ${ }^{1}$ So, on the other hand, one woman may be married to several husbands all living at the same time; yet although dower may have been established on her by each husband, she shall not have dower of them all. For she is the wife of one only, and concubine to the others.

3. If dower be deceivably established of all the tenements which the husband shall purchase, yet whereas it may happen that he may never purchase any land, and the widow ought not to be without dower, if the husband had lands in demesne and in fee, such an appointment is treated as an appointment of reasonable dower according to the nature of the fees and the custom of the place. For the law assists the deceived rather than the deceivers.

4. Dower can be established only of such tenements *as the husband held on the day of his marriage, or shall afterwards have held in fee to him and his heirs, whether the heirs be comprehended in the purchase generally or specially, and whether by a tacit condition in fee $^{2}$ or by being specially named, as thus : to such a husband and to his heirs which he shall beget, and if

1 It appears from Bracton that the last possession prevailed where there was no proof of the legality of another marriage. But where no wife was in possessiom, and no sufficient evidence which claimant was the lawful wife, no dower was assigned. Bracton, f. 94.

2 These words possibly refer to an estate given in frank-marriage, which was subject to a lacit condition in farour of the donor and his heirs. See Stat. West. 2. (13 Edw. I.) c. 1. 
he shall have no issue, or if such issue shall die or fail, that the land thus given shall, alter the decease of the purchaser, return to the donor and his heirs. In such a case, if the husband has issue, although such issue die and fail, the wife shall not be thereby barred from having her dower; for, although the gift was in the beginning conditional and the fee in suspense vet by the birth of issue the feoffment becomes simple and absolute, ${ }^{1}$ and thus an action of dower accrues to the wife. So is it as to tenements purchased in all other cases where the fee is in suspense, and depends upon an event; for if the event named in the feoffment happens, then a fee thereby accrues to the purchaser, so that the gift which was at first contingent and conditional, becomes simple and absolute; and according to the event an action accrues to the wife to demand her dower or not.

5. Moreover, dower which is established out of lands and tenements which the husband wrongfully holds, as being the right of another, is invalid, if without fraud he loses them by judgment in his lifetime, or his heir after his death. "But as at man may enclow his wife out of his own property whether definitely or indefinitely, so he may do it out of lands belonging to others, as where at husband endows his wife with a rea-

1 The Statute de rlonis conditionalibus (Stat. West. 2. (1:3 Edw. I.) c. 1.) had recently been made when this was written. and the doctrine here stated appears to be that which prevailerl before the judicial exposition of that statute. See Coke, Inst. pt. ii. p. 335 . 
somable dower of the inberitance held by his father or mother, with their consent; for such endowment is ineffectual unless the owner of the land is present, and solemnly assents thereto at the church dloor. And although there be a deed witnessing the act, yet it is invalid unless it be made or at least allowed by the tenant of the land at the church door, and this by reason of the words in the count, which ought to say, "whereof he endowed her by assent of his ancestor at the church loor;' for if she counts that he assented elsewhere, the count is defective, and the writ will be abatable for the variance between it and the count. But reasonable dower may sometimes have been established by a man on his wife; and if the heir in the lifetime of the ancestor and his wife, with the assent of the ancestor, endows his wife of the third part of all the linds of the ancestor, such endownent will be prejulicial to the first wife. He must of necessity therefore endow her only of the third part of two parts, and of the third of the third part when it shall fall in. So in the reverse case,--if the ancestor take a wife whom he has to endow after the heir has endowed his wife of the third part of the whole by the assent of the ancestor. ${ }^{1}$

1. If the father be sole and without a wife at the time when his son endows his wife by the father's assent, and the father take a wife afterwards, he cannot endow her except of the third of two thirds; and on the death of the father and son. the son's wife shall have her action to have dower out of the whole. And where the father and mother are joint purchasers and the son endows his wife by their assent, constat. that this is of a third of 
*6. When dower has been once legally established, it cannot be increased to the prejudice of the heir by any agreement between the ancestor and his wife after the marriage. And as it cannot be increased to the prejudice of the heir, so neither can it be diminished to the prejudice of the wife.

\section{CHAPTER III.}

Of the Assignment of Dower.

1. After the husband's death, the establishment of dower is first confirmed. Wherefore let the dowers of widows be forthwith assigned and delivered to them according as they were established, without asking any fine or using any oppression, and not only their dowers, but also the tenements which were given to them in marriage. And because it is improper that such wives should be thrust out of doors with their husbands' bodies, without having a place to lodge in, it is allowed by law and custom that they may abide in the capital messuages which belonged to their husbands forty days after their husbands' deaths, and that in the meantime

the whole, and if the mother dies, and the father takes another wife, the endowment of this wife takes nothing from the son's wife's dower first established. But suppose the father dies, and the mother takes another husband, who has issue by her, and the mother and son die in one day; $q u$. whether the second husband shall hold the whole by the curtesy, or the son's wife have her dower.' (Note in MS. N.) 
their dowers be assigned to them, unless the capital messuage be the *head of the comty or of a barony, or a castle; in which case some other decent house shall be provided for their dwelling, where they may keep their quarantine; and that wheresoever they abide they shall have suitable maintenanee out of the profits of the whole of the lands until their dowers be assigned and delivered to them, aceording to the appointment made at the church door on the day of marriage, in the same state in all points, with the fruits, rents, and all the appurtenances, as they were on the day of the death of their husbands; and that which has been taken or gathered in the meantime shall be restored to them.

2. But where any husband has aliened his inheritallee in his lifetime by feoffment or farms either in part or in the whole, in such case the tenants are not obliged, whether they will or no, immediately to render to the wife her dower, because they have great reason for retaining it, until they are compensated to its value, so far as the law will permit. But if anyone wrongfully delays the rendering of dower, he is obliged to make satisfaction to the wife for her damages, though not in all cases. For if the wife brings her plaint by writ of dower patent demanding the tenements aliened in - the lifetime of her husband, by this writ she ought not to recover damages, as will appear in its proper place. But if she complains by the common writ of dower close, and demands her reasonable dower, she shall by this writ recover the third part of all the tenements which her husband held in demesne and in fee as his 
own right on the daty of his marriage with her, and also of all such tenements as were his after he married her; and if she can prove that she has been wrongfully delayed in obtaining her dower, in such case she shall recover damages, but not where the deforceor has a good reason for keeping back the dower, as before is mentioned. And let him restore the damages who shall be found guilty of the wrong.

3. In some instances the widow shall recover more than the third part, according to the nature of the fee and the custom of the land. For there are many tenements in which reasonable dower extends to a moiety of the land, as is the case in some socage tenements; and in such cases the custom of the country and of the place is to be observed as law.

4. Sometimes also she has a right to recover a certain quantity for her dower pursuant to the establishment of her dower; and in that case let her recover by writ of dower named. And if the dower so specifieally named exceed the value of reasonable dower, the heir may recover the excess by writ of admeasurement of dower. But if that specific dower does not amount to the value of the third part, or to the value of reasonable dower, she must be contented with what there is. *For more than the dower named she cannot claim, since at the establishment of it she was contencled to take it. But if she was not so contented at the establishment, and can verify her dissent, then she shall recover the difference to the extent of the value of reasonable dower. So likewise if she can aver that in the 34 
establishment a condition was made, that if the dower named did not amount to the value of reasonable dower, the difference should be assigned to her to the extent of the value of reasonable dower. And by means of this writ she shall also recover damages against the wrong doer when she shall have recovered her dower. And in like manner shall widows recover damages for the wrongful detainer of dower established out of the tenements belonging to another.

5. Dower onght to be assigned as a whole, and not by parcels; that is to say, the third of all the lands and tenements which the husbands held in demesne and in fee, as well of villenages, knights' fees, services of freemen, and advowsons of churches, as of demesne land. Unless however in the original establishment of the dower special mention was made of adrowsons or third presentations, the widow cannot demand anything for dower in an advowson or presentation, because the advowson of a church is not partible, neither would it admit of division. ${ }^{*}$ *But where the dower was established of an entire manor with all the appurtenances, without any reservation, if the advowson of a chureh be appendant to the manor, the advowson belongs to the dower, and the widow will have a right

1 Bracton states, that, where there were several advowsons, the widow should have her share of them as entireties; but where there was only one, it should not be divided, but she should have satisfaction for its value. If not so satisfied, he suggests that she ought to bave the third presentation. Compare Butler's. Coke Litt. 32 a, 32 b, note 197 . 
to present when the ehurch becomes vacant. For these worls ' without any reservation' are equivalent to a special establishment of the advowson on the wife.

6. In the assignment of dower widows cannot claim anything in mansions or castles which are heads of baronies or counties, nor in mansions in other fees where there is but one capital messuage, nor in preserves of deer, vivaries, hays, stanks, parks, or gardens, nor in the fosses of the messuage, nor anything within the close of the capital messuage beyond her quarantine, unless the heir chooses, so long as the value of her dower can be assigned to her in land, rent, or other thing elsewhere. But let one of the houses of the villain tenements be assigned to her to $d w e l l$ in, and let her be content therewitl. And if there be no such, let her be provided with a plot of ground in some convenient place to build and $d w e l l$ in, and let that be assigned to her in length and breadth in proportion to the third part of the messuage, but not to the value of the third part of the building; and let a sufficient messuage be erected for her out of the issues of the entire inheritanee. But if the heir cannot assign her the *value elsewhere, then of necessity he must endow her of the third part of whatever he has, saring the adrowson of a church, unless special mention was made thereof in the establishment. But dower shall never be assigned of deer or other game, nor of other beasts in parks or chases, nor of fish in waters, nor of homages. Yet in fisheries where the profits are casual, sometimes the third draught may be assigned, 
so that the heir may fish twice and the widow the third time.

7. If a writ of right is to be brought and pleaded, this jurisdiction does not belong to the dower, nor indeed to the court of any one who holds only for term of life; but it must be determined in his court of whom the plaintiff claims to hold the tenements demanded by homage, although he may hold of some other person by fealty. Neither does it belong to dower to have authority to hold view of frank-pledge, or to take cognisance of pleas de retito namio or to have estray or waif, or the correction of assises broken, or the franchise of infangthef, or wreck, or any regal franchise derived from the prerogative of our Crown. For such pleas are pleadable by the heir and his bailiffs, although the widows be endowed of the entire manors to which the franchises belong.

*8. Dower being thus assigned to widlows by certain limits and bounds, the wardships, marriages, reliefs, escheats, perquisites of courts, and pleas of their tenants, and all manner of profits issuing out of the dower, shall belong to them, unless they are barred by some special exception. The escheats however shall be theirs only for the term of the dower. And whereas dower ought to be absolntely free, the widow is not bound to discharge the debts of her husband, but that lies upon the heir. And if he is not able to satisfy our debt, or to perform our service, or the service or lebt owing to another which the ancestor shall have acknowledged in 
our court, then the hand must be extended to reach the dower. 1 If any one refuses to allow dower to the widow of his own aecord, she must be aided by plea.

\section{CHAPTER IV.}

Of the Remedies for recovery of Dower.

1. Plea of dower is determinable in our court, and that for good reason. For if two or more women should contend together about dower, each alleging herself to have been the espoused wife of the deceased husband, and we or any other person desired to be certified which of them all was his lawful wife, *since one only can be so at one time, as before has been said, this point can be certified only by the court Christian ; and therefore if any other than ourselves should direct a mandate to the bishop to be certified upon such a question, and the bishop should refuse, no one except ourselves would have any jurisdiction to compel the bishop to certify against his will. And there are several other reasons.

2. If any widow then would complain of a wrongful

1 This provision, making the dower to some extent liable for the husband's debts in case of the deficiency of his remaining property, is not derived from Bracton or Fleta. It finds however some support, so far as regards debts due to the Crown, in one of the forms of writs, quod mulieres non distringantur, given in the Register. See Regist. Brev. Orig. f. 142 b, 143 ; Fitzherbert, Nat. Brev. $150 \mathrm{Q}$; Coke, Litt. 31 a. 
detaining of her dower, care must be taken to examine narrowly whether the wrong is done to her by the heir or by any other person, and whether by detainer of all the reasonable dower specially named in the original establishment, and whether of tenements whereof her husband was seised, or of tenements of the ancestor of her husband whereof she was endowed by his assent, and whether she has part or not; and if she has part, whether the deficiency be in the principal subject, or in the appurtenance. On each of these points there lies a different remedy; for if she has never been seised of any part, and the establishment made upon her was of reasonable dower, then the common writ of dower elose, ' of reasonable dower whereof she hath nothing,' lies. And if the establishment made was in certain, then there is remedy by another writ. And if of lands of the ancestor by his assent, then she shall have a different remedy. *And if she has part of the tenenent and demands the residue, then the writ of right of dower patent pleadable in the court of the heir is in place. And if she has her reasonable dower of the principal, but is deforced of some of the appurtenances, then the writ of dower patent, called writ of dower de rationabili parte mulieris, lies.

1 ' The writ of dower, unde nihil habet, and the two possessory writs, de dote certa and de dote de assensu patris, are pleaded only in the Bench on account of the precept to the bishop. But the writs of right are pleadable in the lord's court, becuuse the cause of dower, that is, the marriage, cannot be denied after the plaintiff has heen recognized as lawful wife by the delivery of 
3. If several deforceors are in the same county, they may be all comprised in one writ. This plea is real, and pleadable after default by distresses real, as by Cape's ; and essoins are allowed on the first day, and also after each appearance. And if the deforceor makes default after essoin, and also where the deforceor has rouched to warrant, and not caused his rouchee to be summoned against another day, the petty Cape lies. It is intended that this action shall be the most faroured of any of the writs of possession not pleadable by assise, ancl therefore there ought to be greater dispatch therein.

4. The most common writ of dower is the writ elose whereof the widow hath nothing, and therefore we ought to begin with that writ; in which the count is thus: "This sheweth to you, Peronel, who was the wife of John, that Peter wrongfully deforees her of the third part of so much land with the appurtenances in such a vill to her damage of ten pounds, and herein wrongfully, in that the aforesaid John, formerly her lord, endowed her thereof at the church door on the day when he married her, as he that lawfully so might do, and if he admit this, he does well, *and if he deny it, he denies it wrongfully, for she hath thereof suit good and sufficient.'

5. When the widow has thus declared her case, if the deforceor will not say anything or defend himself,

all or part of her dower, whether this was done by plea or without plea.' (Note in MS. N.) For the form of these several writs, see Regist. Brev. Orig. f. 3, 170 ; Fitzherbert, Nat. Brev. $8 \mathrm{G}, 148 \mathrm{~A}$. 
he shall remain in mercy as undefended, and she shall recover her demand in the same state as the tenements were on the day that her husband died, and also her damages. And if the deforceor defends the wrong and force and the lamages of the plaintiff, and so on, according to the proper words of defence, he may then aid himself several ways, either by general dilatory exceptions or by special peremptory exceptions, as will afterwards appear.

\section{CHAPTER V.}

Of rouching to Warranty in Pleas of Dower.

1. If the deforciant rouches to warranty, then the like process shall hold as shall be mentioned of warranties in a plea of right, so far as regards judgments upon defaults. ${ }^{1}$ And if the vouchee appears on the day of the summons and enters into warranty, then let the contest be between the plaintifl and the warrant; and in the meantime the tenant may remain at home in his possession until the plea of warranty is determined, for according to the event of that plea the tenant shall hold the land or lose it. And if the demand be of dower which was named in certain to the wife upon the first establishment, and the action goes against the tenant, the widow shall *recover her demand in full, and the tenant to the value from the warrant. But where

1 The passage referred to is not found in Britton, but the process is stated in Bracton, f. 384, Fleta, p. 411. See Introduction, p. xlii. 
reasonable dower is demanded it is not so ; for of thit dower the widow shall recover to the value of the warrant, and the tenant shall remain in tenancy of the land demanded.

2. Although the warrant be under age, yet, out of favour to widows, it is not the custom or law that the women shall wait until the full age of the warrants, because warranty of dower is not so prejudicial to heirs as to involve disherison. Nevertheless such tenants must show a charter or deed, whereby the court may be certified that the infant is bound to warranty by lis ancestor; and whether the demand be of reasonable dower or of dower in certain, the heir shall answer of whatever age he be. And if the widow recovers her demand, and the heir is disposed to dispute it, he may take proceedings when he comes of age. And so he may possibly regain the land which he himself lost, but if he cannot do so, then the first judgment shall stand.

*3. It should be understood that in every judgment awarding seisin to a widow plaintiff of reasonable dower not named, the corn growing and the grass mowed are always to be excepted.

4. Although the infant is in ward, and the wardship aliened from one to another, this does not prejudice the vouchor, because he shall always vouch to warranty the heir, and not his guardian; but the guardian, whoever he be, is bound to produce the infant in court. And what has been said with regard to a sole heir under age, is also to be understood of several heirs under age who. are parceners and considered as on heir. 


\section{CHAPTER VI.}

Of Exceptions respecting the husband's death.

1. Exceptions may arise to the tenant from the articles in the writ. For where as it is said in the writ, ' who was the wife of such an one, formerly her husband,' the tenant may answer, that he was formerly her husband and is so still, and inasmuch as her husband is still alive, he is not bound to answer her in the absence of her husband. And if this be proved, or not denied, the action is at an end; because gil'ts for marriage, as is the case of lands given in marriage and establishments of dower, are not confirmed until the death of the husband.

2. If the wife says that her husband has talien the habit of profession, and the tenant says that he has not, *this must be certified by the ordinary, and the original plea shall be in the meantime respited. And according to the certificate of the ordinary let judgment be given. ${ }^{1}$

1 Casus. A man takes a wife, and afterwarcls goes to a foreign country, and there enters into religion and is professed. The wife brings her writ of dower. The tenant answers, that the husband is alive ; and she, that he is dead in law (solum ley de terre), and sets forth how and in what place. Qucestio, quid 
3. If she says that her husband is dead by natural death, the proof sometimes lies upon the plaintiff, if the tenant puts her upon proving the same: in which case he shall only say that the husband is not dead. For in general it belongs to the plaintiff to prove his case, unless the defendant unclertakes to prove the contrary. And if the deforceor says that the husband is alive, and that he is ready to prove the same, and the wife only says that he is dead, without tendering averment, then the proof lies on the tenant, inasmuch as it belongs to the person excepting to prove his exception. And if both undertake the proof, it is for the one to prove the man to be alive and for the other to prove that he is dead, and it may happen that both parties furnish proof of their case; but then credit should be given to the most reasonable proof. And although the widlow proves her husband to be dead, yet seisin of dower ought not to be adjudged to her without further answer of the tenant, before she has shown how she is entitled and has right of action in her demand ; for it may well be that she has no right to demand dower.

* 4 . If the proof be found insufficient on both sides, in such case, on account of the favour granted to the widows, judgment onght to be given for the plaintiff; but on this condition nevertheless, that if her husband

juris?' (Note in MS. N.) It was subsequently held that if a husband entered into religion although the heir succeeded to the inheritance, the wife should not be endowed until the husband was naturally dead. See Coke, Littleton, f. 33 . : Perkins, Prófitable Book, p. 61. 
be alive and be produced in court, the wife shall restore the dower with all the profits in the meantime, provided she can find such security to perform this as the court shall award ; and if not, the tenant will continue in seisin until the court is better certified of the husband's death. The plea in the meantime shall be suspended, and renewed by resummons when there shall be occasion.

\section{CHAPTER VII.}

Of Exceptions founded on the invalidity of the marriage, and on the dower established being different from that claimed.

1. It is also said in the writ, " such an one who was the wife of such an one.' To this the tenant may answer, that she never was his wife, inasmuch as she was never married to him, but he had her as his concubine; or if she was married to him, yet she never was so by lawful matrimony, because he had before married another who was living at the time he married the plaintiff, so that if she was his wife, she was so in fact only and not in lawful form by reason of the other, who was his wife in law. That he conld not have two wives at one time appears by the definition *of matrimony, where it is said, that matrimony is the union of a woman to a man, and not of women to men, but in the singular. And if several women, all living at the same time, are united to one man, yet none of 
them but the first is in law his wife; the others being so in fact and wrongfully.

2. Again, although she was his lawful wife, yet the tenant may say that she ought not to have dower by that rule of law which says that the marriage subsist. ing action of dower remains, but the marriage failing the action is extinct, and a divorce was pronounced between her and her husband, whereby the marriage ceased, and consequently her action to demand dower is extinguished. For a divoree is no other thing but a separation of bed between man and wife. And if this be verified, or not denied, the wife shall not recover any dower. To this the widow may perhaps answer, that although there was once a question in court concerning a separation between her husband and her, yet it never came to judgment in the lifetime of the husband; or, that although the divorce was awarded, yet she appealed against the award; and by that appeal the award was annulled and repealed, and judgment given for the wife; so that the husband was seiserl of her as his wife the day he died, and she of him as her husband. *To which the tenant may say, that although she appealed from such award, yet still she ouglit not to have dower, because the husband died before any judgment was given in the plea of appeal.

3. Again, the tenant may say, that although she was his lawful wife, yet she onght not to have dower, because she was never solemnly married at the ehurch door, and consequently dower was never established upon her there. And if this be verified, she shall not 
recover any dower on account of the words of the writ, 'at the church door.'

4. If the Justices would be certified concerning any divorce, they must be eertified by letters of the ordinary ; for the cognizance thereof belongeth not to the lay court,-no more than of matrimony, since the one depends upon the other. Therefore in such case our writ must be directed to the ordinary of the place, that after calling the parties and other necessary persons, he do inquire the truth of the matter, and according as he shall find certify the same to the Justices. In such case the ordinary ought to cause the tenant who propounded the exception, in whatever diocese he resides, to be summoned to be at a certain day and place before him to show whether he can or will say any thing against the marriage. And after he has been solemnly summoned, *whether he come at the day or not, let the widow's proof by the witnesses she shall produce be almitted, so as such witnesses be not liable to challenge; and such proof being solemnly admitted upon the oath of the witnesses, let the ordinary forthwith according to the inquest make a return to the Justices of the fact as found; and in such case no appeal lies by any of the parties, that the plea in our court may not in any way be longer delayed.

5. But now it may be asked, whether if a man kept a mistress in concubinage, and begot a child by her. and afterwards secretly married her elsewhere than at the church door, and after such marriage had another child by her, and then publicly married her at the 
ehurch door, and there endowed her, and after that had a third child by her, which of these children would be admissible to the succession of the inheritance of the father, and by reason of which of them the mother shall be entitled to dower after the decease of the father. The answer in such case is that the micldle son onght to be admitted to the suceession of the inheritance of the father, and shall be accounted legitimate in respect of his birth, although the marriage was secret, provided he ean aver that he was born within wedlock, whether the espousals were publicly or privately performed. *And yet the mother shall not have dower by reason of that ehild, but she shall not have it by reason of the third son, and of the solemn espousals wherein she was endowed at the church door. Hence it appears, and true it is, that sometimes the mother shall not have dower, although the son may be admissible to the suceession of the inheritance of his father, and that no right ever accrues to any woman to demand dower, unless it was established to her at the church door, and this, whether in a time of interdict or not. ${ }^{1}$

6 . When the ordinary has solemnly performed the duty of his office with regard to the making of the inquest upon the points comprised in our mandate, and has thereupon made his return and eertified us or our Justices, the tenant at the instance of the plaintiff shall

1 The meaning seems to be, that though there was an interdict upon the ceremonies of the church, dower could still be 'established' at the church door. Compare Bracton, f. 304. 
then be resummoned, that he be before our Justices at a certain day and place. At which day the parties may be essoined. And if the tenant make default, and the resummons be proved, let the land demanded be forthwith taken into our hand by the petty Cape, and let lim be again summoned to appear at another day to hear his judgment.

7. If the tenant dies before lie is resummoned, the widow must revive her action by a fresh writ against the new tenant; and if the aforesaid exception be again alleged, it will not be necessary to send it again *before the court Christian, after julgment has once passed in her favour, but it is sufficient to prove the marriage in court Christian once for all. Therefore that exception will thenceforth be of no avail in the mouth of any one; but some other defence must be made, or the widow shall recover her demand. In like manner if a woman demands a man as her busband, and judgment is pronouncerl for the woman in court Christian, whether the man has appealed from the judgment or not, yet if he dies before the judgment is reversed, the woman shall recover dower, and that judgment shall for all future time be a sufficient proof of the marriage.

8. If the tenant by way of exception says that she never endowed at the church door in the manner she las declared in her count, and the widow says the contrary, the truth may be inquired by the country. And if she omits the words ' at the church door,' the writ is abatable for the defect in the count. And if the widow 
demands more than was at first established upon her at the church door, although her husband from some foolish fondness afterwards increased it, she shall not be entitled to be answered in respect of that increase. *For as dower was appointed her at the church door, whether in specie, or of the third part, and so not in specie, in that form dower shall be assigned to her, and she has an action to demand so much, and no more, if she be deforced thereof.

9. If the widow demands dower named, as being that which was established upon her at the church door in certain, and the tenant says in answer, that she wrongfully demands dower named, inasmuch as at the establishment she was endowed only of reasonable dower, and therefore uncertain, or of the third part of something certain; in such case the proof lies on the widow ; and if the tenant expressly tenders averment of the negative, then it shall belong to him to prove his exception, as well as to the widow to prove her case. And if the widow produces witnesses who were present at the establishment, or tenders a writing which was made to her thereof on the day of the establishment, and the tenant offers nothing but averment by the country, in such case, as well as in cases where the death of the husband is to be proved, the widow's proof shall be more admissible and of greater weight than that of the tenant. But if the widow brings her witnesses, and none of them were present at the establishment of the dower, or, in the other case, at the burial of the husband, her proof is in 35 
neither case to be admitted against the suit of the tenant. And if neither of them tenders suit, but simply averment by the country, in such case let the truth be inquired by the country.

\section{*CHAPTER VIII.}

Of the pleadings where several women claim dower of one husband.

1. If several women at one time demanded dower by the establishment of a singie husband, an exception thereby arises to the deforciant, that he ought not at the same time to answer several women demanding. dower by reason of the death of one man.

2. If one woman has recovered dower, and another demands it, a distinction must then be made, whether the plaint is against the tenant alone or against him and the wife endowed, she having rouehed the tenant to warrant. For if the tenant has entered into warranty, then the warrant is bound to defend the voucheress against the plaintiff. And if he has not yet entered into warranty, then the dower may answer by herself to the following effect : that the plaintiff ought not to have dower, nor any one exeept herself, forasmuch as she was the espoused wife of him of whose death she is endowed, and was seised of him as of her husband at the time when he died, and she was therefore endowed, and that rightfully. ${ }^{1}$ To which the plaintiff may in

1 In Bracton this pleading is given as that of the warrant, who is there called tenant. In Fleta, as here, it is the pleading of the woman endowed, and she is called tenant, mulier tenens. 
answer say, that the tenant saith wrongfully, for she was not his wife, as plainly appears, inasmuch as this same plaintiff heretofore impleaded the same husband in court Christian *and demanded him as her husband in such a place and before such judges, and in the presence of the same tenant leraigned him as her husband, on which occasion she did not make any counterclaim or opposition. And if the tenant does not deny this, the plaintiff shall recover dower of that which she holds. But if she denies it by affirmation or negation, a doubt arises, which must be ascertained by inquiry of the ordinary, and according to his return the parole shall be continued by resummons, and judgment given; and pending the plea in court Christian, the original plea shall be at rest. And if replication be made of an appeal and judgment reversed, the effect shall be as is above mentioned concerning such a replication.

3. Again, if the tenant in dower says only, by way of exception, that the plaintiff cannot be his wife because she held her tongue when she ought to have claimed her husband, as, when the banns of the second marriage were three times solemnly asked in the church where she was present, upon the negation of the tenant both of them shall be sent to court Christian in order that the Justices may be certified upon this question, which of them was the wife of the husband in law, and which only in fact; and according to the certification of the ordinary judgment shall be given.

4. Although one of the women was lawfully his wife, yét her right may be lost by default of evidence, as 
where she was married out of our jurisdiction. Also by negligence in her claim. *as where the rightful wife never disputed the second contract in the lifetime of her husband who abandoned her; in which ease her right of action is lost, and she ought not to have dower, especially if the second wife remained with the husband until his death. And in like manner her action is lost, even though she disputed the second marriage, if the husband died in the arms of the second wife before judgment of divorce. But in all these cases the first wives shall have dower, if their children are able to recover the succession of their father's inheritance.

\section{CHAPTER IX.}

Of Exceptions relating to the Assent of the Father.

1. Sometimes writings are made of the establishment of dower, and that wisely ; for if such writings are pro. duced at the trial, the wife's demand can be more clearly made out. And if they should be denied, this doubt may be tried and their legality proved by comparison of seals, by the witnesses named in the writings, by the country, or in several other ways. But of all establishments of dower, there is most need of writing where the assent of a third party has coneurred. *The writing may however be so made as to be useless in proving the wife's ease ; for if it is said, that her husband endowed her, and the assent of the possessor of the land is not mentioned, the writing will not avail in 
evidence of her demand. So likewise, if it is stated in the writing, that some other person than the husband endowed her.

2. It is necessary therefore, that in every such writing these points should be specially mentioned, that the husband enclowed the wife at the cluurch door of the third part of his father's land, or of that of some other kinsman or friend, and that the same friend or kinsman assented in the same place and at the same time. And although the writing be made elsewhere, yet in order that it may be of effectual value, it should be granted and confirmed by assent at the church door, or the endowment will be worth nothing, if the friend choose to dispute it, on account of the expression in the writ, 'at the church door.' By this reasoning it appears, and it is true, that a woman shall not recover dower against the will of the tenant, unless she make it appear by writing, or by witnesses present at the establishment and at the marriage, or by the country, that these two things concurred at the marriage, namely, an establishment of dower by the husband and an assent of that friend, or his ancestor, of whose land she demands *dower, and that he assented to the endowment, whether there be writing or not, at the church door ; for an assent at any other place is useless. 


\section{CHAPTER $\mathrm{X}$.}

Of common Exceptions in Actions of Dower.

1. To those words in the writ 'whereof she hath nought,' the tenant may answer that she hath part. But then it will be necessary to distinguish, whether the plaintiff has received part of her dower before the purchasing her writ or after. For if after, although from the same deforceor of whom she complains, and in the same vill named in the writ, yet the writ is not thereby abatable; for she may say that satisfaction was made to her for the difference; ${ }^{1}$ but if she received part before the writ was purchased, 2 then the writ is abatable; and no writ shall lie but the writ patent upon the right.

2. Again, the deforceor may say that the plaintiff ought not to have dower, for that her husband did not hold the tenement, whereof she claims dower, in demesne either on the day on which he married her or

1 That is, she may say by way of replication, that at the time of purchasing the writ she had nothing of her dower, but that an assignment has since been made to her in satisfaction of part of her demand. Compare Bracton, f. $311 b$.

2 This must be understood, if the part was received from the same deforciant and in the same vill. See Statute of Westminster i. c. 49 ; Fleta, p. 347 (§ 4). 
afterwards, or that if he did hold it in demesne, yet he could not endow her, as he had no fee therein. But if her husband had the fee of any tenement which was to return to him or his beirs on the deatl of some person *who held it for term of life, in all such kinds of tenements although the freehold was aliened before the husband married her, a wife may demand dower if she was endowed thereof at the ehurch door.

3. Again, he may say that she ought not to have dower by reason that her husband was a felon and suffered judgment of felony, for whieh he was hanged, or beheaded, or buried in the sands, or dismembered, or drowned, or condemned to some other death, ${ }^{1}$ or abjured the realm, or was outlawed; in which ease the record must be vouched to warrant. And when the record is produced, the widow may dispute the record unless it is proved by some one authorised by us to bear record. For she may say that some one out of hatred caused her husband to be hanged, when in fact he was never found guilty of any felony, and that this act was done by such an one, and by certain others who coloured his death with a sort of judgment. And if this be rerified by the eountry, the widow ought not by such a wrongful judgment to be barred of her dower, nor the heir of the suceession to the inheritance. So neither where the felony did not amount to $12 d$, nor where the outlawry was pronouneed before the fourth county

${ }^{1}$ As to the various modes of execution mentioned above, and the places where they were customary, see Hengham Parra, p. 87 , and Selden's notes thereupon. 
court or pronounced in any other county than in that where the offence was supposed to have been committed. Nor in any case where a lawful defence may be made to the outlawry. Nor in any case of judgment of death, *where the supposed felony is found on examination to be a trespass and not felony, nor in the case of abjurations for trespass, as in parkis or fishponds, or other like trespasses.

4. Although the husband suffered judgment of felony and that deservedly, yet she may say that, notwithstanding this, she ought not to be barred of her demand, for at the time he committed his felony she was not united with him nor married to him, neither was assenting or privy thereto. And inasmuch as the wife of a felon ought not to lose her lower, except by raason that she may be fairly supposed to know of the felony of her husband, and even then she is not bound to accuse him, therefore, where the felony was not committed during the time that she was his wife, she ought to have dower of the lands of the heir which are in the custody of his lord. ${ }^{1}$

1 These last words should apparently be understood of the felon's lands escheated to the lord. 'A man commits a felony which is not discovered; afterwards he purchaseth land, and afterwards taketh a wife, Although he be sentenced for the felony, the wife shall recover dower. Dubium tamen est, quia quicquid acquiritur inter feloniam commissam et ipsius feloniæe convictionem, fit ac si ante feloniam perpetratam propter convictionem ob quam nomen felonis subibit.' (Note in MS. $N$.) I do not find, that in later times an exception was made in favour of the wife of a felon, when the crime was committed before the 
5. The widow shall not have her reasonable dower unless she can aver by the country or in some other manner, that she was capable of deserving dower in the lifetime of her husband, whether she be a maid or not, and though she be twenty or a hundred years old; nor where the husbands died so young, or in any other such condition as to be incapable of consenting to matrimony. ${ }^{1}$ They are not however barred from re-

marriage. See Perkins, Profitable Book, s. 387 ; and compare Coke Litt. $31 a$.

${ }^{1}$ It would appear from the above, that reasonable dower conld not be claimed unless the husband was of an age before his death to consent to the marriage. This was not the rule of later times. 'If the wife be past the age of nine yeares at the time of the death of her husband, she shall be endowed, of what age soever her husband be, albeit he were but four yeares oll.' (Coke Litt. 33 a.) And I do not find any authority for the doctrine of the text in Bracton or Fleta. The former says that the minority of the husband or the wife did not inpede dower, provided the wife was of ability 'dotem pronereri et virum snstinere.' (Bracton f. 92.) And Fleta fixes the required age of the wife at nine years and a half. (Fleta, p. 340, c. $23, \S 3,34 \mathrm{~s}$, $\$ 9$; compare Littleton, Ten. s. 36 ; Coke Litt. 33 a.) But the doctrine of Britton is supported by Hengham (Hengham Parva, 1. 88); and by the Register, where it is said, that a woman will lose her dower if her husband die under age. (Regist. Brev. Orig. 170.) And the annotator in MS. $N$. says that in all cases where the husband was incapable of consenting to the marriage. either because he was 'infra annos nubiles, i. e. arl xiiii. annos, or from any other canse, althongh there was no default in the wife. she should not have dower. So. it is said to have been held in the 13th Edw. I., that a wife would lose her clower if her husband died under nine years. (Fitzh. Abr. Dourer, 172, citing 
covering other kinds of dower. Neither ought a widow to recover dower in the advowson of any church in whole or in part, unless she can aver that she was endowed thereof; *and still she may be barred by negligence, if she afterwards withont question or claim permitted the heir of her husband or some other in his name to present after the death of her husband. And if the writ be obtained against the heir and the guardian jointly, the writ falls if it be challenged, because the guardian must always be summoned to produce the inlant whom the plaintiff alleges to be in his ward.

6. Again, the tenant may say that the plaintiff has forfeited and lost dower by arlultery, inasmuch as she left her husband after he married her for the bed of another, by which act she forfeited her lower. If to this the wife replies that it ought not to bar or affect her because she was afierwards reconciled to him, so that he received her again, and in her seisin died, the

13 Ed. I. Iter North. ; but qu. whether it should not be read ele for $i l$; that is, if the wife died under nine years.) In 12 Ric. II. dower was allowed where the husband was ten years of age, and the wife eleven at his death. Fitzh. Abr. Dover. 54. The clanse which follows in the text refers apparently both to the wives of infants, and to widlows of tender age, who, as it seems, might claim dower certain, but not ' reasonable dower.' ' Although the wife be not of ability to deserve dower, yet she shall have it, provided that the assent of the husband was given at their espousals ; because establishment of dower is a kind of purchase which is not forbidden by the nonage; and is therefore permissible.' (Note in MS. N.) This distinction is also found in Hengham, but does not appear to have been recognized in later times. Compare Coke Litt. $33 \alpha$. 
tenant may say in answer that notwithstanding this she still ought not to have dower, for that he did not receive her of his own accord, but against his will by coercion of Holy Chureh and by sentence of court Christian. And if this be proved, the plaintiff shall take nothing.

7. If the widow brings her plaint against the heir, he may answer thus, that he is bound to warrant her dower to her in ease she was endowed and was impleaded of her dower, provided he has the charters delivered to him, which were his ancestor's, and which she detains from him ; for otherwise he may perhaps lose his inheritance; so that he was never against assigning her clower, provided she would have delivered up to him the *harters which belong to him, relating to his inheritance. And if he can verify this, let it be awarded that the wiclow restore the eharters, and that he assign and deliver to her her dower; and the widow shall remain in merey for her false plaint.

8. Again, the tenant may say that she ought not to be endowed, for that she was once impleaded of part of the dower which she holds, and whereas she ought to have vouched him as the warrant of her dower, she ronched another, such an one by name, in disherison of the right heir. And if the right heir ean verify this, she has forfeited all recovery of the residue of her dower for her malice.

9. Or he may say that she wrongfully complains, forasmuch as satisfaction was made to her for her dower by the value in land or money, wherewith she was con- 
tented. And if the wife admits the agreement, or does not deny it, but replies that satisfaction was never fully made to her, the demand of dower shall thereby cease, and she may proceed by writ of covenant if she thinks proper. Or he may say that heretofore she recovered dower against him of the same tenements by a like writ, and if this be verified or not denied, the last writ shall fall, and the wife, if she pleases, may sue judgment on the former writ.

10. It may also happen that several wives at one time demand dower of the endowment of one husband, whereas they ought not all to be endowed, *for one only was his lawful wife, and she ought to obtain the dower. But which was his lawful wife and which his coucubine, no secular judge can inquire, for the cognizance of marriage and of testannents belongs to the court Christian ; and so long as there is a dispute between two or more wives, dower is not to be allowed, until it be proved in court Christian which of them was the lawful wife of the husband.

11. So where the lawful heir brings an action for his inberitance and the wife for her dower at the same time, dower is not to be granted until the plea relating to the succession is determined, on account of the inconvenience which might ensue. For if two wives who are contending about their clower were to be sent into court Christian, there to determine which of them was the lawful wife of the husband, and which his concubine, it might perhaps fall out that she should prove herself to be the lawful wife, who was not the mother of him who might 
prove himself in our court to be the litwful heir, and that the son of her who in the court Christian was found a concubiue, might prove himself in our court the lawful heir. Therefore in the above case where several heirs are disputing about their inberitance and several wives about their lower, it is proper that the pieas of dower should be suspended until it be decided in our court to whom the succession is to be adjudged. Ind accordingly, in the like *ase of a dispute between two clerks in court Christian, the prohibition by Indicavit was first provided, to cause the plea in court Christian to be suspended, until the question between the patrons be decided in our court, by reason of the risk which might arise to one of the alleged patrons in respect of the advowson, if the plea in court Christian between the clerks was determined before that between the laymen concerning the adrowson. And as soon as the heir has recovered his inheritanee let dower be assigned to his mother, but without awarding any damages for the delay, inasmuch as the delay was warranted by the court, and did not proceed from the wrongful act of the heir. And when the heir is thus in seisin of the inheritance, whether rightfully, or wrong. fully and the wife endowed, and another wife comes and demands dower, and her son demands the inheritance, in such case let the wife be told that she should first cause her son to be proverl lawful heir, and that then, and notbefore, she shall be answered as to her dower.

12. Whether the wife who demands dower has a child or not, that person is always the warrant of her 
dower to whom the dower ought to revert after the death of the wife, whether it be the heir or the chief lord, to whom the two other parts are escheated in any way either by failure of blood, or perhaps for felony, or by reversion. There is a case however excepted, where a wife recovers dower of one who was enfeoffed by the husband or his heir, *the heir having nothing left whereout he conld warrant the dower or make satisfaction in value; in this ease such dower shall revert to him from whom it eame, and yet he shall not be warrant of the dower.

13. Or he may say that she ought not to have dower, because her husband had not any right in the land, inasmuch as it was the inheritance or the estate in marriage of his first wife. Or thus: because she of her own accord and by her free will in her absolute widowhood released and quitclatimed all the right which she had or might have in her dower. Or thus : for that she is his nief holding of him in villenage as an astrer, ${ }^{1}$ and he seised of her and of her chattels and her suit. Or thus: for that the husband lost the tenement by judgment as the right of another. Or, for that by the eustom of the country no widlow was ever wont to be endowed unless there were writings. Or, for that the husband never in his lifetime had fee or demesne in the tenement whereof she demands dower. Or, for that the tenant was heretofore aequitted by judgment of the same demand at the suit of the same plaintiff. Or, for that he held nothing in the tenement whereof

1 See p. 456 , note. 
she demands dower on the day of the writ purehased, or since. Or, for that he does not claim any freehold therein, but holds it in another's right as guardian or bailiff or termor or villain. *Or, for that he holds the tenement jointly, in common with others, without whom he cannot answer.

14. If any one say that he has only a freehold upon condition until he has levied so much out of the profits, or until such or such an event happens, yet the writ shall not thereby abate but stand, and he may vouch to warranty if he thinks proper. And as to the tenant's exception, that she ought not to have dower because her husband lost the said tenement by judgment, she may answer by way of replication, that it was by fraud and collusion, and by consent of the husband; and if this be proved, the exception will not avail.

15. Again, the tenant may say that her husband aliened the land which she demands in dower before he married her; and if she reply, that such alienation was for term of life or otherwise revertible to the feoffor, and that this land was appointed to her for dower in the original establishment thereof, as soon as it became racant; and if the tenant clenies this, let the truth be inquired by the country.

16. Or he may say that she ought not to have dower, for that the husband of whose death she demands dower had another wife, whom he had married before he married her who now complains, and that he endowed that wife of these same tenements, and that she is yet alive. In such case the tenant shall sue out a 
writ to cause the woman, if any such there be, *to come into court to acknowledge whether she makes any claim. But if the plaintiff will aver the negative, to wit, that her husband had not another wife, or that if he had another wife, there is none now living ; in both cases the plea shall be removable into court Christian; and according to the return of the ordinary judgment shall be given.

17. With respect to dower which a wife recovers from a farmer holding for a term of years, let it be awarded by the Justice ex officio that the termor shall retain the other two parts of the land until he has received the value of the third part which he lats lost. And thus he will have a kind of freehold where before he had not. But if the wife recovers all the iand which the farmer holds, as land whereof she was endowed in certain, in such case the termor ought to recover from his lessor by judgment in the plea of warranty to the value of the land. And if the lessor has no land wherewith he can warrant his term, it shall be awarded ex officio by the Justices that he shall recover of his lessor to the value when the land included in the dower shall fall in, or any other out of which he can make satisfaction; and let this award be enrolled, so that when the time comes he may have remedy by writ of judgment upon such enrolment. 


\section{*CHAPTER XI.}

Of the Judgment in an Action of Dower.

I. When it cannot be denied that the widow ought to have dower, let it forthwith be awarded that she recover seisin of her clower, and her damages to be assessed by the jury, as before mentioned.

2. But although the widow recover dower, she may lose it in several ways, as where her warrant loses the two other parts by judgment without any collusion, then she will lose her dower. So she may be deprived of it by the custom of the country, as particularly in Kent, and sometime there was such an usage in London and in many other places, ${ }^{1}$ that as soon as the widnw is married to another husband, or becomes with child by any other than her first husband, she may be immediately ejected from her dower.

3. So if a widow is disseised of her dower, and after a long interval and peaceable seisin of the disseisor she takes the seisin by her own force, refusing to proceed by judgment,-if the disseisor can recover seisin by assise of novel disseisin, the widow shall never re-

1 The forin of expression, which seems to imply that the custom was no longer enforcel in London, is not found in the parallel places of Bracton and Fleta.

36 
(o) ver her dower except by the aid of the heir, or by writ of right of dower wherein she shall count of her own seisin.

\section{CIIAPTER XII.}

\section{Of the Plea of Right of Dower.}

1. There are three cases in which a widlow has no recovery for her dower, save by writ of right of dower patent pleadable in the court of the warrant. *The first is where the widow has lost her seisin by assise of norel disseisin, as before is mentioned. The second, where the widow demands part of the land or tenement in dower, as of her reasonable share, and is already seised of the rest. The third case is where she is deforced of anything which is appurtenant to her dower.

2. These pleas shall be commenced and tried in the same manner as the great writ of right patent, but not so as to admit of deraignment ${ }^{1}$ or of essoin de malo lecti, and are removable into the County, and from thence before our Justices, in all the ways that shall be hereafter mentioned in the plea of right by the great writ. Demand of view and voucher of warrant also lie.

3. If the tenant desires to defend himself, or is warranted by another who defends him, the answer may

1 'This word 'deraign' appears to be used here of the mode of tral used in the ordinary or 'great' writ of right, namely. battle or great assise. The proot $m$ writ of right of dower was by 'the country.' See Bracton, f. 313 b. ; Fleta, p. 359 (\$ 1. 2). 
be, that the plaintiff wrongfully demands dower, for as much as she of her own free will delivered up or surrendered the tenement to him, and released andq uitelaimed her right; or that she heretofore withdrew herself from a like. writ before such a Justice; or that the tenement demanded does not belong to her dower; or that although she was sometime seised thereof, she was not so seised as of her dower; or that she was never endowed thereof, but of other land specially named; or that she was endowed of less than the third part; and was contented therewith; or that she has more than belongs to her to have for her dower; and in the last case if she will not consent to admeasurement, and the tenant is ready to verify this as his *exception, the widow shall take nothing by her writ, but remain in mercy ; and let the tenant proceed for admeasurement of the dower whereof she was endowed, whether in certain or of the third part. .

\section{CIIAPTER XIII. \\ Of Admeasurement of Dower.}

1. Admeasurement is nothing else but the reducing to measure what before was out of measure, and extends as well to a thing which does not belong to dower as to the excess and superfluity of it. But whether the widow holds in dower too much, or a thing which she ought not to hold, yet she is not to be ousted or ejected without judgment. Therefore it is proper to proceed for remedy by writ of admeasurement of dower. 
2. When the sheriff has taken pledges for the prosecution of the plaint, it is his duty to summon the widow to appear on a certain day. He ought likewise to summon the coroner and the knights and other freemen of the neighborhood. At which day, if the plea is not removed by Pone, it is the duty of the plaintiff to set forth his plaint according to the tenor of the writ, if the widow is present. And if she is not there, or if she is there and cannot say anything whereof the admeasurement ought not to be had, let the admeasurement be straightway made upon the oaths or freeholders then present by good and lawful extent. *Then let it be inquired, in what manner her dower was established on her, whether in certain or of the third part, and according thereto let the admeasurement be finished, yet so that any improvement which has been made by the widow be not included in the extent but fall entirely to her.

3. If the widow chooses, she may say in ansiver many reasons why the admeasurement ought not to be taken; as, that the heir was of full age when he endowed her; or, that she has held dower before the time named in the assise of novel disseisin; or, although the heir endowed her by his guardian, or, although she was endowed by our escheator or other when the heir was under age, yet that since he has attained his age he has agreed to and confirmed the said assignment; and by several other exceptions she may hinder the admeasurement.

4. If the plea is in our court, and the defendant makes default, distresses and attachments shall run as per- 
sonal actions and such further process as is mentioned in our statute.

5. When the widow has by just measurement that which belongs to her for her dower, she has no power to make any sale of the dower or anything that belongs to it beyond her life, or to make exile of villains, or enfranchise them, or commit any waste; and if she does so, the remedy provided by our statutes shall be pursued. ${ }^{1}$

\section{*CHAPTER XIV.}

Of the Actions founded on Writs of Entry.

1. There are some possessory causes which savour much of the right of property, as the action of entry, the right of customs and services, where both the words solet and debet are contained, of Quo jure, of reasonable bounds, of reasonable estorers of each kind, and others like.

2. In the plea of entry there are three degrees. The first is, where one demands land or tenement of his own seisin after a term of lease expired. The second is, where one demands land or tenement after the expiration of a term of lease created by another. The

1 - Note, that waste, sale, and exile, are three things that touch disherison; wherefore termor doing them justly loses his tenancy as one who disinherits another: for by his act he proves himself to claim an estate which he ought not to have, and by consequence shall lose all, as it is said in reprobation (en reprover): Often michel yerne bringes littel hom.' (Note in MS. N.) 
third is, when a tenement is demanded of a tenant who had entry by one to whom some ancestor of the plaintiff leased it for a term which is expired; and according to these degrees the writs of remedy are varied. There is still a fourth form, which is out of the degrees, and is derived from a more remote seisin to which the other three degrees do not extend. The second degree contains the word per ; the third the words per and cui ; and the form beyond the degrees the word post, that is to say, after the lease, or after the disseisin which such an one made to such an one. And if any writ of entry is not framed agreeably to the ease, so that one form is obtained instead of another, the writ is defective, and therefore abatable.

3. The form in the first degree is as follows. 'Command $W$. that he render to $\mathrm{P}$. the manor of $\mathrm{C}$. with the appurtenances, which hedemised to him for a term which is past.' The second form is thus. 'Command J. that he render to $P$. the manor of $C$. in which he hath not entry save by E. mother (or uncle, eousin, grandfather, or great-grandfather) *of the same P. who leased the aforesaid manor to him for a term which is past.' The third form is as follows. 'Command d. that he render to $P$. the manor of $O$. in which he hath not entry save by $\mathrm{T}$. to whom such an one father, (or mother, cousin, grandfather, or great-grandfather, (ve.), whose heir the same P. is, leased the said manor for a term which is past.' And the form beyond the degrees is thus:-'in which be hath not entry save after the lease which such an one, father (or mother, kc.) whoso 
heir he is, made, \&c.' And from these four are drawn the forms of all kinds of writs of entry, which are of infinite number.

4. This writ, so long as the degrees and term will permit, lies as well against stranger's who have entered by disseisors, whether one or more, as against the heirs of the disseisors and against those who enter by such heirs as far as the person in the third degree, as for' example in this form. "Command $P$. that he render to J. the manor, \&c., in which he hath not entry save by T. son and heir of S. who leased the same manor to him after the same $\mathrm{S}$. had wrongfully disseised the aforesaid J. thereof;' or, if the disseisee is dead, and his heir brings the action against the heir of the disseisor, then thus:- " in which he hath not entry save by T. son and heir of S. who leased the same manor to him after the * same S. had wrongfully disseised E. father (or mother or other ancestor) of the aforesaid J. and whose heir he is.'

5 . But if one commits disseisin of a tenement which was the right of his own wife, and the disseisor dies, and the wife abides therein, and continues the like seisin as her husband had in his lifetime, and dies so seised, and her heir after her death enters and continues the same seisin, and the disseisee brings a writ of entry agranst the same heir, although the heir should make answer that he had not entry by any disseisin which his fither or ancestor made thereof, but by descent from his mother, who died seised thereof in her demesne as of fee and of right, yet he is bound to answer to the 
entry of the ancestor from whom his mother's seisin was merely derivative. For although the mother die in her demesne as of fee, yet she had a tortious entry by the disseisin of her husband; and because by means. of such defective entry, although derivative, the land is come to the heir, the heir is bound in such case to answer to the entry.

6. If the tenement pass the third degree of blood by succession, the remedy by writ of entry will not avail. ${ }^{1}$ But in such cases a writ is used to be framed as follows. 'Command P. that he render to J. the manor, whereof T. disseised the same J. or others of his ancestors, whose heir he is,'-without making mention of the entry. Again if any one disseised the disseisor, and afterwards *aliened that tenement, he cannot in such case say, ' which the first disseisor leased to him;' and therefore let it be said thus: "in which he hath not entry save

1 'Nota, that if the tenements be come to several hands, as to five, or ten, or twelve, the writ of entry still lies, because nothing has accrued to the last purchaser more than to the first. But if they be come to four heirs in lineal succession, or to three, secundum quosdam, so that each has been seised, and the last is. in possession, he is as it were inherited (come enherité) in the right, although the mere right be in another. And also if a grandfather has leased a tenement for a term, and the grandfather, his son, his son's son, and his son's son's son, die before the term be passed, so that the demandant is in the fourth degree, he cannot recover by writ of entry; because it is a writ of. possession mixed with the right, and he ought not to be in better condition in this case than if his ancestor, i. e. the great-grandfather, hat died seisedl.' (Note in MS. N.) 
by such an one, who disseised such an one, after the last named had disseised the plaintiff,' or his heir ${ }^{1}$ near or remote; or the entry need not be mentioned.

7. This action lies only against those who hold tenements beyond the term for which they are leased, and against their heirs and assigns, and against those who had entry into any tenement by intrusion or by disseisin, and also against the heirs and assigns of the disseisors and intruders, who had entry therein by them by succession, lease, or feoffment; and against those who had entry by feoffment of bailiffs, guardians, villains, or others who had nothing save for term for life or years, or a simple tenancy, or of infants under age, or by feoffments made by compulsion in prison, or by mad persons, or by the parson of a church, or a monk or canon removable, ${ }^{2}$ without the assent of the bishop and the patron; or by felons or bastards, or by others who cannot alien anything of the right. - So likewise against those who have deceivably purchased tenements. upon a promise to do such or such a thing, and when they are enfeoffed thereof, refuse to perform it.

8. The word 'term,' extends as well to a term of life as to a term of years. But he who leases only for a

' This word should apparently be ' ancestor.' The error, if it be so, is probably derived from Fleta, where the word is haredem.

2 See vol. i. p. 159, and the note there; and compare Year Book, 31 Edw. I. p. 454. The words in Bracton are, ' a canon without the assent of the bishop and chapter, an abbot without the consent of his chapter, or a cellarer clerk or other procurator without the consent of his abbot or prior. (Bracton, f. 318.) 
* term of years, although he make the lease for a term of a hundred years, leases the profits only, and retains to himself the fee and the right and the freehold, if he had them before the lease; and all that he retains he will leave at his death to his heir' or he may, without doing any wrong to the farmer, give and alien it to a stranger; or he may release and quitclaim every sort of right to the farmer himself, and enfeoff him, without first ousting the farmer of his seisin, such as it is. This he cannot do to a stranger, unless the farmer of his own consent will attorn to the purchaser; for the seisin of the alienor is all along continued by the farmer who enjoys his seisin in the name of his lessor.

\section{CHAPTER XV.}

\section{Of the Proceedings in an Action of Entry.}

1. The tenant being summoned may cause himself to be essoined de malo veniendi and the plaintiff the like. The tenant may also demand view of the thing in demand; and may vouch to warrant, whether mention be made of entry in the writ or not; so nevertheless that if such mention be made, the voucher shall be from person to person, and from warant to warrant, of the persons named in the writ in order up to the first disseisor, or other entror, or his heir. For other warrants than those named in the writ ought not te be rouched. 1 And if no mention is made of the entry in

1 That is, if the tenant does not deny the entry to have been 
*the writ of degrees, then others who are not named in the writ may be vouched, if the vouchors have sufficient ground for doing so.

2. If the plaintiff founds his case upon the right, counting in the right by descent or by resort, as in the plea of right, and coming down at the end of his count to the entry, in such case the defendant or tenant has two modes of defence. For he may undertake to defend the entry upon the possession, in which case he tenders averment by a jury, or pleads an exception. If, on the other hand, he chooses to defend the descent of the right, he has three ways of defending himself, either by the body of one his freeman, or by putting himself upon the great assise, or by having the plea determined by a jury. If he be defended by battle, or the great assise, where the plaintiff lias tendered deraignment, or agreed to the great assise, then the tenant may on the second lay of plea have himself essoined de malo veniendi as after appearance, and at the next day be essoined de malo lecti, and so he may lie for a year in lanquore. And in this case the proceedings shall be in all points as will be stated concerning the plea of right; because at the tenant's election and by his defence the right of possession is disregarded, so that the action of entry is entirely changed to the nature of a plea of right. But this never happens upon the election of the plaintiff ; therefore in every plea which savours of both rights it is entirely in the defendant's as statnd by the plaintiff. Compare below, c. 16. s. 2 ; Bracton, f. 321 ; Year Book, 31 Eiw. I. p. 336. 
*choice either to defend himself in the right of property by battle or by great assise, or to defend himself in the right of possession. And in some cases also it is in his power to cause the plea of right to be changed into one of possession, as shall afterwards be noticed; for if mention be made of the entry in counting in the plea of right, and the defendant chooses to waive the defence in the right and to defend the entry, and so the possession, the nature of the writ of right is so changed, that neither battle, nor great assise, nor essoin de malo lecti will lie, but the plea shall be determined by jury.

3. Nevertheless there are some writs of entry, and of customs and services, which will nowise admit of being changed from a possessory nature to that of a plea of right; as, where a person has leased for a term of years his tenement which he held for term of his life or for a greater term of years, and at the end of the lease demands back again his own seisin; or if he demands by writ of entry a tenement which he demised for a term, and in which he had a fee without ever having taken esplees; so, the writ of customs and services where the debet is omitted.

4. It is to be well observed, that in all pleas whatsoever, where the writ makes mention of both rights, and the plaintiff in his declaration counts by means of the right as well as concerning the possession, if the defence proceeds upon the right, however the plea is ended, whether by a jury or in any other manner, there is no resort to the writ of right, because all the right is determined. But if the defence of the right 
is waived and the possession only is defended, there will be a further expedient, and a remedy by writ of right, whether the jury find for the plaintiff or for the defendant.

\section{CHAPTER XVI.}

\section{Of Exceptions in the Action of Entry.}

1. In this plea the tenant may aid himself by general dilatory and peremptory exceptions. Thus he may admit the entry by the term, but say that within the said term the land was released and quitclaimed, or given to him in fee. But in this case, it must be distinguished whether the exception can be proved by charter or writing, or not. For if by writing, which is proved or not denied, the judgment is clear. And if not, and both parties have gone to a jury upon the entry by the count and by defence also through the right, then instead of the great assise let the recognisance of the jury be taken in these words :- to recognise upon their oaths whether the aforesaid $P$. had other right or other entry in the aforesaid land save *by J., who demised the land to him for a term which is passed, or whether the said P. had entry in that land by the same J. who sold or gave or quitclaimed the same to him in fee, as the said P. says, and whereof he acknowledges that the abovesaid J. the same land first demised to him for a term, but further says that during his term he released the same to him in fee.

2. Again, the tenant may say that he had not entry 
by such an one, but by another person named; and in such case the tenant is not obliged to vouch the latter to warranty, but it will be sufficient for him to abate the writ. And if he waive the exception, it may perhaps prejudice him.

Here ends the Law of Possession, and begins the Law of Property. 


\section{BOOK VI.}

OF PROPRIETARY ACTIONS.

INTRODUCTION.

Of the Plea of Right.

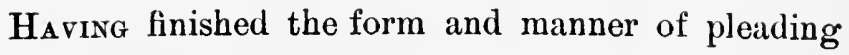
the possessory right, we must now treat of the manner of pleading upon the right of property, which in the order of pleas is the last of all remedies; so that none can descend from a writ of right to a writ of a lower nature, although the reverse may be done.

\section{*CHAPTER I. \\ Of Proximity of Heirs.}

1. This action alone by the manner of counting tries the proximity of heirs with respect to the succession to the inheritance. For inheritance is the succession of the heir to every right of which the ancestor died seised. And from inheritance is derived heir, who is the successor to every right which the ancestor had at the time of his death. And this right sometimes descends like a weighty body, and sometimes ascends. And although the possession does not always follow the mere right, yet in the end it will return to it, if the 
right heir proceeds in a proper manner. For to the right heir descends the mere right which his ancestor had when he died, whether the heir at the time of his ancestor's death be in the country or beyond sea, and whether he is in his mother's womb or already born.

2. All children however are not admissible to the inheritance, for some are natural and legitimate $;^{1}$ and of those who are both legitimate and natural, some are sons and heirs, others sons and not heirs; and some are heirs of their fathers, some of their mothers, and some on both sides, and others are not beirs to either, although they are both legitimate and natural; and some begin by being heirs and afterwards perhaps cease to be so, and others not. And of natural and legitimate heirs, some are near and some again nearer, *and some remote and other's more remote. For all brothers on the father's side are near heirs of their father by reason of the share they have in the possession. This is undeniable, because if the younger brother keeps his elder brother out of his inheritance, and has taken the profits and peaceable seisin thereof, the eldest shall

1 A clause appears to have been left out by the copyist here, owing to the repetition of the same word. The text should probably stand thus: Car acuns sount naturels et mulerez, et acuns sount naturels et nient mulerez, et acuns ne sount ne naturels ne mulerez. See the parallel places in Bracton and Fleta, referred to above. According to Bracton. a natural child is one born of parents between whom at the time of intercourse a legal marriage is possible, as between a bachelor and a maid not of kin to each other. And children born ex prohibito coitu are neither legitimate nor natural. (Bracton, f. 64.) 
have no recovery in the right of possession, as before is mentioned, but he is driven to demand his inheritance by means of the writ of right, which writ alone tries who is nearest heir in blood. And according as it shall be found by counting of the proximity among brothers judgment shall be given. But in all cases that person is next heir at law to whom the mere right soonest descends.

\section{CHAPTER II.}

Of Succession, and the Law of Inheritance.

1. All those who first descend from the common stock from degree to degree in the direct line for ever are lawful and true heirs; and when default is found in the direct line, then those who are found to be the nearest in the collateral degrees for ever are the right heirs; and lastly, when default is found in the transverse line descending, those who appear to be nearest in any *transverse line ascending shall be admissible. But although the heirs so ascending for ever are lawful and right heirs, yet they are not all admissible at the same time to the succession, because the eldest, being nearest, excludes the youngest who is near, and he who is near excludes the remote, and the remote one more remote. And when all these fail, either by their blood becoming extinct, or by their right being forfeited by juilgment of felony, the tenement must of necessity return to the lord of the fee, as to the source from 
which it first issued, for want of any other direction in which it can go: and in such case the homage received for the tenement is extinguished. ${ }^{1}$

2. There are many things which constitute proximity, and confer an inheritance and right of succession, to wit, sex, age, line, a partible inheritance, plurality of female heirs, form of gift, and blood. Sex, because the male is to be received and the female rejected, so long as there is a male heir apparent of the father by the same mother; but the daughter begotten on the first wife is to be preferred in the succession to the marriage granted with her mother to the male begotten by the same father on the second wife.

3. Age is material; because he who is the first born is admissible before the younger son of the same father and mother, and the younger brother will remain nearest heir to the elder, or at least a near heir, *according as the elder shall have issue or not. And if the elder brother dies without heir of his own in the lifetime of his father, the younger brother will take his place, and begin to be next heir to their common father, and the other younger ones will be near; and so of those more remote, without end.

4. If the elder brother dies in his father's lifetime, having begotten an heir, this issue remains under the authority of the grandfather, and shall be next heir to the grandfather by reason of the mere right which descended to him by the death of his father, the grand-

1 See above, pp. 360 and 361 , and the note there. 
father's son, although the son did not live to attain any estate; and the uncle or aunt shall be only near heir, although he is one degree nearer than the grandson, who is next heir. Therefore if the uncle, or aunt, being out of seisin, demand the seisin of his father by assise of Mortdancester, or by writ of right against the grandson the exception of proximity shall bar him; and in like manner if he demand against a stranger. And if the uncle or aunt is in seisin, and keeps out the grandson, the grandson, being next heir, shall recover by means of the writ of right by pleading his descent. And what is here said of the younger brother, uncle to the near heir, may be taken as an example of the position of near heirs in all like cases.

5. Line is material ; because the daughter found in the direct line descending is to be preferred before the male found in the transrerse line.

6. Of a partible inheritance, the younger son, as before has been mentioned, shall have as great a share as the elder; and in this case the custom of the place shall be observed.

*7. Plurality of female heirs affects the succession, as in case of sisters parceners, who, whether they are begotten of one or of several mothers, all present themselves in the place of one heir, and no one of them is to be preferred before another, neither can one be heir to the others ; for that would imply a nearer proximity in one than in another, which there is not, since they are all equally nearest. And if one of them dies, the shares of the rest shall be thereby increased, but not 
by succession, but by a kind of right called that of accruer. ${ }^{1}$

8. The form of gift is also material, as appears in the case of feoffments, whereby strangers are admissible to the succession in preference to the next heirs, who are excluded by the feoffors. For the wills of donors are to be observed as far as the law can permit; and although such strangers are not right heirs, yet they shall be in the place of heirs. And so shall all those stand in the place of heirs to whom lands or tenements fall by any manner of reversion or of escheat, whether it be by default of blood or by forfeiture.

9. Right of blood sometimes causes the female to exclude the male. For if $\mathrm{A}$. begets by one wife a son and a daughter, and by another wife a son, the eldest son is next heir to the father and *the mother, and if he dies without issue of his own, the sister is nearer heir to the deceased brother than the younger brother by the second or third wife. And so likewise the issue of the sister. But the first issue shall never demand any part of the inheritance of their step-mother until

1 It appears to follow from the doctrine of the text, that if an inheritance descended to several daughters by two wives, the share of one coparcener dying without issue would go by survivorship or accruer to all the others, and not by descent to her sisters of the whole blood. A similar doctrine is to be found obscurely expressed in Bracton, f. 66 b. (Compare Bracton, f. $77 b$; and see above, p. 73, and note there ; Blackstone, Commentaries, vol. ii. p. 231, note.) In modern times no jus accrescendi has been admitted between parceners. (Blackstone, Commentaries, vol. ii. p. 188.) 
after the decease of her issue, and if she has no issue by their father, they can never demand any part of the inheritance of their step-mother; nor, although she has issue by their father, if her inheritance did not descend to their brothers or sisters, the children of their common father by their step-mother. But if the inheritance falls to their brothers or sister, the children of the same father by a different mother, and the issue of their step-mother fails, an action immediately accrues to the first children, or to their issue, to demand the seisin of the last children, or of their issue. ${ }^{1}$

10. Of issue begotten upon the same mother by different fathers, the son by the first father and his issue are nearer, and are sooner to be admitted to every inheritance on the part of their mother, as well as on the part of their father, than the younger sons; and if they die seised and without issue, the sisters by the same father and mother are to be preferred to the brothers by the same mother and different fathers. * But if no male child of the first husband, or his issue, survive to attain the inheritance of his mother, then the males by the second husband are admissible to the

1 I do not find any authority in Bracton for the succession of the half-brother to an inheritance descended from his stepmother, a stranger in blood. But see the Year Book, 33 Ellw. I. p. 444. Bracton allows a man to be heir to his half-brother in respect of land purchased by him, in default of brothers or sisters of the whole blood. And in respect of land descended from their common father, he appears to doubt whether the half-brother would not he preferred to the sister of the whole blood. (Bracton, f. 65, 65 b. 66 b.) 
inheritance of the mother before the females by the first husband ; but if any male of the first husband has issue, male or female, this issue is to be admitted to the inheritance of the mother before the males by the second husband.

11. Sometimes also the younger sister excludes the elder brother, as where John begets by his first wife a son, and by his second wife a son and a daughter, and the younger son purchases lands or tenements, and dies without heir of his own body, the sister of the purehaser shall carry off the inheritanee and exclude the elder brother, although the brother would be sooner admitted to the inheritance descending from the person of John the common father. And if John has issue two sons and two daughters by diverse mothers, the elder brother is nearest heir to John, and after him the younger, if the father survive the eldest son; but if one of these brothers makes a purchase, and dies without heirs of his own body, the sister of the same venter as the purchasor shall be the nearest heir, and shall exelude the brother and sister of the other. venter, if not barred by homage. ${ }^{1}$

1 It is probably meant that an elder brother of the half blood will be excluded in favour of a sister of the whole blood, even where the relation of lomage between the two half-brothers does not present an obstacle to the descent to the brother, as would be the case where the tenement of the deceased was derived by gift from the common father. Compare Glanvill, li. vii. c. 1 ; Bracton, f. $65 \mathrm{~b}$; Fleta, p. $371(\$ 15,16)$; and see above, p. 34 , note. 
12. If there are three or more brothers by the same father and mother, and the youngest of them all makes a purchase and dies without heir of his own body, the elclest brother shall be his next heir, and shall exclude the father and mother, although they are nearer in blood, because the brother is found to be the nearest in the same degree, which the father and the mother are not; and he shall also exclude the other brothers and sisters, although they are found in the same degree. And even if the intermediate or other brother be in seisin, yet the eldest shall obtain it by a writ of right. And if the eldest brother dies without heir of his own body, then it shall go to the next eldest brother, and so from brother to brother, until it comes to the sisters. And if neither brother nor sister nor any issue of them appear, then it shall go to the common father ${ }^{1}$ or if the father be dead, and no other be found in any degree nearer on his side, to the common mother; and so of all the other degrees ascending. In what manner the degrees branch out will appear by the following degrees of kindred.

1 See note, p. 325. 


\section{Of Degrees of Kindred.}

1. There are various degrees of kindred, as will appear in the following figure. It must be observed, no one, whether male or female, found in any degree in the collateral line, either ascending or descending, is admissible to succeed, so long as any person is found alive in the direct line descending; but when no one is found there, then we are driven of necessity to seek the degrees in the collateral lines.

2. It is always proper to begin to count from the common stock last seised of both rights, and so descending in *the direct line from degree to degree, without stepping over any, to the plaintiff, and not only through all the occupied degrees in the direct line, but sometimes through the vacant degrees; as in case where the eldest son, having issue, dies before his ancestor. Sometimes in counting by descent the vacant degrees are passed over, as, where the eldest sons die without heirs of their bodies in the lifetime of their ancestors; for if an eldest son dies without issue in the lifetime of his ancestor, it is never necessary to count through hin, because he did not survive until any estate descended to him, but such degree is quite racant; so also if he had 
an heir who died without issue; and in such case the next brother occupies his place by reason of the mere right, which attaches to him as the next of blood. And if there is not any brother, then the right of succession will attach to the sister or sisters; and if there is no sister, then it will resort to the next occupied degree on the side of that ancestor from whom the inheritance moves in some collateral line. And as soon as he becomes seised of both rights, he begins to make a direct line as to issue begotten by him, and to be a common stock with regard to the heirs derived from him. *Yet if any one chooses to count through a person, or ${ }^{\circ}$ his children, who did not live until any estate descended to them by the death of the common ancestor, it does no harm; but in such case he ought not to say that the right of succession descended, but that from John ought the right to have descended to Peter, and from Peter to Thomas as his grandson and heir; but inasmuch as such son or grandson did not live until such right descended to him, because he died in the lifetime of the common ancestor, the right descended to the second brother or to the other next heir. And sometimes the count is divided into branches by reason of plurality of heirs, as in case of sisters parceners, where it is proper first to count through all the degrees of the issue of the first, and then of the second, and so of the rest.

3. For the assistance of learners, a figure may be made to show more plainly the degrees and the lines direct and collateral, whereby a person may be better acquainted with the law of successions. Let therefore 
a perpendicular line bedrawn, and in the middle of it let a void space be left for the supposed plaintiff, and let his father or mother be placed above him as the first ancestor, and that will make the first degree. Above the father or mother let the grandfather or grandmother of the plaintiff be put as in the second degree, and above the grandfather the great-grandfather or the greatgranchmother, *as in the third degree; and above the great-grandfather the great-great-grandfather and so ligher and higher by different degrees as far as the time limited in a writ of right will allow. And directly under the plaintiff let son or daughter be placed, which will make the first degree descending; and under him grandson or granddanghter, to make the second degree; and lower again the son or daughter of the grandson or granddaughter to make the third degree, and so descending from degree to degree ad infinitum.

4. If there be found no plaintiff in the clirect line to whom the right of suceession ean deseend, then of necessity it must descend to the collateral degrees, that is, to the nearest to the father or the mother, as, to the uncle or aunt, and so on, deseending in that line from degree to degree so far as they continue, and then for default of degrees found in the first collateral line, it must resort to the grandfather in the direct line, and afterwards for default there, resort to the brother or sister of the grandfather in the eollateral line, and so from degree to degree so far as they shall be found. full; and so of all the other higher degrees, so that the right of succession shall fall to those who shall be found. 
in the direct line, if none can be found any where below him to whom the right may descend.1 *And for default of him who would have made a legree in the direct line the right shall descend to one who shall be found in the collateral line, and for default of a degree in the collateral line the right shall resort again to the direct line at a higher degree, and if it find that degree full, it shall attach there; if not, it shall go on descencling in the collateral line, and so of all the other degrees.

5. And if no degree be found where the right may rest,--or even if any be found,--the lord of the fee may seize his fee until he in whose person the mere right of stccession rests shall come and demand it, and in the meantime the lord shall stand in the place of the heir.

6. How the degrees are placed in consanguinity, appears by the above figure, whereof the half might

It will be observed, that the writer admits succession by lineal ascendants, contrary to the generally received opinion, and without authority from the writers whom he generally follows. See before, p. 164, note, pp. 319, 320 ; and compare p. 312 ; Glanvill, l. vii. c. 1 ; Bracton, f. 626 . Coke, who frequently in his margin cites Britton upon this very subject, does not appear to have understood him as contradicting the received doctrine; 'I never read,' he says, ' any opinion in any booke, old or new, against this maxime,' (that an inheritance lineally descends, but does not ascend,) ' but only in Lib. Rub., where it is said, Si quis sine liberis decesseret, pater aut mater ejus in hæreditatem succedat, vel pater et soror, si pater et mater desint" (Coke Litt. 11 a.) The authority cited by Coke as Liber Ruber is the Collection of Anglo-Saxon Laws known as Leges Henrici I. c. $\operatorname{lxx} .20$. 
suffice, and then it would resemble a banner; but it is displayed on the one side to show the issue of male ancestors, and on the other to show the issue of female ancestors.

\section{CHAPTER IV.}

Of the proceedings in a Plea of Right before the Court Baron and County Court, and of its removal into the Royal Court.

1. Writs of right patent ought to be brought in the courts of the lords of whom the plaintiffs claim to hold; and therefore if they are brought or purchased in any other courts than those of the chief lords the fees, such chief lords shall have their courts out of our court, as soon as they make demand thereof, and can prove the fees to be theirs; *and the writs and proceedings shall fall to the ground, and the plaintiffs shall remain in our mercy.

2. The plaintiff, having purchased his writ, ought to carry, and show it to him to whom the mandate is directed ; and he forthwith, without demanding pledges to prosecute, is bound to appoint him a day at lis first court, which ought to be within three weeks, upon the same fee; and the writ should be produced and read in full court, and entered on the roll, and the tenant summoned by award of the court.

3. If the plaintiff be longer delayed, and can prove the same, as hereafter mentioned, by plaint and proof, he may by reason of such wrong, and because his lord 
has failed to do him right, waive the court of his lord, and plead in the county court, whether the lord has the franchise of return of writs or not. And thus in some cases the plaint may be removed out of a court, and afterwards brought back into it again. And before proof made of default the plaint shall not be consillered as in the county, but after that, and not before, a Pone will lie to remove it before our Justices.

4. There are many ways besides in which a cause is removable into the county court, as, where the lord refuses to intermeddle therein, or because he has no court, or because he has released his court by his letters patent; also for want of authority in the lord and his court, as where the tenant vouches a warrant out of his jurisdiction, *and whom he cannot compel to appear, or if the tenant cause himself to be essoined de malo lecti elsewhere than in the jurisdiction of his lord, or because he has not authority to send the four knights to judge of the sickness for which he is essoined, or if the tenant put himself upon the great assise, and for many other reasons. Sometimes also the plea is removable by the tenant, as where he does not hold anything of him to whom the writ is directed.

5. As to summonses and defaults and essoins in the courts of freemen, the practice ought to be according to the custom of the country; but in the demanding of view, vouching to warranty, counting by descents and resorts, defencling, excepting, and joining in battle, let the same order of pleading be observed in the court of a freeman as is awarded in our court. 
6. The manner of proving the lord's court false, where the lord himself or the bailiff to whom the mandate was directed, has failed to do justice, is as follows. In the first place, the plaintiff should complain to the sheriff, and produce the writ in full county court, and then, by award of the suitors, and without any security to prosecute being found, the bailiff of the hundred or some other shall be commanded that in the presence of the neighbours he go and take the oath of the plaintiff and two others, in the court of the lord, if he has a court, or at his mansion, *or if he has neither court nor mansion, then upon the land itself, that the lord has failed to do him right; for it is not sufficient to prove that the court has failed to do right, but it must be proved that he to whom the mandate is clirected failed to do right, the words in the writ being, 'And if thou do it not, the sheriff shall do it.'

7. Therefore every plaintiff, before the plaint is removable into the county, onght to complain of the court to him to whom the writ is directed. And then the lord, having heard the plaint, ought straightway to see and examine the proceedings, and to hear the plaintiff in the presence of the suitors, in what point the suitors have done him wrong; and if he finds an error, he has authority to amend it, and to amerce the suitors. And if lue neglects to do so, then the complaint shall be made to the sheriff.

8. When the bailiff has taken the oath of the plaintiff and his cojurors, be is straightway to cause the tenant to be summoned by two freemen terre-tenants 
to appear at the next county court to answer to such a plaintiff upon a demand made against him of so much land with the appurtenances in such a vill, according to the purport of the writ; and he onght to enjoin the summoners to be at such county court to prove the summons, and also to appoint the plaintiff the same day to prosecute his plaint. When the sheriff, or any deputy of the sheriff in a county or franchise, fails to do right to the plaintiff, if he farms his office, he is punishable *by imprisonment and fine as a despiser of our mandate; and if he be sheriff in fee, he hath deserved, if convicted, to lose the franchise, and to milke satisfaction to the plaintiff for his damages.

9. When the plaint is thus adjourned into the county, if the lord of the fee comes into court and complains of plaintiff, and offers to show and instruct the court that the plaintiff has misinformed the sheriff and the county, and that he himself never failed in doing right, whatever his court may have done, he shall be heard, provided he comes before any essoin is adjourned in the county either for the plaintiff or for the tenant. But if he waits till an essoin is entered, allowed, and adjourned, and the plea has been so long in the county, that upon the arrival of the Pone the least spark of a proceeding in the county court can be discerned, the lord of the fee cannot afterwards insist upon his jurisdiction. ${ }^{1}$ If the sheriff maliciously return that there

${ }^{1}$ It may be seen from the above, that although the jurisdiction of the lord was in theory maintained, the utmost facility was afforded for evading it. And it was found that in practice most. 
is no plaint in the eounty court according to the tenor of the Pone, yet the Pone shall not be lost, if by the dates of the writ patent and of the Pone it may be presumed in favour of the plaintiff that the plaint may have been in the county; and afterwards the plea shall take its course according to its nature.

10. At the day of the summons at the county court the parties may be essoined, and to him who shall be essoined another day shall be given by his essoiner at the next county court. At which day the person who before appeared may cause himself to be essoined, and so after each appearanee, though it happen a thousand times, *except in special cases, as will appear in the chapter of essoins de malo veniendi. If the plaintiff makes default, and the tenant appears, let it be awarded that the tenant go without day, and that the plaintiff take nothing by his writ, but remain in our mercy, that is, if the default before view; but if clefault be made after view, let it be awarded that the tenant remain in his seisin quit of the plaintiff and his heirs for ever after, and the plaintiff be in mercy. And if both make default, then one default may be set against the other, the tenant not having had judgment to depart without day.

11. If the tenant makes default, and the summons is

lords were contented to waive their jurisdiction respecting the title to land, for an important reason, which we learn from Hengham, namely, that little or no profit accrued to the lord from holding such pleas in his court. Hengham Magna, c. 3 . p. 11. 
witnessed by the summoners, it shall be awarded, when the default is before appearance, that the land demanded be taken into our hand according to the terms of the great Cape, or otherwise according to the usage of the place. So likewise, where the tenant makes default at the first county court, if the bailiff with the summoners attest the summons; and this summons the tenant cannot defend by his law; and thus the bailiff, with the testimony of summoners, bears record of summonses. And if the tenant makes default after default, judgment shall be immediately given for the plaintiff, saving to the tenant his right to recover when he thinks good. *In like manner it shall be, if the tenant does not within fifteen days replevy the land taken into our hands, unless the case is affected by deceit. What is here wanting upon the subject of defaults in general shall be more particularly supplied hereafter. ${ }^{1}$

12. When the parties have appeared in court, and the plaintiff has counted his count against the tenant, and the tenant has defended the wrong by proper words of defence, then he may vouch to warranty, if he has any one to vouch, and if the warrant does not live within the distress of the sheriff of that county, then the voucher must be aided by the following writ directed

1 The further explanation of the law of defaults here promised is not found in the treatise as it now exists. The same observation applies to the description of trial by battle referred to in s. 14. See the Editor's Introduction, p. xlv. The subject of defaults is more fully treated in Bracton, f. $364 b-380$; Fleta, p. $395-400$. 
to the sheriff of that county where the warrant has his land. 'Command such an one that he warrant to such an one so much land with the appurtenances in such a vill; and that, if he does not do it, he be at the first assises when the Justices make their eyre in those parts to show why he has not warranted.'

13. If the vouchee will thereupon enter into warranty in the county, it is well; if not, let the plaint stand over to the eyre, if it be not first remored before our Justices. For in such case the county court will have no authority to proceed further in the action. And when the plea of warranty is tried before our Justices in eyre, then they may either determine the principal plea themselves, or send it to be determined in the county. *But if the plea be in the meantime removed before our Justices, then the adjournment in eyre is annulled, and the tenant shall vouch to warranty again in the plea of Pone. Where the warrant is under the age of twentyone years, and comes into court to prove his age, the principal plea and the plea of warranty also before the Justices in eyre, are suspended until the warrant is of age.

14. If the tenant defends himself by battle, the proceedings shall be as hereafter mentioned. If by the great assise, then let a day be given at the next county court, and let the tenant in the meantime obtain a letter. from the Chancery ; and by his own mouth he is required to say that he is tenant, and by what words he has put himself on the great assise $;^{1}$ he shall then have a writ

${ }^{1}$ The text of this sentence, either from corruption or other- 
to the sheriff to cause the plea to cease until the eyre, which writ shall be enrolled by way of precaution, on account of the attachment which follows, if the sheriff refuses to cease thereupon. And when the tenant has purchased this writ, then let the plaintiff sue out another writ to the sheriff to cause the great assise to be summoned against the coming of the Justices for the hearing of all pleas. If the tenant has omitted to obtain the prohibition aforesaid, then at the next county court, or at the day given to the essoiner of the tenant, the plaintiff shall recover seisin of his demand by the default of the tenant.

15. Actions are removed out of the county court in several ways ; sometimes at the instance of the plaintiff, and this may be without assigning any cause; *and sometimes at the request of the tenant; but this ought not to be done without affirmation of the cause in the body of the writ of Pone, which cause ought not to be allowed before it has been tried in full county by the oath of the tenant with two cojurors. ${ }^{1}$

wise, is somewhat dislocated. I have restored it in the translation to what appears to have been the proper order. See Bracton, f. 331 ; Fleta, p. 37\%.

1 The reason for making this difference between the plaintiff and the tenant seems to have been, that while the latter might desire to remove the cause for the purpose of delay, the former could have no interest in so doing. (Hengham Magna, c. iv. p. 14.) The cause assigned by the tenant might be a connexion between the sheriff and the plaintiff, or the predominating influence of the latter in the county, or that the tenant was abroad, or too infirm to attend the county court. (Bracton, f. $332 b$; Hengham Magna, c. iv. p. 14.) 
16. If the canse be remored before our Justices at the request of the tenant, and he makes default upon the first day, and the plaintiff proffers himself and demands judgment of the default, the plaintiff shall recover seisin of his demand, and the tenant remain in mercy. And if the eause is removed out of the county at the instance of the plaintiff, and he makes default on the first day, and the tenant is essoined, and his essoiner leares the court, having judgment to go without day, although the plaintiff keeps by him the writ patent, if he brings a fresh Pone to remove the plaint out of the county, this new writ will be of no avail, but must be returned in this manner, that no plaint is depending in the county court according to the tenor of the writ, inasmuch as by another like writ it was remored out of the county before the Justices. And thus all the plea will have to be begun afresh, but not by the same writ.

17. Sometimes the action is by necessity mored out of the county court at the instance of the plaintiff, as, where the tenant is privileged, as the Templars, Hospitallers, and others are, *who have this franchise by royal charters, that they need not to answer any plea elsewhere than before our Justices. If nevertheless they have anywhere entered upon their answer, they cannot afterwards change their minds or withdraw. Sometimes also of necessity, when the county court has no authority to proceed further in the plea, as where bastardy is alleged, or marriage is denied, or in other cases to the cognizance of which the jurisdiction of the county does not extend. Sometimes also the plea is 
removed on account of the folly of the suitors of the county, as where battle is awarded and joined contrary to the common law and the common usages of this realm. Sometimes also by reason of the difficulty of judgment, and for many other causes. The petty writ of right, which contains the clause, 'according to the custom of the manor', and which was provided in favour of sokemen, is never removable before the Justices.

\section{CHAPTER V.}

\section{Of Summons in a Plea of Right.}

1. The plaint being thus removed into the great court at the instance of the plaintiff, the tenant must be summoned to be there at a certain day to answor the plaintiff according to the form of the plaint. There is summons, after-summons, and resummons. And there is also a precept which is not properly a *summons, as where we should command any one to come, or command the sheriff to cause him to come, or that he have or attach such an one, or cause him to know that he be on such a day in such a place. But of proper summonses, some are general and some special. A general summons is one which concerns an entire community, as the common summons in eyre, which is solemnly proclaimed throughout cities, boroughs, and markets, and in other like cases. Such summonses no single person can deny or defend by his law. Special 
summons is, for example, where summons is made upon a certain plea to certain persons. And so possibly one essoin might lie for both summonses; as if any one who is impleaded has his day of plea on the first day of the eyre, and he causes himself to be essoined, the essoin will excuse his absence as well for the general as the special summons.

2. All persons ought not to be summoned. For an infant uncler age is not capable of receiving any summons except through his guardian; nor a person letained in prison, although he may cause a summons to be made without guardian; nor a madman, nor one otherwise deprived of sense, as an idiot; nor deaf and dumb persons; nor married women without their husbands; nor a canon removable without the dean *and chapter, nor other persons in religion removable without the abbot or their prior. ${ }^{1}$

3. When any one then is to be lawfully summoned, wherever he be found in the county where the demand is made, he may be reasonably summoned in his proper person by two freemen terre-tenants of the county. For no one is obliged to receive a summons out of the

1 The word 'removable' appears to be applied to the officers of a religious house holding office during the pleasure of their superior. See 1. i. c. 29. s. 6, and note there, vol. i. p. 159. The parallel passage in Bracton points to the existence in some cases of an irremovable officer charged with the duty of representing the religious foundation in court. 'Item viri religiosi' [summoneri debent] ' per procuratores sindicos et actores perpetuos et non amotibiles, et qui tales sint, quod possint lucrari et perdere et rem in judicium deducere.' Bracton, f. 336 b. 


\section{1, *280.] IN A PLEA OF RIGHT.}

precinct of the county, unless from the mouth of a Justice himself. And if he is not found, then it is sufficient to make the summons at his house, so that he may be informed thereof when he returns. And if the tenant has several houses, let it be made at that which is upon the land demanded, if he be resident there, or has any family there who can inform him of the summons. And if no land is demanded, let it be made at that house where he chiefly resides; and if he has no house in the county, then it is sufficient to make - the summons in the fee where he is distrainable, with a great number of neighbours for witnesses.

4. When any person is to be reasonably summoned, he ought to have fifteen days at least to prepare his defence. If less time is given, and the person summoned chooses to challenge the summons, it is of no force; but the summoners ought to be in mercy, if they are convicted of their unreasonable summons. Tet there are some causes which are so favoured, that reasonable summons is not required in them, as in causes touching ourselves or our kindred, ambassadors from foreign countries, merchants, and crusaders. So likewise in our eyres, or in the eyre of *our Justices, and in disseisins, intrusions, abatements, and fresh force. Nevertheless if any one after such unreasonable summons causes himself to be essoined, or appears without challenging the summons, or if he accepts a day of grace, he cannot afterwards challenge the summons as unreasonable. When the tenant has thus been reasonably summoned, he may not from that time absent 
himself out of the realm or elsewhere, though he afterwards procure our letters of protection; but the plaintiff shall recover lis demand, unless the plea be defended by the tenant or his attorney.

5. In every summons it is proper to have the warrant or transcript sealed with his known seal, ${ }^{1}$ so that the tenant may know before what judge he is summoned, and may be able to arm himself with exceptions against the action of the plaintiff; otherwise such summons shall be unreasonable and of no effect, and the tenant, upon challenging the summons, must be summoned again either by the Justice in court or else by summoners. It is said, before what julge, because one is not obliged to appear before every one who pretends to be a judge; for no one can have authority to cause any to be summoned except from us; and though he should have authority from some Justice, that is of no value, because a Justice, cannot, make another *Justice, nor authorize any person to bear record or pass judgment without warrant from us. And it is a general rule of law that no one shall be affected by a judgment pronounced by one who is not truly his judge. When any one therefore has had a reasonable summons to appear before a person who has power

1 The written warrant for summons is not mentioned in Bracton ; and in Fleta, although the warrant is mentioned, there is no notice of its bearing any seal. The seal required wonld appear to be the seal of the sheriff of the county where the appearance was to be, whether in the county court or before the Justices Itinerant. 
and authority of judging from us, it is his cluty to appear accordingly.

6. And because it may happen that the blame ought to fall upon the sheriff, it is proper to know who is in fault, whether the sheriff or the summoners; and if it be found that the sheriff did not direct any one to make the summons, let him be punished for bis neglect, unless he has a reasonable excuse, as that the plaintiff did not find any security to prosecute his plaint, or that the writ came so late that he could not execute it, or that he received the writ out of his county, and before it came to him he was obliged by such a precept to go elsewhere into some distant place; and by many other reasons the sheriff may reasonably excuse himself. And if the day contained in the writ is passed, then the plaintiff must purchase a new writ. So likewise where the summoners clid not execute the summons, although they were enjoined to do so. This fact the summoners may defend by their law, although the sheriff brings suit to prove it. ${ }^{1}$

1 This is probably net to be understood of the case where the summons was publicly ordered in the county court; in which case, according to Glanvill, Bracton, and Fleta, the suitors bore record, which could not be contradicted by the summoners. Possibly the practice of ordering summons in the county court, which in the time of Glanvill was the regular course, had now become unusual. See Glanvill, lj. 1. c. 30 ; Bracton, f. 336 ; Fleta, p. 380. 


\section{${ }^{*}$ CHAPTER V}

Of Essoins.

1. No person ought to depart unpunished after he has been reasonably summoned, and does not think fit to appear in court, unless upon some reasonable excuse, whence essoins arise, as the service of God, or of ourselves, accusation of crime, sickness, force. Service of God, such as pilgrimage, which ought to be an important excuse, and favoured according to the nature of it, provided that no summons arrived before the journey. Our service, as where a man is in our forces for the defence of us, our people, or our realm. Accousation of crime, for if any person be indicted or appealed of life and limb, he is never obliged to answer in a matter involving loss of land or of chattels, until he has defended himself in the more weighty matter. Sickness, as in the case of those who put themselves in motion towards the court, and are seized with sickness by the way. Force, as in the case of those who are hindered by imprisonment, or by robbers or other enemies on the road, or the breaking of bridges or other passages, storms, or want of boats or ships.

2. If any one therefore desires to excuse his absence, let him presently send some excuser, who may relate in court the impediment as it has occurred. And if 
the latter does not cause the *excuse to be entered on the same day as is specified in the writ, or as was before given to the party in court, the excuse will not afterwards be allowed. Such excuses are called es. soins, and the excusers essoiners.

3. However the essoin is enrolled, the purport ought to be as follows: 'John, the essoiner of Peter, came the first day, and showed, that whereas Peter his master was summoned to be in this court on this day to answer to Robert of a plea of land, the same Peter, before any summons was made to him, had set out from his house on a pilgrimage in the service of the Heavenly King towards parts beyond sea to that holy sepulchre at Jerusalem, in a general passage with other crusaders,' if there was a general passage at that time, or else, 'on an ordinary passage;' or, 'before any summons was made upon him, he went upon the king's service, in pursuance of a precept in that behalf as upon it service due for his land.' In the above form he may cause himself to be essoined of the service of the Heavenly or' Earthly King. Or thus: 'such a sickness overtook him in journeying towards this court, that he could not come forward to gain or lose, but had himself carried back to his own home or elsewhere.' Or, 'such other hindrance came upon him by the way, that he could not proceed to gain or lose ;' and thus be excuses himself by way of essoin de malo veniendi; and therefore the essoiner ought to tender averment.

${ }^{*} 4$. But because the proof of the essoin is the business of his master and not of the essoiner, and because it is 
not yet ascertained whether he is a true or a false messenger, or whether his master will acknowledge him or not, it is customary for the essoiners of rich and powerful persons, as carls, barons, and all others holding by barony, to find pledges to produce their lords at the day appointed, so that such essoiners may not escape unpunished, if they are not warranted in their message. But inasmuch as this would be oppressive if it were done with the essoiners of poor people, it is permitted, out of favour to such persons, that the essoiners of all other sorts of people do promise only, without more, to produce their warrants at the day appointed.

\section{CHAPTER VII.}

Of the Essoin de ultra mare.

1. Essoins are briefly divided into essoins de malo veniendi and essoins de malo lecti. But the first division is again divided into those de ultra mare and those de citra mare. And of those de ultra mare, some are beyond the Grecian sea, and some simply beyond sea, as at Rome or at Saint James. *And of those beyond the Grecian sea, some are in a simple pilgrimage to the sepulchre of Jerusalem, others to the same place in a general pilgrimage.

2. In essoins de citra mare the impediment sometimes arises from sickness, and sometimes from other hindrances. And of those from sickness, some arise from sickness overtaking the party on the road, and some from disease, which is called malum lecti, and 
some from an illness coming on in the town where the court is held. Of other impediments, some arise from the senses, as in cases of idiots, persons deaf and dumb, and others who are not of sufficient capacity to receive a summons; some arise from hindrances of imprisonment, or of roads; some from the service of the earthly king; and from accusation of felony.

3. In the essoin beyond the Grecian sea in a general pilgrimage, it must be observed whether there has been within the year a general passage of any Christian king, or other person sent by the Pope with a great host of Christians; for then this essoin is allowable, and the plea will stand over without day, out of favour for the pilgrims of God, on account of the privilege of those who have taken the cross, until the return or death of the pilgrim. There are some however who obtain our letters patent of protection to be in force for one, two, or three years, and who nevertheless by virtue of our letters patent do also make general attorneys; and such persons do well and wisely. *For no great lord or knight of our realm ought to travel forth of it without our licence, since by that means the kinglom might be left destitute of able persons; and such letters ought to be presently shown in full county or liundred court, or at public places. And if there has not been any general passage to the Iloly Land within the year, then let this essoin be turned into the essoin beyond the Grecian sea to the Holy Land in simple pilgrimage. This essoin is the first of all the essoins : for if it be east after any 
of the others, it will, from its nature, never be allowed.

4. In the essoin beyond the Grecian sea in simple pilgrimage the term of a year and a day is to be granted. Ancl if the essoiner sees that he cunnot be warranted at the end of the year, then again the essoin de ultra mare simply shall take place, which signifies a common pilgrimage to Rome or Saint James ; and such essoin shall be allowed, and the adjournment shall be for the period of forty days, and one flood, and one ebb of the sea. And if the essoiner perceives that his master does not come to warrant him, then again the essoin de malo veniendi shall lie, in which a term of fifteen days at least ought to be given. *And if he is still prevented from appearing by sickness, then a distinction must be made, whether he lies sick on his road, or in the town where the court is held, for if on the road, ${ }^{1}$ this gives rise to an essoin de malo lecti; and this essoin must be made by two messengers or friends, and not by essoiners, as shall be bereafter mentioned. If he lies in the town where the Court is, then the essoin de malo villa takes place, as shall be noticed in its turn. And if the essoinee does not then appear to warrant the essoiner, then and not before the land is to be taken into our hand by way of distress, unless we have received his possessions under our protection by our letters patent, which suspend all pleas but four. ${ }^{1}$

I should prefer to read a sa masoun, ' at home,' here and in the line above; but I find no authority for it.

2 Five kinds of actions are mentioned in Fleta as not being 
5. The manner of entering essoins is as follows: 'John, who is gone over in a general passage of pilgrims to the Holy Land, against Peter, of a plea of land, by such an one.' And if in a simple pilgrimage, then thus: 'John, who is gone in a pilgrimage to the Holy Land, against Peter, of a plea of land, by such an one.' And if in a more ordinary pilgrimage, then thus: 'John, who is gone across the sea in a pilgrimage, against Peter, of a plea of land, by such an one,' whether it be the sea of France, Ireland, or Scotland, which he has crossed. If it be an essoin de malo. veniendi, whatever the hindrance be, whether *sickness, imprisonment, hindrance of passage, or other, then thus : 'John against Peter, of a plea of land, by such an one.'

6. If several holding in common by one title are essoined, then let the essoin be entered according as they please, either thus, 'John against Peter and' the others named in the writ, or against each person severally. Nevertheless they may be all essoined by one essoiner. And if part cause themselves to be essoined and part not, then it will be necessary to mention the names of those who are essoined, and take no notice of the others who are not essoined, as thus : 'John and the

stayed by letters of protection, namely, the assises of novel disseisin, mortdancester, and last presentation, and the actions of quare impedit and dower unde nihil habet. (Fleta, p. 383. \$2). A note in MS. $Z$ mentions the same actions, omitting the assise of mortdancester, and adding plaints commenced before Justices in eyre. 
others named in the writ against Peter, or against $P$. M. and R.' But it is otherwise with the essoins of several persons holding by different rights although they hold or demand in common. For in such cases the entry must be thus : 'John against Peter; 'Thomas, and Simon, of such a plea, by such an one ;' or thus : 'Peter against John, Thomas against John,' and so severally of all the rest ; and in that case every tenant who causes himself to be essoined must have a separate essoiner.

\section{CHAPTER VIII.}

Of the Essoin founded on the King's Service.

The essoin de servitio regis may be received at any period in those cases where it is allowable ; for it is in some cases allowable, and in some not. It is never to be allowed in any of the four petty assises, nor in a plea of lower where a widow complains that she has nothing of her dower, nor in attaints, *nor in certifications, nor in any plea where the plaintiff is under age. Neither does it lie for any person who does not serve us in chief, although he performs his service to some one belonging to us; nor is it to be allowed to those who do service to us, unless they are with us by our command in order to perform the service to which they are bound by reason of some tenement. To such persons our Chancellor ought to grant a writ to warrant their essoiners, and excuse their absence, so long as they 
continue with us in such services; and if any writ be otherwise granted, we will that such writs be impeached and held bad.

\section{CHAPTER IX.}

Of the Essoin de Malo veniendi.

Neither the essoin de malo veniendi nor any other essoin lies for any person under age, because an infant cannot warrant any essoiner. For warranty of essoin is nothing else but swearing upon the evangelists that the cause of his absence was true, according as he was essoined at the former day. Neither does it lie in an accusation of felony ; nor in the person of disseisors or redisseisors; nor for those impleaded of hamsoken, or of fresh force, or of abatement; nor in pleas de vetito namio in the person of the defendants; *nor for such as are let by bail to be answered for by others, body for body; nor in the persons of those whom the sheriff is commanded to cause to come, or to cause to know that they be there if they will; nor of those who have made attorneys in court, unless the attorneys be also essoined ; nor for one attorney, where two have been made in one plea with several powers, unless both be essoined; neither does the essoin lie where the adverse parties are dead, or have not pursued their writs or plaints, or where the writ does not agree with the essoin $;^{1}$ nor

1 This appears to be mistaken rendering of the words of Bracton, ubi breve non conrenit petitioni. The meaning in Bracton 39 
in those cases where the sheriff is commanded to distrain by land and chattels; nor where the parties are adjourned from one day to the next; nor where they have agreed to come without essoin; nor after day of grace given by consent; nor where the plea is suspended for default of jurors, except for the defendant, and that only once; nor where the party essoined, or his attorney, hath been seen in court in the meantime before the adjournment of the essoin, and the Justices have taken notice thereof; neither does an essoin ever lie immediately after default, unless by consent.

\section{*CHAPTER $X$.}

\section{Of Attorneys.}

1. Attorneys cannot be made by every one; for an infant under age, a deaf and dumb person, an idiot, a man simply mad or otherwise without discretion, a person accused of felony, or any one who is forbidden by us to do so, or a leper expelled from society, cannot make an attorney.

2. Of attorneys, some are general and some special. General attorneys are made in two ways, that is to say, either by our letters patent, or by appointment of parties before Justices in eyre. Those attorneys who are made by our letters patent have sometimes more seems to be, that when the whole proceeding is void, as where the plaintiff has not obtained a writ suitable to his plaint, the essoin is null. See Bracton, f. 341 ; Fleta, p. $384(\S 4), 385$ (§6). 
authority than other general attorneys, because they have sometimes the power granted them toattorn others in their place. All general attorneys may levy fines and make chirographs, and final accords in all pleas as fully as those whose attorneys they are. This cannot be clone by special attorneys; for as soon as parties are at accord in any sort of plea, that proceeding is at an end ; and if any question is to be made upon the accord, thereupon begins another sort of plea, and of another nature. And though one be made attorney in the existing proceeding, he is not thereby made attorney in the future proceeding, unless he be made general attorney in all pleas commenced and to be commenced.

*3. No one can admit persons as attorneys by our letters patent, except us and our Chancellor. Neither ought other general attorneys to be admitted save before our Justices in eyres and in full court. Special attorneys cannot be admitted except by us or our Chancellor, or other person whom we may especially assign by our writ in that behalf, or the Judges in full court, whoever they be, sheriffs, or freemen, before whom the party is bound to plead by our writ. Where the proceeding is commenced without our writ, a court of suitors cannot bear record of attorney; and therefore no attorney can be admitted in such a court without our writ, except where the proceeding is commenced by writ. The four knights, who are sent to the sick persons in essoins de malo lecti and de malo villae, can also admit attorneys. If any person offers himself as attorney for us, or for any other, in any of the 
aforesaid cases, and being challenged by the adverse party, is not admitted as attorney, such person may be committed to prison. And when any one has been thus made attorney, he cannot retire pending the proceeding without the consent of his client.

4. When two or more are made attorneys clisjunctively, whether they be made general or special attorneys, *although each has the power of his master, yet the essoin of one attorney will be invalic, unless all the attorneys be essoined, on account of the fraud which might be practised by the attorney who is not essoined, after the adverse party has had a day given him as against the essoiner of the other attorney, and has thereupon left the court. So, when any one has made an attorney, and has then appeared in court and pleaded, and had another day given him in his own person, it is not sufficient at the next day that he alone should be essoined, because there is an attorney; nor that the attorney alone should be essoined, because it was not the attorney that had day given him. It is therefore safer for both to be essoined.

5. When any has made a special attorney against a certain person tenant, and the tenant vouches to warranty, the attorney does not keep his place as against the warrant, but the plaintiff should make a new attorney in the plea of warranty, or else he will lose his writ, if the warrant take the objection, as will be said of husband and wife plaintiffs, in the chapter upon warranties, 1

1 'This is anotlier reference to a future chapter either never supplied or lost. The same chapter is referred to before, li. iii. 
and the attorney would in such a case be liable to be committed to prison. So likewise in all cases where any one offer's himself for attorney, who was so made before any proceeding existed for which he was made attorney, as where the attorney was appointed before the * writ was delivered to the sheriff, or before any summons was made. For before summons, or something equivalent to it, the proceeding is not begun. So, where the sheriff merely informs a person that he is to appear in court on such a day, if he think proper to do so, if any one offers himself as the attorney of such person before he has appeared in court, the attorney is liable to challenge. So also is he who offers himself as attorney of one not named in the writ or the principal plaint, before the party whose attorney he represents himself to be has appeared in court; as where people have purchased tenements after the writs have been sued out against their feoffors, and have friencls in court, who put themselves forward as attorneys of the tenants, to make a defence against the right of plaintiffs,-in such case the attorneys are liable to challenge, whether they have warrant or no; for before such tenants have appeared in court in their own persons, they will not be allowed an attorney. And in our court, however the practice may be in the law Christian, such attorneys are challengeable as offer themselves to make their law for their masters, or to swear upon their souls. So also in all cases where any c. 11. s. 2. The point intended to be mentioned may be found in Bracton, f. 381 ; Fleta, p. 408 ( $\$ 9$ ). 
one offers himself as attorney in the plea of Pone, having been appointed before the Pone was sued out.

6. If any attorney dies pending the plea, a distinction is to be made, whether he whose attorney he was is gone across the sea or not. For if he be not in England, - or not in Ireland, supposing the plea to be there,the action may be suspended without day until his return. ${ }^{1}$

1 It is plain from the above abrupt conclusion, as well as from the references, occurring in several parts of the work, to future passages and chapters which are not found in the existing treatise, that Britton in its present form is incomplete. See before, vol. i. p. 108 ; vol. ii. pp. 411, 414, 612. The few additional lines, which are found in two manuscripts of no great authority, do not appear to me to be a part of the original work, which, if continued, would probably have consisted of several more chapters following the arrangement of the latter part of Bracton and Fleta. See the Editor's Introduction, p. xlv. 


\section{INDEX.}

References are to top, or running pages.

Abatement and intrusion...................... 333

Abatement of writ........................ 254

by death of party......172, 227, 264, 419, 444

by marriage of female plaintiff....... 264

Abjuration of the realm...................

Accessories, in felony, appeal of............. 9, 10, 99

in homicide, prosecution of............ 29

in treason, appeal of ................ 90

in trespass ......................... 109

Accessorium sequitur principale...........120, 261, 471, 483

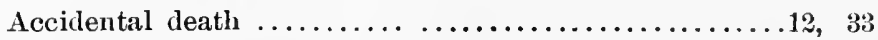

Accidental loss, disseisor liable for................ 286

Accord, plea of.................... 108, 236, 273

termination of action by............... 409

Accretion of land by deposit of river $\ldots \ldots \ldots \ldots \ldots \ldots \ldots 179$

Accruer, title by ..................... 180, 191, 193, 579

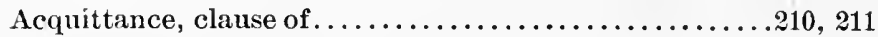

Actio alienari non potest..................... 480

Admeasurement of dower ; see Dower.

of pasture ................. 305 -308

Adultery, forfeiture of dower by ............... 554

Advocate, or patron, of a church................ 471

Advowson, actions relating to................46\% 49.

appendant ...................... 483

cannot be conveyed without land........... 218

how valued $\ldots \ldots \ldots \ldots \ldots \ldots \ldots \ldots \ldots \ldots . \ldots . \ldots 390$ 
References are to top, or running pages.

Advowson not generally assigned in dower ...... 281, 530, 5it of abbey, prebend, \&c............... 4 it

Ael, writ of ............................. 462

Afforcement of jury .................... 280, 514

Aids pur fere fitz chivaler and pur file marier........... 120

Alienation by felons, voidable................. 46

restricted by deed................ 194, 209

Allegiance, obligation of $\ldots \ldots \ldots \ldots \ldots \ldots \ldots \ldots \ldots \ldots$

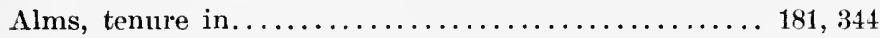

Amendment of record.....................

of false judgment...............

Amercement, power of $\ldots \ldots \ldots \ldots \ldots \ldots \ldots \ldots \ldots \ldots \ldots \ldots 151$

how levied..................... 159

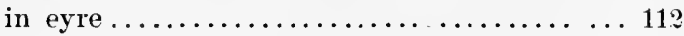

of absent jurors.................... 459

of losing party in action............. 460

Ancient demesne..........58, 182, 202, 258, 344, 345. 394, 446

tenant in, not a freeholder..........233

Appeal of felony .................. 9. $28,81,10 ;$

enrolment of ......................... 14

form of $\ldots \ldots \ldots \ldots \ldots \ldots \ldots \ldots \ldots \ldots \ldots \ldots .63,9 \%$

jurisdiction in................ $48,91,92,96$

trial by battle in $\ldots \ldots \ldots \ldots \ldots \ldots \ldots \ldots \ldots \ldots .84,89$

Appeal from court baron to lord ................. 590

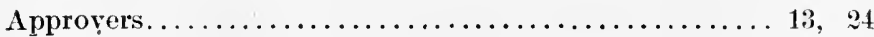

Appurtenances....................208, 219, 28\%-295

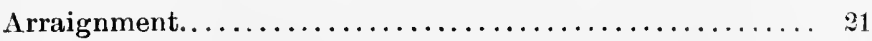

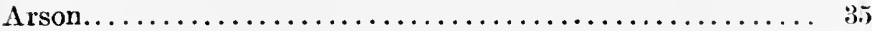

Assigns, effect of gift without mention of...183, 191, :21)1, 4:3r first inserted in feoffments in favor of bastards... . 25:

Assise, Justices of ....................... 4

Assise of common.......................

of darreign presentment.............201, 467-491

of mortdancester, 376-460. See Mortdancester.

of novel disseisin, 222-286. See Novel disseisin. 
References are to top, or running pages.

Assise of nusance

of Utrum

turned into jury 268-281, 45 ;

Astrer, or astrier. 312,456 , note.

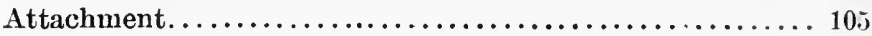
suits pleadable by ................... 174 Attaint. $350,409,501-51 \%$

before judgment. 504

of jurors on inquest of age .............. 350

where it lies......................... 507 Attaints and certifications, by what Justices taken....... 504 Attorney, authority of................ 24\%, 610-614

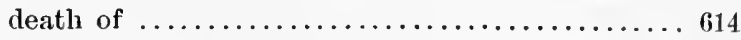

general and special............... 247, 610 general, how constituted...............605. 610 none in capital cases................. 84

special, how made...............6.610, 612 Attornment, by tenant to alienee........... 188, 220,570 of homage................... 371,373 Avoidance of benefice, entire or partial............ 474

Bailiff, his authority as attorney................. 247

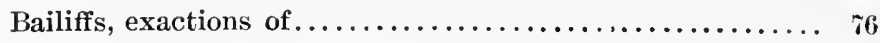

Banns of marriage....................... 547

Baronies, not to be dismembered................ 189

chief castles of, not divisible between coheirs. .. . 398 not assigned in dower................. 522

Bastard, donee to him and his heirs cannot alien..... 182, 569

Bastardy, exception of .............. 264, 436, 452

how proved.................... 436, 452

tried by jury by consent............436, 452

Battle, trial by, in appeal............... 83, 88, 100

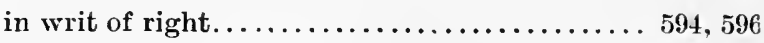

not favoured..................... 104, 42?

betreen lord and tenant................. $37_{0}$ 
References are to top, or running pages.

3east, man killed by ....................... 12

Beau pleader, fines for...................... 66

Bees, law of................................. 177

Bencl, the king's court so called................78, 113

Justices of the ..................17, 111, 392

Besael, writ of .............................. 462

Bishop, prohibited from admitting clerk pending plea of advowson ............................... 495

Bishop's certificate, authority of . . . . . . . . . . . . 475

Bishops, cannot alien the rights of their church ........ 182

Blood, corruption of $\ldots \ldots \ldots \ldots \ldots \ldots \ldots \ldots \ldots \ldots \ldots \ldots \ldots \ldots$

Boroughs, farm of $\ldots \ldots \ldots \ldots \ldots \ldots \ldots \ldots \ldots \ldots \ldots \ldots \ldots \ldots \ldots$

privileges of $\ldots \ldots \ldots \ldots \ldots \ldots \ldots \ldots \ldots \ldots \ldots 165,172$

Borrowing, contract of $\ldots \ldots \ldots \ldots \ldots \ldots \ldots \ldots \ldots \ldots \ldots \ldots$

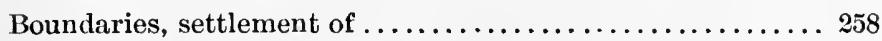

Bridges and roads neglected...................65

Builking on another's land; rights of landowner and builder ... ........................178, 234

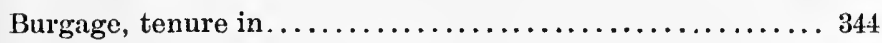

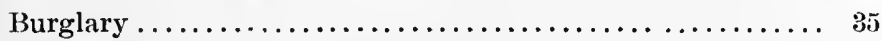

Burning, punishment by $\ldots \ldots \ldots \ldots \ldots \ldots \ldots \ldots \ldots \ldots$. 35

Canon, incapacity of $\ldots \ldots \ldots \ldots \ldots \ldots \ldots \ldots \ldots \ldots \ldots \ldots . \ldots \ldots$

Cape, process by......................... . 593

Castellans, illegal prises by $\ldots \ldots \ldots \ldots \ldots \ldots \ldots \ldots \ldots \ldots$

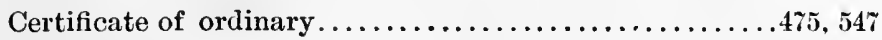

Certification.....................281, 504, 505, 506

Challenge of jurors.... .............25, 245, 277, 278 .

Champerty .................................. 78

Champion, fraudulent voucher of $\ldots \ldots \ldots \ldots \ldots \ldots \ldots \ldots .99$

Charge of jury $\ldots \ldots \ldots \ldots \ldots \ldots \ldots \ldots \ldots \ldots \ldots \ldots, 450,5,501$

Charters...............................206-212

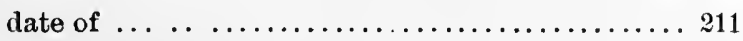

loss of, pleaded..................... 122

proved by witnesses therein named... ...211, 481, 509 
References are to top, or running pages.

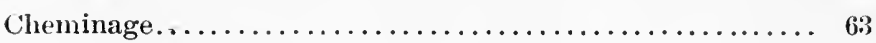

Chester, Justices of . . . . . . . . . . . . . . . . . . . 6

Chevage, or headmoney of villains.............. 166

'Chief lord,' meaning of the term............ 450, note

Church, jurisdiction of...................... 24

Church lands, aliened with consent of bishop and patron... 498 recovery of .................... 496-501

Cities and boroughs, privilege of, in enfranchisement of villains....................................... 162

Clergy, privilege of $\ldots \ldots \ldots \ldots \ldots \ldots \ldots \ldots \ldots \ldots \ldots \ldots$

Clerk, process against in trespass................ 109

Clerk of the market. ......................... 155

Clerks of chancery and other courts, exactions of....... is

Clerks, purgation of $\ldots \ldots \ldots \ldots \ldots \ldots \ldots \ldots \ldots \ldots \ldots \ldots \ldots$

Cloth, assise of .........................

Collateral descent......................... 585

Collusive judgment no bar to dower.............. 558

Common, defined ......................... 296

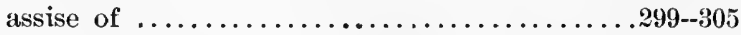

encroachments on ..................... 275

disseisin of ......................... 299

gift of . . . . . . . . . . . . . . . . . . . 299

limitation of right of . . . . . . . . . . . . . . 296

right of, asserted in replevin.............. 126

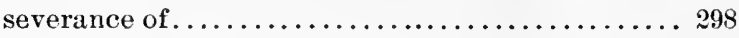

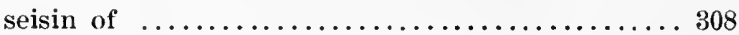

surcharge of ....................... 305, 308

waiver of . . . . . . . . . . . . . . . . . . . $29 \%$

Common Pleas, Justices of, 4. See Bench.

Common property, degrees of community in........ . 175

Common right, disturbance of $\ldots \ldots \ldots \ldots \ldots \ldots \ldots \ldots \ldots 238$

Common soil. ............................ 266

Concealment of felony, amercement of grand jury for..... 25

Condition and consideration distinguished........... 197 
References are to top, or running pages.

Condition, donor's remedy on breach of............. $22_{2}$

ejectment for non-performance of......... 236

fulfilment of, a question for jury .......... 270

various kinds of ................... 19.

casual........................... 19

copulative and disjunctive.............. 198

double................................ 198

enlarging an estate...........199, 200, 435, 43\%

negative.......................195, 198

possible and impossible................ 130, $19 \pi$

unlawful......................... 131

restrictive of estate.................. 199

Conditional contract......................... 130

Conditional judgment in favour of younger brother...... 237

in plea of dower.............. 539

Confirmation, charter of .....................211

effect of......................210, 480

Consanguinity, tables of $\ldots \ldots \ldots \ldots \ldots \ldots \ldots \ldots \ldots \ldots 4,585$

Consecrated objects and places................ 1 i6

Conspiracy to defeat justice...................

Contempt of court. .....................469, 610

Contribution among parceners.................401, 406

Convents, abuse of hospitality of .............. it

incapable of purchasing land without licence,... 186

Conveyance by feoffment.................. 206,207

by fine....................... 280

by recovery .................... 186

of reversions and seigniories..........188, 220

Coparcener, eldest, has no prerogative to present to a

church............................... 468

Coparceners, not heirs to each other, 392, 580. See Parceners.

Coroner......................... (i-14, 391

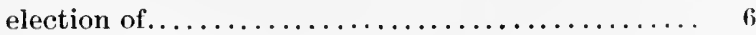

has record of the pleas of the Crown........6, 112

has record of appeals of felony ........... 9.2.94 
References are to top, or running pages.

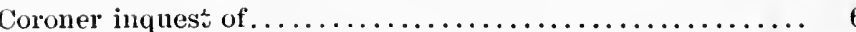

judgment before..................... 31

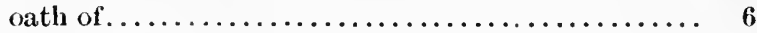

of the king's household................. 3

Coroner's rolls delivered to Justice in eyre............. 19

Corporeal and incorporeal property............... 175

Corrody, disseisin of ....................228, 244

Corrupt verdict, allegation of...................

Cosinage action of $\ldots \ldots \ldots \ldots \ldots \ldots \ldots \ldots \ldots \ldots . \ldots \ldots 28384,462$

Counterfeiting, appeal of .................... 28

Counterfeiting the royal seal or coin............... 20

County court, jurisdiction of, in trespass and debt....... 128

in writ of right. . . . . . . . . . . . . . 591

Court baron............................. 588

false judgment of, remedied in the king's court. 123 practice in .................. 123, 589

record of ........................ 123

Court Christian........................43\%, 452

jurisdiction of................. 556

reference to.................... 475

usurpations of................. 75

Courts, inferior and private, abuses of ............. 76

Covenant, how proved........................ 509

Crusade (See Pilgrimage) ....................60.

Curtesy of England, estate by...... 180, 212, 285, 273, 349, 445

Customary dower....................... 196, 204, $23 \%$

Customs, local...................... 2, 58, 394

contrary to common law .............. 7

Customs levied on merchandize.................. 80

Cut-purses........................... 51,52

Damage fesant, avowry of distress ... . . . . . . 117, 125

Damages, in Novel Disseisin................... 286

in Mortdancester...................... 459

in action of Dower............... 528, 529 
References are to top, or running pages.

Darreign presentment, assise of ............. 46\%-491

Date of instrument should be expressed............ 130

Day, divisions of ........................ 438

De libertate probanda, writ....................

De nativo habendo, writ....................... 1606

De odio et atia, wit....................... 10

De rationabili parte, action so called........ 387, 398--401, 40.)

Deaf and dumb, incapacity of............... 131, 598

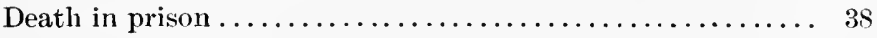

judgment of, in inferior court .............. 14

natural and eivil......................... $4 \pi 4$

of attorney stays suit. ...................6. 614

of tenant, abates writ.................... 22 i

Debt..................................... 128

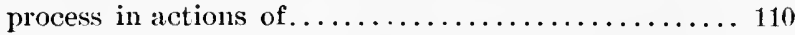

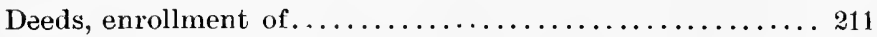

execution of $\ldots \ldots \ldots \ldots \ldots \ldots \ldots \ldots \ldots \ldots \ldots \ldots \ldots \ldots \ldots \ldots \ldots \ldots$

how proved.................... 481, 508

witnesses to, $211 \ldots \ldots \ldots \ldots \ldots \ldots \ldots \ldots \ldots \ldots 481,509$

Defence, time for........................ 21, 599

Deforce, meaning of word ..................

Delivery of possession, necessary in transfer of corporeal prop-

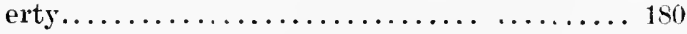

not necessary in transfer of incorporeal property. 186 See Livery of Seisin.

Demesne, meaning of word.................... 431

Deodand........................... 12, 13, 33

Deputies of Judges....................... 6, 600

Deraignment.......................... 562

Descent, canons of ............... 383, 394, 5\% , 584, 58.

collateral....................

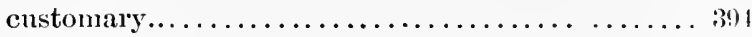

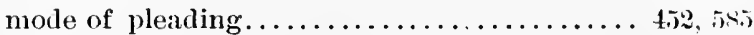

See Inheritance.

Devise of land by will. . ..................... 446 
References are to top, or running pages.

Difficulty of judgment............... 253, 273, $281, \tilde{5} 97$

Disavowal of lord, a cause of forfeiture..... 121, 228, 363, 368

Disclaimer........................... 248, 253

Disclaimer of tenure, a cause of forfeiture.... 121, 228, 363, 368

process for recovery of tenement upon, $228,368,369$

Dismemberment of baronies and knights' fees........ 59,182

Disseisin, what........................ 174, 222

by force and arms..................... 288

distinguished from trespass................ 275

inquest of damage in............... 253, 283, 285

of common........................... 299

peaceable, with white wand................ 284

remedies for...................... 238, 241

various instances of .................. 224-226

Distress, by judgment in the lord's court............. 123

disturbance of, an act of disseisin....... 223, 228, 236

excessive or illegal, $66 \ldots \ldots \ldots \ldots \ldots \ldots \ldots . \ldots, 127,2 \pi 6$

for aid pur faire fitz chivaler or pur file marier.... 120

for service in arrear........................ 119

sheriff to aid in........................ 265

Disuser of fanchise........................66, 157

Divorce, dower defeated by..................... 520

fact of, certified by ordinary............... 542

suit for.............................. 541

Doubt, benefit of .......................... 27

Dowager, to be provided with a house................. 531

when entitled to present to a church............ 484

Dowager's court, jurisdiction of................... 532

Dower, admeasurement of................. 438, 563

at the church door.............. 518, 529, 543, 544

by assent of father..................... 548

by custom...................... 521, 529, 561

customary, forfeited by second marriage........ 561

disseisin of .............................. 236 
References are to top, or running pages.

blishment and assignment of .

extinguished by felony of husband........... 32

favoured in law ..................... 535

forfeited by adultery $\ldots \ldots \ldots \ldots \ldots \ldots \ldots \ldots \ldots \ldots .554$

how to be assigned................. 527, 530

not increased to the prejudice of heir.......... 526

not subject to the debts of husband.......... 532

lost by judgment against heir.............. 561

of money or chattels. . . . . . . . . . . . . . . 523

plea of, governed by plea relating to the inheritance. 557 reasonable ....................... 5 21

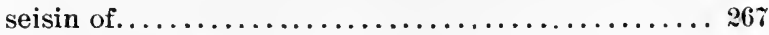

subject to crown debts of husband. ......... 532

unde nihil habet....................... 533

warrant of ................... $55 \pi, 562$

what tenements subject to,.....238, 521, 524,525, 530,

$551,559,591$

Drowning, death by...................... 12

Duel between lord and tenant, homage first to be released. $3 \% 0$

Duress, contracts invalidated by..............40,183

Earldoms, chief castles or heads of, not divisible between colreirs............................ 393

Ecclesiastical courts, abuses of ................ 68

Ejus est interpretari cujus est dare................ 20

Endowment at the church door.......... 205, 218, 269, 518

English language, used in legal proceedings......... 19 note Englishery, presentment of ................ 13, 32 Entry, action of ........... 185, 202, 227, 427, 565, 573. action of, defended either as a possessory or as a proprietary action..................... 571

ad terminum qui prceteriit................ 565 recovery by .............. 202, 234, note 238,297 defective, transmitted by disseisor to true owner.... 56 in the $p e r . \ldots \ldots \ldots \ldots \ldots \ldots \ldots \ldots \ldots \ldots \ldots \ldots \ldots \ldots$ 
References are to top, or rumning pages.

Entry, in the per and cui.................... 566

in the post....................... 566

several forms of writ of ............ $566,56 \%, 568$

time allowed for ....................... 239

Equity of redemption of mortgage, not allowed.........434

Escheat.................. 31, 59, 61, 201, 500, 58

writ of $, \ldots \ldots \ldots \ldots \ldots \ldots \ldots \ldots \ldots \ldots 2,201,202,5 \%$

Escheators of the king, lands taken by ............. i $_{1}$

Esplees, evidence of seisin............... 214, 440

taking of, when pleaded...............440,461

Essoin......................... 16, 408, 602

de citra mare.......................6 604

de malo lecti...................... 604, 606

de malo veniendi. ...................603, 606

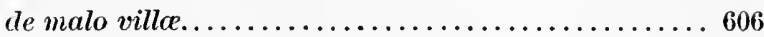

de servitio Regis.................602, 603, 608

de servitio Regis ceterni.............. 602, 603

de ultra mare..................... 604, 606

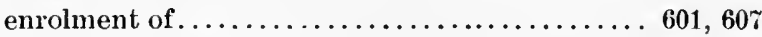

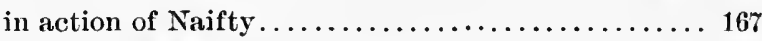

in assise of Mortdancester................. 364

none allowed to disseisor. ................ 167

none in capital cases..................... 84

of jointenants. .....................6. $60 \%$

time allowed in.................240, 605, 606

when and where entered...............602

Essoiners................................6 603

when required to find pledges.............6 604

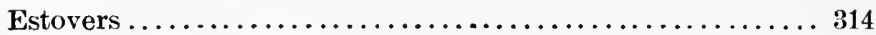

remedy for disturbance of ............... 314

Estrays............................ 57, 177

Ex Contractu, obligation. .................... 129

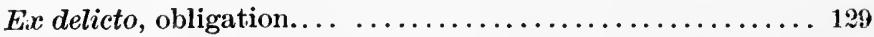

Exceptions in action of Dower.............. 538, 560

in action of Entry................. 573 
References are to top, or running pages.

Exceptions in assise of common.............. 302, 30.5

in assise of last presentation.......... 4\%0, 489

in assise of Mortdancester.......... 424, 456

in assise of Novel Disseisin.......... 253, 26\%

in assise of nusance.............. 323, 328

in assise of $\operatorname{Ctr} u m \ldots \ldots \ldots \ldots \ldots \ldots \ldots, 59,500$

in abatement of writ. ................. 254

to the Judge........................ 253

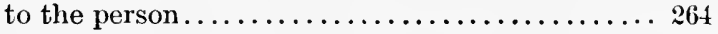

Exceptions peremptory and dilatory .............. 258

Excessive distress.................66, $74,127,2 \% 6$

Exchequer, Court of .................... 4, 80, 111

Excommunication, exception of.................. 260

Execution, disturbance of $\ldots \ldots \ldots \ldots \ldots \ldots \ldots \ldots \ldots \ldots, 6 \%$

Execution for felony, various forms of............. 551

Exigent............................. 10, 29

Exile of villains...........................

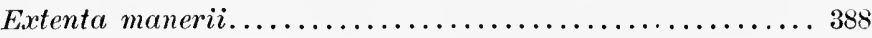

Eyre of Justices.

proceedings in $\ldots \ldots \ldots \ldots \ldots \ldots \ldots \ldots \ldots \ldots \ldots \ldots .15,112$

chapters of $\ldots \ldots \ldots \ldots \ldots \ldots \ldots \ldots \ldots \ldots \ldots \ldots \ldots \ldots, 20$

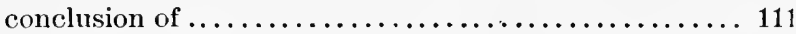

opening of.............................. 16

False imprisonment........................ 40

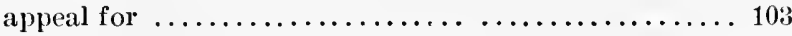

False judgment, writ of $\ldots \ldots \ldots \ldots \ldots \ldots \ldots \ldots \ldots \ldots \ldots \ldots \ldots$

Falsification of writs...................... 28, 254

Farm of the county and hundreds............. 58,73

Farms............................. 329, 331

Fealty, ceremony of $\ldots \ldots \ldots \ldots \ldots \ldots \ldots \ldots 41,152,366,367$

Fee, various meanings of word $\ldots \ldots \ldots \ldots \ldots \ldots \ldots \ldots \ldots 435$

Fee farm.................................... 343

Felo de se ............................ 33

Felons, gifts by $\ldots \ldots \ldots \ldots \ldots \ldots \ldots \ldots \ldots \ldots \ldots \ldots \ldots \ldots \ldots \ldots \ldots$ 
References are to top, or running pages.

Felons, trial of............................ 20, 28

Felony, indictment of, an excuse for not answering in

a civil action...........................6. 602

plea of $\ldots \ldots \ldots \ldots \ldots \ldots \ldots \ldots \ldots \ldots \ldots 450,499,551$

forfeiture of land by............ 30, 33, 46, 90

of chattels by ............. $30,33,38$

Feme covert; see Wife.

Feoffment

Feræ naturæ, animals. ................. 176, 177

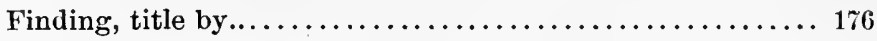

Fine, avoidance of ....................... 454

conveyance of seigniory by $\ldots \ldots \ldots \ldots \ldots \ldots \ldots 188,220$

enforced against tenant by writ of judgment...... 372

infant bound to answer to ................ 481

operation of, in barring reversions.......... 454 note

Fishery..............................

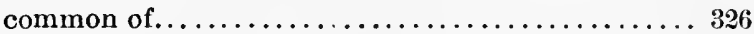

Force and arms.......................... 283

Forceable disseisins, punished................... 283

entry, effect of upon the title..... 255, 273, 561, 567

Forestallers.......................... 69

Forfeiture of chattels of felons ............. 30, 33, 38

by denial of Iord's title......... 121, 228, 363, 368

of felons' goods................. 30, 90

of felons' lands............... 30, 33, 46, 90

of outlaws................... 10, 44, 45

Form of gift, to be observed.................. 193

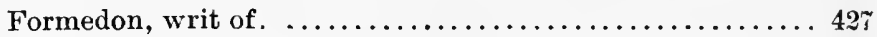

Fortification of houses without license............64

Found property, right to $\ldots \ldots \ldots \ldots \ldots \ldots \ldots \ldots \ldots \ldots$ i

'Four men' of vill........................ 15

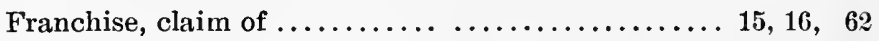

Frankalmoigne....................... 343, 496

Frank-marriage......................... 520

Free farm, tenure in. ...................... 343 
References are to top, or running pages.

PAGE $16 \pi$

Freedom favoured by law $223,225,250,431$ note.

Freehold, what.

how acquired 250

by wrong. 251

Fresh force. 174

Fugitive villain may recover against his lord by assise,

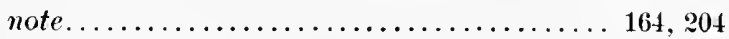

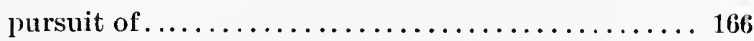

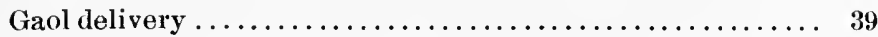

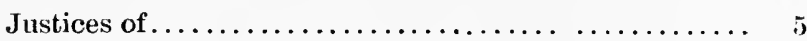

Gaols, defects of........................

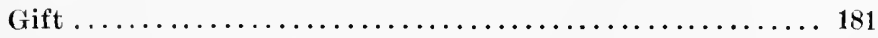

of land, colnmon form of................. 207

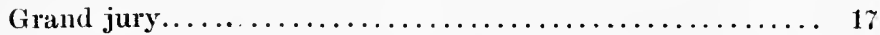

Grand Serjeanty....................... 336, 341

Great assise, where allowed.................60,594

no attaint upon verdict of ............ 512

Guardians, rights of $\ldots \ldots \ldots \ldots \ldots \ldots \ldots \ldots \ldots \ldots 338,350,351$

Guest, host responsible for $\ldots \ldots \ldots \ldots \ldots \ldots \ldots \ldots \ldots \ldots$

Half blood, inheritance by... ............ 580, 58:3

Hamsoken ............................ 70,148

Heirs, camnot be purchasers $\ldots \ldots \ldots \ldots \ldots \ldots \ldots \ldots \ldots \ldots$ 19:3

near and remote....................... 576

of donor, when bound to warranty........... 18;

of full age may hold possession against the lords.... 335

'Heirs.' word not necessary in grant of a fee ......... . 435

Heresy . . . . . . . . . .

Heriot........................... 356

Hoghenhine......................... 49

Homage............................ 358, 3\%:3

action against lord for refusing......... 360, 36:

ancestral...........................

ceremony of...................... 364.365 
References are to top, or running pages.

Homage, for what tenements due......... 356, 357, 370

inheritance barred by................ 582

not reserved in a gift of land $\ldots \ldots \ldots \ldots \ldots 208,366$

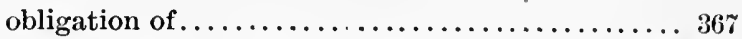

of pensioner or servant ............. 365, 371

remedy against tenant refusing............ 362

released before battle between lord and tenant... 370

Homicide, prosecution of $\ldots \ldots \ldots \ldots \ldots \ldots \ldots \ldots \ldots \ldots \ldots$

appeal of $\ldots \ldots \ldots \ldots \ldots \ldots \ldots \ldots \ldots \ldots \ldots, 91$

Hospitallers............................. 102, 596

Hotchpot.................................. 396

Household, king ${ }^{\prime}$, coroner of ................... 3

Steward of, see Steward.

Hue and cry $\ldots \ldots \ldots \ldots \ldots \ldots \ldots \ldots \ldots \ldots \ldots \ldots \ldots \ldots, 147$

Hundred, amercement of . . . . . . . . . . . . . . .

held in private hands................ 58

Hundred court. ..................... 18

Hundreders $\ldots \ldots \ldots \ldots \ldots \ldots \ldots \ldots \ldots \ldots \ldots \ldots \ldots,{ }_{4}$

Hunger, an excuse for theft................. 35

Husbancl, disseisin of, by wife........... 228, 241, 244

gift by, to wife and another............. 192

Husband and wife, gifts between, void.......... 186, 192 their power over wife's land......... 183 See Wife.

Idiot, incapacity of................ 183, 186, 456, 598

Idiot a nativitate, in custody of the king. . . . . . . . . 349

Incapacity of party to suit. ................ 260,456

Incorporeal tenements, disseisin of ............. 287

Incumbrance of church by bishop.............. 475

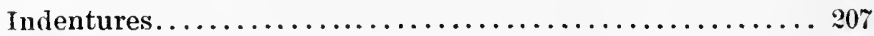

Indicavit. writ of $\ldots \ldots \ldots \ldots \ldots \ldots \ldots \ldots \ldots \ldots \ldots \ldots$

Infancy of husband or wife, a bar to dower... . . . . . $55_{3}$ of party to action........44, 405, 448, 456, 481, 598 See Infaut. 
References are to top, or running pages.

PAGE

Infangthef $\ldots \ldots \ldots \ldots \ldots \ldots \ldots \ldots \ldots \ldots \ldots \ldots, 48,62,182,187$

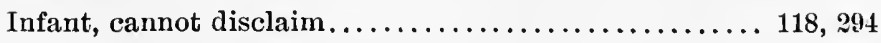

capable of doing homage............... 358

incapacity of $\ldots \ldots \ldots \ldots \ldots \ldots \ldots \ldots 135,183,186,218$

liability of, as vouchee..............4 410,420

must answer to writ of Entry founded on disseisin,

404,448

must answer to fine................... 481

See Infancy.

Inheritance, by ascendants............. 380, 386, 583

questions of, tried by writ of right..... 224, 576 rules of $\ldots \ldots \ldots \ldots \ldots \ldots .383,384,394,57 \%, 588$

Inheritance. See Descent.

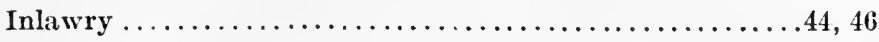

Inquest, Coroner's......................... 6

of age of heir, tenant in capite............. 349

Interdict............................. 543

Interpretation of royal grants reserved to the king....... 327

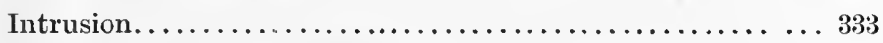

Investiture, by lord of fee...................

Ireland, Justices of ........................ 6

Island, formation of, in river or sea .............. 179

property in newly-discovered............ 178

Jointeuancy . . ........................... 189

Jointenants, assise must be by all ... . . . . . . . . . 230

Jointenement, disseisin of .................. 230

Judge, exception to the...............108, 253, 302, 600

Judgment, amendment of . . . . . .

in former suit, plea of................ 45

creditor, his estate, $435 \ldots \ldots \ldots \ldots \ldots \ldots \ldots .445$

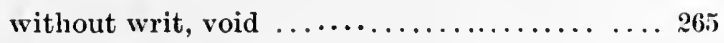

Judicial authority not delegable................6, 600

must be derived from the Crown ... ...6600 
References are to top, or running pages.

Judicial franchise, usurpation of ...................62, 65

Judicium non sui judicis non obligat.................600

Juises, or instruments of correction............148, 15\%, 158

Jurisdiction, exception to..................... 85, 99

of Coroner ...........................

of County Court..................... 589

of Courts Baron.......................5, 588

of Justices in Eyre.................. 15, 133

of the King ........................... 2,3

of the Royal Courts..................... 2,6

of the Steward of the Household............3, 140

of the Court of Exchequer............... 4

must be derived from the crown........... 600

usurpation of .......................... 157

Jurors.................................... 40 , 409

amercement of absent.................... 459

challenge of........................25, 278,459

disagreement of ........................ 26,280

majority of, to prevail...................... 26

oatl of $\ldots \ldots \ldots \ldots \ldots \ldots \ldots \ldots \ldots \ldots . .26,2 \pi 8,489,500$

to inform themselves of facts before trial........ 403

Jury, charge of .....................26, $280,460,501$

discharge of, without verdict..........26, 270,488, 491

consent of parties to try question by, how compel-

led.......................... $458,509,263$

how compelled to give verdict................ 381

service upon, evidence of freedom............ 17\%

upon question of legitimacy by consent........186, 436

upon question of villenage................263, 508

Justices, authority of......................... 2

itinerant, jurisdiction of................ 14,111

special, appointed by letters patent........... 242

Kindred, table of................................ 584 
Referencee are to top, or running pages.

King cannot alien the right of his crown........... 182

his grants, interpreted by himself............ 327

his jurisdiction ........................ 3

his legislative power..................... 2

his right as guardian of tenant $i$ eapite.....338, 349, 351

not bound by limitation of time. . . . . . . . . 182

plea that he is interested in a suit $\ldots \ldots \ldots \ldots \ldots 269,455$

when bound to warranty $\ldots \ldots \ldots \ldots \ldots \ldots \ldots \ldots 420,454$

writ abated by his death................. 172

King's Bench, Justices of .................... 3

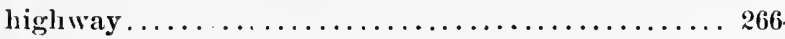

officers, complaints of................. 1

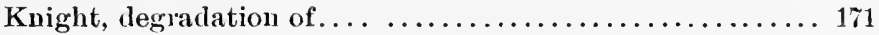

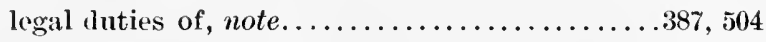

punishment for striking................. 104

Knighthood, exactions for evading.............. q $_{2}$ villain enfranchised by ............165, 171

Landmarks.....................6\%, 148, 231

Lapse, presentation by bishop upon...............472

Larcency............................. 47

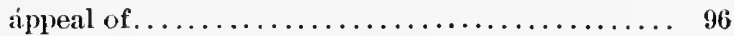

Last presentation, assise of ...............469-491

See Darreign presentment.

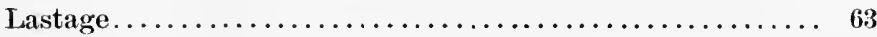

Law, wager of ............................. 406

Leases for years (See Termor).........272, 330, 432 note, $5 r_{0}$

Leather and wool, customs on................. 80

Jegislative power of King and Council............. 1

Legitimacy, tried by court Christian.............. 436

tried by jury by consent...........264, 436

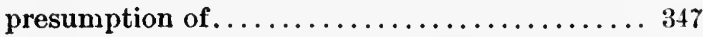

Lepers, incapacity of . . . . . . .

Lessee for years; see Termor.

Lestage.................................. 69 
References are to top, or running pages.

Limitation of actions

Lis pendens $.61,171,462,497$

Livery of seisin. $.448,45 j$ $\ldots \ldots \ldots \ldots \ldots \ldots \ldots \ldots \ldots \ldots \ldots \ldots \ldots \ldots \ldots \ldots, 214,218,230$

by $\operatorname{rod}$ or glove............... 215

by attorney....................218

See Delivery of possession.

Locality, statement of, in writ............... 257

London, custom of ........................... 561

Lord, his right of entry after death of tenant, $223,23 \%, 376$,

$378,58 \%$.

Lords of liberties, their oath in the Eyre............. 17

Lunatic, incapacity of . .........131, 183, 186, 456, 569, 598

Mainpast................................. 149

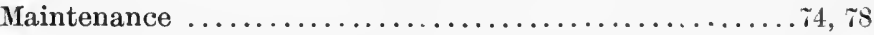

Market, clerk of the king's... . . . . . . . . . . . . . . . .

disturbance of $\ldots \ldots \ldots \ldots \ldots \ldots \ldots \ldots \ldots . \ldots \ldots, 328$

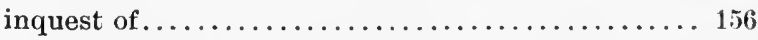

not to be held within ten miles of Eyre......... 18

overt, purchase in ................... 50

Marriage................................... 518

at church door....................... 541

estate given in, subject to hotchpot.......... 396

favoured by law........................ 164

gift in, made without charter... ........... 209

not to be forced . . . . . . . . . . . . . . . . . $35 ;$

of heir minor, right of lord to ..........351, :353,40.5

rights of the king as lord................ 61

right of, is a chattel devisable by testament...... 398 secret, may legitimate the issue, but not give

right to dower.................519, 543

to be tendered to wards under age.......... $35^{3}$

validity of, determined by Court Christian, 2it,

$436,523,542,54 \%$

Marshal, Earl, his office........................ 141 
References are to top, or running pages.

Master, action by, for damage to servant........... 109

Mayhem, appeal of ........................ 103

Measures and weights.......................

Meat, stale or diseased ........................ 158

Ielior est conditio possidentis..............230, 231, 241

Menace, writ of $\ldots \ldots \ldots \ldots \ldots \ldots \ldots \ldots \ldots \ldots \ldots \ldots, 10$

Merchet... .......................... 161, 203

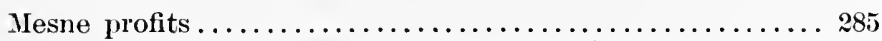

Mesne, writ of .......................... 121,210

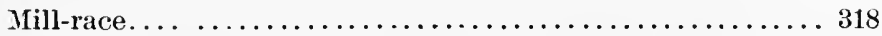

Ministers of the king, delinquencies of ............. 71

Minor ; see Infant.

Miscleseription .......................... 442

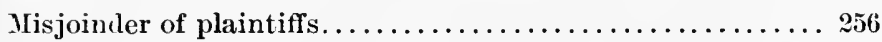

Misnomer...........................256, 450

Mixed action...........................385-392

Money, forgery of $\ldots \ldots \ldots \ldots \ldots \ldots \ldots \ldots \ldots \ldots \ldots \ldots \ldots$

Monks, incapacity of ..........131, 182, 184, 186, 569, 59s

Monster............................ 349

Mortdancester, assise of....................... 379 , 385

brought by heir against his lord........ 379

cannot be brought by one parcener without

the others $\ldots \ldots \ldots \ldots \ldots \ldots \ldots \ldots \ldots . \ldots . \ldots . \ldots 48$

lies only between strangers in blood....381, 383

pleadings in . . . . . . . . . . . . . . $424-455$

process in . . . . . . . . . . 402-408

trial of . . . . . . . . . . . . . . .

within what degrees permitted........380, 381

Mortgage, construction of condition in.........200, 432-43;

Mortmain......................... 186

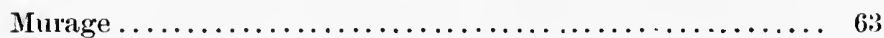

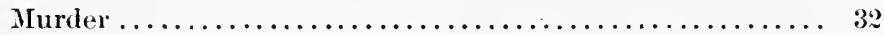

Mute, penance for standing $\ldots \ldots \ldots \ldots \ldots \ldots \ldots \ldots \ldots \ldots, 2$

Naam.................................. 114 
References are to top, or running pages.

PAGE

159

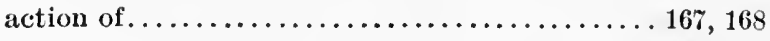

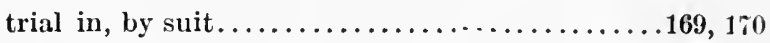

Ve admittas, writ of ......................... 495

Necessitas vincit legem........................ 52:

Nemo potest simul esse hares et dominus............362, 58:3 Nonjoinder, exception of ...........256, 264, 267, 384, 444

of parcener in writ.............256, 444

Non-tenure, plea of .................... 448,449

Novel disseisin, assise of $\ldots \ldots \ldots \ldots \ldots \ldots \ldots \ldots \ldots \ldots 22$

judgment in.................... 282

parties to..................226, 242

pleadings in.............253-267, 30 ?

process in..................242, 245;

taken in absence of tenant............ 301

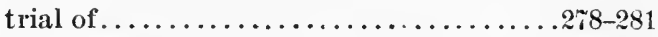

where allowed................233, 238

Nudum pactum ............................ 129

Vullum tempus occurrit regi................... 182

Nusance...........................290, 316-328

legal remedies against, by assise . . . .317, 319, 320-323

legal remedies at the sheriff's tourn.... ..... 319

legal remedies, by Justicies.............320, 323

pleadings in assise of . . . . . . . . . . . . $323-328$

treated as a disseisin .................. 227

view in cases of .................... 245

Oath, manner of taking.................. 279

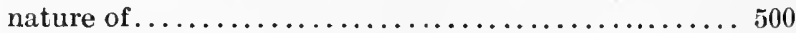

Obligation, nature of $\ldots \ldots \ldots \ldots \ldots \ldots \ldots \ldots \ldots \ldots \ldots$

Occupancy, title by ....................... 176

Office in fee, disseisin of ...................228, 24i

Ordination, villain enfranchised by ............... 165 , 1

Outfangthef .......................... 18 r

Outlawry $\ldots \ldots \ldots \ldots, \ldots \ldots \ldots \ldots \ldots \ldots \ldots \ldots \ldots \ldots, 41$ 
References are to top, or running pages.

Outlawry after death. . . . . . . . . . . .

fraudulent ...................... 45

of women, called waiver............... 43

plea of ...................... 451

process of $\ldots \ldots \ldots \ldots \ldots \ldots \ldots \ldots \ldots \ldots \ldots \ldots \ldots \ldots \ldots, 10$

Parcener, disseisin of one by another..........232, 300, 398

Parceners, assise between....................... 400,44

contribution among................ 406

do homage and fealty to eldest parcener. .351, 35i, 36i must sue together..........140, 256, 299, 384, 444 See Coparceners.

Parish, manor, and hamlet.................... 268

Parson, cannot alien without bishop and patron ........ 569

his remedy to recover common............. 294

his remedy to recover land $\ldots \ldots \ldots \ldots \ldots \ldots \ldots 496$

Parsons, two of one church ................. 49 r

Parties, abatement for want of ..............24, 454

Partition of estate between parceners . . . . . . . . . 385-39;

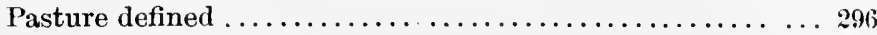

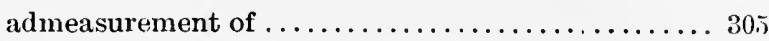

common of ........................ 296

Patent of Justices ... . . . . . . . . . . . . 249, 408

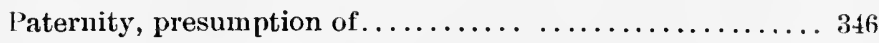

Pauper's suit without pledges.................. 243

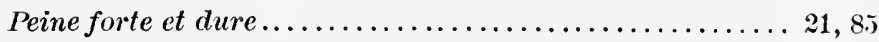

Penalty, contract under...................... 131

Penance..........................

Pendente lite, alienation.................... 448

Pending action, plea of..................... 454

Pension reserved from a church to save right of infant.... 472

Perambulation for fixing of boundaries.......... 258,460

Perjury ................................ 502

degrees of. .................... 506

procuring of, criminal............... 502 
References are to top, or runuing pages.

Person, exception to the........................ 260

Petty larceny....................48, 52, 100, 102

Petty serjeanty ............................ 341

Pilgrimage.............................602, 606

general..................240, 604, 606

Pledges for appearance of defendant........ 108, 167, 246 of prosecution.......... 105, 114, 16\%, 242, 3\%9, 402 when required from essoiners..............604

Pone, writ of ...................... 168, 589, 595

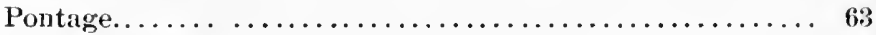

Possessio fratris ....................... ; 80

Possession, gifts by persons out of. ...............210

title by........................... 251

See Seisin.

Pound, breach of.......................... 148

Pregnant women, execution of, delayed till delivery...... 101

Prescription, none against the right of the Crown.......61

Presentation, last, assise of. ................ 46i-91

See Darreign presentment.

Presentments in the eyre..................... 19

Presentments of murder and homicide............. 42

Prisage of spices, silk, \&c................... 80

Prison, breach of.......................... 36,72

private....................... 40, 67

felons to be detained in king's............. 6 \%

Prisoners, actions by and against............... 39

contracts by $\ldots \ldots \ldots \ldots \ldots \ldots \ldots \ldots \ldots \ldots \ldots, 40$

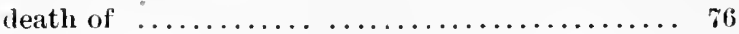

escape of...................... $3 \pi, 72$

fees to be taken of $\ldots \ldots \ldots \ldots \ldots \ldots \ldots \ldots \ldots$

treatment of $\ldots \ldots \ldots \ldots \ldots \ldots \ldots \ldots \ldots \ldots \ldots \ldots$ si

Process in action of debt $\ldots \ldots \ldots \ldots \ldots \ldots \ldots \ldots \ldots \ldots \ldots$

in action of trespass..............105, 10\%, 110, 132

in assise of novel disseisin . . . . . . . . . . 242, 245, 246 
References are to top. or rmning pages.

Process in assise of mortdancester.

in assise of darreign presentment........... 469

in county and luundred court.... . . . . . . . 132

in court baron................. 123, 132. 589

in real actions......................... 1it

Production of deed by adverse party in action not compelled. 20 i

Proof, various modes of .................... 545

Proprietary action.............................

Protection, letters of ....................6. 605, 606

Prothonotary............................. 279

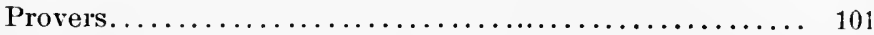

to be sent to the king's prison........... 40.6i

Provost of vill. ............................

Proximity of blool, tried only by writ of right.......223, 5i.

Prudehomme, what...............................

Purchase........................... 175, 176

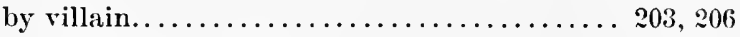

conditional.................... 193-200

joint....................... 189, 193

Purprestures........................... 60

Purveyance.............................

Quare impedit, action of .............. 484, 48\%, 49?

Quare non admisit, writ of ...................... 494

Quare non permittit, writ of............448,493 note

Quid juris clamat, writ of.................. 188 note

Quitclaim, charter of................ 188, 211, 453

requisites to validity of $\ldots \ldots \ldots \ldots \ldots \ldots \ldots 210,453$

plea of................... 273, 453

Quo juve, writ of........................ 309-314

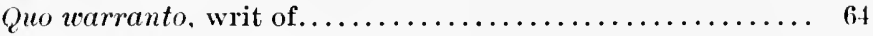

Quod permittat, writ of $\ldots \ldots \ldots \ldots \ldots \ldots \ldots \ldots \ldots \ldots \ldots \ldots \ldots \ldots$

Rape.............................. 46

appeal of $\ldots \ldots \ldots \ldots \ldots \ldots \ldots \ldots \ldots \ldots \ldots \ldots \ldots \ldots, 96$ 
References are to top, or running pages.

Rape, inquest of, before coroner............... 14

Real actions............................ 575

Reclaimer of jurisdiction by lord................ 531

Record, authority of................. 504,506

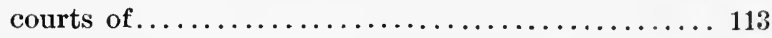

of Justices.................... 5, 504

of court baron $\ldots \ldots \ldots \ldots \ldots \ldots \ldots \ldots \ldots \ldots \ldots \ldots \ldots$

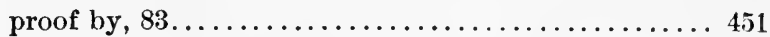

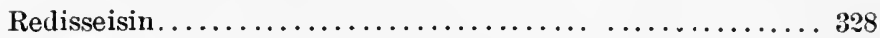

Redubbers of clothes...................69, 147

Re-entry, remedy by ...................... . 238

Release, how proved............................. 373

Relief.................................... $3{ }^{4}$

distinguished from heriot. ............... $3 \%$

Remainder, in gift of land. . .................. 209

'Removable' canon or monk, incapacity of ........ 131, 598

Rent charge, grant of ......................220

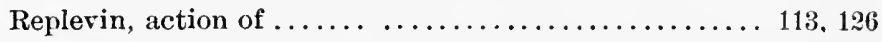

Representation, right of, in inheritance........ 578, 582

Resort............................ 168, 465)

Restitution of conjugal rights, suit for.......... 546, 54\%

Resummons of defendant................. 406, 598

Reversion ............................. 201

Reversion barred by fine...................... 4.53

conveyance of $\ldots \ldots \ldots \ldots \ldots \ldots \ldots \ldots \ldots 189,514$

dower of ................... 227,521

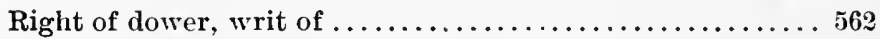

patent, writ of . . . . . . . . . . . .

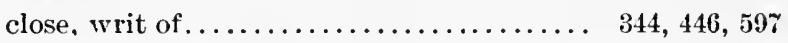

of marriage, writ of $\ldots \ldots \ldots \ldots \ldots \ldots \ldots \ldots \ldots \ldots$

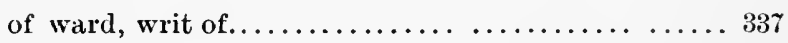

Robbery............................ 46, 98

Rod, livery of seisin by.................. 215, 345

Rolls of Coroner........................ 14, 19

of Justices..................... 5, 504 
References are to top, or running pages.

Rolls of the clerk of the market............... 158

Royal charters, construction of.

Royal demesnes, privilege of, in enfranchisement of villains,

Sakeber 48,150

Same clescent, exception of, in assise of mortdancester.... . 424 not allowed to be pleaded by vouchee...... 421

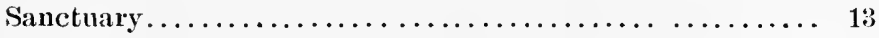

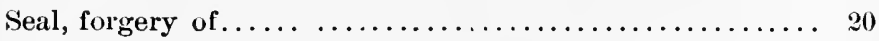

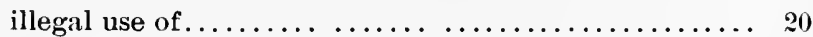

use of borrowed........................211

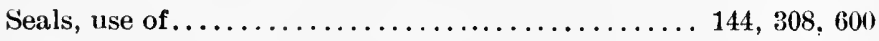

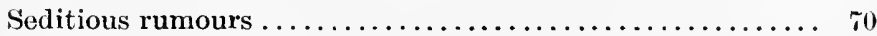

Seigniory, conveyance of $\ldots \ldots \ldots \ldots \ldots \ldots \ldots \ldots \ldots$ 188, 220

Seisin, definition of $\ldots \ldots \ldots \ldots \ldots \ldots \ldots \ldots \ldots \ldots \ldots 212$

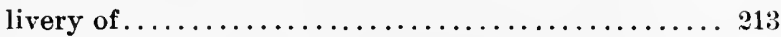

of heir................................

of pasture, how acquired................293

simple; see Simple seisin.

Serjeant, false pleading by .................. 84

Serjeanty, tenure by ................ 336 note, 341

Servitudes or easements. . . . . . . . . . . .

seisin of . . . . . . . . . . . . . . . . . 293

Severance of jointenancy ................... 191

Sheriff........................ 4,

neglect of duty to parties to suit......... 591, 601

oath of $\ldots \ldots \ldots \ldots \ldots \ldots \ldots \ldots \ldots \ldots \ldots \ldots \ldots$

Sheriff's court........................... 113

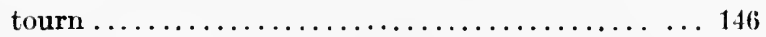

redress of nusance at................ 291

Sic utere tuo ut alienum non loedas.................. . 2s:

' Simple seisin,' lord entitled to, on deatl of tenant....... 3; See Lord.

Slavery, origin of . 
References are to top, or running pages.

Socage, tenure in.............. 336 note, 340, 341, 521, 529

guardian in............................ 339

Sokeman, tenant in ancient demesne................. 344

cannot alien his land................. 183, 20:

immunities of ........................... 344

Sorcery................................ 35, 147

Statute de donis conditionalibus, alteration of law by,

194 note, 196 note.

quia emptores terrarum, effect of, $19 \dot{x}$ note, 197 note,

208,336

\section{Statutes :-}

Magna Charta, c. 1.............................. 2t

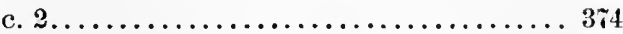

c. $3 \ldots \ldots \ldots \ldots \ldots \ldots \ldots \ldots . . \ldots, 358,360,374$

c. $3,4,5 \ldots \ldots \ldots \ldots \ldots \ldots \ldots \ldots \ldots \ldots .350$

ø. 6. . $\ldots \ldots \ldots \ldots \ldots \ldots \ldots \ldots \ldots \ldots, 359$

c. $7 . \ldots \ldots \ldots \ldots \ldots \ldots \ldots \ldots \ldots \ldots . .246,35: 3$

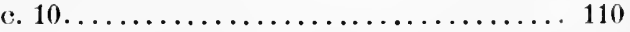

c. $11 \ldots \ldots \ldots \ldots \ldots \ldots \ldots \ldots \ldots \ldots, 4$

c. $12 \ldots \ldots \ldots \ldots \ldots \ldots \ldots \ldots \ldots \ldots \ldots, 4,50,5$

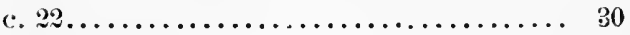

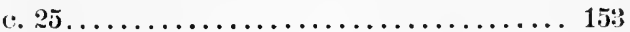

c, $27 \ldots \ldots \ldots \ldots \ldots \ldots \ldots \ldots \ldots \ldots \ldots . \ldots . \ldots 30$

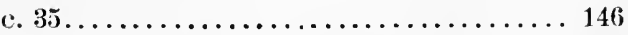

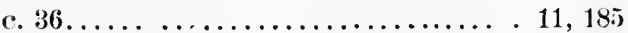

c. $63 \ldots \ldots \ldots \ldots \ldots \ldots \ldots \ldots \ldots \ldots \ldots+466$

Statutum Hibernice de Cohœeredibus (14 Hen. III.).... . . . 3: Statute of Merton (20 Hen. III.)

c. 1 ...............................

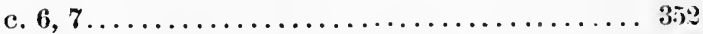

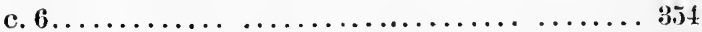

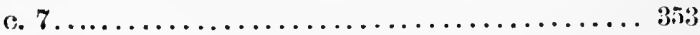

of Marlborough (52 Hen. III.)

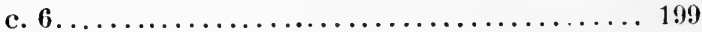

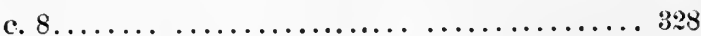


References are to top, or running pages.

Statutes :-

PAGE

c. $10 \ldots \ldots \ldots \ldots \ldots \ldots \ldots \ldots \ldots \ldots \ldots \ldots, 146,15 \ldots \ldots \ldots \ldots$

c. $16 \ldots \ldots \ldots \ldots \ldots \ldots \ldots \ldots \ldots \ldots \ldots \ldots \ldots \ldots \ldots \ldots \ldots$

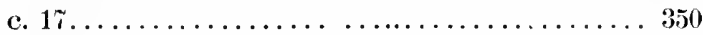

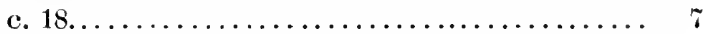

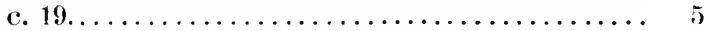

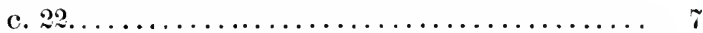

c. $23 \ldots \ldots \ldots \ldots \ldots \ldots \ldots \ldots \ldots \ldots \ldots \ldots 144,339$

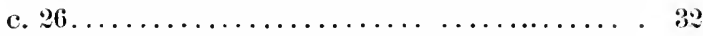

of Acton Burnell (2 Edw. I.) ................ 138

of Westminster I. (3 Edw. I.)

c. $1 \ldots \ldots \ldots \ldots \ldots \ldots \ldots \ldots \ldots \ldots \ldots \ldots \ldots \ldots \ldots \ldots \ldots \ldots, 2$

c. $2 \ldots \ldots \ldots \ldots \ldots \ldots \ldots \ldots \ldots \ldots \ldots \ldots \ldots \ldots \ldots$

c. $t \ldots \ldots \ldots \ldots \ldots \ldots \ldots \ldots \ldots \ldots \ldots \ldots \ldots \ldots$

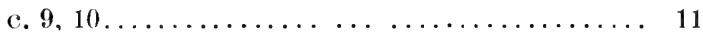

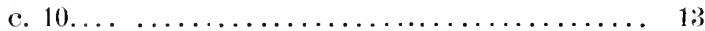

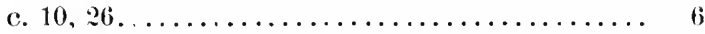

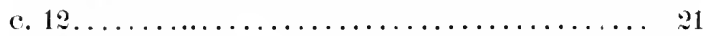

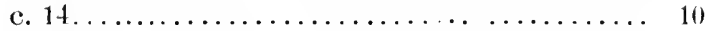

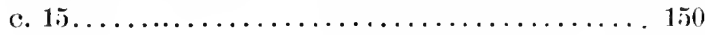

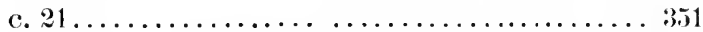

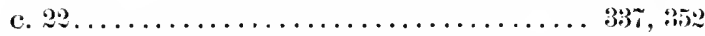

c. $24 \ldots \ldots \ldots \ldots \ldots \ldots \ldots \ldots \ldots \ldots \ldots \ldots \ldots \ldots \ldots$

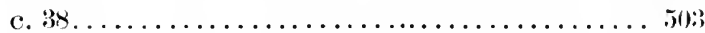

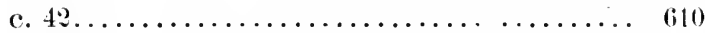

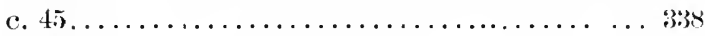

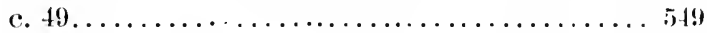

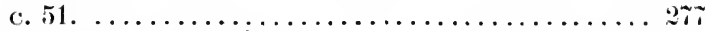

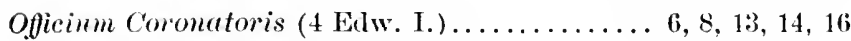
Statutum de Bigamis (4 Edw. I.)

Preamble...................... 1

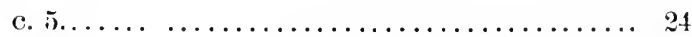

c. $6 \ldots \ldots \ldots \ldots \ldots \ldots \ldots \ldots \ldots \ldots \ldots, 183$

Statute of Gloucester (6 Elw. I.)

c. 1 .

15. 16.286 
References are to top, or running pages.

Statutes:-

PAGE

c. $4 \ldots \ldots \ldots \ldots \ldots \ldots \ldots \ldots \ldots \ldots \ldots \ldots \ldots \ldots \ldots, 196,343$

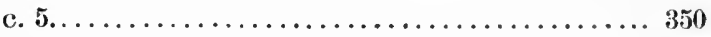

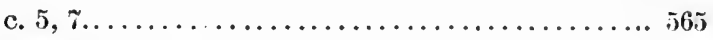

c. $9 . \ldots \ldots \ldots \ldots \ldots \ldots \ldots \ldots \ldots \ldots \ldots \ldots \ldots \ldots \ldots \ldots, 5$

Statutum de. Militibus (6 Edw. I.)..................

Statute of Mortmain (7 Edw. I.) ............. 186, 234 of Wales (12 Edw. I.)

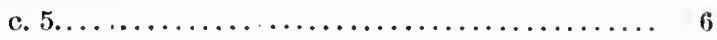

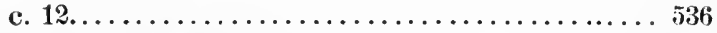

Provisiones in Scaccario (12 Edw. I.)............... 4

Statutum de Moneta (12 Edw. I.)................ 21. 28

Statute of Westminster II. (13 Edw. I.) ............. 28

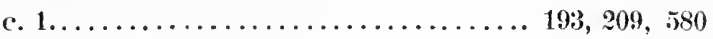

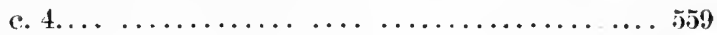

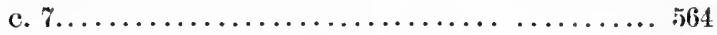

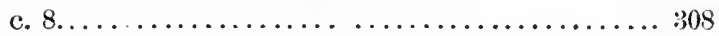

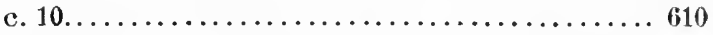

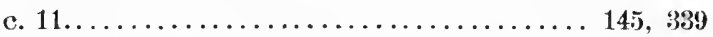

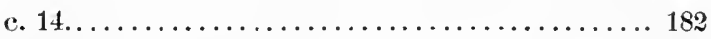

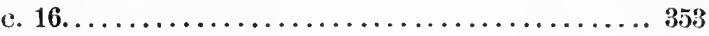

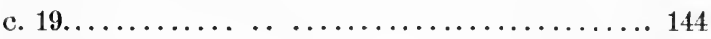

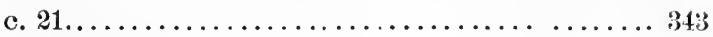

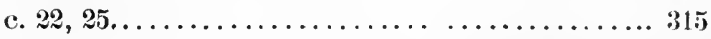

c. $25 \ldots \ldots \ldots \ldots \ldots \ldots \ldots \ldots \ldots$........... 226, $22 \pi, 228,314$

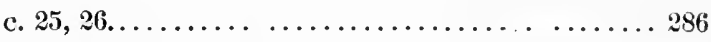

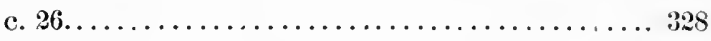

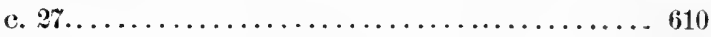

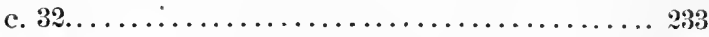

c. $34 \ldots \ldots \ldots \ldots \ldots \ldots \ldots \ldots \ldots \ldots \ldots \ldots \ldots \ldots \ldots \ldots, 52,554$

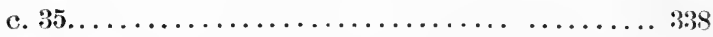

of Merchants (13 Edw. I.)................. 299

of Winchester (13 Edw. I.), c. 2........... . 32

Circumspecte agatis (13 Edw. I.)................. 24

Statute of Exeter (14 Edw. I.) . . . . . . . . . . . . . 8. 19 
References are to top, or running pages.

Statutes :-

Statute of Westminster III. (18 Edw. I.),

PAGE

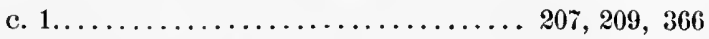

Modus levandi fines (18 Edw. I.)............... 188

Articuli super Chartus (28 Edw. I.)

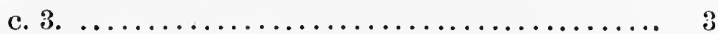

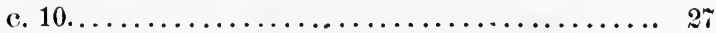

Statutum de Prarogativa Regis, c. 2......... 13, 18, 338

Assisa Panis...................... 153, 154, 155

Statutum de Pistoribus, c. 2................... 154

de Sacramentis Ministrorum Regis........ 16, 17

Steward of the household, his jurisdiction........... 3, 141

Strangers, under the king's protection . . . . . . . . . . . 105

Sturgeons and whales, king's right to............ 5 r

Subornation of jurors....................... 27

Subtraction of homage, cause of forfeiture........... 369

Succession, title by $\ldots \ldots \ldots \ldots \ldots \ldots \ldots \ldots \ldots \ldots \ldots, 252$

Sufferance, common by .................... 297

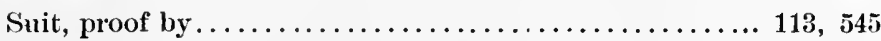

of kindred, proof of villenage by ...... 169, 170, 449, 509

Suitors judges, in what courts..............6, 113

Summons, various kinds of $\ldots \ldots \ldots \ldots \ldots \ldots \ldots \ldots \ldots \ldots$.

in assise of Mortdancester............4402, 406

in writ of right $\ldots \ldots \ldots \ldots \ldots \ldots \ldots \ldots 590,597,599$

of jurors in Disseisin.................. 243

Supposititious children..................... 345, 348

Surname, double....................... 259

Tail, estate.................... 184, 194 note, 455

Tanners, not to be butchers................. 69

Templars... .......................... 182, 596

Tenant for life, feoffment by .................. 185

Tenants in chief. dismemberment of fees by ......... 182

Tenure does not affect status .................. 162

Tenures, various kinds of ................. 336. 350 
References are to top, or running pages.

Term, fore and years. lif.......... 431 note, 569 Termor, assise against... $\ldots \ldots \ldots \ldots \ldots \ldots \ldots \ldots \ldots 42,43 \%$

Termor feoffment by ......................... 18j his remedy if ejected............ . 399, 431 note nature of his estate................. 570 his right suspended during minority of lessor's

heir..................... 330, 339 ousted by dowager, how compensated......... 560

Thefbote ...........................69, 148

Theft........................... 47, 98

how punished upon fresh suit............4 $4 \pi, 150$

'Time of peace,' how understood... . . . . . . . . . . . 471

Tithing............................ 10, 41, 149

mode of admittance into.............. 152

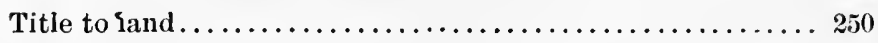

by possession.......................... 251

Title-deeds, detainer of by widow............... 5.55

Tourn; see Sheriff's tourn.

Tournaments, injuries at.................... 104

Traverse, impost so called.................. 62

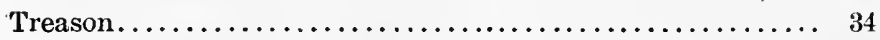

appeal of $\ldots \ldots \ldots \ldots \ldots \ldots \ldots \ldots \ldots \ldots \ldots \ldots, 82$

how prosecuted $\ldots \ldots \ldots \ldots \ldots \ldots \ldots \ldots \ldots \ldots . \ldots \ldots$

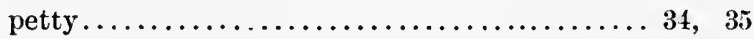

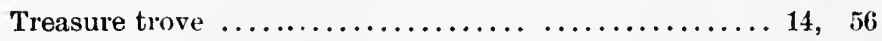

Trespass contra pacem, process in .............. 10

expeditious process in special cases of........ 110

form of proceeding in ................. 10,

punishment in.................... 104

Trial of appeal of felony................ 87, 95, 100

Trial of felons at the king's suit................. 29

of assise....................... 279,459

of attaint.........................

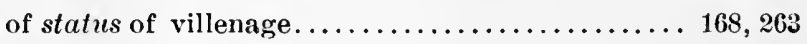

Triplication........................ 425, 428 
References are to top, or running pages.

Uncertainty.

Uncouth, guest so called..................... 42

Usage, easement founded on.................... 289

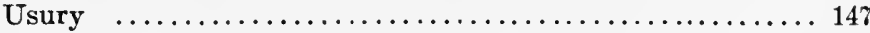

Utrum, assise of......................... 496-501.

the parson's writ of right................. 49 r

Vacations...................................

Vee de naam. ........................4,62, 114

Ventre inspiciendo, proceedings in .............. 345

Ventre sa mere, infant in, may inherit............ 575

Verge royal. ..................... $3,141,155,156$ inquest of market within............ 156 jurisdiction of the Steward of the Household within........................ 141

Vicarage, vacant, merged in parsonage............. 474

Vicinage, common by ..................... 297

View, process of ............. 242, $282,403,408,442,589$ in assise of nusance....................... 215

Villain, actions by and against................. 164 alienation of $\ldots \ldots \ldots \ldots \ldots \ldots \ldots \ldots \ldots \ldots . \ldots \ldots$ assise by, against lord for his wife's tenement..... . 229 belonging to several lords............... 205 by birth........................ 162

by recognizance...................... 160

camnot be devised..................... 163

contracts by .......................... 131

conveyance by ...................... 20;

enfranchisement of........... 164, 165, 171, 203

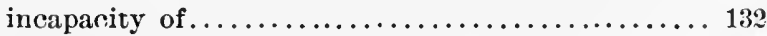

Villain, purchase by ......................... 203

Villains, their lives protected................. 160

no distinction among................... 162

Villenage.............................. 159-173 exception of......... 165, 260, 302, 401, 455, 508 
References are to top, or running pages.

Villenage, proof of, by suit of kindred.

tenure in............................... 345

tried by assise by consent of parties.... $263,508,510$

Volenti non fit injuria ... . . . . . . . . . . . . . . . 130

Voucher of claimant adverse to lord, a forfeiture........ . 5.5.)

of warrant in Disseisin................. 28,

in larceny................49, 97

in Mortdancester................ 410

in plea of dower...............5.56

in writ of right. . . . . . . . . . 593

Wager of law, no attaint of proceedings in ........ 24, 512

when admitted................... 12j

Waifs ................................. 5\%. 148

Walmand, Robert de, penned the Statute of Marlborough,

c. 6 ................................ 200

Wand, white, sign of peace $\ldots \ldots \ldots \ldots \ldots \ldots \ldots \ldots \ldots \ldots \ldots$

Wardship....................... 386, 349-351

incident to what tenure............... 336

Warrant, voucher of ; see Voucher.

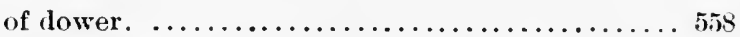

Warranty by homage................... . 35i -359

clause of, in charter of feoffment..........210

obligation of $\ldots \ldots \ldots \ldots \ldots \ldots \ldots \ldots \ldots 18,355,413$

of charter, writ of $\ldots \ldots \ldots \ldots \ldots \ldots \ldots \ldots 121,478$

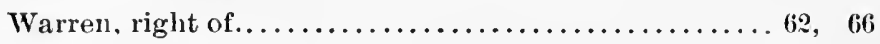

Waste by dowager,........................... 565

by guardians. ..................... 351,410

entry by reversioner on account of........... 235

Watch, neglected.......................6\%, 148

Watereourse, disturbance of ...................... 31 \%

Watering-place, common................... 318

Way, disturbance of....................... 317

Way and water, rights appurtenant to ............ 290

Weights and measures....................68, 158 
References are to top, or running pages.

Weirs, nusances in

White rod, sign of peace......................284

Whitetawers

69 note, 163

Wife, co-defendant with husband 255,455 incapacity of $\ldots \ldots \ldots \ldots \ldots \ldots \ldots \ldots \ldots 183,186,272,598$ of felon, punishable as an accomplice.......... 100 See Husband.

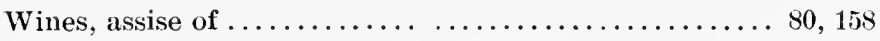

Withernam................................... 115

Witnesses, proof by, in Court Christian............ 542

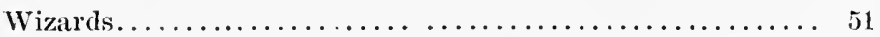

Women, appeals by $\ldots \ldots \ldots \ldots \ldots \ldots \ldots \ldots \ldots \ldots \ldots .65$

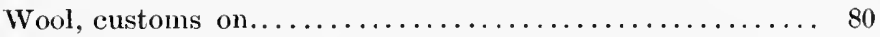

Wounding ................................. 14

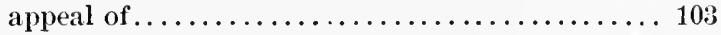

Wreck..................... 14, 57, 62, 148, 17s

Writ de retate probanda..................... 350

de libertate probanda. .................. 167

de magna assisa eligenda. .................. 59.

de nativo habendo ......................... 166

de odio et atia............................ 102

de pace habend $a . \ldots \ldots \ldots \ldots \ldots \ldots \ldots \ldots \ldots \ldots \ldots \ldots \ldots$

de rationabili parte......................... 439

de terris liberandis...................... 350

de ventre inspiciendo....................... 345

effect of abandoning................. 236,247

false or forged $\ldots \ldots \ldots \ldots \ldots \ldots \ldots \ldots \ldots \ldots \ldots \ldots$

judicial. .................................... 265

jurisdiction limited by ................... i

oath administered without..................

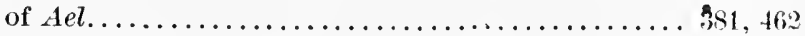

of Assise of Common...................

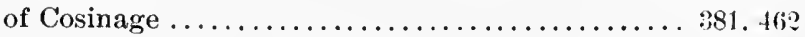

of customs and services.......................

of Entry....................... 
References are to top, or running pages.

Writ of Escheat.

of formedon.

of Indicavit.

of Partition.

of Pone.

of Quare impedit.

$589,591,595$

of Quare non admisit.

of Quare non permittit.

of Quid juris clamat. $487,49: 3$ of Quo Jure. 188 note

of Quo warranto. 289

of Quod pernittat. 64

of right close.

of right, defended as a possessory action. $344,446,597$ of right of dower.

of right of marriage. 562

of right of ward. 338 of right patent.

of right patent in county court. . ................. 588

of right patent in court baron.............. 588

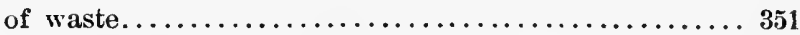

to compel warranty in plea of right ............ 594

to compel warranty in prosecution for theft....... 50

oyer of............................. 249

pending, plea of $\ldots \ldots \ldots \ldots \ldots \ldots \ldots \ldots \ldots \ldots \ldots \ldots \ldots$

Writs, distinction of, to be observed.............. 126

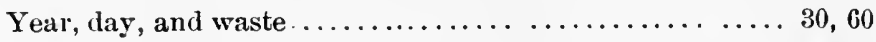

Years, estate of lessee for................... 229-231

Younger brother, entry by .................223

entitlec to possession until appearance of the right heir................ $23 \%$ 




University of California
SOUTHERN REGIONAL LIBRARY

Return this material to the FACILITY fronRw6ith thus so the library

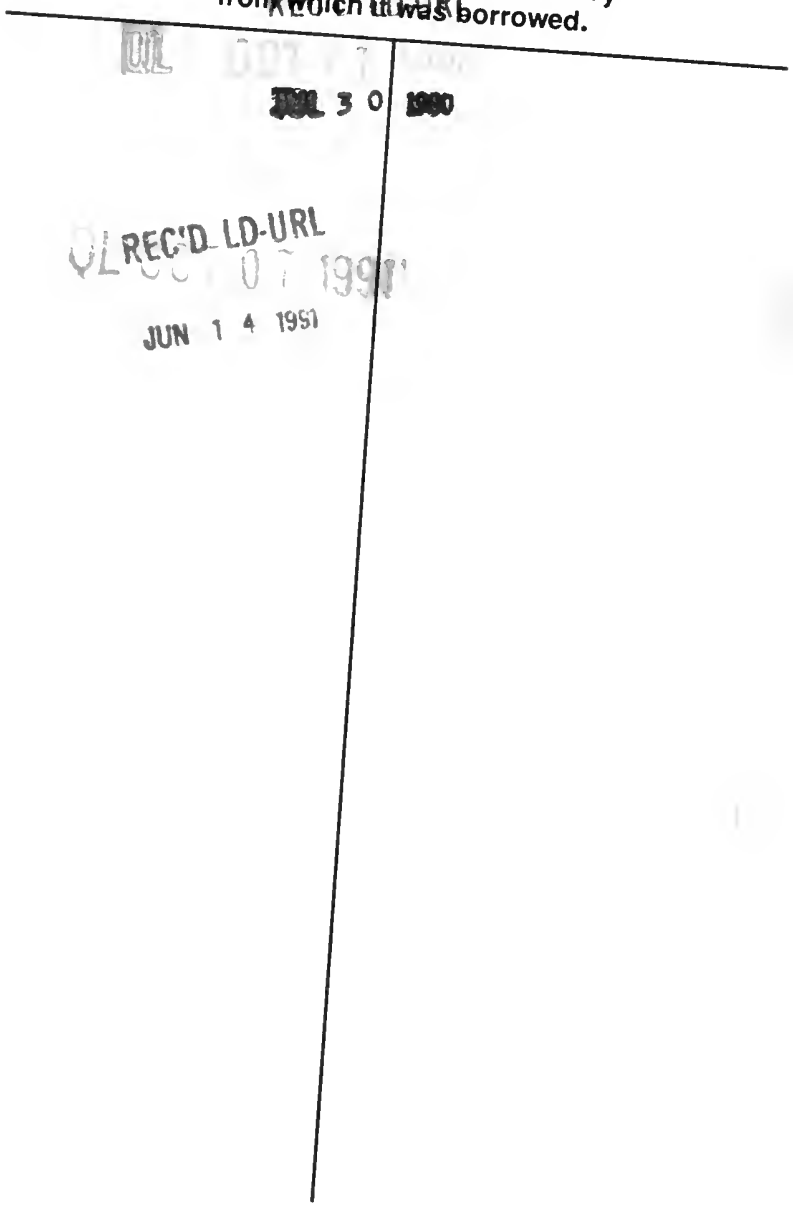


A. (n) 
Hous

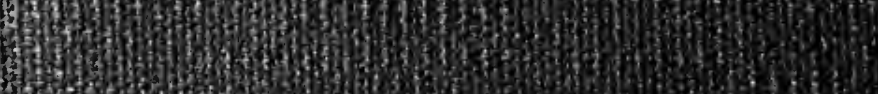

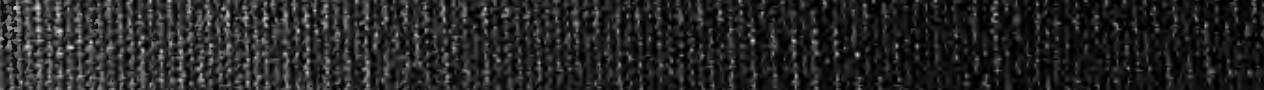

What

19.

15)

(1)

(16)

thas

thes

5)

36)

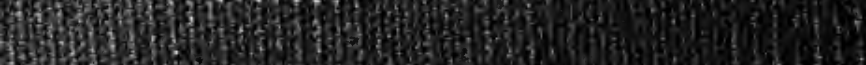

S.

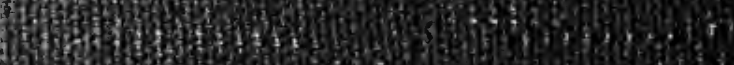

2.

in

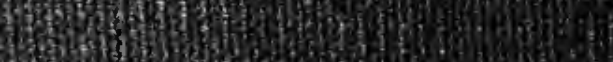

Hor

astion

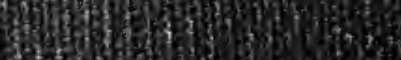

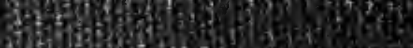

3x-1

S.

sasing

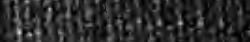

(x)

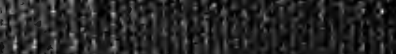

26.

Afy

Sotis

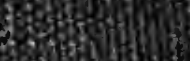

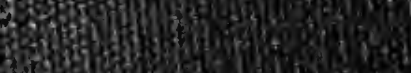

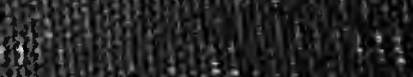

(1)

II

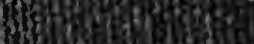

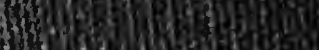

1 Hog

3.

3.

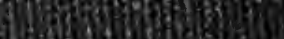

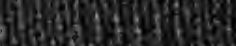

8.520

18)

sectis

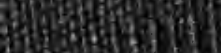

thos

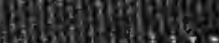

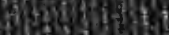

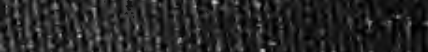

s.

tong

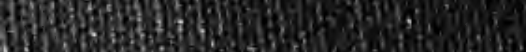

Hets

Hent

I.

gathes

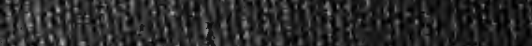

Hithis

felly

5. 